Disiecta Membra Musicae 


\section{Studies in Manuscript Cultures}

Edited by

Michael Friedrich

Harunaga Isaacson

Jörg B. Quenzer

\section{Volume 21}




\section{Disiecta Membra Musicae}

Studies in Musical Fragmentology

Edited by

Giovanni Varelli

\section{DE GRUYTER}


ISBN 978-3-11-071722-8

e-ISBN (PDF) 978-3-11-071788-4

e-ISBN (EPUB) 978-3-11-071790-7

ISSN 2365-9696

DOI https://doi.org/10.1515/9783110717884

\section{(cc) BY-NC-ND}

This work is licensed under the Creative Commons Attribution-NonCommercial-

NoDerivatives 4.0 International License. For details go to http://creativecommons.org/licenses/ by-nc-nd/4.0/.

\section{Library of Congress Control Number: 2020947345}

\section{Bibliographic information published by the Deutsche Nationalbibliothek}

The Deutsche Nationalbibliothek lists this publication in the Deutsche Nationalbibliografie; detailed bibliographic data are available on the Internet at http://dnb.dnb.de.

(C) 2020 Giovanni Varelli, published by Walter de Gruyter GmbH, Berlin/Boston Printing and binding: CPI books $\mathrm{GmbH}$, Leck

www.degruyter.com 


\section{Contents}

Giovanni Varelli

Preface - 1

\section{Overview}

Margaret Bent

Polyphonic Fragments: Destruction, Recovery, Reconstruction — 9

\section{Models}

Susan Rankin

Processional Chants in the Early Medieval Period: The Lesson of Fragments -39

David Hiley

Some Medieval Relics of Saints' Plainchant Offices - 77

\section{Trails}

Jurij Snoj

Music Fragments from Slovenia: Towards a Reconstruction of the Medieval Plainchant Manuscript Production -97

David Catalunya

Polyphonic Music of the Fourteenth Century in Aragon: Reassessing a

Panorama of Fragmentary Sources -117

Pawet Gancarczyk

Fragments of Local Polyphony in Late Medieval Central Europe: Towards a Semiotic Interpretation of Musical Sources - 165 


\section{Receivers}

\section{Sanna Raninen}

Make Do and Mend: Reworking Liturgical Parchment Manuscripts in Post-

Reformation Sweden - 185

\section{Karl Kügle}

The Aesthetics of Fragments: Reading Pastedowns in Context or, Late Medieval Bookbinders, Readers, and Their Choices - 205

\section{Representations}

\section{Reinhard Strohm}

A Collection of Fragments, or a Fragment of a Collection? The Musical Appendix of A-Wn Cod. $5094-241$

\section{Daniele Sabaino}

The Unexpected Song: An Early Italian Vernacular Poem, a Neumatic Notation, and How to Detect Their Interrelationships in the Ravenna Charter-263

\section{Processes}

\section{Zsuzsa Czagány}

Fragmenta Manuscriptorum Musicalium Hungariae Mediaevalis: From Traditional Methodologies Towards a Digital Corpus - 301

Julia Craig-McFeely

Restoration, Reconstruction, and Revisionism: Altering Our Virtual Perception of Damaged Manuscripts - 323

\section{Indexes}

Index of Manuscripts and Fragments -369

Index of Chants and Compositions - 375

General Index — 383 


\section{Giovanni Varelli Preface}

Manuscript fragments are medieval musicologists' old acquaintances. Membra disiecta of music codices often constitute the only surviving corpus of sources for entire periods, styles, or genres in the history of early European music. There is hardly any historian working on pre-1500 music who would not have directly studied a fragment, or a fragment's content, or even discovered one at some point in their research. Yet, despite the long familiarity with this type of source material, there has never before been a wide-ranging reflection on fragments as a particular object of study within the discipline, and especially on their role in last century's musicological research. While it is largely acknowledged that the set of techniques and processes required for the analysis of fragmentary sources relies on a particularly wide range of skills and data to counterweigh the inherent lack of information, a collective, up-to-date, and comprehensive discussion of the various techniques and approaches for their study was still lacking.

In recent years, attention to fragments has surged considerably across all disciplines that share manuscripts not only as primary carriers of a textual tradition, but also as material objects and agents of cultural interactions and historical dynamics. Narratives evolving around ideas of exclusion and neglect, rejection, marginalisation, and utilitarianism can be easily constructed, and the ex-centricity of this material, its unexpectedness, can constitute a strong element of fascination. Fragments, however, clash decidedly with our idea of a past in which a richly decorated missal, for example, would necessarily acquire an almost absolute status as a sacred, precious, and untouchable object. No matter how aware we are that this was evidently not the case in medieval society, fragments can still challenge our set of values and how we relate to historical artefacts: we would probably expect to see the ruins of a monastery as the result of neglect or destruction, but we are always somehow struck by the sight of a parchment folio being reused as a wrapper or inside a binding. Besides fragments' significance as historical objects, it is possibly also because of such - very modern - projection of a sense of cultural 'self-harming' if specialists, and public alike, have been so powerfully drawn to the remains of destroyed manuscripts. Yet, fragments often offer an answer also to the converse question of survival, especially by providing a glimpse into the remarkably diverse spectrum of grades in manuscript production; with some notable exceptions, fragmentary material predominantly

Ә Open Access. (c) 2020 Giovanni Varelli, published by De Gruyter. (cc) BY-NC-ND This work is licensed under the Creative Commons Attribution-NonCommercial-NoDerivatives 4.0 International License.

https://doi.org/10.1515/9783110717884-001 
represents those categories of compilations that fell outside the highest grades, such as objects of everyday use and/or carriers of widely circulated texts.

Similarly to other types of texts, wear, a repertory going out of fashion, censorship or ecclesiastical reforms were some of the reasons why a music manuscript was neglected and consequently discarded. Overall, however, the re-use of parchment as binding material, thanks to which some of the most important testimonies of musical practice survived, was more related to social and economic historical dynamics than antiquity or artistic taste. Because of their particular volatility, music manuscripts go through an often-overlooked middle phase, occurring between the moment when the original codex, libellus, or roll ceases to be of use and its becoming an object of antiquarian interest; a phase in which the object is simply obsolete, yet not valuable enough to ensure its preservation, and during which recycling usually takes place. A manuscript must thus survive this interregnum (as well as fires or other calamities) for it to be handed down to us in its original form; otherwise, fragments start their own, independent existence. Once reused as part of a binding, readers interacted with fragments in multifarious ways. These range from more content-related comments, deletions, or additions of similar nature (e.g. a series of antiphons for a saint's office, inspired by the liturgical content of the fragment), to a more contingent use of the manuscript material to host a table of contents and exlibris, including recording texts of transactions, accounts, doodles and pen trials (probationes pennae/calami). In other words, fragments constituted a presence which was well-noted and that often prompted an 'afterlife' as carriers of information. ${ }^{1}$ The study of membra disiecta is not only a remarkably valuable source of evidence for both the manuscript cultures that produced the original codex and any 'posthumous' engagement by reader-users, but also on later book cultures, up to eighteenth-century antiquarianism. So, what can fragments tell us about specific manuscript cultures and musical communities in medieval society? What is the 'lesson' that we can learn from them? How did fragmentary material shape our conception of the written transmission of music in the Middle Ages?

The aim of this collection of essays is to answer these questions by taking a 'snapshot' of the current state of the art in the study of fragmentary music manuscript sources from the Latin Middle Ages (c.800-1500), namely the variety of approaches for the analysis of the repertory and its transmission, musical

1 Fragments of Note. The Afterlives of Medieval Manuscripts was indeed the title of an exhibition I co-curated with Daryl Green and that took place at Magdalen College, Oxford in November 2017-April 2018. The exhibition was accompanied by a series of talks; speakers included David Rundle, Christopher De Hamel, artist Janet Boulton, and lutenist Lynda Sayce. 
palaeography, codicology, liturgy, historical and cultural contexts, etc. ${ }^{2}$ At the basis of this volume there was certainly an emphasis on new discoveries, but it was primarily intended as a hub to reflect on issues of methodology, historiography, and materiality raised by surviving medieval music fragments in Europe. A few scholars actually devoted a significant part of their research only to fragments, be it from the necessity imposed by the state of surviving source material for a specific period or geographical area, or for a particularly vested interest in these relics of our musical past. Reflections emerging from a long-standing and intense engagement with membra disiecta of music manuscripts provide the most apt introduction to this volume ('Polyphonic Fragments: Destruction, Recovery, Reconstruction' by Margaret Bent). Most of the twelve authors, moreover, endeavoured to discuss fragments from particular historical regions, corresponding to modern-day Austria, Britain, Czechia, Germany, Hungary, Italy, Poland, Scandinavia, Slovenia, and Spain, thus including areas that have been - for too long a time - considered 'peripheral' to a factitious 'centre'.

The vast majority of musical sources from the early Middle Ages are fragments of liturgical manuscripts, with or without musical notation. The recent identification, study and reassessment of the role and importance of ninthcentury fragments, in particular, altered considerably our previous knowledge of the early phase of development of certain book types such as the missal, or the process of codification of processional chants ('Processional Chants in the Early Medieval Period: The Lesson of Fragments' by Susan Rankin). The study of saints' offices too relies quite substantially on fragments. The diffusion of some local saints' cults, their reception and variants, as well as the possibility of considering other material forms of manuscript transmission - such as libelli containing a saint's historia - are often only answered through a large-scale survey and

2 Almost all contributions in the volume are based on papers presented at the international symposium Disiecta Membra Musicae. The Study of Medieval Music Manuscript Fragments took place at Magdalen College, Oxford, 19-21 March 2018. The keynote was delivered by Margaret Bent. The symposium, which was initially conceived as a one-day workshop, saw the participation of more than twenty-five attendees. I would like to thank also the participant-respondents Nicolas Bell, Nigel Palmer, Henrike Lähnemann, Tosca Lynch, and Sean Curran for their contributions and active engagement in the discussions. For conference reports see J. Mason, 'Peering Through the Gaps in Music History', in Early Music, 46/2 (2018), 358-359; Nicolas Bell, Report in the Oxford Medieval Studies Blog <https://www.torch.ox.ac.uk/disiecta-membra-musicaeconference-report> (accessed 17 May 2020); B. Dolce, Report in the newsletter of the National Early Music Association UK. Papers by Helen Deeming (Royal Holloway), Christian Leitmeir (Oxford), Sean Dunnahoe, and Christoph Flüeler (Fribourg) were not included in this volume. The contribution by Sanna Raninen (Uppsala) was not presented at the conference. 
meticulous analysis of surviving fragmentary material ('Some Medieval Relics of Saints' Plainchant Offices' by David Hiley). One such survey, which was carried out in libraries and parish archives across Slovenia, brought to light some unexpected finds like a fragment containing music and liturgy in Old Church Slavonic and written in Glagolitic script. The study of Slovenian membra disiecta provided important data to reconstruct the number of original manuscripts from which the fragments came, coming up with at least 140 different volumes, far more than the expected need of ecclesiastical institutions in this territory ('Music Fragments from Slovenia: Towards a Reconstruction of the Medieval Plainchant Manuscript Production' by Jurij Snoj).

Long neglected or partially studied fragmentary sources provide the opportunity to radically rewrite the history of royal and ecclesiastical institutional networks, the spreading of a particular repertory, music production, fruition and performance in areas like the kingdom of Aragon, for which now mostly fragments survive ('Polyphonic Music of the Fourteenth Century in Aragon: Reassessing a Panorama of Fragmentary Sources' by David Catalunya). The importance of investigating the particular historical context in order to shed light on the dynamics behind the dispersion of a repertory of polyphonic music is also crucial, especially in the case of historic regions such as Silesia ('Fragments of Local Polyphony in Late Medieval Central Europe: Towards a Semiotic Interpretation of Musical Sources' by Paweł Gancarczyk). Scandinavian collections have attracted considerable scrutiny in the past twenty years, mainly because of the impressive number of fragments and the relatively few complete surviving manuscripts. By directing our attention to the reuse of parchment in the early modern period it is possible to shed light on what is usually a lost or hidden phase, that of modification and experimentation - and their relative material implications when dealing with reformed liturgical repertories, including early sacred music in Swedish and Finnish vernaculars ('Make Do and Mend: Reworking Liturgical Parchment Manuscripts in Post-Reformation Sweden' by Sanna Raninen). Manuscript studies have long been exploring the possible interactions between material objects and their reader-users with interesting results. However, this has never been attempted for music fragments in later bindings; looking out for such connections in well-defined intellectual contexts has the potential to challenge our assumptions of a lack of cultural significance of pastedowns and flyleaves, especially in relation to their host volumes ('The Aesthetics of Fragments: Reading Pastedowns in Context or, Late Medieval Bookbinders, Readers, and Their Choices' by Karl Kügle).

Like Roman spolia in a medieval wall, traces of fragmentation and fragmentary transmission can be observed even in cases of complete volumes of 
miscellaneous content such as anthologies, reflecting the cultural context and intellectual interests of the individuals responsible for their compilation ('A Collection of Fragments, or a Fragment of a Collection? The Musical Appendix of A-Wn Cod. 5094' by Reinhard Strohm). The present book also provided the opportunity for further methodological reflections on known sources, like the earliest song in Italian vernacular found on the back of a charter, an unusual manuscript context for a fragmented musical entry which provides a glimpse into a fascinating, now-lost vocal repertory ('The Unexpected Song. An Early Italian Vernacular Poem, a Neumatic Notation, and How to Detect Their Interrelationships in the Ravenna Charter' by Daniele Sabaino).

To date, the number of musical fragments discovered is enormous, its extent surpassing that of any other forms of manuscript evidence, and new fragments are still being discovered. On-line resources have recently become increasingly important for the identification, study, and textual/musical reconstruction of music manuscript fragments. However, the considerable number of different available databases and digital platforms still calls for the first ever experts' assessment of accessibility and potential for use in musicological research. Collecting, organising, cataloguing, and describing fragments is not - as it is often portrayed - a mere positivistic exercise, but the key to disclosing information as wide-ranging as the number of original manuscripts circulating in a certain historical geopolitical region, its extent and institutional networks, and spreading of notational types, to name but a few. The most challenging operation is often that of setting precise standards for catalographic descriptions within, for the creation of a digital corpus of music fragments ('Fragmenta Manuscriptorum Musicalium Hungariae Mediaevalis: From Traditional Methodologies Towards a Digital Corpus' by Zsuzsa Czagány). Since accessing fragments' content may be hindered by wear, mutilation, or rewriting - either before or after their dismembering - the considerable potential of digital image restoration and forensic reconstruction is bound to alter the way we approach the study of damaged sources ('Restoration, Reconstruction, and Revisionism: Altering Our Virtual Perception of Damaged Manuscript's' by Julia Craig-McFeely).

The title of this collection of essays includes the term 'fragmentology'. ${ }^{3}$ This is a word that is both new and old, for a field of study that is very much characterised by the same duality: the term is constructed compositely from a Latin root and Greek suffix, but its recent use makes it certainly a neologism; the study of fragments is as old as early philology, yet never before have they received such

3 See William Duba and Christoph Flüeler (2018), 'Fragments and Fragmentology', in Fragmentology, 1 (2018): 1-5. 
attention, shifting from being mere objects for a most complete recensio - as if ancillae fragmenta philologiae - to acting as informants of historical and social phenomena, through the looking-glass of particular manuscript and book cultures. Fragmentology is a specific competence, a range of skills benefiting from an ever-growing availability of tools, and now entering fruitful interdisciplinary dialogues as essential components of its scholarship.

Each of the twelve essays in this book explores one or more issues related to the complex topic of music fragments through historical, systematic, and comparative approaches, and by setting it in the broader context of medieval manuscript culture. Senior and established musicologists encounter here colleagues in earlier stages of their careers, showing that the interest in fragments is still very much thriving. Finally, it is appropriate to stress that the community of international scholars who are actively engaged in the study of membra disiecta is by all means a larger one, and that only the physical limitations of an edited book prevented it from covering every single aspect of these specific manifestations of the written transmission of music. The hope is that this volume will also contribute to strengthen that very sense of community and that further such initiatives will be undertaken in the future.

\section{Acknowledgements}

I would like to thank Magdalen College, the 'J. M. M. Hermans Donation' of the Association Paléographique Internationale. Culture. Écriture, Société (APICES), all authors, the Series editors Michael Friedrich, Harunaga Isaacson, and Jörg B. Quenzer at the Centre for the Study of Manuscript Cultures (Hamburg), and Caroline Macé and Laurence Tuerlinckx for their incredible support. Without them it would not have been possible to bring the present volume to completion. 
Overview 



\title{
Margaret Bent Polyphonic Fragments: Destruction, Recovery, Reconstruction
}

\begin{abstract}
The mostly fragmentary survival of medieval music manuscripts is reviewed against the contrast between a romanticisation of fragments, ruins and unfinished work, and the utilitarian discarding of obsolete materials for recycling, notably music on parchment. Besides accidents of fire and flood, and politically or religiously motivated iconoclasm, peak periods for deliberate destruction were the advent of printing in the 16th century, creating a demand for parchment by bookbinders, and the 19th-century habit of dismembering manuscripts for their initials, with a related cult of forgery.
\end{abstract}

Many works of the ancients have become fragments.

Many works of the moderns are fragments at birth. ${ }^{1}$

Friedrich Schlegel

A Romantic - or romanticised - view of fragments applies to artefacts, artistic or literary, either left incomplete by the artist, and which came to be revered as precious testimony to the creative process, or deliberately composed as fragments, in Schlegel's second sense. In his first sense, some artefacts made incomplete by damage, deliberate neglect, or accidental, did indeed come to be romanticised - the picturesque ruins of Fountains abbey are an example - but musical disiecta membra have never been romanticised, nor, until the nineteenth century, were composers' drafts or incomplete works. A romantic mystique around unfinished works came to be attached to the end of the Art of Fugue and, especially, to Mozart's Requiem. Alan Tyson's seminal article on the Mozart fragments exposed

1 Friedrich Schlegel, famous for creating and theorising literary fragments, in a much-quoted phrase: 'Viele Werke der Alten sind Fragmente geworden. Viele Werke der Neuern sind es gleich bei der Entstehung' (Eichner 1967, 169). The title of this collection of essays, Disiecta membra musicae, signals that only the former kind is under consideration.

Note: I thank Julian Gardner, Nicolas Bell and Martin Kauffmann for helpful comments and references.

๑ Open Access. (๑) 2020 Margaret Bent, published by De Gruyter. (cc) BY-NC-ND This work is licensed under the Creative Commons Attribution-NonCommercial-NoDerivatives 4.0 International License.

https://doi.org/10.1515/9783110717884-002 
the basis of the abiding mythology contrasting Mozart's easy abundance with Beethoven's chiselled struggles, a contrast sharpened and exaggerated by the mundane fact that Mozart had a wife who tidied up after his death - keeping only fragments or torsos that could be 'useful', i.e. potentially completed by somebody else - while Beethoven did not, thus leaving a paper trail which both attained mythical status and invited scrutiny of his creative process. ${ }^{2}$ All the medieval music fragments of which I am aware fall into Schlegel's first category: fragments made incomplete by subsequent damage, whether by acts of God or man, neglect, recycling or mutilation, but not saved because they were intrinsically prized. Unlike fragments of pottery, or ruins of buildings, notated musical fragments have never been valued for themselves nor, until recently, had any commercial value.

The invitation for a Getty conference in 2007 referred to the cultivation of fragments as one of the hallmarks of the Middle Ages, citing inter alia partition of the body. ${ }^{3}$ The separate burial of hearts and viscera of kings and queens was a practice condemned by the papacy; they were not saints, but the practice multiplied sites for commemoration and could involve intercession. ${ }^{4}$ Physical remains, or personal possessions of saints were objects of veneration as talismans for particular powers or properties. Most such relics are fragments. ${ }^{5}$ Saints' relics were more highly valued than most visual art, though we now set more store by the art they inspired. Gifts of relics from the crown of thorns and the true cross were the impetus for the foundation of the Sainte Chapelle by Louis IX (Saint Louis, 12141270). The highest arts of the architect, glazier, goldsmith and painter enhanced the display and protection of relics. Sculptures are more durable than paintings, paintings than music. The trade in relics continues today, despite Vatican prohibitions, which alternate on the internet with relics sales advertisements.

Relics apart, fragments as such were not particularly cultivated by the Middle Ages. Indeed, the opposite is true for medieval music. Composed music went out of fashion very quickly; its written form is tightly linked to the performative canons of taste within which it was notated, much more so than for literary and poetic verbal texts. Tinctoris and Martin le Franc both set their music's shelf life

2 Mozart's widow Constanze listed for sale to publishers 'those fragments that are of lasting value (for many others have been destroyed on account of their total unusability). 'Use' appears to mean potential completion by her son Karl. Otherwise, 'What a fraud could be perpetrated with them! Why, one could have fine themes at a stroke!' If they were published, 'no one could ever deck himself in borrowed plumes, and Mozart would retain the credit that is Mozart's due.' (Tyson 1981, 472-473).

3 Some of the papers were published in Tronzo 2009.

4 See Brown 1981.

5 In some cases, notably St Francis and Dominic, store was set by keeping the body intact. 
at about forty years which, I have argued, is roughly the span of living memory for the age before sound recording. ${ }^{6}$ Old books of polyphonic music quickly became obsolete, and were discarded often within a generation or two of their creation. There are exceptions, like the retrospective Italian Trecento anthologies: repertorial longevity can vary. In some cases, music was updated with added or alternative voices. The fragments that survive have done so incidentally, mostly from being recycled as binding material, not because they were saved or cultivated for their own sake. There is no significantly recoverable music from Antiquity, hence no musical classics as candidates for humanist renaissance revival, as there are in architecture, sculpture and literature. Polyphonic music not only lacks authoritative antecedent texts; it is more evanescent than objects and verbal texts. Its notation is only the vulnerable blueprint for the irrecoverable sound.

Although it could be argued that, for the plastic arts, original physical objects need minimal mediation for modern viewing, it is nonetheless true that old canvases or panels were over-painted, church walls whitewashed, altarpieces cut down and reshaped, statues damaged, and in more recent times badly restored. Guillaume Du Fay had his stone funerary tablet made in his lifetime for eventual display in St Stephen's chapel in Cambrai cathedral, where his obsequies were to be celebrated. It shows the resurrected Christ stepping out of the tomb, observed by stunned soldiers, and the kneeling Du Fay protected by St Waudru. The old cathedral was destroyed at the Revolution in the late eighteenth century, and the slab was discarded. Considerably damaged, it was found in a well a century later; its importance now appreciated, it was restored, giving Christ a face, but then rerestored in the late twentieth century, removing the previous restoration and leaving Christ faceless again: its loss, discovery and restoration history superimpose two centuries of changing tastes and values. ${ }^{7}$

The last 500 years have seen three main technical revolutions relevant to our story. First, the printing press generated multiple copies, resulting in redundant manuscripts being discarded for recycling from the late fifteenth century onwards, just when the new tsunami of printed books accelerated the need for waste

6 See Bent 2004.

7 <https://pba.lille.fr/Collections/Chefs-d-OEuvre/Moyen-Age-et-Renaissance/Monument-Funerairede-Guillaume-Dufay/(plus) > (accessed 8 Sept. 2020). The earlier restoration is reproduced as Plate 1 in Fallows 1982. The vicissitudes of this monument contrast with the excellently preserved Landini tomb-slab in the church of San Lorenzo in Florence, which was not subjected to Napoleonic vandalism. 
parchment in their bindings. Second, in the twentieth century, photography and then the photocopier made it unnecessary to cannibalise unique copies, as had been the case, for example, when the autograph score of a nineteenth-century opera was adapted in haste for a different theatre and cast. Previous versions could now be kept and archived, avoiding the destruction of originals in making revisions. Third, more recently, digital technology has greatly advanced the possibilities of examining and restoring content without damage or change to the original, reducing the need to handle fragile documents. The internet and digital images have made paper copies, microfilms and slides largely redundant - a recent chapter of destruction history. Books and journals are euphemistically 'deacquisitioned' by libraries, and are nearly impossible to sell or even give away by individuals - discarded, destroyed; often pulped, even by charity shops. Acts of God, man and animals, accidents and war, fire and flood are the main agents, and indeed some of our fragments, or even complete manuscripts, are survivors. A fire of 1731 destroyed many of the Cotton manuscripts which were destined to form the foundational nucleus of the British Museum, and left others as charred fragments; the Cyprus manuscript escaped relatively lightly from the 1904 fire in Turin, but all the folios are now separate, distorted, and charred round the edges. ${ }^{8}$ Other music manuscripts were less lucky; the early fifteenth-century Strasbourg manuscript 222 C.22 was completely lost in the fire of $1870 .^{9}$ The Florence flood of 1966, and the more recent earthquakes in L'Aquila and Assisi, caused irreparable loss and damage to art works and rare books. Damp or flood has rendered many manuscripts illegible, and rodents have done their share of harm. Misguided restorations have often inflicted further damage, and chemical treatment of illegible passages has sometimes made them worse. The Egidi fragment of $c .1400$ may simply have been thrown out with the professor's papers after his death; we only have a poor microfilm..$^{10}$ Going further back in time, the professors in the famous Bologna funerary sculptures handled books in a way that would not pass muster with modern librarians and may have contributed to wear and loss. ${ }^{11}$ Even in the late twentieth century catastrophic fires befell the

8 Turin, Biblioteca Nazionale Universitaria, MS J.II.9, a large collection of liturgical and polyphonic compositions of the early fifteenth century, all anonymous and unica.

9 Van den Borren 1924. Welker 1993.

10 Preserved only in negative microfilm given to Kurt von Fischer by Francesco Egidi, who published it in Egidi 1925. The fragment was last located at Montefiore Dell'Aso, but not found following Professor Egidi's death in 1969.

11 <http://www.bolognawelcome.com/en/home/discover/places/culture-and-history/museumsand-art-galleries/museo-civico-medievale/> (accessed 15 Oct. 2019). 
Duchess Anna Amalia Library in Weimar and the Fenice theatre in Venice. Human intervention and negligence have much to answer for.

Binding fragments that survived the Middle Ages endured a second hazard; they were often routinely destroyed when the same books were rebound in later centuries. Many libraries undertook wholesale rebinding in the nineteenth century, notably the British Library (then the British Museum), which holds disappointingly few polyphonic fragments. While many important ancient literary fragments came to light in this process, interest in polyphony came too late to save most such remains. Music fragments fare better in libraries that did not undertake extensive rebinding; more remain in situ in Bodleian bindings. The early fifteenth-century Old Hall manuscript (now London, British Library, Additional MS 57950) was rebound in the 1890s, removing any clues to its earlier ownership; and the mid-century Trent codices sent for restoration after I saw them in the 1960 s came back in nice new bindings - the original bindings having been discarded together with any precious evidence of provenance. ${ }^{12}$ Unilluminated fragments were so little valued that they were often thrown out along with the bookbindings that had housed them until then; the importance of bindings and endpapers in turn has been shockingly undervalued.

Stone is more durable than parchment. Ancient stone gets recycled - demolished temples or churches provide quarry for new ones, and for houses, walls and barns. Stone coffins become cattle troughs or planters. Two pieces of old timber in Suffolk - one in Weatheringsett was recycled as a dairy door - were recognised by knowledgeable observers as the soundboards (wind-chest tops) of pre-Reformation organs, and rescued as the basis for making working copies of those instruments (Fig. 1). ${ }^{13}$

12 For the little that can be said about its earlier ownership see Bent 1969, available on $<$ https://www.diamm.ac.uk/resources/> (accessed 15 Sept. 2019).

13 A brief report is on the Royal College of Organists website: <https://www.rco.org.uk/ library_tudor_organs.php> (accessed 15 Sept. 2019). I thank John Harper for referring me to a detailed historical construction report with images and diagrams for the Weatheringsett organ, reconstructed by Dominic Gwynn. See also <https://www.goetzegwynn.co.uk/> (accessed 15 Sept. 2019). 

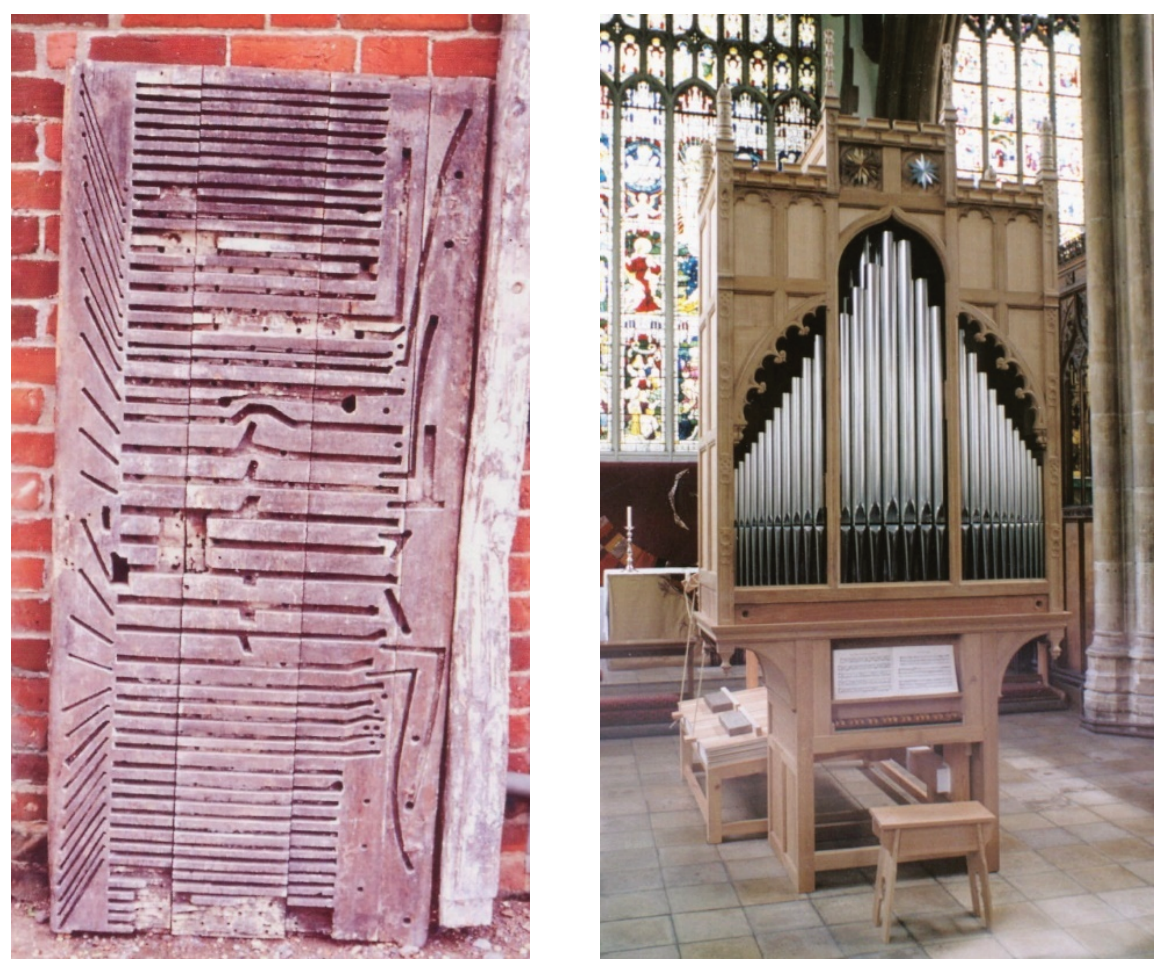

Fig. 1: The Weatheringsett soundboard and the reconstructed Tudor organ; @ Dominic Gwynn.

Less durable than stone, yet tough, parchment proved ideal book-binding material, either as external covers, or internally as flyleaves, pastedowns and reinforcement strips in wood and leather bindings. However, many remain partly concealed in bindings which cannot be dismantled for conservation reasons. The recycled material was valued only for its new use, not for its written content, or what it had been or formed part of. Recycled parchment has served many other terminal purposes: shoe repairs, fish wrappings, and especially, in the kitchen, pie liners. ${ }^{14}$ Apart from occasional survivals as box linings, insides of organs and lutes, and wall patching, ${ }^{15}$ all we have is fragments from the least perishable use,

14 Some of these uses are related, with amusing citations from Addison and Thomas Gray, in Brownrigg/Smith 2000, xii.

15 Ipswich, Suffolk Record Office, S1/2/40, lining of a box; Rodez, Archives départementales de l'Aveyron, J 2001, paper fragments retrieved from the inside of an organ; Oxford, New College, MS 368/1-3, about 50 'wallpaper' fragments with music from one or more choirbooks c.1500. 
in bookbinding. Paper waste was also used instead of wood to pad bindings, especially when parchment was less available. The Oxford antiquary Anthony à Wood (1632-1695) reported the use of discarded manuscripts to wrap soap and gloves, and in the privy. A colleague informally reported visiting a Spanish convent in the late twentieth century, and finding the nuns cutting up their old liturgical manuscripts to stiffen their wimples.

'Biblioclasm' has sometimes been used as a general term for book-breaking, but because, like iconoclasm, it carries the implication of heresy, I reserve it for ideologically motivated book destruction. Whole libraries or categories of books have been deliberately burned throughout history for political or religious reasons, or in war, such as the Great Library at Alexandria, burnt by Julius Caesar's army in the first century AD, burnings by Savonarola in Florence in the late fifteenth century, ideological book burnings by the Nazis in the 1930s, the Naples archives destroyed by German troops in 1943, to name only a few. And we hardly need to be reminded of the tragic iconoclasm in our own time which has seen the demolition of ancient sites and libraries. While old books were in earlier centuries destroyed to make new ones (by palimpsest or binding waste), there was little large-scale plundering of books in order to keep selected parts of them until the nineteenth century, and then it was mostly whole pages or sections of manuscripts that were saved for their interest, from Amplonius Rating de Berka in the fifteenth century to Ruskin in the 1850s. ${ }^{16}$ Much pre-Romantic appreciation or collection of medieval artefacts had been of objects which could have decorative value in contemporary surroundings.

A unique case which I have investigated involved an obsessive fifteenth-century compiler cutting out nearly 100 capitals from his own manuscript, for later reuse in the same book (Fig. 2). This is Bologna Q15, the largest and most important repository of international repertory of the first half of the fifteenth century. The first stage of the manuscript, compiled 1420-25, consisted of about 300 folios of which less than half remain - this we can tell from old folio numbers and revisions to them as the manuscript expanded. ${ }^{17}$ From around 1430 , the same compiler cannibalised his own work in order to paste the capitals in on new repertory and on recopies of his existing repertory (sometimes adapted) in a

16 For Amplonius I am indebted to Christian Leitmeir's hitherto unpublished paper at the Disiecta Membra Musicae Symposium: 'Fragmentation and the Creation of Knowledge: Music in the Library of Amplonius Rating de Berka (c.1363-1454)', which in turn refers to Pfeil 2010 and 2012.

17 Bent 2008, I, 243-292. 
remaking of his own book. Cutting an initial disabled music on both sides of a leaf; he presumably discarded the now useless mutilated leaves. Identification of many of the fragments of music on the backs of the initials enabled me to ascertain which of those pieces had been in the original compilation, and whether in the same order; to identify some pieces that he discarded and did not recopy; to say when an initial had been reused to decorate a copy of the same piece; to comment on the original ordering, and to suggest reasons for the recopying, some of which have to do with musical updating. ${ }^{18}$ Major repertorial updatings were more usually accomplished by starting a new manuscript.
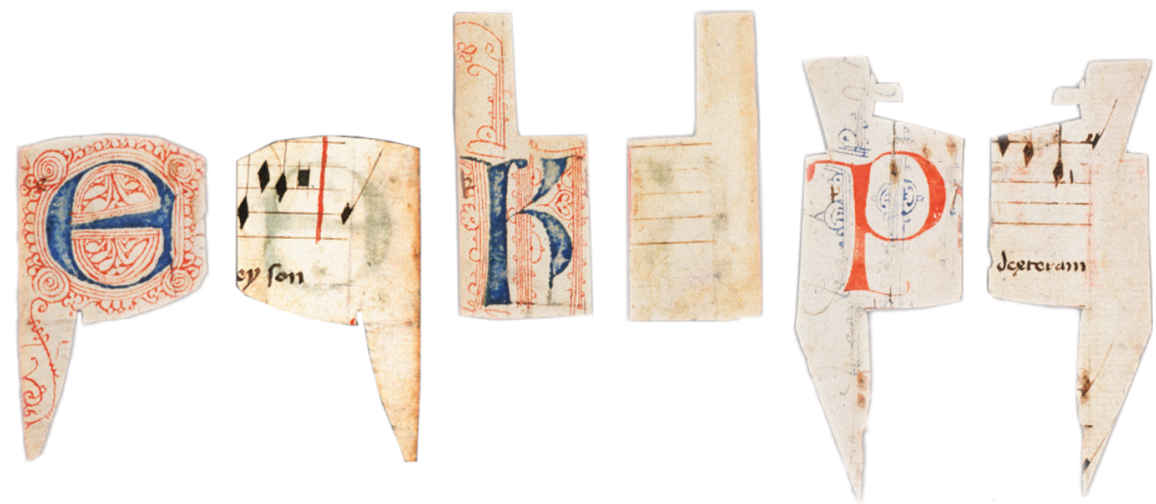

Fig. 2: Bologna, Museo Internazionale e Biblioteca della Musica, MS Q.15; samples of pasted initials, front and back; (c Bologna, Museo Internazionale e Biblioteca della Musica.

18 I knew of no other examples of such cannibalisation (albeit on a smaller scale) until Henrike Lähnemann drew my attention to her inaugural lecture, published as Lähnemann 2016, esp. 134-135. She shows how a Cistercian nun's psalter from Medingen (Oxford, Bodleian Library, MS. Don. e. 248) was adapted to Lutheran understanding in the mid-sixteenth century. Pages addressed to John the Evangelist were excised and replaced with a vernacular prayer addressed to God the Father, invoking Christ as intercessor. The prayer is decorated with an initial presumably cut from the excised pages, and pasted onto the new prayer. Professor Lähnemann thinks it likely that this revision (and other pastings of cut initials in this manuscript) were made by the same nun, the cantrix Margarete Hopes, notwithstanding the different appearance of the vernacular script. 
There are isolated cases of initials cut out for decoration before the nineteenth century, ${ }^{19}$ but it was mainly in the wake of the French Revolution, which released quantities of manuscripts for looting, sale or plunder, that mutilation became rampant, especially the harvesting of illuminated initials from large Italian antiphoners that had not previously suffered the destruction of a northern protestant Reformation. Sandra Hindman and Nina Rowe provide a fascinating cultural history of a growing nineteenth-century appreciation of manuscript illumination, which led to the cutting out of thousands of illuminated initials, deemed to have more value than when left in their original contexts; isolating the image could elevate it to the status of a great master painting. ${ }^{20}$ Cutters, like their medieval forebears, were not troubled by our notion of books or works of art as unique inviolable objects. The attitudes that informed the restoration and recreation of Gothic churches and cathedrals to suit contemporary taste also underlay the readiness to cut up manuscripts. The perception that extracted images were more valuable and saleable than intact manuscripts is thus completely different from the earlier dismemberment of manuscripts as waste for binders and other transient uses. The nineteenth-century isolation, collection and sale of images coincided with a new appreciation of the Middle Ages - think of the medievalising of William Morris - expressed in literature, art, and the Gothic revival in architecture.

Cutting out illuminated initials gathered pace in the nineteenth century, whether large ones for sale as art works, or for collections pasted into albums. This was done, often by collectors themselves, with no regard for their context or provenance, or for the manuscripts thereby mutilated. Francis Douce (1757-1834) bequeathed his books and manuscripts to the Bodleian. Like many nineteenthcentury collectors he was also a book-breaker: he bought cuttings himself, and cut out initials from his own illuminated manuscripts, although he criticised others for doing so. ${ }^{21}$ The library has reunited initials from his albums with the manuscripts from which he had cut them. ${ }^{22}$ Two albums catalogued as London, British Library, Additional MSS 29704-5 were expensively bound in tooled

19 For example, by Robert Cotton in the early seventeenth century (d. 1631). Samuel Pepys was a minor cutter from his own manuscripts, and there are a few other instances of removal of illuminations prior to the nineteenth century.

20 Hindman/Rowe 2001.

21 Including some from the Chertsey Breviary. See Freeman Sandler 1986, n. 62.

22 See his critical note in the mutilated manuscript Douce 372. Other manuscripts from which he cut initials include manuscripts Douce 31, Douce 266, and Douce 267, all of which have had miniatures restored to them in recent years from his albums, and especially from manuscript Douce 381. 
morocco with gilt leaves, and contained initials, many with miniatures, cut from a late fourteenth-century English Carmelite missal owned by the Hanrott family in the early nineteenth century. These luxurious volumes were evidently made up specially for this purpose in the late 1820s, and valued more highly than the intact manuscript, whose mutilated remains were presumably thrown away. Three more scrapbooks, with residual initials, were found subsequently. One motivation was clearly to use the initials to.spell family names (Fig. 3a).

The brilliant reconstruction of the missal by Margaret Rickert is an exemplary instance of what can be achieved with such material. ${ }^{23}$ Working from the text on the backs of the removed initials, she calculated the space required for the known intervening text to reconstruct the original locations of the 1588 fragments, now mounted in those volumes with both sides visible (Fig. 3b).

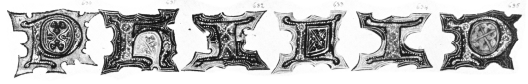 \\ (I) II

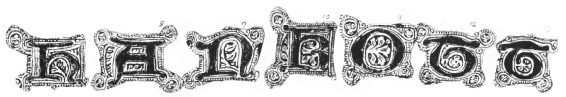

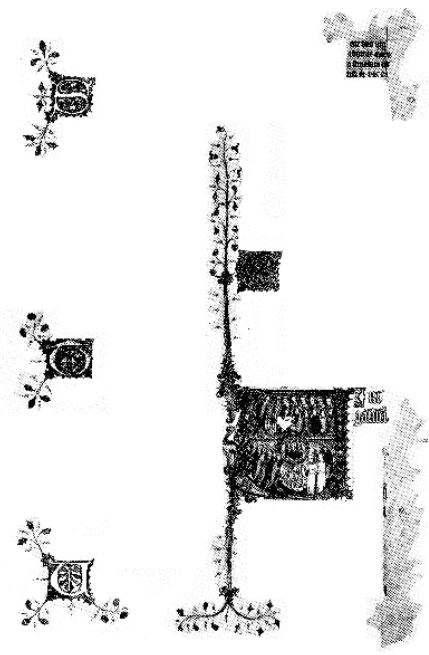

Fig. 3a (above): Hanrott family names (Philip, Ellen) made out of the initials of the Carmelite Missal;

Fig. 3b (below): Reconstruction of the original leaves. From Rickert 1952

(๔ Margaret Rickert).

23 See Rickert 1952. 
This achievement was in my mind when working on the Q15 initials, with the big difference that the fifteenth-century compiler was revising his own ongoing work, while the Hanrotts were destroying an intact medieval missal. On a smaller scale, a similar fate very probably befell the initials cut out from the Old Hall manuscript, none of which have ever been found. Those were removed in the nineteenth century, probably for a scrapbook, or transient decoration. Many S's were removed (from Sanctus settings), which throws suspicion on Gertrude Stafford Smith, who inherited it from her father. Patches with substitute initials were provided in the late nineteenth century (Fig. 4). ${ }^{24}$

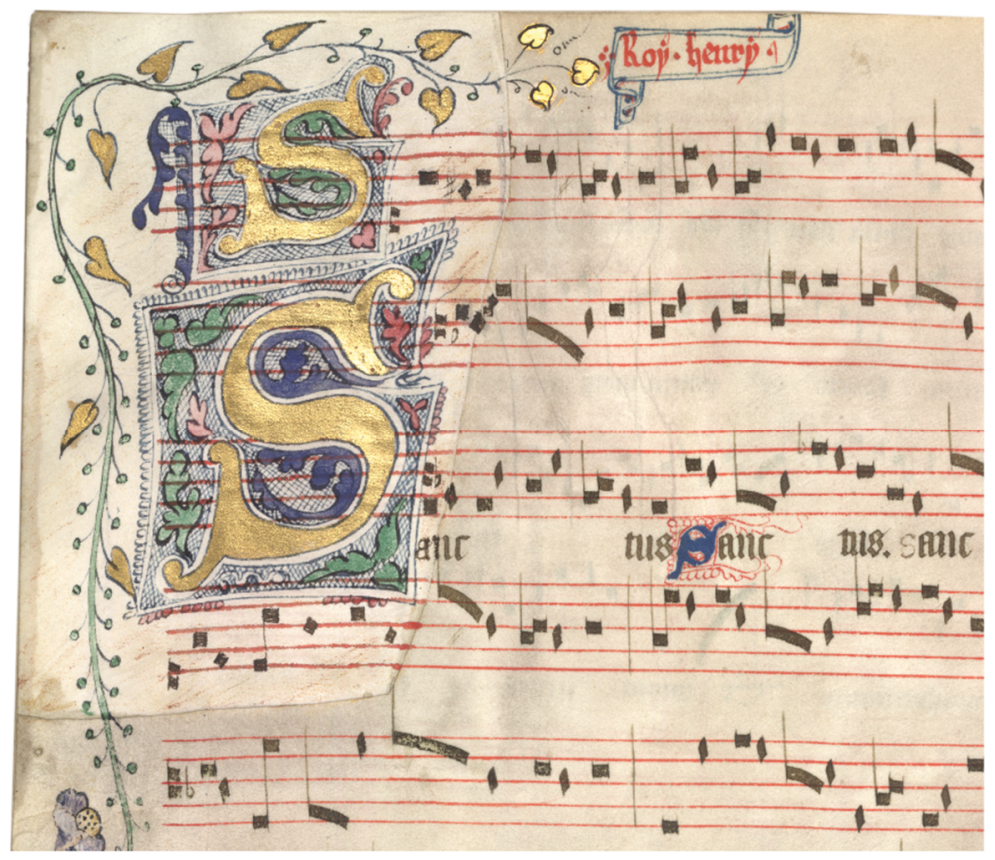

Fig. 4: The Old Hall Manuscript (British Library, Add. 57950), showing remains of the original border continued onto the late nineteenth-century replacement patch ' $S$ S', compensating for the original initial which was cut out earlier in the century (Sanctus by Roy Henry, f. 80v); (c) London, The British Library.

24 Bent 1966. 
We are now horrified by such vandalism, but the same priority persists nondestructively in published facsimiles which contain only the pages with illuminations, and in descriptions of liturgical manuscripts by art historians who discuss and reproduce only the miniatures. Several collectors in the nineteenth and twentieth centuries dismembered manuscripts as specimens of style or calligraphy, often with didactic intent. ${ }^{25}$ John Frederick Lewis of Philadelphia (1860-1932) collected copiously to further his interests in the arts and history of the book. In addition to many of his books and manuscripts, the Philadelphia Free Library has some 2000 cuttings, mostly not illuminations, and many as binding fragments, including two polyphonic leaves. His library included a number of 'extra-illustrated' books: decoration cut from a fifteenth-century manuscript was rather clumsily added to other books in his collection. Otto Ege from Pennsylvania (1888-1951) spent most of his career at the Cleveland Museum of Art. Ege was not particularly wealthy so, rather than specialising in illuminations, he avidly collected manuscripts and fragments, famously cutting up his own manuscripts to distribute leaves among a series of portfolios, which he then sold as specimens of scripts, with little printed commentaries. ${ }^{26}$ Christopher de Hamel has eloquently - and shockingly - documented the lively ongoing trade in manuscript fragments. ${ }^{27}$ Medieval manuscripts are still being broken up in order to sell single leaves more profitably; many are available on online auction sites and from book dealers.

There was often a didactic motive (or excuse) to this activity, as well as a pecuniary one. Objects and architectural remains generated an interest in decorative motives which gradually spread to books. Interest in medieval art led both to the practice of removing illuminations from their contexts, and to a fashion for copying medieval illuminations and decorating texts, not merely as a genteel pastime. Some, like Coella Lindsay Ricketts (1860-1941) aimed to recreate the medieval past, copying and creating new works precisely following medieval techniques. In an age before colour facsimiles, his Chicago Scriptorium produced copies of miniated pages from the Book of Kells and other works. ${ }^{28}$ It is a small

25 This paragraph is indebted to Hindman/Rowe 2001. In a chapter on reconstructions, in addition to Lewis (232-237), they report the activities of J. P. Morgan, Henry Walters and Robert Lehman, among many other American collectors.

26 See now the comprehensive study by Gwara 2013.

27 De Hamel 1996; De Hamel 2000, and in a number of memorable lectures.

28 Hindman/Rowe 2001, 262-272. This was differently motivated from the fifteenth century practice whereby images painted on single leaves by Netherland illuminators could be sold separately, to be inserted or pasted in books of hours, or mounted as devotional images. These are 
step from copying to the skills required for forgery of medieval manuscripts or illuminations that could indeed have commercial value. The cutting out of fragments for their intrinsic value, not as disiecta membra, comes full circle to the second type of fragments, those newly-created as such, whether by honest copying or dishonest forgery. Some collectors, including Lewis, were taken in by modern fakes.

Most polyphonic manuscripts either have no initials, or they are not of sufficiently high quality to have attracted the attention of nineteenth-century collectors, or indeed present-day art historians; music fragments, almost without exception, have survived as recycled waste, not from being saved for their content or artistic quality. As I mentioned, initials were cut out from the Old Hall manuscript, as were pages containing them at the head of each of the Naples L'homme armé masses, and several other instances. To my knowledge only one music manuscript, fortunately unscathed, has attracted forgery of its illuminations: the famous Squarcialupi codex. ${ }^{29}$

A little-known after-story of this manuscript comes from at least five sets of copies or forgeries. Some years ago, I saw a medieval antiphoner in Toronto to which painted initials have been added, several with composer portraits copied from the Squarcialupi codex, including that of Landini, a page to which the Medici stemma with palle doubtless added value. The additions, probably of the late nineteenth century, sometimes cover the text (Fig. 5). ${ }^{30}$ Another medieval antiphoner in Zagreb has added initials, using the outlines and instruments of the Squarcialupi Landini page, but replacing the composer with a saint and two other figures. ${ }^{31}$ Whereas Lewis cut up a medieval manuscript to decorate a plain modern book, here two real but plain medieval manuscripts have been embellished with over-painted copies of Squarcialupi miniatures, presumably to increase their value. This succeeded insofar as the only article on the Toronto manuscript - by an art historian - did not recognise it as a modern fake. ${ }^{32}$

neither recreations, forgeries nor disiecta membra, but they share with some of the examples given here the goal of ornamenting plain books.

29 Florence, Biblioteca Medicea Laurenziana, Med. Pal. 87.

30 University of Toronto, Thomas Fisher Rare Book Library, MS 09700 (formerly 09255).

31 Zagreb, National and University Library, MS 179.

32 Krug 2013. 


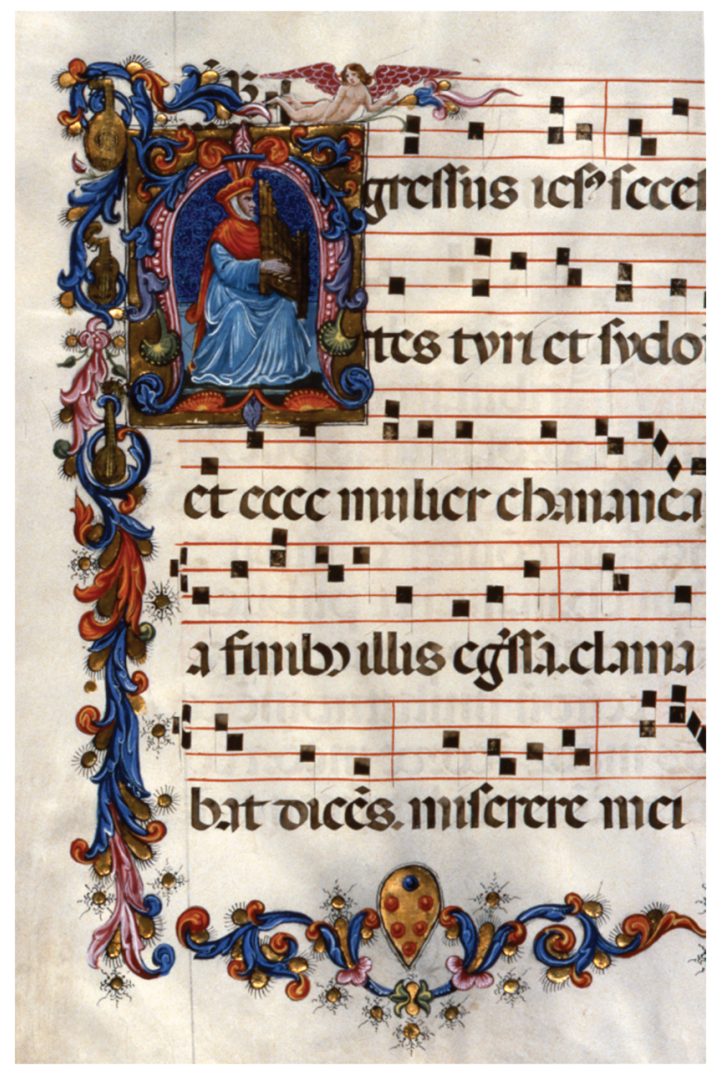

Fig. 5: The Toronto antiphoner with forged initials adapted from Squarcialupi covering some of the text; () University of Toronto, The Thomas Fisher Rare Book Library.

Two others are probably also forgeries, with poor attempts to replicate the musical notation: a single leaf in Yerevan, Armenia imitates the notation of Gerardello's Tosto che l'alba, but with an entirely different initial, showing King David..$^{33}$ A Doyle auction of 9 April 2014 advertised a pair of similar fragments, one with a copy of the Squarcialupi composers Egidius and Guilielmus de Francia. The music and text scribe are similar, the notation similarly faked (Fig. 6). ${ }^{34}$

33 First reported by Fischer 1990, 162-165.

34 <https://doyle.com/auctions/14bp01-rare-books-autographs-photographs/catalogue/106manuscript-two-large-cuttings > (accessed 17 Jan. 2020). Posted on 24 August 2017 by Dominique Gatté on the Musicologie Médiévale website. 


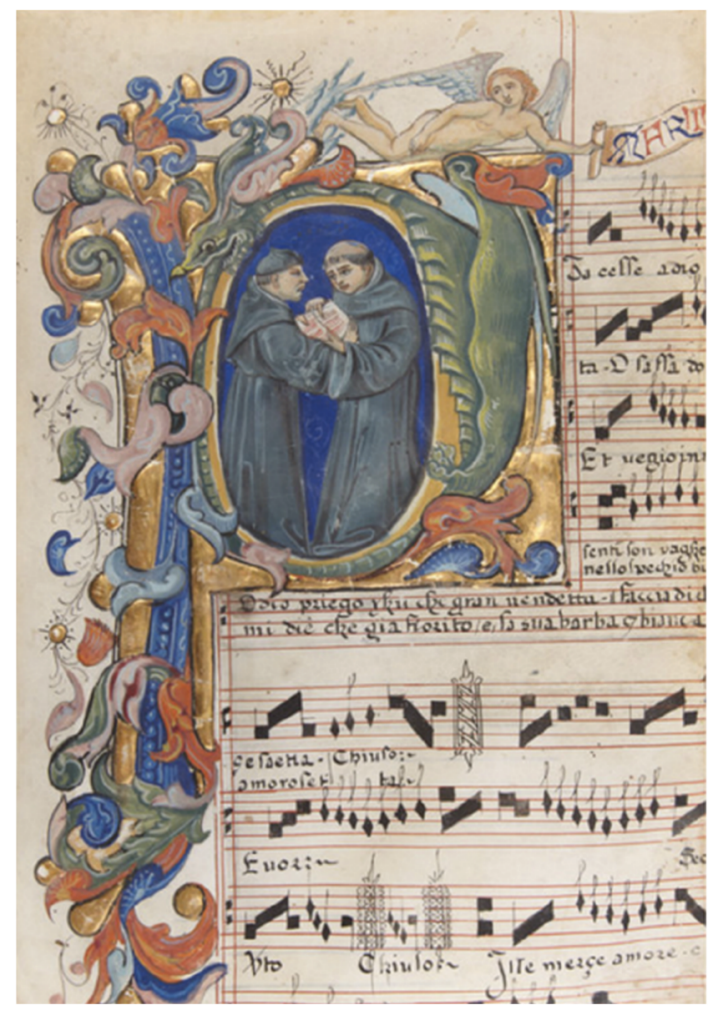

Fig. 6: One of two cuttings auctioned by Doyle in 2014; @ Doyle Auctions.

A sale by Deutsch auctioneers, Vienna, on 25 September 2018, included as lot 53 a further pair of forged pages (framed, with only one side exposed). In these cases a Squarcialupi composer portrait is imitated and the notation faked to different degrees. ${ }^{35}$ There was little financial or aesthetic incentive, or indeed competence, to forge musical notation accurately; these cases easily give themselves away to anyone familiar with the notation. It is very hard to tell when these were done

35 In an e-mail of 6 September 2018, Bojan Bujic alerted me to this sale announcement, where they are misdescribed as follows: 'Pair of illuminated Incunables, from a song book, watercolour with black ink and gild on parchment, partly described in Latin, signs of age, framed under glass, north Italy 15th/16th Century or later. $42 \times 30 \mathrm{~cm}$ '. The left-hand image is loosely based on the portrait of Lorenzo da Firenze on Squarcialupi f. 45v, but different music is presented (Nella fine del di); the other image is copied (but with different colours) from Jacopo on $\mathrm{f} .7 \mathrm{v}$, and the same music, for Sotto l'imperio, more accurately transcribed than in most other cases. 
and why, how they relate to, and how they had access to Squarcialupi; and why Squarcialupi is the only music manuscript known to have been copied in this way. ${ }^{36}$

Pictures or buildings can speak directly - if sometimes misleadingly - to uninformed observers, and incompleteness can be appreciated as tantalising. We can wonder at a Michelangelo sculpture left incomplete, or a fresco partially lost to damp, but incomplete music cannot normally be programmed, except as a curiosity. ${ }^{37}$ The recently coined term 'fragmentology' gives the impression of a new discipline. Rather than invoking Monsieur Jourdain, let us welcome anything that gives fresh impetus to what some have been doing for decades. Neil Ker's pioneering catalogue of pastedowns in Oxford bindings should not be under-estimated.$^{38}$ Effort has been focussed on the identification of known texts in binding fragments, which may cast light on their location, use and transmission. Liturgical fragments can usually be related to known or local liturgies, as with the Carmelite missal. But because each polyphonic anthology is unique in content and ordering, the challenge of identification is different. While individual compositions may have concordances, polyphonic fragments cannot be placed in the same way within a larger known entity. For recognition and reconstruction, polyphony is different both from verbal texts that can be identified, and from chant fragments, whose texts and music usually correspond to a known liturgical book - even if with local variation. 'Digital fragmentology' now offers the possibility to reunite widely scattered fragments virtually, if not physically. You could say that collectors of illuminations or of antiquities taken from their contexts were doing for art what medieval compilers of florilegia did for texts; but copying texts for florilegia did not involve physical destruction of the original.

Palimpsests are disiecta membra of a different kind, but likewise result from recycling material valued only for its parchment, no longer for its contents. There are many palimpsests in music manuscripts where erased music made way for newer music. Examples are found in the Worcester Fragments and ModenaA. ${ }^{39}$ More commonly, music is erased to accommodate other texts as in Fig. 7); and in

36 I am indebted to Michael Scott Cuthbert for helping me see images of the Zagreb and Yerevan leaves; he and Andreas Janke have both expressed interest in working on this fascinating material. 37 I explored the issues inhibiting performance of incomplete and fragmentary medieval pieces with Christopher Page and live illustrations by the Orlando Consort in a Radio 3 'Spirit of the Age' broadcast on 14 May 1995.

38 Ker 1954.

39 For the Worcester Fragments, see n. 43 below. For ModenaA, see Stone 2005. 
Faenza 117, where erased music is overwritten with a later music theory text. ${ }^{40}$ The most spectacular case is the San Lorenzo palimpsest, an entire palimpsest book scraped clean to be reused for records of the acquisition and rental of church properties. ${ }^{41}$ In all these cases, parchment was reused for new written material, musical or otherwise, rather than for bookbinding or more destructive uses. Offsets on a board can sometimes be digitally combined with a lifted pastedown; sometimes only the reverse imprint of a lost leaf remains on the boards and can be reversed to make it readable (Fig. 8).
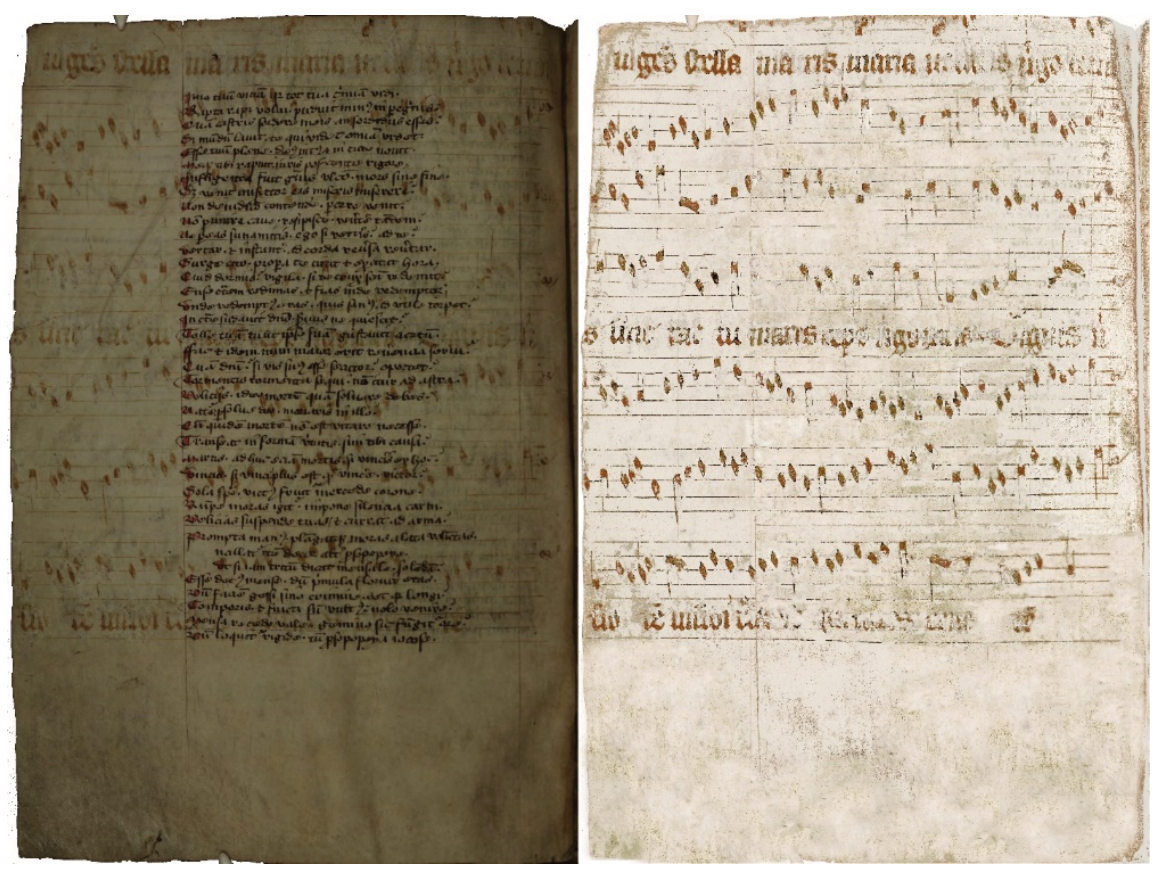

Fig. 7: Oxford, Corpus Christi College, MS 144, f. 25v. Overwriting then removed and gaps filled in. Digital editing by Julia Craig-McFeely, reproduced by kind permission.

40 See Memelsdorff 2013.

41 See Nádas/Janke 2016. See the review by Bent 2017, and the contribution of Julia CraigMcFeely to this volume, §2, 336-339. 


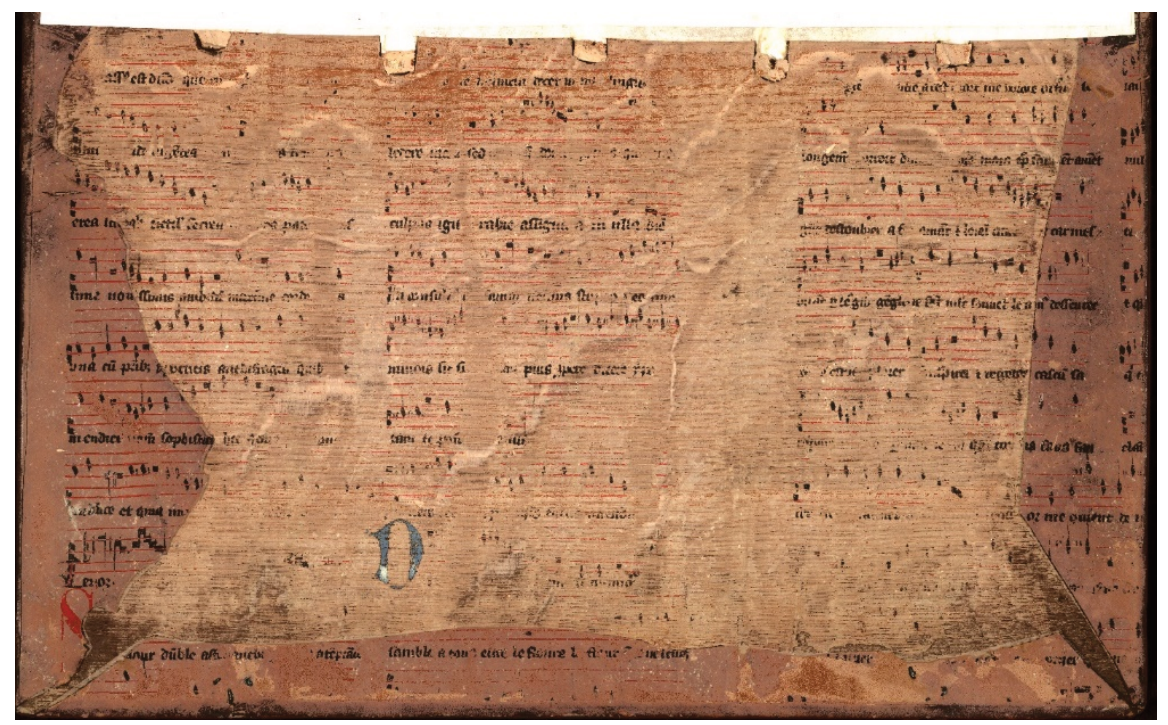

Fig. 8: Cambrai, Bibliothèque Municipale, MS C 647, front board. Digital editing by Julia CraigMcFeely, reproduced by kind permission.

There are no complete, or even nearly-complete, English manuscripts of polyphony between the Winchester Troper of $c .1000$ and the Old Hall manuscript of the early fifteenth century. We think of Old Hall and the Eton choirbook as complete manuscripts, but even they are respectively only $3 / 4$ and 2/3 complete..$^{42}$ Thus for English music of the thirteenth and fourteenth centuries we are almost entirely dependent on fragments, a significant number of which can be grouped together, as coming from the same original manuscripts. This is made simpler in cases where they are mostly still in the same place, as with the musical Worcester fragments, about 100 surviving leaves datable $c .1300$, the largest body of English music to survive from the thirteenth and fourteenth centuries. All the leaves were removed from Worcester bindings, some of the fourteenth century, a few of the fifteenth, but most by a Worcester monk-binder of the 1520s. Many of the fragments from dismembered music manuscripts can be grouped into three main 'reconstructions', plus a few outliers. ${ }^{43}$ The majority are still in Worcester, but a few

42 See Williamson 2010.

43 Summers/Lefferts 2016. The authors detail the contents of the motet book, with foliation up to the 130s, the large format book, and the conductus book. In some cases, the same binding had waste parchment from two different manuscripts; Worcester must simply have accumulated a 
have escaped, to Oxford and London. For everything else between Winchester and Old Hall, in England, we are entirely dependent on binding fragments each of 1 to 8 leaves, representing at least a hundred dismembered manuscripts, some of which were demonstrably large. The three leaves of British Library, Additional MS 24198 are from an alphabetical collection; the letters R, S, and T which had up to eight numbered items under each letter; the ten leaves of Oxford, New College, MS 362 have folio numbers in the 70 s and 80 s, and so on. ${ }^{44}$

Cases of many leaves from the same original book or books being retrieved from the same library, as at Worcester, are quite rare. On the Continent, three such cases are particularly important:

- nearly fifty folios, out of more than 100, mostly in Lucca and dating from about 1410, were used to make covers for notarial archives dating from the late fifteenth to the late sixteenth centuries. ${ }^{45}$

- eighty-two leaves, out of over 180, from a later Lucca choirbook of the 1460s, discovered and assembled by Reinhard Strohm, were used to bind archives of the early seventeenth century. ${ }^{46}$

- remnants of four early fifteenth-century manuscripts from bindings from the Paduan monastery of Santa Giustina have been augmented over many decades, one of them scribally signed by the humanist monk Rolandus de Casali. Thirty leaves survive from an original total of over $300 .{ }^{47}$ The manuscripts were dismembered between $c .1435$ and 1453 , starting only about thirty years

pile of obsolete musical waste used indiscriminately over a long period. In a virtuoso lecture on Philip Bliss at Magdalen College on 9 April 2018, Christopher de Hamel demonstrated some Oxford instances where leaves of the same manuscript originated from different binders, some already documented by Ker 1954 .

44 Other manuscripts may have been smaller, perhaps only a fascicle or two. Although many surviving leaves are singletons, some manuscripts have two nested bifolios each at the beginning and end. Examples are Bodleian Library, MS E Mus. 7, Durham Cathedral, MS C I 20, possibly Yoxford (now Ipswich, Suffolk Record Office, HA 30: 50/22/13.15) and New College MS 362 $(1+2+2$ bifolios); in all these cases we have at least eight leaves (in several cases, two quaternions) apparently from the same original manuscript. When do we have enough of a manuscript that it no longer qualifies as a fragment?

45 See, building on earlier work, Nádas/Ziino 1990. Forty-four leaves discussed there are augmented by two more in Nádas/Ziino 2005.

46 Strohm 2008. See p. 3 for an account of initials cut from these leaves when they were already in use for binding covers, with some further loss of notes. This must have happened after the seventeenth century, because of inscriptions on the leaves, and very probably in the nineteenth. 47 Most recently and thoroughly documented and analysed by Cuthbert 2006 and 2011. 
after compilation, possibly due in this case to a monastic reform which outlawed polyphony. . $^{8}$

In all three cases, even where the use was local, and the music leaves are mostly in one archive, some escaped to other libraries, and have gradually come to light over several decades; there is still hope of finding more leaves. ${ }^{49}$

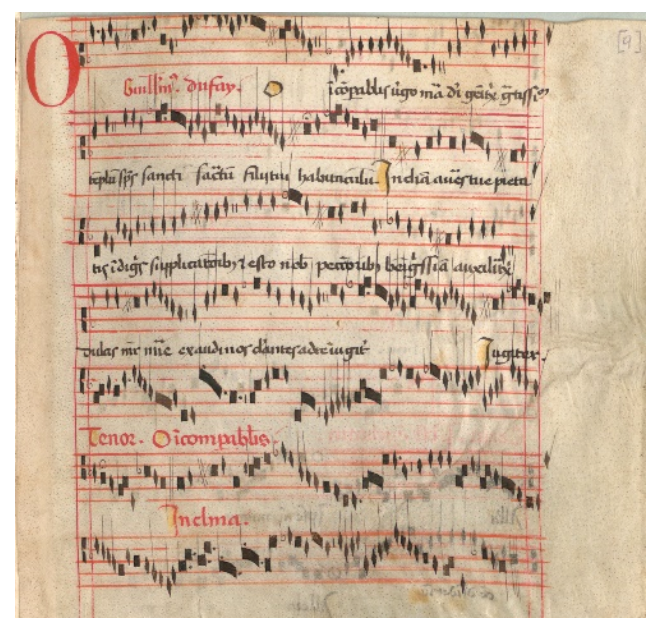

Fig. 9: (a) Munich, Bayerische Staatsbibliothek, Mus. ms. 3224, p. 9; ( ) Munich, Bayerische Staatsbibliothek; (b) Vienna, Österreichische Nationalbibliothek, Fragm. 661, f. 4r; (C) Vienna, Österreichische Nationalbibliothek.

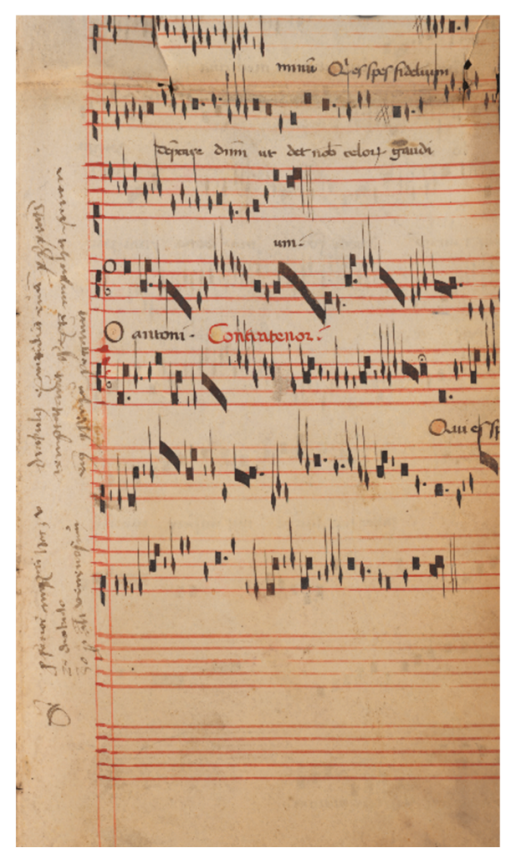

I collaborated in the reconstruction of a fragmentary Veneto polyphonic anthology from leaves already known in Munich and discoveries in Vienna by Robert Klugseder (Fig. 9). ${ }^{50}$ It has been possible to link the Munich fragments to their host incunable volumes bound at the Bavarian monastery of Weihenstephan in

48 The dates for reuse of the fragments is discussed in Cuthbert 2006, 168.

49 For the early fifteenth-century Boverio fragments recovered from bindings, see Ziino 1994. Reinhard Strohm has linked up an important series of now separated fragments to the same original manuscript in Vienna (including the Nuremberg and Melk fragments), see Strohm 1984.

50 Bent/Klugseder 2012. 
the late 1490s, and indeed to find and identify offsets of further leaves now lost in other Weihenstephan bindings. They are very fragmentary, and photographic images were reversed and digitally manipulated; but enough notes remained to permit identification (Fig. 10).

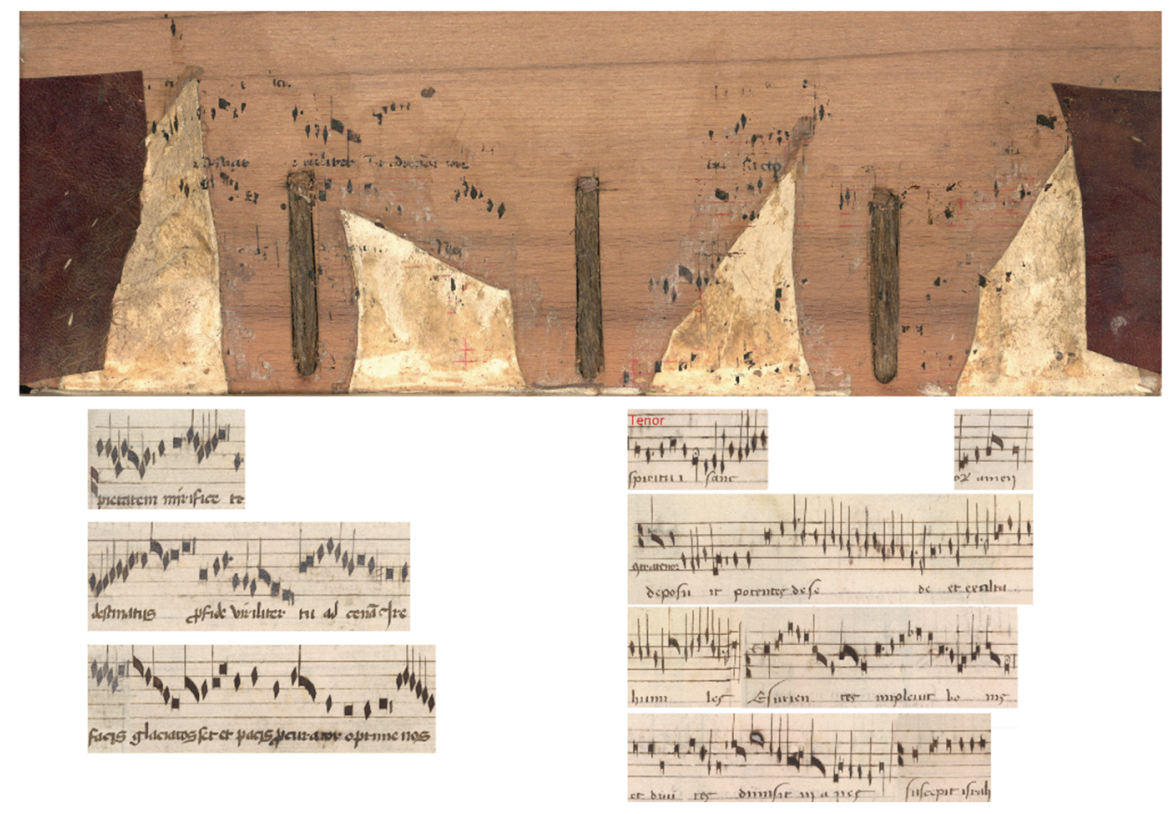

Fig. 10: Offsets on the boards of Munich, Bayerische Staatsbibliothek, 2 Inc.c.a.3375d with corresponding passages from Bologna Q15 showing excerpts from Du Fay's Magnificat sexti toni and Antonius de Civitate's Pie pater Dominice; @ Munich, Bayerische Staatsbibliothek.

The Vienna fragments from the same original manuscript were used twenty years later to cover a book printed in Venice in 1516. This might caution against assuming - as I had done in other cases - that a single binder usually had an entire discarded music volume on his waste pile. Binders' waste is usually fairly local, so how did parts of the Veneto manuscript get to a Bavarian monastery? Could the unbound books have been shipped in barrels, protected with this waste parchment, while some of the book remained in Venice? Further leaves could turn up anywhere, not necessarily from Weihenstephan.

A major obstacle to finding more widely dispersed leaves from this and other choirbooks is the watershed of 1501 . Incunabula are mostly well catalogued, and documented as to provenance and binders. The same alas is not generally true 
for books published after 1501 and bound in the early sixteenth century, during the period when dismemberment of manuscripts to bind printed books reached a peak. If more of that manuscript was ever at Weihenstephan, leaves could also have been used in binding books printed after 1501, now dispersed beyond ready identification. Those sixteenth-century Weihenstephan books still in the Bayerische Staatsbibliothek are not kept separately, their provenances not recorded. Future discoveries will be largely dependent on chance. ${ }^{51}$ Considering the ignorance or fear of music by many cataloguers, and the inadequate reporting and description of musical pastedowns, we should be thankful that so much has turned up. Another impediment to locating books is that libraries change call numbers. Binding historians have sometimes identified a book only by call number and perhaps date and place of publication: this makes identification difficult or impossible if the library has not kept a record of previous call numbers. ${ }^{52}$

The dates of reuse of several early fifteenth-century manuscripts are, as one might expect, in bindings of the early sixteenth century. What is surprising, however, is the case of the dismembered late fifteenth-century English manuscript known as 'Lost choirbook 2', with repertory contemporary with the Eton choirbook. ${ }^{53}$ Three of its fragments were reused in the bindings of two books printed as early as 1505 and $1514 .{ }^{54}$ Even if there was some delay between printing and binding, the dates of binding are shockingly close to that of the discarded musical repertory. These relative datings have a lot to tell us about obsolescence and the shelf life of notated music; apart from a few individual instances, they have not been much investigated. For example, the date of dismemberment in relation to the date of the repertory or its copy can be an eloquent - if sometimes unexpected - testimony to taste and longevity.

Finally, a volume of facsimiles of English fifteenth-century fragmentary sources up to about 1470 is currently in preparation..$^{55}$ There are nearly 100 call numbers, representing about 200 leaves (400 pages). Eighteen of these leaves (nearly 10\%),

51 After the dissolution of the Weihenstephan monastery in 1803, its more valuable collections passed to various libraries including (but not only) the Bayerische Staatsbibliothek. Many modern works were considered worthless and sold to paper mills.

52 This was the case following World War II at Lambeth Palace Library, where I failed to locate Spierinck bindings, for which I had only that limited information.

53 See Curtis/Wathey 1994.

54 The current call numbers of these books are respectively Oxford, New College, BT1.89.8 (olim C.1.2) and BT1.7.14 (olim $\Omega .14$ ).

55 See Bent/Wathey forthcoming 2021. 
now widely scattered, came from the same original manuscript. Building on an initial link made by Bukofzer in a posthumously published article, ${ }^{56}$ these fragments have been identified over the past fifty years as belonging to a royal choirbook of the 1420s. I originally named it for Henry VI because it shared repertory with Old Hall, including music by a chaplain of Henry $\mathrm{V}$ who continued service under his son. It seemed repertorially to be from that decade, and was decorated with royal animals. However, when Dunstaple turned up in pride of place in the Tallinn fragment I had to think again, since he was not known to have served the king. There is insufficient evidence to link it firmly to one of Dunstaple's other royal patrons, though the duke of Bedford has the strongest claim. Four constituent leaves in Magdalen College, Oxford can be linked with their original two host volumes by offsets on the boards and old call numbers on the pastedowns; the books were bound by the early-sixteenth-century Cambridge binder Nicholas Spierinck. Two leaves at Columbia University are still in situ in a Spierinck binding. ${ }^{57}$ But inspection of almost all the known Spierinck bindings that were reasonably accessible has so far yielded no further leaves, raising the question whether Spierinck had the entire manuscript on his waste pile, or whether indeed all the unprovenanced binding fragments that once belonged together were from bindings by him. While church reforms and the protestant reformations may account for the dismemberment of many liturgical books, they do not seem to be the major reason for the destruction of polyphonic manuscripts, many of which were broken up much earlier because of rapidly changing tastes.

Digital images have enabled me to revise the scribal judgments made when I had access only to poor photocopies or microfilm, and memory of fragments seen in different libraries on different days. Two main scribes worked before the manuscript was sent for its very distinctive monochrome illumination; additions by later scribes link to the same complex. This will be set out in the introduction to the above-mentioned Early English Church Music volume (EECM 62). The point for present purposes is that this reconstruction depends not on identifying parts of a dismembered manuscript on the basis of a known text, but on common physical features of size, ruling, illumination, scribes, and gradually building up a picture of its repertory and ordering, with and without concordances. On that basis, the contents and even the order of a unique anthology can be partially reconstructed. In this case, the general organisation of the fragmentary source echoes

56 See Bukofzer 1958.

57 Kindly signalled to me by Michael Laird. 
the Old Hall manuscript, but this could largely have been inferred independently by building up from the succession of pieces on two sides of the same leaf.

Provenance is sometimes easier to determine, if sometimes deceptively, for fragments when they are still in their host volumes, especially where assumptions about local origins for binders' waste seem justified. Many fragments are no longer in those volumes, and only in rare cases can they be matched up by offsets or old call numbers (as reported above for Magdalen, Padua and Munich). Fragments without context are hard to evaluate. Dating of the few whole codices is often difficult and controversial, especially if they have been rebound and shorn of evidence. Fragments are not necessarily easier, but with some provenance clues and in quantity they provide some control when brought into dialogue with the larger sources, and add dimensions to an overall picture. Concordances place some limits on our assessment of the total repertory that once existed. Most new discoveries have, at a very rough estimate, about $50 \%$ or more of pieces known from elsewhere. ${ }^{58}$

Since World War II, only four major late-medieval polyphonic manuscripts have come to light, in contrast to dozens of fragments. They are British Library manuscript Egerton 3307 first reported in 1946, the Aosta codex in 1948, the San Lorenzo palimpsest in 1982, and a late fifteenth-century Leuven chansonnier in 2014. The internet and projects including the Digital Image Archive of Medieval Music (DIAMM) have contributed significantly to raising awareness and reporting of fragments..$^{59}$ We may still hope that more whole codices may come to light, but this is likely to be an increasingly rare occurrence. ${ }^{60}$

Because more attention has understandably been paid to whole codices, it has taken longer for musical cultures and periods without surviving codices to be studied and recognised, as for English music of the fourteenth century, which is reconstructed entirely from fragments. What has happened, as the lower-hanging

58 The provenance of then-known English fragments was addressed in Bent 1973. The incidence of concordances has since been explored statistically by Cuthbert 2009.

$59<$ http://www.diamm.ac.uk/>. The project, now based at the Oxford Faculty of Music and managed by Julia Craig-McFeely, was established in 1998 by Margaret Bent and Andrew Wathey. 60 Following an early interest in medieval music manuscripts in Italy by Padre Martini and a few others in the late eighteenth century, and in England a century later by Stainer, Wooldridge and Barclay Squire, the main discovery and documenting of the principal surviving manuscripts of French and Italian medieval polyphony was undertaken in the early twentieth century by German scholars such as Ludwig, Wolf, Besseler. Fragments have been considered alongside codices from an early stage, as seen in the astonishing list of over 100 Italian manuscripts and fragments in order of discovery compiled by Michael Scott Cuthbert in a postscript to his dissertation. 
fruit of large codices in major European libraries has been assimilated, is the success of greater efforts to bring to light scattered fragments, which may have been undervalued by their owners and curators. Fragments have always been vulnerable, and several have disappeared since they were first reported. The setting up of DIAMM as a safe repository was prompted in part by the loss and theft of fragments, but it has also led to the discovery of many more fragments in archives where their importance had not been understood.

In conclusion, the destruction of medieval manuscripts has taken place over many centuries and for many purposes. Peak times for destruction were the early sixteenth century as waste material for book bindings, and the nineteenth century for harvesting miniatures and decorative initials. In both cases, the destruction continued - and in the latter case it continues today. The main difference is that, in the sixteenth century, waste parchment was recycled for mundane purposes, of which book binding was the most durable: manuscripts with transient content, including music, were no longer valued, while others were prized by collectors. Destruction was spurred largely by the advent of printing, but also by the Reformation and the suppression of monastic libraries. The nineteenth-century peak was entirely different: it was enabled by the post-Napoleonic availability of manuscripts from suppressed corporations, and fuelled by a new appreciation of medieval art and architecture, medievalism, and the Gothic revival. Although, by contrast with the sixteenth century, the nineteenth valued its cuttings, both artistically and financially, it was equally destructive of intact books.

Polyphonic music occupies a distinct position in the processes of destruction, recovery and reconstruction. It was always the preserve of a small number of specialists, and its books were far fewer than those needed for the liturgy. As for destruction: whereas chant books were mainly discarded when they wore out, needed revision, or en masse at the Reformation, the much smaller outputs of polyphonic music were discarded when it went out of fashion, and musical fashions shifted fast. Music was much more expendable than standard verbal texts. The process of recovery has produced many things we would not have or know, were it not for surviving fragments. These include Italian motets before Ciconia; English Kyries (mostly not exported to the Continent with English masses), and much more. When it comes to reconstruction, we have no standard compilations to guide us, as was the case for the Carmelite missal; each anthology was unique. Reconstructions such as I have outlined tell their own stories; their testimony to a wide range of lost manuscripts immeasurably amplifies that of the very few surviving complete codices. 


\section{References}

Bent, Margaret (1966), 'Initial Letters in the Old Hall Manuscript', in Music and Letters, 47: 225-238.

Bent, Margaret (2008), Bologna Q.15: The Making and Remaking of a Musical Manuscript, Lucca: Libreria Musicale Italiana.

Bent, Margaret (1969), The Old Hall manuscript: a paleographical study, unpublished Ph.D. dissertation, Cambridge University.

Bent, Margaret (2004), 'The musical stanzas in Martin le Franc's Le champion des dames', in John Haines and Randall Rosenfeld (eds), Music and Medieval Manuscripts: Paleography and Performance, Ashgate: Aldershot, 91-127.

Bent, Margaret (1973), 'The Transmission of English Music 1300-1500: Some Aspects of Repertory and Presentation', in Hans Heinrich Eggebrecht and Max Lütolf (eds), Studien zur Tradition in der Musik. Kurt von Fischer zum 60. Geburtstag, Munich: Musikverlag Emil Katzbichler, 65-83.

Bent, Margaret (2017), Review of Nádas/Janke 2016, in Plainsong and Medieval Music, 26: 186-198.

Bent, Margaret, and Andrew Wathey (eds) (2021), Fragments of English Polyphonic Music c.1390-1475: A Facsimile Edition (Early English Church Music 62), London: Stainer and Bell, forthcoming.

Bent, Margaret, and Robert Klugseder (2012), Ein Liber cantus aus dem Veneto (um 1440): Fragmente in der Bayerischen Staatsbibliothek München und der Österreichischen Nationalbibliothek Wien / A Veneto Liber cantus (c.1440): Fragments in the Bayerische Staatsbibliothek, Munich, and the Österreichische Nationalbibliothek, Vienna, Wiesbaden: Reichert.

Brown, Elizabeth A. R. (1981), 'Death and the Human Body in the Later Middle Ages: The Legislation of Boniface VIII on the Division of the Corpse', in Viator, 12: 221-270.

Brownrigg, Linda L., and Margaret M. Smith (eds) (2000), Interpreting and Collecting Fragments of Medieval Books. Proceedings of The Seminar in the History of the Book to 1500, Los Altos Hills, CA and London: Anderson-Lovelace and The Red Gull Press.

Bukofzer, Manfred F. (1958), 'Changing Aspects of Medieval and Renaissance Music', in The Musical Quarterly, 44: 1-18.

Curtis, Gareth, and Andrew Wathey (1994), 'Fifteenth-Century English Liturgical Music: A List of the Surviving Repertory', in RMA Research Chronicle, 27: 1-69.

Cuthbert, Michael S. (2011), 'Groups and Projects among the Paduan polyphonic sources', in Francesco Facchin and Pietro Gnan (eds), I frammenti musicali padovani tra Santa Giustina e la diffusione della musica in Europa, Padua: Biblioteca Universitaria, 183-214.

Cuthbert, Michael Scott (2009), 'Tipping the Iceberg: Missing Italian Polyphony from the Age of Schism', in Musica Disciplina, 54: 39-75.

Cuthbert, Michael S. (2006), Trecento Fragments and Polyphony Beyond the Codex, Ph.D. dissertation, Harvard University.

De Hamel, Christopher (1996), 'Cutting up Manuscripts for Pleasure and Profit', in Terry Belanger (ed.), The Rare Book School 1995 Yearbook, Charlottesville, VA: Rare Books School.

De Hamel, Christopher (2000), 'Selling Manuscript Fragments in the 1960s', in Brownrigg/Smith (eds), 47-55. 
Egidi, Francesco (1925), Un frammento di codice musicale del secolo XIV (In cop.: Nozze Bonmartini-Tracagni. XIX novembre M(MXXV), Rome: La Speranza.

Eichner, Hans (ed.) (1967), Kritische Friedrich-Schlegel-Ausgabe, I/2: Charakteristiken und Kritiken I. 1796-1801, Paderborn: Schöningh.

Fallows, David (1982), Dufay, London: J.M. Dent [revised paperback 1987].

Freeman Sandler, Lucy (1986), Gothic manuscripts, 1285-1385, London: Harvey Miller with Oxford University Press.

Gwara, Scott (2013), Otto Ege's Manuscripts: a study of Ege's manuscript collections, portfolios, and retail trade : with a comprehensive handlist of manuscripts collected or sold, Cayce, SC: De Brailes Publishing.

Hindman, Sandra, and Nina Rowe (2001), Manuscript Illumination in the Modern Age: Recovery and Reconstruction, Evanston, IL: Mary and Leigh Block Museum of Art.

Ker, Neil R. (1954), Pastedowns in Oxford bindings with a survey of Oxford binding c.1515-1620, Oxford: Oxford Bibliographical Society.

Krug, Ilana (2013), 'The Fisher Antiphonary: A Gilded Window onto the Strozzi and Late Fifteenth-Century Florentine Politics', in Digital Philology, 2/1: 113-134.

Lähnemann, Henrike (2016) 'The Materiality of Medieval Manuscripts', in Oxford German Studies, 45/2: 121-141.

Memelsdorff, Pedro (ed.) (2013), The Codex Faenza 117. Instrumental Polyphony in Late Medieval Italy, Lucca: Libreria Musicale Italiana.

Nádas, John, and Andreas Janke (eds) (2016), The San Lorenzo Palimpsest: Florence, Archivio del Capitolo di San Lorenzo, Ms. 2211, 2 vols, Lucca: Libreria Musicale Italiana.

Nádas, John, and Agostino Ziino (eds) (1990), The Lucca codex. Codice Mancini. Lucca, Archivio di Stato, MS 184 [\&] Perugia, Biblioteca Comunale Augusta, MS 3065, Lucca: Libreria Musicale Italiana.

Nádas, John, and Agostino Ziino (2005), 'Two Newly Discovered Leaves from the Lucca Codex', in Studi musicali, 34: 3-23.

Pfeil, Brigitte (2010), 'Die Einbände des "S-Meisters” in der Bibliotheca Amploniana', in Einbandforschung: Informationsblatt des Arbeitskreises für die Erfassung, Erschließung und Erhaltung historischer Bucheinbände (AEB), 27: 6-15.

Pfeil, Brigitte (2012), 'Das “Matrjoschka-Prinzip”. Büchersammlungen von Gelehrten und Universitätslehrern des 14. Jahrhunderts im Bestand der Erfurter "Bibliotheca Amploniana", in Mitteldeutsches Jahrbuch für Kultur und Geschichte, 19: 31-47.

Rickert, Margaret (1952), The reconstructed Carmelite Missal: an English manuscript of the late XIV century in the British Museum (Additional 29704-5, 44892), London: Faber and Faber.

Stone, Anne (ed.) (2005), The Manuscript Modena, Biblioteca Estense, MS a.M.5.24, 2 vols, Lucca: Libreria Musicale Italiana.

Strohm, Reinhard (1984), 'Native and Foreign Polyphony in Late Medieval Austria', in Musica Disciplina, 38: 205-230.

Strohm, Reinhard (2008), The Lucca choirbook: Lucca, Archivio di Stato, Ms 238; Lucca, Archivio Arcivescovile, Ms 97; Pisa, Archivio Arcivescovile, Biblioteca Maffi, cartella 11/III, Chicago, London: University of Chicago Press

Summers, William J., and Peter M. Lefferts (eds) (2016), English Thirteenth-Century Polyphony: A Facsimile Edition (Early English Church Music 57), London: Stainer and Bell.

Tyson, Alan (1981), 'The Mozart Fragments in the Mozarteum, Salzburg: A Preliminary Study of Their Chronology and Their Significance', in Journal of the American Musicological Society, 34: 471-510. 
Tronzo, William (ed.) (2009), The Fragment: An Incomplete History, Los Angeles: Getty Research Institute.

Van den Borren, Charles (1924), Le manuscrit musical M. 222 C. 22 de la Bibliothèque de Strasbourg (XVe siècle) brûlé en 1870, et reconstitué d'après une copie partielle d'Edmond de Coussemaker, Antwerp: Imprimerie E. Secelle.

Von Fischer, Kurt (1990) 'Remarks on Some Trecento and Early Quattrocento Fragments', in Angelo Pompilio (ed.), Atti del XIV congresso della società internazionale di musicologia, Bologna, 27 agosto - 1 settembre 1987, Turin: E.D.T., I, 162-165.

Welker, Lorenz (1993), Musik im Oberrhein im späten Mittelalter: Die Handschrift Strasbourg, olim Bibliothèque de la Ville, C.22, Habilitationsschrift, University of Basel.

Williamson, Magnus (ed.) (2010), The Eton Choirbook (Eton College, MS 178), Oxford: DIAMM Publications.

Ziino, Agostino (ed.) (1994), Il Codice T.III.2: Studio introduttivo ed edizione in facsimile, Lucca: Libreria Musicale Italiana. 
Models 



\title{
Susan Rankin
}

\section{Processional Chants in the Early Medieval Period: The Lesson of Fragments}

\begin{abstract}
Writing in his catalogue Les Manuscrits du Processionnal, Michel Huglo described the processional as 'pas un livre "officiel”, mais un livre créé par les chantres pour leur usage personnel'. In proposing a category of 'personal' as opposed to 'official' for the description of a book, Huglo alludes to a larger body of material support for musical practice: the description 'personal' can be applied to a larger field of books for the use of cantors (tropers, sequentiaries, collections of polyphony). This paper focusses on the process of codification of processional chants in particular, using as starting points two fragments from eastern Switzerland. Sankt Gallen, Stiftsbibliothek, 18, pp. 21-40 consists of a full gathering containing processional chants, while a more unusual example, Müstair, Benediktinerinnenkloster St. Johann, XX/48 no. 14, consists of three folios containing processional chants mixed with incipits for chants of the Mass and the office.
\end{abstract}

Dominica secunda ante natale domini . In euuangelio ad uesperem A[ntiphona] Tu es qui uenturus . nullo modo hic alia canatur. ${ }^{1}$ While liturgical books are always in the business of saying 'do this here and that there', to express such an instruction negatively as 'don't under any circumstances sing another chant at this point' is, at the very least, unusual: I have never seen it before. The rubric indicates the antiphon to be sung with the Magnificat on the third Sunday of Advent (counting from the beginning rather than backwards from Christmas). Since the antiphon draws on Mt 11.2-3, corresponding directly to the usual gospel reading assigned to this Sunday ${ }^{2}$ - as was often the case - it is quite unclear why this explicitness was necessary.

1 I have not reflected the original capitalisation and use of colours in this transcription.

2 Mt 11.2-3; see Klauser 1935, 43, 89, 127, 168, 182.

Note: I am immensely grateful to Jesse Billett and Henry Parkes for their help in the preparation of this study.

Ә Open Access. (C) 2020 Susan Rankin, published by De Gruyter. (cc)BY-NC-ND This work is licensed under the Creative Commons Attribution-NonCommercial-NoDerivatives 4.0 International License.

https://doi.org/10.1515/9783110717884-003 
Even more odd is the intensity of instructions included in what at first sight seems to be a book of chants. There are instructions for how to handle the Lauds antiphons if Christmas Day falls on a Thursday: Si natale domini feria V. euenerit ad unum matutinum colligende sunt . quod sabbato . congruentissimae fiet hoc modo. ${ }^{3}$ Then there are instructions about what to sing if Christmas Eve falls on a Sunday: Illud diligenter obserua . Ut si uigilia natiuitatis domini die dominica euenerit per quatuor ebdomadas plenas . secundum constitutum . de aduentu canas . et in ipsa quinta [dominica] responsoria de priori ebdomadas colligas hoc modo. ${ }^{4}$ This rubric refers to a famous conundrum, that is, how to handle the liturgy in this circumstance: either the liturgy for Advent IV can be prematurely curtailed, or a fifth Advent Sunday (for which no canonical liturgy exists) can be fabricated. In his chapter on the Advent of the Lord, Amalarius points out a discrepancy between, on the one hand, books of readings which have an 'ebdomada quinta ante natale domini' and on the other, sacramentaries and antiphoners, which have liturgy for only four Sundays. ${ }^{5}$ Later, Bern of Reichenau dedicated a long letter addressed to Aribo, Archbishop of Mainz, to the discussion 'qualiter adventus domini celebretur quando nativitas domini feria secunda evenerit'. ${ }^{6} \mathrm{Al}-$ though Bern is not in favour of having a fifth Advent Sunday, that is in fact the solution offered in this rubric, borrowing chants and lections from previous weeks (as already carried on for the 'vacat' Mass of Advent IV, following an ember day).

All of this is copied on the first of two leaves of a bifolium (treated on the website backwards, as ff. 2 and 1): a third folio was later attached to this bifolium (now listed as f. 3) - allowing the whole to act as a wrapper for another book. The group survives as Müstair, Benediktinerinnenkloster St. Johann, XX/48 Nr. 14 (Fig. 1). ${ }^{7}$

3 'If Christmas Day should fall on a Thursday, [? the antiphons at Lauds on Wednesday] are to be combined [? with those that are] most appropriately [assigned] to Saturday, which shall be done in this way.'

4 'Observe this carefully: if Christmas Eve falls on a Sunday, you sing [the chants] from Advent throughout four complete weeks, according to what has been established. And on the fifth [Sunday] you select responsories from the preceding week, in this manner.'

5 Knibbs 2014, Book III.40 (II, 240-245).

6 Patrologia Latina, vol. 142, 1079-1086: see also Parkes 2019, 5-21.

7 Online at <https://www.e-codices.ch/en/list/one/kjm/XX-0048-0014> (accessed 21 Oct. 2019). The numbering of folios on the website reflects the current physical state of the material, with ' 1 ' for the first in the series of three laid out flat, ' 2 ' for the middle folio and ' 3 ' for the last (attached by glue, and some stitching): this has the consequence of listing as a recto a page which was originally a verso, and vice versa. The original order would have been (current) $2 r / 2 v$, then (current) $1 \mathrm{v} / 1 \mathrm{r}$; representing a different part of the book, the current $3 \mathrm{r} / 3 \mathrm{v}$ could have come before or after the bifolium. The textual content of this fragment is transcribed in Appendix 1. 

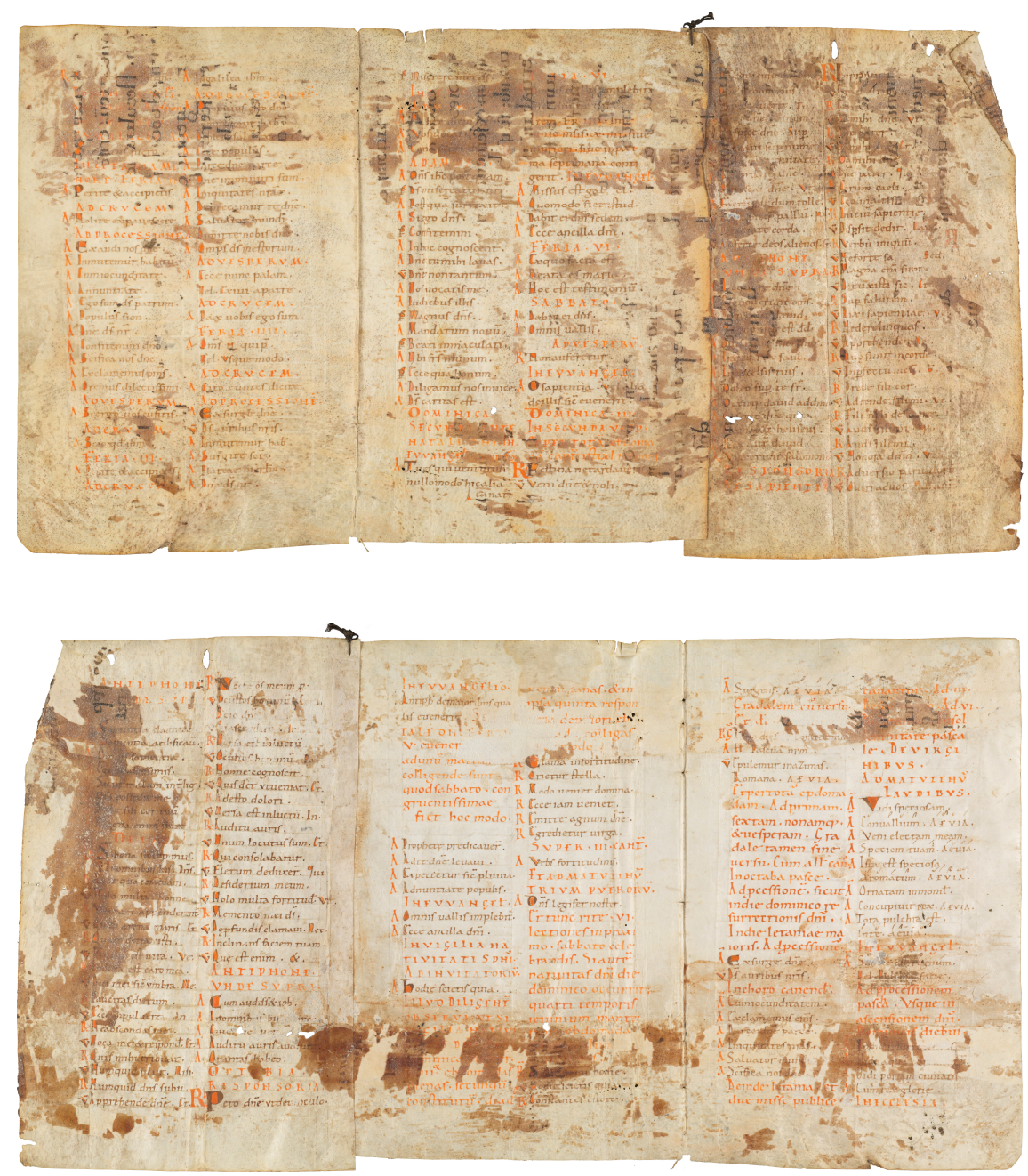

Fig. 1: Müstair, Benediktinerinnenkloster St. Johann, XX/48 Nr. 14, recto (above) and verso (below); () Müstair, Benediktinerinnenkloster St. Johann.

The original book from which these three folios came was not small, measuring at least $225 \mathrm{~mm}$ in height and $145 \mathrm{~mm}$ across the page. Its precise origin is 
unknown: the script is very like that of Sankt Gallen in the late tenth and early eleventh centuries. ${ }^{8}$

The second bifolium leaf (now f. 1v-r) opens with directions for the Easter liturgy: it is thus clear that there must have been at least one more bifolium inside the surviving leaves, and probably more. Here there is an explanation about the gradual responsory to be sung in the office hours of Easter week (in place of an office responsory):

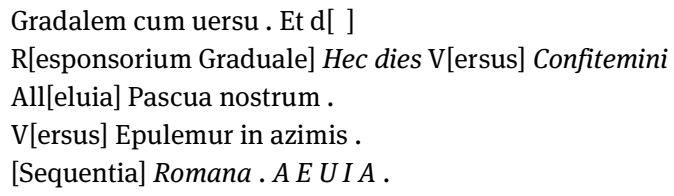

Et per totam epdomadam . Ad primam . sextam . nonamque . et uesperam . Gradale tamen sine uersu. Cum alleluia cantatur .

Here it is made clear that in the offices of Prime, Sext, None and Vespers, the Easter Alleluia - presumably with its two verses Pascha nostrum and Epulemur in azimis - are to follow the gradual, rendering this moment in the offices especially jubilant. Of considerable interest here is the entry, after the two Alleluia verses, of the word Romana. This refers to a well known sequentia melody. ${ }^{10}$ Since it is clear that the fragment was copied in the southern German/Alemania region, it would seem reasonable to compare it with practice at Sankt Gallen, from where Notker's influential Liber ymnorum has been disseminated. At that abbey, however, Romana was the melody used for sequences for the feasts of St John Evangelist (27 December, Iohannes Iesu christo) and Lawrence (10 August, Laurenti David magni). ${ }^{11}$ In Western Francia, in contrast, the melody was used for two sequences both sung on the Easter feast: Clara gaudia and Dic nobis. ${ }^{12}$ Thus, it is quite clear that while this fragment shares much with Sankt Gallen liturgy, not to mention script, it cannot itself be related to the liturgy practised at that abbey: indeed, the mention of the sequentia melody may imply a relation to a more

8 Here I differ from the judgement of Albert Bruckner, who dated the fragment as late ninth/ early tenth-century: see his Bruckner 1935, I, 80.

9 'And throughout the whole week, at Prime, Sext and None, and at Vespers, the gradual is sung (but without its verse), with the Alleluia.'

10 See Hughes 1934, 70.

11 See Bower 2016, II, 121-122; I, 140, 235.

12 On this complex of material see Crocker 1977, 146-159; also Bower 2003, 351-398, esp. 361-362. 
Western source - although, of course, it may not have been intended here to associate the melody with a texted sequence.

Other parts of this group of three folios list processional antiphons for the Mandatum ceremony on Maundy Thursday (f. 2r), and processional antiphons for the period after Easter and for the Major Litany on 25 April (f. 1v), and for the Minor Litany on the three Rogation days before the feast of Ascension (f. $1 \mathrm{v}-\mathrm{r}$ ). Here, for each of Monday, Tuesday and Wednesday, the antiphons are set out in a series of groups: ad crucem, ad processionem, ad uesperum, and again ad crucem. These rubrics indicate a clear itinerary, to and from a station marked by a cross.

On the third folio, now attached to the bifolium, there is a list of antiphon and responsory incipits for the summer Sundays de libro Regem, de Sapientia, de Iob, and de Tobia: these lists are more directly concordant with Eastern Frankish manuscript sources than Western, above all the Hartker Antiphoner (Sankt Gallen, Stiftsbibliothek, 390-391) and Rheinau Breviary (Zurich, Zentralbibliothek, Rheinau 28) edited in Corpus antiphonalium officii. ${ }^{13}$ Yet, even here, the identity of the fragment's repertory can again be seen as not directly concordant with Sankt Gallen: where in the list of responsories and then antiphons de libro regem the chants sit in different orders in the Sankt Gallen and Rheinau books, the Müstair fragment aligns itself with the record preserved in the Rheinau book (see Table 1). Apparently this is no mere chance: the same is true of the antiphons de Sapientia and de Iob which are much closer to the Rheinau list, while the lists of responsories from these two biblical books do not match the order of either Sankt Gallen or Rheinau directly.

Table 1: Summary of the festal contents of the fragment Müstair, Benediktinerinnenkloster St. Johann, XX/48 Nr. 14.

\begin{tabular}{lll}
\hline single folio & {$[3 \mathrm{r}-\mathrm{v}]$} & Responsories de libro regum, de Sapientia, de lob, de Tobia \\
\cline { 2 - 3 } bifolio & {$[2 \mathrm{r}-\mathrm{v}]$} & $\begin{array}{l}\text { Maundy Thursday: antiphons for the Mandatum ceremony } \\
\end{array}$ \\
& $2^{\text {nd }}$ Sunday of Advent \\
& $3^{\text {rd }}$ Sunday of Advent \\
& Christmas Eve \\
\hline$[1 \mathrm{v}-\mathrm{r}]$ & $\begin{array}{l}{[\text { Easter week }]} \\
\text { Easter octave }\end{array}$ \\
\hline
\end{tabular}

13 Only the Hartker volumes are more or less contemporary with this fragment: the Rheinau book dates from the thirteenth century. See CAO II, VI-XI. 
Table 1 (continued): Summary of the festal contents of the Müstair fragment.

\author{
[1v-r] Major Litany (25 April) \\ Lauds for a Virgin's feast \\ Easter to Ascension processions \\ Minor Litany for Rogations \\ (Monday, Tuesday, Wednesday before Ascension)
}

Further assessment of the Müstair fragment can be achieved through the comparison of this last leaf with other extant liturgical books. The presentation of antiphon and responsory incipits in lists (rather than full texts) is typical of tonaries, but their listing in festal order is less typical. Nevertheless there are two other early medieval books which preserve this same format, including one from the monastery of Prüm made in the mid-ninth century (Trier, Stadtbibliothek, 1245/597 8 , ff. 107r-129r), and one from somewhere close to Prüm made in the early tenth century (Leipzig, Universitätsbibliothek, Rep I 93, ff. 52r-147v). ${ }^{14}$ This latter manuscript also includes the earliest text of Regino's Epistola de armonica institutione, and its antiphoner list is markedly interested in the same issues as those explored by Regino, above all, use of correct modal categories, as can be seen in the many notes added before and after the incipits. ${ }^{15}$ Lists of chants for defined periods within the liturgical year are otherwise found in two Anglo-Saxon manuscripts. Among the additions made to a Durham manuscript in the later tenth century are lists of office chant incipits for the summer historiae ${ }^{16}$ Incipits for office chants, including the period from September to November, were entered into the margins of a copy of Bede's Historia ecclesiastica in the mid eleventh century. ${ }^{17}$ These Anglo-Saxon lists may reflect earlier continental exemplars first made 'to supplement existing liturgical books that lacked texts' for specific parts of the liturgical year. ${ }^{18}$

That hint, from books made a long way from the place of origin of the Müstair fragment, may nevertheless help towards understanding its unusual content, at the very least providing some kind of background against which the contents of the single folio can be assessed. It is the bifolium, with its mixture of incipits for

14 On this manuscript see Haubrichs 1979, 91-92; BK, III, n. 6195.

15 On this manuscript see Bernhard 1979, 3-6; and Rankin 2020.

16 Durham, Cathedral Library, A.IV.19, f. 76 [69]; for an edition see Lindelöf 1927; on the palaeography of these additions see Brown 1969; and for recent commentary, Billett 2014, 220-251.

17 Cambridge, Corpus Christi College, 41, pp. 475-477; on these see most recently Billett 2014, 220-251.

18 See Billett 2014, 225-227. The idea of a supplement was first proposed by Christopher Hohler 1980. 
office chants and for processional chants, many provided with extensive directions about their use, which is more peculiar. The directions are of the kind which might be found in later books such as the ordinal: but to find all of this together in a book of chants is entirely unique, above all for this early period. And then we have to take notice of the mixture of liturgical occasions - offices and procession - and of the festal order, which is a little confused, with, for example, antiphons for the Mandatum ceremony on Maundy Thursday copied immediately before chants for the season of Advent (see Table 1, f. 2r).

As exemplified by the Müstair fragment, the transmission of processional chants before the advent of the processional book is a subject which lends itself well to the theme of musical fragments. The history of 'the processional book' is now well documented in Michel Huglo's two RISM volumes 'Les Manuscrits du processional', as well as elsewhere. ${ }^{19}$ Yet his catalogue deals only with two of the three periods into which he set out the history of transmission of processional chants. ${ }^{20}$ In the latest period, stretching between the thirteenth and sixteenth centuries, ${ }^{21}$ the processional had come into its own: there are hundreds of extant examples, including (sometimes) several made at the same period in the same institutions. The principal content of these books was office responsories which were adopted for individual Sundays of the year. ${ }^{22}$ Two new factors were at work here: where previously, the choice of office responsory for use in a Sunday procession would have been the responsibility of the cantor, and left unrecorded, now an increasing exactitude led to the designation of specific chants. In addition, increasing economic prosperity allowed for ownership of more books: thus the specified responsories - which were often already notated in office antiphoners - could be extracted from their normal office use and re-copied into special books: 'processionals'. In the two periods before this, nothing was quite so sharply determined. In an early period which extends well into the eleventh

19 Huglo 1999-2004; see also Gy 1960 and Palazzo 1993, 236-238. The interest of these accounts is, of course, in the processional as a book, and thus some way away from the subject of this study.

20 Huglo provides nine tables for the 'nine types of processional' (Huglo 1999-2004, I, 43*$\left.55^{\star}\right)$ : the first is entitled as 'Les antécédents du processional', which I take as intending a first period; the second is entitled 'Antiennes des rogations ou litanies mineures', and the third 'processional à antiennes' (feasts of the time and saints), which I take as intending a second period; the fourth table, for the 'processional responsorial', indicates a third period. The other tables (V to IX) deal with books proper to specific uses (Cistercian, Sarum, Dominican, Roman-Franciscan, Augustinian and Prémonstratensian).

21 I use here the date given by Huglo in his Table IV (Huglo 1999-2004, I, 48*) rather than on $38^{\star}$.

22 Huglo 1999-2004, II, 36*-38*, 48*. 
century, a repertory of processional antiphons for the Major Litany on 25 April, for the Rogation days before Ascension, for feasts such as Purification and Ash Wednesday, and other votive rituals, was often collected together, thus recognized as having a special function. ${ }^{23}$ The earliest mention of such a collection known to me is in a list made between 835 and 842 of books made by or for the Reichenau librarian Reginbert, where reference is made to litany antiphons and 'antiphons for any kind of tribulation':

In XXIII libello est antiphonarius gradualis, antiphonae de litaniis vel de quacunque tribulatione et de institutione stationum et de obseruationae diuini officii erga psalmos et de ordine librorum , quomodo per anni circulum poni possunt $[\ldots]^{24}$

Here, as in all extant ninth-century examples, the processional repertory was codified along with other liturgical material: independent books made for these chants were rare. Later, from the late tenth through to the twelfth century, these antiphons were sometimes collected into books, and for that Huglo provides two tenth-century examples. ${ }^{25}$ The fundamental contrast between Huglo's first and third periods is that what is collected together in the first period for processional use is essentially quite different from what is being codified in individual books in the third period. That issue certainly deserves more study, even if it is not my target in this paper about fragments. Nonetheless, I do want to point to the potential confusion introduced by linking the book-type 'processional' directly with the transmission of chants for processions, and then seeking to trace this backwards to a period when no such book existed. The study of processional chants sung in the early Middle Ages needs to be separated from the study of the processional book.

Such misunderstandings are not untypical in the study of medieval liturgical books, many of which survive only as fragments, allowing a great deal of misunderstanding. In many rather surprising ways, the history of the nature and content of liturgical books has largely been written on the basis of complete or largely complete manuscripts, sometimes leading to views easily contradicted once fragments are brought to notice. The most widely held views about the history of the missal, for example, date this book type in the eleventh century: what existed before this has been categorised as an embryonic form, constructed from libelli missarum containing all that was necessary for the celebration of one or several feasts. Yet fragments of up to twenty separate missals copied from the late eighth

23 Huglo 1999-2004, II, 35^. On the different types of processional chants see Martimort 1955 and Fernandez 2014.

24 Lehmann 1918, 260.

25 Huglo 1999-2004, I, 36*-37^: Vatican, BAV, Pal. lat. 489 and Vienna, ÖNB, 1888. 
up to the end of the ninth century indicate the degree to which this assessment must be wrong: the earliest such example, a palimpsested folio now in the Vatican Library, written in uncials, can certainly be dated in the late eighth century (Biblioteca Apostolica Vaticana, Vat. lat. 10644, f. 2). Although palimpsested, this can be read quite easily, and includes prayers, readings and chant texts. In that these fragments appear not to differ in layout or content from later missals, the description 'embryonic' seems quite mistaken. ${ }^{26}$ One conclusive argument is the existence of a complete - absolutely non-fragmentary - missal from the monastery of Bobbio, copied c.900 (Milan, Biblioteca Ambrosiana, D 84 inf.): this has been dated by Fabrizio Crivello on the basis of the painted initials. ${ }^{27}$ If the many fragments had not survived, however, this one complete book might have been treated as an individual and odd case. As it is, this Bobbio codex conclusively seals the argument that the missal book type was in wide use in Italy long before the eleventh century. This is another case in which theory has led scholars astray: a possible link between missals and certain theological views of how the Mass should be conducted seems to have rendered scholars blind to the extant fragments.

Another fragment containing processional chants and originating in the same area as the Müstair fragment presents an eminently suitable point from which to begin an examination of the Müstair repertory of processional antiphons. A twenty-page fragment now bound into Sankt Gallen, Stiftsbibliothek, 18 (pp. 21-40) was copied at the abbey of Sankt Gallen in the first half of the tenth century. My own dating of this fragment - in the second quarter of the tenth century - now appears conservative beside the more recently published catalogue of Bernard Bischoff, where it appears as last quarter of the ninth century: perhaps it is possible to compromise, and suggest first half of the tenth century - thus allowing a date closer to 900 for its manufacture. ${ }^{28}$

The fragment consists of one gathering of ten folios, its content entirely processional chants (for named feasts and for votive occasions). ${ }^{29}$ Michel Huglo was well aware of this fragment, but declined to include it in his catalogue, since he believed this to be a gathering made for (and subsequently separated from) a gradual. Although these ten folios are no longer attached to a gradual - nor is there any extant Sankt-Gallen gradual to which they could have been attached - it is extremely

26 See Rankin 2016.

27 Crivello 2001; see also $B K$, II, no. 2616.

28 See Rankin 1995, 385-408. See also BK, III, no. 5513; the entry may not represent a settled view on Bischoff's part, since it refers to general notes in his papers, and was published long after his death in 1991.

29 The repertory of processional chants in SG 18 is set out in Appendix 2 in alphabetical order. 
likely that such a book once existed. For it is the established pattern in a series of unnotated and then notated graduals made from the late eighth through to the eleventh century to include a collection of processional chants at the end of the year's cycle of proper chants for the Mass, often also following a repertory of Alleluias for the year. Thus, in a book made for Charles the Bald in the 870s, the Alleluias 'de circulo anno' - listed by incipit - follow the gradual propers, and then there are six and a half pages of processional antiphons (Paris, Bibliothèque nationale de France, latin 17436, ff. 26r-29r). ${ }^{30}$ Other early medieval examples which follow this same procedure include Albi, Bibliothèque municipale, 44 (ff. 48r-52r), where the processional antiphons sit at the end of the Mass antiphoner (and thus before the office antiphoner), ${ }^{31}$ Chartres, Bibliothèque municipale, 47 (ff. 62r-68v), ${ }^{32}$ Paris, Bibliothèque nationale de France, latin 12050 (f. 16v), ${ }^{33}$ and Paris, Bibliothèque Sainte-Geneviève, 111 (ff. $22 \mathrm{r}-23 \mathrm{r}$ ). ${ }^{34}$

As in most of these early collections, the Sankt Gallen fragment begins with antiphons for the Major Litany, a Roman ceremonial procession held on $25^{\text {th }}$ April: although there is no rubric here, the series of antiphons written out is so closely concordant with others that there is no doubt about its liturgical use. In this series the Sankt Gallen choice and ordering of antiphons is identical to those in several other tenth-century manuscripts, from both Eastern and Western regions, including Ch 47 (from the west, towards Brittany), Ei 121 (from the Abbey of Einsiedeln), Ba 6 (from St Emmeram, Regensburg), Wi 1888 (from St Alban's, Mainz), and the antiphoner of Mont-Renaud (from somewhere in northeastern France): these various series are set out in Table $2 .^{35}$

30 This is manuscript ' $C$ ' in $A M S$; on this manuscript see Koehler/Mütherich 1982, 127-130; also Colette 2003 and Lafitte 2007, 87. The manuscript is online on the Gallica website.

31 See Emerson/Colamore 2002, nos 199-214; the manuscript is online on the website $<$ http://archivesnumeriques.mediatheques.grand-albigeois.fr/>.

32 Destroyed in 1944; see PM 11; images from extant photographs of the manuscript are online at $<$ https://bvmm.irht.cnrs.fr/consult/consult.php?reproductionId=17706>.

33 MS ' $\mathrm{K}$ ' in $A M S$; online on the gallica website.

$34 \mathrm{MS}$ ' $\mathrm{S}$ ' in $A M S$.

35 For details of the manuscript sources included in this and subsequent tables see 'Manuscripts and sigla' below. 


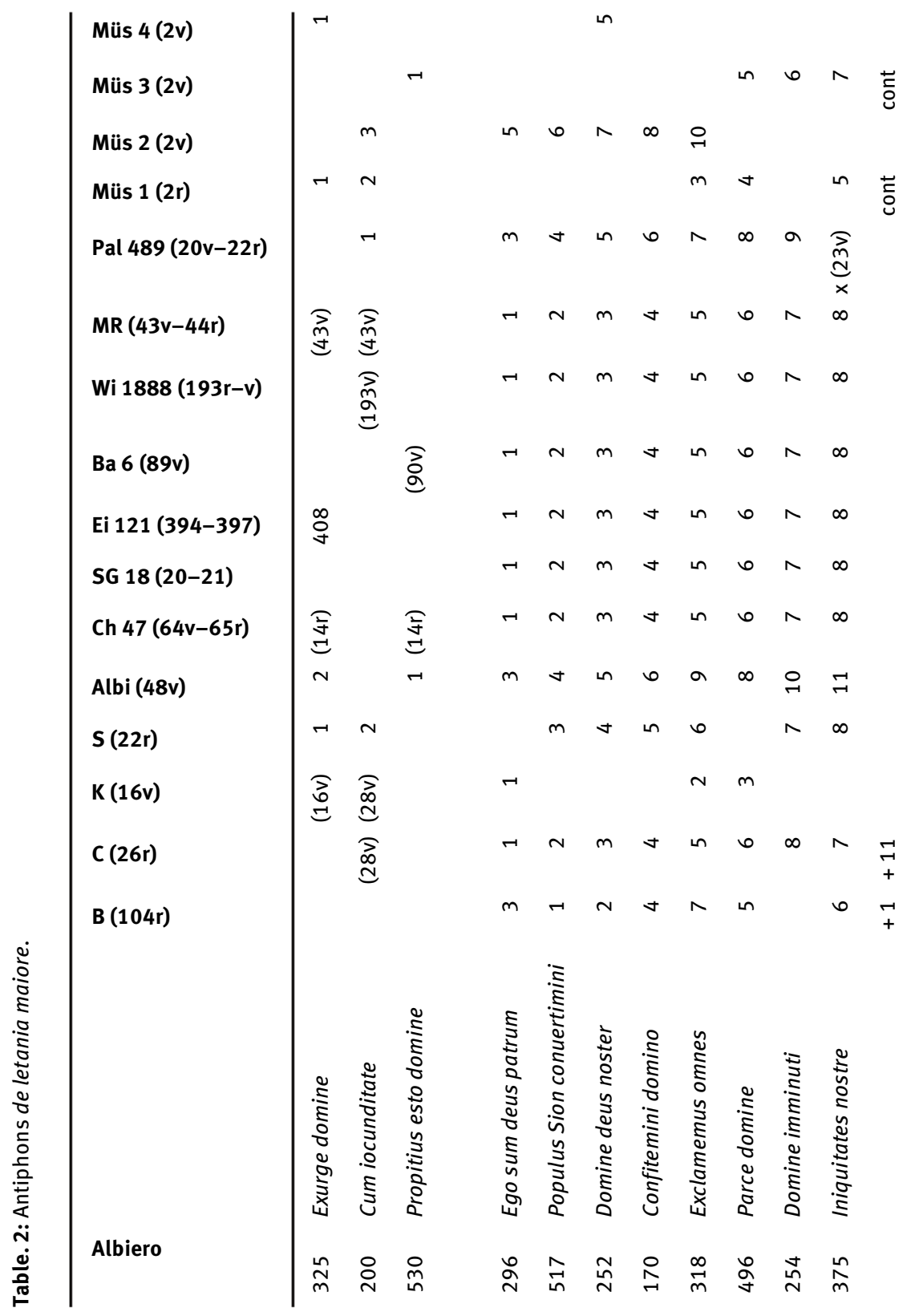


All of these tenth-century records also show considerable similarities with the various series copied in ninth-century manuscripts, and it is clear that an older layer of processional antiphons for this ceremony was widely shared. Seen in this comparative context, it is evident that the Müstair fragment comes from a different kind of book: instead of listing eight or more antiphons for the Major Litany together, it has what appears as a selection from the older lists under the heading 'In die letaniae maioris ad processionem' (Müs 1). This group includes only five of the eleven antiphons more commonly associated with this ceremony, and only three of the eight most often recorded. It is not the case that the other processional antiphons missing from the Major Litany list were unknown to the book's maker, however: for, one way or another, they are all used in other processions under the heading 'in letania minore'. For each of the three Rogation days preceding the feast of Ascension further lists of processional antiphons are made (Müs 2, 3, and 4). As for the Major Litany, antiphons from what appears to be an older series have been selected and mixed with others to create groups of eleven antiphons for each procession. ${ }^{36}$ The Müstair fragment thus reveals its maker (or the maker of its exemplar) dividing up the available litany antiphons to make different series for each Rogation day, as can be seen in later Aquitanian and Italian graduals. ${ }^{37}$ Besides representing the earliest Eastern Frankish example of such a practice, the Müstair fragment appears to show a moment of changeover from the more general lists typical of the earlier medieval books to lists in which there is considerably more specificity about exactly what should be sung when.

In SG 18 this set of Major Litany antiphons is followed by chants for a series of votive occasions: a first series - which continues without break from those used elsewhere for the Major Litany - is again directly concordant with lists in other tenth-century manuscripts (see Table 3).

36 The Wednesday series has only five antiphons before the end of f. $2 v$, at which point the fragment breaks off.

37 See Albiero 2016, 20. 
Table 3: Further Litany Antiphons.

\begin{tabular}{|c|c|c|c|c|c|c|c|c|c|c|c|c|}
\hline$\frac{\circ}{\frac{0}{0}}$ & & 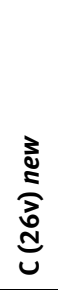 & 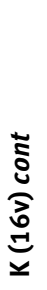 & 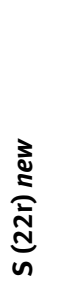 & 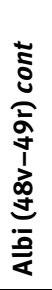 & 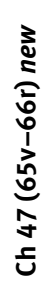 & 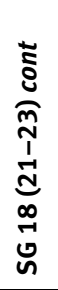 & 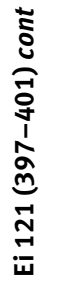 & 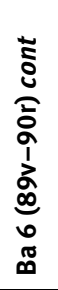 & 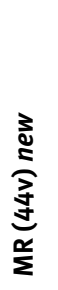 & 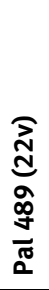 & $\stackrel{m}{n}$ \\
\hline 257 & Domine non est alius & 1 & & 1 & 7 & 1 & 9 & 9 & 9 & 1 & 1 & \\
\hline 308 & $\begin{array}{l}\text { Exaudi domine deprecationem } \\
\text { seruorum }\end{array}$ & 2 & & 2 & 12 & 2 & 10 & 10 & 10 & 2 & & \\
\hline 424 & Miserere domine plebi tue & 3 & 4 & 3 & 13 & 3 & 11 & 11 & 11 & 3 & & \\
\hline 243 & $\begin{array}{l}\text { Dimitte domine peccata } \\
\text { populi }\end{array}$ & 4 & & 4 & 17 & 4 & 12 & 12 & 12 & 4 & & \\
\hline 307 & $\begin{array}{l}\text { Exaudi deus deprecationem } \\
\text { nostram }\end{array}$ & 5 & & 5 & 18 & 5 & 13 & 13 & 13 & & & \\
\hline 647 & Usquequo domine & 6 & & 6 & & & & & & & & \\
\hline 452 & Numquid ualet & 7 & & 7 & & & & & & & & \\
\hline 221 & Deprecamurte & 8 & & 8 & 14 & 6 & 14 & 14 & 14 & 5 & & 8 \\
\hline 366 & Inclina domine aurem tuam & 9 & & 9 & 19 & 7 & 15 & 15 & 15 & & & \\
\hline 439 & Multa sunt domine & 10 & 5 & 10 & 15 & 8 & 16 & 16 & 16 & 6 & & \\
\hline 499 & $\begin{array}{l}\text { Peccauimus domine et tu } \\
\text { iratus }\end{array}$ & 11 & & 11 & 20 & 9 & 17 & 17 & 17 & 7 & & \\
\hline 382 & Inuocantes dominum & 12 & & 12 & 16 & 10 & 18 & 18 & 18 & 8 & & \\
\hline 242 & $\begin{array}{l}\text { Dimitte domine peccata } \\
\text { nostra tibi }\end{array}$ & 13 & & 13 & & 11 & 19 & & 19 & & & \\
\hline
\end{tabular}

In the two ninth-century books $\mathrm{C}$ and $\mathrm{S}$, this series has a new rubric (in C 'Antiphonas de quacumque tribulatione', and in S 'Incipiunt antiphonas de misericordia in letania'). This series is also set out with a new rubric - now illegible - in both Ch 47 and the Mont Renaud antiphoner, whereas none of the three Eastern lists (SG 18, Ei 121 and Ba 6) has any break. Despite these differences of rubrication, the series of litany antiphons presented here is very similar across all of the manuscript sources shown in the table, excepting the Müstair fragment, which has just one of these antiphons included in the series for the second Rogation day. Across the other manuscripts, there is even less variation of order and content than in the Major Litany series. 
Table 4: Summary of the Processional Chants in SG 18 pp. 21-40.

\begin{tabular}{lrl}
\hline Page & Number & Occasion \\
\hline 21 & 19 & [Major Litany (25 April] \\
24 & 5 & Ad pluuiam postulandum \\
25 & 3 & Ad serenitatem \\
25 & 2 & De mortalitate \\
25 & 2 & De poenitentia \\
26 & 3 & In natalitiis sanctorum \\
26 & 7 & Ad reliquias ducendas \\
27 & 3 & De quacumque tribulatione \\
28 & 2 & De uno confessore \\
28 & 1 & Ad communicandum in natale domini \\
29 & 1 & Item ad communicandum \\
29 & 1 & Antiphona quando uolueris \\
30 & 2 & De sancta Maria \\
30 & 1 & De sancto Petro \\
31 & 2 & De sanctis apostolic \\
31 & 1 & De sancto Gallo \\
31 & 4 & In dominica sancta paschali ad processionem \\
32 & 1 & De dominica resurrectione \\
33 & & Versos Thiotolfi presbiteri in palmis [Gloria laus] \\
33 & 14 & Ad Mandatum in cena domini \\
35 & 3 & In palmis \\
37 & & Ad salutandum crucem \\
38 & & \\
\hline & Versos Furtunati presbiteri [Crux fidelis \& Pange lingua] \\
& & \\
35 & &
\end{tabular}

After this there are antiphons for processions to beg for rain, to ask for less rain or at least for the ceasing of storms, then antiphons 'de mortalitate', which seem to deal with the community rather than an individual ('libera domine populum tuum de manu mortis'), antiphons for penitence, and for saints (plural) 'de nataliciis sanctorum', then antiphons to accompany a procession with relics, and antiphons 'for whatever tribulation' (see Table 4). All of this is extremely standard: the same groups appear in a significant number of early medieval books, including both the unnotated group of graduals made between 800 and 900 , and notated graduals made from the 880 s on. 
Juxtaposition of the SG 18 chants with those in earlier and contemporary manuscript sources leads to some unexpected but useful conclusions. In the series 'in nataliciis sanctorum' the short Sankt Gallen series lines up with the beginning of a longer series in the Western Frankish manuscript Ch 47 (see Table 5); and both of these differ from series in two ninth-century books, C and S. In face of admittedly thin evidence, we can continue to the antiphon series 'ad reliquias deducendas' (see Table 6).

Table 5: Antiphons de nataliciis sanctorum.

\begin{tabular}{|c|c|c|c|c|c|c|c|c|}
\hline$\frac{\frac{0}{\frac{0}{0}}}{\frac{0}{\frac{1}{\alpha}}}$ & & 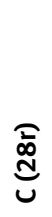 & $\underset{\sim}{\stackrel{\tilde{N}}{\tilde{n}}}$ & 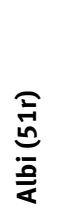 & \begin{tabular}{l} 
I \\
0 \\
1 \\
0 \\
0 \\
0 \\
\multirow{1}{*}{} \\
ป
\end{tabular} & 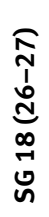 & 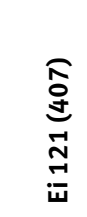 & $\stackrel{\mathscr{\Sigma}}{\Sigma}$ \\
\hline 335 & Gaudete iusti & 1 & 1 & & & & & \\
\hline 213 & Custodit dominus & 2 & 2 & 1 & 1 & 1 & (409) & \\
\hline 418 & Memento congregationis & 3 & 3 & & & & & \\
\hline 115 & Annunciate inter gentes & 4 & (4) & & 3 & 2 & 1 & $(45 v)$ \\
\hline 361 & In sanctis gloriosus est deus & & (5) & & 4 & 3 & 2 & \\
\hline 621 & Surgite sancti & & & & 2 & & & \\
\hline 233 & Deus qui es benedictus & & & 2 & & & & \\
\hline 321 & Exite sancti orate & & & 3 & & & & \\
\hline 580 & Sanctos portamus & & & & 5 & & & \\
\hline
\end{tabular}

Table 6: Antiphons ad reliquias deducendas.

\begin{tabular}{|c|c|c|c|c|c|c|c|c|c|c|}
\hline$\frac{\frac{0}{\frac{0}{0}}}{\frac{0}{2}}$ & & 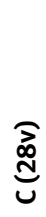 & 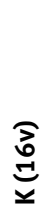 & 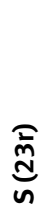 & 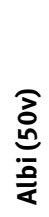 & 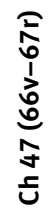 & 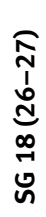 & 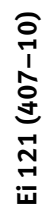 & 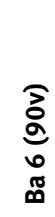 & 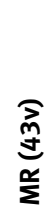 \\
\hline & Ad reliquias deducendas & & & & & & & & & \\
\hline 290 & Ecce populus custodiens & 1 & 1 & 1 & 1 & 1 & 1 & 1 & & 1 \\
\hline 200 & Cum iocunditate & 2 & 2 & & 2 & 2 & 2 & 2 & (1) & 2 \\
\hline 215 & De lerusalem exeunt & 3 & & 2 & 3 & 3 & 3 & 3 & $(2)$ & 5 \\
\hline
\end{tabular}


Table 6 (continued): Antiphons ad reliquias deducendas.

\begin{tabular}{|c|c|c|c|c|c|c|c|c|c|c|}
\hline 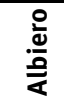 & & $u$ & $\simeq$ & $n$ & $\overline{\bar{\alpha}}$ & $\begin{array}{l}\text { ป } \\
\text { ป }\end{array}$ & 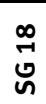 & $\underset{i}{\stackrel{i}{ت}}$ & $\begin{array}{l}0 \\
\mathbb{D}\end{array}$ & $\stackrel{\text { Q }}{\Sigma}$ \\
\hline 369 & Ingredere benedicte & 4 & & 3 & & & & & & \\
\hline 370 & Ingredere benedicte & & & & & & 4 & 4 & & \\
\hline 667 & Via iustorum & 5 & & 4 & & & & & & \\
\hline 291 & Ecce Sion filii & 6 & & 5 & & & & & & \\
\hline 347 & lerusalem ciuitas & 7 & & 6 & & & & & & \\
\hline 109 & Ambulate sancti dei ad locum & 8 & & 8 & 6 & 6 & 7 & 7 & & \\
\hline 110 & Ambulate sancti dei ingredimini & 9 & & 9 & 5 & 5 & 5 & 6 & & \\
\hline 577 & Sanctificabo te Hierusalem & & & 7 & & & & & & \\
\hline 511 & Plateae lerusalem & & & & 4 & 4 & 6 & 5 & & \\
\hline 213 & Custodit dominus & & & & & & & 8 & & \\
\hline \multirow[t]{2}{*}{359} & In nomine domini dei nostri & & & & & & & & & 3 \\
\hline & Archangelus domini Michael & & & & & & & & & 4 \\
\hline
\end{tabular}

The pattern suggested in the saints' series is more pronounced here: all of these series, in both ninth- and tenth-century books, begin similarly. After the third antiphon, De Ierusalem exeunt there is a clear divergence, however. At this point, the early book $\mathrm{C}$ has the chant Ingredere benedicte domino praeparatio habitatio plataeae Hierusalem gaudebunt et omnes uici eius canticum laetitiae dicunt. It is impossible to judge whether this was the version also intended in S, given that this book only has incipits, but given its closeness to the $\mathrm{C}$ series, it is likely. At this same point SG 18 and Ei 121 have a shorter version of Ingredere benedicte domino: 'Ingredere benedicte domini preparata est habitatio sedis tuae'.

Meanwhile in Albi and Ch 47 we find the rest of the earlier chant: 'Plateae Hierusalem gaudebunt et omnes uici eius canticum laetitiae dicent alleluia alleluia'. This second part of the earlier long chant is also present in SG 18 and Ei 121, indeed in this latter immediately following Ingredere benedicte. The division of the older chant into two parts was thus observed in all of these four books, even if one of the two parts was abandoned in two of them. The relation of the repertory in all four tenth-century books, two from the West (Albi, Ch 47) and two from the East (SG 18, Ei 121) is further confirmed by the continuation of the relics series, with the two Ambulate chants. All of this underlines the fact that the point of division between repertories collected in these books is not between chants sung in the West and chants sung in the East, but between chants collected in the earlier unnotated ninth-century books and those in the tenth-century notated books. 
The same clear pattern is apparent in the antiphon series 'de siccitate' (also named 'ad pluuiam postulandum') and 'de nimia pluuia' (also named 'de serenitatem' or 'ad poscendam serenitatem') (see Table 7). A long list in the two unnotated ninth-century books $\mathrm{C}$ and $\mathrm{S}$ contrasts with shorter lists in the tenthcentury books: and again there is a high level of agreement about which chants have been selected from the longer lists. Several more such comparisons of groups of processional antiphons in the SG 18 fragment reveal similar patterns among the set of concordances. Besides underlining the degree to which the Sankt Gallen fragment reflects a much more general transmission of processional chants, this difference between the repertories copied in the earlier unnotated books and those in the tenth-century notated books seems to point to some common point of changeover in the transmission of processional chants to which all the notated books go back. That is a characteristic which, although it shows with clarity in the processional chant repertory, could never be so surely demonstrated for the wider Roman-Frankish chant repertory, but it might have implications for that wider repertory.

Table 7: Antiphons de siccitate and de nimia pluuia.

\begin{tabular}{|c|c|c|c|c|c|c|c|c|c|c|c|}
\hline$\frac{\frac{O}{\frac{0}{0}}}{\frac{0}{\frac{0}{\alpha}}}$ & & 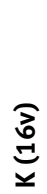 & 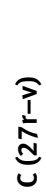 & 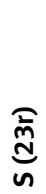 & 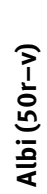 & 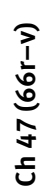 & 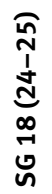 & 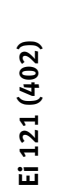 & 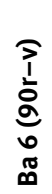 & 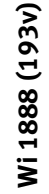 & 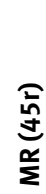 \\
\hline \multirow[t]{2}{*}{ rubrics } & Antiphone de siccitate & $\mathrm{x}$ & $\mathrm{x}$ & & $\mathrm{x}$ & & & & & $\mathrm{x}$ & \\
\hline & $\begin{array}{l}\text { Antiphonae ad pluuiam } \\
\text { postulandum }\end{array}$ & & & & & & $\mathrm{x}$ & & $x$ & & $\mathrm{x}$ \\
\hline 262 & Domine rex deus Abraham & 1 & 1 & 1 & 1 & 1 & 1 & 1 & 1 & 1 & 1 \\
\hline 643 & Ubi sunt misericordiae tuae & & 2 & 2 & & 6 & & & & & \\
\hline 451 & Numquid est in idolis & & 3 & 3 & 5 & 2 & 2 & 2 & 2 & 2 & 2 \\
\hline 548 & Recordare mei domine quid & & 4 & 4 & & & & & & & \\
\hline 310 & Exaudi domine populum tuum & 2 & 5 & 5 & 2 & 3 & 3 & 3 & 3 & & 3 \\
\hline 557 & Respice domine quia aruit & & 6 & 6 & 3 & 4 & 4 & 4 & 4 & & \\
\hline 309 & Exaudi domine lacrimas & & 7 & 7 & & & & & & & \\
\hline 391 & Iustitia tua sicut montes & & 8 & 8 & & & & & & & \\
\hline 266 & Domine rigans montes & & 9 & 9 & 4 & 5 & 5 & 5 & & & \\
\hline
\end{tabular}


Table 7 (continued): Antiphons de siccitate and de nimia pluuia.

\begin{tabular}{|c|c|c|c|c|c|c|c|c|c|c|c|}
\hline$\frac{\frac{0}{\frac{0}{2}}}{\frac{1}{2}}$ & & $\underline{\simeq}$ & $u$ & $n$ & $\overline{\bar{\alpha}}$ & $\begin{array}{l}\hat{y} \\
\text { 는 }\end{array}$ & $\stackrel{\substack{\infty \\
心}}{\mathscr{N}}$ & $\underset{i}{i}$ & $\begin{array}{l}\text { ○ } \\
\widetilde{\infty}\end{array}$ & $\begin{array}{l}\infty \\
\infty \\
\infty \\
\infty \\
\stackrel{+1}{\Sigma}\end{array}$ & $\stackrel{\alpha}{\Sigma}$ \\
\hline \multirow[t]{2}{*}{ rubrics } & Antiphone de nimia pluuia & $\mathrm{x}$ & $x$ & $\mathrm{x}$ & $x$ & & & & & & $x$ \\
\hline & Ad serenitatem & & & & & & $\mathrm{x}$ & $\mathrm{x}$ & $\mathrm{x}$ & & \\
\hline 381 & Inundauerunt aquae & 3 & 10 & 10 & 6 & 7 & 6 & 6 & 5 & & 4 \\
\hline 446 & Non nos demergat domine & & 11 & 11 & 7 & 8 & 7 & 7 & 6 & & \\
\hline 226 & Deus canticum nouum & & 12 & 12 & & & & & & & \\
\hline 316 & $\begin{array}{l}\text { Exaudi nos domine qui } \\
\text { exaudisti }\end{array}$ & 4 & 13 & 13 & 8 & 9 & 8 & 8 & 7 & & 5 \\
\hline 505 & Per memetipsum & & 14 & 14 & & & & & & & \\
\hline 238 & Dicit dominus: uidete uidete & & 15 & 15 & & & & & & & \\
\hline 314 & Exaudi nos deus in ueritate & & 16 & 16 & & & & & & & \\
\hline 442 & Ne nos demergat tempestas & & 17 & & & & & & & & \\
\hline 375 & Iniquitates nostre domine & & & 17 & 9 & & & & & & \\
\hline 349 & Immutemur habitu & & & & 10 & & & & & & \\
\hline 366 & Inclina domine aurem tuam & & & & 11 & & & & & & \\
\hline
\end{tabular}

All of the processional pieces in SG 18 mentioned so far can be linked back to older Roman traditions. Much of what follows in the fragment - now dealing with feasts for named saints and feasts of the time - is either of more recent composition or rooted in Gallican traditions. In the group of antiphons for feasts of named saints, a pair of chants copied under the rubric 'de sanctis apostolis' seem to be limited only to Sankt Gallen and Einsiedeln, or, in the case of the second, just SG $18{ }^{38}$ Although these may have been more widely known there is no evidence of older roots, when compared with, for example, the preceding antiphon for the feast of St Peter, Dum duceretur Petrus apostolus, which can be found in the repertories of Albi and Ch 47, as well as Wi 1888 representing Mainz..$^{39}$ The last piece in this group for named saints is in honour or St Gall: Suffragante domino beato

38 Deus cuius dextera beatum Petrum (Albiero 2016, 228) and Beatus Petrus dum penderet in cruce ; neither is listed in Huglo's index of processional chants (Huglo 1999-2004, II, 591-621); the first is listed by Albiero 2016 (for SG 339 and Ei 121), the second not at all.

39 Albiero 2016, 278: Albi f. 51r; Ch 47 f. 63v; Wi 1888 f. 194v. 
Gallo confessore tuo. This appears only in books from Sankt Gallen and Einsiedeln..$^{40}$

There follow antiphons for the main procession on Easter Sunday, and after this (sic) chants for Theodulf's Gloria laus et honor, sung on Palm Sunday; then chants for the Mandatum ceremony on Maundy Thursday (to which I shall return below), followed by (sic) Palm Sunday chants, and then chants for the adoration of the cross on Good Friday, with Venantius Fortunatus' hymn Pange lingua and refrain Crux fidelis as the last original entry..$^{41}$ The lack of correct festal order among these chants which follow the older Roman layer - even to the extent that chants for Palm Sunday are copied in two separate places, underlines the fact that the maker of the book probably copied this material from different parts of another book, or from more than one exemplar. That disorganization applies also to the two communion chants, Emitte angelum and Venite populi, ${ }^{42}$ the first rubricated here for Christmas, the second presumably to be used at Easter. These are copied towards the end of the votive section, between chants for the common of a confessor and chants to be used 'as needed' ('quando uolueris').

These ten pages, evidently intended to comprise the repertory of processional antiphons in use at the abbey of Sankt Gallen at the time of their copying in the late ninth or first half of the tenth century, can be summarised in two parts: antiphons for feasts of the time and of named saints, and antiphons of the Major Litany and other votive occasions. The Major Litany/votive group is close to the list of processional antiphons provided by Huglo for the early medieval period, named by him as 'antecedent to the processional [book]' ${ }^{43}$ The combined Major Litany/votive and festal repertory is a good match for other contemporary collections, such as that at the end of the west Frankish gradual Ch 47 (see Table 8). While this book is no longer extant, and its rubrics often difficult to reconstruct from faint images, comparison across several manuscripts allows clear identification of the series of occasions for which processional chants were provided.

40 Albiero 2016, 612.

41 A later (thirteenth-century) hand then added the Improperia chants Popule meus, Agyos o theos, Quia eduxi te, and Quid ultra debui.

42 Albiero 2016, 298, 664. These two Gallican fraction antiphons survived the adoption of Roman chant in the Carolingian empire: see Huglo 1955, 86.

43 Huglo 1999-2004, I, 43*-45*. 
Table 8: Summary of the Processional Chants in Ch 47, ff. 62r-68v.

\begin{tabular}{ll}
\hline Folios & Occasion \\
\hline $62 \mathrm{r}-\mathrm{v}$ & Palm Sunday \\
$62 \mathrm{v}-63 \mathrm{r}$ & Mandatum \\
$63 \mathrm{r}$ & Good Friday \\
$63 \mathrm{v}$ & Communion antiphon \\
$63 \mathrm{v}$ & Easter procession \\
$63 \mathrm{v}$ & Communion antiphon \\
$63 \mathrm{v}$ & St John Baptist \\
$63 \mathrm{v}$ & St Peter \\
$64 \mathrm{r}-\mathrm{v}$ & Common of saints \\
$64 \mathrm{v}-66 \mathrm{r}$ & Major Litany \\
$66 \mathrm{r}$ & Ad pluuiam postulandum \\
$66 \mathrm{v}$ & Ad serenitatem \\
$66 \mathrm{v}$ & De mortalitate \\
$66 \mathrm{v}$ & De poenitentia \\
$66 \mathrm{v}-67 \mathrm{r}$ & In nataliciis sanctorum \\
$67 \mathrm{r}$ & Ad reliquias ducendas \\
$67 \mathrm{r}-68 \mathrm{r}$ & Antiphone de quacumque tribulatione \\
$68 \mathrm{r}-\mathrm{v}$ & De misericordia \\
$68 \mathrm{v}$ & Ad spargendum aquam \\
\hline
\end{tabular}

Copied in reverse order compared to SG 18, this collection starts with feasts of the time and saints, followed by those for the Major Litany and votive occasions. This west Frankish repertory is largely similar to that in the Sankt Gallen fragment, if a touch more expansive: of the ninety-six chants written out in Ch 47, sixty are directly concordant with the content of SG 18. Through such examples it is possible to win a fairly solid sense of what might have been the normal expectation for the codification of processional chants in the late ninth and early tenth centuries.

In graduals and antiphoners made at Sankt Gallen at the end of the tenth century, the material recorded for processions remains similar, ${ }^{44}$ but with two notable differences: the Easter week processions are now inserted into the main se-

44 The two main manuscript sources in question here are the gradual Sankt Gallen, Stiftsbibliothek, 339 and the office antiphoner Sankt Gallen, Stiftsbibliothek, 390-391. 
ries of temporal feasts (rather than set apart with the votive and Major Litany processional chants), and by this time the Quem queritis in sepulchro dialogue had been integrated into the liturgy for the Easter morning procession. ${ }^{45}$

All of this provides a very clear background in both time and place against which the repertory of processional chants in the Müstair fragment can be set: this also comes from the southern German area, and was probably made in the late tenth century, thus contemporary with not only the fragment SG 18 but also the Hartker antiphoner (SG 390-391) and the (probably slightly earlier) Regensburg gradual Ba $6 .^{46}$ Indeed, the degree to which the Müstair fragment is close to other East Frankish uses may be estimated from antiphons for the Mandatum ceremony. In order to be able to evaluate that closeness, it is worth looking first at this repertory across the broadest geographical range, in manuscripts made between the ninth and the early eleventh centuries. ${ }^{47}$

Table 9: Antiphons for the Mandatum Ceremony.

\begin{tabular}{|c|c|c|c|c|c|c|c|c|c|c|}
\hline$\frac{\frac{0}{\frac{0}{0}}}{\frac{0}{2}}$ & & 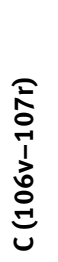 & 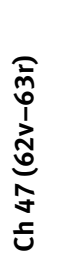 & 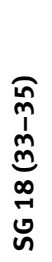 & 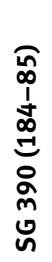 & 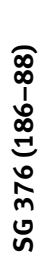 & 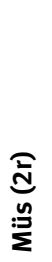 & 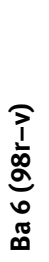 & 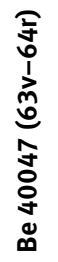 & 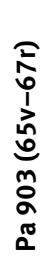 \\
\hline 406 & Mandatum nouum & 1 & 1 & 10 & 12 & 12 & 12 & 10 & 6 & 1 \\
\hline 521 & Postquam surrexit dominus & 2 & 3 & 4 & 5 & 5 & 5 & 4 & 4 & 2 \\
\hline 272 & Dominus ihesus postquam & 3 & & 1 & 4 & 4 & 4 & & & \\
\hline 204 & Cum surrexisset dominus & 4 & & & & & & & & \\
\hline 356 & In diebus illis & 5 & 6 & 12 & 11 & 11 & 11 & 11 & 9 & 5 \\
\hline 240 & Diligamus nos & 6 & 4 & 14 & 14 & 14 & 14 & 12 & 10 & 6 \\
\hline 588 & Si ego dominus & 7 & 2 & 9 & 6 & 6 & 6 & 5 & 5 & 3 \\
\hline 357 & In hoc cognoscent & 8 & 7 & 11 & 7 & 7 & 7 & 6 & 11 & 10 \\
\hline 400 & Locutus est omnipotens & 9 & & & & & & & & \\
\hline
\end{tabular}

45 SG 391, p. 37; SG 339, p. 106; the earliest transmission of this dialogue in a Sankt Gallen manuscript is in SG 484, p. 111: there it is treated as a trope.

46 On the dating of this see Paucker 1986, 32-40; also Hoffmann 1986, I, 280-281.

47 This category of antiphon is not listed or indexed in Huglo 1999-2004, but it is incorporated in Albiero 2016, also with a separate list (Table 7). 
Table 9 (continued): Antiphons for the Mandatum Ceremony.

\begin{tabular}{|c|c|c|c|c|c|c|c|c|c|c|}
\hline$\frac{\circ}{\frac{0}{0}}$ & & $u$ & $\begin{array}{l}\hat{y} \\
\text { ป }\end{array}$ & 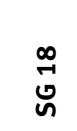 & : & $\underset{\substack{0 \\
m \\
心}}{w}$ & $\stackrel{n}{\Sigma}$ & $\begin{array}{l}0 \\
\mathbb{\infty} \\
\infty\end{array}$ & $\begin{array}{l}\text { 于े } \\
\text { ○ } \\
\text { ஸे }\end{array}$ & $\begin{array}{l}m \\
\stackrel{m}{\alpha} \\
\tilde{\sigma} \\
\alpha\end{array}$ \\
\hline 245 & $\begin{array}{l}\text { Discumbens dominus } \\
\text { accepit }\end{array}$ & 10 & & & & & & & & \\
\hline 399 & Locutus est dominus & 11 & & & & & & & & \\
\hline 641 & Ubi est caritas & 12 & & & & & & & & \\
\hline \multirow[t]{2}{*}{269} & Domine tu mihi lauas & 13 & & $5(\mathrm{v} 4)$ & 8 & 8 & 8 & 8 & 7 & 4 \\
\hline & $\begin{array}{l}\text { Domine non tantum } \\
\text { pedes }\end{array}$ & 14 & & $6(\mathrm{v} 4)$ & 9 (v8) & 9 (v8) & $9(\mathrm{v} 8)$ & 9 (v8) & 8 & \\
\hline 681 & Vos uocatis me ... etenim & 15 & & 7 & 10 & 10 & 10 & 7 & & \\
\hline 437 & Mulier quae erat & 16 & & & & & & & & 13 \\
\hline 411 & Maria autem unxit & 17 & & & & & & & & 14 \\
\hline 173 & Congregauit nos christus & 18 & & & & & & & & 16 \\
\hline 642 & Ubi fratres in unum & & 5 & 13 & 13 & 13 & 13 & 13 & 12 & 7 \\
\hline 117 & Ante diem festum & & & 2 & 1 & 1 & 1 & 1 & & \\
\hline$(681)$ & $\begin{array}{l}\text { Vos uocatis me ... et uos } \\
\text { debetis }\end{array}$ & & & 3 & 2 & 2 & 2 & 2 & 2 & \\
\hline \multirow[t]{3}{*}{162} & Cena facta dixit & & & 8 & 3 & 3 & 3 & 3 & 1 & \\
\hline & Suscepimus deus & & & 15 & 15 & & & 14 & & \\
\hline & Ubi est gaudium & & & & & 15 & & & & \\
\hline 227 & Deus caritas est & & & & & & 15 & & & 11 \\
\hline $\begin{array}{r}521 \\
\text { [short] }\end{array}$ & $\begin{array}{l}\text { Postquam surrexit } \\
\text { dominus }\end{array}$ & & & & & & & & 3 & \\
\hline 408 & Maneant in uobis spes & & & & & & & & & 8 \\
\hline 409 & Manete autem & & & & & & & & & 9 \\
\hline 639 & Tunc praecinxit & & & & & & & & & 12 \\
\hline 246 & Dixit autem Ihesus & & & & & & & & & 15 \\
\hline 174 & Congregauit nos in unum & & & & & & & & & 17 \\
\hline 154 & Karitas est summum & & & & & & & & & 18 \\
\hline
\end{tabular}

In Table 9 antiphons for the Mandatum ceremony in one ninth-century manuscript, and a series of tenth- and early eleventh-century manuscripts are listed; Western Frankish sources are represented by the early gradual C, then $\mathrm{Ch}$ 47 and the early eleventh-century manuscript from St Yrieix, Pa 903. The table is not intended to be comprehensive, but it was of interest to include this 
Aquitanian manuscript, ${ }^{48}$ to see how that repertory lined up alongside those in Eastern Frankish manuscripts. For this latter category, besides the Müstair fragment and a series from Sankt Gallen (SG 18, 390 and 376, of the mid-eleventh century), the Regensburg gradual and an eleventh-century antiphoner from Quedlinburg (Be 40047) are included. ${ }^{49}$

Since the table has been organized so that the earliest manuscript $\mathrm{C}$ provides the first ordering, it quickly becomes clear that a large number of pieces which were part of this earlier repertory, simply disappeared in the tenth century, at least from the sources collated here. ${ }^{50}$ This leaves a basic repertory, shared across Western- as well as Eastern-Frankish manuscripts. Although the repertory is largely shared, however, the ordering is not: even the starting point differs, with Mandatum nouum favoured in the West, and Ante diem festum favoured in the East. Beyond this large-scale sharing, relations across this large geographical area break down: even the Quedlinburg list and ordering is relatively unlike those from southern German areas.

Table 10: Antiphons for the Mandatum Ceremony in East Frankish manuscripts.

\begin{tabular}{|c|c|c|c|c|c|c|c|}
\hline$\frac{\circ}{\frac{0}{0}}$ & & 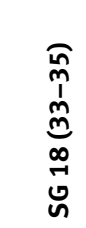 & 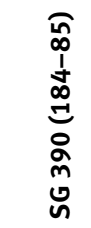 & 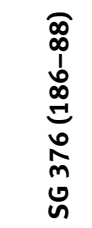 & 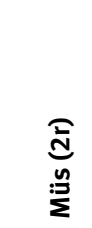 & 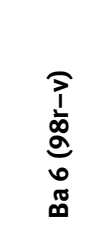 & 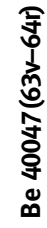 \\
\hline 117 & Ante diem festum & 2 & 1 & 1 & 1 & 1 & \\
\hline$(681)$ & $\begin{array}{l}\text { Vos uocatis me ... et uos de- } \\
\quad \text { betis }\end{array}$ & 3 & 2 & 2 & 2 & 2 & 2 \\
\hline 162 & Cena facta dixit & 8 & 3 & 3 & 3 & 3 & 1 \\
\hline 272 & Dominus ihesus postquam & 1 & 4 & 4 & 4 & & \\
\hline 521 & Postquam surrexit dominus & 4 & 5 & 5 & 5 & 4 & 4 \\
\hline 588 & Si ego dominus & 9 & 6 & 6 & 6 & 5 & 5 \\
\hline 357 & In hoc cognoscent & 11 & 7 & 7 & 7 & 6 & 11 \\
\hline \multirow[t]{2}{*}{269} & Domine tu mihi lauas & $5(\mathrm{v} 4)$ & 8 & 8 & 8 & 8 & 7 \\
\hline & Domine non tantum pedes & $6(\mathrm{v} 4)$ & 9 (v8) & 9 (v8) & 9 (v8) & 9 (v8) & 8 \\
\hline
\end{tabular}

48 On Aquitanian processional chants see Clément 2017.

49 See Möller 1990.

50 If Albiero's Repertorium can be taken as reasonably representative, the first four of the antiphons not found in other sources in this table $(204,400,245,399)$ are indeed unica. 
Table 10 (continued): Antiphons for the Mandatum Ceremony in East Frankish manuscripts.

\begin{tabular}{|c|c|c|c|c|c|c|c|}
\hline$\frac{\circ}{\frac{\circ}{\frac{0}{0}}}$ & & $\underset{\sim}{\stackrel{\infty}{\sim}}$ & $\begin{array}{l}\stackrel{8}{\text { mे }} \\
\text { un }\end{array}$ & 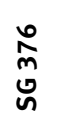 & $\stackrel{n}{\Sigma}$ & $\begin{array}{l}0 \\
\widetilde{D} \\
\end{array}$ & $\begin{array}{l}\text { 寸े } \\
\text { ઠ } \\
\text { ஸे }\end{array}$ \\
\hline 681 & Vos uocatis me ... etenim & 7 & 10 & 10 & 10 & 7 & \\
\hline 356 & In diebus illis & 12 & 11 & 11 & 11 & 11 & 9 \\
\hline 406 & Mandatum nouum & 10 & 12 & 12 & 12 & 10 & 6 \\
\hline 642 & Ubi fratres in unum & 13 & 13 & 13 & 13 & 13 & 12 \\
\hline 240 & Diligamus nos & 14 & 14 & 14 & 14 & 12 & 10 \\
\hline 227 & Deus caritas est & & & & 15 & & \\
\hline & Suscepimus deus & 15 & 15 & & & 14 & \\
\hline & Ubi est gaudium & & & 15 & & & \\
\hline (521) & Postquam surrexit dominus & & & & & & 3 \\
\hline
\end{tabular}

The relations between repertories and ordering in the southern German manuscripts are much closer (see Table 10). The Müstair repertory corresponds directly to those recorded in Sankt Gallen manuscripts, leaving out only the last chant, Suscepimus deus. But the order of chants in the Müstair fragment is identical not to the early tenth-century witness SG 18 but to the later antiphoner made by the monk Hartker in the last years of the tenth century. The mid eleventh-century gradual SG 376 has precisely the same series again, indicating that some sort of rearrangement of chants had been carried out between the period when SG 18 was made and the end of the tenth century, but that from that later time onwards, the choice and order of chants for the Mandatum ceremony at Sankt Gallen remained stable. When compared with Mandatum antiphons in other manuscripts, such as the mid tenth-century Regensburg gradual, $\mathrm{Ba}$ 6, or the early eleventhcentury Quedlinburg antiphoner, Be 40047, it is clear that while there is a closely shared list of processional chants for the Mandatum ceremony, and thus a sense of how many pieces are required, there is also considerable variation in the ordering of these pieces. Juxtaposed in this way, the identity of the Müstair series with that in the Hartker antiphoner is striking.

Even if its general context can be established with some clarity, however, the nature of the book from which the Müstair fragment comes is much less evident: while the contents of the bifolium are primarily processional chants, there is much else besides. The book these fragments came from was certainly not a simple collection of processional chants, nor was it even a book used in association with the Mass. The single folio comes from a book listing incipits for office chants, while much of the rubrication on the bifolium is concerned with details of chant 
assignments for offices. In the chants listed immediately after the Mandatum procession on f. $2 r$, it is the specification of individual chants to be sung 'in euangelio', thus with the Benedictus at Lauds or the Magnificat at Vespers, which appears to be the main concern. Likewise, when giving instructions about a fifth Advent week, a series of six responsories already sung in the fourth week is singled out as suitable. Then on Christmas Eve, for the Benedicite canticle at Lauds, referred to here as 'ad matutinum trium puerorum', the antiphon Dominus legifer noster is to be sung. And so on. In all of these cases, the maker of this book, or of its exemplar, must have been working from an undifferentiated list of antiphons and responsories for these feasts, and working out which ones would be most suitable for precise liturgical moments. Such a list would have looked exactly like the content of the single folio, which details all of the chants suitable for use on a particular feast day, but does not specify exactly which ones should be used at precise moments. The book maker seems to have been concerned with tying down such details.

All of this begins to emerge with more clarity when these directions are compared with the Hartker antiphoner. There, on a page with antiphons for days in the fourth week of Advent (SG 390, p. 39) one of the antiphons designated as 'in euangelio' in Müstair for this last week (Omnis uallis) is here also marked 'in euangelio' for the fourth day of this last week of Advent. The Müstair record then moves on to the invitatory for Christmas Eve, Hodie scietis, which appears two pages later in Hartker's book (on p. 41, immediately after the ' $O$ ' antiphons). Going backwards on f. 2r, the instruction that Festina ne tardaueris with the verse Veni domine should be sung as the responsory at vespers in the third week of Advent is concordant in both manuscripts (SG 390, p. 34). Nevertheless, it is not the similarities but the differences between the Müstair fragment and the Hartker Antiphoner which are interesting, and it is because these similar designations underline a close relation between the Müstair fragment and another contemporary book, that the differences between the two manuscript sources begin to talk. We become much more aware of what kind of information the Müstair copyist was trying to preserve, what he knew was required, and what resources were not available to him.

In Hartker's antiphoner, individual chants are written out in full, with clear rubrication - 'in euangelio' or 'super tria cantica' for the third canticle in the monastic night office, and so on. Whether for lack of parchment or time or inclination, the Müstair copyist was not able to stretch to these lengths. He may have had to work with more limited material resources. Yet he knew that these kinds of specificity mattered, and found a way of doing something about that, preserving his instructions in conjunction with an office antiphoner constituted by un- 
differentiated lists. The Müstair copyist was also concerned with twists and turns of the liturgy as feast days fell on different days of the week in subsequent years. From this point it is but a short step to explaining why so much processional information was preserved. For the person most directly responsible for dealing with these situations was certainly also the person responsible for the conduct of the liturgy of processions, the cantor. In this case, he may not have been a particularly distinguished scribe, but he was most assured in the navigation of the liturgy. What he seems to have been making was a personal book - or maybe even a book for the use of a younger cantor who would succeed him..$^{51}$ A very strong hint in this direction is provided by the use of musical notation in the fragment: it appears sporadically, but clearly added by the first hand. Its main purpose is clearly to guide the reader to select the right chant, using notation as a melodic guide, so that there would not be confusion with other chants with similar or identical texts. Here I use 'personal' in the same way as Michel Huglo in his description of the processional book type as 'not an official book, but one created by singers for their own personal use'. ${ }^{52}$ Yet that binary description depends on a clear division between, on the one hand, a large category of books such as tropers, sequentiaries, collections of polyphony and so on - books made by cantors for cantors; and, on the other hand, the books which contained the 'official' Roman chant repertory, graduals for the Mass and antiphoners for the office. What the Müstair fragment demonstrates is the degree to which those categories are too simplistic - since here we encounter working material related to both sides of the binary division.

Despite the singularity of their content, the Müstair pages were always intended to be supremely serviceable: those ways in which they were meant to be useful to a reader can indeed be reconstructed, and the purpose of the host book well understood in relation to the day to day tasks of a monastic musician. Even if this three-folio fragment is more or less sui generis, representing a book which does not match any established type, it nevertheless provides an extremely useful lesson in piecing together a history of liturgical books.

51 It is worth noting the use of second person singular verbs in the rubrics: 'obserua' (2v/1), 'canas' (2v/2).

52 Huglo 1999-2004, I, 35*. 


\section{Appendices}

\section{Appendix 1: Müstair, Benediktinerinnenkloster St. Johann XX/48 Nr. 14 transcription}

In this transcription abbreviations have been silently expanded, punctuation rationalised, and chant texts italicized; * indicates original musical notation.

[fol. 2r/1]

Ps Miserere mei deus

IN CENA DOMINI AD MANDATUM

A Ante diem festum

A Vos uocatis me

A Cena facta dixit

AD AMBAS

A Dominus ihesus postquam

Ps Deus misereatur nostri

A Postquam surrexit

A Si ego dominus

Ps Confitemini

A In hoc cognoscent

A Domine tu mihi lauas

$\mathrm{V}$ Domine non tantum

A Vos uocatis me

A In diebus illis

Ps Magnus dominus

A Mandatum nouum

Ps Beati immaculati

A Ubi fratres in unum

Ps Ecce quam bonum

A Diligamus nos inuicem

A Deus caritas est

DOMINICA SECUNDA ANTE NATALE DOMINI.

IN EVVANGELIO secundum uesperem

A Tu es qui uenturus nullo modo hic alia canatur [fol. $2 r / 2$ ]

FERIA VI

A Omnis uallis implebitur Item FERIA IIII In ieiunio mensis decimi. siue in priori. siue in proxima septimana contigerit. IN EVVANGELIO

A Missus est gabriel

A Quomodo fiet istud

A Dabit ei dominus sedem

A Ecce ancilla domini

FERIA VI

A Exquo facta est

A Beata es maria

A Hoc est testimonium

SABBATO

A Dabit ei dominus

A Omnis uallis

AD VESPERUM

$\mathrm{R}$ Non auferetur

IN EVVANGELIO

A O sapientia

uel alia de illis sicut euenerit

DOMINICA III IN SECUNDA VESPERUM ET PER

TOTAM ebdomadam

cantatur istud responsorium

$\mathrm{R}$ Festina ne tardaueris

$\mathrm{V}$ Veni domine et noli 
[fol. 2v/1]

IN EVVANGELIO. Antiphona de maioribus qualis euenerit.

SI NATALE DOMINI FERIA V euenerit ad unum matutinum colligende sunt. quod sabbato congruentissimae fiet hoc modo.

A Prophetę predicauerunt

A Ad te domine leuaui

A Expectetur sicut pluuia

A Adnuntiate populis

IN EVVANGELIO

A Omnis uallis implebitur

A Ecce ancilla domini IN VIGILIA NATIVITATIS DOMINI AD INVITATORIUM

A Hodie scietis quia

ILLUD DILIGENTER OBSERVA UT SI VIGILIA NATIVITATIS DOMINI die dominica euenerit per quatuor ebdomadas plenas. secundum constitutum de ad [fol. 2v/2]

uentu canas. et in ipsa quinta [ebdomada] responsoria de priori ebdomadas colligas hoc modo

$\mathrm{R}$ Clama in fortitudine

$\mathrm{R}$ Orietur stella

$\mathrm{R}$ Modo ueniet domina

$\mathrm{R}$ Ecce iam ueniet

$\mathrm{R}$ Emitte agnum domine

$\mathrm{R}$ Egredietur uirga

SUPER . III . CANTICA.

A Urbs fortitudinis

ET AD MATUTINUM TRIUM PUERORUM

A Dominus legifer noster

Et tunc rite vi lectiones in proximo sabbato celebrandis. Si autem natiuitas domini die dominico occurrit. quarti temporis ieiunium. in anteriori ebdomada celebrandum responsoriis.
$\mathrm{R}$ Sanctificamini hodie
$\mathrm{V}$ Hodie scietis quia
$\mathrm{R}$ Constantes estote 
[fol. 1v/1]

A Surgens [Ihesus mane prima] ALLELUIA*

Gradalem cum uersu. Et di[ ]

RG Hec dies V Confitemini

All Pascua nostrum

$\checkmark$ Epulemur in azimis

Romana. A EUIA.

Et per totam epdomadam. Ad primam. sextam. nonamque. et uesperam. Gradale tamen sine uersu. Cum alleluia cantatur. In octaba pasce ad processionem sicut in die dominico resurrectionis domini.

In die letaniae maioris ad processionem
A Exsurge domine
$\checkmark$ Deus auribus nostris

In choro canendum
A Cum iocunditatem
A Exclamemus omnes
A Parce domine parce
A Iniquitates nostras
A Saluator mundi
A Sanctifica nos domine

Deinde letania. et due missę publice [fol. 1v/2]

canantur. Ad . iii . De sancto Marco. Ad ui de letania. In sollemnitate pascale.

DE VIRGINIBUS. AD MATUTINUM LAUDIBUS
A Vidispeciosam
A Conuallium* AEUIA*
A Veni electam meam
A Speciem tuam AEUIA*
A Ista est speciosa
... aromatum . AEUIA*

A Ornatam in monilibus

A Concupiuit rex AEUIA

A Tota pulchra est ... in te . aeuia*

\section{IN EVVANGELIO}

A Simile est regnum*

Vel [A] Pulchrafacie

Ad processionem pascha usque in ascensionem domini. dominicis diebus
A In die resurrectionis
A Vidi aquam
A Vidi portam ciuitatis
A Cum rexglorie 
[fol. 1r/1]

IN ECCLESIA

$\mathrm{R} \quad$ Haec est hierusalem

DOMINICA $V$ et $V I$ pascha responsoriis de psalmis CUM ALLELUIA

$\mathrm{R}$ Si oblitus fuero

IN LETANIA MINORE FERIA II

AD CRUCEM

A Petite et accipietis

A Nolite expauescere

AD PROCESSIONEM

A Exaudi nos domine

A Inmutemur habitum

A Cum iocunditate

A Annuntiate

A Ego sum deus patrum

A Populus Sion

A Domine deus noster

A Confitemini domino

A Sanctifica nos domine

A Exclamemus omnes

A Oremus dilectissimi

AD VESPERUM

A Si ergo uos cum sitis

AD CRUCEM

A Scio quod ihesum

FERIA III

A Petite et accipietis [fol. 1r/2]

AD CRUCEM

A In galilea ihesum

AD PROCESSIONEM

A Propitius esto domine

A Inmutemur habitum

A De hierusalem exeunt

A Ecce populus

A Parce domine parce

A Domine imminuti sumus

A Iniquitates nostrae

A Deprecamur te domine

A Saluator mundi

A Dimitte nobis domine

A Omnipotens deus mestorum

AD VESPERUM

A Ecce nunc palam

Vel $[\mathrm{A}] \quad$ Exiui a patre

AD CRUCEM

A Pax uobis ego sum

FERIA IIII

A Omnis enim qui petit

Vel [A] Usque modo

AD CRUCEM

A Cito euntes dicite

AD PROCESSIONEM

A Exsurge domine

V Deus auribus nostris

A Inmutemur habitum

A Surgite sancti

A Plateae hierusalem

A Domine deus noster 
[fol. 3r/1]

[RESPONSORIA DE LIBRO REGUM]

[V] Domine qui custodis. Bene[dic]

[R Exaudisti domine]

[R] Domine si conuersus

[V] Si peccauerit. Tu

[R] Audi domine [ym]num

[V] Respice domine. Super

[R] [Pecc]aui super nume[rum]

$\mathrm{V}$ [Quonia]m [ini]quitatem

$\mathrm{R}$ Recordare domine

[V] [Quie]scat domine. Ut

$\mathrm{R} \quad$ Factum est dum tolle[ret]

$\mathrm{V}$ [Eleua]bitque pallium. pater

[R] Preparate corda

$\mathrm{V}$ Auferte deos alienos. Et

ANTIPHONE UNDE SUPRA

A Loquere domine

A Cognouerunt omnes

A Preu[aluit] dauid

A [Non]ne [iste] est dauid

A Quis enim in omnibus

A Iratus rexsaul

A In excelsis tuis

A Doleo super te frater

A Dixitque dauid ad dominum

A Obsecro domine quia

A [Clamab]atheliseus

A Rexautem dauid

A Unxerunt salomonem

RESPONSORIA DE SAPIENTIA [fol. 3r/2]

$\mathrm{R} \quad$ In princi[pio deus antequam]

$\mathrm{V}$ Ego in alti[ssimis. antequam]

$\mathrm{R} \quad$ Emit[te] domine [sapientiam]

$\mathrm{V}$ Da mihi domine. Ut

$\mathrm{R} \quad$ Domine pater

$\mathrm{V}$ Da mihidomine. Et

$\mathrm{R} \quad$ Da mihi domine

V Domine pater. Quo[niam]

R Girum caeli

$\mathrm{V}$ Ego in altissimime. Super

$\mathrm{R} \quad$ Initium sapientie

$V \quad$ Dispersit dedit. Laud[atio]

$\mathrm{R} \quad$ Verbum iniquum

$V \quad$ Ne forte sa[tiatus]. Sed

$\mathrm{R} \quad$ Magna enim sunt

V Deduxisti sicut. Et

$\mathrm{R} \quad$ Super salutem

$\mathrm{V} \quad$ Dixi sapientiae. V[enerunt]

$\mathrm{R} \quad$ Ne derelinquas

$\mathrm{V}$ Apprehende. Ne

$\mathrm{R} \quad$ Que sunt in corde

$\mathrm{V}$ Inperfectum meum. h[omo]

$\mathrm{R}$ Prebe filicor

$\mathrm{V}$ Adtende fili mi. Ut

$\mathrm{R} \quad$ Fili noli deficere

V Audi fili mi. q[uem]

$\mathrm{R} \quad$ Audifili mi

$\mathrm{V}$ Honora dominum. Ut

R Aduersio paruulorum

V O uiri ad uos. Qui autem 
[fol. 3v/1]

ANTIPHONE [UN]DE SUPRA
A Sapientia clamitat
A Sapientia aedificauit
A Omnis sapientia
A Ego [in] altissimis
A Sicut malum inter ligna
A Dominus possedit me
A Prebe fili cor tuum
A Magna enim sunt

DE IOB

\section{$\mathrm{R} \quad$ Sibona suscepimus}

[V] In omnibus his. Dominus

$\mathrm{R}$ Antequam comedam

$\checkmark \quad$ Nolo multa. Nonne

$\mathrm{R} \quad$ Utinam apprehenderentur

V Quasi arena maris. Et

$\mathrm{R} \quad$ Quare detraxisti

$\mathrm{V}$ Mili[tia] est uita. Ve[rumtamen]

$\mathrm{R} \quad$ Induta est caro mea

V Dies mei sicut umbra. Me[mento]

R Paucitas dierum

$\mathrm{V}$ Ecce in puluere. An[tequam]

$\mathrm{R} \quad$ Ne abscondas me

$\mathrm{V} \quad$ Voca me \& respondebo. Et

$\mathrm{R} \quad$ Quis mihi tribuat

$\mathrm{V} \quad$ Numquid sicut. Nisi

R Numquid dominus sub[plantat iudiciu]m

$\mathrm{V} \quad$ Apprehende domine. Et [fol. 3v/2]

$\mathrm{R} \quad$ Nocte os meum per[foratur]

V O custos hominum . Com[paratus]

$\mathrm{R}$ Scio domine

$\mathrm{V}$ Si ascendero.In[de]

$\mathrm{R}$ Versa est in luctum

V O custos hominum. Pa[rce]

$\mathrm{R}$ Nonne cognoscit

$\mathrm{V}$ Quis det ut ueniat. Et

$\mathrm{R}$ Adesto dolori

V Versa est in luctum. In

$\mathrm{R}$ Auditu auris

V Unum locutus sum. Et

R Qui consolabitur

V Fletum deduxerunt. Qui[a]

$\mathrm{R}$ Desiderium meum

V Nolo multa fortitudinem. Ut

$\mathrm{R}$ Memento mei deus

$\checkmark$ De profundis clamaui. Nec

$\mathrm{R}$ Inclinans faciem tuam

$\mathrm{V}$ Que est enim. Et

ANTIPHONE UNDE SUPRA

A Cum audisset iob

A In omnibus his [non] pec[cauit]

A Ciues mei uer[mes]

A Auditu auris audiui

A Quantas habeo

DE TOBIA RESPONSORIA

$\mathrm{R}$ Peto domine ut de uinculo 


\section{Appendix 2: Chants in SG 18 pp. 21-40 (listed alphabetically)}

This list includes antiphons as well as versified pieces: some of the latter are omitted from Albiero's Repertorium, but appear in a dedicated part of Huglo's index (Huglo 1999-2004, 610-619).

\begin{tabular}{|c|c|c|}
\hline Incipit & page in SG 18 & Albiero no. \\
\hline Agyos o theos & 40 & - \\
\hline Ambulate sancti dei ad locum & 27 & 109 \\
\hline Ambulate sancti dei ingredimini & 27 & 110 \\
\hline Annunciate inter gentes & 26 & 115 \\
\hline Ante diem festum & 33 & 117 \\
\hline Beatus Petrus dum penderet & 31 & - \\
\hline Cena facta dixit Ihesus & 34 & 163 \\
\hline Christe qui regnas & 29 & 157 \\
\hline Collegerunt pontifices & 36 & 168 \\
\hline V. Unus autem & & 644 \\
\hline Confitemini domino & 21 & 170 \\
\hline Conuertere domine aliquantulum & 25 & 177 \\
\hline Crucem tuam ... ecce enim & 39 & 185 \\
\hline Crucem tuam ... quia uenit & 39 & 184 \\
\hline \multicolumn{3}{|l|}{ Crucifixum in carne: see Stetit angelus } \\
\hline Crux fidelis & 38 & 189 \\
\hline Cum appropinquarent & 35 & 193 \\
\hline Cum audisset populus & 36 & 195 \\
\hline \multicolumn{3}{|l|}{ Cum fabricator: see Dum fabricator } \\
\hline Cum iocunditate & 26 & 200 \\
\hline Cum rex glorie & 32 & 202 \\
\hline Custodit dominus & 26 & 213 \\
\hline De lerusalem & 26 & 215 \\
\hline Deprecamur te domine & 23 & 221 \\
\hline Deus cuius dextera beatum Petrum & 31 & 228 \\
\hline Diligamus nos inuicem & 35 & 240 \\
\hline Dimitte domine peccata nostra & 24 & 242 \\
\hline Dimitte domine peccata populi & 22 & 243 \\
\hline Dimitte nobis domine debita & 28 & 244 \\
\hline
\end{tabular}


Incipit

page in SG 18

Albiero no.

Domine deus noster qui cum

Domine imminuti

Domine miserere nostri

Domine non est alius

Domine non tantum: see Postquam

Domine rex deus Abraham

Domine rigans montes

Domine tu mihi lauas: see Postquam

Dominus Ihesus postquam

Dum duceretur Petrus

Dum fabricator mundi

Ecce lignum

Ecce populus 290

Ego sum deus patrum 296

Emitte angelum 298

Exaudi deus deprecationem 307

Exaudi domine deprecationem 308

Exaudi domine populum tuum 310

Exaudi nos domine qui exaudisti 316

Exclamemus omnes

Gloria laus et honor

Homo iste fecit mirabilia

In die resurrectionis

In diebus illis mulier

In hoc cognoscent

In sanctis gloriosus es

Inclina domine aurem tuam

Ingredere benedicte

Iniquitates nostrae

Inundauerunt aquae

Inuocantes dominum

Libera domine populum tuum

Mandatum nouum

Miserere domine plebi tuae 
Incipit

Non nos demergat domine

Numquid est in idolis

o quam uenerandus

Omnipotens deus mestorum

Oremus dilectissimi

Parce domine

Pange lingua

Peccauimus domine

Plateae lerusalem

Popule meus

Postquam surrexit

V. Domine tu mihi lauas

V. Domine non tantum

Quia ego eduxi te

Quid ultra debui facere

Recordamini quomodo: see Stetit angelus

Respice domine quia aruit

Saluator mundi salua nos

Sanctificabo te lerusalem

Si ego dominus

Stetit angelus

$$
\begin{aligned}
& \text { V. Crucifixum in carne } \\
& \text { V. Recordamini quomodo }
\end{aligned}
$$

Suffragante domino beato Gallo

Surrexit enim sicut dixit dominus

Suscepimus deus

Ubi fratres

Unus autem: see Collegerunt

Venite populi

Vidi aquam

Vos uocatis me ... et uos debetis

Vos uocatis me ... etenim page in SG 18

Albiero no.

25

446

451

477

486

491

496

38

23

500

27

511

516

521

269

543

544

30

557

567

30

577

35

588

32

585

186

547

612

623

35

35

642

29

664

32

34

34 


\section{Manuscripts and sigla}

$\begin{array}{ll}\text { Albi } & \text { Albi, Bibliothèque municipale Rochegude, 44 } \\ \text { Ba 6 } & \text { Bamberg, Staatsbibliothek, Msc. lit. 6 } \\ \text { Be 40047 } & \text { Berlin, Staatsbibliothek Preußischer Kulturbesitz, Mus. Ms. 40047 } \\ \text { B } & \text { Brussels, KBR (olim Bibliothèque royale), 10127-10144 } \\ \text { Ch 47 } & \text { [olim] Chartres, Bibliothèque municipale, 47 } \\ \text { Ei 121 } & \text { Einsiedeln, Stiftsbibliothek, 121 } \\ & \text { Leipzig, Universitätsbibliothek, Rep I 93 } \\ & \text { Milan, Biblioteca Ambrosiana, D 84 inf. } \\ \text { MR } & \text { Antiphoner of Mont Renaud [private collection] } \\ \text { Müs } & \text { Müstair, Benediktinerinnenkloster St. Johann, XX/48 Nr. 14 } \\ \text { Pa 903 } & \text { Paris, Bibliotheque nationale de France, lat. 903 } \\ \text { K } & \text { Paris, Bibliotheque nationale de France, lat. 12050 } \\ \text { C } & \text { Paris, Bibliotheque nationale de France, lat. 17436 } \\ \text { S } & \text { Paris, Bibliothèque Sainte-Geneviève, 111 } \\ \text { SG 18 } & \text { Sankt Gallen, Stiftsbibliothek, 18 } \\ \text { SG 376 } & \text { Sankt Gallen, Stiftsbibliothek, 376 } \\ \text { SG 390-391 } & \text { Sankt Gallen, Stiftsbibliothek, 390-391 } \\ \text { SG 484 } & \text { Sankt Gallen, Stiftsbibliothek, 484 } \\ & \text { Trier, Stadtbibliothek, 1245 597 } 8^{\circ} \\ \text { Pal. 489 } & \text { Vatican, Biblioteca Apostolica Vaticana, Pal. lat. 489 } \\ \text { Wi 1888 } & \text { Vatican, Biblioteca Apostolica Vaticana, Vat. lat. 10644, fol. 2 } \\ & \text { Vienna, Östereichische Nationalbibliothek, lat. 1888 } \\ & \text { Zurich, Zentralbibliothek, Rheinau 28 }\end{array}$

\section{Abbreviations}

AMS

$B K$

CAO

PM 11
René Jean Hesbert (ed.), Antiphonale missarum sextuplex, Rome: Herder, 1933. Bernhard Bischoff (ed.), Katalog der festlandischen Handschriften des neunten Jahrhunderts (mit Ausnahme der wisigotischen), Vol. I: Aachen Lambach; Vol. II: Laon -Paderborn; Vol. III: Padua - Zwickau, Wiesbaden: Harrassowitz, 1998-2014.

René Jean Hesbert, Corpus antiphonalium officii, Rome: Herder, 1965.

Antiphonale missarum Sancti Gregorii, Xe siècle, Codex 47 de la Bibliothèque de Chartres (Paléographie musicale 11), Tournai: Desclée, 1912. 


\section{References}

Albiero, Laura (ed.) (2016), Repertorium antiphonalium processionalium (Adhoc 1), Lugano: Vox Antiqua.

Bernhard, Michael (1979), Studien zur Epistola de armonica institutione des Regino von Prüm (Veröffentlichungen der musikhistorischen Kommission 5), Munich: Bayerische Akademie der Wissenschaften.

Billett, Jesse D. (2014), The Divine Office in Anglo-Saxon England 597- c.1000 (Henry Bradshaw Society Subsidia 7), London: Boydell and Brewer.

Bower, Calvin M. (2003), 'From Alleluia to Sequence: Some Definitions of Relations', in Sean Gallagher, James Haar, John Nádas, and Timothy Striplin (eds), Western Plainchant in the First Millenium. Studies in the Medieval Liturgy and its Music, Aldershot: Routledge.

Bower, Calvin M. (ed.) (2016), The Liber Ymnorum of Notker Balbulus (Henry Bradshaw Society 121-122), 2 vols, Woodbridge: Boydell \& Brewer.

Brown, T. Julian (ed.) (1969), The Durham Ritual: A Southern English Collectar of the Tenth Century with Northumbrian Additions (Early English Manuscripts in Facsimile 16), Copenhagen: Rosenkilde and Bagger.

Bruckner, Albert (1935), Scriptoria medii aevi Helvetica, Vol. 1: Schreibschulen der Diözese Chur, Geneva: Verlag Roto-Sadag.

Clément, Gisèle (2017), Le Processional en Aquitaine, IXe-XIIle siècle. Genèse d'un livre et d'un répertoire (Musicologie 2), Paris: Classiques Garnier.

Colette, Marie-Noël (2003), 'Séquences et versus ad sequentias dans l'antiphonaire de Charles le Chauve (Paris, BnF, Lat. 17436)', in Revue de musicologie, 89: 5-29.

Crivello, Fabrizio (2001), La miniatura a Bobbio tra IX e X secolo e i suoi modelli carolingi, Turin: Allemandi.

Crocker, Richard (1977), The Early Medieval Sequence, Berkeley: University of California Press. Emerson, John A., with Lila Colamore (eds) (2002), Albi, Bibliothèque Municipale Rochegude, Manuscript 44: A Complete Ninth-Century Gradual and Antiphoner from Southern France, Ottawa: Institute of Medieval Music.

Fernandez, David Andrés (2014), 'Fit processio et cantantur antiphonae sequentes. Tipología de las formas de música litúrgica en los libros procesionales', in Medievalia, 17: 103-129.

Gy, Pierre-Marie (1960), 'Collectaire, Rituel, Processional', in Revue des Sciences philosophiques et théologiques, 44: 441-468.

Haubrichs, Wolfgang (1979), Die Kultur der Abtei Prüm zur Karolingerzeit: Studien zur Heimat des althochdeutschen Georgsliedes (Rheinisches Archiv 105), Bonn: L. Röhrscheid.

Hoffmann, Hartmut (1986), Buchkunst und Königtum im ottonischen und frühsalischen Reich, 2 vols (Schriften der Monumenta Germaniae Historica 30), Stuttgart: Anton Hiersemann.

Hohler, Christopher (1980), Review of Raymond J. S. Grant, Cambridge, Corpus Christi College 41: The Loricas and the Missal, Costerus n.s. 17, in Medium Aevum, 49: 275-278.

Hughes, Anselm (ed.) (1934), Anglo-French Sequelae. Edited from the papers of the late Dr. Henry Marriott Bannister, Burham: The Plainsong and Medieval Music Society.

Huglo, Michel (1955), 'Antifone antiche per la “fractio panis”, in Ambrosius, 31: 85-95.

Huglo, Michel (ed.) (1999-2004), Les Manuscrits du processional, 2 vols (Répertoire International des Sources Musicales B XIV), Munich: Henle. 
Klauser, Theodor (1935), Das Römische Capitulare Evangeliorum. Texte und Untersuchungen zu seiner ältesten Geschichte (Liturgiegeschichtliche Quellen und Forschungen 28), Münster: Aschendorff.

Knibbs, Eric (ed.) (2014), On the Liturgy. By Amalar of Metz, 2 vols (Dumbarton Oaks Medieval Library 35-36), Cambridge, MA: Harvard University Press.

Koehler, Wilhelm, and Florentine Mütherich (eds) (1982), Die Karolingische Miniaturen V: Die Hofschule Karls des Kahlen, Berlin: Deutscher Verein für Kunstwissenschaft.

Lafitte, Marie-Pierre (2007), 'Les manuscrits impériaux', in Marie-Pierre Lafitte and Charlotte Denoël (eds), Trésors carolingiens. Livres manuscrits de Charlemagne à Charles le Chauve, Paris: Bibliothèque nationale de France, 85-119.

Lindelöf, Uno (ed.) (1927), 'Rituale ecclesiae Dunelmensis': The Durham Collectar. A New and Revised Edition of the Latin Text with the Interlinear Anglo-Saxon Version (Surtees Society 140), London: B. Quaritch.

Lehmann, Paul (ed.) (1918), Mittelalterliche Bibliothekskataloge Deutschlands und der Schweiz, I: Die Bistümer Konstanz und Chur, Munich: O. Beck.

Martimort, Georges (1955), 'Les diverses formes de procession dans la liturgie', in La MaisonDieu, 43: 43-73.

Möller, Hartmut (1990), Das Quedlinburger Antiphonar (Berlin, Staatsbibliothek Preußischer Kulturbesitz Mus. Ms. 40047), 3 vols (Mainzer Studien zur Musikwissenschaft 25), Tutzing: Hans Schneider.

Palazzo, Eric (1993), Histoire des livres liturgiques. Le Moyen Âge. Des origines au XIIle siècle, Paris: Beauchesne.

Parkes, Henry (ed.) (2019), Berno Augiensis, Tractatus liturgici (Corpus Christianorum Continuatio Medievalis 297), Turnhout: Brepols.

Paucker, Günther Michael (ed.) (1986), Das Graduale Msc. Lit. 6 der Staatsbibliothek Bamberg. Eine Handschriften-Monographie unter besonderer Berücksichtigung des Repertoires und der Notation (Forschungsbeiträge zur Musikwissenschaft 30), Regensburg: G. Bosse.

Rankin, Susan (2016), 'Carolingian liturgical books: problems of categorization', in Gazette du livre médiéval, 62: 21-33.

Rankin, Susan (2020), 'Searching for Order Amidst Carolingian Chaos: The Musical Work of Regino of Prüm', in Warren Pezé et al. (eds), Culture and Knowledge in Times of Threat: Europe around 900 (Monographien zur Geschichte des Mittelalters), Stuttgart: Hiersemann Verlag.

Rankin, Susan (1995), 'Ways of Telling Stories', in Graeme M. Boone (ed.), Essays on Medieval Music in Honor of David G. Hughes (Isham Library Papers 4), Harvard: University Press, 371-394 [reprinted in Thomas Forrest Kelly (ed.) (2009), Oral and Written Transmission in Chant, Ashgate: Routledge, 385-408]. 


\title{
David Hiley
}

\section{Some Medieval Relics of Saints' Plainchant Offices}

\begin{abstract}
The transmission of cycles of office chants for local saints often follows a path different from that of the main body of liturgical chant. While some offices were known across a fairly large area, others were restricted to only one diocese, or even a single institution. The value of fragments of such offices varies correspondingly. Examples are discussed from the offices for Emmeram, Vitus, Catherine, Margaret, Afra, and George. The problems they present concern variously the liturgical occasion and order of the chants, their musical notation, and their place in the wider tradition of medieval chant.
\end{abstract}

The transmission of cycles of office chants for local saints - sometimes called historiae - often follows a path different from that of the main body of liturgical chant. In earlier sources, with small, compact script and notation, a historia with between twenty and forty chants could easily be accommodated in a single gathering, perhaps no more than half a dozen leaves. No doubt all historiae were first recorded thus, before eventually finding their way into a full antiphoner or notated breviary, sometimes clearly as additions to the older, established repertory. A few are to be found together with the vita of the saint, and in some cases vita and historia were written by the same author/composer. ${ }^{1}$ One cannot always know if a particular fragment comes from a libellus of this sort, or from a larger service book.

Historiae were made to enhance the veneration of a particular saint in a particular area or institution. Depending on the importance of the saint, cycles might be known across a fairly large area (e.g. Afra throughout all of Southern Germany), or in only one diocese (e.g. Corbinian in the diocese of Freising), or only one institution within that diocese (e.g. Marinus and Anianus at the Benedictine monastery of Rott-am-Inn, Juliana at Schäftlarn, Quirinus and Chrysogonus at

1 Berschin 1975; Hiley 2015a.

๖ Open Access. (๐ 2020 David Hiley, published by De Gruyter. (cc) BY-NC-ND This work is licensed under the Creative Commons Attribution-NonCommercial-NoDerivatives 4.0 International License.

https://doi.org/10.1515/9783110717884-004 
Tegernsee, Mechthild at Diessen). ${ }^{2}$ The value of fragments of such offices varies correspondingly.

The number of fragmentary remains is at present impossible to assess accurately, but is certainly very large. While the investigation of saints' offices has naturally concentrated on fully preserved cycles, significant contributions to research have been made, such as the work of John Toy on fragments of English saints' offices in Scandinavian libraries. ${ }^{3}$ As examples of those presently known, one might mention just four: for Oswin of Deira a substantial amount can be recovered, yet not a full cycle; for Alban and for Augustine of Canterbury only a handful of chants are known from sources in staff notation, for Etheldreda of Ely only a small fragment survives. ${ }^{4}$ In the following, I shall discuss six examples: not, however, from England but from southern Germany. Each example raises questions either about the original function and transmission of the chants, or about our resources and methods of investigation.

\section{Munich, Bayerische Staatsbibliothek, Clm 29316(38 - Emmeram}

My first examples are three leaves from a twelfth-century antiphoner preserved in the Bavarian State Library in Munich, under the shelfmark Clm 29316(38. The original book was certainly quite large, $19 \times 26.5 \mathrm{~cm}$. Two of the leaves are known to have been taken from a book from the Benedictine monastery at Tegernsee, and Hermann Hauke was able to add a third to them. ${ }^{5}$ Very probably they are the remains of a Tegernsee antiphoner, and the order of chants follows the Benedictine cursus. The first leaf in order of the liturgical cycle has chants for one of the summer Sundays (De Sapientia), while the second leaf has office chants for the Assumption of Mary (15 August), the Beheading of John the Baptist (29 August) and the Nativity of Mary (8 September). Then there is another gap, yet not a large one: the third leaf has a good part of the office for St Maurice (22 September) - most of the Second Nocturn, the Third Nocturn, and Lauds - and then just the

2 Editions and studies are gradually making the wealth of material from this area better known. See, for example: Hiley/Berschin 2004; Hiley 2014; Klugseder 2008a.

3 Toy 2009.

4 Hiley 2015b.

5 Three very useful volumes describing fragments in the Bayerische Staatsbibliothek have been published, following the reordering of the sources according to liturgical type: Hauke 1994-2013. For Clm 29316(38 see vol. 2 (2001), 50. 
start of an antiphon for St Emmeram of Regensburg, who shares the same feast day (see Figs 1a and 1b). Maurice obviously had priority over Emmeram at the monastery where the antiphoner was used; presumably the antiphon for Emmeram was for the Magnificat at Second Vespers, where he could be commemorated.

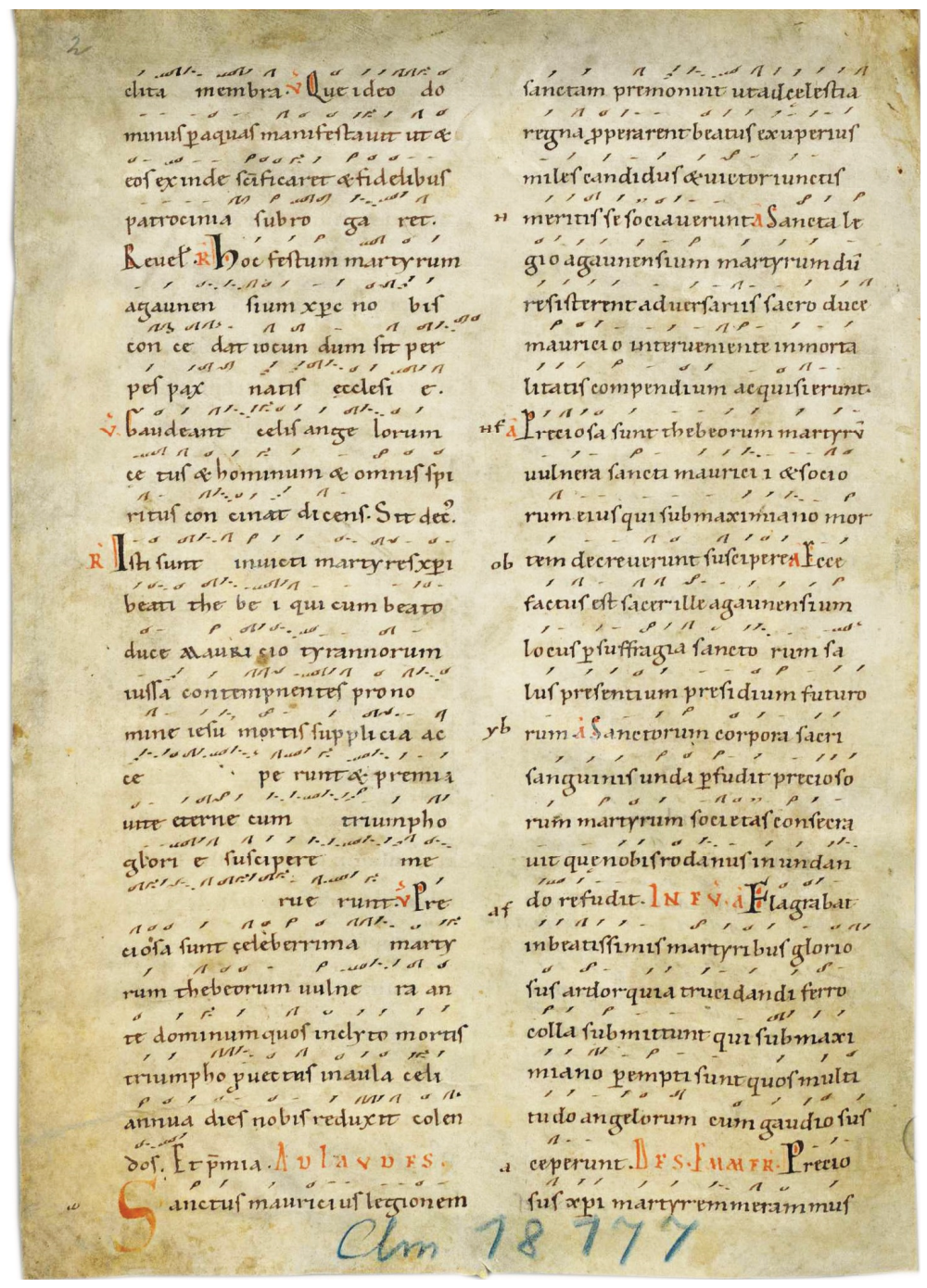

Fig. 1a: Munich, Bayerische Staatsbibliothek, Clm 29316(38, f. 3v; (C) Munich, Bayerische Staatsbibliothek. 
The Emmeram antiphon, Preciosus Christi martyr, is a very rare item. The situation is somewhat complicated. The story begins toward the end of the eighth century. Manuscript Paris, Bibliothèque Nationale, lat. 2990A, according to Bernhard Bischoff from the circle of Arn, abbot of Saint-Amand and bishop (later archbishop) of Salzburg, contains the vita of St Emmeram written by Arbeo of Freising about 770, followed by the texts of a full cycle of Matins chants (but neither Vespers nor Lauds) for the saint's feast day. While it is certain that at least some of these chants were sung in Regensburg, around 1030 the monk Arnold of the Benedictine monastery of St Emmeram composed a new cycle, and almost all preserved sources of Emmeram chants have Arnold's cycle. ${ }^{6}$ However, a fragment written in the late tenth or early eleventh century, originally from St Emmeram's and now in the Lilly Library at the University of Indiana in Bloomington, has eight 'pre-Arnold' Emmeram chants, or the remains of them.

We have no other Regensburg sources for this office, only for Arnold's new cycle. ${ }^{7}$ However, Barbora Kabátková recently made the surprising - and very welcome - discovery that a form of the older Emmeram office was still sung in St George's Prague in the twelfth century. A St George's antiphoner with staff notation enables us to transcribe all the old antiphons, but only three of the nine old responsories are used. What about the fragment Clm 29316(38 from Tegernsee? The antiphon, of which just the start is preserved, is the opening antiphon in Indiana and Prague, where it functions as the Magnificat antiphon at First Vespers; it is not in Paris 2990A, which has only the Matins cycle. We may conclude that in Tegernsee, on St Maurice's Day, it was customary to include a commemoration of Emmeram, and the antiphon still used at Tegernsee in the twelfth century was one dating back at least to the tenth century, perhaps even to Carolingian times.

\footnotetext{
6 We have what may be Arnold's autograph in Munich, Bayerische Staatsbibliothek, Clm 14870, which contains one of the two books he wrote about the St Emmeram, then the historia.

7 See Yeager 2009. The relationship between the source in Paris (early ninth century) and the fragment in Indiana (up to two centuries later) is not clear. Yeager argues that Indiana retains something of a yet older version, of which the Matins cycle in Paris is a revision.
} 


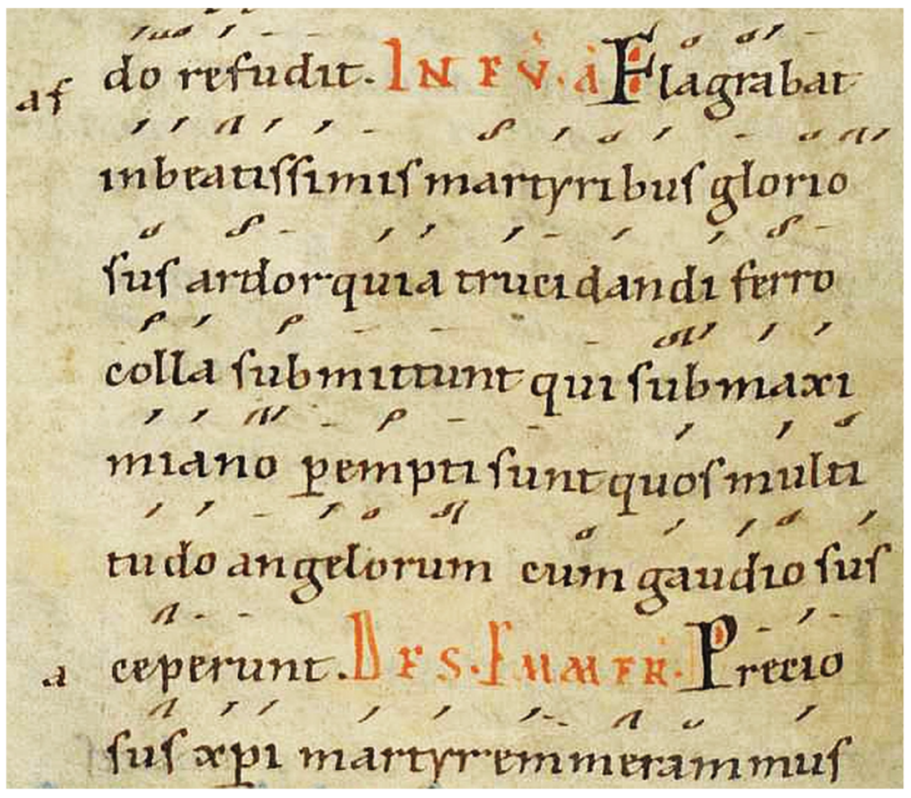

Fig. 1b: Munich, Bayerische Staatsbibliothek, CIm 29316(38, f. 3v (detail); (C) Munich, Bayerische Staatsbibliothek.

\section{Munich, Bayerische Staatsbibliothek, Clm 536 - Vitus}

It is extremely fortunate that so much of the Carolingian office for Emmeram can be transcribed. There are numerous examples where this is not the case. One may be found in Munich, Bayerische Staatsbibliothek Clm 536, a book of miscellaneous, non-liturgical content written mostly in the Benedictine monastery of Prüll, on the south side of Regensburg, which can be dated fairly exactly to the 1140s. On $\mathrm{f} .1$ there is a drawing of the patron saint of the monastery, Vitus, and Abbot Wernher (1143-1147). At the back of the book are several leaves $(14 \times 20 \mathrm{~cm})$ with a liturgical office for the saint (see Fig. 2):

f. 136v 1V-Am (hexameters)

$$
\text { M-I, M-A1-A5 }
$$

f. 137r M-A6, M-R1-R3

f. 137v M-R4, M-A7-12 


\section{frlager fanch vic}

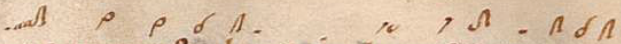

uvs umenfa des sume buruf fefta dre

Flor lucamorum '

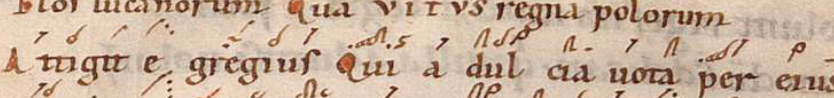

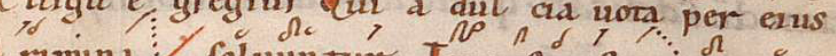

( rmina I foluuntux Tompeftaref re promunzá

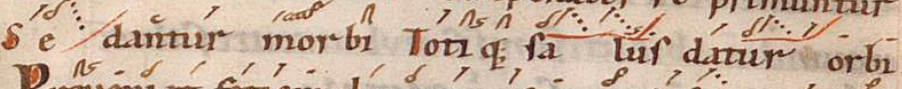

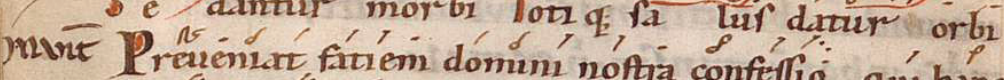

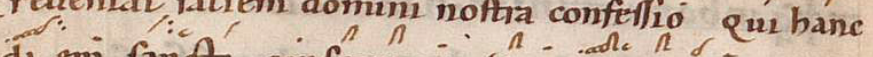
di eni fanch confectaure visi margrizo.

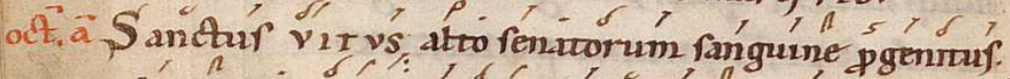
In prouincia lucánía préencí unte gaudá contemp

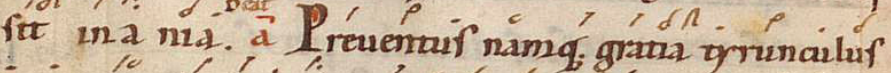

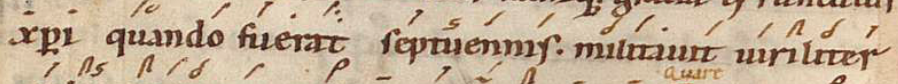

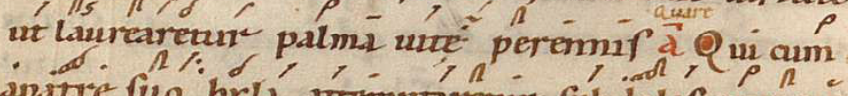

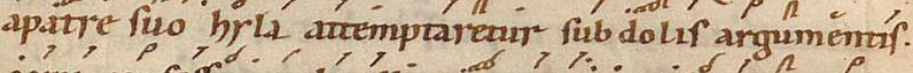

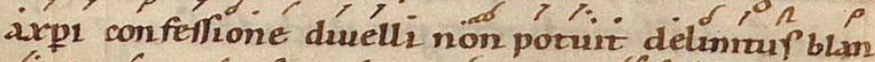

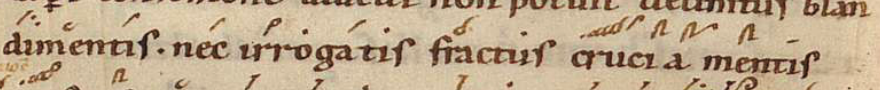

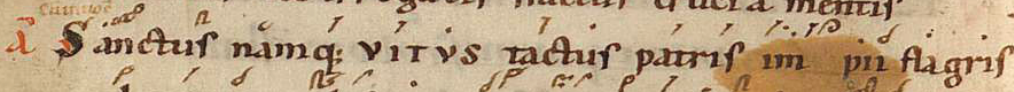
ad parrem celeftem cordir intentionem dirgebat.

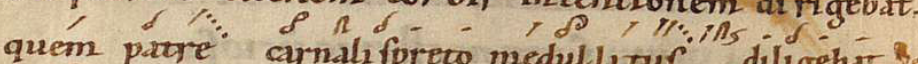
ar of..., carnalifpreco medull our diligebat. Bet a X protani nommif inimicum domine aunc deftruxifi

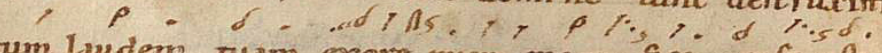
cum laudenn taum exore puen magni fice perfecufti.

Fig. 2: Munich, Bayerische Staatsbibliothek, Clm 536, f. 136v; @ Munich, Bayerische Staatsbibliothek. 
At this point a leaf from an older gospel book has been put in, but the binding material is completed by a half-leaf, on which the Vitus chants continue. On the recto, the responsories for the Second Nocturn, M-R5-R8, are detectable; red V initials, and melismata typical of responsories can be made out. On the verso of the half leaf we have the end of M-R8, then the canticle antiphon at the start of the Third Nocturn, followed by three of the last set of responsories, M-R9-R11 (start). Very little can be seen on the leaf itself, but a great deal more on the offset inside the back board.

We are still short of the end of R11, and final responsory, and Lauds. However, at the front of the book there is another half-leaf, cut the same way as the one at the back, and again a lot can be read from the offset inside the front board. There, we have the end of the Matins responsories, the antiphons for Lauds, and on the verso of the half leaf the two big antiphons for the Benedictus at Lauds and the Magnificat at Second Vespers. One may hope that an undamaged later source with staff notation may some day be discovered.

\section{Schlägl, Stiftsbibliothek, Cpl 262 - Exaltatio crucis}

Since the monastery in Prüll was dedicated to St Vitus there is a good chance that the historia was written there; so far, it has not been found anywhere else. When searching for such chants one relies to a great extent on the immense CANTUS database in Canada. ${ }^{8}$ The larger the database becomes, the more reliable are the indications it gives about concordances and patterns of transmission. As a test case, I may cite some fragments in the library of the Premonstratensian monastery of Schlägl in Austria, north of Passau, quite close to the Czech border. ${ }^{9}$ A few dozen fragments of liturgical music books are preserved there, including two leaves from an antiphoner, now bound at the front and back of a later book, a breviary following the use of Passau. The leaves run consecutively, with chants not for a saint's day but for the feast of the Exaltation of the Cross (14 September) (see Fig. 3). I use this example for two reasons: it demonstrates the usefulness of the CANTUS databases in tracing office chants, and it shows up the lack of comprehensive surveys of neumatic notations.

$8<$ http://cantus.uwaterloo.ca> (accessed 12 Nov. 2019). The project is now directed by Debra Lacoste.

9 For further information on chant sources in the Stiftsbibliothek at Schlägl see Hiley 2019. 


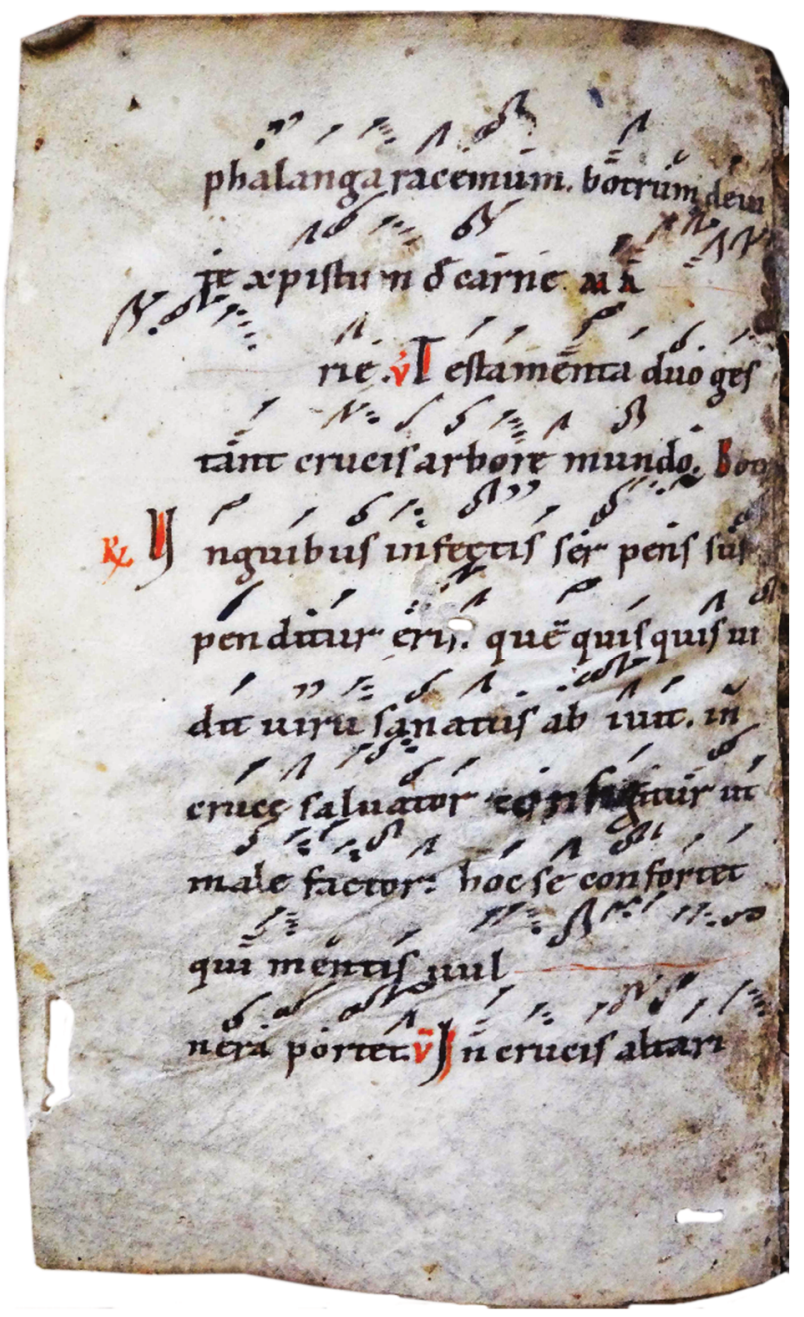

Fig. 3: Schlägl, Stiftsbibliothek, Cpl 262, f. Bv; @ S Schlägl, Stiftsbibliothek.

The original antiphoner was a small book, only about $9 \times 14 \mathrm{~cm}$. In the fragment, there are altogether eight fully notated chants for the First and Second Nocturn of Matins, following the secular, not monastic cursus; of these eight chants, I have found only four elsewhere. Interestingly, the four peculiar to this fragment have texts in hexameters, a poetic technique quite popular in twelfth-century offices (though used earlier as well). It seems possible, therefore, that the author took a previously existing set of chants and added new pieces in a newer style. 
However, his starting point was not an old antiphoner of the Roman-Frankish mainstream, but something more local. Of the four pieces known elsewhere, the responsory Adoramus te Christe is found quite often among South German antiphoners, but the remaining three turn up only in Bohemian sources. One may therefore surmise that the fragment is from a book compiled under Bohemian influence, perhaps brought to Schlägl from Bohemia, since it follows the cursus saecularis, rather than the cursus monasticus obtaining at Premonstratensian Schlägl.

The notation has plenty of individual character which should make at least an approximate localization possible, but unfortunately we do not yet have reliable surveys against which it can be measured. The neumes are obviously German; they slant steeply, which not all varieties of Germanic neumes do. Among the finer details I would single out the final serif on liquescent neumes (cf. Fig. 3: e.g. testament $a$, inguibus, quem); this should in theory be enough to help place the fragments in the chant notation landscape. ${ }^{10}$

\section{Regensburg, Staatliche Bibliothek, Theol.syst.704 - Catherine and Margaret}

The same is true of my third example, a moderately large leaf pasted around the outside of a smaller book. The leaf is now about $16.5 \mathrm{~cm}$ across and $24 \mathrm{~cm}$ high (see Fig. 4). With regard to the notation, we would still classify these as German neumes, although of a quite different variety from the previous example: the musical signs in the Regensburg fragment stand bolt upright, and for most of the vertical strokes the pen moves downwards, from top to bottom. Once again, a detailed map of German chant notations would help localise the fragment.

10 An early witness to this scribal trait is the Reichenau troper, Bamberg, Staatsbibliothek, msc. lit. 5 <https://bavarikon.de/object/SBB-KHB-00000SBB00000127> (accessed 12 Nov. 2019). 


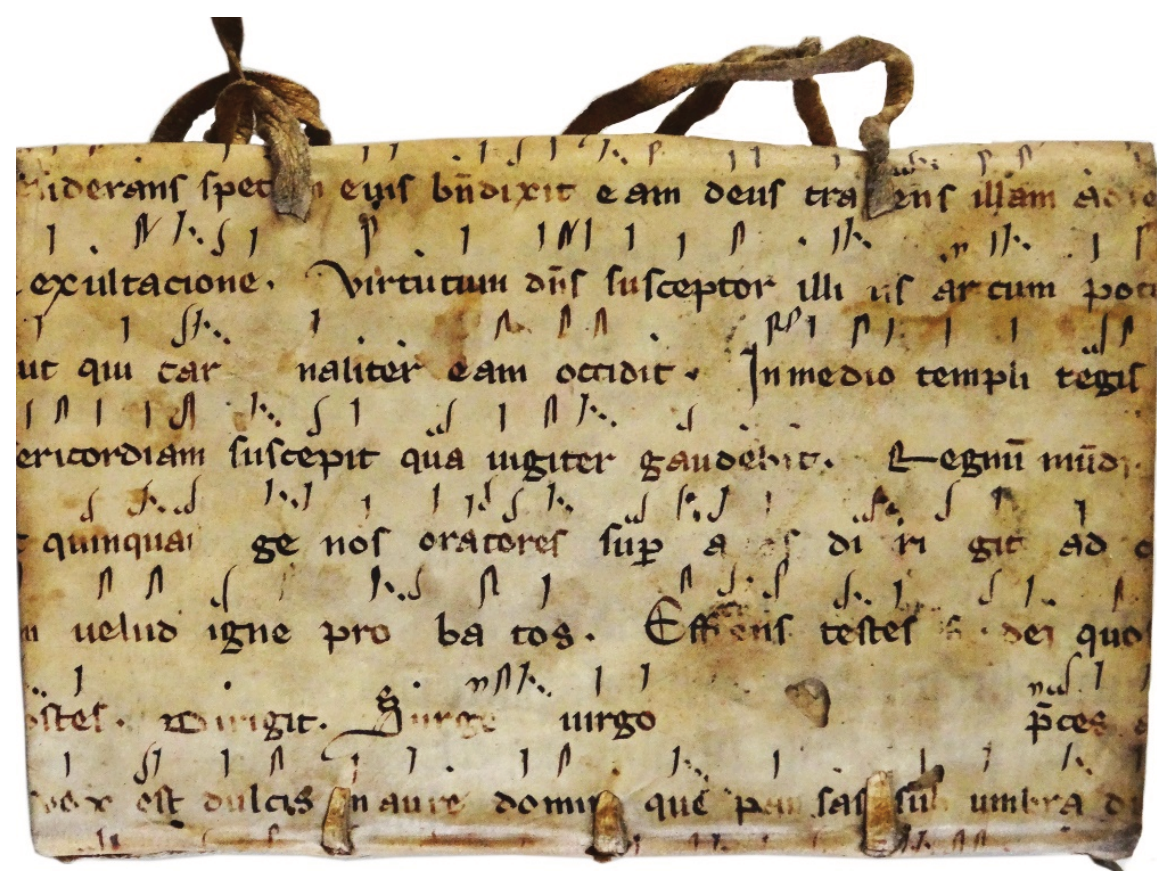

Fig. 4: Regensburg, Staatliche Bibliothek, Theol.syst.704, front cover; @ Regensburg, Staatliche Bibliothek.

The chants belong to the Second and Third Nocturns of Matins, and the start of Lauds (see Table 1). Checking concordances with the aid of the Cantus website produces intriguing results. It turns out that these items are from two distinct offices, both well known in South Germany. The Margaret set usually starts with the Magnificat antiphon Magnificemus Dominum, the Catherine cycle with Magnificat antiphon Inclita sancte virginis. At present, it is not clear how or why the cycles have been combined, or if something similar can be found elsewhere.

Table 1: Contents of Regensburg, Staatliche Bibliothek, Theol.syst.704.

\begin{tabular}{llll}
\hline & & \multicolumn{2}{l}{ Second Nocturn of Matins } \\
$\begin{array}{l}\text { upper } \\
\text { board }\end{array}$ & Ant. 1 & $\begin{array}{l}\text { [De]siderans speciem eius benedixit eam deus } \\
\end{array}$ & Margaret \\
& Ant. 2 & Virtutum dominus susceptor illius arcu & Margaret \\
& Ant. 3 & In medio templi regis [sempiternam] & Margaret \\
\hline
\end{tabular}


Table 1 (continued): Contents of Regensburg, Staatliche Bibliothek, Theol.syst.704.

\begin{tabular}{|c|c|c|c|}
\hline & Resp. 1 & Regnum mundi * [s.n.] & Commune \\
\hline & Resp. 2 & $\begin{array}{c}{[\mathrm{He}] \text { c quinquagenos oratores superatos }} \\
\text { V. Efficiens testes fidei }\end{array}$ & Catherine \\
\hline \multirow[t]{2}{*}{ spine } & Resp. 3 & $\begin{array}{l}\text { Surge virgo [et nostras sponso] } \\
\text { V. [Pulchre Sion filia]. [Gloria P]atri }\end{array}$ & $\begin{array}{l}\text { Catherine and } \\
\text { Margaret* }\end{array}$ \\
\hline & & Third Nocturn of Matins & \\
\hline \multirow{9}{*}{$\begin{array}{l}\text { lower } \\
\text { board }\end{array}$} & Ant. 1 & Dicta sunt gloriosa de te [virgo] & Margaret \\
\hline & Ant. 2 & In populis [annuntiemus] & Margaret \\
\hline & Ant. 3 & Tubis inductilibus psallat omnis spiritus & Margaret \\
\hline & Resp. 1 & Ex eius $t[u m b a]$ * [s.n.] & $\begin{array}{l}\text { Nicholas and } \\
\text { Catherine }\end{array}$ \\
\hline & Resp. 2 & [Vir]go veneranda * [s.n.] & Margaret \\
\hline & Resp. 3 & Felix regina * [s.n.] & Catherine \\
\hline & & Lauds & \\
\hline & Ant. 1 & Passionem gloriose [virginis] Katherine & Catherine \\
\hline & Ant. 2 & $\begin{array}{l}\text { Post plurima supplicia martir alma ad } \\
\text { decollan[dum] }\end{array}$ & Catherine \\
\hline
\end{tabular}

* R. Surge virgo et nostras sponso (602290) is common to Margaret (f. 179v) and Catherine (f. 322v) in Graz, Universitätsbibliothek, MS 30 (St Lambrecht, fourteenth century). ${ }^{11}$

\section{Munich, Bayerische Staatsbibliothek, Clm 17212 - Afra}

MS Clm 17212 in Munich is a very interesting compilation of medieval texts (Marbod, Hildebert, etc.). The book came to the royal library from Premonstratensian Schäftlarn, although it may not have originated there. Inside the front cover is a pastedown and four leaves of disparate content including liturgical chants. The first of the four, measuring $11.5 \times 18 \mathrm{~cm}$, is of significance for the present chapter (see Fig. 5).

11 Available online: <http://143.50.26.142/digbib/handschriften/Ms.0001-0199/Ms.0030> (accessed 12 Nov. 2019). 


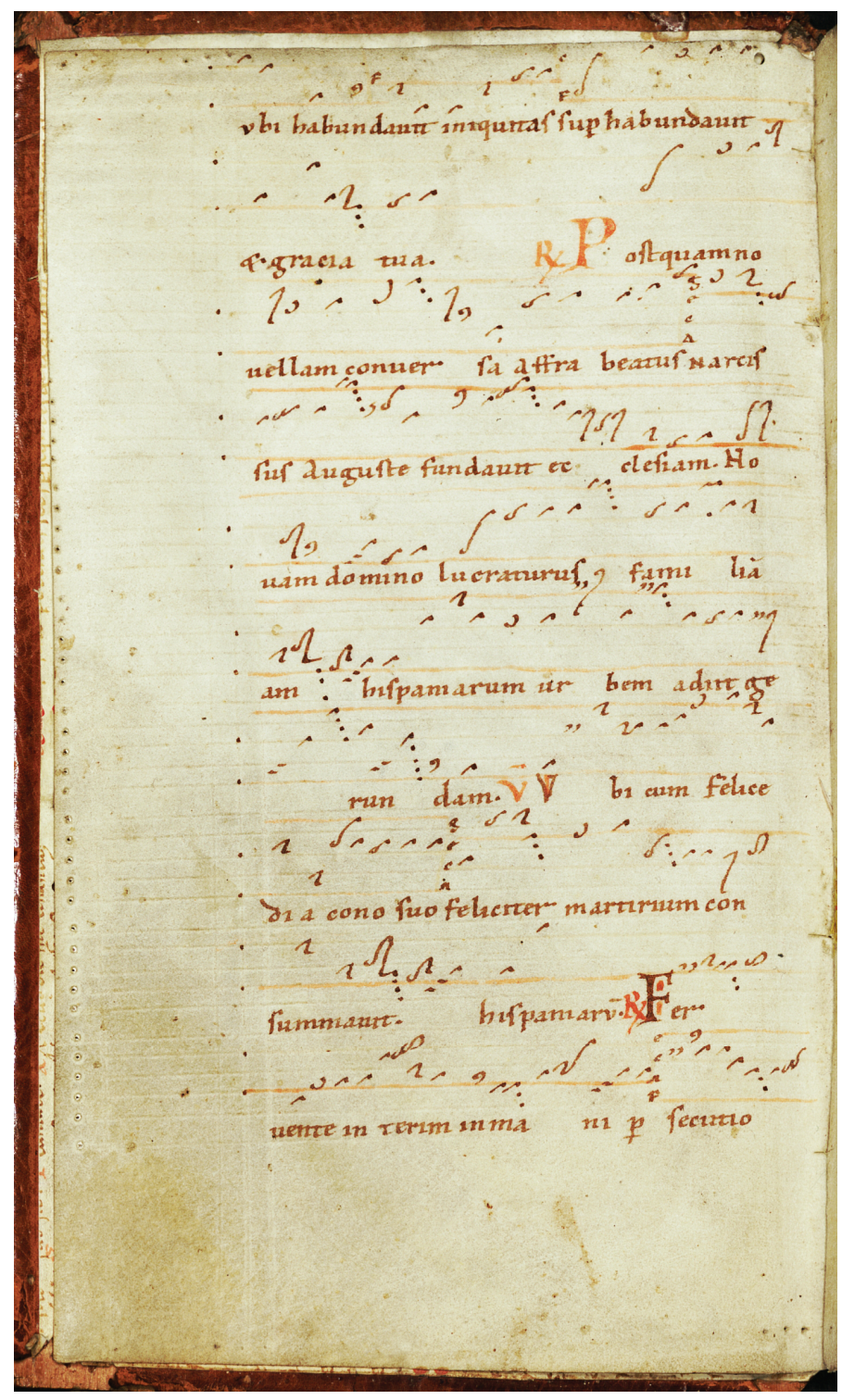

Fig. 5: Munich, Bayerische Staatsbibliothek, Clm 17212, f. Iv; @ Munich, Bayerische Staatsbibliothek. 
The recto is ruled for music but remains blank, the verso has the remains of three responsories from the office of St Afra of Augsburg. ${ }^{12}$ This is a well-known historia, composed by Hermannus Contractus of Reichenau (1013-1054).

We have two other complete offices composed by Hermannus, and all three share a very ornate and adventurous melodic style, far removed from 'classical Gregorian'. Their transmission would have been greatly helped by the use of staff notation, but there is no evidence that Hermannus had them copied this way. He did invent an ingenious interval notation, where the interval from one note to the next, up or down, is indicated, but this seems usually to have been used not for notating complete melodies, rather only as a supplement to normal neumatic notation, for marking isolated tricky intervals. There are several early copies of the Afra chants with unheighted neumes, and one twelfth-century copy with staff notation, Munich, Bayerische Staatsbibliothek, Clm 23037, a notated breviary from the Benedictine monastery of Prüfening, on the outskirts of Regensburg.

Fascinatingly, all other chants in the Prüfening breviary are notated with unheighted neumes, and only Hermannus's difficult chants are written using staff notation. ${ }^{13}$ However, the staff notation in the Prüfening copy, Clm 23037, is not the same as in the fragment Clm 17212. Prüfening follows the old practice of making a distinction between single low notes and single high notes, punctum and virga, whereas all single notes in the fragment are written as small barbs ('uncinus'), or upside-down ticks. This is a well-known distinction, one of several, between neumes descended from the old German type found in St Gall, or Regensburg, or Quedlinburg, and a type related perhaps rather distantly to the old North-East French type sometimes called 'Messine' (from Metz) or 'Lotharingian'. Prüfening was one of several houses affiliated to the reform monastery of Hirsau in the Black Forest, and houses of this group use the German type of early staff notation. The other type is found among other places at Ottobeuren (Clm 9921), and we find it in Klosterneuburg on the Danube north of Vienna. But it was also used in Augsburg (Vienna, Österreichische Nationalbibliothek, 573; Munich, Bayerische Staatsbibliothek, Clm 22025 [flyleaf]; and the music theory collection Wolfenbüttel, Herzog August Bibliothek, Gud.lat.334). ${ }^{14}$ It is distinctly possible that the fragment Clm 17212 was also written in Augsburg, specifically at the monastery of St Ulrich and Afra, in which case it would constitute the oldest known source from that monastery with chants of its patron saint. What I cannot explain is why the Afra chants start in the middle of a responsory on the verso side of the leaf.

12 I am most grateful to Henry Parkes for bringing this fragment to my attention.

13 Edition cited in n. 2 above. On the change of notation see Schlager 1984.

14 Szendrei 1992; Klugseder 2008b, 72-75. 


\section{Munich, Bayerische Staatsbibliothek, Clm 12027 - George}

Finally, I come round in a circle to Regensburg again, or more specifically to Prüfening, and two other leaves with the abbey's early staff notation. Clm 12027 is a large collection of sermons copied by Johannes Kopp, monk and later abbot of Prüfening, dated 1468. The flyleaves, one at the front and one at the back, are from an antiphoner, certainly of the twelfth century. They are nearly continuous, a bifolio between the two is lost (see Fig. 6, Table 2).

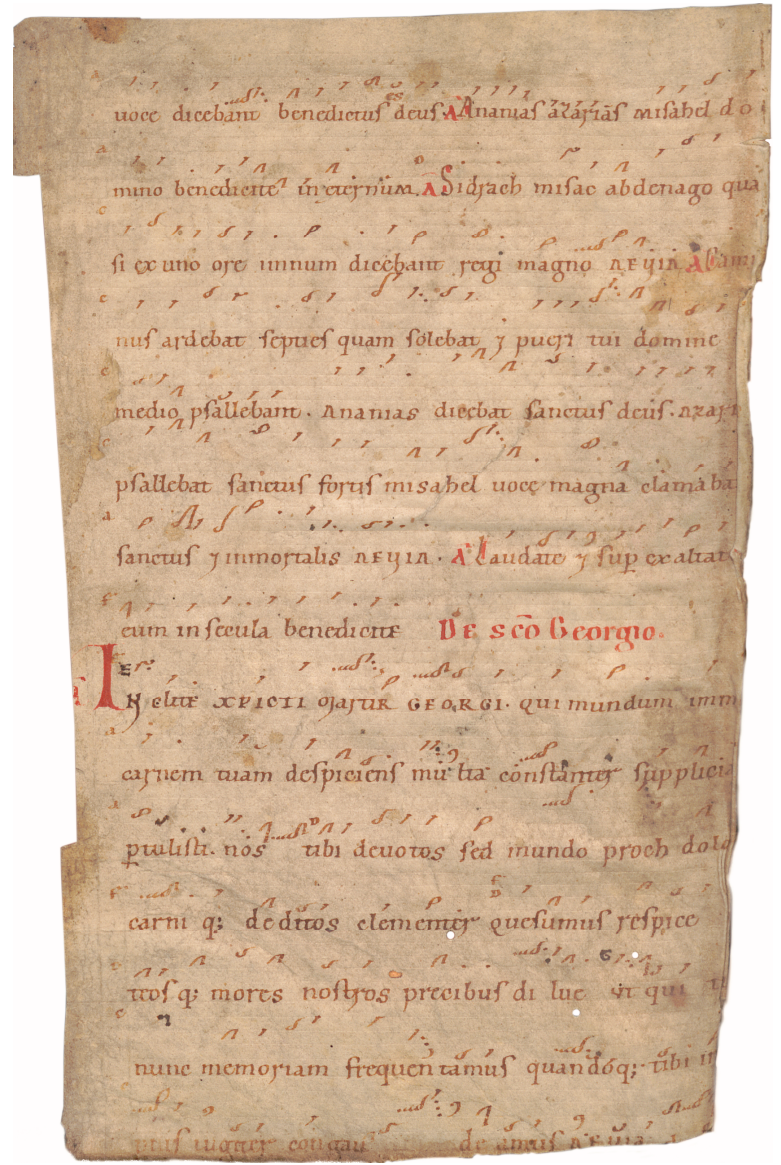

Fig. 6: Munich, Bayerische Staatsbibliothek, Clm 12027, f. Iv; @ Munich, Bayerische Staatsbibliothek. 
Table 2: Flyleaves in CIm 12027.

\begin{tabular}{lll}
\hline flyleaf at front $[\mathrm{A}]$ & recto & George, Officium Defunctorum \\
& verso & Ad Benedicite, George \\
flyleaf at rear $[\mathrm{B}]$ & recto & De Prophetis \\
& verso & De Prophetis \\
Correct order: $\mathrm{Bv}, \mathrm{Br}, \mathrm{Av}, \mathrm{Ar}$ & \\
\hline
\end{tabular}

$\mathrm{Bv}$ [De Prophetis]

[R. Super muros tuos Iherusalem. V. Qui reminisci]mini domini ne taceatis

R. Muro tuo inexpugnabili. V. Erue nos Domine in mirabilibus tuis

R. Sustinuimus pacem et non venit. V. Peccavimus cum patribus nostris

R. Misit dominus angelum suum et conclusit ora leonum. V. Misit deus misericordiam suam

R. Angustie [mihi sunt undique]

$\mathrm{Br} \quad[\mathrm{R}$. Angustie mihi sunt undique ..... l]egem dei mei. V. Si enim hoc egero mors

R. Laudabilis populus quem dominus. V. Beata gens cuius est dominus

R. Genti peccatrici populo. V. Esto placabilis

R. A facie furoris tui Deus. V. Converte nos Deus

R. Qui celorum contines thronos

Av [A. Tres pueri iussu regis .....] voce dicebant benedictus Deus

A. Ananias Azarias Misahel domino

A. Sidrach Misac Abdenago quasi ex uno ore

A. Caminus ardebat septies quam solebat

A. Laudate et superexaltate

De Sco Georgio

Inclite Christi martir

Ar [A. Egregius Dei martyr Georgius .....] per illum Dominus

[Pro Defunctis]

R. Scio enim quia redemptor meus vivit. V. Surgent

[Ottosen 85]

R. Putasne mortuus homo rursum. V. Ecce in pulvere [Ottosen 70]

R. Ne tradas.

[Ottosen 58]

There is in fact no good reason to query the provenance of the fragment, found in a Prüfening book, employing early Germanic staff notation like that of the Afra office in the Prüfening breviary $\mathrm{Clm}$ 23037, and with two chants for the monas- 
tery's patron saint George. But it is worth identifying all the pieces on the fragment more exactly.

The two leaves would originally have come towards the end of an antiphoner. The leaf now at the back comes first, what is now the verso side was originally the recto. In their original order, the chants start with responsories for the series De Prophetis, that is, for the Sundays at the end of the church year, just before Advent and the start of a new annual cycle. Matins lessons through the summer are taken from various books of the Old Testament: Kings, Ecclesiastes, Job, Tobit, Judith, Maccabees, Ezekiel [or Prophets], and the responsories take verses from the same books.

Some chants are gone with the lost bifolio, because the next items on the fragment are Benedicite antiphons for Lauds (L-A4) for the same Sundays, we have the last five of the group. We can compare these responsories and antiphons with completely preserved series, using the CANTUS lists and checking other sources - I have been able to compare about two dozen sources from the South German area. There must originally have been seventeen responsories in the series. The first three and the last five are lost from the fragment, and those that are left correspond with the selection and order in just two other sources known to me: the Prüfening breviary Clm 23037, and an antiphoner from Zwiefalten, Karlsruhe, Badische Landesbibliothek, MS 60. Karlsruhe 60 is a well-known member of a group of sources from the Hirsau congregation of Benedictine monasteries, of which Prüfening was also a member. Fewer sources include the Benedicite antiphons, but Karlsruhe 60 is one of those few, so we can complete this fragmentary series as well.

At this point the two antiphons for St George appear, and finally the start of another series of responsories, for the Office of the Dead, only three items out of the nine which were usual, but nevertheless significant. The Danish liturgist Knud Ottosen, building on the work of Gabriel Beyssac, Michel Huglo and others, compiled lists of these responsories from over 2000 sources. ${ }^{15}$ Although only just over 100 different responsories are involved, their selection and order is very variable. ${ }^{16}$ Our fragment has only two responsories and the start of a third, Ottosen numbers 8570 58. The result is surprising. Only one source in Ottosen's lists begins thus: Munich, Bayerische Staatsbibliothek, Clm 26221. Ottosen gives no

15 Ottosen 1993.

16 The work of comparing series across so many sources was transformed when Robert Klugseder transferred them from Ottosen's book into a database, where they can be sorted very conveniently. <https://www.uni-regensburg.de/Fakultaeten/phil_Fak_I/Musikwissenschaft/cantus/index.htm> Databases Responsories for the Office of the Dead (accessed 12 Nov. 2019). 
provenance for the manuscript, nor does the summary catalogue of the Bavarian State Library. ${ }^{17}$ In fact, Clm 26221 is one of the group of ten more or less unknown breviaries now shelved together, several of which come from Regensburg. ${ }^{18}$ Both $\mathrm{Clm} 26221$ and the previous item in the catalogue, $\mathrm{Clm} 26220$, turn out to be from Prüfening: they both have special prayers for Bishop Otto of Bamberg, founder of the monastery, both observe Otto's translation day as well as his main feast, and both rubricate the two St George antiphons for the canticles at Lauds and Vespers. One is still left with the question of why the two George antiphons should have been copied at this point in the original antiphoner. It may be hoped that, with the expansion of resources for comparing both fragments and more fully preserved sources, an answer to this question and to some of the others raised above will be found. Time will tell.

\section{Abbreviations}

$\begin{array}{ll}\text { 1V } & \text { First Vespers } \\ 2 \mathrm{~V} & \text { Second Vespers } \\ \mathrm{A} & \text { Antiphon } \\ \mathrm{Ab} & \text { Antiphona ad Benedictus } \\ \mathrm{Am} & \text { Antiphona ad Magnificat } \\ \mathrm{L} & \text { Lauds } \\ \mathrm{M} & \text { Matins } \\ \mathrm{R} & \text { Responsory }\end{array}$

\section{References}

Berschin, Walter (1975), 'Uodalscalcs Vita S. Kuonradi im hagiographischen Hausbuch der Abtei St. Ulrich und Afra [Uodalscalc-Studien I]', in Freiburger Diözesan-Archiv, 95: 82106.

Hauke, Hermann (ed.) (1994-2013), Katalog der lateinischen Fragmente der Bayerischen Staatsbibliothek München, 3 vols, Wiesbaden: Harrassowitz.

Hiley, David (2014), 'The historia for Sts Marinus and Anianus composed at Rott am Inn in Bavaria', in Robert Klugseder (ed.), Cantare amantis est. Festschrift zum 60. Geburtstag von Franz Karl Praßl, Purkersdorf: Hollinek, 163-171.

17 Schmeller 1881, II/4, 178.

18 The library has scores of such books, still awaiting investigation. 
Hiley, David (2015a), The Office of Saint Julian of Le Mans by Letald of Micy (ca. 1000) (Wissenschaftliche Abhandlungen/Musicological Studies 65/25), Lions Bay: Institute of Medieval Music.

Hiley, David (2015b), 'Gens laudum titulis concrepet Anglica: The Proper Office for St Oswin, King of Deira', in John Bergsagel, David Hiley, and Thomas Riis (eds), Of Chronicles and Kings. National Saints and the Emergence of Nation States in the High Middle Ages, Copenhagen: Museum Tusculanum Press, 251-270.

Hiley, David (2019), 'Die Choralhandschriften in der Stiftsbibliothek Schlägl im Kontext der süddeutschen liturgischen Traditionen', in Ulrich G. Leinsle and Petrus A. Bayer (eds), Stift Schlägl - Beiträge zu Geschichte und Kultur, Linz: Wagner, 49-84.

Hiley, David, and Walter Berschin (2004), Hermannus Contractus (1013-1054): Historia sanctae Afrae martyris Augustensis (Wissenschaftliche Abhandlungen/Musicological Studies 65/10), Ottawa: Institute of Medieval Music.

Klugseder, Robert (2008a), Historia Sancti Quirini, Historia Sancti Chrysogoni aus dem Benediktinerkloster Tegernsee (Wissenschaftliche Abhandlungen/Musicological Studies 65/14), Ottawa: Institute of Medieval Music.

Klugseder, Robert (2008b), Quellen des gregorianischen Chorals für das Offizium aus dem Kloster St. Ulrich und Afra Augsburg (Regensburger Studien zur Musikgeschichte 5), Tutzing: Hans Schneider.

Ottosen, Knud (1993), The Responsories and Versicles of the Latin Office of the Dead, Aarhus: University Press.

Schlager, Karlheinz (1984), 'Neumenschrift und Liniensystem. Zum Notationswechsel in der Münchener Handschrift Clm 23037', in Musik in Bayern, 39: 31-41.

Schmeller, [Johann] Andreas (1881), Catalogus Codicum Latinorum Bibliothecae Regiae Monacensis, vol. II/4: Codices num. 21406 - 27268 complectens, München: Bibliotheca regia [repr. Wiesbaden: Harrassowitz, 1969].

Szendrei, Janka (1992), 'Linienschriften des zwölften Jahrhunderts auf süddeutschem Gebiet', in László Dobszay, Ágnes Papp, and Ferenc Sebő (eds), Cantus Planus. Papers Read at the 4th Meeting, Pécs, Hungary, 3-8 September 1990, Budapest: Institute for Musicology of the Hungarian Academy of Sciences, 17-54.

Toy, John (2009), English saints in the medieval liturgies of Scandinavian churches (Henry Badshaw Society, Subsidia 6), London: Henry Bradshaw Society.

Yeager, Travis N. (2009), 'The Old Office of St. Emmeram: A New Source Recovered', in Barbara Haggh and László Dobszay (eds), Cantus Planus. Papers Read at the 13th Meeting, Niederaltaich, Germany, Aug. 29 - Sept. 4 2006, Budapest: Institute for Musicology of the Hungarian Academy of Sciences, 683-689. 
Trails 

Jurij Snoj

\title{
Music Fragments from Slovenia: Towards a Reconstruction of the Medieval Plainchant Manuscript Production
}

\begin{abstract}
The article presents the results of a systematic search for fragments of medieval music manuscripts in Slovenian libraries. The material found is analysed in respect of contents (types of manuscripts), notation, and date of the origin. Conjectures are made about the time of the destruction of the manuscripts to which the fragments belonged, as well as concerning the question of which fragments belonged to manuscripts that were actually in use in the country and which have just casually arrived in their present locations. Some more interesting fragments are described in detail.
\end{abstract}

A few decades ago, a systematic search for medieval music manuscripts and fragments was carried out in the libraries and archives of Ljubljana, Slovenia. The aim was to collect and describe all documents written before the Tridentine reforms that included some kind of music notation, be they complete or mutilated music manuscripts, fragments of destroyed music manuscripts or just small music entries in otherwise non-music manuscripts. ${ }^{1}$ In conjunction with the search, a database was compiled, containing all the most important information about the sources found. ${ }^{2}$ At present, the work is in progress and there are still some important libraries or archives outside Ljubljana that need to be thoroughly

1 The following institutions were examined: SI-Lna (Nadškofijski arhiv Ljubljana / Archiepiscopal Archives of Ljubljana), SI-Ln (Narodna in univerzitetna knjižnica / National and University Library), SI-Lz (Zgodovinski arhiv Ljubljana / Historical Archives Ljubljana), SI-Las (Arhiv Republike Slovenije / Archives of the Republic of Slovenia), Uršulinski samostan Ljubljana / Ursuline Convent Ljubljana, SI-Lsa (Biblioteka SAZU / The Library of the Academy of Sciences and Arts), SI-Lsk (Semeniška knjižnica / The Seminary Library), SI-Lf (Frančiškanski samostan Ljubljana - Center / The Franciscan Monastery Ljubljana), Knjižnica Narodnega muzeja / The Library of the National Museum. Some other areas across Slovenia were explored in a similar way on a later campaign.

2 Published as a catalogue in the following collection of essays, Snoj 2018, 353-463.

๖ Open Access. ( 2020 Jurij Snoj, published by De Gruyter. (cc)BY-NC-ND This work is licensed under the Creative Commons Attribution-NonCommercial-NoDerivatives 4.0 International License.

https://doi.org/10.1515/9783110717884-005 
surveyed for the presence of medieval music sources. The whole undertaking may be compared to other similar and sometimes much more extensive projects carried out elsewhere at the same time. ${ }^{3}$

The typology of medieval music manuscript sources that have emerged is varied. Even in a relatively small area such as Slovenia, it is possible to find different classes of codices, or fragments thereof, that are of relevance for the study of the musical life in the Middle Ages: plainchant manuscripts of various types, primarily intended for singers; other liturgical manuscripts not intended for musical performance yet occasionally containing notated chants (e.g. missals, psalters, pontificals); non-notated liturgical manuscripts where individual chants were only later provided with musical notation; music records and marginalia in non-musical codices which seem to have no connection with the contents of the manuscripts; scraps of polyphony; music treatises and printed chant books either complete or fragmentary. Such typological diversity implies, at least to some degree, a variety of functions that music and singing had in the daily life of medieval liturgical communities. Not surprisingly, the great majority of the sources found represent fragments of destroyed music codices.

\section{A statistical overview}

I will start by presenting a statistical overview of the whole collection of fragments. ${ }^{4}$ At the current stage of research, in Slovenia there are 618 complete and incomplete folios and 158 tiny parchment or paper scraps containing some kind of music notation, possibly coming from 222 different original manuscripts. Among these, the most numerous by far are liturgical manuscripts containing plainchant, while others include a few fragments with polyphonic music and a fragment of a theoretical treatise.

3 Such as Szendrei 2002; Brunius 2005; Veselovská 2002; Veselovská 2006. There are several reports on similar projects in the proceedings quoted above as well as in the following ones Brownrigg/Smith 2000; Hiley 2004. Collections of medieval music fragments can also be found in a number of different websites, e.g. Slovakian Early Music database <http://cantus.sk>, Medieval Manuscripts and Parchment Fragments from Finland <https://pro.europeana.eu/data/ medieval-manuscripts-and-parchment-fragments-from-finland>, Musikalische Quellen des Mittelalters in $\operatorname{der} O ̈ N B<$ http://www.cantusplanus.at/de-at>, etc.

4 The overview is based on the printed catalogue of medieval music sources in Slovenian libraries Snoj 2018. 
The difference between the number of folios found and the number of manuscripts they belonged to suggests that many of the reconstructed fragments consist just of a small number of folios. Table 1 shows the number of the preserved folios of 215 fragments of plainchant manuscripts. The most numerous are fragments consisting of just one or two complete or almost-complete folios, constituting more than half of the whole collection. The number of destroyed liturgical manuscripts surpasses the needs of the churches that existed in the territory of Slovenia, suggesting that they come from a wider central-European area, and not just from Slovenian locations.

Table 1: The extent of the plainchant fragments.

\begin{tabular}{|c|c|}
\hline No. of fragments & No. of folios \\
\hline 118 & 1 \\
\hline 52 & 2 \\
\hline 5 & 3 \\
\hline 13 & 4 \\
\hline 2 & 5 \\
\hline 6 & 6 \\
\hline 1 & 7 \\
\hline 4 & 8 \\
\hline 2 & 9 \\
\hline 3 & 10 \\
\hline 1 & 11 \\
\hline 1 & 14 \\
\hline 1 & 16 \\
\hline 1 & 21 \\
\hline 1 & 22 \\
\hline 1 & 24 \\
\hline 1 & 28 \\
\hline 1 & 35 \\
\hline 1 & 39 \\
\hline Total: & 265 \\
\hline
\end{tabular}

The most extensive group, that of liturgical plainchant manuscripts, requires further distinguishment. Firstly, the group can be divided according to the type of musical notation and, thus, also according to an approximate date of 
production (Table 2). The most numerous are fragments in German 'GothicMessine' notation, followed by fragments in square notation, and those in German adiastematic neumes, while other types of notation are less represented.

Table 2: The notation of plainchant fragments. ${ }^{5}$

\begin{tabular}{lll}
\hline Notation & No. of folios & No. of manuscripts \\
\hline German adiastematic & $50,51^{\star}, 46^{\star \star}$ & 30,4 \\
Other adiastematic & $1,5^{\star}, 10^{\star \star}$ & 4,1 \\
German stave & $2,6^{\star}$ & 5 \\
Cistercian & $2,2^{\star}$ & 2 \\
Italian stave & $6,2^{\star}, 1^{\star \star}$ & 3 \\
Gothic Messine & $218,138^{\star}, 40^{\star \star}$ & 88 \\
Hufnagelschrift & $5,6^{\star}$ & 8 \\
Other Gothic & $11,7^{\star}, 34^{\star \star}$ & 22,3 \\
Square & $48,46^{\star}, 26^{\star \star}$ & 44,1 \\
\hline Total: & $343,263^{\star}, 157^{\star \star}$ & 215 \\
\hline
\end{tabular}

Strictly speaking, however, every fragment calls for a detailed analysis of its notation. Some fragments were too small to allow for an identification of the notation. Furthermore, the identification of notational types by following commonly accepted categories may not always lead to an adequately exact definition of the notation of a particular fragment. This is due to a multitude of hybrid types of music scripts, as well as the different practices of writing music. By analysing the notation of fragments in German adiastematic neumes, for example, it is possible to observe that they do not function in a fully systematic, and internally coherent way. Besides those graphical differences between particular elements of the script that do not affect the musical meaning (e. g. the graphical form of the virga, the axis of the script, etc.), discrepancies are evident in the composition of the signs and in their meaning. For instance, in one fragment (Fig. 1) there are many quilisma signs but no scandicus signs: from the comparison of the melodic

5 In the third column, the second number refers to fragments of liturgical manuscripts with occasional musical entries that do not appear to be an essential part of their contents, e.g. breviaries and lectionaries with later music insertions. Incomplete folios and scraps are marked respectively with one asterisk, and two. 
version with other sources, it becomes clear how in this fragment the quilisma stands for the ordinary scandicus. ${ }^{6}$

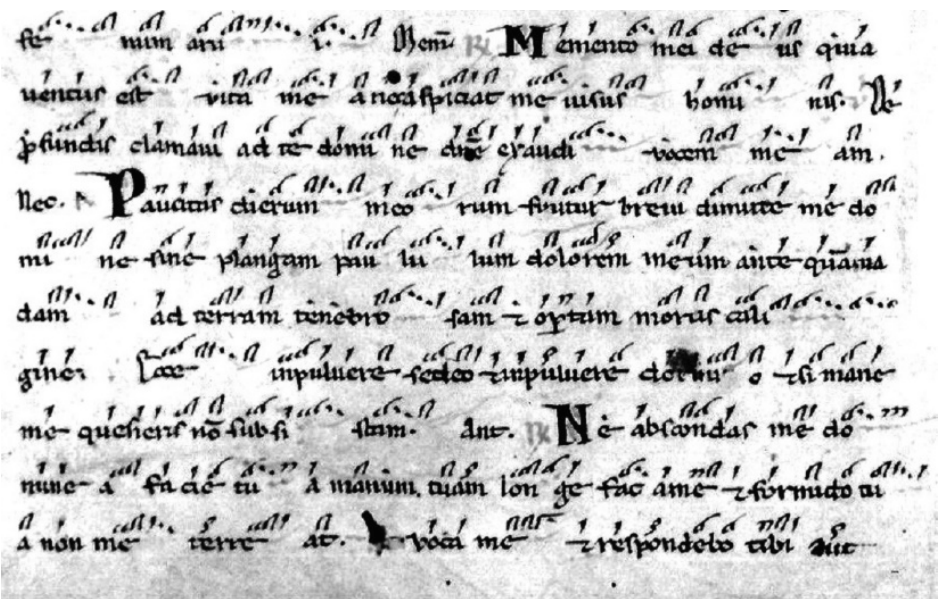

Fig. 1: Novo mesto, Franciscan Monastery, inv. n. 7202 (fragment in the binding), Historia Job; (c) Novo mesto, Franciscan Monastery.

Unlike fragments featuring German neumes, the notation of those in German 'Gothic-Messine' appears to be more homogeneous. 'The essential characteristics of this notation are (cf. Figs 2 and 5): (1) the punctum is normally used as the sign for a single note, while the virga is employed for this function only exceptionally; (2) the clivis (or flexa) is represented by two joined puncta, rather than with the graphic element of the upside-down U, which appears only in various torculi; (3) the compound signs are composed of both punctum and virga, the latter standing normally for the highest note in the group, giving the notation its characteristic appearance. All eighty-eight fragments featuring this type of notation match such criteria, with the exception of some fragments in which the virga is used occasionally as a sign for a single note. German 'Gothic-Messine' notation, which seems to have been the most usual way of writing music in South German areas during the late Middle Ages, should be distinguished both from other types of

6 The fragment is no. 2.9 in Snoj 2018.

7 There is no commonly accepted term for such type of notation. Bruno Stäblein refers to this notation as 'Metzer Notation der III. Epoche'; Stäblein 1975, 67-68. The term 'German Messine Gothic' is taken from Hiley/Szendrei 2001. 
Gothic notation, like the so-called 'Hufnagel' which employs the virga as a standard sign for a single note, and the shape of upside-down $U$ for the clivis, as well as from Eastern types of Gothic notation that avoid instead the use of the virga, be it as a sign for a single note or in compound signs.

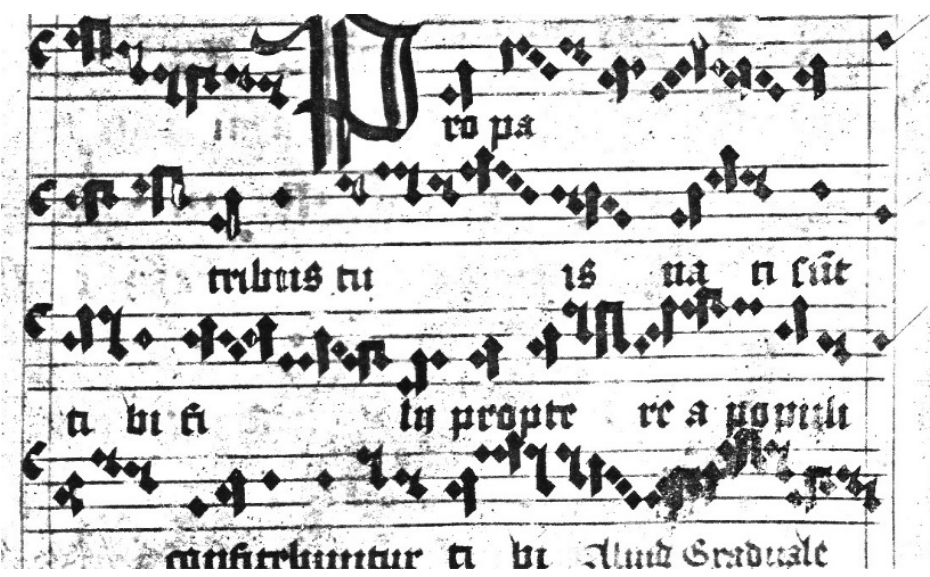

Fig. 2: SI-Lz, LJU/0338, Maculatures II (2), Folder 8, Gradual Constitues eos; @ Ljubljana, Historical Archives.

From this initial survey, it is possible to conclude that the picture of notational types emerging from the fragments discussed corresponds roughly to particular historical circumstances. In the Middle Ages, most of the territory of modern Slovenia belonged to the Holy Roman Empire and, from the mid-fourteenth century, to the Inner Austrian Provinces. This may have been the main reason why South German types of neumatic notation, and later the type of Gothic notation described above, were normally used in this territory, similarly to South German regions and Austria. The notational picture presented gives the impression that, as far as music writing is concerned, political ties affecting every-day life exerted a stronger influence than ecclesiastical ones: ecclesiastically, during the Middle Ages, most Slovenian territories belonged to the Patriarchate of Aquileia (see below) in whose main centres square notation was used already from the second half of the thirteenth century onward. ${ }^{8}$ Notwithstanding, it seems that nonmonastic churches in the Slovenian lands employed manuscripts containing South German notational types. This relationship can be further observed in

8 Camilot-Oswald 1997. 
manuscripts featuring square notation that were in use in the Istrian towns Koper/Capodistria and Izola/Isola, situated in the Venetian part of the Patriarchate. ${ }^{9}$ Instead, the existence of fragments in square notation and in Cistercian notation in Slovenian libraries may be explained by the presence in the country of communities that belonged to monastic orders originating in the West which, in turn, used manuscripts in square notation. Furthermore, all known Carthusian and Franciscan chant manuscripts connected to Slovenian lands are compiled in square notation, and the only known Cistercian manuscript features instead Cistercian notation. ${ }^{10}$

With regard to the content of plainchant fragments, the number of Mass manuscripts almost equals that for the Divine Office (Table 3).

Table 3: Types of manuscripts.

\begin{tabular}{lr}
\hline Type of manuscript & No. of fragments \\
\hline Mass & 11 \\
Notated missal & 49 \\
Gradual & 13 \\
Sequentiary & 2 \\
Kyriale & 7 \\
Missal & \\
Divine Office & 14 \\
Notated breviary & 59 \\
Antiphoner & 5 \\
Psalter & 1 \\
Hymnal & \\
Other & 9 \\
$\quad$ Occasional mus. records & 1 \\
Glagolitic compendium & 44 \\
Unidentified & 215 \\
\hline Total: &
\end{tabular}

9 Snoj 2006.

10 For Carthusian, Franciscan, and Cistercian sources see respectively Šter 2013; Snoj 2013; Snoj 2008. 
It may be mentioned that the majority of plenarium manuscripts, i.e. seven notated missals and eleven notated breviaries, are written in adiastematic neumes, testifying for the gradual disappearance of this type of liturgical manuscripts in the late Middle Ages. In some cases, the book typology cannot be defined unambiguously because of the incompleteness of the fragments, e.g. a folio containing a sequence may be designated as a fragment of a sequentiary, but it could also have come from a gradual, etc. The contents, indeed, of a high number of fragments remain unidentified due to their small size or illegibility.

Another question that can be raised in connection with the fragments of plainchant manuscripts concerns how they have been preserved. Almost all of them survived as bookbinding material. There are, however, noteworthy exceptions, such as the parchment strips employed in an organ mechanism discovered during the restoration of the instrument, or parchment pieces used in the construction of a wooden altar in a village church, discovered during its replacement by a new one. ${ }^{11}$ These examples suggest that it was not only for bookbinding, but also for various other practical purposes that sheets from redundant manuscripts were employed; the majority of these purposes were of such a nature that the sheets disappeared for ever.

Since it is likely that the original manuscripts may have been dismembered at, or close to the moment when their parchment was used by bookbinders, the date of binding may cast light on the history of the manuscripts from which the fragments came from. The figures in Table 4 show the approximate numbers of books, manuscripts or archival documents that were bound at a particular moment of time using folios coming from plainchant manuscripts, revealing that it was most probably in the second half of the seventeenth and early eighteenth centuries that the majority of plainchant manuscripts fell victim to bookbinders' scissors. ${ }^{12}$

11 Respectively, no. 2.41 and no. 2.203 in Snoj 2018. Three fragments have been preserved as complete fascicles (nos. 2.113, 1.181, 2.182).

12 The figures refer to the number of bindings and are therefore higher than the number of fragments. They are approximate: in several cases, it was not possible to determine the time of binding. 
Table 4: Date and number of bindings containing fragments.

\begin{tabular}{rr}
\hline Time & No. of bindings \\
\hline-1500 & $\sim 23$ \\
$1500-1550$ & $\sim 11$ \\
$1550-1600$ & $\sim 17$ \\
$1600-1650$ & $\sim 70$ \\
$1650-1700$ & $\sim 183$ \\
$1700-1750$ & $\sim 66$ \\
$1750-$ & $\sim 4$ \\
\hline
\end{tabular}

Finally, it is possible to place the fragments of music manuscripts within the wider context of medieval book production. In order to gain a more precise idea about the proportion of music manuscripts among the fragmentary sources, a brief survey of the fragments in the National and University Library in Ljubljana is necessary here (Table 5).

Table 5: Fragments in the National and University Library in Ljubljana. ${ }^{13}$

\begin{tabular}{lr}
\hline Types of manuscripts & Number \\
\hline Liturgical manuscripts & $\sim 90$ \\
Other Latin & $\sim 88$ \\
Music manuscripts & 38 \\
Non-Latin manuscripts & $\sim 4$ \\
\hline
\end{tabular}

The bindings of the library's oldest holdings comprise approximately 220 fragments of destroyed medieval codices, the majority of which came from various liturgical manuscripts. It is also possible that a significant number of liturgical fragments survive among the group of unidentified Latin fragments (cf. 'Other Latin' in Table 5). Moreover, given that the contents of music manuscripts, with

13 Here, the term 'fragment' refers to what has been preserved in one binding, irrespective of whether the folios of the same codex appear in several bindings. The figures in the Table are approximate. They refer to what has been found in the bindings of books in ordinary location (excluding special collections) up to the shelfmark 22000 , which may be regarded as the oldest library collection. 
only few exceptions, may also be related to a liturgical use, it is possible to conclude that two thirds of the total number of destroyed codices, the remnants of which are kept in the said library, were liturgical manuscripts.

\section{Some notable examples}

A number of interesting fragments whose origin cannot be securely connected to Slovenian territories were also discovered. The National and University library preserves a fragment of a twelfth-century manuscript containing texts by Guido of Arezzo. On one of the two preserved folios, there is a section of Chapter XVII of Guido's Micrologus, in which he describes his method of automatic composition; that is, how a melody can be obtained from the succession of vowels in a given text. ${ }^{14}$ On the other folio, it is possible to read a section of Guido's Prologus in Antiphonarium. A close examination of the texts, and a comparison of their variant readings with fifty-five sources for the Micrologus and fifty sources for the Prologus on which the modern edition of these treatises is based, reveals that the version in the fragment is very close to that in a manuscript from the Benedictine abbey of St Ulrich and Afra in Augsburg (eleventh-twelfth century). ${ }^{15}$ However, the older Augsburg manuscript cannot have been used as an exemplar of the Ljubljana copy; the latter does not exactly match the former, but contains instead some variants that can be found in some other traditions of Guido's texts. It is, thus, possible that the scribe of the fragment copied the text by comparing two different versions, or that the Ljubljana fragment bears testimony to another, hitherto unknown, written tradition of Guido's texts. The fragment itself does not include any clue enabling a more precise definition of its place of origin.

Among the few surviving fragments containing polyphonic music, two are particularly noteworthy. In the Archiepiscopal Archives in Ljubljana, there are two incomplete bifolios written in Italian mensural notation (Fig. 3). ${ }^{16}$ So far, the pieces have not been identified, mostly due to the poor conservation conditions of the fragments which makes the script hard to read. It is likely, however, that the folios belonged to a copy of an unidentified theoretical treatise. One folio con-

14 SI-Ln, inv. 11/97, 1.

15 The manuscript is Wolfenbüttel, Herzog-August Bibliothek, Gud. Lat. 8,334. Van Waesberghe 1955; Van Waesberghe 1975.

16 SI-Lna, NŠAL 102, 75 (collection of various fragments, uncatalogued and so far without shelfmark). See Höfler 1966. 
tains psalmodic formulas written in square notation, while on the other the indications prima divisio and secunda divisio can be read in the right margin, possibly as explanations of the notated pieces.

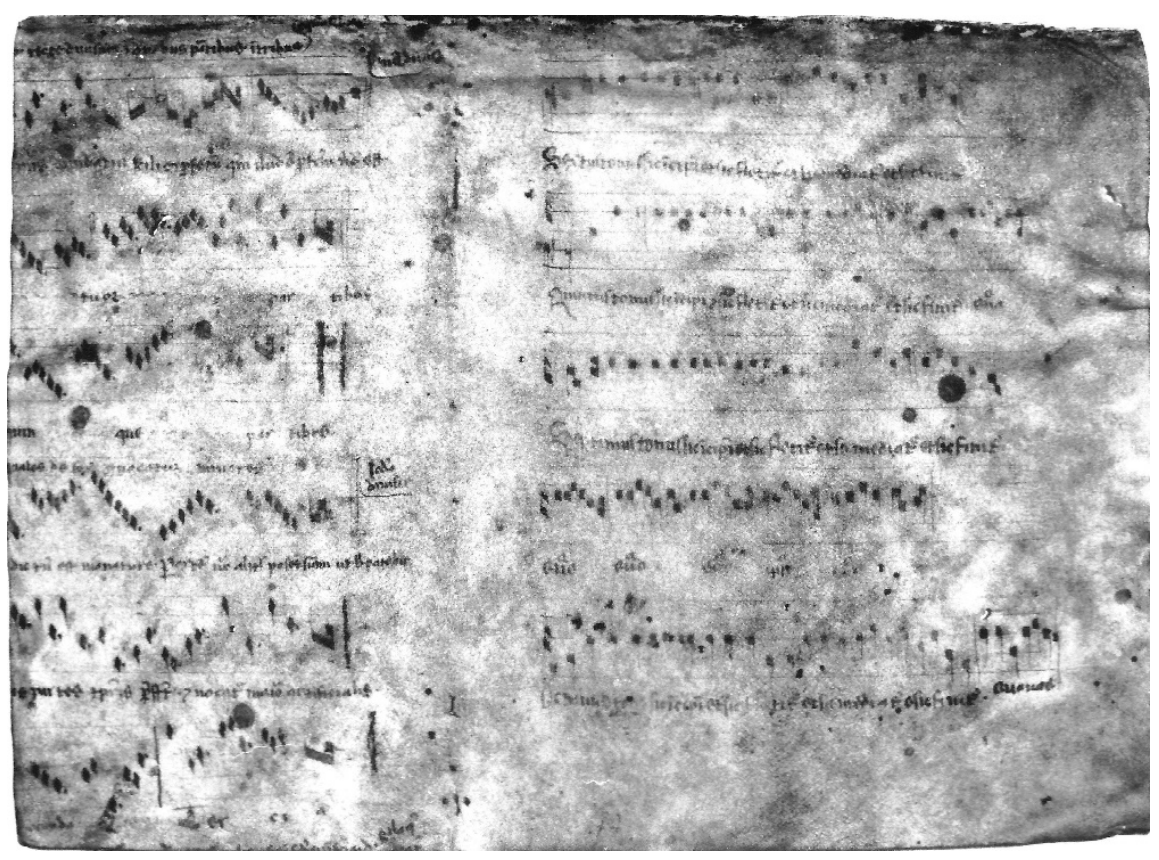

Fig. 3: SI-Lna, 102, 75 (Collection of Fragments); @ Ljubljana, Archiepiscopal Archives.

A unique example is a fragment consisting of two parchment folios both containing plainchant pieces with texts translated into Old Church Slavonic and written in Glagolitic script. ${ }^{17}$ On the first folio, there is the Genealogy according to Matthew and on the second, an unidentified and incomplete chant, followed by the Alleluia Laetamini in domino for the feasts of martyrs, and a Sanctus (Fig. 4). The original manuscript from which the folios came was probably some kind of plainchant 'compendium', rather than a more common gradual or antiphoner. It is likely that it was compiled and used at one of the Roman Church communities that were allowed to perform liturgy in the Slavonic language, such as those that existed in Croatia along the Adriatic coast.

17 SI-Ln, R, inv. n. S. f. 48/5. See Snoj 2017. 


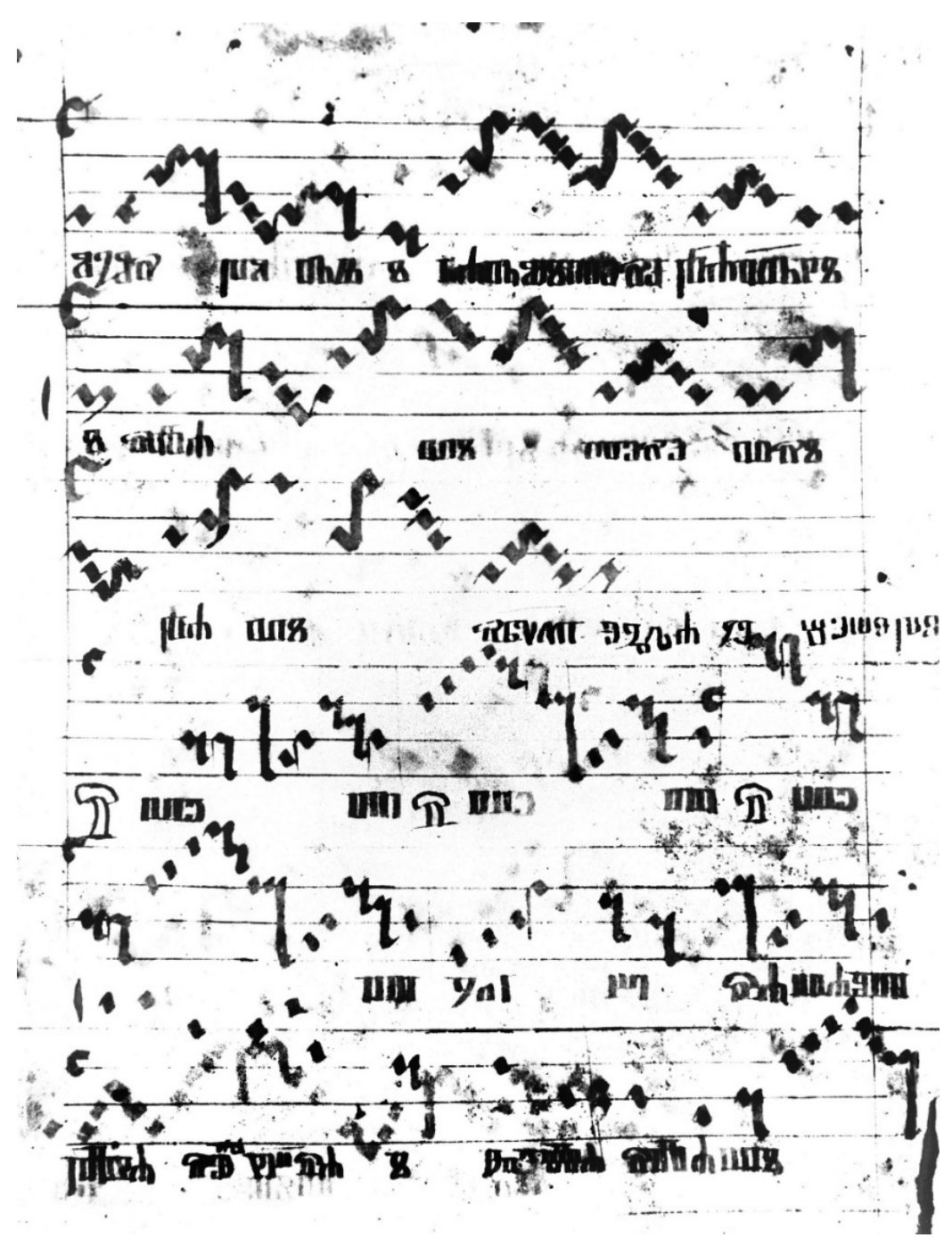

Fig. 4: SI-Ln, R, inv. n. S. f. 48/5; final portion of the All. Laetamini in domino, and beginning of the Sanctus; (C) Ljubljana, National and University Library.

The liturgy in Old Church Slavonic was also performed in the Emmaus Benedictine abbey in Prague, founded by Emperor Charles IV in 1346. Having witnessed the Slavonic liturgy in Croatia, the Emperor decided that the newly-founded abbey should perform it in Slavonic, too; thus, he purposely summoned monks from Croatia to Prague. The melodic variants of the pieces preserved in the frag- 
ment are, indeed, very close to those in Bohemian manuscripts of the fifteenth and sixteenth centuries. Furthermore, because the Gothic notation of the fragment discloses several Eastern characteristics such as the tendency to avoid virga, or the absence of the upside-down $\mathrm{U}$ shape in the torculus, whose melodic progression is rendered always by a succession of pes and clivis, the Glagolitic 'compendium' was probably produced somewhere in Central Europe rather than on the Adriatic coast. However, it is possible that the manuscript was not used by the monks of Emmaus, since the abbey was taken over by the Hussites already in 1419, whereas the script of the fragment appears to be of a later date.

So far, only one other similar fragment containing Western plainchant with texts in Old Church Slavonic written in the Glagolitic script has been found. However, the fragment, now held in Prague, cannot come from the same manuscript as the fragment kept in Ljubljana. ${ }^{18}$

Plainchant fragments, especially those dating to the late Middle Ages, may at first seem less interesting. However, since two identical plainchant manuscripts hardly existed in the Middle Ages, almost every fragment bears some features worthy of note, be it the presence of a rare saint's Office, a unique variant of an otherwise known Office, a special arrangement of chants, particular melodic variants not encountered in other sources, or certain peculiarities of the notation. In addition, it is only by collecting and comparing fragments that the possible extent of the medieval production of plainchant manuscripts may be surmised. And it is only in this way that the web of once existing plainchant manuscripts could be reconstructed as much as possible, leading up to a more accurate factual history of the spread, growth and development of liturgical chant in the Middle Ages.

\section{The question of provenance}

One of the main challenges in the study of surviving fragments in Slovenia is establishing where the original manuscripts might have been in use. The history of these manuscripts can, at least in part, be illuminated by exploring the ways in which their membra disiecta have been preserved. If a fragment consists of just one or two parchment folios, preserved in the binding of a book published abroad, it is reasonable to assume that either the fragment came to its present location together with the already bound book, or that the book was bound - or

18 Prague, Strahovská knihovna, inv. č. 290 / sign. Tres I - 7/m. See Eben 2017. 
re-bound - locally using discarded material from nearby libraries. There are many such cases. On the other hand, if a fragment consists of several folios, scattered in the bindings of printed volumes and archival documents that were produced somewhere in the Slovenian territory, it is more probable that the original manuscript was located somewhere in surrounding areas at the time of its destruction. One such example is a fragment of a psalter consisting of eight folios. ${ }^{19}$ Some of these survived in the archival documents of the Cistercian Abbey of Stična / Sittich, one in a register from a nearby parish church, and a few in the archival documents of Ljubljana, all dating to the 1630s. In other words, the psalter in question must have been somewhere in the vicinity of Ljubljana at the beginning of the 1630s, when it was dismembered and its folios used for various purposes, including as wrappers. If we apply this methodology to the entire extent of surviving fragments, only some forty plainchant manuscripts out of 215 may have been in Slovenian territories at the time of their destruction..$^{20}$

This number seems to correspond roughly to the needs of churches that existed in Slovenian territories during the Middle Ages. In that period, the territory that constitutes modern-day Slovenia was divided among different political entities: the Duchy of Carniola with its capital in Ljubljana/Laibach; the Duchy of Styria with its southern parts now being part of Slovenia; the Duchy of Carinthia with a small portion now belonging to Slovenia; the strip of land on the Adriatic coast formed instead part of the Republic of Venice, while some areas in the east belonged to the Hungarian Kingdom. From the point of view of ecclesiastical history, the regions south of the river Drava/Drau, including the Venetian strip at the Adriatic coast, belonged to the Patriarchate of Aquileia, while those to the north belonged to the Archdiocese of Salzburg; the areas under the Kingdom of Hungary, instead, formed part of the Hungarian ecclesiastical organisation. This vast territory was subdivided into several parishes, and included about fifty monasteries and several canon chapters. Apart from the Diocese of Koper/Capodistria, which was politically affiliated to Venice, there was no diocese in this territory until 1461, when Emperor Frederick III established a new diocese with a chapter of canons in the capital of Carniola (Ljubljana). ${ }^{21}$

The medieval history of the majority of these ecclesiastical institutions is obscure. With the exception of some major monasteries (Stična/Sittich, Žiče/Seitz, Kostanjevica/Landstrass), very few written records and manuscripts

19 No. 2.77 in Snoj 2018.

20 This is an approximate figure; in many cases, it is difficult to establish securely the time and place of the destruction.

21 Ambrožič 2010, 162-184, 188-191, 194-197. 
from Slovenian monasteries and chapters have survived to the present day. The difficulty in attributing particular fragments to particular churches is also due to there being hardly any specific knowledge concerning the liturgy performed in the churches across Slovenian territories, as well as to the incompleteness of the fragments. In addition, these only contain a small portion of the liturgy, which often does not show those peculiarities that would allow for a reasonable hypothesis about their origin. It is, in fact, only rarely that the place of use of a plainchant manuscript preserved only fragmentarily can be deduced with some degree of certainty.

One such example is the fifty-five folios scattered across the archives and libraries in Ljubljana that were written by the same easily recognizable hand (Fig. 5), and notated in the type of German 'Gothic-Messine' notation described above. These fragments, used in the bindings of various archival records from the second half of the seventeenth century up to the first decades of the eighteenth century, are the remnants of a two-volume antiphoner and of a psalter. ${ }^{22}$ Since one folio contains a segment of the versified Office of the Aquileian martyrs St Hellarus and St Tatianus, it is safe to assume that the antiphoner followed the Aquileian rite and must have therefore been in use somewhere in the Patriarchate. However, the place of use must have been within the Imperial, Austrian part of the Patriarchate rather than the Venetian one, where manuscripts were instead ordinarily written in square notation. The charter of the then newlyfounded Diocese of Ljubljana (1461) contains an instruction for the chapter of the diocese to perform the liturgy in accordance with the Aquileian rite. Furthermore, it is known that the Diocese of Ljubljana replaced the Aquileian rite with the Roman liturgy after the second half of the seventeenth century. It is, therefore, reasonable to assume that the antiphoner and the psalter in question were compiled for the new diocese chapter and that they were then abandoned some time after 1650, that is, in the period when the archival documents containing their folios came into being..$^{23}$

The fact that there are remnants of more than 200 plainchant manuscripts in Slovenia, many of them consisting of just one folio, leads to the assumption that the leaves of the original manuscripts may have been scattered across larger areas, and that their other remnants could have been preserved in neighbouring regions. The largest and most relevant collection of music fragments for the study of Slovenian fragments is now in the National Library in Vienna; its online catalogue includes at present 675 items from different periods, written in various

22 Ns. 2.127-2.129 in Snoj 2018.

23 There is scarcely any other fragment for which a similar assumption could be made. 
types of notation. ${ }^{24}$ By browsing through the Viennese collection it is possible to observe close similarities with the scribal hands of the Slovenian fragments. Yet, upon a detailed examination of the scripts, it was only in a couple of cases that the same hand was recognised with a considerable degree of certainty. Let us take as an example the thirty fragments in German adiastematic neumes that were found in Slovenian libraries. Of the 306 fragments written in adiastematic neumes in the Viennese collection, the great majority contain German adiastematic neumes. However, individual comparisons of the Slovenian fragments with any of the Viennese ones showed only three or four cases where a more convincing correspondence could be established. ${ }^{25}$

It is clear from this presentation that medieval plainchant manuscript production in Central European regions must have been very intensive. However, the actual number of compiled manuscripts still remains a matter of speculation. In order to gain a more precise idea of the extent of the Central European production, which includes also what has been preserved in modern Slovenia, all the existing fragments scattered across European libraries should be collected and put in one large database to enable various comparisons. The study of individual fragments or smaller collections of fragments is certainly necessary and unavoidable, yet without broader considerations it cannot lead to reliable results.

24 Musikalische Quellen des Mittelalters in der ÖNB; the head of the project: Alexander Rausch, researchers: Robert Klugseder, Ana Čizmić, Eva Veselovská, Hanna Zühlke, etc. $<$ http://www.cantusplanus.at/de-at/> (accessed July 2020).

25 The fragment in the binding of SI-Ln, 11963 might come from the same manuscript as Vienna, Österreichische Nationalbibliothek, Cod. 1248; the notation (but not the text) of the fragment SILz, LJU/0338, Maculatures II (3), Folder 24 appears to be the work of the same notator as Vienna, Österreichische Nationalbibliothek, Cod. 1797; the fragment in the binding of one of the birth registers from Limbuš (Limbuš, r. 1624-1646, now in the Archiepiscopal Archives of Maribor) seems very similar to Vienna, Österreichische Nationalbibliothek, Cod. 2212; the notation of the adiastematic fragment kept in the Franciscan Monastery Kamnik (without shelfmark) is very close to Vienna, Österreichische Nationalbibliothek, Cod. 3081. 


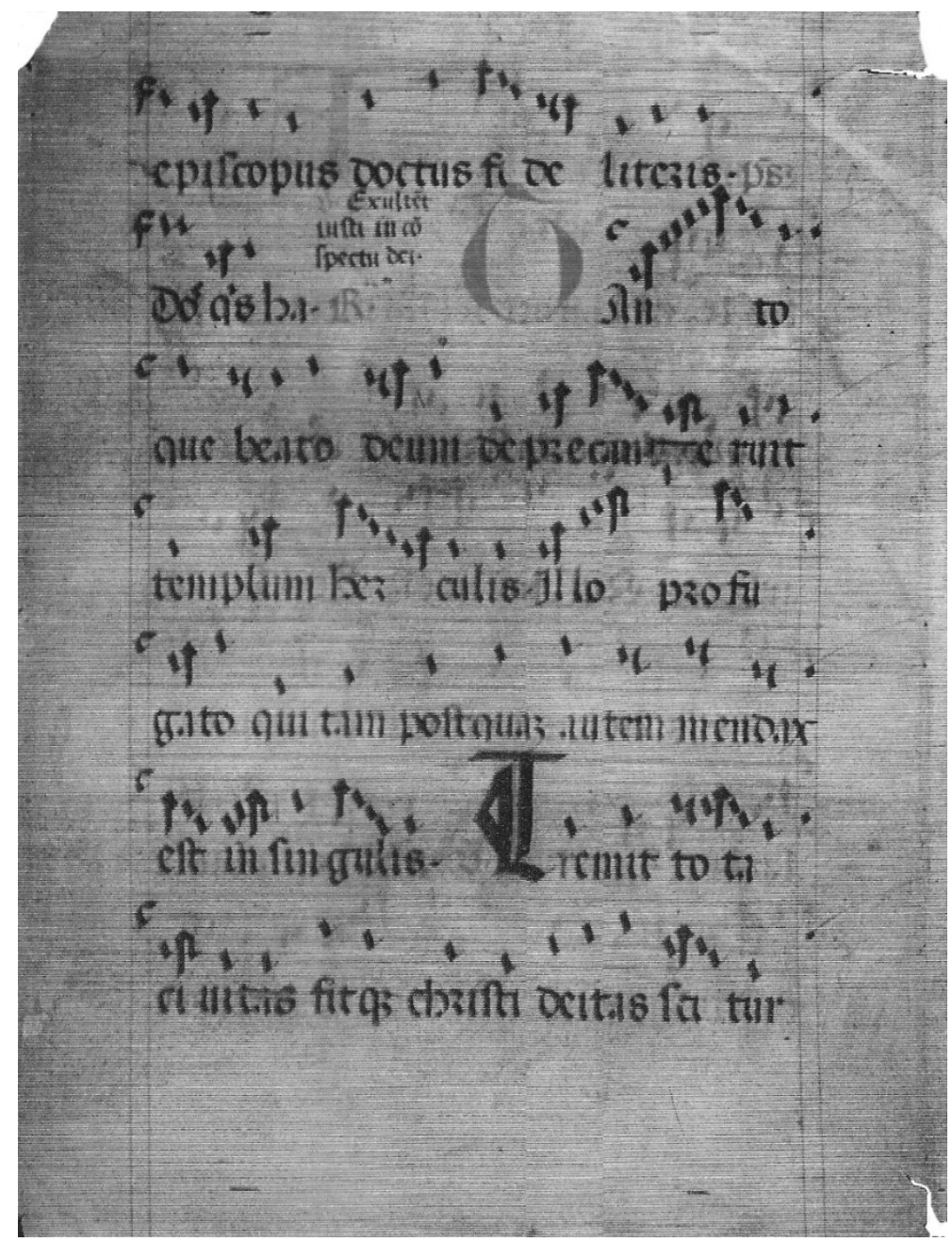

Fig. 5: SI-Lz, LJU/0338, Maculatures II (3), Folder 22; from the versified Office of St Hellarus and Tatianus; @ Ljubljana, Historical Archives. 


\section{References}

Ambrožič, Matjaž (2010), Prvih 1000 let krščanstva na Slovenskem [The First Millenium of Christianity in Slovenia], Ljubljana: Teološka fakulteta.

Brownrigg, Linda L., and Margaret M. Smith (eds) (2000), Interpreting and Collecting Fragments of Medieval Books. Proceedings of The Seminar in the History of the Book to 1500, Los Altos Hills, CA and London: Anderson-Lovelace and The Red Gull Press.

Brunius, Jan (2005), 'Medieval manuscript fragments in the National Archives - a survey', in Jan Brunius (ed.) Medieval book fragments in Sweden, Stockholm: Kungliga Vitterhets historie och antikvitets adademien, 9-17.

Camilot-Oswald, Raffaella (1997), Die liturgischen Musikhandschriften aus dem mittelalterlichen Patriarchat Aquileia (Monumenta Monodica Medii Aevi, Subsidia 2, Teilband 1), Kassel: Bärenreiter.

Eben, David (2017), 'Strahovské hlaholské zlomky a jejich vztach k pražské chorální tradici', in Kubinová et al. (eds), 55-65.

Hiley, David (ed.) (2004), Die Erschliessung der Quellen des mittelalterlichen liturgischen Gesangs (Wolfenbütteler Mittelalter-Studien 18), Wiesbaden: Harrassowitz.

Hiley, David, and Janka Szendrei (2001), 'Notation: History of Western notation, Plainchant', in Grove Music Online, <doi.org/10.1093/gmo/9781561592630.article.20114〉.

Höfler, Janez (2006), 'Menzuralni fragment iz nadškofijskega arhiva v Ljubljani’, in Muzikološki zbornik / Musicological Annual, 2: 12-17.

Kubinová Kateřina, et al. (eds) (2017), Karel IV. a Emauzy. Liturgie - text - obraz, Prague: Artefactum.

Medieval Manuscripts and Parchment Fragments from Finland, <https://pro.europeana.eu/ data/medieval-manuscripts-and-parchment-fragments-from-finland $\rangle$.

Musikalische Quellen des Mittelalters in der ÖNB, 〈http://www.cantusplanus.at/de-at〉. Slovakian Early Music Database, <http://cantus.sk>.

Snoj, Jurij (2006), 'The Plainchant Manuscripts from Koper/Capodistria', in László Dobszay (ed.), Cantus Planus. Papers Read at the $12^{\text {th }}$ Meeting of the IMS Study Group Cantus Planus, Budapest: Institute for Musicology of the Hungarian Academy of Sciences, 489-502.

Snoj, Jurij (2018), Gregorijanski koral v srednjeveških rokopisih na Slovenskem [Plainchant in Medieval Manuscripts in Slovenia], Ljubljana: Založba ZRC.

Snoj, Jurij (2013), 'The Franciscans in Carniola and their Chant', in Barbara Haggh-Huglo and Debra Lacoste (eds), Cantus Planus. Papers Read at the $15^{\text {th }}$ Meeting of the IMS Study Group Cantus Planus, Lions Bay: The Institute of Mediaeval Music, II, 597-617.

Snoj, Jurij (2008), 'The Gradual of Stična / Sittich', in David Hiley and Gábor Kiss (eds), 'Dies est leticie'. Essays on Chant in Honour of Janka Szendrei, Ottawa: The Institute of Mediaeval Music, 463-483.

Snoj, Jurij (2017), 'Nově objevený zlomek rukopisu hlaholského chorálu’, in Kubinová, et al. (eds), 67-75.

Stäblein, Bruno (1975), Schriftbild der einstimmigen Musik (Musikgeschichte in Bildern III/4), Leipzig: VEB Deutscher Verlag für Musik.

Szendrei, Janka (2002), 'Source research in Hungary after 1970', in Mauro Perani and Cesarino Ruini (eds), Fragmenta ne pereant. Recupero e studio dei frammenti di manoscritti medievali e rinascimentali riutilizzati in legature, Ravenna: Angelo Longo Editore, 141-155. 
Šter, Katarina (2013), Srednjeveški koral v kartuziji Žiče [Plainchant in Charterhouse Žiče (Seitz)], 〈https://mi.zrc-sazu.si/en/publikacije/srednjeveski-koral-v-kartuziji-zice-1\#v〉 (accessed July 2020), Ljubljana: Založba ZRC SAZU.

Van Waesberghe, Joseph Smits (ed.) (1955), Guidonis Aretini Micrologus (Corpus scriptorum de musica 4), Rome: American Institute of Musicology.

Van Waesberghe, Joseph Smits (ed.) (1975), Guidonis Prologus in Antiphonarium (Divitiae musicae artis A III), Buren: F. Knauf.

Veselovská, Eva (2002), Mittelalterliche liturgische Kodizes mit Notation in den Archivbeständen von Bratislava, I, Bratislava: Slowakisches Nationalmuseum - Musikmuseum.

Veselovská, Eva (2006), Mittelalterliche liturgische Kodizes mit Notation in den Archivbeständen von Bratislava, II, Bratislava: Institut für Musikwissenschaft der Slowakischen Akademie der Wissenschaften. 


in Aragon: Reassessing a Panorama of Fragmentary Sources

\begin{abstract}
This essay takes a further step in identifying the patterns of provenance of the Aragonese fragments of ars nova polyphony, thus recalibrating the way we think about the connection between the original manuscripts and local institutions and individuals. Most of the manuscripts' provenances curiously coincide with court itineraries in royal cities such as Barcelona, Gerona and Vilafranca del Penedès, while a number of fragments were recovered from parish archives in small villages within the area between the Royal Monastery of Poblet and city of Cervera. While none of the surviving fragments can be securely identified with the polyphonic books commissioned by kings John I (b. 1350, r. 1387-1396) and Martin I (r. 1396-1410), archival evidence suggests that the royal court was indeed a major force behind the dissemination of ars nova polyphony in late medieval Catalonia.
\end{abstract}

Modern understanding of late medieval music history owes much to the publication of the monumental series Polyphonic Music of the Fourteenth Century (hereinafter $P M F C$ ). ${ }^{1}$ Carefully organised in twenty-four volumes, the edition not only made available the contents of a large number of sources, but also shaped a largescale picture of the polyphonic styles that arose in fourteenth-century Europe. Volume PMFC 23, French Sacred Music, thus contributed to consolidating the notion of a 'French repertory' of liturgical polyphony. ${ }^{2}$ Its main sources are the well-known codices Ivrea, Biblioteca Capitolare, MS 115 (Iv 115) and Apt,

1 Schrade et al. (eds) 1956-1991.

2 In general lines, $P M F C$ classified these repertoires according to three main areas of provenance: French, Italian and English. The notion of a 'French repertory' had already been established in Stäblein-Harder 1962a and 1962b. The idea that most of this repertory emanated from papal Avignon has its origins in the early twentieth century. See Besseler 1925.

Note: This essay was written at the University of Oxford as part of the ERC project 'Music and Late Medieval European Court Cultures' (grant no. 669190; <malmecc.eu>) and in collaboration with the ERC project 'loculator seu mimus. Performing Music and Poetry in Medieval Iberia' (Universitat de Barcelona, grant no. 772762; <mimus.ub.edu>). 
Cathédrale Sainte-Anne, Trésor, 16bis (Apt 16bis), as well as a large number of fragmentary manuscripts preserved in libraries and archives of Catalonia - formerly a territory of the Crown of Aragon. Although the very idea of a 'central French tradition' needs to be nuanced or even challenged, the fact is that PMFC 23 provides a stylistically consistent body of repertory, to which the Aragonese sources contribute substantially. No fewer than one third of the 130 pieces edited in PMFC 23 are transmitted in Aragonese manuscripts.

In contrast with other regions of modern-day France and Spain, Catalonia presents an extraordinary panorama of sources of ars nova polyphony; a dozen manuscripts datable roughly between the late 1370s and the 1420 s come from historical archives within this relatively small area. The great majority of these manuscripts have survived fragmentarily. ${ }^{3}$ The most substantial codices were dismembered in the sixteenth century, some of their parchment leaves being reused as wrappers for documents that happened to survive in ecclesiastical archives. Most of these fragments were discovered by Higini Anglès between the 1910s and the early 1930s, and six of them were brought to the Biblioteca de Catalunya in Barcelona by Anglès himself, who was appointed the library's Head of the Music Department in 1917.4 Unfortunately, with only one exception, Anglès did not provide the library with information on the fragments' provenance. His scholarly writings offer a few clues, but given that some of the fragments remained unpublished during Anglès' lifetime, crucial information on their provenance was lost with his death in 1969. This essay traces back the patterns of provenance of the Aragonese fragments of ars nova polyphony, and provides new insights into the nature of the original manuscripts as well as the mechanisms of dissemination of the repertory. ${ }^{5}$

3 Ironically, the only two Aragonese collections of ars nova polyphony that have been preserved intact are not codices, but small booklets. The famous Llibre vermell of the Abbey of Montserrat (Mo 1) constitutes an exception. The manuscript originally consisted of 172 folios (around 36 were lost in the nineteenth century), of which six contain music (21r-26v; only a few musical folios are lost, see Anglès 1955, 45). This manuscript was preserved because of the literary value of the compilation of miracles it contains.

4 For a Anglès' biography, see Dolç 1988.

5 Reproductions and inventories of the manuscripts are available at $<$ diamm.ac.uk $>$. For reference to the cities' and villages' locations, see the map in Fig. 13 below. The documents from the Arxiu de la Conona d'Aragó (ACA) cited in this article are available in the database Ministrers $i$ música a la Corona d'Aragó medieval (MiMus DB), in progress at $<$ mimus.ub.edu>. 


\section{Barcelona}

\subsection{Barcelona, Biblioteca de Catalunya, M. 853 (Ba 853)}

Ba 853 consists of a fragmentary bifolio containing three Mass movements - all of them unica - and possibly three motets, including [Apollinis]/Zodiacum and Zolomina/[Nazarea]. ${ }^{6}$ Anglès never specified where exactly he found Ba $853 .{ }^{7}$ In 1941, however, he felt safe in stating that 'this fragment comes, without any doubt, from the Chapel Royal in Barcelona'. ${ }^{8}$ Since then, the fragment's origin has never been questioned. Anglès' categorical statement might have lead readers to assume that his conclusion was based on the fragment's actual 'provenance', that is, the place where it was discovered. Anglès had indeed long studied the rich archives of the Crown of Aragon, marvelling at the wealth of references to singers and books of polyphony in royal letters and documents. ${ }^{9}$ However, while there are good reasons for believing that Anglès found $\mathrm{Ba} 853$ somewhere in Barcelona, evidence suggests that the fragment was not discovered in royal archives.

Ba 853 was used as a wrapper for a booklet whose contents were recorded by a hand from the middle or second half of the sixteenth century, writing: 'Llibre de albarans de la Senyora Francina Corneta' ('Book of invoices of Lady Francina Corneta'; see Fig. 1). ${ }^{10}$

6 The possible identification of a third motet is discussed below in this section. The bifolio was not the centre of a gathering; most of the pieces are incomplete because of the missing facing pages.

7 The fragment was described for the first time by Besseler (1925, 200-201), whom Anglès had provided with photographic reproductions.

8 Anglès 1941, 26: 'Este fragmento procede, sin duda, de la Capilla Real de Barcelona'. Anglès insisted on this idea when he referred to 'algunos códices fragmentarios, procedentes de la antigua Capilla Real de Barcelona’, Anglès 1948, 21.

9 See especially Besseler 1925, 200, and Anglès 1925a, 1925b, 1930 and 1957.

10 My warmest thanks to Daniel Villarubias for helping to decipher this inscription. For reference in future research, the booklet of documents measured around $215 \times 155 \mathrm{~mm}$. The inscription (current f. 2v) was written over an erasure, which indicates that the fragment had previously been used to cover other documents. Current $\mathrm{f}$. $1 \mathrm{r}$ contains pen trials with Latin phrases and traditional proverbs in Catalan: 'Dominus Domino meo sede a dextris meis / poca conciència, molta diligencia / poca vergonya, molta [...] e paga ab bossa'. 

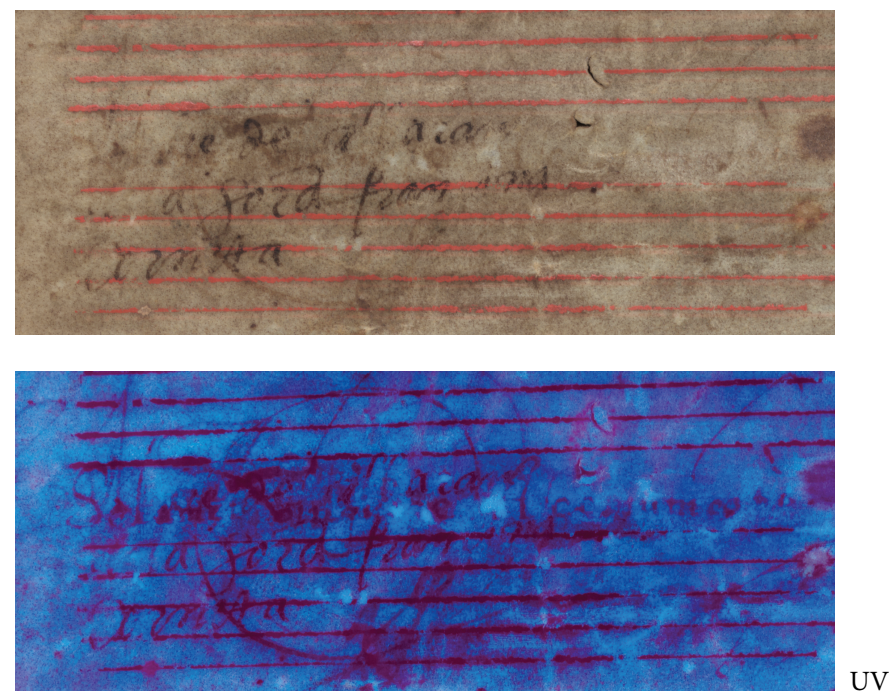

Fig. 1: Ba 853, f. 2v (inscription: 'Llibre de albarans de la S[eny]ora Francina Corneta'); (c) Barcelona, Biblioteca de Catalunya.

The Cornets were a well-known family of merchants in Barcelona. ${ }^{11}$ Berenguer Cornet was a member of the City Council and founded an ecclesiastical benefice at the Cathedral. ${ }^{12}$ A document dated August 1534 records the name of his widow, 'Francina Corneta', due to her involvement in the sale of a large house in Barcelona. ${ }^{13}$ Although tracing the archival history of Francina's book of invoices will require further research, the connection between the Cornet family and Barcelona Cathedral invites us to entertain an alternative hypothesis on the

11 Obradors 2015, 109-110. See also Marimon 2002.

12 A benefice which, in 1573, was granted to his grandson, Pau Cornet Franquesa, doctor in theology. Marimon 2002, 276. The Cathedral archives attest to further interesting connections between the Cornet family and the Cathedral throughout the sixteenth century (Carbonell 2000). For Berenguer's involvement in the City Council, see Carreras 1912, 45.

13 Barcelona, Biblioteca de Catalunya, Arxiu Històric, Perg. 310 (Registre 20940). Francina is referred to as the widow of Berenguer Cornet, merchant of Barcelona. The name 'Francina Corneta' appears in the last line of the document. Thus far, this is the only Francina Corneta that I was able to find in documents preserved at the Arxiu Històric de la Ciutat de Barcelona, Arxiu Municipal de Barcelona, and Arxiu Històric of the Biblioteca de Catalunya. As for Berenguer Cornet's death, a supplication to the City Council dated August 1533 states that he was elderly and had an incurable illness (Carreras 1912, 146). 
origins of $\mathrm{Ba} 853$ by shifting the focus from the Royal Palace to the building standing next to it.

Polyphonic music had been cultivated at Barcelona Cathedral since at least the thirteenth century. A late medieval inventory records a substantial book of polyphony displaying all the features typical of an ars antiqua manuscript such as the famous codex Florence, Biblioteca Medicea Laurenziana, Pluteus 29.1 (manuscript F). The inventory describes a small-sized book of old counterpoint, which began with the organum Viderunt omnes (also the opening piece in manuscript F) and ended with the word Samsonis on the last folio (this might be the end of Vite perdite, a two-part conductus of which manuscript F copies only the first strophe on f. 356r). ${ }^{14}$ Moreover, the cathedral archives still preserve a practical treatise on mensural notation and ars nova theory that can be dated to the 1330s, thus suggesting that the ars nova was already being explored in Barcelona prior to the arrival of the first French singers at the royal chapel in 1347. ${ }^{15}$ The cathedral school of Barcelona was a major learning hub which attracted clerics and cantors from all over the Principality of Catalonia, especially Vilafranca del Penedès, Gerona, Tarragona, Vic, and Urgell. ${ }^{16}$ Barcelona Cathedral, therefore, acted not only as a training centre but also as an important dissemination point for polyphonic music in fourteenth-century Catalonia.

When considering the possible origins of $\mathrm{Ba} 853$, we should also bear in mind that the cathedral was one of the main providers of old parchment in sixteenth-century Barcelona. Like the royal singers, cathedral priests and canons owned their own personal manuscripts, which, after the owner's death, were legated to other fellows or to the cathedral chapter to be sold in public auctions. At least eight different manuscripts of polyphony are unambiguously recorded in inventories of books that had belonged to cathedral priests and

14 'Item alium librum parvum, cohopertum de corio rubeo laborato, de contrapuncto antiquo; habet in primo folio scriptum Viderunt et finit ultimo Samsonis'. Arxiu Diocesà de Barcelona, Visites Pastorals, XII, recording the visit of the bishop-patriarch of Barcelona Francesc Climent Sapera on 13 March 1421. For further insights into the standardization of thirteenth-century Parisian books of polyphony, see Bevilacqua/Catalunya/Torres 2018. The recent discovery of a new fragment in the library of an antiquarian in Barcelona represents the first example matching this type of ars antiqua manuscript found in Catalan archives (see my forthcoming study: 'New Fragments of a Thirteenth-century liber organi: A Note of Discovery').

15 Catalunya 2018. On the hiring of French singers at the royal chapel, see Gómez 1979, 83-85. 16 The lay cathedral school taught the full liberal arts curriculum and awarded the degree of Master of Arts. It reached its peak with 562 students enrolled in 1345 (Murall 2012). 
canons deceased between 1436 and $1470 .{ }^{17}$ Some of these polyphonic books are described as old (antich) and could date from the fourteenth century or c.1400. Obsolete manuscripts of little value (poch valor) were then sold as scrap parchment to notaries and bookbinders.

The extremely close ties between the cathedral and the royal palace in Barcelona, however, also need to be considered here. The cathedral was certainly a major platform for the communication of royal power. Historians have long argued that the cathedral functioned in many respects as an extension of the royal palace. ${ }^{18}$ Since only a very narrow street separated the two buildings, King Martin I built a bridge with a passageway that enabled him to attend the cathedral Offices privately from the palace. Unsurprisingly, the monarchy took great care to ensure the solemnity of the cathedral liturgy. In 1385, for example, when repairs were commenced on the Barcelona Cathedral organ, King Peter IV immediately ordered one of the organs in the chapel of the royal palace to be moved to the cathedral, because 'it would not be good for the see to remain without an organ'. ${ }^{19}$ The intensive cultivation of ars nova polyphony fostered by John I and his French singers at the Royal Palace obviously had an important impact on the cathedral's musical life. We can assume with confidence that cathedral cantors copied or acquired polyphonic manuscripts originating in the context of the royal chapel.

But even assuming the possibility that a book from the royal chapel could potentially have ended up at the cathedral library, one reason for casting doubt on the 'royal' origins of Ba 853 - at least as a formal commission - is the manuscript's moderate scribal quality. Most notably, the initial letters remained incomplete, and the fact that the staves lack indentation to accommodate these initials suggests that there was no intention to execute refined decorative work. Close palaeographical analysis, moreover, reveals the manuscript's informal nature. The bifolio's content results from the work of three different scribes (see Fig. 2):

17 Iglesias 1996, nos 184.68; 218.8 (=219.19); 223.10,11; 288.1,3,7; 323.19 (=324.18).

18 See Sobrino 2013, and Carrero 2014.

19 Gómez 1979, doc. 222. The same instrument was lent to the cathedral again in 1390, this time referred to as the 'orgens menors' of King John I (Baucells 1988, 64-65). This implies that the Chapel Royal was provided with two organs: a large, fixed instrument, and a smaller, positive organ. For insights into the connection between the organ and the cultivation of polyphony in Iberian cathedrals see Catalunya 2017 and 2020. 
- Scribe A copied the duplum Zodiacum (f. 1r, lines 1-5), the tenor In omnem terram (f. 1r, line 5) and the beginning of an untexted additional triplum ${ }^{20}$ for the motet [Apollinis]/Zodiacum (f. 1r, line 6), as well as the triplum of the motet Zolomina/[Nazarea] (f. 1v). His textual script is an inelegant cursiva formata cancelleresca. ${ }^{21}$ This script is more typical of episcopal documents than of high-standard codices. Scribe A's hand can be dated approximately to around 1395 or 1400 .

- Scribe B copied the three Mass movements on f. $2 \mathrm{r}-\mathrm{v}$, as well as the continuation of the untexted additional triplum for the motet [Apollinis]/Zodiacum on f. 1r, of which Scribe A copied only the beginning. Scribe B combined two kinds of textual scripts; a textualis formata (libraria) for the Gloria's upper voice on $\mathrm{f}$. $2 \mathrm{r}$, and an angular cursiva for the textual incipits of the lower voices. The textual incipits of the Gloria on $\mathrm{f}$. $2 \mathrm{v}$, however, are written in textualis script. This inconsistency in the use of different kinds of scripts, even by the same scribe, is indicative of the informal status of the original codex. Scribe B's musical hand appears in the additional triplum for [Apollinis]/Zodiacum (f. 1r, line 6) from the eleventh note onwards. ${ }^{22}$ The use of different forms of custodes at the end of lines confirms that the music Scribes A and B are different persons. ${ }^{23}$ Scribe A's custodes consist of a curl with a short wavy ending, while Scribe B draws his custodes with a simpler hook ending with a long stroke.

- Scribe C copied the contratenor labelled Per sanctam civitatem on the eleventh staff of $\mathrm{f}$. 1r. The pens he used for text and music are slightly thicker than those of Scribes A and B. Subtle distinctive features in the textual script are also noticeable. Moreover, Scribe $C$ used yet a third form of custos: a square notehead-like pen stroke with upward and downward tails. ${ }^{24}$

20 This added triplum is an unicum in Ba 853; it was not reported in PMFC 5, no. 9, but is transcribed in Gómez 1985c. For new transcriptions of all the added parts for this motet, see Bent 2021 (forthcoming).

21 In this article, I use script nomenclatures according to the Lieftinck system, as used in Derolez 2003.

22 Evidence of this shift in hands is the change in the ink and in the size of the diamondshaped note heads.

23 In her study of Dominican music scribes, Eleanor Giraud shows how variations in elements such as clefs and custodes are often better indicators of the presence of different hands than the square components of notation (Giraud 2013).

24 Here the custos is meant to clarify the repetition of the talea. The same form of custos is found in other manuscripts, such as Ba 853c/d (see below). 


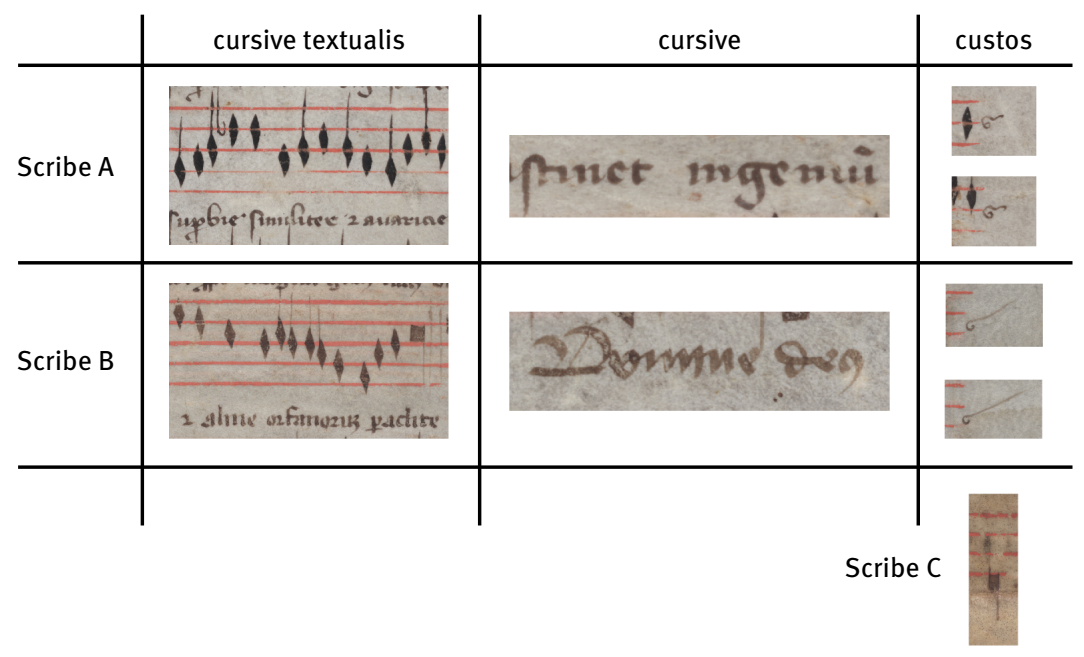

Shift of scribes in Apollinis' add. triplum
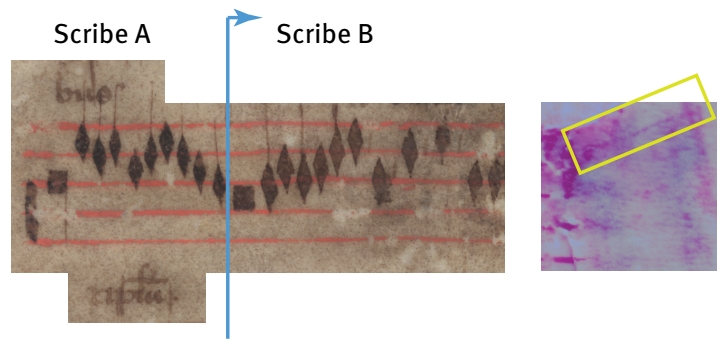

custos (Scribe B) UV photograph

Scribe A
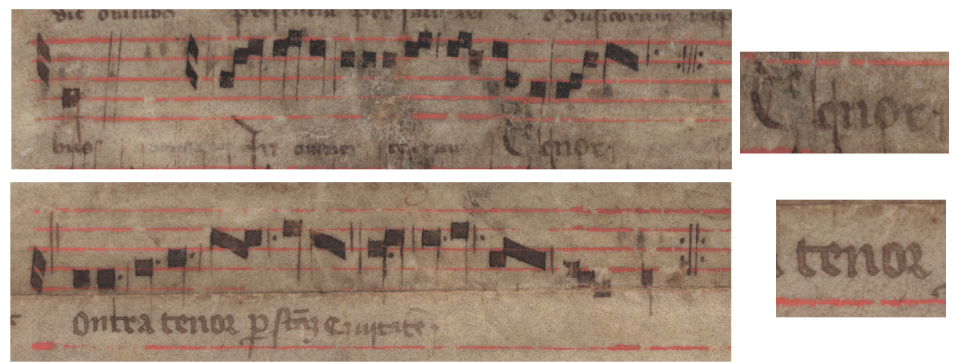

Scribe C

Fig. 2: Ba 853, scribal hands; manuscript reproduction @ Barcelona, Biblioteca de Catalunya.

It has been claimed that Ba 853 transmits a five-part version of the motet Apollinis/Zodiacum, the contratenor labelled Per sanctam civitatem being inter- 
preted as its fifth voice. ${ }^{25}$ While this claim has long persisted without criticism in musicological literature, a close look at Gómez Muntanés proposed transcription reveals some considerable issues. ${ }^{26}$ In order to force the contratenor to fit the piece, Gómez Muntané introduced a great deal of rhythmic 'modification'. ${ }^{27}$ Even so, the resulting polyphony is dissonant to the extent that it should be considered unviable; the emended contratenor collides with the original duplum and triplum on at least twelve occasions. Having now established that this contratenor was copied by a secondary scribe, it would seem more likely that Scribe $C$ notated the contratenor of another, now lost motet, one of whose upper voices began with the words Per sanctam civitatem. ${ }^{28}$ According to the reconstructed layout of the motet [Apollinis]/Zodiacum in Fig. 3, the missing facing page of current f. 1r would have left little space to accommodate the tenor and duplum of this additional motet. Scribe $C$ must have added this motet elsewhere on spare staves and did not have enough space to copy the entire piece in one single manuscript opening. The labelling of the untexted contratenor was thus necessary in order to identify the piece to which it belonged.

$25 \operatorname{RISM}$ (1969), 89; Gómez 1985c.

26 I thank Margaret Bent for calling my attention to the problems raised by this contratenor. In an unpublished paper on the 'musician motets' circulated to participants in the Novacella conference 2013, she stated that the contratenor Per sanctam civitatem does not fit the motet Apollinis/Zodiacum. This work will appear in revised form as a chapter in her new book on the late medieval motet (Bent 2021, forthcoming).

27 Gómez 1985c, 25.

28 No plainchant containing these words has been identified. The labelling of untexted tenor lines, such as In omnem terram, served to identify the plainchant melody from which the tenor was excerpted, which was usually chosen by the composer for its symbolic meaning relevant to the topic of the motet's text. In the case of the motet Apollinis/Zodiacum, the tenor line In omnem terram is taken from an Offertory for the common of apostles, whose full text is eloquently suited to a motet exalting famous musicians and singers: In omnem terram exivit sonus eorum, et in fines orbis terrae verba eorum ('Their voice has gone out through all the earth, their words to the end of the world'). 


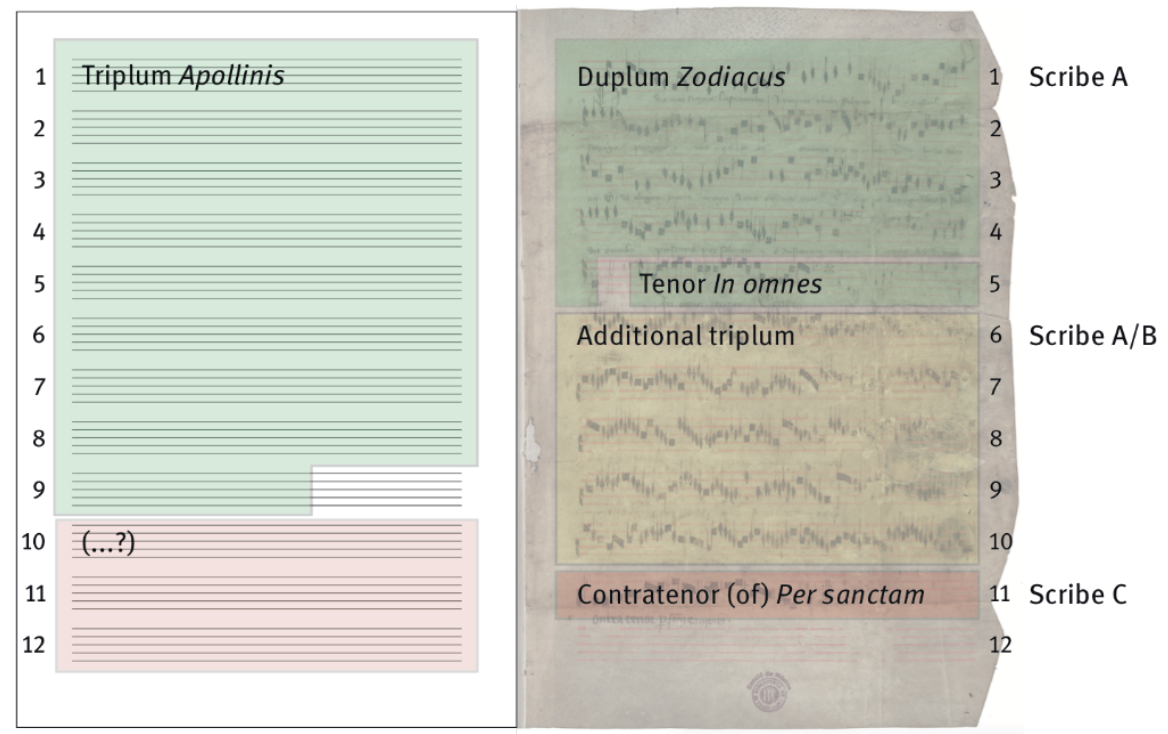

Fig. 3: Ba 853, page layout of the motet Apollinis/Zodiacus; manuscript reproduction \ Barcelona, Biblioteca de Catalunya.

The identification of a new, now-lost motet highlights the uniqueness of Ba 853's repertory; four out of six fragmentarily surviving pieces are unica, while the widely-spread motet Apollinis/Zodiacum was provided with a new triplum. The original manuscript possibly passed through various hands before it was dismembered, yet, in any case, it does not seem to have originated as a royal commission. While the scribal quality reveals the collection's informal character, the fact that motets and Mass movements were copied in the same gathering by different scribes suggests some degree of randomness in the compilation process. These scribes were possibly a group of learned clerics or professional singers copying music in a 'working document'. ${ }^{29}$

29 See the parallels with the codex Iv 115, which Kügle describes as a 'working document' (Kügle 2019, 19). 


\subsection{Barcelona, Biblioteca de l'Orfeó Català, Ms 2 (Orf 2)}

Orf 2 is a single-quire booklet of eight folios, which has survived nearly intact. ${ }^{30}$ It contains four pieces, all of them Mass movements: one troped Gloria, one Agnus Dei, one Credo, and one troped Kyrie. Only ff. $1 v-5 r$ are filled with music, while the remaining pages contain empty staves. Modern scholarship has often remarked on the informal character of the compilation, which would seem 'more typical of an amateur than a professional musician'.${ }^{31}$ Tomasello distinguished the hands of three different scribes who worked in close collaboration, and suggested a dating of c.1430 for the compilation of the manuscript. ${ }^{32}$ As in $\mathrm{Ba} 853$, various scribes were involved in the copying of one single piece. Orf 2 thus features all the elements typical of a personal collection of a small circle of aficionados, who held informal performances or copied music for reference and study.

The booklet's last verso contains an annotation, likely written by a later owner of the manuscript, recording a short list of books: a juridical treatise, a sermon for Good Friday, and a short treatise on sexual encounters between clerics and women. ${ }^{33}$ While this annotation offers us an idea of the intellectual milieu of the manuscript's owner, the historical archives of Barcelona provide us with evidence of various individuals who would have been interested in consulting all these books, including a music booklet such as Orf 2. The case of Guillem Rovira (d. 1436) is one of the most fitting. Rovira was priest who held an ecclesiastical benefice linked to the altar of Saint Thecla at Barcelona Cathedral. A document dated 1425 mentions his name as an administrator of the cathedral school, where he also taught. ${ }^{34}$ The inventory of goods found in his private house reveals an impressive personal library consisting of no fewer than 110 volumes. ${ }^{35}$ While most of Rovira's books were treatises of logic and grammar the subjects he taught at the cathedral school - he also owned other manuscripts covering topics related to Orf 2's list, such as Llull's Ars iuris and Ovid's De remedio amoris. ${ }^{36}$ As a cathedral cleric, Rovira also possessed liturgical manu-

\footnotetext{
30 A portion of $\mathrm{f} .7$ was excised.

31 Besseler 1925, 205. See also Schrade 1956, 147, and Gómez 1993, 13.

32 Tomasello 1995, 100-105.

33 This seems to be a list of books to be consulted, acquired or loaned. The annotation is transcribed and analysed in Tomasello 1995, 101.

34 Document published in Hernando 2001, 44-45, doc. 5. See also Hernando 2001, 34, n. 79.

35 The full inventory is published in Iglesias 1996, no. 184.

36 Although the list in Orf 2 does not reveal any interest in Classical literature, Ovid's De arte amandi et de remedio amoris relates to the clerics' sexuality insofar as Ovid discuses rules for erotic love and also advises on how to rid oneself of an unwanted passion.
} 
scripts, some of which were described as containing musical notation; his collection of musical manuscripts included a 'llibret de cant d'orga' ('one booklet of polyphonic music'). ${ }^{37}$ Some of these manuscripts were sold in a public auction after Rovira's death. ${ }^{38}$ Although it would be naïve to claim that Guillem Rovira was Orf 2's owner, his profile clearly matches that of a cultivated cleric whose main occupation did not revolve around the performance of polyphonic music but who could have been, nevertheless, interested in acquiring a booklet similar to Orf 2 .

The Biblioteca de l'Orfeó Català does not preserve any record of the provenance of this manuscript. Anglès was one of the first to see Orf 2 shortly after its discovery; he then sent photographs to Friedrich Ludwig and Heinrich Besseler, who published the first descriptions of the manuscript in 1924 and $1925 .{ }^{39} \mathrm{In}$ 1958, however, Anglès alluded to a source of fourteenth-century polyphony from the Church of Santa Maria del Mar in Barcelona. ${ }^{40}$ Given that the provenance of all other Catalan sources of ars nova polyphony has now been established (see Fig. 13 below), Anglès' allusion to a manuscript from Santa Maria del Mar can only be taken to refer to Orf $2 .^{41}$ The Church of Santa Maria del Mar is one of the most magnificent buildings of the Catalan Gothic architecture. ${ }^{42}$ The history of this parish church serves as another example of the complex cultural network flourishing between different institutions in late medieval Barcelona. The building's foundation stone was laid by King Alfonso of Aragon in March

37 On the Iberian Peninsula, cant d'orga (cant d'orgue, canto de órgano, cantu organico) was the standard term for mensural, composed polyphony until the seventeenth century. Llibret is the diminutive form for llibre (book).

38 Iglesias 1996, 251 and 255.

39 Ludwig 1924, 236. Besseler 1925, 205.

40 Anglès 1958, 9-10 [7-8]: 'la música [polifónica] sagrada y la profana fue muy practicada en las capillas y casas reales de la Península, en algunos monasterios y también en las catedrales principales'; ibidem, n. 28: 'otros fragmentos demuestran que la catedral de Gerona, Santa María del Mar en Barcelona y indicios que tenemos de iglesias castellanas son otros testimonios de lo que venimos diciendo'.

41 Anglès' biography gives full credibility to this hypothesis. In a letter addressed to the bishop of Barcelona (preserved in Tarragona, Arxiu Històric Arxidiocesà, Correspondència Anglès, 6 November 1926), Anglès stated that in 1918 he worked at the archive of Santa Maria del Mar and at the Biblioteca de l'Orfeó Català. He photographed the works of Josep Reig and Joan Pau Pujol before the archive of Santa Maria del Mar was burned during the 1936 war. Moreover, Anglès was friend with Lluis Millet, the founder of the Orfeó Català, who acquired the thirteenth-century MS 1 of the Orfeó Català from the cardinal Francesc d'Assís Vidal (Biblioteca Orfeó Català, registre del MS 1; Tarragona, Arxiu Històric Arxidiocesà, Correspondència Anglès, 30 March 1927; 16 July 1927). The Biblioteca del Orfeó Català is only 800 meters away from Santa Maria del Mar.

42 See Domenge/Vidal 2018, and Español 2002, 131-142. 
1329; the last vault boss was placed in November 1383, and in August 1384 the church was consecrated by the bishop of Barcelona. Barely ten years later (1393), the construction of an organ for the new building was commissioned from Bernat Ponç, a French cleric who was also a singer in the Aragonese royal chapel. ${ }^{43}$ Moreover, there is evidence of the circulation of musical books between the parish church and the cathedral. In 1441, for example, a priest of Santa Maria del Mar acquired various books from a deceased priest of Barcelona Cathedral, including a treatise of music theory and a book of polyphony. ${ }^{44}$ These records of book trade show the difficulty of tracing back the precise origins of manuscripts such as Orf 2 and Ba 853, which feature themselves as personal collections that might have passed through various hands.

\section{Vilafranca del Penedès}

Another polyphonic booklet that has survived intact is Barcelona, Biblioteca de Catalunya, M. 971 (Ba 971). It consists of a single quire of twelve folios containing nine pieces: five consecutive Mass movements known as the Barcelona Mass, two additional Mass movements, and two motets. Anglès found this manuscript in Vilafranca del Penedès, although he never specified in which archive. ${ }^{45}$ For him, its specific provenance was merely a secondary issue. In Anglès' view, the most important aspect of $\mathrm{Ba} 971$ was that it transmitted the kind of polyphony that was performed at the Chapel Royal 'in Barcelona' ${ }^{46}$ Gómez Muntané, following Anglès intuition regarding the royal connection, claimed that Vilafranca could in no way be the manuscript's place of origin, since there was no musical centre in Vilafranca in the fourteenth century that could justify the presence of a manuscript like Ba 971. She argued, instead, that Ba 971 was most likely commissioned and owned by the Royal House of Aragon, and suggested that the manuscript reached Vilafranca merely by chance,

43 Baldelló 1962, 232. In another document, dated on 26 July 1393, Bernat Ponç is referred to as both 'magister organorum' and 'xantre domini regis'. He held an ecclesiastical benefice in a church in Narbonne. The royal archives in Barcelona record payments to 'Bernat Ponç, xantre de la Capella del senyor rey’ from 1393 to 1397; see MiMus DB (ACA, Cancelleria, reg. 1964, f. 47v).

44 Iglesias 1996, nos 218.8 and 219.19.

45 Ba 971's acquisition register at the Biblioteca de Catalunya is dated in November 1926.

46 Anglès 1941, 26: 'Esta polifonía es la que se ejecutaba en la capilla de los reyes de CataluñaAragón en Barcelona' (Ba 971 here referred to as M. 946; includes photographic reproduction). 
possibly after the royal belongings were dispersed. ${ }^{47}$ However, both codicological and archival pieces of evidence challenge Gómez Muntané's hypothesis.

In the first place, the manuscript's typology quite clearly corresponds to that of a personal booklet compiled with limited resources. The strikingly irregular quality of Ba 971's parchment seems unsuitable for a royal commission. The manuscript's compiler, perhaps unable to acquire a homogeneous batch of parchment sheets, appears to have used spare material from different origins. He combined three different kinds of parchment ranging from the highest to the lowest quality, as shown in Fig. 4.

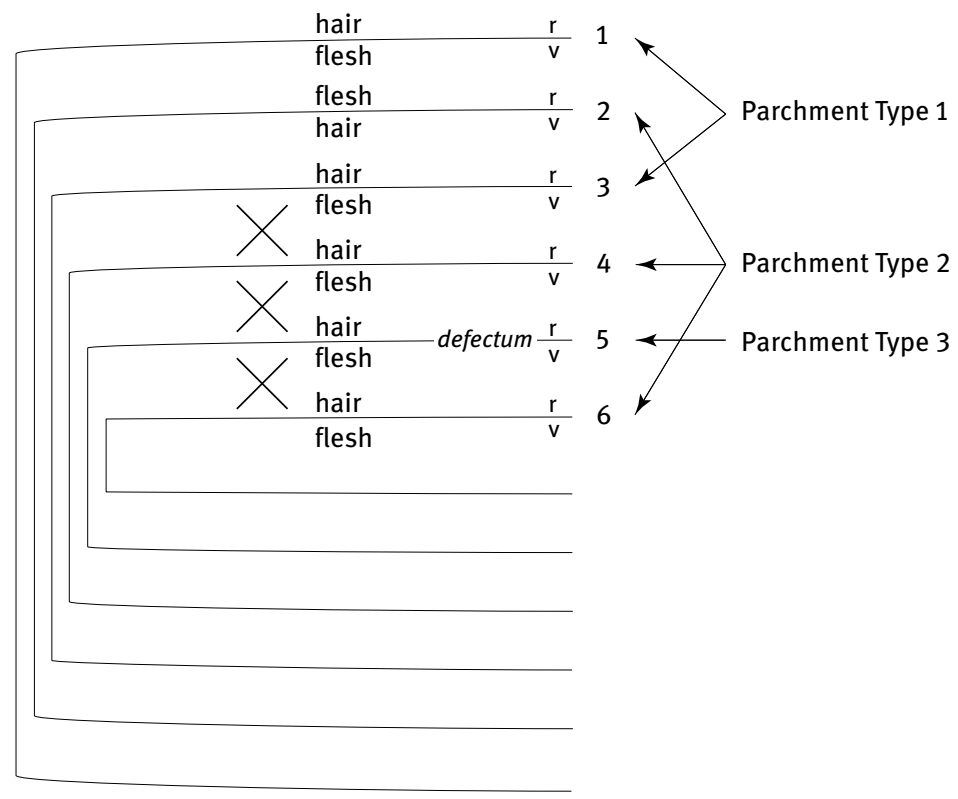

Fig. 4: Ba 971, codicological structure.

Parchment Type 1 is of the highest quality and is characterized by its thinness, light brown tone and the distinction between the skin's hair and flesh sides. Parchment Type 2 is also of good quality, albeit clearly of a different origin; its fabrication involved chemical treatment in order to whitening it, which make it hard to distinguish between the skin's hair and flesh sides. Parchment Type 3 is

47 Gómez 1989, 6 and 24. See also Gómez 1985b, 177, and Gómez 1984, 79. 
of the poorest quality; it has a yellowish colour, greasy texture, and an irregular, defective edge. Although the compiler made an effort to optimise the quire's appearance by arranging the order of the bifolios, the parchment's heterogeneity was so great that he did not consider it necessary to follow the customary practice of collating parchment leaves so that hair-side faces hair-side, and flesh-side faces flesh-side (Gregory's rule).

Moreover, the style of Ba 971's pen-flourish decoration is not consistent with that of royal manuscripts from the same period, which usually involve a much higher degree of refinement in the penwork filigrees (see a comparative example in Fig. 5).
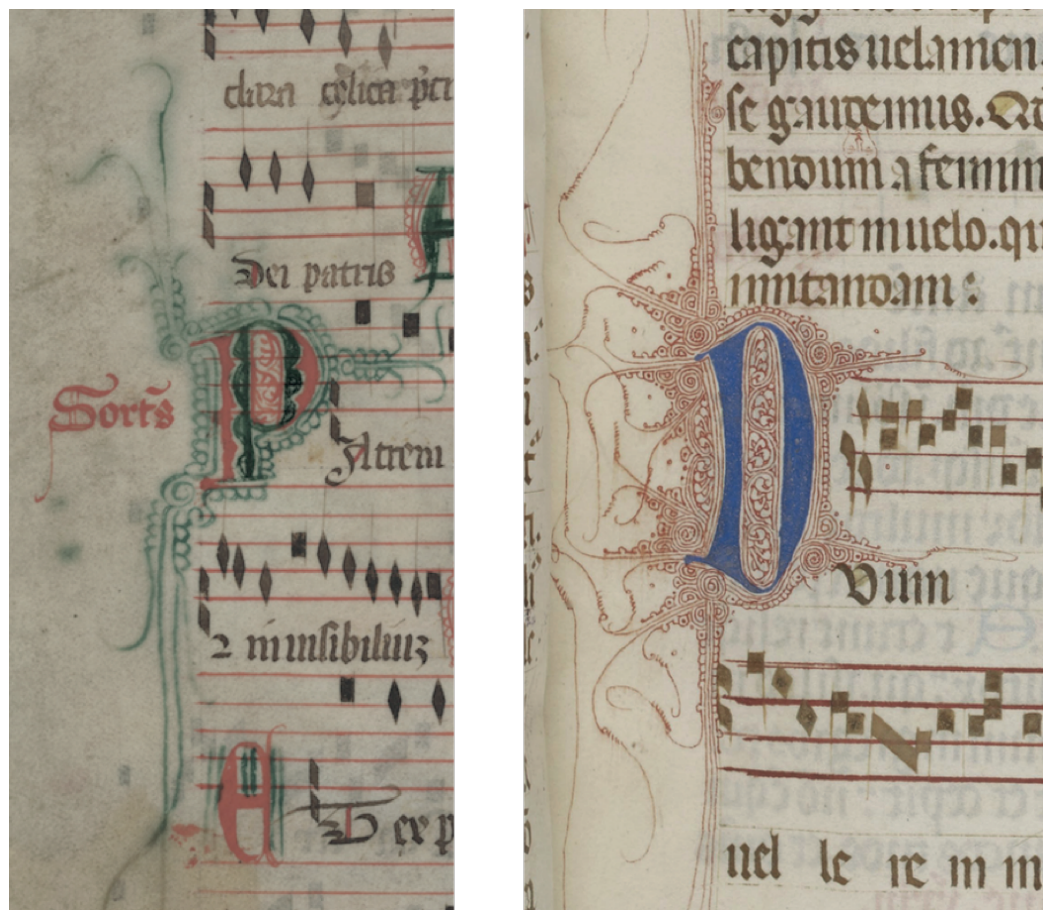

Fig. 5: Ba 971, f. 3v (left) and Pa 5264, f. 35r, from the Chapel of Martin I of Aragon, 1409 (right); (c) Barcelona, Biblioteca de Catalunya and Paris, Bibliothèque nationale de France.

The compiler not only seems to have had difficulties finding good parchment, but was also apparently unable to afford the costly blue ink - instead, he used less 
expensive green ink. ${ }^{48}$ While the use of green ink in penwork decoration is certainly atypical in royal manuscripts, this feature is not entirely uncommon in fragments recovered from parish archives in the Archdiocese of Tarragona and elsewhere.

Finally, Ba 971's copying process suggests that the manuscript's contents were not all planned as a unitary project. The five consecutive Mass movements and the motet Degentis vita/Cum vix (ff. 1r-9r) were copied in an initial compilation stage by the principal scribe (Scribe A). The Kyrie and the Gloria on ff. 9v$11 \mathrm{r}$ were copied by the same scribe in a second compilation stage; the use of a different ink and the variation in the script's module suggest some chronological distance between these two compilation stages. The motet Apollinis/Zodiacum on ff. $11 v-12 \mathrm{r}$ was copied even later by a secondary scribe (Scribe B). ${ }^{49}$ Such a cumulative compilation process would seem atypical for a commissioned manuscript. In fact, although Scribe A was a professional scribe who produced a beautiful, formal script, he does not seem to have been very much at home with copying polyphonic music. He made many mistakes, often involving rhythmic notational issues, and struggled in calculating the coordination of the parts within the page layout so that the polyphony would be complete in each opening of the manuscript. The pieces occupying more than one opening contain massive erasures of text and music, while the contratenor of the Sanctus was left incomplete because it did not fit the space reserved for it..$^{50}$ Despite the copy's low quality, a few corrections introduced by Scribe B suggest that the manuscript was, after all, used. ${ }^{51}$

In the light of the foregoing evidence, we should consider the hypothesis of a local origin of Ba 971 in Vilafranca. If, like Orf 2, Ba 971 features itself as an amateur's collection, it is still tempting to associate it with the influence of the court on the musical life of this city. Vilafranca had been a royal city since the thirteenth century, and the court spent long periods there, staying both at the city's royal palace and at the Monastery of Saint Francis. ${ }^{52}$ King John I used to travel with his chapel of singers and minstrels, and there is ample evidence that he took charge of musical affairs during his long stays in Vilafranca. The Archives of the Crown offer us a glimpse into the interaction of court musicians with local institutions in Vilafranca. In a letter dated in November 1387, for example, John I

48 On ink costs, see Clarke 2001.

49 Here the chronological distance is suggested by the fact that Scribe B worked after the manuscript had been decorated.

50 Although these erasures clearly detract from the manuscript's appearance, they seem to have remained unnoticed in modern scholarship. See ff. 2r, 3v, 4r, $5 \mathrm{r}$.

51 See ff. 2v (line 3) and 4r (line 1).

52 For an overview of the city's history, see Arnabat/Vidal 2008. 
requested the presence of the organist Nicolau dels orguens at Vilafranca, and only a few days later, he asked his chamberlain to bring a strung keyboard instrument called exaquier (checker) to the same city. ${ }^{53}$ Apparently, the checker was used in the performance of liturgical music, possibly as a replacement for the organ when it was not available. ${ }^{54}$ This instrument must have travelled back and forth between Vilafranca and Barcelona on more than one occasion. In February 1392, John I ordered the checker and its wooden bench to be sent back to Barcelona, after the instrument had remained at the Monastery of Saint Francis in Vilafranca, where the king had been staying. ${ }^{55}$ The circulation of courtly manuscripts in Vilafranca is also evidenced in the archives. In October 1391, Violant de Bar - John's queen - asked to have her 'cançoner gros' ('large chansonnier') brought to Vilafranca. ${ }^{56}$ Barely two months later (December 1391), John acknowledged the arrival at court in Vilafranca of two new minstrels from Avignon.

Although Anglès did not specify where exactly he found Ba 971, it is not difficult to guess which archive he visited in Vilafranca. The richest musical archive in the city is that of the Church of Saint Mary. It preserves a large collection of manuscript sources from the fifteenth to the eighteenth centuries. ${ }^{57}$ Moreover, the library of the Monastery of Saint Francis was dispersed in 1835, and part of its music collection ended up at Saint Mary. ${ }^{58}$ In a letter addressed to the bishop of Barcelona in November 1926, Anglès stated that in 1918 he had classified the musical sources in Vilafranca with the aim of preparing a cata-

53 MiMus DB (ACA, Cancelleria, reg. 1954, f. 22r; f. 27v). Nicolau dels orguens is often referred to as a 'ministrer de corda' ('string minstrel'), for which reason it must have been he who played on the checker at Vilafranca. On the instrument called checker, see Page 1979.

54 In an earlier letter (1379) John speaks of both the organ and the exaquier in connection with the daily performance of sung Mass (Gómez 1979, doc. 227). There is also evidence that the Chapel Royal of John I kept other string instruments such as the lute, see MiMus DB (ACA, Cancelleria, reg. 2343, f. 13v). The customary involvement of instrumentalists in the performance of sacred music is further suggested by the reference to a 'jutglar de kíries' in a document from 1356, see MiMus DB (ACA, Reial Patrimoni, MR, reg. 880, f. 77v). Tellingly, some of the court minstrels were commanded to obey the orders of the chief singer of the royal chapel, Jean Armer or Armetis. The ACA preserves numerous documents about this cantor since 1387, see MiMus DB (for example, ACA, Cancelleria, reg. 1963, f. 163r).

55 MiMus DB (ACA, Cancelleria, reg. 1963, f. 31r).

56 MiMus DB (ACA, Cancelleria, reg. 2054, ff. 118v-119r).

57 Cuscó 1997.

58 The musical archive of Saint Mary, including the Fons Musical de Sant Francesc, was transferred to the Vinseum in the 1940s. More recently, the Fons Musical de Sant Francesc was moved to the Arxiu Comarcal de l'Alt Penedès. I thank Joan Cuscó, director of the Musical Archives of the Vinseum, for clarifying the archival history of this collection. 
logue of Spanish music up to the eighteenth century; the Church of Saint Mary was practically the only place where such a task would have made sense. As a tentative hypothesis, I suggest that Ba 971 could have originated at the Monastery of Saint Francis in Vilafranca or at the Church of Saint Mary in the same city. The possible connection with the community of Saint Francis would seem obvious; the monks must have been charmed by the polyphonic performances they witnessed while John I stayed at the monastery with some of his musicians, and may have wanted to compile a small token of the repertory. As for the Church of Saint Mary, it is not difficult to imagine that the clerics of the city's main church also developed an interest in emulating the splendour of royal liturgy, as Barcelona Cathedral did..$^{59}$ The local clergy of Vilafranca might have been less experienced in polyphonic music than the royal singers, but would nonetheless have had no difficulty in accessing manuscript exemplars.

\section{Gerona}

Like Barcelona and Vilafranca, Gerona was another royal city in which the presence of the court left remarkable imprints. Gerona Cathedral was one of the largest and richest sees in the Principality of Catalonia. The magnificence of its medieval liturgy is well known in modern scholarship thanks to a celebrated customary dated to $1360 .{ }^{60}$ Nonetheless, while this customary prescribes polyphonic performances cum triplo of responsories and alleluias on major feast days such as Holy Innocents, it does not reflect the practice of the kind of repertory transmitted in ars nova sources - namely Mass movements and motets. Manuscript evidence discussed below suggests that the cultivation of ars nova polyphony was fostered at Gerona Cathedral - at least with greater intensity in the times of John I, who was also the duke of Gerona. A good example of the direct influence of the court ceremonial in royal cities is found in a 1395 mandate of John I addressed to his officials in Gerona, commanding them to have the Feast of the Immaculate Conception solemnised with trumpet processions and Divine Offices in the church the same way as this was done 'at court'. ${ }^{61}$ As a

59 For an overview of the history of this church, see Miret 1987. The choir school is documented since 1314; the church had been provided with an organ probably in the late fourteenth century. See also Cuscó 2013.

60 Gerona, Arxiu Capitular, MS 9. This customary exhibits pen-flourish decoration worthy of a royal manuscript. For a selected bibliography on this customary, see Sureda 2014, 43-44.

61 MiMus DB (ACA, Reial Patrimoni, MR, reg. 397, f. 166v). 
royal city, Gerona hosted the court on numerous occasions. In December 1381, for example, John asked his entire chapel to move to Gerona, as he had decided to celebrate Christmas there. ${ }^{62}$ John visited the city again in June 1390 and asked to have his checker brought to Gerona. ${ }^{63}$ At least one singer in his royal chapel was also a priest in Gerona. ${ }^{64}$

Around 1930, Anglès brought to the Biblioteca de Catalunya a fragment from a beautiful manuscript of ars nova polyphony that he had discovered in the archives of Gerona Cathedral, and attached it as an appendix to Ba 971. In 1956 Hana Harder and Bruno Stäblein discovered a second bifolio from the same manuscript at Gerona Cathedral. This second bifolio, Ge 33/I, is still kept in Gerona together with yet another ars nova fragment from the same cathedral, Ge 33/II. ${ }^{65}$ The two bifolios Ba 971b-Ge 33/I contain five fragmentary pieces: one Gloria, three Credos, and one motet in the Provençal language. ${ }^{66}$ This fragment can be dated, on palaeographic grounds, in the last quarter of the fourteenth century or $c .1400$. Because the surviving leaves preserve original foliation, we can partially reconstruct the original manuscript's gathering structure (Fig. 6; includes Ge 33/II, discussed below).

Unlike the sources discussed above, Ba 971b-Ge 33/I epitomises the highest standards of manuscript production and shares features with royal commissions such as Pa 5264 (Fig. 7). ${ }^{67}$ The parchment is of top quality, the script extremely refined and legible, and the copying process sophisticated and laborious. The staves were rastrated after the text had been written in order to accommodate the many beautiful initial letters placed in the middle of the lines with indentations. ${ }^{68}$ The initials were further highlighted with a yellow pigment, which has faded due to the fragment's deterioration, but which is still clearly noticeable under certain light conditions, especially UV radiation. The manuscript's original appearance must therefore have been much more luminous than it is today.

62 MiMus DB (ACA, Cancelleria, reg. 1665, f. 74r). Gómez 1979, doc. 236.

63 MiMus DB (ACA, Cancelleria, reg. 1873, f. 67v). Gómez 1979, doc. 191.

64 'a l'amat nostre en Pere Banyut, prevere de Gerona, lo qual per xantre ha servit en nostra Capella', MiMus DB (ACA, Cancelleria, reg. 1889, f. 142r).

65 Harder/Stäblein 1957.

66 See the comments on the motet's language in PMFC 5, Supplement, 32, texts of motet 34.

67 Manuscript Pa 5264 (Paris, Bibliothèque nationale de France, lat. 5264), was commissioned by John I's successor, Martin I. See Avril et al. 1983, 110, no. 121.

68 This practice was abandoned in f. xxiiii $r-v$, where the pages were rastrated throughout, before the text was written, although the initials are just as elaborate as those on the other folios. It is not uncommon in large collections for some pages to follow slightly different copying processes. The same occurs in the royal manuscript Pa 5264 cited above. 
Gathering structure

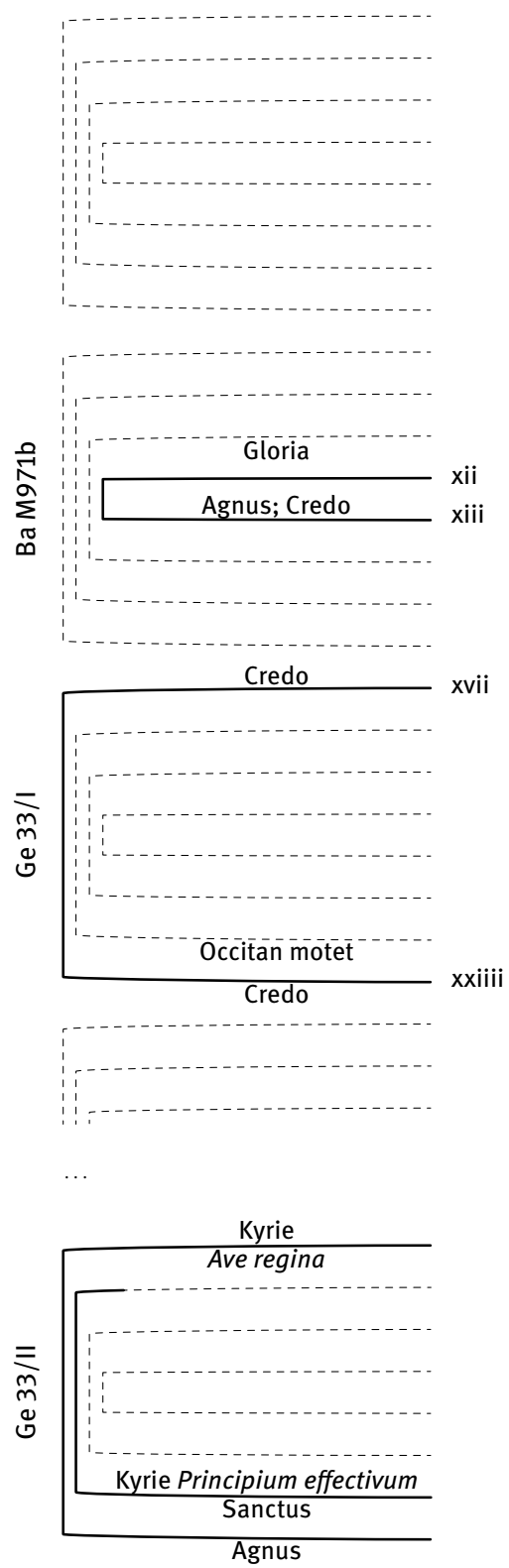

Binding punched holes

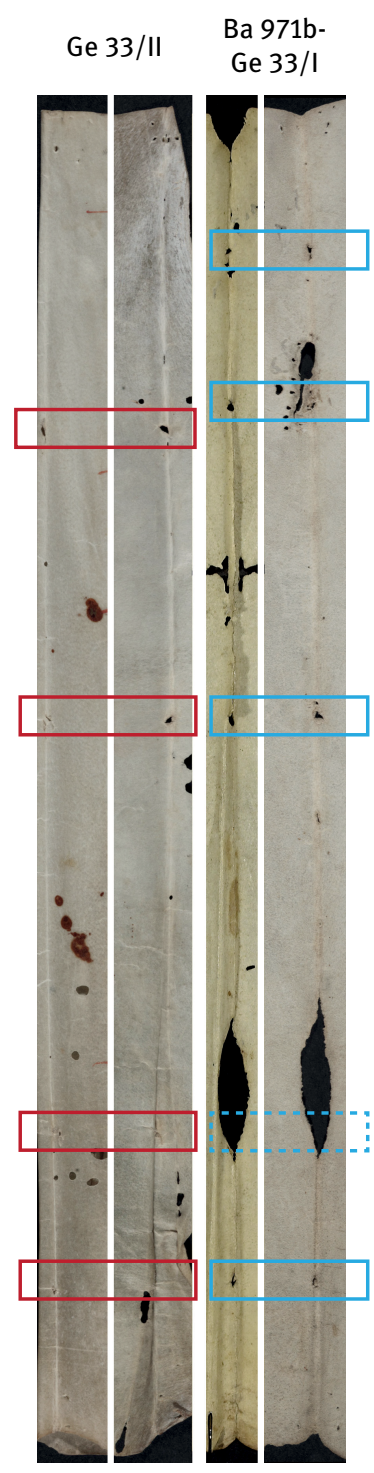

Fig. 6: Ba 971b, Ge 33/I and Ge 33/II, codicological structure. 

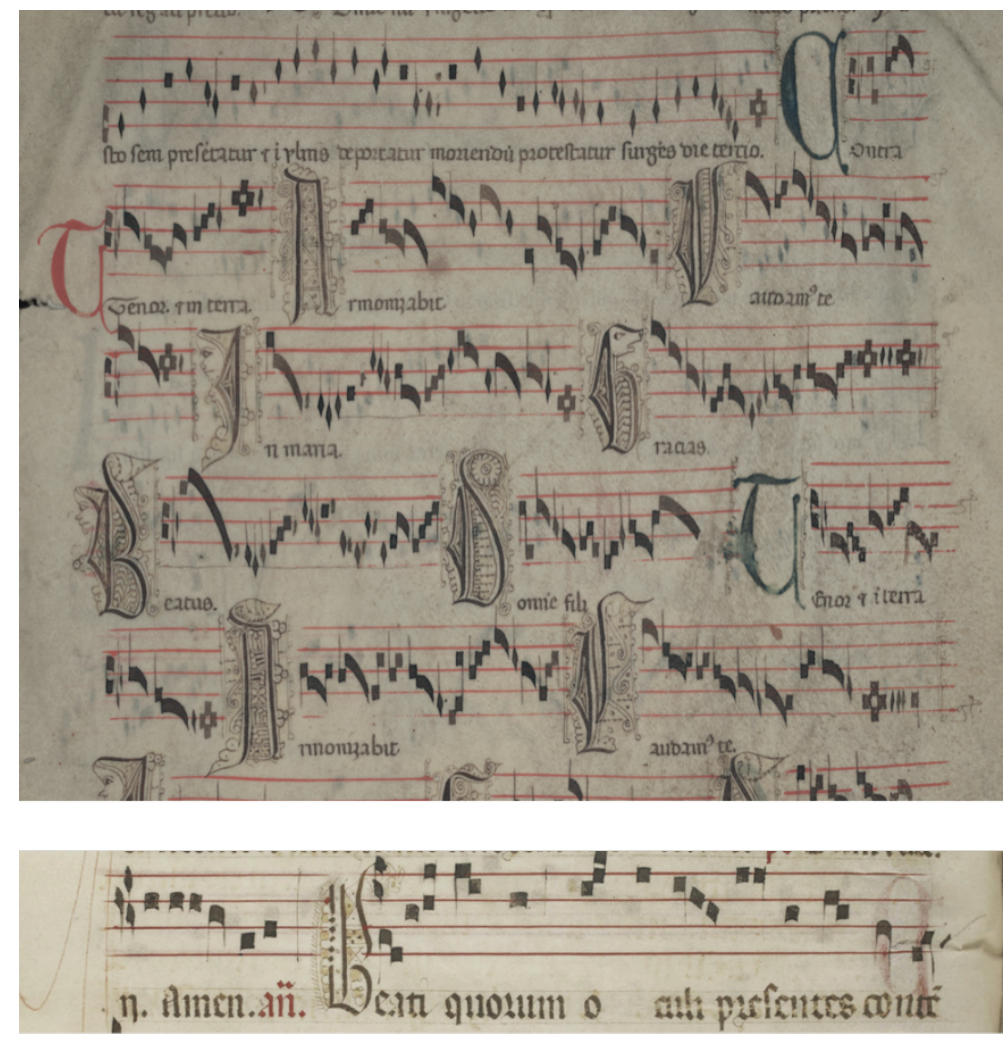

Fig. 7: Ba 971b, f. xiir (above) and Pa 5264, f. 28v (below); @ Barcelona, Biblioteca de Catalunya and Paris, Bibliothèque nationale de France.

The second Gerona fragment, Ge 33/II, consists of one bifolio and one folio containing two Kyries, one Ave regina setting, one Sanctus, and one Agnus dei. This fragment was written by a different scribe and is much more modest than Ba 971b-Ge 33/I in terms of manuscript production. Yet, interestingly, the dimensions of both fragments, Ba 971b-Ge 33/I and Ge 33/II, are suspiciously identical $(292 \times 202 \mathrm{~mm})$, so much so that the two manuscript sections would seem to have been trimmed together. This raises the question of whether Ge 33/II was part of an extension to the manuscript to which Ba 971b-Ge 33/I belonged. The analysis of the binding punched holes on the bifolios' folds is not absolutely conclusive, but sufficiently suggestive; three of the holes seems to align, while a fourth hole is close enough to its counterpart (see Fig. 6). The fact that a hole is missing in Ge 33/II, thus breaking the usual symmetry in the 
position of the binding threads along the book's spine, suggests that, in any case, the bookbinder did not perform his task very carefully. Available evidence, therefore, allows for the assumption that Ba 971b-Ge 33/I and Ge 33/II were bound together in a composite codex, which I will refer to as Ba 971bGe $33 .{ }^{69} \mathrm{It}$ is tempting to speculate whether, at least the most luxurious section of the codex, had its origins in a royal commission.

\section{Poblet}

The most notorious example of musical exchange between the court and an ecclesiastical institution in the Crown of Aragon involves the Cistercian Monastery of Poblet. Located in the countryside at some $10 \mathrm{~km}$ from the royal city of Montblanc, Poblet was one of the largest and most important monasteries in the Principality of Catalonia, reaching its apex in the fourteenth century, when it became a royal monastery under the patronage of the House of Aragon. ${ }^{70}$ In 1340 King Peter the Ceremonious founded a dynastic mausoleum in the abbey church of Poblet and, thenceforth, the Aragonese monarchy promoted important construction work, including a royal palace built inside the monastic complex. ${ }^{71}$ The abbot of Poblet held the office of royal almoner, which implied important duties within the king's household beyond merely administrating the charity funds; he joined the itinerant court, acted as a confessor and a counsellor of the king, and officiated the Divine Offices and other courtly rituals together with the clerics of the royal chapel. ${ }^{72}$

Although John I did not stay in Poblet for long periods, the abbot's presence at court must have sparked his interest in polyphonic music. Monastic records bear witness that a singer of the royal chapel, the French cleric Colinet le Forestier, had lent Fra Vicenç Ferrer, abbot of Poblet, a book of motets and bal-

69 European libraries preserve various examples of similar composite codices. One of the most illustrative cases is the well-known codex Modena, Biblioteca Estense, $\alpha . M .5 .24$ (Mod A), which comprises a luxurious manuscript core section that was supplemented with a later, inexpensive extension of the codex. See Stone 2005; Stoessel 2014. Another pertinent example is Apt 16bis (Tomasello 1982).

70 For a history of Poblet, see Altisent 1974.

71 Altisent 1974, 261-336.

72 Monclús 2005, 161. 
lades. ${ }^{73}$ The document alludes to the close relationship between the abbot and the singer, who served John I from $1391 .^{74}$ After John I's death in 1396, Colinet passed to serve Charles III of Navarre and, later, the duke of Burgundy. When the news of Colinet's death reached Barcelona in 1408, two fellow singers of the royal chapel went to Poblet and asked for Colinet's book. ${ }^{75}$ Since the abbot was absent, the book was handed over the two singers only after they swore an oath before a monk that they would return the book were the abbot to claim his right to inherit it. This clearly shows that the monks of Poblet had access to Colinet's manuscript, and we might suppose that they copied some of its contents. ${ }^{76}$

At least three dismembered manuscripts of ars nova polyphony were used as wrappers for notarial documents in villages that were under the jurisdiction of the Monastery of Poblet. The new identification of Verdú and Fulleda as the provenance of these fragments, now preserved in Barcelona and Tarragona, reveals a pattern of dispersion of obsolete manuscripts possibly originating in Poblet. None of these fragments, however, transmits ballades, but Mass movements and motets.

\subsection{Barcelona, Biblioteca de Catalunya, M. 853c/d (Ba 853c/d)}

Ba $853 \mathrm{c} / \mathrm{d}$ is a very substantial fragmentary manuscript consisting of four bifolios and one folio from a relatively large-format codex $(350 \times 240 \mathrm{~mm})$. The surviving leaves contain ten polyphonic compositions for the Ordinary of the Mass, five of which are unica. The fact that seven of ten pieces include two equalrange upper parts suggests that the manuscript's repertory fulfilled the needs of a specific chapel or group of singers. Ba $853 \mathrm{c} / \mathrm{d}$ was initially classified and described as two different fragments, $853 \mathrm{c}$ and $853 \mathrm{~d} .{ }^{77}$ However, while these two manuscript sections were copied by different scribes, codicological evidence

73 Document published in Anglès 1930 and Gómez 1989, doc. 29. For further manuscript exchanges between Abbot Vicenç Ferrer and the monarchy, see Altisent 1974, 244-245 and 367-368.

74 Colinet had been in the service of Gaston Phébus until the count's death in August 1391. In September of that same year, John I referred to Colinet as 'feel chantre de la nostra Capella' ('trusty singer of our chapel', MiMus DB [ACA, Cancelleria, reg. 1878, f. 168v]). The Poblet document mentions the abbot's friendship with the singer.

75 In the singers' words, 'quia nos desideramus multum habere dictum librum' ('as we would very much like to have the said book').

76 The community's commitment to increase the solemnity of the monastic liturgy is reflected in the commission of an organ around 1422 (Altisent 1974, 368).

77 Gómez 1978, 211-215. 
leaves no doubt that $853 \mathrm{c}$ and $853 \mathrm{~d}$ belonged to the same codex. ${ }^{78}$ Whereas the two sections share the same page-layout and display similar decoration for the capital letters, the punched holes on the bifolios' folds confirm that they were originally bound together (Fig. 8). Even though the manuscript has no original foliation, the fact that some bifolios present the same pattern of damage at the fold's bottom suggests that the gatherings to which these damaged bifolios belonged were originally bound next to each other. Fig. 8 shows a reconstruction of the manuscript's surviving, fragmentary gatherings.

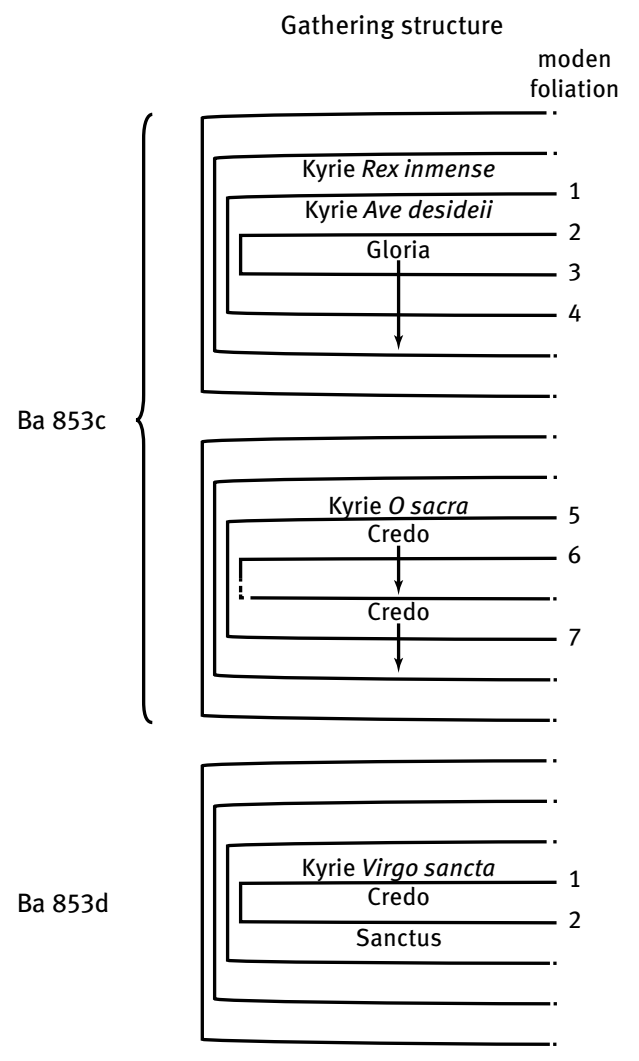

Binding punched holes

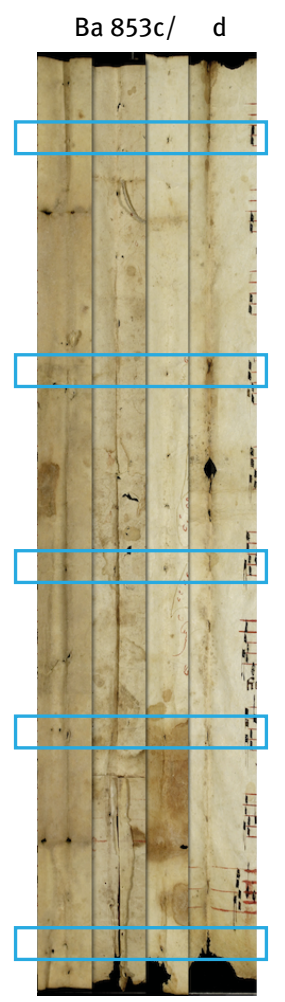

Fig. 8: Ba 853c/d, codicological structure.

78 Tomasello 1995, 110-112. 
Ba 853c/d remained unpublished during Anglès' lifetime, and the library records in Barcelona preserved no information about the provenance of this particular fragment. The identification of the fragment's provenance, however, was made possible by examining the annotations that were written on its leaves while they were used to cover notarial documents. ${ }^{79}$ One of these annotations (f. 6r, bottom right corner) reveals that $\mathrm{Ba} 853 \mathrm{c} / \mathrm{d}$ was used at the parish archive of Verdú, a small town that belonged to the Monastery of Poblet. ${ }^{80}$ The annotation in question records that the community of priests of Verdú had been disturbed by someone called mestre Johan Fistch. ${ }^{81}$ The Verdú provenance of Ba 853c/d indeed matches Anglès' veiled allusions in two of his publications to the existence of polyphonic sources from Verdú. In his 1935 book La música a Catalunya fins al segle XIII, Anglès mentions 'the finding of different fragmentary codices with polyphony from the second half of the fourteenth century in Barcelona, Gerona, Vilafranca and Verdú, ${ }^{82}$ In the same book, Anglès describes seven fragments of plainchant from the parish archive of Verdú that are preserved at the Biblioteca de Catalunya under the shelfmark M. 1451/1-7, which he believed originated in Poblet. ${ }^{83}$ Therefore, Anglès must have referred to $\mathrm{Ba} 853 \mathrm{c} / \mathrm{d}$ and $\mathrm{Ba} 853 \mathrm{~b}$ (see below) when he alluded to two fragmentary codices of polyphony from Poblet. ${ }^{84}$

79 I thank Daniel Vilarrubias and Manel Fuentes for their help in deciphering these annotations in March 2012. The Curator and Head of the Manuscripts Department of the Biblioteca de Catalunya, Anna Gudayol, came to the same conclusion about the fragment's provenance independently; see Gudayol 2014.

80 On the connection between Poblet and Verdú, see Piquer 1968.

81 The beginning of annotation reads: 'A notiçia de la venerable comunitat de preveres de Verdú és previnguda estada intimada per mestre Johan Fistch de dita villa, per en Johan Rialb, beneficiat de dita villa, per manament de mossèn Luis de Seda, balle de dita villa'. Ba 853c, f. 6 r, bottom right corner.

82 Anglès 1935, 265.

83 Anglès 1935, 178. Gudayol 2014 has identified the entire collection of Verdú fragments acquired by Anglès in 1934. For further information on the Verdú fragments, see Salisi 2009 and 2013.

84 Anglès 1935, 263, and Anglès 1957, 8. In 1959, however, Anglès commented on a 1930 publication and noted that 'por detalles conocidos posteriormente puedo añadir que la iglesia de Verdú (Lérida), como filial de Poblet, practicó también la polifonía durante el siglo XIV' ('because of details that I became aware of at a later time, I can add that the church of Verdú, as a filial of Poblet, also practiced polyphony during the fourteenth century'). Anglès 1958, 9 n. 27 (commenting on Anglès 1930). 


\subsection{Barcelona, Biblioteca de Catalunya, M. 853b (Ba 853b)}

Ba $853 \mathrm{~b}$ consists of four fragmentary bifolios in small format $(226 \times 162 \mathrm{~mm})$, which transmit eight polyphonic Mass movements and one Ave regina setting. These four bifolios have been described as having belonged to one single-quire manuscript of six bifolios. ${ }^{85}$ However, the bifolio bearing modern foliation $5 \mathrm{r}-8 \mathrm{v}$ presents a different page layout, and the punched holes on the inner fold which still preserve the original binding threads - indicate that this bifolio formed part of another collection (see Fig. 9). This suggests that Ba 853b's four surviving bifolios originally belonged, not to one, but to two independent single-quire booklets compiled by the same scribe. The manuscripts' single-quire feature is suggested by the fact that the outer folios of one quire are blank (modern foliation $1 \mathrm{r}-12 \mathrm{v}$ ).

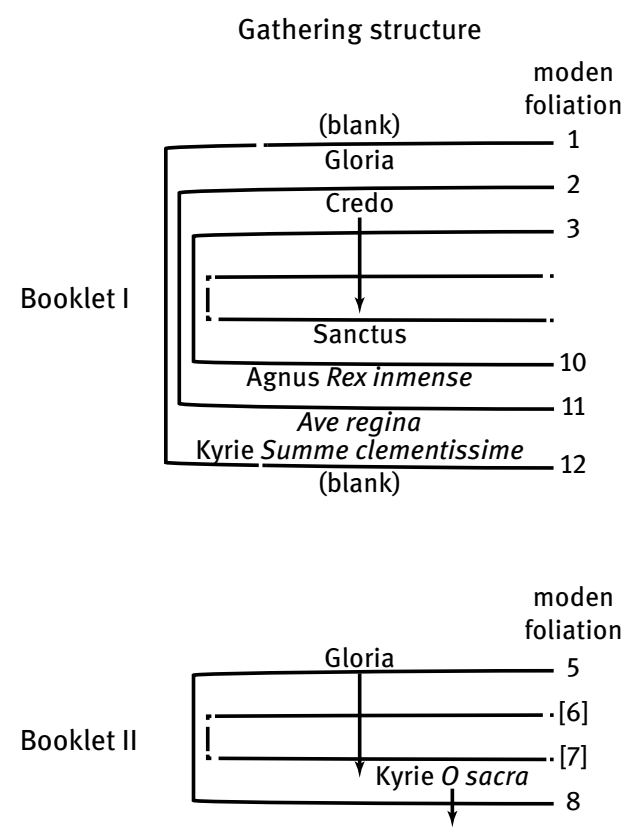

Binding punched holes

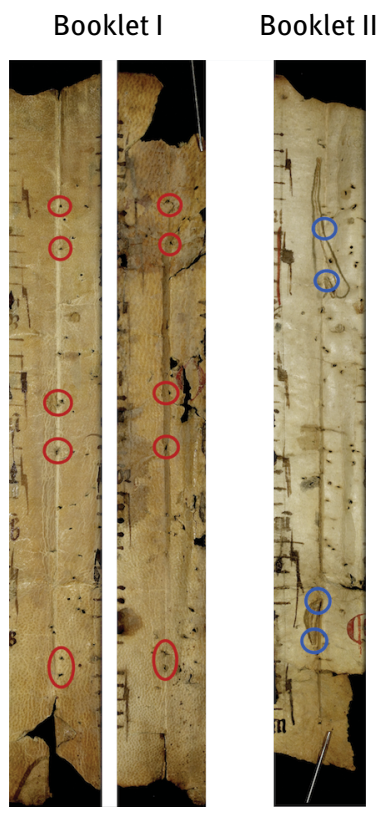

Fig. 9: Ba 853b, codicological structure.

85 Gómez 1978, 208. 
Ba 853b contains many annotations written on its leaves while it was used to cover notarial documents; most of these annotations are in the same hand as those in Ba 853c/d, ${ }^{86}$ from which it clearly follows that Ba 853b, too, comes from the parish archive of Verdú. Yet unlike the repertory contained in Ba 853c/d, the eight compositions for the Ordinary of the Mass transmitted in both of Ba 853b's quires include only one upper voice, which indicates that its repertory fulfilled the needs of a different group of singers. The notoriously large size of the writing, in combination with the manuscript's small format, which made it suitable to be held in the hand, suggests that these quires were intended for practical use in performance. Similar types of small-format single-quire manuscripts were also used to perform plainchant, as witnessed by an exemplar preserved in the archives of Barcelona Cathedral - which even presents the same kind of binding technique as that of $\mathrm{Ba} 853 \mathrm{~b}$ 's second quire. ${ }^{87}$

\subsection{Tarragona, Arxiu Històric Arxidiocesà, Frags. 2 and 3 (Ta 2 and Ta 3)}

Ta 2 and Ta 3 were described for the first time by Gómez Munané in 1981 and, since then, have always been treated as fragments from two different manuscripts - in fact, that is what they look like at first glance; they were copied by different scribes, and they come from different parish archives. ${ }^{88}$ Nonetheless,

86 See, for example, the annotations in Ba 853b, f. 2r and Ba 853c, f. 5r. Gudayol and I came to the same conclusion independently; see Gudayol 2014.

87 Barcelona, Arxiu de la Catedral, Miscel-lànea 23-5. It contains two monophonic Glorias.

88 The Arxiu Històric Arxidiocesà de Tarragona was founded in 1920 for the purpose of centralizing all parish archives of the archdiocese in the ecclesiastical capital of the province. Most of the documents (mostly notarial protocols) arrived in Tarragona between 1921 and 1924. According to the archival policy established by the first director, Sanç Capdevila, any document bound with parchment from medieval codices was to be detached from its cover, and the parchment covers were archived separately in a collection called Fragments de pergamí. At the time of their detachment, each fragment was systematically marked with a pencil annotation recording its provenance - that is, the parish archives where it was found serving as a cover. Currently this collection consists of over 400 fragments dating from the tenth to the fifteenth centuries, including sacramentaries, Bibles, calendars, theological treatises, philosophical commentaries, and an enormous number of plainchant manuscripts. Partially studied by Capdevila (1930), Janini/Ricomà (1965), Companys/Virgili (1995), and Garrigosa (2003), the collection is still not fully inventoried and catalogued. Three folios containing ars nova polyphony were discovered within the Tarragona collection Fragments de pergamí. These three fragments, archived with the signatures MS Fragments 1, 2 and 3 (Ta 1, Ta 2 and Ta 3), became 
here I will suggest that these two fragments belonged to the same codex, possibly originating in the Monastery of Poblet.

Ta 2 consists of one folio in large quarto format containing two fragmentary motets, [Apollinis]/Zodiacum and Colla iugo/[Bona condit]; each motet occupied a manuscript opening, with the triplum on the verso side and the duplum and tenor on the recto side. The folios of this manuscript section were ruled at a preparatory stage with eight pairs of heavily drawn guiding lines for the text, but the staves were rastrated after the text had been entered in order to allow staff indentations to accommodate initial letters. This fragment comes from the parish archives of Passanant, a very small, rural village in central Catalonia, more precisely, near the area of Poblet's fief, although the village itself was not the property of the monastery. ${ }^{89}$ The parish archives of Passanant made use of parchment from other medieval codices, some of which display Cistercian features and can be linked to the Monastery of Poblet with some certainty. ${ }^{90}$

Ta 3 consists of a very damaged folio in large quarto format containing two fragmentary, three-part Glorias, both unica. The Gloria on the verso side is attributed to a certain Guido. ${ }^{91}$ Examples 1 and 2 provide new transcriptions of the surviving musical segments based on UV photographs. Unlike Ta 2, the folios of Ta 3's manuscript section were ruled with nine staves, and the guiding lines for the text were drawn so subtly that they are practically invisible even in the bestpreserved areas of the fragment's surface. Yet, like Ta 2, the staves were rastrated after the text had been entered, in order to leave room for large initial letters. Ta 3 comes from the parish archives of Fulleda - not Fullola, as Gómez Muntané mistakenly reported. Fulleda was a small, rural village, which belonged to the Monastery of Poblet. ${ }^{92}$

known to modern scholarship through the 1981 publication of Gómez Muntané. The collection also includes a fragment of fifteenth-century polyphony (Ta 4) worthy of mention here.

89 For an overview of the village's history, see GEC.

90 Especially fragment 21.14 of the Arxiu Històric Arxidiocesà de Tarragona; see Companys/Virgili 1995, 191 and 194 note 3; Janini/Ricomá 1965, 8.

91 This could be the same Guido, author of two pieces transmitted in the codex Chantilly, Bibliothèque du château, MS 564, f. 25r-v, Dieu gart and Or voit.

92 Poblet had long had possessions in Fulleda, and finally acquired full jurisdiction over the village in 1367 with the mediation of Peter III. Poblet's lordship over Fulleda was confirmed by John I in 1392 along with other lordships near the abbey, which persisted until 1841. Altisent 1974, 389-390 and elsewhere. See also GEC. 


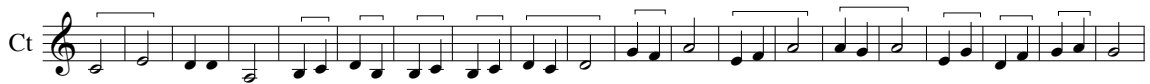
[D]omine Deus

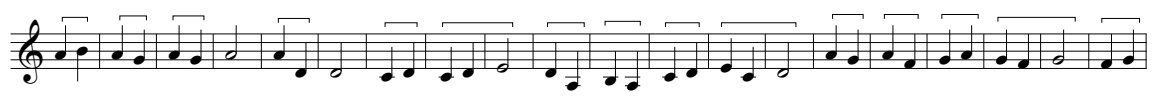

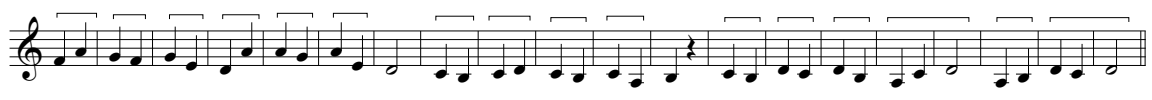

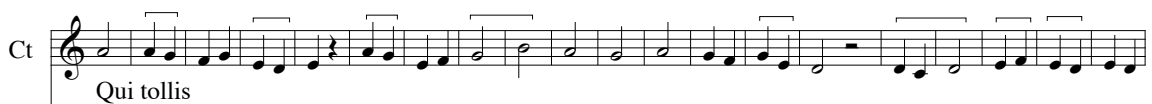

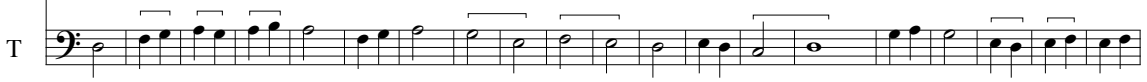
Qui tollis
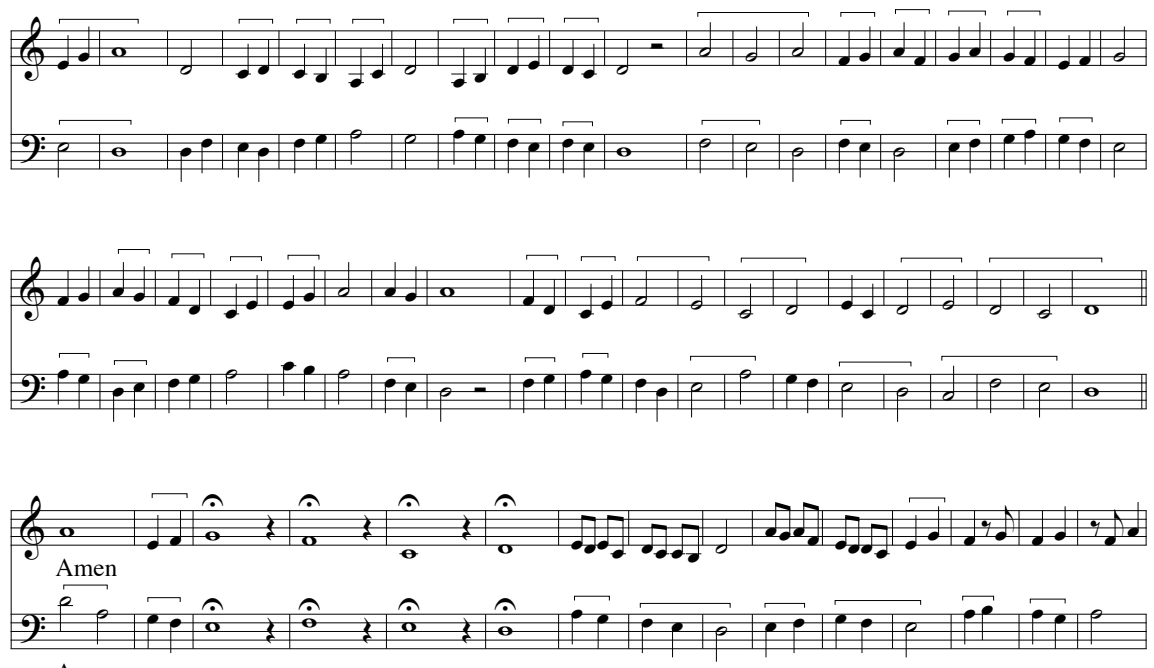
Amen

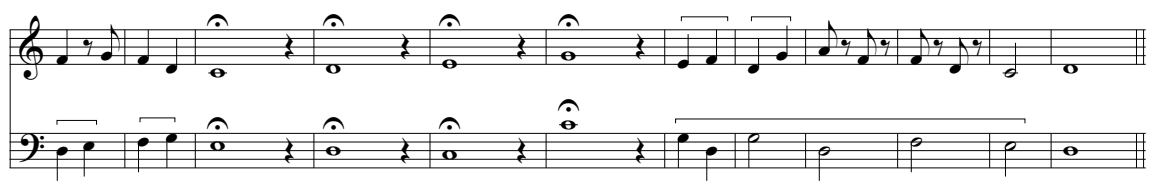

Example 1: Ta 3, recto, end of a Gloria (only tenor and contratenor). 
$\mathrm{C}$
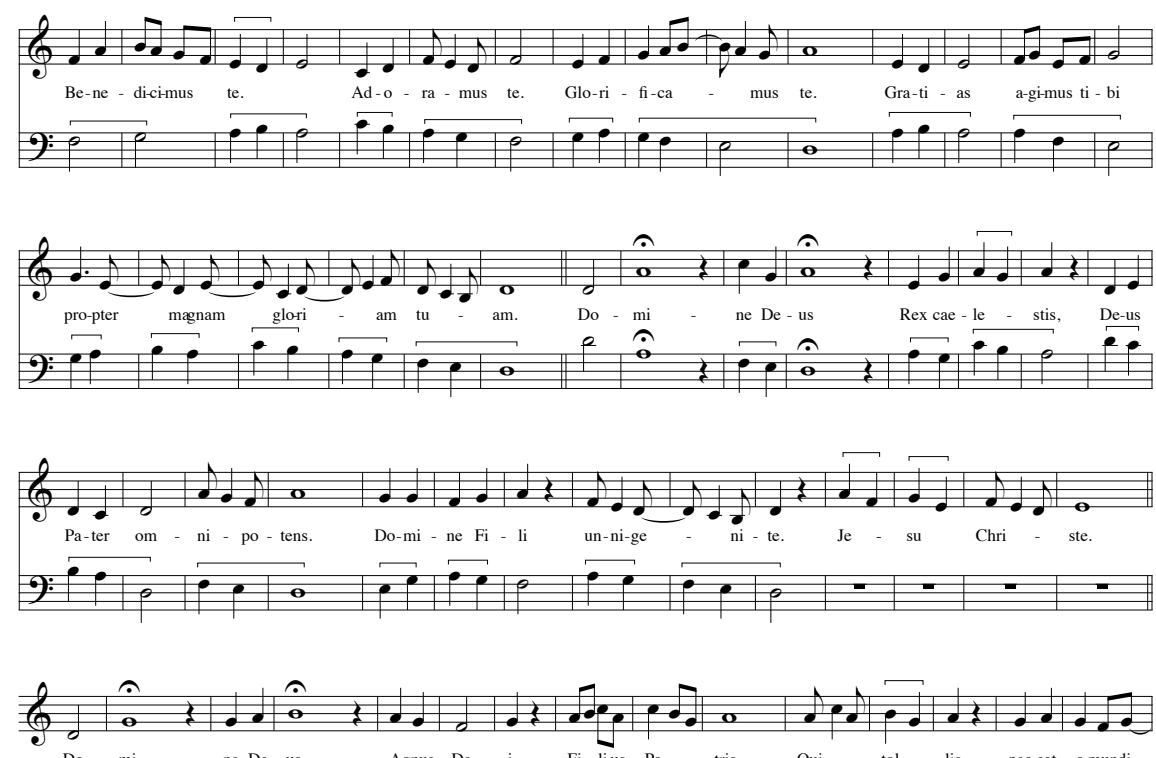

Do - mi - ne De - us Agnus De - i, Fi-li-us Pa - tris. Qui tol - lis pec-cat - a mundi,
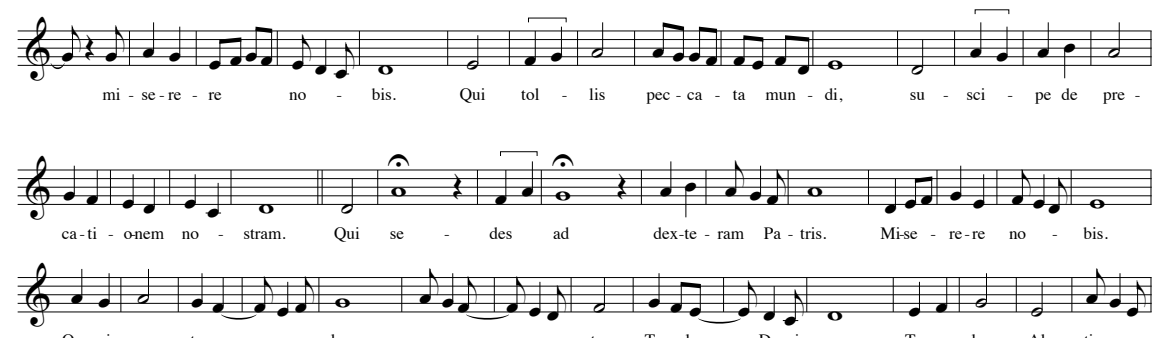
Quo-ni - am tu
so - lus
san
ctus. Tu solus
Domi - nus.
Tu so - lus $\mathrm{Al}$ - tis

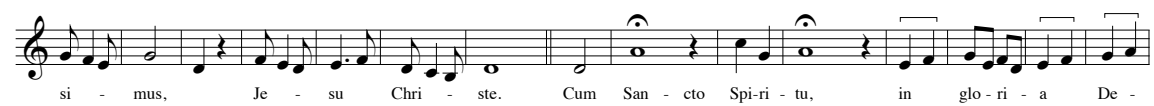

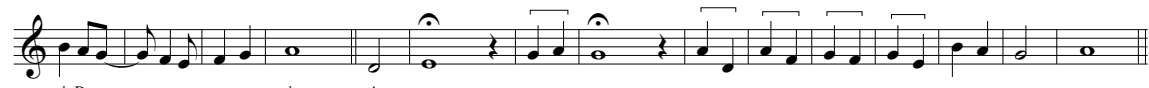

Example 2: Ta 3, verso, beginning of a Gloria attributed to Guido. 


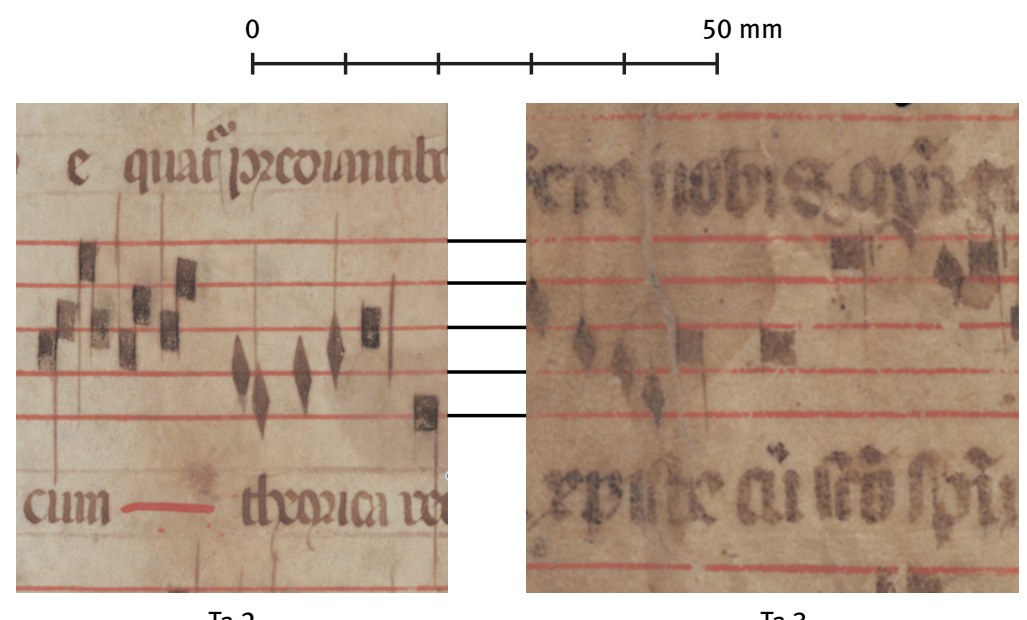

Ta 2

Ta 3

Fig. 10: Ta 2 and Ta 3, rastrum; (C) Tarragona, Arxiu Històric Arxidiocesà.

As surprising as it might seem, Ta 2 and Ta 3 share the same rastrum (Fig. 10). Both fragments have staves that are $18.95 \mathrm{~mm}$ high and are characterised by a slight irregularity in their inter-linear spacing, the first space (counting from above) being the smallest, and the second space the largest. The first and second spaces differ from each other by $0.42 \mathrm{~mm}$; the third and fourth, by $0.26 \mathrm{~mm}$. In both fragments and in each staff, these features remain constant, leaving no doubt that the two manuscript sections were rastrated with the same tool by different scribes.

Despite the divergences in the number of ruled staves per page, the size of the manuscripts' writing frame $(287 \times 192 \mathrm{~mm}$ in Ta 2; $282 \times 200 \mathrm{~mm}$ in Ta 3; see Fig. 11) is similar enough to assume that the two fragments formed part of the same codex. ${ }^{93}$

93 To give a well-known comparative example, codex Iv 115 also involved various scribes, and presents variations in the writing frame ranging from a minimum of $250 \times 175 \mathrm{~mm}$ to a maximum of $292 \times 184 \mathrm{~mm}$. See Kügle 2019 . 


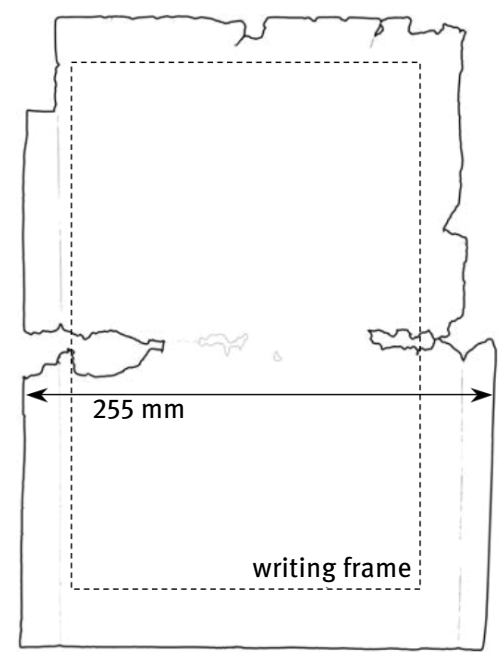

Ta 2

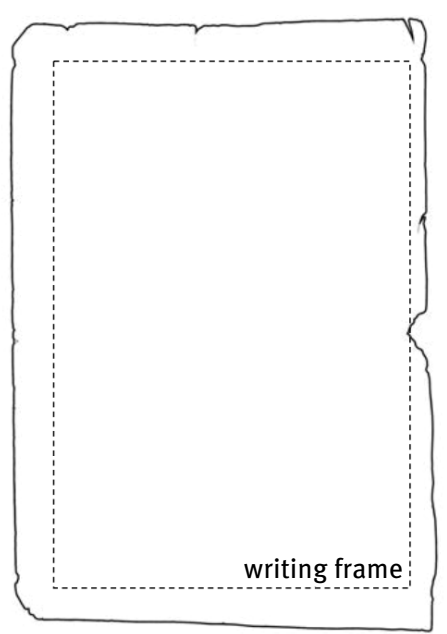

Ta 3

Fig. 11: Ta 2 and Ta 3, format.

There are other cases of dismembered manuscripts whose fragments were dispersed among various institutions in the Poblet area. ${ }^{94}$ In the light of the foregoing evidence, I suggest that Ta 2 and Ta 3 must be treated as one source. The original codex could have been kept at the library of Poblet until it was dismembered and its parchment was sold as recycling material to parish churches within the monastic fief and neighbouring villages.

\subsection{Tarragona, Arxiu Històric Arxidiocesà, Frag. 4 (Ta 4)}

Although Ta 4 transmits a repertory that is slightly younger than that analysed in this study, this fragment sheds further light on the pattern in which presumably monastic manuscripts were dismembered and dispersed among parishes neighbouring Poblet's feudal properties. Ta 4 consists of two fragmentary folios from a fifteenth-century paper manuscript, which served as a wrapper for

94 Codex 13 of the Monastery of Poblet preserves fifteen folios from a twelfth-century Commentary on the Psalms; two further folios from the same manuscript were used to cover documents at the Monastery of Santes Creus. These fragments from Santes Creus are now kept at Tarragona. Janini/Ricomá 1965, 3 (Ms 18.6), Janini 1966, 218 (Còdex 13), Companys 1994, 193. 
notarial documents at the parish archive of Sant Martí de Maldà, a small, rural village situated midway between Verdú and Fulleda. ${ }^{95}$ The fragment contains two polyphonic songs, one of them attributed to Johannes Cornago, and two fragmentary settings of the Lamentationes Ieremiae possibly dating from the middle or second half of the fifteenth century. ${ }^{96}$ Marginal annotations written in Italian by the manuscript's main scribe, as well as the paper's watermark (Fig. 12), could suggest that the manuscript was produced in Italy, either within the realm of the Neapolitan court of Alfonso the Magnanimous, king of Aragon and Naples (r. 1416-1458), or, most likely, within that of his son Ferdinand I of Naples (r. 1458-1494). ${ }^{97}$ Given the location of Sant Martí de Maldà, adjoining the

95 This village is now called Sant Martí de Riucorb. For an overview of the village's history, see GEC.

96 Ta 4 was (partially) published in Escalas 2005. For the polyphonic songs and their concordances, see Fallows 1999, 434-435 (contrafactum of Elend du hast with the text Madamme helas) and 621-622 (Non gusto; An gusto in Ta 4). The two Lamentation settings are not reported in Escalas 2005. The text corresponds to Lam 3.26-28 (recto, tenor part); Lam 5.1-5 (verso, upper part). While these texts are not the most familiar sections set from the Lamentations (especially Lam 3; see Scott 2004, 42-43, Table 2.02), Ta 4 has musical concordances with Petrucci's Lamentationum Jeremie I (8 April 1506) and II (29 May 1506). The music - but not the text corresponds to the anonymous three-part setting in Petrucci (I) between Ycart and Agricola, possibly also by Ycart if the attribution continues. Given that Ta 4 sets different Lamentations texts to adaptations of the same music, it is possible that Ta 4's segments belonged to a longer setting of which only the opening sections are in Petrucci. The fragment's mise en page suggests that Ta 4's copy is in only two parts; the (inessential) bassus was either removed in Ta 4 or added in Petrucci. I thank Margaret Bent for sharing her views on this material.

97 F. lx r, bottom: 'Senza [?a]moranza'; f. lx v, bottom: 'affe[?...]i e lamoranza' (i.e. either l'amoranza or la moranza). Moranza is an earlier Italian word meaning stanza (in the sense of room) or dimora (dwelling place); amoranza is a noun derived from amore (love). The inscriptions' meaning in this context, however, remains unclear. The phrase 'Senza moranza' on $\mathrm{f}$. lx $\mathrm{r}$ does not seem to be a song incipit, as the verso of the folio contains a different piece. I thank Bonnie Blackburn and Leofranc Holford-Strevens for sharing their views on these inscriptions. As for the watermark, Briquet 1907 classifies scissors watermarks as exclusively Italian, although similar watermarks are found in Iberian manuscripts due to the trade of Italian paper on the Iberian Peninsula (Carvajal 2011, 295). Johanes Cornago served in Alfonso's royal chapel in Naples from at least 1453. After Alfonso's death in 1458, Cornago worked for Ferdinand I of Naples, and in 1475 returned to Spain and entered the service of Ferdinand the Catholic in Aragon. The well-known MS 871 of the Montecassino Abbey, dated around 1480, transmits musical repertory associated with the Aragonese court in Naples (including songs by Cornago and a now-lost setting of the Lanentationes Ieremiae), although the manuscript itself is thought to have originated within a monastic setting. Interestingly, the Montecassino manuscript contains a watermark similar to that of Ta 4 (see a reproduction in Pope/Kanazawa 1978, 265266). See also Atlas 1985, and Knighton 2019, esp. 242-244. 
area of Poblet's fief (Verdú and Fulleda), and considering the strong connections between the monastery and the royal court, the Monastery of Poblet emerges as the most likely provenance of the fragment before it reached Sant Martí.
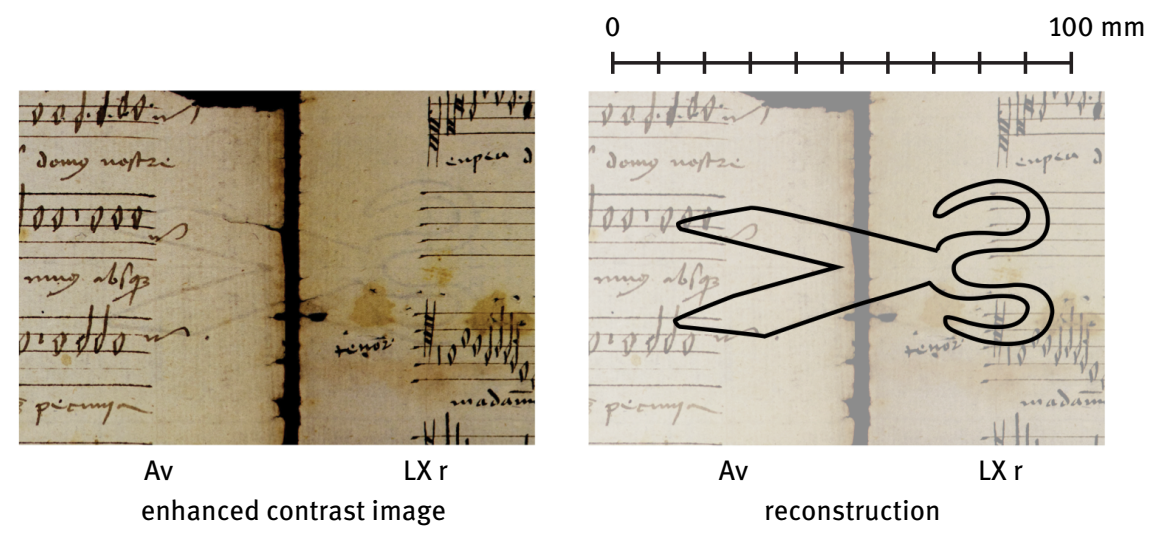

Fig. 12: Ta 4, watermark; @ Tarragona, Arxiu Històric Arxidiocesà.

Poblet kept close ties with the Aragonese royal chapel throughout the entire fifteenth century, even when the court had moved to Naples. Alfonso's court included two monks from Poblet among the royal chaplains, and the king maintained ongoing correspondence with the monastery throughout his reign. ${ }^{98}$ This tradition continued during the reign of Alfonso's successor in Aragon, John II, whose chapel also included two monks from Poblet. ${ }^{99}$ Ferdinand I of Naples also had close connections with Poblet and was buried there in the royal mausoleum at the abbey church. Musical exchanges between the monastery and the royal chapel persisted further into the times of the Catholic Monarchs, Isabel of Castile and Fernando of Aragon; in 1493 Isabel and Fernando attended a pontifical office at the Abbey Church of Poblet, after which the queen asked for a copy of the Credo performed by the monks, in order to have it sung by the royal chapel. ${ }^{100}$

98 See Anglès 1961, 90-91, and De Diego 2001.

99 Anglès 1961, 92-93.

100 Altisent 1979, 369, citing Finestres 1753, IV, 71. 


\section{Cervera}

Finally, a key piece in this provenance puzzle of ars nova fragments involves the small village of Granyena and its neighbour city Cervera. The sixteenth-century notaries of Granyena made use of a large number of medieval fragments to bind their notarial manuals, including a bifolio removed from a collection of ars nova polyphony now preserved in the Diocesan Archives of Solsona under the shelfmark Còdex 109 (Sol 109). ${ }^{101}$ Sol 109 contains four fragmentary pieces: three Glorias and one Credo. ${ }^{102}$ The manuscript fits the typology of a practical, inexpensive volume in large quarto format (originally some $335 \times 240 \mathrm{~mm}$ ) possibly dating from c.1400. Sol 109 was compiled by a skilled music scribe who produced a copy practically free of errors, although the poorly drawn initial letters detract from the manuscript's appearance.

The village of Granyena was officially incorporated into the neighbourhood of Cervera in 1462, and thus began to be called Granyena de Cervera. ${ }^{103}$ The sixteenth-century notaries of Granyena, therefore, could easily have acquired old parchment from the many religious institutions in Cervera, including the city's main church and various notable monasteries. ${ }^{104}$ With this respect, it is worth having a closer look at the Church of Saint Mary in Cervera, where the practice of polyphonic music seems to have responded to the demands for an increasingly elaborate liturgy that was in accordance with the importance of the building.

The Church of Saint Mary in Cervera constitutes a remarkable example of Catalan Gothic architecture. Its structure comprises three wide naves with

101 The Bishopric of Solsona was created in 1595; before that, the churches of Granyena and Cervera had belonged to the Bishopric of Vic.

102 Gómez 1985b, 177-179; Gómez 1993, 17-19.

103 Cervera had enjoyed the status of royal town since 1275, which led many nearby villages to join its neighbourhood in order to take advantage of its special rights and privileges. In the fourteenth century, it was considered the eighth most important city in the Principality of Catalonia. Its strong commercial and industrial activity gave rise to an incipient bourgeois class. For an overview of the history of Cervera, see GEC.

104 The collection of fragments recovered from the parish archive of Granyena is very interesting in itself. An earlier fourteenth-century fragment that includes non-mensural twopart settings of liturgical chants attests to a certain tradition of polyphonic singing in the area (Gómez 1985a). Other liturgical fragments with plainchant date from the twelfth to the fifteenth century; the earlier fragments are described in Garrigosa 2003, 207-208. Another fragment used at the same parish archive contains a fifteenth-century copy of Dante's Inferno with Catalan glosses. Sabaté (2016, 90-91) connects this fragment with the fact that, in this period, wealthy merchants began to send their sons to study in Italy. 
lateral chapels and a polygonal apse with an ambulatory and eight radial chapels. ${ }^{105}$ The project of this cathedral-like structure began to take shape in the early fourteenth century, when King James II proposed Cervera as the seat of a new bishopric. Although James' plan for a restructuration of the Catalan ecclesiastical map was finally frustrated, the City Council of Cervera brought together the necessary capital to move the monumental project forward. The active participation of local guilds is most evident, given the presence of their emblems on the pillars that separate the ambulatory from the main chapel. Merchants, citizens and officials assumed the cost of the radial and lateral chapels and turned them into family mausoleums. ${ }^{106}$ The prosperity of this emerging bourgeois class in Cervera is clearly reflected in the sumptuousness of their tombs.

One sign of the citizens' interest in the musical solemnization of the church's liturgy was their financial contribution to the construction of an organ at Saint Mary of Cervera in the early fifteenth century. ${ }^{107}$ In 1408 the community of priests took the initiative and commissioned a large instrument from a young organ builder who was visiting the city. ${ }^{108}$ Because the community alone was not able to pay the full amount, they asked the City Council for help; the Council made no objection to the commission, but resolved that it had to be paid directly by the town's citizens and that no Council funds could be spent. The fundraising was extremely successful and, by late 1413, the new organ was being decorated with paintings by the same French glassmaker who made the church's beautiful stained-glass windows. ${ }^{109}$ Cervera's community of priests also had occasional contacts with the royal court in Barcelona. In 1419 they bought a second, smaller organ (orguens menors) from the reputed organ builder Pere Granyena, one of the most beloved courtiers of King Alfonso the Magnanimous. ${ }^{110}$

105 By 1344, many of the secondary chapels were in place; in 1358 the high altar was consecrated, and five years later the presbytery was completed. For more information on this church, see the especial issue of Miscel-lània Cerverina 16 (2003), in particular Verdés 2003, and Beseran 2003.

106 Indeed, the Church of Saint Mary of Cervera preserves the largest group of tombs of medieval merchants in the entire Principality of Catalonia (Español 2002, 147-150).

107 The participation of Cervera's citizens and corporations in the finances of the church was constant throughout the fourteenth and fifteenth centuries. See Verdés 2003.

108 Arxiu Històric Comarcal de Cervera, Fons Municipal, Consells 1408, f. 64r-v. See Miró 2003, 229-230.

109 Barral/Mundó 2014, 50, 51, 53. The original stained-glass windows are still preserved.

110 This small organ cost 30 gold florins. Later documents suggest that this instrument was carried in Corpus Christi processions (Miró 2003, 230). For more on the organ builder Pere 
The inventory of books drafted by the episcopal notary on the occasion of a pastoral visitation by the bishop of Vic in 1425 attests to the fact that the choir of the church in Cervera was provided with, not just one, but three books of polyphony. ${ }^{111}$ The bishop was content with what he saw, and ordered that the books be attached with chains to the new lecterns. While no direct evidence of a music teacher in Cervera prior to the late fifteenth century has survived, some of the church organists could potentially have acted as teachers of music, including polyphony, as occurred in other Iberian churches. ${ }^{112}$ The first organists at Cervera were generally priests of the church, although lists of payments also record occasional appearances of other organists, such as a student at Cervera (1419), a Franciscan friar (1422), and a Dominican monk (1429). ${ }^{113}$

The case of Cervera shows the extent to which the sophistication of church music mirrored the aspirations for prestige of the city's emerging bourgeois society. The integration of the Church of Saint Mary in the heart of Cervera's urban life therefore suggests that, by the turn of the century, polyphonic music had begun to have a certain social impact in Central Catalonia. The cultivation of ars nova polyphony might have been seen as an important element of the liturgy in big cathedrals. In this respect, the connection between the church of Cervera and Vic Cathedral is highly suggestive, as the cathedral archives of Vic preserve the fragment of yet another volume of ars nova polyphony. ${ }^{114}$

\footnotetext{
Granyena, see Anglès 1940 [1975], 944; Baldelló 1966, 132, and Gómez 1979, docs. 264, 278, 279 , 281, 282. See also MiMus DB (ACA, Cancelleria, reg. 2609, f. 116r-v).

111 'Item [...] tres libros de cant d'orgue'. There was a total of nineteen books in the choir, including six psalters. Another group of nine books had been legated by a deceased priest. The document of the pastoral visitation is published in Junyent 1967, 226-227; the list of books is further reproduced in Miró 2003, 246.

112 On the involvement of organists in music teaching and polyphonic performance around 1400, see Catalunya 2020.

113 See Miró 2002 and Miró 2003, 236-237.

114 Vic, Arxiu i Biblioteca Episcopal, Fragment V/60 (Vic 60). It consists of a fragmentary folio, of which only the lower half has survived, containing a Credo (unicum). The original manuscript was a volume in large format measuring around $400 \times 270 \mathrm{~mm}$. Although the monarchs did not visit the city very often during the second half of the fourteenth century, there is evidence that Prince John was in Vic with his entire chapel of singers and minstrels in 1385 (Gómez 1979, doc. 240). The main stream of cultural exchange at Vic, however, seems to have involved other big cathedrals, especially those of Tarragona, Barcelona and Gerona.
} 


\section{Coda: Mapping the Dissemination of ars nova Polyphony in Aragon}

King John I of Aragon was an enthusiast music lover. His reign is characterised by a chronic administrative disorder that plunged the kingdom into political chaos, while he emptied the royal coffers towards the creation and maintenance of a flamboyant court. Over 460 letters and documents preserved in the royal archives in Barcelona attest to John I's compulsive, obsessive attitude towards bringing the best and most demanded singers and minstrels to his service. The formation of his musical chapel took place in 1379, when he was still a prince, with the hiring of Avignonese singers and the commissioning of a book of polyphony from French singers. ${ }^{115}$ John ascended to the throne in January 1387 and, barely one year later, he convened the first assembly of the General Courts of the Crown of Aragon of his reign. ${ }^{116}$ The meeting lasted more than one full year (from November 1388 to December 1389) and served as a stage for the exhibition of the court's wealth before the representatives of the kingdoms' cities and the noble and ecclesiastical factions. John's hiring of foreign musicians increased exponentially during precisely this period, as his marriage to Violant de Bar ensured fluent connections with the French aristocracy. ${ }^{117}$ The letters issued during this General Courts meeting show the extent to which the royal couple, John and Violant, intensified the musical exchanges with the Duke of Burgundy, the Count of Foix, the Duke of Berry, the King of France, and the papal chapel in Avignon. As a result of these exchanges, not only musicians, but also books of polyphonic music, including the famous Machaut manuscript Vg,

115 Gómez 1979, doc. 223. This manuscript cost eleven gold florins, which were paid to the French singer Ambrós Porcellet (Gómez 1979, doc. 232). While this was not an especially expensive manuscript, it probably reached the scribal quality standards shown in the Trem fragment (Paris, Bibliothèque nationale de France, nouv. acq. fr. 23190, olim Angers, Château de Serrant, Duchesse de la Trémoïlle), a polyphonic manuscript copied in 1371 by a chaplain of the royal chapel of King Charles V of France for the use of the chapel (see Droz/Tibault 1926). The Trém fragment features a formal libraria textualis script, red and blue initials letters, and professional pen-work decoration. For the documents concerning the formation of Prince John's musical chapel, see Gómez 1979, docs 223-234.

116 The meeting took place at Monzón Cathedral and brought together simultaneously the Courts of the Principality of Catalonia and of the Kingdoms of Aragon, Valencia and Mallorca.

117 Queen Violant de Bar is an extremely interesting character in this story; her involvement in political affairs and musical and artistic patronage deserves a study of its own. 
reached Aragon during the 1389 assembly. ${ }^{118}$ In May of that year, John commissioned a second book of motets from the singers of the pope in Avignon. ${ }^{119}$ John I even presented himself as an amateur composer of polyphonic music when he stated that he had 'made a rondeau notated with its tenor, contratenor and cantus' with the help of some of his singers. ${ }^{120}$

Surviving manuscript evidence suggests that the court's new musical fashion had an extraordinary impact on Catalan churches. While many ecclesiastical archives throughout the Iberian geography preserve thousands of fragments from medieval plainchant codices, the archives in the region of the Principality of Catalonia present an exceptional concentration of fragments of ars nova polyphony (see Fig. 13). Most of these polyphonic fragments come from churches and cathedrals and in those royal cities where John I's court had a particularly strong influence (Barcelona, Vilafranca, Gerona). Barcelona Cathedral, closely tied to the Royal Palace, also emerges as an important dissemination centre for polyphonic music, thanks to which this musical practice reached other Cathedrals (Vic, Tarragona). Finally, a third pattern of provenances of ars nova fragments involves parish churches in small, rural villages, where this kind of complex polyphony is indeed rather unlikely to have been practiced (Granyena, Fulleda, Passanant, Sant Martí de Maldà, Granyena, Verdú). ${ }^{121}$ Most of these villages, however, fall into the area situated between the Royal Monastery of Poblet and the city of Cervera, where the existence of polyphonic manuscripts in the period c.1390-1425 is attested to in historical documents and inventories.

118 On the Vg manuscript (Cambridge, Corpus Christi College, Parker Library, Ferrell MS 1, the Ferrell-Vogüé Machaut Manuscript), see Alberni 2012, 94, Alberni 2018, and Earp 2014, esp. 47-55. 119 MiMus DB (ACA, Cancelleria, reg. 1956, f. 73r-v); Gómez 1979, doc. 243. The only ars nova fragment that comes from this region of Aragon is Barcelona, Biblioteca de Catalunya, M971c (Ba 971c). It consists of one folio in quarto format containing two fragmentary troped Kyries. Although Anglès never mentioned this source in any of his scholarly writings, his handwriting can be identified in a pencil annotation written in Catalan in the fragment's margin, stating: 'Coberta d'un llibre provi- / nent d'Aragó' ('Cover of a book that comes from Aragon'). Whereas the lack of further information does not allow us to trace the fragment's specific provenance, the cathedrals and monasteries in Zaragoza, Monzón, Roda de Isábena and Huesca come easily to mind. In terms of manuscript production, this and the Gerona fragments are definitely the most refined ars nova sources that have survived in the territories of the Crown of Aragon. Somewhat ironically, however, Ba 971c's possible connection with the royal court has never been suggested.

120 Gómez 1979, doc. 229.

121 The Verdú scenario, however, is rather complex and deserves especial consideration in a future study. 


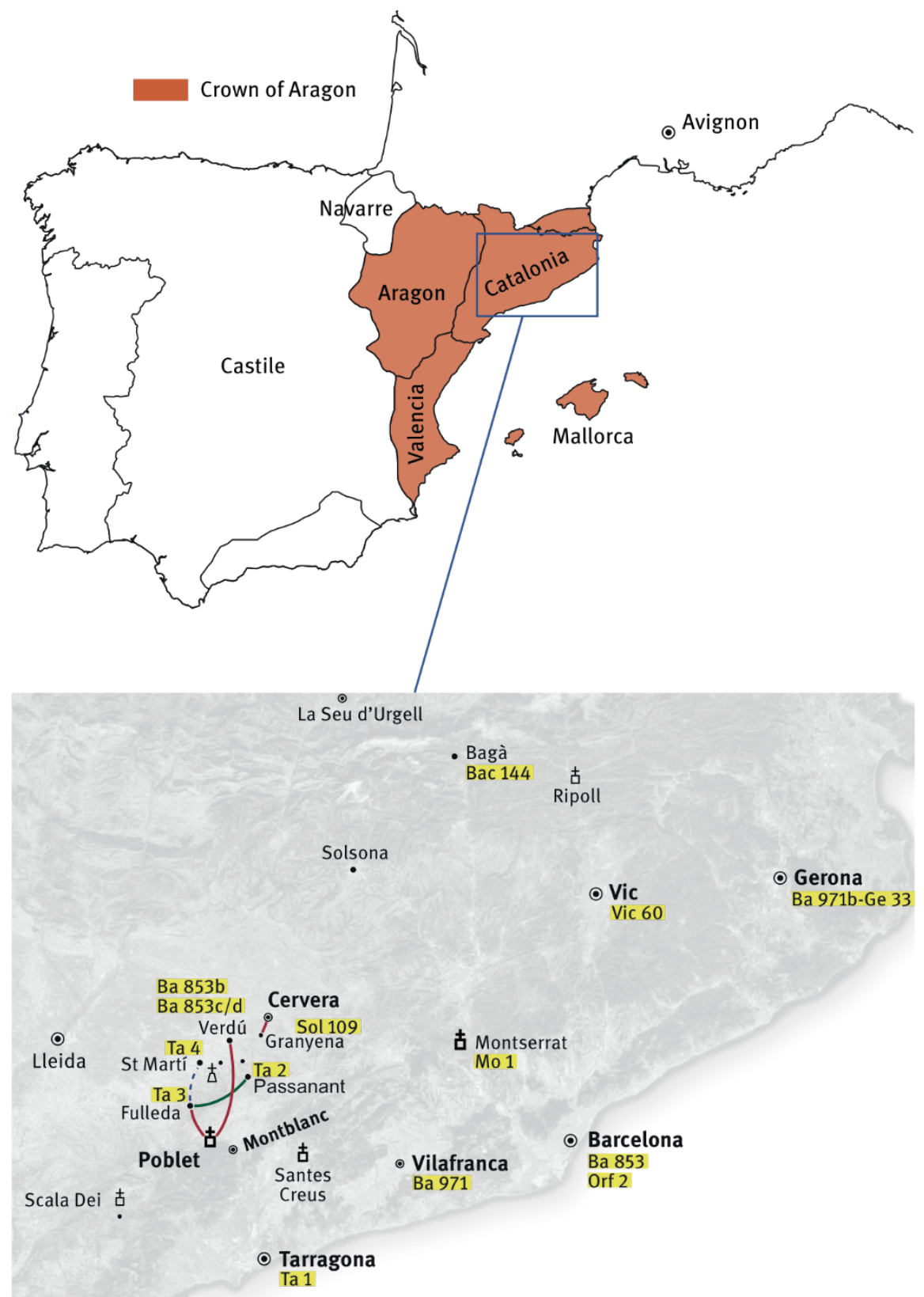

Fig. 13: Provenances of the Aragonese sources of ars nova polyphony. 
The presence of further Cistercian fragments in some of these parish archives confirms a pattern of dispersion and reuse of parchment originating in nearby institutions such as Poblet.

Despite these highly suggestive patterns of provenance, the fragmentary folio reused as a wrapper for notarial documents in the church of Bagà (a small village in northern Catalonia) is a good example of how the trade of medieval books and fragments does not always fit any expected path. ${ }^{122}$ Thus far, no obvious connection of this ars nova manuscript to any institution or individual can be established; the village of Bagà seems to be too far away from the main urban, political and ecclesiastical centres. At the present stage of research, the only statement can be made about the origins of this manuscript is that it does not fit the context of a small village like Bagà.

If John I's court emerges as a major force behind the introduction and dissemination of ars nova polyphony in Catalonia, by 1400 the new musical fashion had filtered down into popular culture. The famous Llibre Vermell of Montserrat (Mo 1), dating from the late fourteenth century, provides a remarkable example of this. As is well known, the Benedictine Abbey of Montserrat was a major pilgrimage site. The Llibre Vermell contains a compilation of miracles performed by the Virgin Mary of Montserrat, and includes a few pieces in a less sophisticated style of ars nova polyphony. ${ }^{123}$ The manuscript compiler noted that:

Because the pilgrims wish to sing and dance while they keep watch at night in the Church of the Blessed Mary of Montserrat [...] these songs that appear here have been written. And these should be used modestly, without disturbing those who keep watch in prayer and contemplation. ${ }^{124}$

122 Barcelona, Arxiu de la Corona d'Aragó, MS frag. 144 (Bac 144), published in Gómez 1978, 216. The Arxiu de la Corona d'Aragó preserves not only the historical archives of the Royal House of Aragon, but also documents from a number of ecclesiastical institutions, whose archives were confiscated in the nineteenth century. Bac 144 contains a troped Kyrie, unique to this source. The original manuscript seems to have been an ambitious project that remained unfinished; both the text and music scripts were carefully produced, and the staff indentation comprises the first two lines, leaving space for a large decorated initial letter. For an overview of the history of village of Bagà, see GEC.

123 On the Llibre Vermell, see Anglès 1955, Altés 1989, Gómez 1990, and Lannutti 2012. Lannutti is currently preparing a more detailed study of the Llibre Vermell.

124 Abadia de Monserrat, MS 1, f. 22r: 'Quia interdum peregrini quando vigilant in ecclesia Beate Marie de Monte Serrato volunt cantare et trepudiare, et etiam in platea de die, et ibi non debeant nisi honestas ac devotas cantilenas cantare, idcirco superius et inferius alique sunt scripte. Et de hoc uti debent honeste et parce, ne perturbent perseverantes in orationibus et devotis contemplationibus'. 
The manuscript sources of ars nova polyphony, the vast majority of which survive only in fragmentary form, thus offer us a fascinating glimpse, not only into the topography, but also the sociology of this musical style in Catalonia. Probably because it was intensively cultivated at the royal court, this musical practice became fashionable also among cathedral clerics, church priests and monks, and increasingly appreciated by citizens and pilgrims. The wide dissemination of ars nova polyphony in Catalonia is well reflected in a variety of manuscript typologies, which range from the relatively luxurious codex to the amateur's inexpensive booklet.

\section{Acknowledgements}

The author wishes to thank Daniel Vilarrubias and Manel Fuentes for their help in elucidating the provenance of several musical fragments, Giovanni Varelli, Karl Kügle, Anna Alberni, Margaret Bent, Grantley McDonald, Uri Smilansky and Soterraña Aguirre Rincón for reading and commenting on an earlier version of this essay, and all members of the MiMus project team for granting the privilege to consult the documents ahead of their publication.

\section{Abbreviations}

$\begin{array}{ll}\text { ACA } & \text { Barcelona, Arxiu de la Corona d’Aragó. } \\ \text { GEC } & \begin{array}{l}\text { Gran Enciclopedia Catalana <https://www.enciclopedia.cat/gran- } \\ \text { enciclopedia-catalana>. }\end{array} \\ \text { MiMus DB } & \begin{array}{l}\text { Database Ministrers i música a la Corona d'Aragó medieval } \\ \text { <http://mimus.ub.edu>. }\end{array} \\ \text { PMFC } & \begin{array}{l}\text { Polyphonic Music of the Fourteenth Century, see Schrade } \text { et al. (eds), 1956-1991. } \\ \text { RISM }\end{array} \\ & \text { Gilbert Reaney (ed.), Répertoire International des Sources Musicales, Series B, } \\ & \text { vol. IV/2: Manuscripts of Polyphonic Music (c.1320-1400), Munich: G. Henle } \\ & \text { Verlag, 1969. }\end{array}$

\section{References}

Alberni, Anna (2012), ‘El Roman de Cardenois i l'empremta de Guillaume de Machaut en la poesia catalana medieval', in Romania, 130: 74-108.

Alberni, Anna (2018), 'Machaut's Literary Legacy in the Crown of Aragon: the Catalan Chansonnier Vega-Aguiló and the Anonymous Roman de Cardenois', in Nicola Morato and Dirk Schoenaers (eds), Medieval Francophone Literary Culture Outside France. Studies in the Moving Word, Turnhout: Brepols, 391-410. 
Altés i Aguiló, Francesc Xavier (1989), Llibre Vermell de Montserrat. Edició facsímil parcial del manuscrit núm. 1 de la Biblioteca de l'Abadia de Montserrat. Introducció, Barcelona: Publicacions de l'Abadia de Montserrat.

Altisent, Agustí (1974), Història de Poblet, L’Espluga de Francolí: Publicacions de l'Abadía de Poblet.

Anglès, Higini (1925a), 'Cantors und Ministrers in den Diensten der Könige von Katalonien-Aragonien im 14. Jahrhundert', in Wilhelm Merian (ed.), Bericht über den musikwissenschaftlichen Kongress in Basel veranstaltet anlässlich der Feier des 25-jährigen Bestehens der Ortsgruppe Basel der Neuen Schweizerischen Musikgesellschaft Basel von 26. bis 29. September 1924, Leipzig: Breitkopf \& Härtel, 56-66.

Anglès, Higini (1925b), 'Els cantors i organistes franco-flamencs i alemanys a Catalunya els segles XIV-XVI', in Gedenkboek aangeboden aan Dr. D.F. Scheuerleer op zijn 70sten verjaardag, 49-62.

Anglès, Higini (1930), 'Gracian Reyneau am Königshof zu Barcelona in der Zeit von 139... bis 1429', in Festschrift für Guido Adler, Vienna: s.n., 64-70.

Anglès, Higini (1935), La música a Catalunya fins al segle XIII, Barcelona: Biblioteca de Catalunya [reprint 1988].

Anglès, Higini (1940), 'La música en la corte del rey don Alfonso V de Aragón, el Magnánimo (años 1413-1420)', in Spanische Forschungen der Görresgesellschaft, 8: 339-380; reedited in José López-Calo (ed.), Hygini Anglés: Scripta Musicologica, vol. 1, Rome: Edizioni di Storia e Letteratura, 1975, 913-962.

Anglès, Higini (1941), La música española desde la edad media hasta nuestros días. Catálogo de la exposición histórica, Barcelona: Biblioteca Central.

Anglès, Higini (1948), 'España en la historia de la música universal', in Arbor, 11(33-34): 1-52.

Anglès, Higini (1955), 'El “Llibre Vermell” de Montserrat y los cantos y la danza sacra de los peregrinos durante el siglo XIV', in Anuario Musical, 10: 45-78.

Anglès, Higini (1957), 'La música sagrada de la capilla pontificia de Avignon en la capilla aragonesa durante el siglo XIV', in Anuario Musical, 12: 35-44.

Anglès, Higini (1958), 'De cantu organico: Tratado de un autor catalán del siglo XIV', in Anuario Musical, 13: 3-24.

Anglès, Higini (1961), 'La música en la corte real de Aragón y de Nápoles durante el reinado de Alfonso V el Magnánimo', Escuela Española de Historia y Arqueología en Roma, in Cuadernos de Trabajos, 11: 81-140.

Arnabat Mata, Ramon, and Jordi Vidal i Pla (eds) (2008), Història de Vilafranca del Penedès, Vilafranca del Penedès: Ajuntament de Vilafranca.

Atlas, Allan W. (1985), Music at the Aragonese Court of Naples, Cambridge: Cambridge University Press.

Avril, François, et al. (1983), Manuscrits enluminés de la péninsule ibérique, Paris: Bibliothèque nationale de France.

Baldelló, Francesc (1962), 'La Música en la Basílica Parroquial de Santa María del Mar, de Barcelona', in Anuario Musical, 17: 209-241.

Barral i Altet, Xavier, and Anscari M. Mundó (eds) (2014), Els Vitralls de la Catedral de la Seu d'Urgell i de la Col-legiata de Santa Maria de Cervera (Corpus Vitrearum Medii Aevi 5), Barcelona: Institut d'Estudis Catalans.

Baucells, Josep (1988), 'Les notícies més antigues sobre els orgues de la Catedral de Barcelona', in Medievalia, 8: 41-74.

Bent, Margaret (2021), The Late-Medieval Motet, Oxford: Oxford University Press (forthcoming). 
Beseran i Ramon, Pere (2003), 'El temple gòtic de Santa Maria de Cervera', in Miscel-lània Cerverina, 16: 19-68.

Besseler, Heinrich (1925), 'Studien zur Musik des Mittelalters. I. Neue Quellen des 14. und beginnenden 15. Jahrhunderts', in Archiv für Musikwissenschaft, 7(2): 167-252.

Bevilacqua, Gregorio, David Catalunya, and Nuria Torres Lobo (2018), 'The Production of Polyphonic Manuscripts in Thirteenth-Century Paris: New Evidence for Standardised Procedures', in Early Music History, 37: 91-139.

Capdevila, Sanç (1930), 'Notes d'Arxius. De l'Arxiu Arxidiocesà de Tarragona', in Analecta Sacra Tarraconensia: Anuari de la Biblioteca Balmes, 6: 295-296.

Carbonell i Buades, Marià (2000), 'Bartolomé Ordóñez i el cor de la catedral de Barcelona', in Locus amoenus, 5: 117-147.

Carreras i Candi, Francesch, and Bartomeu Gunyalons y Bou (eds) (1912), Ceremonial dels Magnífics Consellers y regiment de la Ciutat de Barcelona. Volum primer, Barcelona: Ajuntament Constitucional, 1912.

Carrero Santamaría, Eduardo (2014), 'La Catedral de Barcelona y la liturgia', in Eduardo Carrero Santamaría (ed.), Arquitectura y liturgia. El contexto artístico de las consuetas catedralicias en la Corona de Aragón, Mallorca: Objeto Perdido, 11-42.

Carvajal González, Helena (2011), 'Aproximación a la iconografía de la filigrana medieval en España', in Actas del IX Congreso Nacional de Historia del Papel en España, Zaragoza: Asociación Hispánica de Historiadores del Papel, 280-298.

Catalunya, David (2017), 'Thirteenth-Century “Organistae” in Castile', in Hans Fidom (ed.), Medieval Organ Art, Amsterdam: Orgelpark, Amsterdam University Press, 105-140 (ebook available at <www.orgelpark.nl>).

Catalunya, David (2018), 'Insights into the Chronology and Reception of Philippe de Vitry's Ars nova Theory: Revisiting the Mensural Treatise of Barcelona Cathedral', in Early Music, 46/3: 417-438.

Catalunya, David (2020), 'Ars subtilior in Organ Playing c.1380-1420: Another Glimpse into a Late Medieval Unwritten Performance Practice', in Kirchenmusikalisches Jahrbuch, 103 (forthcoming).

Clarke, Mark (2001), The Art of All Colours: Mediaeval Recipe Books for Painters and Illuminators, London: Archetype Publications.

Companys i Farrerons, Isabel, and M. J. Virgili i Gasol (1995), 'Fons de còdexs de l'Arxiu Històric Arxidiocesà de Tarragona (Segles IX-XIII)', in Catalunya romànica, vol. 21: El Tarragonès, el Baix Camp, l'Alt Camp, el Priorat, la Conca de Barberà, Barcelona: Enciclopèdia Catalana, 191-195.

Cuscó i Clarasó, Joan (1997), 'Mestres de capella i organistes a Vilafranca del Penedès durant els segles XVII i XVIII', in Bulletí de la Societat Catalana de Musicologia, 4: 205-212.

Cuscó i Clarasó, Joan (2013), 'Ministrers i joglars a la Catalunya Nova (segles XIV-XVII)', in Revista Catalana de Musicologia, 6: 11-29.

De Diego Rodríguez, Natividad (2001), 'Correspondencia de Alfonso V con el monasterio de Poblet', in Guido D'Agostino and Giulia Buffardi (eds), Atti XVI Congresso Internazionale di Storia della Corona d'Aragona (Napoli, 1997), Naples: Paparo, 213-224.

Derolez, Albert (2003), The Palaeography of Gothic Manuscript Books: From the Twelfth to the Early Sixteenth Century, Cambridge: Cambridge University Press.

Dolç i Cartanyà, Jordi (1988), Higini Anglès (1888-1969), Barcelona: Edicions del Mèdol. Domenge, Joan, and Jacobo Vidal (2018), Santa Maria del Mar, Barcelona: Fundació Uriach. 
Droz, Eugénie, and Geneviève Thibault (1926), 'Un Chansonnier de Philippe le Bon', in Revue de Musicologie, 7: 1-8.

Earp, Lawrence (2014), The Ferrell-Vogüe Machaut Manuscript: Facsimile and Introductory Study, 2 vols, Oxford: DIAMM Publications.

Escalas, Romà (2005), 'Dues cançons polifòniques del segle XV a l'Arxiu Històric Arxidiocessà de Tarragona', in Revista Catalana de Musicologia, 3: 35-43.

Español, Francesca (2002), El Gòtic Català (Patrimoni Artístic de la Catalunya Central 9), Manresa: Angle Editorial.

Finestres y de Monsalvo, Jaime (1753), Historia del Real Monasterio de Poblet, 5 vols, Barcelona: Pablo Campins.

Garrigosa, Joaquim (2003), Els manuscrits musicals a Catalunya fins al segle XIII, Lleida: Institut d'Estudis Ilerdencs.

Giraud, Eleanor J. (2013), The Production and Notation of Dominican Manuscripts in ThirteenthCentury Paris, PhD thesis, University of Cambridge.

Gómez Muntané, Maricarmen (1978), 'Neue Quellen mit mehrstimmiger geistlicher Musik des 14. Jahrhunderts in Spanien', in Acta Musicologica, 50: 208-216.

Gómez Muntané, Maricarmen (1979), La Música en la Casa Real Catalano-Aragonesa durante los años 1336-1432, 2 vols, Barcelona: Antoni Bosch.

Gómez Muntané, Maricarmen (1981), 'Más códices con polifonía del siglo XIV en España', in Acta Musicologica, 53/1: 85-90.

Gómez Muntané, Maricarmen (1984), 'Musique et musiciens dans les chapelles de la maison royale d'Aragon (1336-1413)', in Musica Disciplina, 38: 67-86.

Gómez Muntané, Maricarmen (1985a), 'Un nuevo manuscrito con polifonía antigua en el Archivo Archidiocesano de Solsona', in Recerca Musicològica, 5: 5-11.

Gómez Muntané, Maricarmen (1985b), 'Quelques remarques sur le répertoire polyphonique de l'Ars Nova provenant de l'ancien royaume d'Aragon', in Acta Musicologica, 57: 166-179.

Gómez Muntané, Maricarmen (1985c), 'Une version à cinq voix du motet Apollinis eclipsatur/ Zodiacum signis dans le manuscrit E-Bcen 853', in Musica Disciplina, 39: 5-44.

Gómez Muntané, Maricarmen (1989), El manuscrito M971 de la Biblioteca de Catalunya (Misa de Barcelona) [= Separata del Bulletí de la Biblioteca de Catalunya 10 (1982-1984) 1986], Barcelona: Biblioteca de Catalunya.

Gómez Muntané, Maricarmen (1990), El Llibre Vermell de Montserrat. Cantos y Danzas s. XIV, Sant Cugat del Vallés: Los libros de la Frontera.

Gómez Muntané, Maricarmen (1993), Manuscrito 2 de la Biblioteca del Orfeó Català \& Manuscrito 109 del Archivo Diocesano de Solsona (Polifonía Aragonesa 8), Zaragoza: Institución Fernando el Católico - Consejo Superior de Investigaciones Científicas.

Gudayol, Anna (2014), 'Pervivència de una biblioteca litúrgica: fragments de còdexs de l'Arxiu parroquial de Verdú a la Biblioteca de Catalunya', in Miscel·lània litúrgica catalana, 22: 53-94.

Harder, Hanna, and Bruno Stäblein (1957), 'Neue Fragmente mehrstimmiger Musik aus spanischen Bibliotheken', in Festschrift Joseph Schmidt-Görg zum 60 Geburtstag, Bonn: Beethovenhaus, 131-141.

Hernando i Delgado, Josep (2001), Escoles, ensenyament de lletra i llibre de gramàtica a Barcelona (segles XIV-XV) (Quaderns del Seminari d'Història de Barcelona 6), Barcelona: Arxiu Històric de la Ciutat. 
Iglesias, J. Antoni (1996), Llibres i lectors a la Barcelona del s. XV. Les biblioteques de clergues, juristes, metges i altres ciutadans a través de la documentació notarial (anys 1396-1475), $\mathrm{PhD}$ thesis, Universitat Autònoma de Barcelona.

Janini, José, and Francesc Ricomà (1965), 'Fragmentos litúrgicos del Archivo Histórico Diocesano de Tarragona', in Analecta Sacra Tarraconensia, 38: 217-230.

Janini, José, and Francesc Ricomà (1966), 'Manuscritos latinos existentes en Poblet', in Miscellanea Populeti, Poblet: Publicacions de l'Abadia de Poblet, 209-228.

Junyent, Eduard (1967), 'Visites Pastorals a Cervera', in Cuadernos de Arqueología e historia de la ciudad, 10: 221-245.

Knighton, Tess (2019), 'The Written Transmission of Polyphonic Song in Spain c.1500: The Case of the Segovia Manuscript', in Wolfgang Fuhrmann and Cristina Urchueguía (eds), The Segovia Manuscript: A European Musical Repertory in Spain, c.1500, Woodbridge: The Boydell Press, 231-270.

Kügle, Karl (2019), Manuscript Ivrea, Biblioteca Capitolare 115: Introductory Study and Facsimile Edition, Lucca: Libreria Musicale Italiana.

Lannutti, M. Sofia (2012), 'L’ultimo canto. Musica e poesia nella lirica catalana del medioevo (con una nuova edizione del Cançoneret di Sant Joan de les Abadesses)', in Romance Philology, 66: 309-363.

Ludwig, Friedrich (1924), 'Die Geistliche nicht liturgische, weltliche einstimmige und die mehrstimmige Musik des Mittelalters bis zum Anfang des 15 Jahrhundert', in Guido Adler (ed.), Handbuch der Musikgeschichte, Frankfurt am Main: Frankfurter Verlags-Anstalt, 127-250.

Marimon i Llucià, Ma Rita (2002), 'La desamortització eclesiàstica a Igualada', in Miscel·lània Aqualatensia, 10: 231-324.

Miret i Nin, M. Montserrat (1987), La Basilica de Santa Maria de Vilafranca del Penedès, Vilafranca del Penedès: Museu de Vilafranca.

Miró i Baldrich, Ramón (2002), 'Música i esglèsia a Cervera [Annexos documentals]', in Miscel-lània Cerverina, 15: 215-308.

Miró i Baldrich, Ramón (2003), 'Música i església a Cervera (segles XV a inicis del XVIII)', in Miscel-lània Cerverina, 16: 229-260.

Monclús Guitar, Ricard (2005), 'El Abad del Monasterio de Poblet como Limosnero Real y su rendición de cuentas (s. XIV)', in De Computis: Revista Española de Historia de la Contabilidad, 2: 154-180.

Murall, Oriol (2012-2013), 'Els escolars tonsurats de la Catedral de Barcelona', in Acta Historica et Archaeologica Mediaevalia, 31: 197-211.

Obradors Suazo, Carolina (2015), Immigration and Integration in a Mediterranean City: The Making of the Citizen in Fifteenth-Century Barcelona, PhD thesis, European University Institute, Florence.

Page, Christopher (1979), ‘The Myth of the Chekker’, in Early Music, 7/4: 482-489.

Piquer, Josep Joan (1968), El senyoriu de Verdú. Introducció per a l'estudi del règim jurisdiccional que els abats de Poblet exerciren sobre la vila, Tarragona: Reial Societat Arqueològica.

Pope, Isabel, and Masakata Kanazawa (eds) (1978), The Musical Manuscript Montecassino 871: A Neapolitan Repertory of Sacred and Secular Music of the Late Fifteenth Century, Oxford: Clarendon Press, 1978.

Sabaté i Marín, Glòria (2016), ““Aquells qui ho voldran saber, lligen...”: Llibres i lectors a la Barcelona del segle XV', PhD thesis, Universitat de Barcelona. 
Salisi i Clos, Josep M. (2009), ‘El “Fons Verdú” de la Biblioteca de Catalunya. Trajectòria i problemàtica del trasllat', in Anuario Musical, 64: 109-136.

Salisi i Clos, Josep M. (2012), El repertori litúrgic marià a Catalunya a finals del segle XVII (Les antífones marianes majors de l'M 1168 del 'Fons Verdú' de la Biblioteca de Catalunya), $\mathrm{PhD}$ thesis, Universitat Autònoma de Barcelona.

Salisi i Clos, Josep M. (2013), 'Manuscrits musicals dels segles XI-XV a l'església de Santa Maria de Verdú', in Romànic tardà a les terres de Lleida. Estudis sobre Vilagrassa, Sant Martí de Riucorb: Grup de Recerques de les Terres de Ponent, 515-546.

Schrade, Leo (1956), Polyphonic Music of the Fourteenth Century (PMFC). Commentary to Volume I [typescript], Monaco: Editions de L'Oiseau-Lyre.

Schrade, Leo, et al. (eds) (1956-1991), Polyphonic Music of the Fourteenth Century (PMFC), 24 vols, Monaco: Editions de l'Oiseau-Lyre.

Scott, Peter James David (2004), Ottaviano Petrucci's Lamentationum liber primus and liber secundus (1506/1 and 1506/2); a bibliographical, contextual and analytical study, PhD thesis, Durham University.

Sobrino González, Miguel (2013), 'Palacios catedralicios, catedrales palatinas', in Anales de Historia del Arte, 23: 551-567.

Stäblein-Harder, Hanna (1962a), Fourteenth-Century Mass Music in France. Critical Text. Companion Volume to Corpus Mensutabilis Musicae 29 (Musicological Studies and Documents 7), Rome: American Institute of Musicology.

Stäblein-Harder, Hanna (ed.) (1962b), Fourteenth-Century Mass Music in France (Corpus Mensurabilis Musicae 29), Rome: American Institute of Musicology, 1962.

Stoessel, Jason (2014), 'The Angevin Struggle for the Kingdom of Naples (c.1378-1411) and Politics of Repertoire in Mod A: New Hypotheses', The Journal of Music Research Online, 5 〈http://www.jmro.org.au/index.php/mca2/article/view/95〉.

Stone, Anne (2005), The Manuscript Modena, Biblioteca Estense, $\alpha$. M.5.24. Commentary [to the facsimile edition], Lucca: Libreria Musicale Italiana.

Sureda i Jubany, Marc (2014), 'La Catedral de Girona', in Eduardo Carrero Santamaría (ed.), Arquitectura y liturgia. El contexto artístico de las consuetas catedralicias en la Corona de Aragón, Mallorca: Objeto Perdido, 43-55.

Tomasello, Andrew (1982), Music and Ritual at Papal Avignon, 1309-1403, PhD thesis, Yale University.

Tomasello, Andrew (1995), 'A Footnote on Aragonese Mass Manuscripts and the Decline of the Great Court Theory of Music History', in Musica Disciplina, 49: 95-119.

Verdés Pijuan, Pere (2003), 'L'obreria de l'església de Santa Maria de Cervera (s. XIV-XV)', in Miscel.lània Cerverina, 16: 165-193. 



\title{
Fragments of Local Polyphony in Late Medieval Central Europe: Towards a Semiotic Interpretation of Musical Sources
}

\begin{abstract}
A number of fragments was recently discovered dating from the second quarter of the 15 th century and containing mensural polyphony practised in Central Europe. To date, the particular repertory they preserve has only been known from much later manuscripts in use by the Czech Utraquists. In this chapter, the analysis of these fragments will lead us to investigate why some manuscripts containing Central-European mensural polyphony were destroyed, while others, such as the Utraquist books, were instead preserved. The question of preservation-destruction and the creation of fragments is also approached theoretically by proposing a semiotic interpretation based on the theory by Krzysztof Pomian.
\end{abstract}

Around eighty manuscripts, dating from the period between the end of the fifteenth century and the beginning of the seventeenth century, and containing polyphony written mostly in full black mensural notation are preserved in various collections in the Czech Republic. ${ }^{1}$ This polyphonic repertoire, consisting of Latin songs (cantiones), polytextual motets and Mass sections may be considered 'local', since it is not known from any sources outside Central Europe. The musical features, type of notation, and concordances suggest that it was composed during the first half of the fifteenth century or, in many cases, even earlier. Besides anonymous pieces, there are also works by Petrus Wilhelmi de Grudencz, born in 1392 and active until at least 1452. Therefore, this repertoire is much older

1 See Fisher/Lütolf 1972, 127-315; Graham 2006.

Note: The author gratefully acknowledges funding through the HERA project 'Sound Memories: The Musical Past in Late-Medieval and Early-Modern Europe' (<soundme.eu>). This project has received funding from the European Union's Horizon 2020 research and innovation programme under grant agreement no. 649307. Translated by John Comber.

¿ Open Access. (c) 2020 Pawet Gancarczyk, published by De Gruyter. (c) BY-NC-ND This work is licensed under the Creative Commons Attribution-NonCommercial-NoDerivatives 4.0 International License. https://doi.org/10.1515/9783110717884-007 
than its manuscript transmission, and there are examples of songs and motets which were copied for more than 150 years. Within the context of the music written in the fifteenth and sixteenth centuries, this style of polyphonic singing might be regarded as conservative, even archaic. This would explain why it occupied a marginal place in modern historiography, traditionally focussed instead on describing musical innovation and progress.

The books in question are linked to Bohemia and to the Utraquists, a moderate Hussite faction, and they are most often associated with educated urban citizens belonging to litterati brotherhoods (fraternitates litteratorum), which together with choirboys provided the musical setting for the liturgy in Utraquist churches. ${ }^{2}$ Besides containing polyphony in full mensural notation, the manuscripts preserve Mass chants and monophonic songs in varying proportions; for this reason they tend to be classified as graduals or 'cantionals'. The appearance and contents depended on the wealth of the sponsors and the needs of their users. For example, the Franus Codex (CZ-HK II A 6), completed in 1505 for the Church of the Holy Spirit in Hradec Králové, eastern Bohemia, took the spectacular form of a richly illuminated parchment volume. ${ }^{3}$ Much more modest in appearance is the famous Speciálník Codex (English: 'special codex', CZ-HK II A 7), which was possibly copied in Prague in c.1485-1500. As the name suggests, this codex is not a typical Utraquist manuscript, as its contents are almost wholly polyphonic: both local, conservative repertoire in full mensural notation, and more contemporary repertoire in void mensural notation, including early works by Josquin. ${ }^{4}$

Such a large number of surviving manuscripts from a single region and linked to a particular social group may lead to the assumption that Utraquist Bohemia was the focal point for the cultivation of this polyphonic repertoire. Moreover, there is no reason to deny the special role played by the Utraquists in cultivating polyphony in full mensural notation, to which they were evidently attached and with which they must have identified. However, in this study I would like to focus on surviving fragments in order to argue that the prevailing historiographical views of this phenomenon are distorted. A comprehensive account will have to consider the state of preservation of the sources, what was

2 See Horyna 2006, 117-134.

3 Mráčková [Hlávková] 2009. See also the description: <http://www.manuscriptorium.com/ apps/index.php?direct=record\&pid=AIPDIG-MVCHK_HR_6_II_A_6_0OSL9UC-cs> (accessed 23 May 2019)

4 Mráčková [Hlávková] 2002. See also the description: <http://www.manuscriptorium.com/ apps/index.php?direct=record\&pid=AIPDIG-MVCHK_HR_7_II_A_7_2PGBZM4-cs> (accessed 23 May 2019). 
destroyed during the fifteenth and sixteenth centuries, and what was instead preserved: in the field of fragmentology I believe it is important to reflect on why some manuscripts became waste paper, whilst others were treated with care. My work is guided by the assumption that, in ontological terms, fragmentary sources and complete sources represent two different categories, and that such consideration should also affect the way these are interpreted. I will return to this issue in the second part of the article.

\section{Fragments of Local Polyphony in Central Europe}

The polyphony in Utraquist manuscripts was first studied by Jaromír Černý (19392012). In an extensive study published in 1971, Černý showed that the models of polytextual motets preserved in Bohemia should be sought in the motets from the Engelberg Codex (CH-EN 314), dated to 1372/73. ${ }^{5}$ In later work, Černý linked the genesis of some cantiones to the conductus tradition. ${ }^{6}$ A link connecting Utraquist manuscripts with those older repertoires was established by manuscripts from the turn of the fifteenth century, especially the so-called Trnava Manuscript (H-Bn lat. 243, c.1400), probably from Moravia, ${ }^{7}$ and a manuscript from the Cistercian monastery of Vyššì Brod in southern Bohemia (CZ-VB 42, c.1410). According to Černý, motets and songs of such distant origins were adapted and rearranged in Czech lands, also coming to form the basis for a more 'modern' output in the fifteenth century. During the second half of that century, they filtered through into the Utraquist repertoire, where they survived over the following decades. ${ }^{8}$ From Bohemia, then, this music spread to neighbouring regions.

Since the time of Černý's research, the pool of sources of local polyphony has grown, especially with regard to fifteenth-century manuscripts. Familiar sources have been reinterpreted and shown in new contexts. Today, one can distinguish among them a group of fragments, ranging from single leaves to larger sets, linked by common features. This list is certainly not complete and may well increase thanks to further research (see Table 1).

5 Černý 1971 and Černý 1972.

6 Černý 1984.

7 Černý 1971, 10-11.

8 Hlávková 2020. 
Table 1: Fragments of local polyphony in Central Europe 1420-1460.

\begin{tabular}{|c|c|c|c|}
\hline Siglum & $\begin{array}{l}\text { Provenance } \\
\text { (suggested) }\end{array}$ & No. of folios & Repertoire / Composers \\
\hline CZ-UO A $3^{9}$ & Bohemia & $34 \mathrm{ff}$. & $\begin{array}{l}\text { cantiones, motets, Mass sections, } \\
\text { chant / Petrus Wilhelmi }\end{array}$ \\
\hline$D-G s X X X, 1^{10}$ & Silesia & $30 \mathrm{ff}$. & $\begin{array}{l}\text { cantiones, motets, Mass sections, } \\
\text { chant / Petrus Wilhelmi }\end{array}$ \\
\hline H-Bn lat. $534^{11}$ & Spiš & $6 \mathrm{ff}$. & $\begin{array}{l}\text { cantiones, motets, rotula, Mass } \\
\text { section / Petrus Wilhelmi }\end{array}$ \\
\hline H-Bu U.Fr.I.ch. $299^{12}$ & Slovakia & $1 \mathrm{f}$. & cantiones \\
\hline PL-GD $2153 a^{13}$ & Gdańsk & $2 \mathrm{ff}$. & motets, cantio, rotulum \\
\hline PL-Kj $2188^{14}$ & Kraków & $1 \mathrm{f}$. & cantiones \\
\hline PL-Wn BOZ 64a ${ }^{15}$ & Mazovia & $2 \mathrm{ff}$. & $\begin{array}{l}\text { cantiones, chant / Nicolaus?, Petrus } \\
\text { Wilhelmi }\end{array}$ \\
\hline PL-WRu I F $269^{16}$ & Silesia & $2 \mathrm{ff}$. & cantiones, rotulum / Petrus Wilhelmi \\
\hline PL-WRu IV Q $223^{17}$ & Silesia & $2 \mathrm{ff}$. & textless compositions (cantiones?) \\
\hline PL-WRu XV Q 1066a & Silesia & $1 \mathrm{f}$. & motet, cantiones \\
\hline
\end{tabular}

The date of these fragments is hard to establish, yet judging by the handwriting, watermarks, and repertoire, none of them dates from before 1420 or after 1460 . They belong, therefore, to the period before the Utraquist repertoire had taken shape, when in Central Europe full mensural notation was gradually giving way to void notation. In some instances, it is difficult to determine the provenance of these sources; it goes without saying that the provenance of a fragment is not necessarily identical to that of the host book. However, even if we take the various possibilities into account, it is abundantly clear that these fragments come from quite a large area of Central Europe: Upper Hungary (present-day

\footnotetext{
9 Brewer 1984, II, 520-525. For dating of the fragments see Gancarczyk 2017, 8-9.

10 Staehelin 2001.

11 Rajeczky 1972.

12 Brewer 1990, 15-17.

13 Zwolińska 2000, 53-60; Gancarczyk 2013, 49-50.

14 Brewer 1984, II, 359-360, 542.

15 Szyller 1996, 109-116.

16 Staehelin 2001, 104-106.

17 Staehelin 2001, 106-108.

18 Gancarczyk 2013.
} 
Slovakia), Bohemia, Silesia, southern Poland, Mazovia and Pomerania. Some of them (H-Bn lat. 534, PL-GD 2153a, PL-Wn BOZ 64a) were found with books used in monasteries, which could shed some light on their possible provenance.

The fragments, however, do not resemble later Utraquist manuscripts; they appear to have once been part of lower grade manuscripts, probably for everyday personal use, produced without the direct support of a sponsor or an institution. The material of the writing support is paper, most frequently in small folio format, less often in quarto. The initials are rather modest, drawn by dilettantes rather than professional artists. Red ink was used to highlight the initials as well as some elements of the notation. The degree of care taken over the notation varies from one fragment to the next, but it never reaches the level of professional calligraphy. As it is common in many fifteenth-century Central European manuscripts, mensural signs are missing. The scribes often left out the clefs, whilst in other cases they adopted a rather liberal approach, giving two clefs at once (in D-Gs XXX,1 and PL-WRu I F 269). ${ }^{19}$ There is instead a consistent use of custodes, most often in the form of a rhombus with two caudae (see Figs 1 and 2), another common feature in Central European mensural manuscripts.

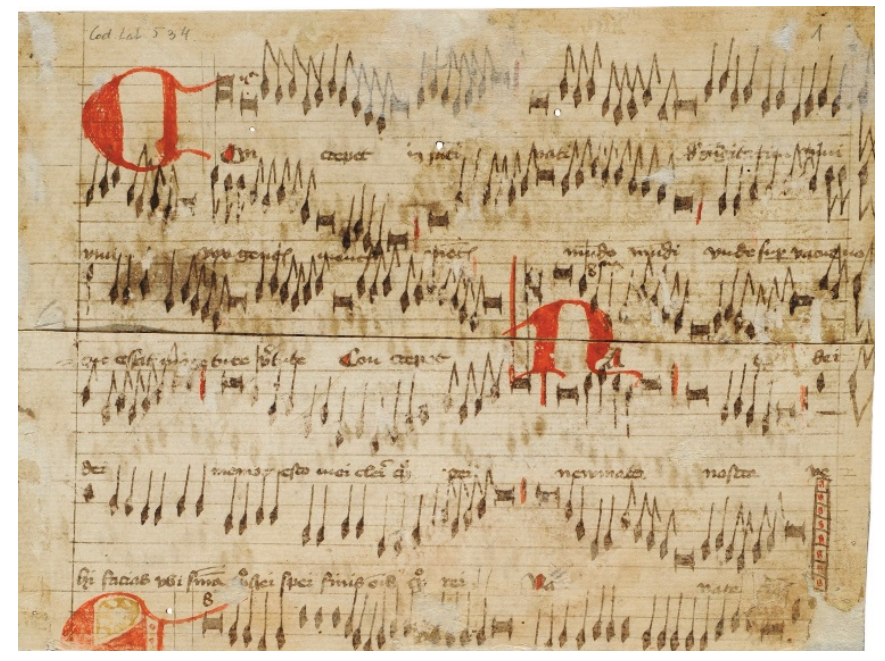

Fig. 1: Budapest, Országos Széchényi Könyvtár, Ms. lat. 534 (H-Bn lat. 534), f. 1r; @ Budapest, Országos Széchényi Könyvtár.

19 On the practice of using clefs in Central Europe, see Schmid 2004, 57-78. 


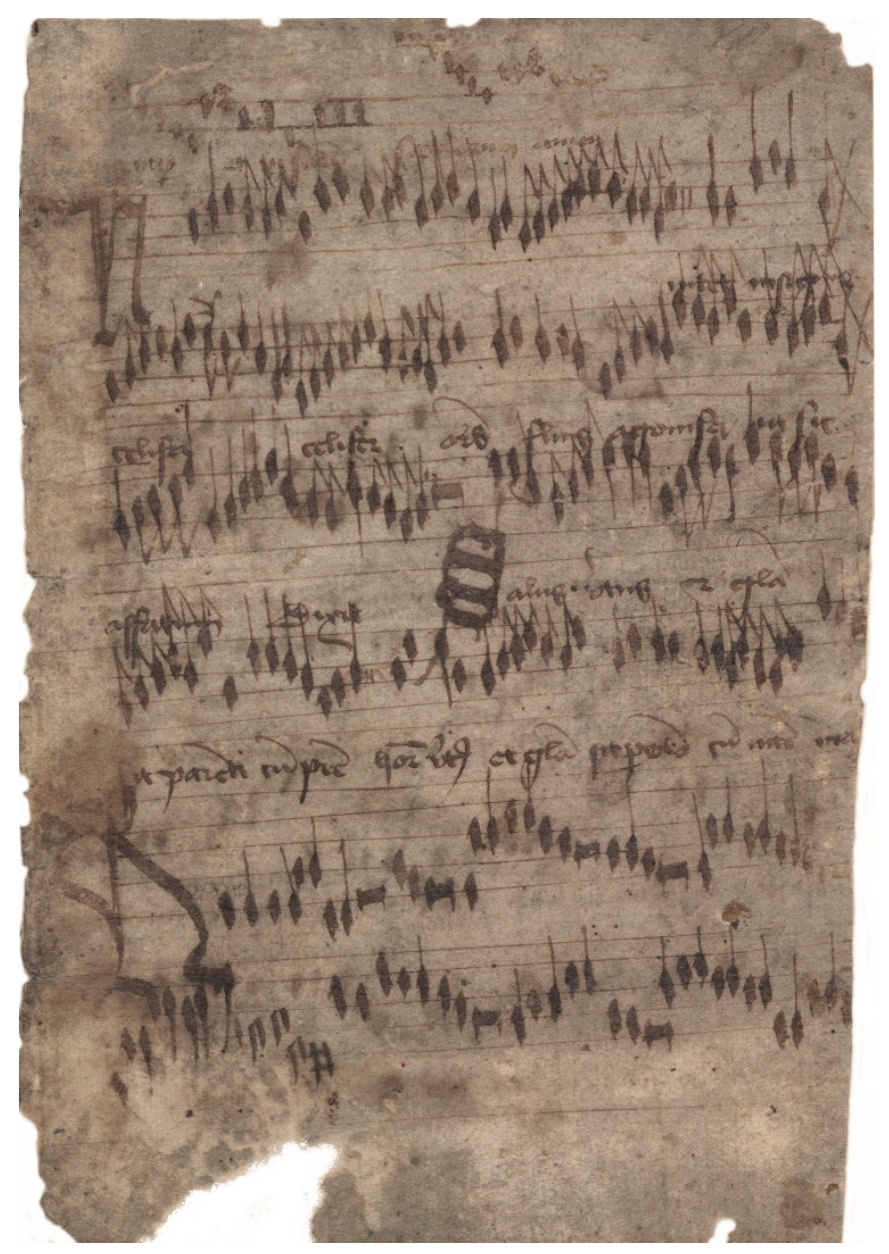

Fig. 2: Warsaw, Biblioteka Narodowa, BOZ 64a (PL-Wn BOZ 64a), f. Ilv; @ Warsaw, Biblioteka Narodowa.

The foliation visible in fragments D-Gs XXX,1 and PL-WRu XV Q 1066a suggests that they were part of larger manuscripts, possibly volumes containing both polyphony in full mensural notation and plainchant (such a combination appears in three fragments, including D-Gs XXX,1). In some fragments, we also find works added in void notation, which reflects the notational changes that occurred in the middle decades of the fifteenth century.

The most crucial element linking all these fragments is the similar repertoire. They contain the same type of compositions as later Utraquist manuscripts. Moreover, one of the fragments (CZ-UO A 3) was produced in the Utraquist 
environment, in eastern Bohemia, but a few decades before the Speciálník Codex - the oldest and most extensive source of this polyphony. This repertoire comprises a trio of genres: cantio, polytextual motet and rotulum. The first two genres are well known, while rotulum denotes a circular canon written in the form of a single melody. In Utraquist manuscripts, rotula were written as polytextual motets; that is, in the form which canon assumes in its climactic phase, when all the parts sing at once. The fragments from the group under discussion include numerous compositions by Petrus Wilhelmi; fragments D-Gs XXX,1, from Silesia and dating from $c .1450$, are among the central sources of his musical output.

Table 2 shows a list of concordances of identified compositions. These are for the most part works from larger sets of fragments held in Ustí nad Orlicí (CZ-UA A 3), Göttingen (D-Gs XXX,1) and Budapest (H-Bn lat. 534), although the content of smaller fragments like single leaves appears to lead to the same conclusions. Of the thirty-three compositions, just one is known from a source dated prior to 1420; that is the motet Voce cordis / Pulchre Syon copied in the Engelberg Codex and, eight decades later, in the fragments CZ-UO A 3. Most of the compositions possess concordances solely with younger manuscripts, dating from after 1460, and for the most part with Utraquist manuscripts, at times very numerous (e.g. Petrus Wilhelmi's song Phonicorum ethicorum).$^{20}$ The list of concordances also includes complete manuscripts produced more or less contemporaneously with our fragments such as the St Emmeram Codex (D-Mbs Clm 14274) - the repertoire of which, besides compositions by Petrus Wilhelmi, includes several anonymous cantiones - and also a recently-discovered manuscript from Opava, in Czech Silesia (CZ-OP RC 4), in which local polyphony appears alongside monophonic passions and lamentations. ${ }^{21}$ In other concordant manuscripts from Kraków (PL-Kj 2464), Trier (D-TR 322/1994), Leipzig (D-Leu 1236), and Bohemia (CZ-TRE A 4) ${ }^{22}$ the musical part appears in an otherwise non-musical context.

20 Such manuscripts as CZ-HK II A 14 and CZ-Pnm AZ 34 date from the turn of the seventeenth century.

21 Welker et al. 2006; Ward 1981, 325-343. On the Opava manuscript see Ciglbauer/Gancarczyk 2017, 99-105.

22 Perz 1973, xxi-xxii, 15-35; Brewer 1990; Ewerhart 1955; Ward 1981, 337-338; Ward 1994, 5473; Weber et al. 1958, 29-53. 
Table 2: List of concordant sources.

\begin{tabular}{|c|c|c|}
\hline Composition & Pre-1460 sources & Post- 1460 sources \\
\hline Compangant omnes & CZ-UO A 3, H-Bn lat. 534 & CZ-K 179 \\
\hline $\begin{array}{l}\text { Concrepet infanti / Nate dei / } \\
\text { Exordium quadruplate / } \\
\text { Verbum caro }\end{array}$ & $\begin{array}{l}\text { CZ-UO A 3, H-Bn lat. 534, } \\
\text { PL-Kj } 2464\end{array}$ & $\begin{array}{c}\text { CZ-CH } 12580, \text { CZ-HK II A 6, CZ- } \\
\text { HK II A 7, CZ-Pu } 59 \text { R } 5116\end{array}$ \\
\hline $\begin{array}{l}\text { Congaudemus pariter / En lux } \\
\text { immensa }\end{array}$ & CZ-UO A 3 & $\begin{array}{l}\text { CZ-CH } 12580, \text { CZ-HK II A 6, CZ- } \\
\text { HK II A 7, CZ-KH 88/85, CZ- } \\
\text { KL 403, CZ-Pst 376, CZ-Pn } \\
\text { XIII A 2, CZ-Pu VI B 24, CZ- } \\
\text { Pu } 59 \text { R } 5116\end{array}$ \\
\hline Dies iam letitie & CZ-UO A 3 & CZ-Pn XIII A 2 \\
\hline Ecce renascentis testatur & CZ-UO A 3 & $\begin{array}{l}\text { CZ-Pn I A 17, CZ-Pst 376, CZ- } \\
\text { Pu XVII A 3, CZ-Pu NG 3, CZ- } \\
\text { TAoa, CZ-TEm } 2\end{array}$ \\
\hline Ex stirpe paganorum & $\begin{array}{l}\text { CZ-UO A 3, PL-WRu XV } \\
\text { Q 1066a }\end{array}$ & $\begin{array}{l}\text { CZ-HK II A 6, CZ-CH } 12580, \text { CZ- } \\
\text { KH } 88 / 85\end{array}$ \\
\hline Genti confer opem & CZ-UO A 3 & $\begin{array}{l}\text { CZ-CH } 12580, \text { CZ-KUm 88/85, } \\
\text { CZ-HK II A } 6\end{array}$ \\
\hline Ihesus Christus nostra salus & CZ-OP RC 4, D-Gs XXX,1 & \\
\hline $\begin{array}{l}\text { Iacob scalam / Pax eterna / } \\
\quad \text { Terribilis } \\
\text { (Petrus Wilhelmi) }\end{array}$ & D-LEu 1236, D-Gs XXX,1 & $\begin{array}{l}\text { CZ-CH 12580, CZ HK II A 6, CZ- } \\
\text { HK II A 7, CZ-KL 403, CZ-Pn } \\
\text { XIII A 2, CZ-Pu } 59 \text { R 5116, }\end{array}$ \\
\hline Laudes dicat omnis & CZ-UO A 3 & CZ-Pst 376, CZ-Pu VI B 24 \\
\hline $\begin{array}{l}\text { Methaphisice saliit / In tempesto } \\
\text { adiit / Ordo naturae }\end{array}$ & CZ-UO A 3 & CZ-HK II A 7 \\
\hline Nicolai solempnia & H-Bn lat. 534 & SK-BRmp Inc. 33 \\
\hline Novus annus adiit & H-Bn lat. 534 & $\begin{array}{l}\text { CZ-CH } 12580, \text { CZ-HK II A 6, CZ- } \\
\quad \text { HK II A 7, CZ-KL } 403\end{array}$ \\
\hline $\begin{array}{l}\text { Panis ecce / Panis ewus / Pange } \\
\text { exul / Patribus / Tantum ergo } \\
\text { (Petrus Wilhelmi) }\end{array}$ & CZ-UO A 3 & $\begin{array}{l}\text { CZ-CH 12580, CZ-HK II A 6, CZ- } \\
\text { HK II A 7, CZ-KUm 88/85, } \\
\text { CZ-Pn XIII A 2, CZ-Pu 59 } \\
\text { R 5116, PL-Kj 8a }\end{array}$ \\
\hline $\begin{array}{l}\text { Paraclitus egrediens } \\
\qquad \text { (Paranymphus adiit) }\end{array}$ & $\begin{array}{r}\text { D-TR 322/1994, } \\
\text { H-Bn lat. } 534\end{array}$ & $\begin{array}{l}\text { CZ-CH } 12580, \text { CZ-HK II A 6, CZ- } \\
\text { HK II A 7, CZ-KL 503, CZ- } \\
\text { KUm 88/85, CZ-Pn XIII A 2, } \\
\text { CZ-Pu VI B 24, CZ-Pu } 59 \\
\text { R } 5116\end{array}$ \\
\hline Patrem omnipotentem (Credo) & $\begin{array}{r}\text { D-TR 322/1994, } \\
\text { H-Bn lat. } 534\end{array}$ & $\begin{array}{l}\text { A-Wn 5094, D-Z 119,1, } \\
\text { DK-Kar } 687\end{array}$ \\
\hline
\end{tabular}


Table 2 (continued): List of concordant sources.

\begin{tabular}{|c|c|c|}
\hline Composition & Pre-1460 sources & Post-1460 sources \\
\hline $\begin{array}{l}\text { Phonicorum ethicorum } \\
\text { (Petrus Wilhelmi) }\end{array}$ & PL-Wn BOZ 64a & $\begin{array}{l}\text { CZ-CH } 12580, \text { CZ-HK II A 6, } \\
\text { CZ-HK II A 7, CZ-HK II A 14, } \\
\text { CZ-KL 403, CZ-Pam 7847, } \\
\text { CZ-Pn IV B 9, CZ-Pn XIII A 2, } \\
\text { CZ-Pnm AZ 34, CZ-Pu } 59 \\
\text { R 5116, CZ-Pu XVII A 32, } \\
\text { CZ-Pu XVII A 53a, } \\
\text { CZ-RY 829/87, CZ-S M-3, } \\
\text { CZ-TEm 2, CZ-VO }\end{array}$ \\
\hline $\begin{array}{l}\text { Pneuma eucaristiarum / Veni vere / } \\
\text { Dator eia / Paraclito tripudia } \\
\text { (Petrus Wilhelmi) }\end{array}$ & D-MERa 13b, D-Gs XXX,1 & $\begin{array}{l}\text { CZ-CH 12580, CZ-HK II A 6, } \\
\quad \text { CZ-HK II A } 7\end{array}$ \\
\hline $\begin{array}{l}\text { Poligena exanimes } \\
\text { (Petrus Wilhelmi) }\end{array}$ & CZ-OP RC 4, D-Gs XXX,1 & \\
\hline $\begin{array}{l}\text { Pomi morsum / Hominem / Sed } \\
\quad \text { paratus / Paraneuma eructemus } \\
\text { (Petrus Wilhelmi) }\end{array}$ & D-Gs XXX,1 & $\begin{array}{l}\text { CZ-CH 12580, CZ-HK II A 6, } \\
\text { CZ-HK II A 7, CZ-KL 403, } \\
\text { CZ-KUm 88/85, } \\
\text { CZ-Pam 7847, CZ-Pn IV B 9, } \\
\text { CZ-Pn XIII A 2, CZ-Pu 59 } \\
\text { R 5116, CZ-Pu VI B 24, } \\
\text { CZ-Pu XVII A 32, CZ-VO }\end{array}$ \\
\hline $\begin{array}{l}\text { Preconia etroclita } \\
\text { (Petrus Wilhelmi) }\end{array}$ & D-Gs XXX,1 & $\begin{array}{l}\text { CZ-CH 12580, CZ-HK II A 6, } \\
\text { CZ-HK II A } 7\end{array}$ \\
\hline $\begin{array}{l}\text { Predulcis eurus } \\
\text { (Petrus Wilhelmi) }\end{array}$ & $\begin{array}{l}\text { CZ-OP RC 4, CZ-TRE A 4, } \\
\text { D-Mbs Clm 14274, } \\
\text { PL-WRu I F } 269\end{array}$ & CZ-CH 12580, CZ-HK II A 7 \\
\hline $\begin{array}{l}\text { Presidiorum erogatrix } \\
\text { (Petrus Wilhelmi) }\end{array}$ & D-Gs XXX,1 & $\begin{array}{l}\text { CZ-CH 12580, CZ-HK II A 6, } \\
\text { CZ-HK II A } 7\end{array}$ \\
\hline $\begin{array}{l}\text { Presulem ephebeatum } \\
\text { (Petrus Wilhelmi) }\end{array}$ & $\begin{array}{l}\text { D-LEu 1236, D-Mbs } \\
\text { Clm 14274, H-Bn } \\
\text { lat. } 534\end{array}$ & $\begin{array}{l}\text { CZ-CH } 12580, \text { CZ-HK II A 6, } \\
\text { CZ-HK II A 7, CZ-Pn XIII A 2, } \\
\text { CZ-Pu } 59 \text { R 5116, CZ-Pu VI } \\
\text { C 20a, D-F Fragm. lat. VII } 20\end{array}$ \\
\hline $\begin{array}{l}\text { Probleumata enigmatum } \\
\text { (Petrus Wilhelmi) }\end{array}$ & CZ-TRE A 4, CZ-UO A 3 & $\begin{array}{l}\text { CZ-CH } 12580, \text { CZ-HK II A 6, } \\
\text { CZ-HK II A 7, CZ- } \\
\text { KUm 88/85, D-Z 17.8.39 }\end{array}$ \\
\hline Procedentem sponsum & CZ-UO A 3, H-Bn lat. 534 & $\begin{array}{l}\text { CZ-HK II A 15, CZ-Pu V H 11, } \\
\text { CZ-Pu VI G 10a }\end{array}$ \\
\hline Resonet in laudibus & CH-SGs 392, CZ-UO A 3 & \\
\hline Resultet gens angelica & CZ-UO A 3 & $\begin{array}{l}\text { CZ-CH } 12580, \text { CZ-HK II A 6, } \\
\text { CZ-HK II A } 7\end{array}$ \\
\hline
\end{tabular}


Table 2 (continued): List of concordant sources.

\begin{tabular}{|c|c|c|}
\hline Composition & Pre-1460 sources & Post- 1460 sources \\
\hline $\begin{array}{l}\text { Salve domina / Recordare virgo / } \\
\text { Alma redemptoris }\end{array}$ & D-Gs XXX,1, PL-GD 2153a & $\begin{array}{l}\text { CZ-CH 12580, CZ-HK II A 7, } \\
\text { CZ-HK II A } 6\end{array}$ \\
\hline $\begin{array}{l}\text { Sophia nasci fertur / O quam } \\
\text { pulchra / Magi videntes }\end{array}$ & CZ-UO A 3 & $\begin{array}{c}\text { CZ-CH 12580, CZ-HK II A 6, } \\
\text { CZ-HK II A 7, CZ-K 179, } \\
\text { CZ-KL 403, CZ-Pn XIII A } 2\end{array}$ \\
\hline Surrexit Christus hodie & CZ-UO A 3 & CZ-CH 12580 \\
\hline Voce cordis / Pulchre Syon & CH-EN 314, CZ-UO A 3 & \\
\hline [Unidentified] & $\begin{array}{l}\text { D-Gs XXX,1, PL-WRu IV } \\
\text { Q } 223\end{array}$ & \\
\hline
\end{tabular}

The remarks set out above lead to the following conclusions: before the Utraquist manuscripts were produced, their polyphonic repertoire in full mensural notation was familiar also beyond Bohemia, across the area that we call Central Europe. The provenance of the fragments from the period 1420-1460, as well as of the complete manuscripts mentioned here, suggests that this repertoire was cultivated in monastic and university circles. ${ }^{23}$ Previous research into the songs of Petrus Wilhelmi revealed that this repertoire, adopted by the Utraquists during the second half of the fifteenth century, sometimes functioned independently within the Catholic tradition..$^{24}$ Its perception as being very strongly linked to post-Hussite Bohemia stems from the specific information provided by the sources. This, however, does not necessarily reflect the actual state of affairs, since we should bear in mind that Utraquist manuscripts were protected more than earlier monastic and university manuscripts, which were destroyed just a few decades after they were produced, as demonstrated by from the dating of the host books.

\section{Towards a Semiotic Interpretation of Musical Sources}

At this point, we should ask how some manuscripts came to be preserved for centuries whilst others were destroyed. What did late medieval communities wish to

23 We should certainly link the preparation of manuscripts D-Mbs Clm 14274, PL-Kj 2464, and D-Leu 1236 to a university environment; see above footnotes 21 and 22.

24 Gancarczyk 2017. 
preserve for posterity and what did they discard? The rational explanation that more expensive, more carefully produced and presentable manuscripts were safeguarded more than cheaper manuscripts belonging to 'pragmatic literacy'25 seems insufficient and does not seem to match with the facts. If we remain within the sphere of the manuscript sources we discussed here, and follow this line of reasoning, one could only wonder why an elegant parchment manuscript containing works by Du Fay and Petrus Wilhelmi (D-MERa 13b) was destroyed, whilst a sloppy student notebook (PL-Kj 2464), a bane for editors today, was instead preserved. ${ }^{26}$ Equally inadequate is the explanation that it was manuscripts containing out-of-date repertoire or with hindered legibility due to changes in notation that were discarded. If that were the case, then no medieval music manuscript would have come down to us.

In attempting to shed some light on this phenomenon, I would like to turn to the works of Krzysztof Pomian, who proposes a semiotic interpretation of the history of culture. Amongst visible artefacts, Pomian distinguishes five functional classes: bodies (les corps), waste (les déchets), things (les choses), semiophores (les sémiophores) and media (les médias). ${ }^{27}$ He classifies books and all written documents, including - one should assume - musical sources, as semiophores, that is, objects combining a material dimension with a semiotic dimension. Semiophores are visible objects bearing meaning that refers us to what cannot be seen. It goes without saying that every music manuscript refers to the invisible domain, but its semiotic dimension is not confined solely to the visual representation of the world of sounds: it often possesses additional meanings, on account of which the manuscript itself is looked after, regardless of whether it is being used in the musical practice, or instead excluded from that use. It is precisely such a set of meanings and values which prevents - saves - the manuscript object (as semiophor) from becoming simply a thing (chose): in our case, waste paper.

Utraquist manuscripts were something more than merely collections of words and music that could be read. They were an important part of the identity and representation of a specific social group: urban Bohemians belonging to litterati brotherhoods. Significantly, in the iconography of those fraternities, an open book of music is placed at the centre of the image: the fellows are not

25 See Keller 1992.

26 On D-MERa 13b see Fischer 1964, 92-94. Despite the best efforts, many works from PL-Kj 2464 have not been satisfactorily read and edited; see Brewer 1990. Many problems are also posed by D-TRs 322/1994; see Ewerhart 1955, 21-105, and Lubieniecki 2019, 91-98.

27 Pomian 1999, 200-208. 
singing from it, but presenting it. ${ }^{28}$ Utraquist manuscripts retained their significance even after the progressive re-Catholicisation of Bohemia during the seventeenth century. In 1783, when Emperor Joseph II issued a decree abolishing litterati brotherhoods, on the basis of which their property was confiscated and put up for sale, urban citizens bought up the books which their predecessors had funded. One of the graduals from Hradec Králove contained an inscription informing readers that it had been purchased by the townsfolk 'for themselves and for generations to come'. ${ }^{29}$ Towards the end of the nineteenth century, 'outlawed' brothers were still inscribing their names and professions, as well as the date on which they joined the brotherhood, on the pages of a manuscript from Vodñany in southern Bohemia (CZ-VO).

Books excluded from practical use but belonging to some collection - such as D-Mbs Clm 14274 from the collection of Hermann Pötzlinger, donated to St Emmeram monastery in Regensburg - also remained semiophores. ${ }^{30}$ Adding a book to a monastery or university library ensured its preservation, since all collections are by nature of semiotic significance. ${ }^{31}$ This was probably also the reason behind the survival of the above-mentioned miscellanea manuscripts (i.e. PLKj 2464 and D-TRs 322/1994), which in themselves form small collections of a sort, since besides the musical 'addenda' they contain homiletic, grammatical or philosophical texts. The fragments of local polyphony listed in Table 1 were not so fortunate; they ceased to be semiophores when they lost their utilitarian function of bearing a musical repertoire. In this instance, the exclusion from practical use resulted in their discarding or - abandoning our present-day 'destruction' narrative - in something 'useless' being turned into something 'useful'.

It should be stressed that an object's possession of a semiotic dimension does not guarantee its survival. Indeed, it exposes that object to great danger from individuals and institutions hostile to the meanings invested in it. History abounds in examples of books being destroyed for ideological reasons: they went from being semiophores to things (e.g. waste paper) or, in the more dramatic cases, waste (e.g. ashes). ${ }^{32}$ For this reason, during the Reformation, masses of medieval fragments were produced in Scandinavia. ${ }^{33}$ During the seventeenth and eighteenth centuries, Jesuit censors removed pages containing texts linked to the

28 Graham 2006, 628-629, Plates 10, 12, and 14.

29 CZ-HK II A 13a, f. 4r; see Graham 2006, 58.

30 Rumbold/Wright 2009, 201-248.

31 Pomian 1987, 53.

32 See Bosmajian 2006.

33 See Heikkilä/Ommundsen 2017. See also in this book Sanna Raninen's chapter, 185-203. 
cult of Jan Hus from Utraquist books. ${ }^{34}$ In 1944, the German Brandkommando ('fire command') in Warsaw burned priceless collections of books housed in the Krasiński Family Library. ${ }^{35}$ Thousands of manuscripts lost forever included PLWn F.I.378 (dated to c.1440), containing works by Antonio Zacara da Teramo, Johannes Ciconia and Mikołaj Radomski. ${ }^{36}$

Our view of musical culture is, to a considerable extent, contaminated by the circumstance that some sources have been preserved, because they have remained semiophores, while others have been destroyed, which equated to depriving them of their semiotic significance. The size of the losses increased due to accidental cataclysms, such as fires and floods. In many cases, it is difficult to establish what exactly caused particular manuscripts to be turned into waste paper, yet it seems necessary to reflect on such questions. Going back to Pomian's categories, for many generations now, especially thanks to collectors and scholars, membra disiecta musicae have turned from things into semiophores. Yet, while we can certainly study their actual physical form, a large part of that which cannot be seen still remains concealed to us.

\section{List of sources}

A-Wn 5094

CH-EN 314

CH-SGs 392

CZ-CH 12580

CZ-HK II A 6

CZ-HK II A 7

CZ-HK II A 13a

CZ-HK II A 14

CZ-HK II A 15

CZ-K 179

CZ-KH 88/85

CZ-KL 403

CZ-OP RC 4

CZ-Pam 7847
Vienna, Österreichische Nationalbibliothek, Cod. 5094

Engelberg, Benediktinerkloster, Musikbibliothek, MS 314 ('Engelberg Codex')

Sankt Gallen, Stiftsbibliothek, MS 392

Chrudim, Regionální muzeum, MS 12580

Hradec Králové, Muzeum východních Čech, MS II A 6 ('Franus Codex')

Hradec Králové, Muzeum východních Čech, MS II A 7 ('Speciálník Codex')

Hradec Králové, Muzeum východních Čech, MS II A 13a

Hradec Králové, Muzeum východních Čech, MS II A 14

Hradec Králové, Muzeum východních Čech, MS II A 15

Český Krumlov, Státní oblastní archiv v Třeboni, pobočka Český Krumlov, MS Kaplanské knihovny 179

Kutná Hora, České muzeum stříbra, rkp. sign. 88/85

Klatovy, Vlastivědné muzeum Dr. Hostaše, MS 403

Opava, Slezské zemské muzeum, MS RC 4

Prague, Archiv hlavního města Prahy, MS 7847

34 Graham 2006, 124-128.

35 Nastulczyk 2016, 464-465.

36 Perz 1973, xxvi-xxix, 103-160. A pre-war photographic copy of this manuscript has come down to us. 


CZ-Pn I A 17
CZ-Pn IV B 9
CZ-Pn XIII A 2
CZ-Pnm AZ 34
CZ-Pst 376
CZ-Pu 59 R 5116
CZ-Pu V H 11
CZ-Pu VI B 24
CZ-Pu VI C 20a
CZ-Pu VI G 10a
CZ-Pu XVII A 3
CZ-Pu XVII A 32
CZ-Pu XVII A 53a
CZ-Pu NG 3
CZ-RY 829/87
CZ-S M-3
CZ-TAoa
CZ-TEm 2
CZ-TRE A 4
CZ-UO A 3
CZ-VB 42

CZ-VO
Prague, Knihovna Národního muzea, MS I A 17

Prague, Knihovna Národního muzea, MS IV B 9

Prague, Knihovna Národního muzea, MS XIII A 2

Prague, Národní muzeum - České muzeum hudby, AZ 34

Prague, Národní archiv, MS 376

Prague, Národní knihovna ČR, Hudební oddělení, 59 R 5116

Prague, Národní knihovna ČR, MS V H 11

Prague, Národní knihovna ČR, MS VI B 24

Prague, Narodní knihovna ČR, MS VI C 20a

Prague, Národní knihovna ČR, MS VI G 10a

Prague, Národní knihovna ČR, MS XVII A 3

Prague, Národní knihovna ČR, MS XVII A 32

Prague, Národní knihovna ČR, MS XVII A 53a

Prague, Národní knihovna ČR, MS NG 3

Rychnov nad Kněžnou, Muzeum Orlických hor, 829/87

Sedlčany, Městské muzeum, MS M-3

Tábor, Státní okresní archiv, MS s.s.

Teplice, Regionální muzeum, Knihovna, MS 2 (olim MS B)

Třeboň, Státní oblastní archiv, MS A 4

Ustí nad Orlicí, Státní okresní archiv, MS A 3

Vyšší Brod, Knihovna cisterciáckého kláštera, MS 42 ('Hohenfurter Liederhandschrift')

Vodňany, Městké muzeum a galerie, inv. 18551

D-F Fragm. lat. VII 20 Frankfurt am Main, Stadt- und Universitätsbibliothek, Fragm. lat. VII 20

D-Gs XXX,1

D-LEu 1236

D-Mbs Clm 14274

D-MERa $13 \mathrm{~b}$

D-TR 322/1994

D-Z 17.8.39

D-Z 119,1

DK-Kar 687

H-Bn lat. 243

H-Bn lat. 534

H-Bu U.Fr.l.ch.299

PL-GD 2153a

PL-Kj 2188

PL-Kj 2464

PL-Kj 8a

PL-Wn F.I.378

PL-Wn BOZ 64a

PL-WRu I F 269

PL-WRu IV Q 223

PL-WRu XV Q 1066a

SK-BRmp Inc. 33
Göttingen, Niedersächsiche Staats- und Universitätsbibliothek, Handschriften und Seltene Drucke, Nachlass Ludwig XXX,1

Leipzig, Universitätsbibliothek, MS 1236

Munich, Bayerische Staatsbibliothek, Clm 14274 ('St Emmeram Codex’)

Merseburg, Domstiftsbibliothek, Hs. 13b

Trier, Stadtbibliothek, MS 322/1994

Zwickau, Ratsschulbibliothek, MS 17.8 .39 (olim 84,2)

Zwickau, Ratsschulbibliothek, MS 119,1

Copenhagen, Det Arnamagnæanske Institut, MS AM 687B, $4^{\circ}$

Budapest, Országos Széchényi Könyvtár, Cod. lat. 243

Budapest, Országos Széchényi Könyvtár, Cod. lat. 534

Budapest, Eötvös Loránd Tudományegyetem Egyetemi Könyvtár,

U.Fr.l.ch.299

Gdańsk, Polska Akademia Nauk - Biblioteka Gdańska, MS 2153a

Kraków, Biblioteka Jagiellońska, MS 2188

Kraków, Biblioteka Jagiellońska, MS 2464

Kraków, Biblioteka Jagiellońska, MS 8a

Warsaw, Biblioteka Narodowa, MS F.I.378 (lost)

Warsaw, Biblioteka Narodowa, MS BOZ 64a

Wrocław, Biblioteka Uniwersytecka, MS I F 269

Wroctaw, Biblioteka Uniwersytecka, MS IV Q 223

Wrocław, Biblioteka Uniwersytecka, XV Q 1066a

Bratislava, Miestne Pracovisko Matice Slovenskej, Inc. 33 (lost) 


\section{References}

Bosmajian, Haig A. (2006), Burning books, Jefferson, NC: McFarland.

Brewer, Charles E. (ed.) (1990), Collectio cantilenarum saeculi XV rkp. Biblioteki Jagiellońskiej Kj 2464, Kraków: PWM Edition.

Brewer, Charles E. (1990), 'The Historical Context of Polyphony in Medieval Hungary: An Examination of Four Fragmentary Sources', in Studia Musicologica, 32: 5-21.

Brewer, Charles E. (1984), The Introduction of the ars nova into East Central Europe: A Study of Late Medieval Polish Sources, 2 vols, PhD dissertation, The City University of New York.

Černý, Jaromír (1971), K nejstarším dějinám moteta včeských zemích [On the earliest history of the motet in Czech lands] (Miscellanea musicologica 24), Prague: Karolinum.

Černý, Jaromír (1972) 'Die mehrtextige Motette des 14. und 15. Jahrhunderts in Böhmen', in Rudolf Pečman (ed.), Colloquium Musica Bohemica et Europaea Brno 1970 (Colloquia on the History and Theory of Music at the International Musical Festival in Brno 5), Brno: International Musical Festival, 71-88.

Černý, Jaromír (1984), 'Vícehlasé písně konduktového typu v českých pramenech 15. stoletî’ [Polyphonic songs of the conductus type in Czech sources of the 15th century], in Miscellanea musicologica, 31: 39-142.

Ciglbauer, Jan, and Pawet Gancarczyk (2017), 'Manuscript RC 4 from the Silesian Museum in Opava and an Unknown Song by Petrus Wilhelmi de Grudencz', in Muzyka, 62/2: 99-105.

Ewerhart, Rudolf (1955), Die Handschrift 322/1994 der Stadtbibliothek Trier als musikalische Quelle (Kölner Beiträge zur Musikforschung 7), Regensburg: Bosse.

Fischer, Kurt von (1964), 'Neue Quellen zur Musik des 13., 14. und 15. Jahrhunderts', in Acta musicologica, 36: 92-94.

Fisher, Kurt von, and Max Lütolf (eds) (1972), Handschriften mit mehrstimmiger Musik des 14., 15. und 16. Jarhunderts (Répertoire International des Sources Musicales B IV³), Munich: Henle.

Gancarczyk, Pawet (2017), 'Changing Identities of Songs by Petrus Wilhelmi de Grudencz', in Hudební věda, 54/1: 5-24.

Gancarczyk, Pawet (2013), 'A New Fragment of 15th-Century Polyphony in Silesia and the Tradition of the Central-European Repertoire', in Pawet Gancarczyk, Lenka Hlávková-Mráčková, and Remigiusz Pośpiech (eds) The Musical Culture of Silesia before 1742. New Contexts New Perspectives, Frankfurt am Main: Peter Lang, 45-54.

Graham, Barry F. H. (2006), Bohemian and Moravian Graduals 1420-1620, Turnhout: Brepols. Heikkilä, Tuomas and Åslaug Ommundsen (2017), 'Piecing Together the Past: The Accidental Manuscript Collections of the North', in Åslaug Ommundsen and Tuomas Heikkilä (eds), Nordic Latin Manuscript Fragments: The Destruction and Reconstruction of Medieval Books, London: Routledge, 1-23.

Hlávková, Lenka (2020), 'Using the Past, Shaping the Present: Tracing the Tradition of Specific Polyphonic Repertories in Bohemian Utraquist Sources (c.1450-1540)', in Karl Kügle (ed.), Sounding the Past: Music as History and Memory, Turnhout: Brepols, 199-213.

Horyna, Martin (2006), 'Vicehlasá hudba v Čechách v 15. a 16. století a její interpreti’ [Polyphony in fifteenth- and sixteenth-century Bohemia and its performers], in Hudební věda, 43/2: 117-134. 
Keller, Hagen (1992), 'Pragmatische Schriftlichkeit im Mittelalter. Erscheinungsformen und Entwicklungsstufen. Einführung zum Kolloquium in Münster, 17.-19. Mai 1989', in Hagen Keller, Klaus Grubmüller, and Nikolaus Staubach (eds), Pragmatische Schriftlichkeit im Mittelalter. Erscheinungsformen und Entwicklungsstufen, Munich: Wilhelm Fink, 1-7.

Lubieniecki, Ryszard (2019), 'Epulemur in azimis from the Manuscript D-TRs 322/1994: An Attempted Reconstruction in the Form of a Circular Canon', in Muzyka, 64/3: 91-98.

Mráčková [Hlávková], Lenka (2009), 'Codex Franus - a Mirror of the Musical Practice of the Bohemian Utraquist Church around 1500?', in Journal of the Alamire Foundation, 1: 79-85. Mráčková [Hlávková], Lenka (2002) 'Kodex Speciálník. Eine kleine Folio-Handschrift böhmischer Provenienz', in Hudební věda, 39/2-3: 163-84.

Nastulczyk, Tomasz (2016), 'Two Centuries of Looting and the Grand Nazi Book Burning. The Dispersed and Destroyed Libraries of the Polish-Lithuanian Commonwealth: Historical Losses and Contemporary Attempts at Reconstruction', in Flavia Bruni and Andrew Pettegree (eds), Lost Books. Reconstructing the Print World of Pre-Industrial Europe, Leiden: Brill, 464-465.

Perz, Mirosław (ed.) (1973) Sources of Polyphony up to c.1500. Facsimiles (Antiquitates Musicae in Polonia 13), Warsaw and Graz: PWN-Polish Scientific Publishers and Akademische Druck- und Verlagsanstalt.

Pomian, Krzysztof (1987), Collectionneurs, amateurs et curieux. Paris, Venise: XVIe-XVIIle siècle, Paris: Gallimard.

Pomian, Krzysztof (1999), 'Histoire culturelle, histoire des sémiophores', in Krzysztof Pomian, Sur l'histoire, Paris: Gallimard.

Rajeczky, Benjamin, (1972), 'Ein neuer Fund zur mehrstimmigen Praxis Ungarns im 15. Jahrhundert', in Studia Musicologica, 14: 147-168.

Rumbold, Ian, and Peter Wright (2009), Hermann Pötzlinger's Music Book. The St Emmeram Codex and its Contexts, Woodbridge: Boydell \& Brewer.

Schmid, Bernhold (2004), “'Rozpaczliwy rozgardiasz z kluczami”. Użycie kluczy w kodeksie menzuralnym St. Emmeram w świetle środkowoeuropejskiej teorii muzyki' ['A desperate confusion of clefs'. The use of clefs in the St Emmeram Codex in the light of Central European music theory], in Muzyka, 49/2: 57-78.

Staehelin, Martin (2001), Neues zu Werk und Leben von Petrus Wilhelmi. Fragmente des mittleren 15. Jahrhunderts mit Mensuralmusik im Nachlaß von Friedrich Ludwig (Nachrichten der Akademie der Wissenschaften in Göttingen 1; Kleinüberlieferung mehrstimmiger Musik vor 1550 im deutschen Sprachgebiet III), Göttingen: Vanderhoeck \& Ruprecht.

Szyller, Stawomir (1996), 'Nieznana średniowieczna kompozycja muzyczna z rękopisu Biblioteki Narodowej BOZ 64' [The unknown medieval musical composition from the National Library BOZ 64 manuscript], in Muzyka, 45/3: 109-116.

Ward, Tom R. (1981), 'A Central European Repertory in Munich, Bayerische Staatsbibliothek, Clm 14274', in Early Music History, 1: 325-343.

Ward, Tom R. (1994), 'Music in the Library of Johannes Klein', in John Kmetz (ed.), Music in the German Renaissance. Sources, Styles, and Contexts, Cambridge: Cambridge University Press, 54-73.

Weber, Jaroslav, Josef Třǐška, and Pavel Spunar (1958), Soupis rukopisů v Třeboni a v Českém Krumlově [A catalogue of manuscripts in Třeboň and Český Krumlov], Prague: NČSAV. 
Welker, Lorenz, et al. (eds) (2006), Der Mensuralcodex St. Emmeram: Faksimile der Handschrift Clm 14274 der Bayerischen Staatsbibliothek München. Kommentar und Inventar von Ian Rumbold unter Mitarbeit von Peter Wright. Einführung von Martin Staehelin (Elementa Musicae 2), Wiesbaden: Reichert.

Zwolińska, Elzbieta (2000), 'Fragmente mit mehrstimmiger Musik des 15. Jahrhunderts aus dem Zistersienserkloster in Oliwa', in Musica Baltica. Danzig und die Musikkultur Europas, Gdańsk: Wydawnictwo Akademii Muzycznej, 53-60. 

Receivers 



\title{
Make Do and Mend: Reworking Liturgical Parchment Manuscripts in Post-Reformation Sweden
}

\begin{abstract}
The implementation of religious Reformation in the new Kingdom of Sweden required the local clergy to reinvent their working library, and many of the medieval parchment manuscripts of liturgical music ended up recycled as covers for bailiff's books during the sixteenth and seventeenth centuries. This change was not immediate, however, as some of the surviving fragments bear signs of their content being refashioned to fit the new aspects of Reformation liturgy. Furthermore, parchment fragments from sources made after the Reformation survive, containing liturgy for the Mass in Swedish, and attesting to the continued appeal of the material format. My chapter examines techniques of reworking parchment fragments and their musical repertory for the purposes of the Reformation worship.
\end{abstract}

The Kingdom of Sweden in the sixteenth century consisted of most of modernday Sweden and Finland, with the inclusion of much of Karelia and exclusion of some parts of southern Sweden. Most of the liturgical books from this area that predate the Reformation survive now only as a collection of parchment fragments. The main collections of surviving fragments from the kingdom of Sweden are the Fragmenta Membranea collection in the National Library of Finland, and the Medeltida pergamentsomslag (MPO) held in the National Archives in Stockholm and several provincial archives. The former consists of nearly 10,000 parchment leaves coming from almost 1,500 separate medieval volumes, while the latter amounts to $c .23,000$ leaves from as many as 11,000 separate volumes. ${ }^{1}$ The destruction of these books, however, was not born out of fervent reformatory mood as in some other European regions. The formation of the new kingdom of

1 Both collections are available online at <https://fragmenta.kansalliskirjasto.fi $>$ and $<$ https://sok.riksarkivet.se/mpo> (accessed 28 May 2020). A selection from the Fragmenta Membranea collection is also presented in Europeana at <https://pro.europeana.eu/data/ medieval-manuscripts-and-parchment-fragments-from-finland> (accessed 28 May 2020).

Ә Open Access. (c) 2020 Sanna Raninen, published by De Gruyter. (cc) BY-NC-ND This work is licensed under the Creative Commons Attribution-NonCommercial-NoDerivatives 4.0 International License.

https://doi.org/10.1515/9783110717884-008 
Sweden in 1523 and the financial challenges relating to it prompted king Gustav Vasa to utilise as many assets as possible at his disposal, which included the confiscation of church and monastic properties and income, as dictated in the Västerås Recess in 1527. The crown's main interest was focussed on items with monetary value such as objects made of precious metals, but also church bells or anything else of value. ${ }^{2}$ There is no evidence of a royal order for a deliberate confiscation and destruction of liturgical books because of their contents, as their fragmented state of survival is due to more pragmatic considerations. As part of his efforts to establish the kingdom, Gustav Vasa organised the administration of the area by appointing royal bailiffs who were responsible for tax collection and other fiscal matters in their given areas; the bailiffs repurposed old books of liturgy as covers for their account books, and thus inadvertently preserved some part of the medieval book culture of the area. ${ }^{3}$

The surviving medieval parchment fragments held in both main collections are well documented, and have been a subject of research in terms of their provenance and the early history of books in Sweden. ${ }^{4}$ These fragments are not just a treasure trove for medievalists: among the notes and scribblings by the bailiffs, the liturgical manuscript fragments reveal important historical evidence for the modifications to original texts and melodies made by Lutheran clergy, who continued to rely on their old books when keeping up with the changes in worship. In this chapter I present case studies from both fragment collections regarding the methods used by the clergy in amending their pre-existing parchment books of liturgy to match the new requirements in worship. These case studies illustrate the often hidden phase of material modifications and experimentation that occurs during times of change. Although legislation for the Lutheran worship was implemented, the pace of change remained moderate due to risks of political unrest and local practices; many aspects of pre-Reformation worship and church interior remained untouched for much of the sixteenth century, including the use of Latin for worship. ${ }^{5}$ Even the Church Ordinance of

2 Brunius 2011, 144.

3 Brunius 2017, 66-81.

4 A survey of the research history of manuscript fragments in Nordic countries in Heikkilä/Ammundsen 2017, esp. 10-15; Medeltida pergamentsomslag collection is further presented in Brunius 2013, and the Fragmenta Membranea collection is presented in Heikkilä 2010.

5 The post-Reformation changes to the parchment fragments are discussed in detail for the first time in Haapanen 1930, esp. 94. For further description of the parchment sources see Taitto 1992, 452-456; Taitto 2002. The manuscripts produced after the Reformation are further discussed in 
1571 allows the use of Latin in singing, and the language was still taught in schools. ${ }^{6}$ The old liturgical books, then, retained their relevance for worship for a long time after the Reformation.

A considerable portion of the collections consists of fragments from liturgical music manuscripts; among these, the largest group is that of fragments coming from large-format books. The reason for the survival of fragments in this particular format was practical, as bifolia from large-format books were particularly suitable to be reused as covers for bailiffs' accounts. ${ }^{7}$ The margins of the parchment fragments often contain a heading added by the bailiffs in reference to the contents of the accounts, but these do not necessarily reveal the provenance of the parchment manuscript. All bailiffs would have their accounts audited in Stockholm annually; on this occasion their account books could possibly be dismantled and rebound to another piece of parchment, and in some cases parchment books were imported from other areas to Stockholm for their further re-use. Moreover, since bailiffs often moved between districts, they could very plausibly have taken a few bifolia from one parish for later use before moving to another area. Parishes and dioceses also sold fragments for a variety of uses, from bookbinding to saddle-making. ${ }^{8}$

The Reformation liturgy retained much of its Latin repertory for the first hundred years. For this reason, many printed books and liturgical manuscripts were still being used for their original purpose well into the sixteenth century. The material value of medieval parchment books is evident in a church inventory made in Vallentuna in 1556, which among all the items owned by the church, lists six gamble pergament böker ('old parchment books') under the heading of sångeböker ('songbooks'). ${ }^{9}$ Many printed books and liturgical manuscripts predating the Reformation may include an additional quire of musical material in vernacular language (Swedish or Finnish), suggesting that the prior material was still useful for the book's owner and thus was not discarded in a hurry. Much of the post-Reformation alterations are inscribed in manuscript fragments that belonged to books made in the fifteenth century; they can be observed in

Hannikainen 2006, 20-30; Hannikainen/Tuppurainen 2016, esp. 159; Tuppurainen 2019. See also Berntson 2019.

6 'Så mångha ock än nu några Latiniska songer medh ibland sungne warda, för theras skul som thet Latiniska målet kunna eller ock lära skola' (Kjöllerström 1971, 103); also discussed in Nordlind 1909, 22; Knuutila 2010, 79-114 (esp. 95-6); Hannikainen 2006, 29.

7 Heikkilä/Ommundsen 2017, 5-6, 8, 10; Brunius 2017, 67, 69-70.

8 Taitto 2002, 17; Taitto 2002a, 221-226 for a case study on a fragment group known as Graduale Aboense; Abukhanfusa 2004, 12; Jan Brunius 2017, 73-78; Heikkilä 2017, esp. 83-84.

9 Stockholm, Stadsarkiv, Vallentuna kyrkoarkiv, N 1. 
graduals, antiphonaries, missals, sequentiaries and hymnals. Indeed, the first printed book of music containing post-Reformation worship repertory in Latin, such as music for the Office for main feast days, was not published until $1620 .^{10}$ Many fragments of antiphonaries containing post-Reformation alterations have bailiffs' notes dating from the first twenty years of the seventeenth century, suggesting that they remained in use until then. This period also represents the final stage of repurposing liturgical books for administrative uses. ${ }^{11}$ Although the bailiffs' notes may not always be helpful in determining the provenance of the fragment, they often provide a terminus ante quem for the liturgical use of a particular manuscript, and its preservation as a valuable object.

\section{Post-Reformation changes found in fragments: style and substance}

Although the changes in worship resulting from the Reformation did not lead to the eradication of all references to the Catholic worship, the calendar of celebrated saints was considerably reduced, and many of the non-biblical feasts were removed. The main saints and key figures such as the Holy Virgin, St John the Baptist, and the most popular saints continued to be revered, though with altered references. ${ }^{12}$ The most common ways of accommodating old music to new worship practices is to replace a few key words with something deemed more suitable. The majority of changes detectable in the fragments are mainly a replacement of one or two words with an equal number of syllables, thus requiring no adjustments to the melody. One example is fragment F.m.II.47, which contains the sequence Praecursorem summi regis for the feast of the Beheading of St John the Baptist. The sequence was included in two pre-Reformation printed missals (Missale Aboense and Missale Strengnense), and it is also found unaltered in several other fragments. ${ }^{13}$ On f. $8 \mathrm{r}$ the text Laudes ergo mirifico Johanni per magnifico was changed into Laudes ergo mirifico Jesu Christo

10 Liber cantus in quo glorificationes, hoc est: Kyrie et Venite, nec non: Sequentiae ac Antiphonae, in summis \& simplicibus Festis, atq; diebus Dominicalibus usitatae, continentur, Uppsala: Eskil Mattsson, 1620.

11 Brunius 2017, 73.

12 Taitto 1992, 454.

13 MPO Fr 8581, Fr 27097, Fr 28203, Fr 28248; The sequence is found also in Uppsala University Library, C.415, which is a defective manuscript copy of Missale Lincopense. See Björkvall 2015, 116-117; Moberg 1927, 50-51; Haapanen 1930, 96. 
magnifico by smudging over the original text and adding the changes underneath (Fig. 1).

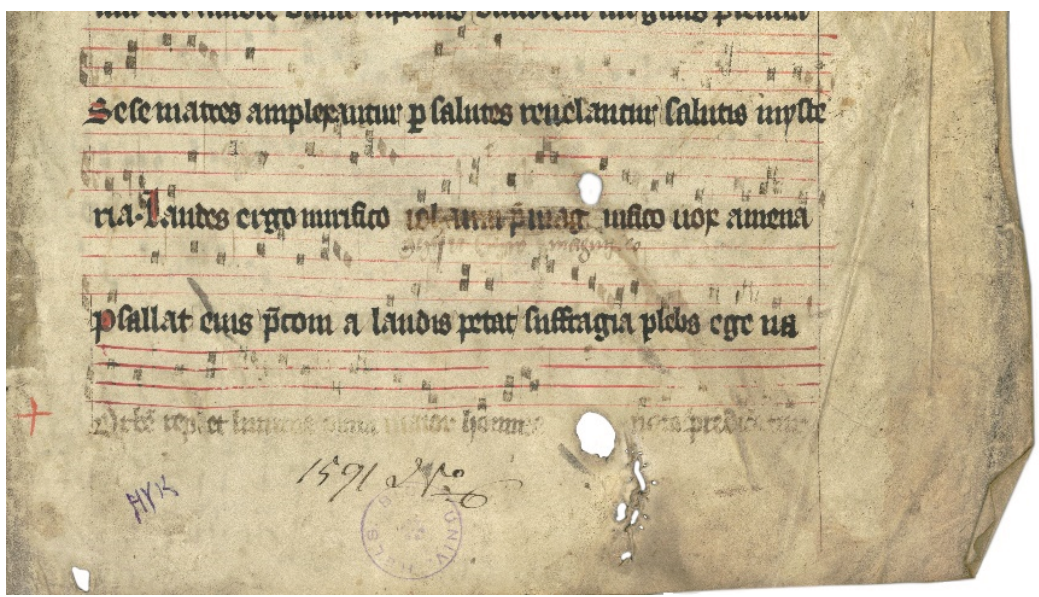

Fig. 1: Helsinki, National Library of Finland, F.m.Il.47, f. 8r (detail); (C) Helsinki, National Library of Finland.

Similarly, the phrase virgo, martir, doctor bone on the verso side was altered to Jhesu Christe, doctor bone. In both places the melody and the poetic structure remained intact. Usually, the changes that can be observed in fragments concern only one piece instead of being consistently applied to all repertory: while in F.m.II.47 the sequence Praecursorem summi regis was altered, the following sequence Jubar mundo geminatur for the feast of Sts Peter and Paul remains in its original form, while this is altered in fragment F.m.II.120. ${ }^{14}$ Here too, the textual change was made by simply swapping one word, from vestre solvat pietatis to Christi solvat pietatis. ${ }^{15}$ Furthermore, some text alterations might also appear due to differences in practices between dioceses. ${ }^{16}$ For example, the text of the antiphon Paulus et Iohannes dixerunt ad Terentianum for the Feast of Sts John and Paul was replaced with that of the antiphon Petrus apostolus et Paulus doctor for the Feast of Sts Peter and Paul in F.m.IV.89, including a number of alterations in the melody; based on

14 The sequence is found unaltered in MPO Fr 28205, Fr 28346, Fr 28349, Fr 30883, Fr 30884, and in F.m.II.120, F.m.I.145, F.m.I.219, F.m.I.232. See Björkvall 2015, 118; Haapanen 1922, 70-71, 107-108, 115; Haapanen 1925, 70-71.

15 Haapanen 1930, 97.

16 Brunius 2008, 89-91 
the style of the script, the changes are more likely to be from the sixteenth century rather than from prior to Reformation. ${ }^{17}$ Here the textual changes do not refer to Christ as in the example above, so the change was possibly due to using the chant melody in a different context rather than accommodating a change in the doctrine.

Most of the alterations to the repertory for saints' feasts appear as individual cases, with the exception of the feast of St Lawrence, featuring three instances of text alteration. ${ }^{18}$ The antiphon Levita Laurentius bonum in MPO Fr 284 shows another frequent case in the changing of certain key words, with signum crucis changed to nomen Christi. Different textual adaptations for the sequence Stola jocunditatis have survived in two parchment fragments. ${ }^{19}$ In F.m.II.96 f. 2 r, the sequence's original text underlay $u$ t hunc ergo per patronum was changed into per te ergo Jhesu Christe. The original text was carefully scraped off and the new text addition modelled following the original script, in an attempt to preserve the visual integrity of the manuscript (Fig. 2).

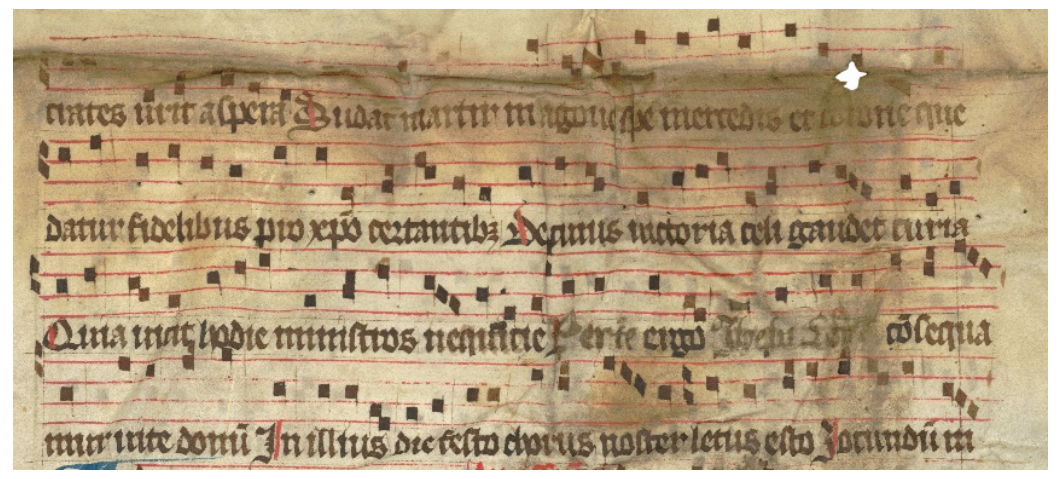

Fig. 2: Helsinki, National Library of Finland, F.m.Il.96, f. 2r (detail); @ Helsinki, National Library of Finland.

17 Taitto 2002, 111.

18 Two of the changes are also noted in Haapanen 1930, 96-97.

19 The sequence seems to have been very popular as it survives in several fragments. Unaltered versions are found in sixteen fragments from the MPO collection (Fr 25288, Fr 27059, Fr 27087, Fr 27677, Fr 28080, Fr 28093, Fr 28109, Fr 28127, Fr 28130, Fr 28159, Fr 28175, Fr 28205, Fr 28222, Fr 28245, Fr 28254, Fr 28306) and in eight fragments of the Fragmenta Membranea collection (F.m.I.219, F.m.I.287, F.m.I.337, F.m.I.360, F.m.II.70, F.m.II.51, F.m.II.102, F.m.II.112). See Björkvall 2015, 130; Haapanen 1922, 107-8, 144-145, 172, 185-186; Haapanen 1925, 30-31, 41-42, 44-46, 58-59, 64-65, 73. 
In F.m.II.77, preserving the metric pattern of the text was more of a concern for the scribe, as the same verse was changed from ut hunc ergo per patronum to ut per Christum vite thronum, in the more usual way of crossing over the original text and adding the correction above. ${ }^{20}$ This particular alteration had a wider appeal and use, as it appears also in manuscripts written after the Reformation. ${ }^{21}$

The most extensive reworking of Latin text and consequently melody can be seen in an antiphonary fragment F.m.IV.168, f. 1r, containing the antiphon $O$ beatum pontificem for the Vespers of the feast of St Martin (Fig. 3). ${ }^{22}$ The original text reads:

O beatum pontificem, qui totis visceribus diligebat Christum regem, et non formidabat imperii principatum. $O$ Martine dulcedo medicamentum et medice, o sanctissima anima, quam etsi gladius persecutoris non abstulit, tamen palmam martyrii non amisit

The text has been corrected in the fragment into a rather inventive form:

O Christum pontificem Deum patrem et non formidabat imperium Pilati. O salvator, dulcedo medicamentum et medice, o sanctissima anima, quam (et)si gladius persecutoris interemit, tamen palmam martyrii non amisit.

The later scribe started to alter the text by erasing or amending it with a similar size script: the result was not wholly successful as the same amended words were added a second time, either above or below the text, for further clarification. However, the new text required the melody to be adapted accordingly. The repeated note $\mathrm{F}$ was removed because of the change from pontificem to Christum, while the melisma resulting from changing principatum to pilati has been adapted by connecting the punctum on D to the following torculus E-F-E in order to be sung as one single melodic gesture D-E-F-E (Fig. 4). Unlike the changes in the sequence Stola jocunditatis, the alteration on the antiphon seems to remain unique to this fragment, as later manuscripts retain the original text. ${ }^{23}$ Other individual efforts in text alterations of similar length appear also in sources without accompanying notation, for example the hymn text Ave maris stella for

20 Haapanen 1930, 97-98.

21 The sequence with similarly altered text is found in Turku, Municipal Archives, Loimaa Parish Archives, III d.1, ff. 104r-105r, which was copied between the last quarter of sixteenth century to early seventeenth century.

22 Taitto 2002, 181.

23 An unaltered version of the antiphon is found for example in Vöyri, Church Archives, Käsik. Ia, f. 114r, and in Helsinki, National Library of Finland, A.ö.II.29, f. 113r-v, both copied in the latter half of the sixteenth century. 
Marian devotion altered with references to Christ instead of the Holy Virgin in a breviary fragment, F.m.III.119. ${ }^{24}$

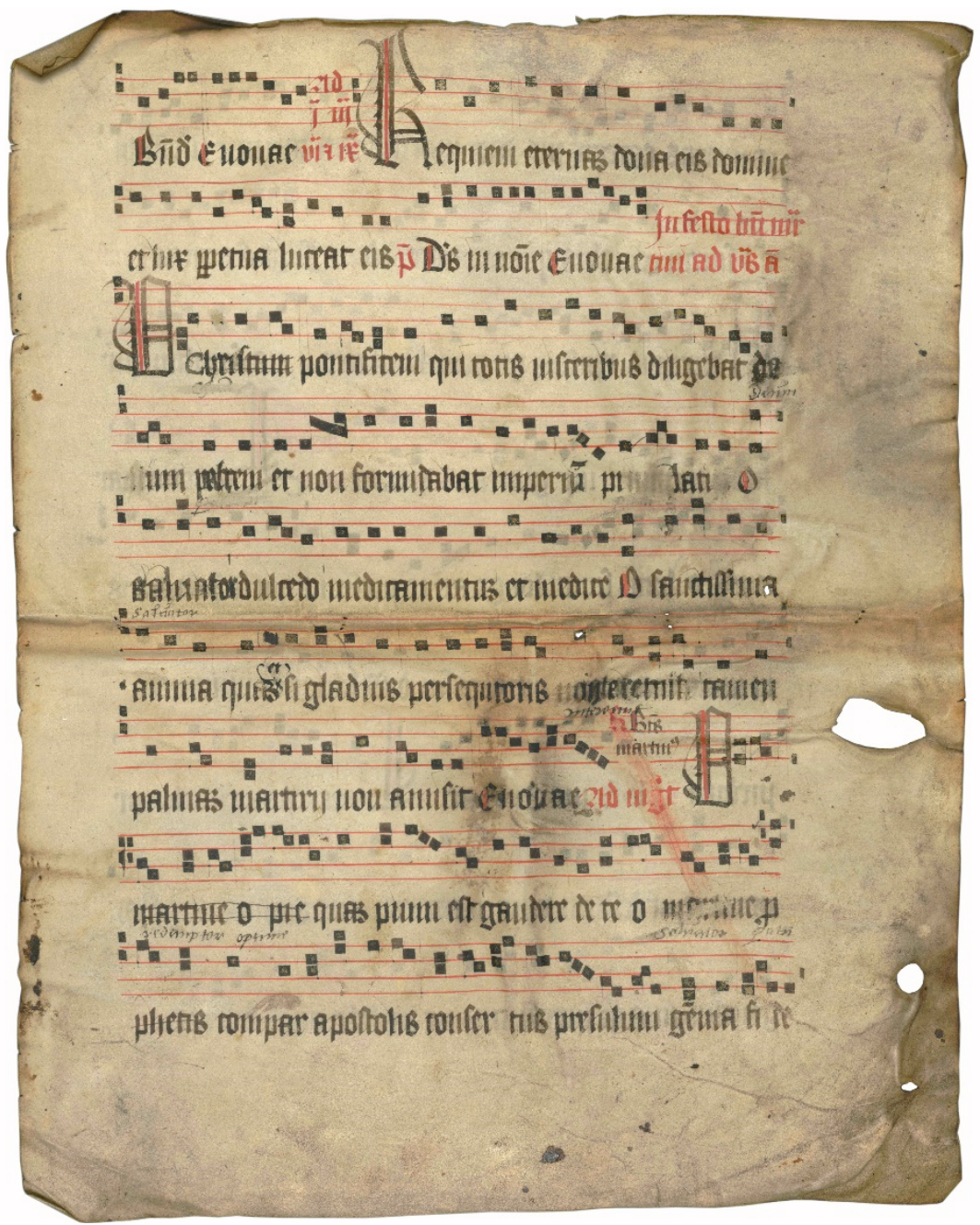

Fig. 3: Helsinki, National Library of Finland, F.m.IV.168, f. 1r; @ Helsinki, National Library of Finland.

24 Haapanen 1930, 100-102; Haapanen 1932, 53-54. 


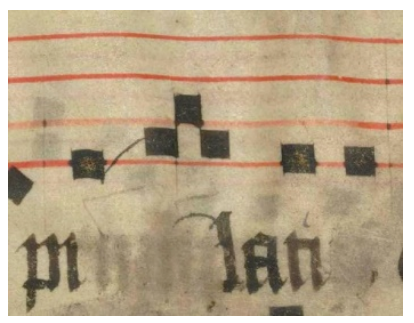

Fig. 4: Helsinki, National Library of Finland, F.m.IV.168, f. 1r (detail); @ Helsinki, National Library of Finland.

The alterations to repertory in reference to local saints are also similarly occasional as the examples described above. The hymn Gaude coetus fidelium for St Henrik, the patron saint of Finland, is altered in a hymnal fragment F.m.III.125 (Fig. 5). ${ }^{25}$ The original text Huius nobis precatibus Jhesu da perpes gaudium has been scraped off and changed to Christe Iesu precatibus da perpes gaudium, with the space of removed word Jhesu left blank.$^{26}$ The printed hymnals published after the Reformation contained predominantly hymns in the vernacular, with translations made from a mix of influences from Latin and German sources; in addition, the first hymnal in Finnish published in 1583 relied also on preceding sources in Swedish. ${ }^{27}$ Only the more popular hymns and sequences are referred to with their original Latin title, and hymns for some main feasts like Christmas could contain the complete text both in Latin and in vernacular. Although the later hymnals did not include this hymn for St Henrik, nor was there a translation made from it, this survives in two post-Reformation sources with similar text alteration as seen in the fragment, suggesting that it may have had wider appeal. Manuscripts Loimaa, Parish Archives, III d 1, and the Liber Olaui Lauri norbotnensis (Vöyri, Church Archives, Ib) were both written at the end of the sixteenth century at the earliest, and contain extensive collections of hymns in Latin. In both manuscripts, the alteration is seen in its full poetic form as Christe Iesu precatibus Deus da perpes gaudium and, just like the fragment, they retain all other references to St Henrik in other verses. The notation in the fragment is partially missing due to its poor condition, but the post-Reformation sources contain the full melody in two phrases for each verse.

25 For an edition of the hymn see Taitto 1998, 78-79.

26 Haapanen 1930, 98; Haapanen 1932, 56.

27 Kurvinen 1929, 82-140. A facsimile of the first Finnish hymnal is Lempiäinen 1988. 


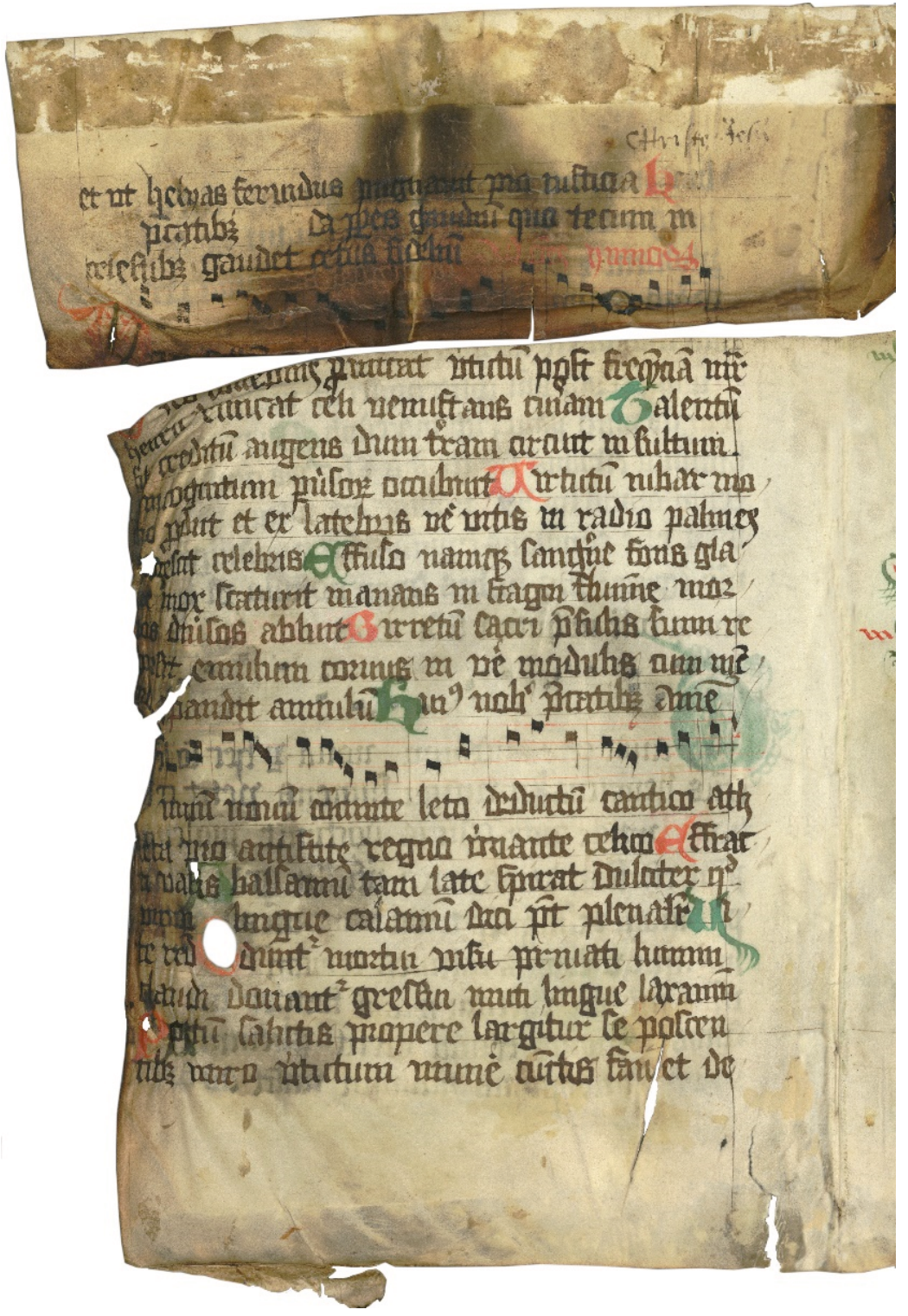

Fig. 5: Helsinki, National Library of Finland, F.m.III.125, f. 2v; @ Helsinki, National Library of Finland. 


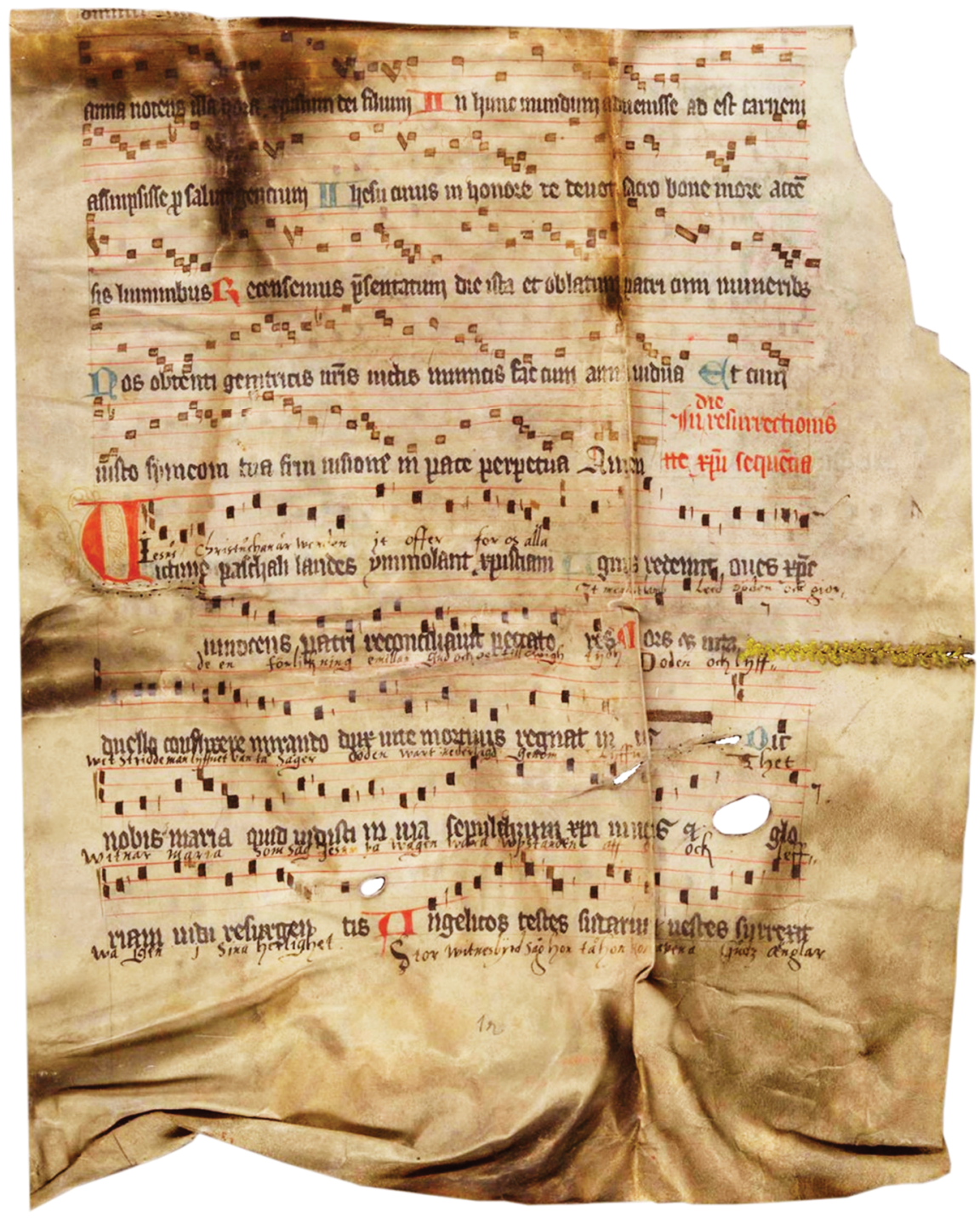

Fig. 6: Stockholm, National Archives, MPO Fr 2580; (C) Stockholm, National Archives.

Latin was not the only language used for textual modifications. Most of the core pre-Reformation repertory survived thanks to the text being translated to either Swedish or Finnish. This is the case of the sequence Victimae paschali laudes, which remained in use in both its vernacular and Latin versions. The Swedish translation Jesus Christus han ähr worden follows the syllabic structure of Latin 
very closely, thus not requiring any adjustments in the melody. ${ }^{28}$ In both MPO Fr 2580 and F.m.I.137 the original Latin text was retained, with the new text in Swedish aligned neatly underneath it (Fig. 6). Instead of writing the melody once, but with multiple text underlay, as seen in the fragment, and despite the close match of the syllabic structure of the vernacular translation, the scribes of later codices usually decided to copy the sequence several times consecutively. ${ }^{29} \mathrm{An}$ exception to this practice is found in an early seventeenth-century manuscript from Dannäs parish in Småland, in which the sequences Victimae paschali laudes, Sancte spiritus adsit nobis gratia and Rex omnipotens are set with double text underlay in both Latin and Swedish..$^{30}$ The design of the pages was certainly deliberate, since the scribe anticipated the placement of two lines of text under the melodies by increasing the space between the staves and reducing the number of staves to seven, instead of the more prevalent pattern of nine staves per page.

Familiar melodies for the Ordinary of the Mass remained in use, as can be seen in F.m.II.44, where the melodies for the first Kyrie and Gloria for a double feast are amended with a Finnish translation: Herra armahda meidem pällem ('Lord have mercy upon us'), Cunnia olkon Jumalan corceuxes ('Glory to God in the highest') (Fig. 7). ${ }^{31}$ The fragment belongs to a group identified as Graduale Aboense, which is a partial reconstruction of a book that originates from the beginning of the fifteenth century and was used in the Diocese of Turku (Åbo). ${ }^{32}$ In addition to the Kyrie and Gloria the fragment also has a translation of Agnus Dei ( $O$ Jumalan Caritza) for a Sunday or a simple feast, all presumably by the same scribe. The Finnish translation is set under the original Latin text, written in approximately the same script size and closely following the chant melody, including additional vertical lines indicating word divisions. In some cases, the new text underlay required the addition of repeated notes, as well as the division of the long melismas: particularly in the Kyrie, the word armahda ('have mercy') is consistently placed at the point of a distinct leap of fifth indicated by a pes.

28 Taitto 1992, 243-246; Hannikainen 2006, 22-23.

29 Helsinki, National Library of Finland, C.ö.IV.12 ('Urjalan Laulukirja') copied in the early seventeenth century has the sequence in Latin, Swedish and Finnish on ff. 81v-84r, as does Helsinki, National Library of Finland, Coll. 762.3, on ff. 16v-18r.

30 Landsarkivet i Vadstena, Dannäs kyrkoarkiv, P IV 1, ff. 80r-v, 83v-87r.

31 The fragment discussed here is also used as an example to illustrate the continued use of familiar melodies in Hannikainen/Tuppurainen 2016, 160 (esp. Fig. 5.1).

32 Taitto 2002a, 6, 207, 216-220. 


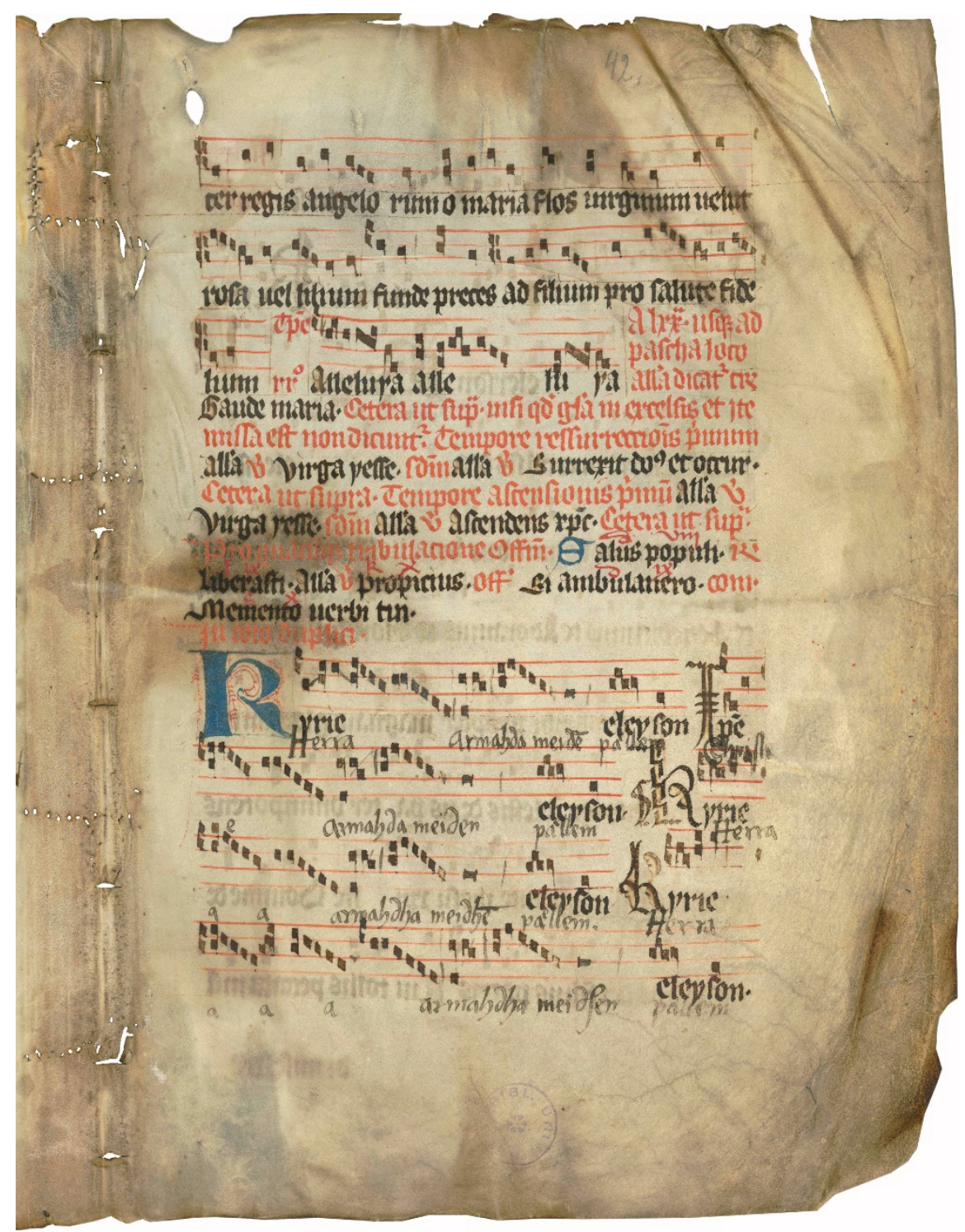

Fig. 7: Helsinki, National Library of Finland, F.m.II.44, f. 42r; @ Helsinki, National Library of Finland.

Melodic alterations and divisions of melody to fit the vernacular text seen in the fragment are present also in later sources in both Finnish and Swedish, either 
retaining the original rubric or referring to the melody as In summis festis. ${ }^{33}$ The sources preserving the Finnish translation reveal slight alterations of the melody and text compared to the version in the fragment. A manuscript from the early seventeenth century (National Library of Finland, A.ö.II.33) has altered the placement of the text for Kyrie by leaving the leap of fifth for word armahda to the end of the melisma for Herra. In an early post-Reformation manuscript copied in the first half of the sixteenth century (National Library of Finland C.III.19, 'Codex Westh'), the translation for the Gloria (f. 94r-v) is slightly different from the fragment, resulting in small variance in the melody: Cunnia olcon Jumalan corkeuxis ia rauha maan pällä ia inhimisten hyvä tahto; as opposed to fragment's version Cunnia olcon Jumalan corkeuxes, ia maassa rauha [ia] inhimisten hyvä tahto.

The psalm verse Confitemini Domino quoniam bonus quoniam in saeculum misericordia eius (Ps 118:1) in F.m.II.66 (f. 1r) is supplemented with a Finnish text above the original Latin: Kittek[ät] herra sille hen ombi h[yvä] ja henen Laupiudens onbi janka[ikkinen]. ${ }^{34}$ The text is a straightforward translation, written above the original text in small script with no particular setting of syllables to the melody. In the first printed translation of the Book of Psalms in Finnish published in 1551 (Dauidin Psaltari), Mikael Agricola's translation Kijtteket Herra Sille hen on Armachtaia ja henen Laupiudhens pysypi ijancaikisesta mirrors the syllabic count of the original Latin text, unlike the version seen in the fragment. ${ }^{35}$ Finally, the bailiffs' notes on the fragment were made around 1600, so it is not possible to ascertain whether the translation in the fragment predates Agricola's publication, or whether it was a variation used around the same time or after the printed publication. ${ }^{36}$

33 Sources that include the Kyriale melodies are Helsinki, National Library of Finland, C.ö.III.17 (late sixteenth century), f. 1r; Landsarkivet i Vadstena, Järstads kyrkoarkiv P IV 2 (early seventeenth century?), ff. 33r-35r; Landsarkivet i Vadstena, Rumskulla kyrkoarkiv P IV 1 (early seventeenth century) ff. 24v-26v; Landsarkivet i Vadstena, Östra Husby kyrkoarkiv P IV 1 (early seventeenth century), ff. 13r-14v. The Kyriale melodies more generally used in Finnish sources are further illustrated and discussed in Tuppurainen/Hannikainen 2010, 13.

34 Haapanen 1925, 40.

35 Agricola 1551, f. 86v.

36 A selection of psalms was published again in 1583 by Jacobus Finno as part of the first printed hymnal in Finnish, which however did not include Psalm 118. A facsimile of Finno's hymnal is found in Lempiäinen 1988. 


\section{Production of parchment manuscripts after the Reformation}

The material format of parchment manuscripts maintained some appeal even after the Reformation, as attested by seven pieces of fragments surviving from a source containing chants for the Mass dating to the 1530s. The surviving fragments come possibly from as many as three separate manuscripts that contained the same repertory. Five folios are held in Uppsala Landsarkiv (of which two folios are from Kungsåra, two from Tortuna, and one from Folkärna), and one further bifolium, MPO Fr 4286, was bound with bailiffs' notes from Glanshammar in Västmanland from 1588 (Fig. 8). ${ }^{37}$ All fragments have similar dimensions for the notation, with noteheads of $c .3-4 \mathrm{~mm}$ in height, and red staves made with a rastrum of approximately $17 \mathrm{~mm}$ in height. Since the same Kyrie melody De Apostolis appears in three of the fragments, it is very likely that these came from as many separate volumes, instead of one single codex. Moreover, although the fragments are not identical in terms of content, the consistent layout and appearance suggests that they were produced in the same place and in a relatively short period of time. ${ }^{38}$ Based on the melodic versions in the fragments Folke Bohlin's research suggests an origin for the original manuscripts in the diocese of Västerås, commissioned by bishop Henricus Johannis (1534-1556). ${ }^{39}$

The abandoning of Latin in favour of local vernacular languages for the celebration of the Mass did not happen immediately throughout the kingdom. Even though from 1530 the Mass began to be sung exclusively in Swedish in Stockholm, followed by the publication of Messan på Swensko by the royal printing house, some areas resisted changes to the point of open rebellion. ${ }^{40}$ The first written evidence of a Mass sung in Swedish outside Stockholm was in Rytterne church in 1535, which belonged to the Västerås diocese. Bohlin suggests that the fragments in question may predate this record, as bishop Henricus most likely undertook some 'trial runs' in his own cathedral prior to introducing the repertory in smaller parishes. ${ }^{41}$

37 Uppsala, Landsarkiv, Pärmfynd 23. In MPO Fr 4286, the passion hymn, written in cantus fractus 'O rene gudz lamb' to be sung instead of the Agnus Dei (De Sanctis et de Apostolis), followed by Kyrie ('Herre förbarma tigh') (In adventu et in quadragesima dominicus diebus).

38 Fransén 1927, esp. 24-34.

39 Bohlin 2004, esp. 96.

40 Berntson 2010.

41 Bohlin 2004, 97 


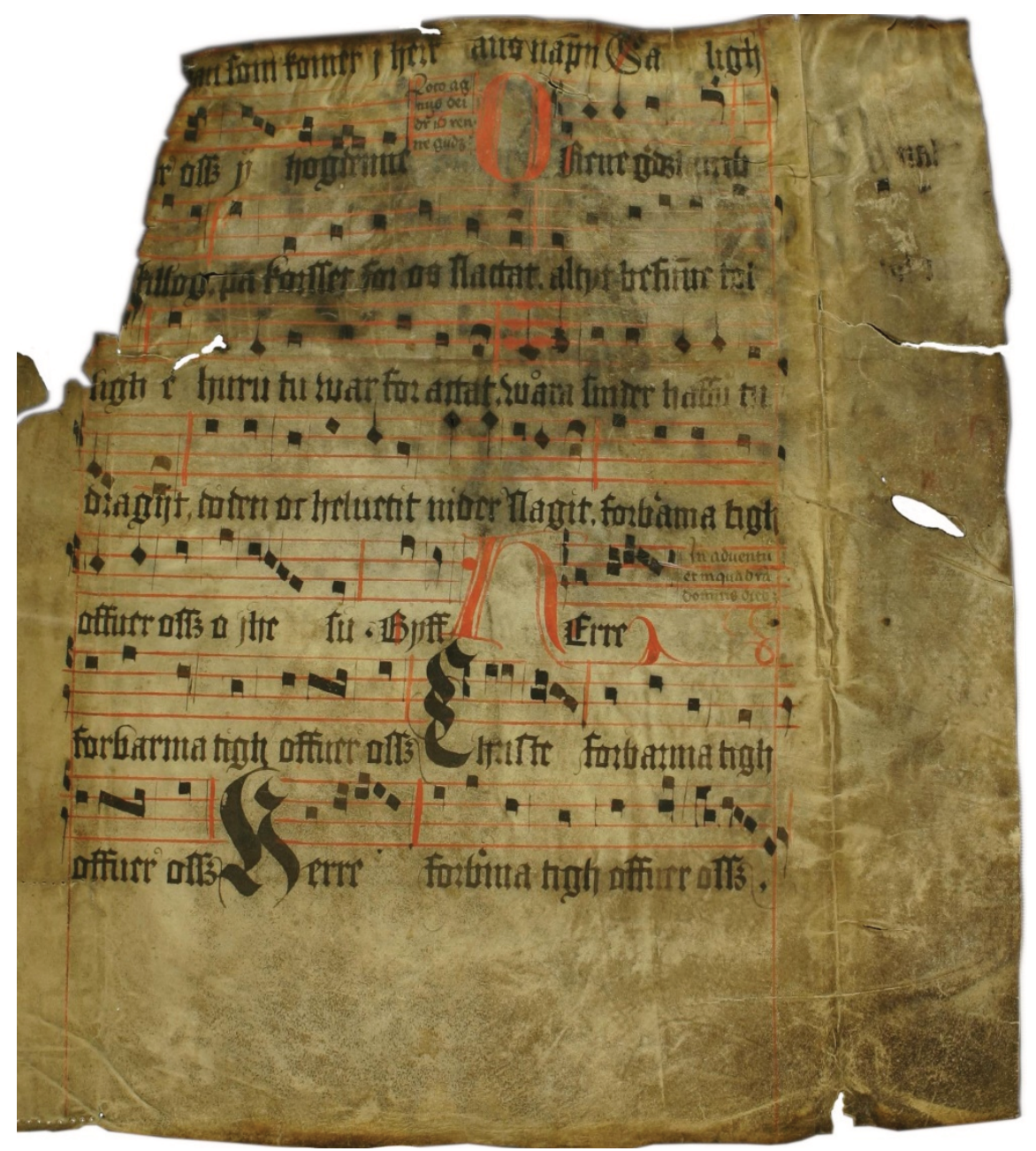

Fig. 8: Stockholm, National Archives, MPO Fr 4286, f. 1r; @ Stockholm, National Archives.

The surviving parchment leaves are not only a testament to the financial means and eagerness for reform in worship of the Västerås bishop, but could also be interpreted as a method for incorporating the new worship into the pre-existing liturgical books; the dimensions of the largest surviving fragment, the Kungsåra fragment $(432 \times 305)$ and the visual appearance of all the fragments relate closely to the books used preceding the Reformation. We cannot exclude the possibility that, instead of complete codices, the bishop commissioned only a few quires with the purpose of incorporating them into the existing pre-Reformation 
liturgical books, which in turn would attest to the continued use of old books. ${ }^{42}$ Evidence for the production of several manuscripts may indicate that the bishop was giving the parchment quires as gifts in an attempt to spread the Mass in Swedish, rather than imposing the acquisition of newly printed books.

\section{Conclusions}

The examples discussed here attest to the continuing use of the pre-Reformation manuscripts for post-Reformation worship. Although it was often sufficient to write the new text near the pre-existing text underlay, occasionally interventions present in the manuscript fragments indicate the scribes' concern with preserving the appearance of the original book by carefully removing old text and writing the replacement in similar hand. Moreover, attention to melodic changes caused by the addition of the new text is not consistent between the surviving examples. Alterations, therefore, further illustrate the absence of large-scale systematic efforts in the renewal of liturgy throughout the kingdom during the sixteenth century. The opposition to change in particular areas, as well as the differing attitudes to Reformation held by King Gustav Vasa and his successors, the production of new manuscripts by the clergy, as well as the eventual increase in printed books being published by the royal printing house, are all contributing factors to a gradual and diversified reception of Church reforms. Alterations seen in these fragments should be considered as valuable material evidence of the variety of approaches taken by local clergy in negotiating the complexities of implementing new aspects of worship in their respective areas; they are also highly important witnesses to the continuing use of Latin in Lutheran worship across Sweden. Old books certainly did not end up on the scrapheap immediately, and parchment manuscripts continued to be used to some extent in the Kingdom parishes, possibly as late as the beginning of the seventeenth century.

42 Old printed missals also bear evidence to their continued use after the Reformation with additional quires added to accommodate changes in worship, for example the copy of Missale Aboense held in Kangasala church archives has additional text and notation added both at the beginning and end of its original bindings. For the digital facsimile see <http://urn.fi/URN:NBN: fi-fe201102171251c> (accessed 28 May 2020). 


\section{References}

Abukhanfusa, Kerstin (2004), Mutilated Books. Wondrous leaves from Swedish bibliographical history, Stockholm: Almqvist \& Wiksell Tryckeri AB.

Berntson, Martin (2011), Mässan och armborstet: uppror och reformation i Sverige i 1525-1544, Skellefteå: Artos \& Norma.

Berntson, Martin (2019), 'Social Conflicts and the Use of Vernacular in Swedish Reformation Liturgy', in Maria Schildt, Mattias Lundberg, and Jonas Lundblad (eds), Celebrating Lutheran Music: Scholarly Perspectives at the Quincentenary (Acta Universitatis Upsaliensis, Studia Musicologia Upsaliensia, Nova Series 29), Ödeshog: DanagårdLiTHO Ab.

Björkvall, Gunilla (2015), Liturgical Sequences in Medieval Manuscript Fragments in the Swedish National Archives: Repertorial investigation, inventory, and reconstruction of sources, (Kungliga Vitterhets, Historie Och Antikvitetsakademiens Handlingar 31), Stockholm: Kungl. Vitterhets historie och antikvitets akademien.

Bohlin, Folke (2004), 'Tidig mässång på svenska i Västerås stift', in Svensk Gudstjänstliv, 79: 95-104.

Brunius, Jan (2008), Atque Olavi. Nordiska helgon i medeltida mässböcker (Sällskapet Runica et Medievalia, Scripta Minora 17), Stockholm: Runica et Mediævalia, Centrum för medeltidsstudier vid Stockholms universitet.

Brunius, Jan (2011), Vasatidens Samhälle: En vägledning till arkiven 1520-1620 i Riksarkivet (Skrifter utgivna av Riksarkivet 32), Elanders: Vällingby.

Brunius, Jan (2013), From Manuscripts to Wrappers: Medieval Book Fragments in the Swedish National Archives (Skrifter utgivna av Riksarkivet 35), Växjö: Davidsons Tryckeri.

Brunius, Jan (2017), 'The recycling of manuscripts in sixteenth-century Sweden', in Ommundsen/Heikkilä (eds), 66-81.

Fransén, Natanael (1927), 'Svensk mässa präntad på pergament. Graduale-Kyrie (Ordinarium Missae) på svenska från 1500-talet', in Svensk tidskrift för musikforskning, 9: 19-38.

Hannikainen, Jorma (2006), Suomeksi suomalaisten tähden: Kansankielisen tekstin ja sävelmän suhde Michael Bartholdi Gunnaeruksen suomenkielisessä Officia Missa introituskokoelmassa (1605) (Studia Musica 29), Kuopio: Sibelius-Akatemia.

Hannikainen, Jorma and Tuppurainen, Erkki (2016), 'Vernacular Gregorian Chant and Lutheran Hymn-singing in Reformation-Era Finland', in Tuomas M.S. Lehtonen and Linda Kaljundi (eds), Re-forming Texts, Music and Church Art in the Early Modern North, Amsterdam: Amsterdam University Press, 157-178.

Haapanen, Toivo (1930), Uskonpuhdistusajan muunnoksia katolisista kirkkolauluista, Suomen Kirkkohistoriallisen Seuran Toimituksia 28), Helsinki: Suomalaisen Kirjallisuuden Seuran Kirjapaino, 93-103.

Haapanen, Toivo (1922), Verzeichnis der mittelalterlichen Handschriftenfragmente in der Universitätsbibliothek zu Helsingfors, I: Missalia, (Helsingin yliopiston kirjaston julkaisuja 4), Helsinki: Suomalaisen Kirjallisuuden Seuran Kirjapaino.

Haapanen, Toivo (1925), Verzeichnis der mittelalterlichen Handschriftenfragmente in der Universitätsbibliothek zu Helsingfors, II: Gradualia, Lectionaria Missae, (Helsingin yliopiston kirjaston julkaisuja 7), Helsinki: Suomalaisen Kirjallisuuden Seuran Kirjapaino.

Haapanen, Toivo (1932), Verzeichnis der mittelalterlichen Handschriftenfragmente in der Universitätsbibliothek zu Helsingfors, III: Breviaria (Helsingin yliopiston kirjaston julkaisuja 16), Helsinki: Suomalaisen Kirjallisuuden Seuran Kirjapaino. 
Heikkilä, Tuomas (2017), 'From fragments towards the big picture: reconstructing medieval book culture in Finland', in Ommundsen/Heikkilä (eds), 82-111.

Heikkilä, Tuomas (ed.) (2010), Kirjallinen kulttuuri keskiajan Suomessa, Helsinki: Suomalaisen Kirjallisuuden Seura.

Heikkilä, Tuomas and Ommundsen, Åslaug (2017), 'Piecing together the past: The accidental manuscript collections of the North', in Ommundsen/Heikkilä (eds), 1-23.

Kjöllerström, Sven (ed.) (1971), Den svenska kyrkoordningen 1571: jämte studier kring tillkomst, innehåll och använding, Lund: Håkan Ohlssons Förlag.

Knuutila, Jyrki (2010), ‘Tukholman suomalaisen seurakunnan “messukirja” ja jumalanpalveluselämän muuttuminen evankeliseksi 1500-luvulla', in Jorma Hannikainen (ed.), Facultas Ludendi: Erkki Tuppuraisen juhlakirja, Kuopio: Sibelius-Akatemia, 79-114.

Kurvinen, P. J. I. [Pietari Jonas Immanuel] (1929), Suomen virsirunouden alkuvaiheet vuoteen 1640 (Suomalaisen Kirjallisuuden Seuran Toimituksia 180), Porvoo: WSOY.

Lempiäinen, Pentti (ed.) (1988), Jacobus Petri Finno, Jaakko Finnon virsikirja: Näköispainos ensimmäisestä suomalaisesta virsikirjasta sekä undelleen ladottu laitos alkuperäisestä tekstistä ja sitä täydentävistä käsikirjoituksista (Suomalaisen Kirjallisuuden Seuran Toimituksia 463), Mänttä: Mäntän Kirjapaino Oy.

Moberg, Carl-Allan (1927), Über die Schwedische Sequenzen. Eine Musikgeschichtliche Studie, Uppsala and Stockholm: Almqvist \& Wiksells Boktryckeri AB.

Nordlind, Tobias (1909), Latinska skolsånger i Sverige och Finland (Lunds Universitets årsskrift n.f. afd. 1 Bd. 5/2), Lund: Håkan Ohlssons boktryckeri.

Ommundsen, Åslaug, and Tuomas Heikkilä (eds) (2017), Nordic Latin Manuscript Fragments, Oxford and New York: Routledge.

Taitto, Ilkka (1992), Documenta Gregoriana. Latinalaisen kirkkolaulun lähteitä Suomessa, Porvoo: WSOY.

Taitto, Ilkka (1998), Missa et officium Sancti Henrici: Suomen suojelupyhimyksen liturgian keskeiset lauluosat (Helsinki: Sulasol, Suomen laulajain ja soittajain liitto r.y., 1998).

Taitto, Ilkka (2002), Fragmenta Membranea IV. Inventory of Sources of Medieval Latin Chant in Finland (Studia Musica 15), Helsinki: Sibelius-Akatemia.

Taitto, Ilkka (2002a), Graduale Aboense 1397-1406. Näköispainos käsikirjoituskatkelmasta, Vammala: Vammalan Kirjapaino Oy.

Tuppurainen, Erkki and Hannikainen, Jorma (2010), Suomenkielisiä kirkkolauluja 1500-1600luvuilta (Kirkkomusiikin osaston ja Kuopion osaston julkaisuja 33), Kuopio: SibeliusAkatemia.

Tuppurainen, Erkki (2019), 'Latin Liturgical Chant in Finnish and Swedish around 1600', in Maria Schildt, Mattias Lundberg, and Jonas Lundblad (eds), Celebrating Lutheran Music: Scholarly Perspectives at the Quincentenary (Acta Universitatis Upsaliensis, Studia Musicologia Upsaliensia, Nova Series 29), Ödeshog: DanagårdLiTHO Ab, 67-80. 



\title{
Karl Kügle
}

\section{The Aesthetics of Fragments: Reading Pastedowns in Context or, Late Medieval Bookbinders, Readers, and Their Choices}

\begin{abstract}
Fragments become material and visual signifiers in their own right when worked into bindings as pastedowns. The potential of pastedowns - musical or otherwise - to create meanings in the perception of users attuned to such messages is investigated through four case studies. Understood emphatically as metatexts, pastedowns, by virtue of their material, visual and semantic qualities, not only may reflect binders' and patrons' aesthetic strategies and intentions but also have the potential to contribute in subtle ways to the construction of institutional or collective memories and identities.
\end{abstract}

Fragments of earlier or even contemporaneous manuscripts and prints are regularly encountered as material components of late medieval and early modern book bindings. Indeed, bindings of the fifteenth and sixteenth centuries are widely recognised as exceptionally fertile grounds among fragment hunters. It is generally assumed that the voracious appetite for binding materials in late medieval and early modern Europe resulted from a significant increase in book production across the continent. Such growth went hand in hand with a rise in economic wealth and increased literacy rates, in combination with the introduction of paper as a comparatively low-cost writing surface and, in its wake, the arrival of the printing press. The Reformations of the sixteenth century are acknowledged as a further stimulus for the production of new books as well as the discarding or re-use of older, now obsolescent items. The impact of fifteenthcentury Church reform on generating disused parchment was probably considerable too, even if has not yet been explored in similar detail as the impact of later Reformations. ${ }^{1}$ All these developments combined made disused

\footnotetext{
1 For some introductory literature, see Riley 2017 (with a focus on book production in England; in particular 9-11 on the importance of fifteenth-century bindings and 12-13 on the specifics of flyleaves and pastedowns). Gillespie 2011. Szirmai 1999, § 9: ‘Gothic bindings', 173-284, in particular on endleaves 178. See also Mazal 1997.
}

Ә Creative Open Access. ( 2020 Karl Kügle, published by De Gruyter. (cc)BY-NC-ND This work is licensed under the Commons Attribution-NonCommercial-NoDerivatives 4.0 International License.

https://doi.org/10.1515/9783110717884-009 
parchment, sometimes also paper, the materials of first choice for the production of quire guards, flyleaves, and pastedowns.

It has been an unspoken premise of fragment studies that fifteenth- and sixteenth-century bookbinders inevitably made random or purely utilitarian choices when selecting the specific materials that they used in creating a binding for a particular volume. While the immediately visible features at the outside of bindings (spine and outside covers) have long been the objects of attentive scrutiny and classification, no such attention has been paid to the internally visible components of bindings (pastedowns, flyleaves and quire guards), nor to the availabilities and choices that might have influenced the selection of particular materials by a bookbinder or a patron when creating a specific binding, including the selection of a particular folio, or a section of it, for conversion into a pastedown. ${ }^{2}$ This approach nullified much of the potential of perceiving any semantic or aesthetic links between a codex tradens and the fragments worked into its binding.

It may, however, be worthwhile to pause for a moment and consider some arguments that might militate against the automatism implicit in this established view. In craftsmanship, attention to detail is a consistent hallmark of quality work across the ages. This suggests that some kind of reflection on the part of bookbinders and their patrons must have taken place while choosing a specific piece of disused parchment for a binding. Criteria no doubt included both aesthetic and utilitarian considerations. In practice, decisions probably were almost always based on a combination of the two. Bookbinding historians seem to agree that, during the late medieval and early modern period, growing attention was paid to visual aspects of bindings - in particular, the decoration of front and rear covers, and of the spine - along with the invention and growing attractiveness of personal libraries. ${ }^{3}$ Why, then, should we assume that at a cultural moment of increasing attention to books as aesthetic objects no care was ever - if not necessarily always - lavished on the aesthetic impression created by a book's inside covers? Quire guards, flyleaves and pastedowns are visible to the user, even if they may not catch the eye as rapidly or as firmly as other visual

2 See, for example, Bosquet 1894; Schreiber 1932; Kyriss 1957; Helwig 1970; Mazal 1997; Szirmai 1999; $L G B^{\mathrm{II}}$; Lanoë/Grand 2008. See also the pertinent databases such as the Einbanddatenbank (<https://www.hist-einband.de> [accessed 30 Apr. 2020]).

3 See, for example, the discussion of the personal library of the Cologne patrician and professor at the University of Cologne, Peter Rinck (1429-1501), who had a personal stamp added to the outer front covers of many of his books. On the bindings of Rinck's books, see, most recently, Ottermann 2016, 541-45. Also Ottermann 2013, at 19-24. For a concise biography, see Schmid 2003. 
elements of a binding, such as its outside. Therefore, neglecting the visual impact of these 'secondary' elements may cause us to overlook some of the messages embedded in the material, visual, and semantic attributes of such recycled components of late medieval books - messages conveyed primarily through an aesthetic language that coeval users might have been attuned to and relished, but that might require some effort to re-construct for present-day sensibilities.

Deborah McGrady recently explored how different ways of deploying organisational, visual and material elements such as metatexts (e.g. marginal glosses or tables of contents), illuminations, decorations in the page margins, and the spatial distribution of text within the page layout impact on the perception of a given text and, therefore, the reading experience. ${ }^{4}$ McGrady's study concerns itself primarily with a small group of deluxe codices that transmit Guillaume de Machaut's Voir Dit, and the differences in the internal structure of their textblocks. Particular importance in generating internal ecologies of a book lies with those whom she calls 'intermediary readers' - the craftsmen and, as applicable, the patrons interacting with them during the production process. They were the agents who jointly designed the material features of a manuscript. Even if bindings are not part of McGrady's study, her observations about the way in which material aspects of a book shape and channel perceptions can fruitfully be extended to the relationship between a book and its binding, including its pastedowns. If we allow ourselves 'to identify [a] manuscript as a cultural matrix that registers the voices of multiple creators ranging from authors and patrons to scribes and artists, ${ }^{5}$ there is no reason to exclude bookbinders, patrons (individuals and institutions), and by extension fragments of other manuscripts or documents worked into bindings as pastedowns, from agency in the construction of meanings. A chronological gap between the production of a binding and the creation of the text-block it surrounds is no hindrance to this approach: a cultural analysis of the much later bindings of the manuscripts McGrady studied - or the awareness of the prolonged absence of a binding would reveal a great deal about the history of these sources and the cultural appreciation they received in the course of their centuries-long biographies. In short, a close reading of all the materials worked into a codex including bindings and pastedowns, understanding them as an interconnected network of potential signifiers for readers attuned to their messages, is wont not only to provide evidence about the internal landscape created by binder and patron for a particular book but also to reveal previously overlooked details about the context

4 McGrady 2006.

5 McGrady 2006, 80. 
and place of the volume - when, where and why it was bound in a particular way, how it was valued, stored and used by its individual or institutional owner(s), and what was its role in the libraries that housed or house it.

As stated earlier, practical considerations such as size, state of preservation, and availability no doubt played a vital role when selecting a specific piece of discarded writing material for use as a pastedown in a particular binding. Yet, whatever the random elements in this decision-making process may have been, all visible components of a binding, once chosen, invariably send a message, intentional or not, inviting owners and users to reflect upon the tactile, visual, and semantic qualities of the materials used. Their sheer presence prompts aesthetic and semantic relations to the surrounding components of the book, and the physical, institutional, and intellectual environment that they were part of. This is all the more important in a culture where books were still relatively rare and considered highly precious items both as material objects and as carriers of ideas. Owners and users would return to their books over and over again, allowing them to savour, even meditate on physical features that today's readers are much more likely to miss or ignore - except, perhaps, in the case of so-called 'coffee table books'. Material details inevitably convey information about the institutional or private patrons involved, the owners who commissioned a binding, as well as the artisan(s) or workshop(s) that produced it. It therefore seems nothing more than plausible to assume that some attention from both a practical and an aesthetic perspective would usually have been paid to all components of a binding when it was designed, and that the choices made would - consciously or unconsciously - have been understood by patrons and craftsmen as signifiers conveying implicit messages to users. Then as now, the properties of material objects owned by a person or an institution inevitably communicate a great deal about that person's or institution's history and identity. An awareness of the presence of such messages in the make-up of a binding, and of their potential impact, among late medieval bookbinders and their patrons therefore would hardly be surprising.

Just like the outer covers of a book, pastedowns can tell us about the institution or the individual who commissioned the binding, about the workshop that made it, and about the cultural context of the place and time when and where the binding was produced. In other words, taking the insides of bindings seriously may lead us to a purloined place of dynamic, creative interaction between binders, owners, and users where touch, design, semantics, and the users' gaze jointly trigger, and influence, chains of meanings and associations. These intertextual and material sequences of perceptions and the associations resulting from them may differ every time a book is taken up by a user; they can 
be controlled by the patron or the craftsman only to a limited extent, making it all the more seductive to use them consciously, carefully, and as clearly as possible. Admitting the potentialities inherent in such a dynamic approach, allowing meanings to ricochet between users and the material body of the book, may disturb familiar, comfortable fixities. Yet, this should not prevent us from attempting to trace and pursue some of these potentialities within their historical and cultural contexts.

A brief review of some of the technical aspects of creating bindings and in particular pastedowns, thus rehearsing some of the criteria that necessarily guided the selection of suitable binding materials, will be a useful point of departure for such considerations. Four case studies, all chronologically situated at a high-water mark of fragment production, the end of the fifteenth century, will illustrate some of the potential for semantic and aesthetic links between pastedowns and the contents of a codex tradens. This will lead to some concluding thoughts about the heuristic potential, but also the geographical, chronological, and sociological limits of the phenomena observed. I hope to show that the approach to the materiality of fragments proposed in this essay may refine our methodology by adding a new dimension to it - that of aesthetic experience, and invite us to read pastedowns as re-contextualised signifiers that have the ability to engender novel and different meanings in their new contexts. Adding this layer to the study of bindings and the role of fragments may elucidate aspects of late medieval and early modern books, as well as the book (sub-)cultures wherein they were embedded, that would otherwise remain undetected.

\section{Technical aspects: bookbinders and their patrons - choices and constraints}

Binders usually had a stock supply of binding materials in their workshops, enabling them to meet the various requirements associated with the full range of book types and book sizes that they might customarily come across. Surviving inventories include stamps, clasps, and leathers in various colours for the outside of the binding, wood (usually oak or pine) to be turned into cover plates, assorted tools for cutting, pasting and sewing such as knives, thread, needles, and glue, as well as stacks of - usually disused - parchment or, in some cases, paper. ${ }^{6} \mathrm{~A}$

6 For some archaeological evidence concerning the period under consideration here, see IrásMelis 1974. For an inventory of the bookbinder's workshop at the electoral court in Heidelberg 
full inventory from Leipzig dated 18 November 1592, for example, includes Ein und zwanzigk pfund alt Pergament vor 1 [fl]. $101 / 2$ [Groschen] ('21 pounds of old parchment valued at $1 \mathrm{fl} .101 / 2$ Groschen'). ${ }^{7}$ Indeed, various records of thefts (!) of scrap parchment illustrate that the material was of some monetary value and, at least for those in the book trade, a sought-after commodity. Such thefts are documented in Leipzig in 1536 and 1574, including one case (in 1574) of etliche hundert bogen Pergament, aus alten Meßbüchern geschnitten ('several hundred sheets of parchment cut from old Missals'). The thieves attempted to sell the merchandise conspicuously under the usual price, thereby arousing suspicion from the authorities. ${ }^{8}$

At a given moment, a binder may have been limited in his choices by a constrained supply - for example when a large, relatively homogeneous stack of parchment drawn from a single group of codices like the alten Meßbüchern had come in and needed to be processed, temporarily leading to a higher than usual ratio of bindings with pastedowns recycled from that supply. There is, however, no need to assume that a stack of 21 pounds of disused parchment was entirely homogeneous in provenance and appearance. Unlike the case of palimpsests, where typically a single or a very small number of source manuscripts of matching size and parchment quality was selected for recycling, the diverse sizes and contents of the materials arriving at a binder's shop both as books to be bound and as scrap to be recycled were by necessity somewhat random. Over time, a workshop active over several years or decades would therefore have accumulated in all likelihood a relatively varied assortment of disused parchments, offering patrons and buyers a range of options to match a book with potential pastedowns. Moreover, large codices like the Missals mentioned provided a rather impressive range of texts and potential visuals in themselves, in this case all drawn from the liturgy and in conformity to the codicological strictures typical of that particular book type but still with highly divergent options in terms of layout, appearances, and contents. This would have provided binders and patrons with a significant range of aesthetic choices to match potential pastedowns

in 1550 (Heidelberg, Universitätsbibliothek, Cod. Pal. germ. 839), see Koch 1889; a partial reproduction of this source is included in Schlechter et al. 2003, catalogue nos. 4-5. For various inventories from sixteenth-century Leipzig, see Kirchhoff 1889.

7 Kirchhoff 1889, 165. Twenty-one Saxonian pounds are equivalent to approximately ten kilograms. 1 florin corresponded to 21 groschen, bringing the total value of the parchment to $1 \frac{1}{2}$ florins or $31 \frac{1 / 2}{2}$ groschen. The daily wage of a mason would have been around $3-31 / 2$ groschen. See <http://wiki-de.genealogy.net/Geld_und_Kaufkraft_ab_1450\#Beispiele_von_Lebenshaltungs kosten_1552_Dresden> (accessed 6 Apr. 2020).

8 Kirchhoff 1889, 174-175, n. 6. 
with the contents of the books they were working on, even if not each workshop or patron in every region or social setting might necessarily have been susceptible to such considerations. The presence of musical notation would have been an aesthetic category kat'exochen by default. Some patrons might have deemed it highly desirable, at least in certain situations, and others not; within the musical subset, there is also a significant difference in the aesthetic effect between a pastedown created from a manuscript of mensural polyphony or square chant notation and one generated from a folio containing staffless neumes, which are much more discrete visually, and resemble the workaday sources of pastedowns such as notarial documents, charters, or similar archival materials.

Once a piece of parchment had been chosen to serve as a pastedown, a practical aspect needed to be considered, that is, which side of a prospective pastedown would be left visible, and which one would be glued onto the wooden plates, thus rendered invisible. From an aesthetic point of view, pastedowns work in ways similar to a frame for a picture: they provide a visual and also a semantic context for the material that is contained in the book. Such contexts may invite interpretations; once placed, their presence cannot be erased. The content that would be made visible therefore was very plausibly factored into the decision whether to select a particular folio for conversion into a pastedown. Moreover, based on the adhesive qualities of parchment, the flesh side of a sheet would have been the preferred side to be glued onto the boards. From a purely technical point of view, then, we should expect the visible side of a given parchment pastedown consistently to be the hair side. ${ }^{9}$ As we shall see, however, this was not always the case, providing internal evidence for intentionality on the part of the bookbinder when choosing a particular side of a disused folio to remain visible or not. Sometimes the two sides of the hides concerned can no longer be distinguished with certainty in their present state. When this happens, the question of adhesion must remain open from a technical point of view but the contents of the two sides of the pastedown can still be compared. The resulting 'frame' for a book might have looked quite different depending on the decisions made or avoided, thereby illuminating the choices that were available when the binding was created, and their consequences for the internal ecology of a book. In the case of a paper pastedown the question is moot by definition; since either side could have been turned into the invisible part from a purely technical point of view, the choice cannot have been made on functional criteria alone, and semantic and aesthetic factors therefore played a significant role.

9 See Szirmai 1999, 192 and 228; Fuchs et al. 2001; Rück 1991. 


\section{Case study 1: the front and rear pastedowns of Koblenz, Landeshauptarchiv, Best. 701 Nr. 243}

Codex Koblenz, Landeshauptarchiv, Best. 701 Nr. 243 transmits a set of music fragments that survive as front and rear pastedowns, alongside thirty sewing guards, in the binding of a mid-fifteenth century manuscript copy of sermons by the Austin friar Jordan of Quedlinburg (Iordanus de Quedlinburgo, c.1300c.1380). ${ }^{10}$ The copy was probably prepared between 1450 and 1455 at the Carmelite convent in Boppard (Middle Rhine). An ex libris (f. 2v) shows that the volume was part of the working library of Heinrich of Montabaur (Henricus de Montebuir de Boppardia), a native of Boppard who studied at Cologne University (14391445) and later occupied positions as informator and lector within the Carmelite convents of Boppard, Trier and, by 1449, Mainz. Later in his life Heinrich of Montabaur returned to his home institution, explaining how the volume entered the Boppard Carmelites' library; his date of death remains unknown. ${ }^{11}$ The volume retains its original, late fifteenth-century binding which can incontrovertibly be associated with the library of the Boppard convent. Via several intermediate steps the codex passed into the present-day ownership of the Görres-Gymnasium Koblenz. It is kept on permanent deposit among the holdings of the Landeshauptarchiv Koblenz. The volume originated, circulated and was bound in an educated, university-trained milieu of mendicants, and can be situated within a geographical area limited by Cologne, the Middle Rhine and the Moselle regions.

The binding consists of two wooden plates $(205 \times 145 \mathrm{~mm})$, covered with brown calf leather and decorated with a simple geometric pattern, a double rectangular frame that encloses four internal rectangles, each of which is subdivided by two diagonal lines resulting in a cross of St Andrew. The wooden plates are connected to the text-block by two pastedowns drawn from a music manuscript copied at an unknown location. The two folios contain four pieces of mensural polyphony that were indubitably composed within the orbit of early fourteenth-century motet culture assumed to be centred on Paris, but dissemi-

10 See Kügle 2018 for a first assessment. A second publication is underway introducing the additional material discovered in the manuscript since 2018. Selected aspects of this additional material will be presented in what follows. For a recent account of Jordan of Quedlinburg's biography, influence, and reception, see Saak 2015, 4-12.

11 See Kügle 2018; Overgaauw 2002, 45, 229-231; Lickteig 1981, 67-69, 448, 511. 
nated and cultivated also in England and the Low Countries, including the Liège and Cologne regions.

The visible side of the front pastedown (Fig. 1a) is an extensive fragment (about one quarter of the triplum, and the entire motetus and tenor) of the threevoice motet Mater formosa / Gaude virgo / Tenor in praise of the Virgin. The piece is transmitted in full in the rotulus Brussels, KBR 19606, a manuscript from the Liège area, probably Stavelot-Malmedy, and copied in $1335 .^{12}$ There are also two versions of the triplum text transmitted in two monastic manuscripts from the Lower Rhine area, Darmstadt, Universitäts- und Landesbibliothek 521 (f. 192r) and 2653 (ff. 74v-75r). These two manuscripts both contain collections of rhymed prayers and were copied in the second half of the fifteenth century at the Cistercian abbey of Kamp (Darmstadt 521) and the Charterhouse at Wesel (Darmstadt 2653). ${ }^{13}$ Koblenz provides important additional information about the source of the motet's tenor, which has a close match in a late medieval rhymed Office for St Catherine documented in Aachen and Utrecht. ${ }^{14}$

The visible side of the rear pastedown (Fig. 2a) shows an incomplete copy (the full triplum, and almost the entire duplum but not the tenor) of another motet a 3, Firmissime / Adesto / Tenor. ${ }^{15}$ The motet survives complete, again, in KBR 19606 and is transmitted first in an interpolated version of the Roman de Fauvel, Paris, BnF, fr. 146. This manuscript has been studied extensively and is associated with aristocratic and clerical circles in Paris in the early reign of French King Philip V (r. 1317-1322). ${ }^{16}$

12 On Brussels 19606, see, most recently, Kügle 2008, 145-185.

13 For Darmstadt 521, see Achten et al. 1972, 47-64. For Darmstadt 2653, the in-house catalogue entry by U. Spyra remains unpublished. The date 1459, found on f. 146v of Darmstadt 2653, seems to apply to that entry only.

14 The Koblenz copy of the tenor has the designation ' $\mathrm{O}$ Christi pietas'. This caption helped identify its source, the opening phrase of the third responsory for the third nocturn of Matins in a rhymed Office for St Catherine. Sources: Aachen, Domarchiv, Ms. G 20, fol. 342v (antiphoner from Aachen Dom = formerly collegiate church of St Mary); Utrecht, Universiteitsbibliotheek, Ms. 406, fol. 236v (antiphoner from the collegiate church of St Mary in Utrecht). The closest match is provided by the Aachen source.

$15 \mathrm{BnF}$ fr. 146 gives 'Alleluya Benedictus et cetera' as the designation of the tenor. KBR 19606 has '[A]lleluya alleluya alleluya'. The pitches and rhythms are the same in both sources.

16 On fr. 146, see, most recently Bent/Wathey 1997; Dillon 2002; Marinescu 2014. For the latest discussion of the motet Firmissime/Adesto, see Zayaruznaya 2015. See also Robertson 1997; Vetter 1987. 


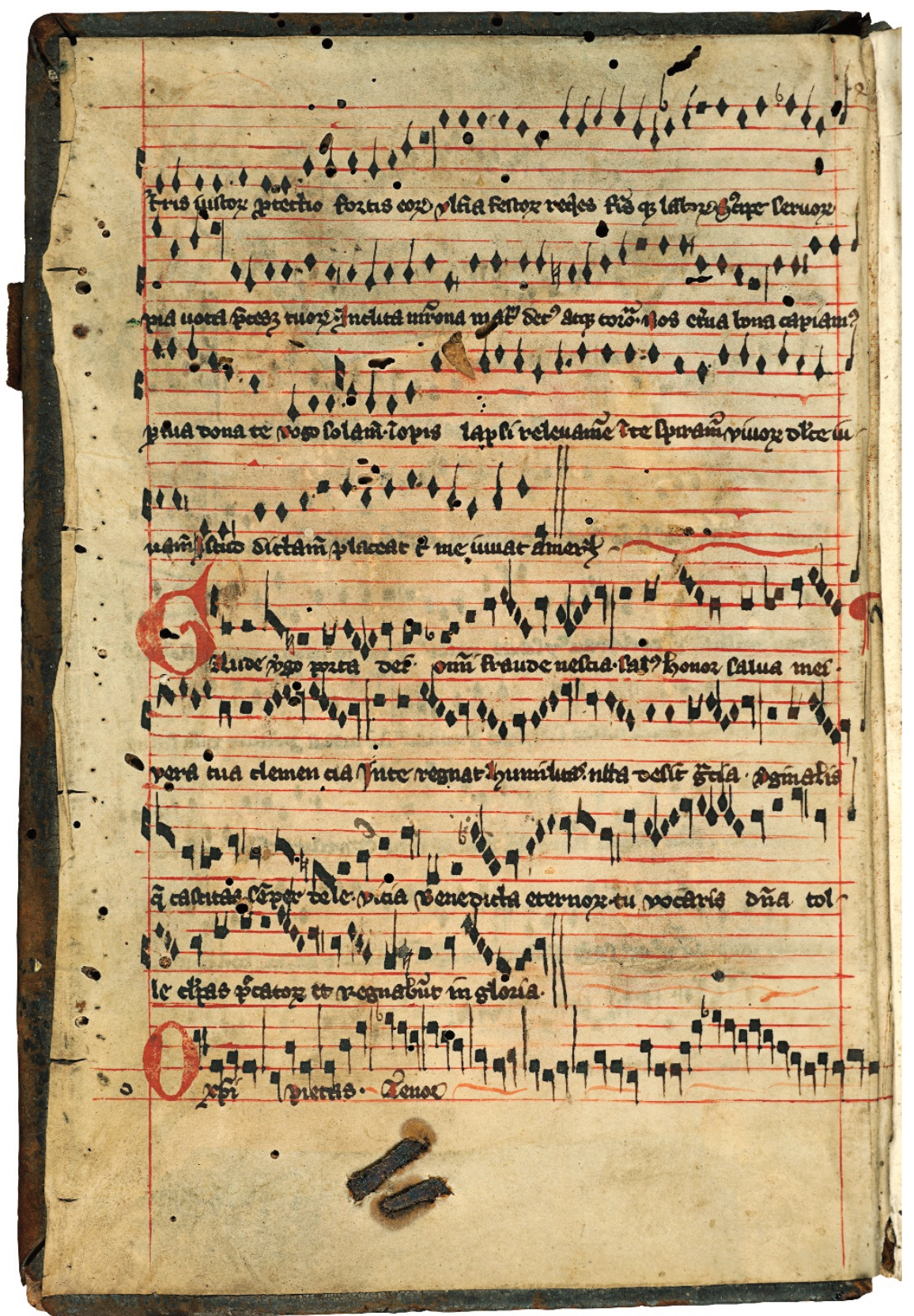

Fig. 1a: Koblenz, Landeshauptarchiv, Best. 701 Nr. 243, front pastedown; @ Koblenz, GörresGymnasium. 


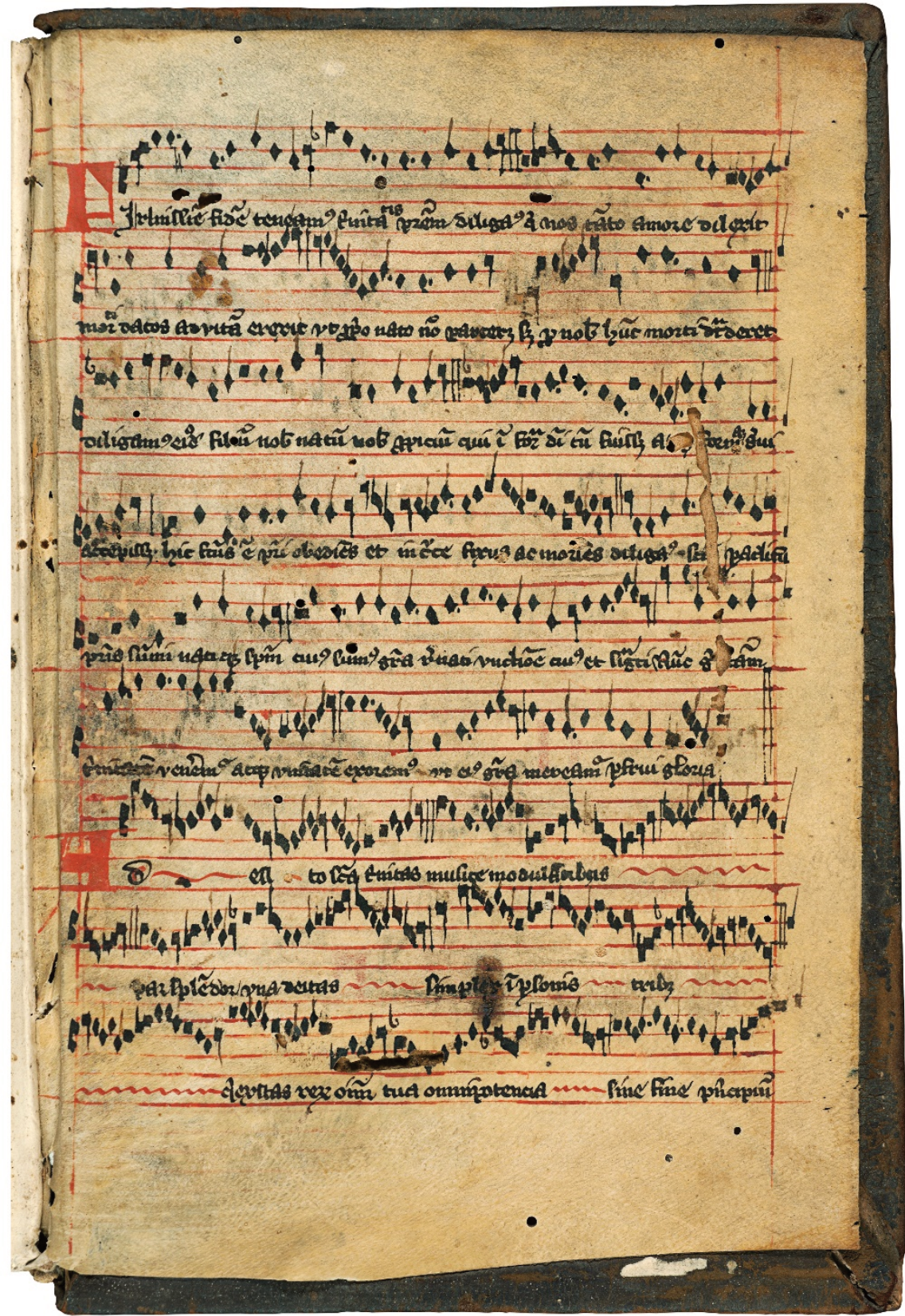

Fig. 2a: Koblenz, Landeshauptarchiv, Best. $701 \mathrm{Nr}$. 243, rear pastedown; (c Koblenz, GörresGymnasium. 
An intabulated version of Firmissime / Adesto / Tenor survives in the so-called 'Robertsbridge fragment', London, British Library, Add. 28550 (ff. 43v-44r), associated with the Cistercian abbey of Robertsbridge (East Sussex). ${ }^{17}$ A copy of the triplum text has come down to us in the aforementioned manuscript Darmstadt 521 (f. 228r), and the Analecta Hymnica list a (possibly spurious) concordance for the motetus text in MS '7977' of the Österreichische Nationalbibliothek in Vienna. ${ }^{18}$

Specialists at the Landeshauptarchiv Koblenz recently unglued the two pastedowns sufficiently from their wooden plates to enable photography and identification of the pieces on the downward sides of the two pastedowns (the binding otherwise remains undisturbed). The obverse of the front pastedown contains the triplum of a previously unknown motet, Aaron virga / Isayas ... / [Tenor] (Fig. 1b). ${ }^{19}$ Its subject is the miraculous flowering of Aaron's rod (Numbers 17, 16-26) and Isaiah's prophecy of the glorious reign of the Messiah who will spring like a flower from the Tree of Jesse (Isaiah 11, 1-10). Both passages were widely seen in late medieval theology as Old Testament pre-figurations of the birth of Christ through the Virgin. The text ends with a self-referential request for Divine intercession on behalf of those singing the motet. The setting was identified by a medieval copyist or user by the words 'de nativitate marie' added to the top margin of the folio.

The verso of the rear pastedown (Fig. 2b) shows an almost complete version of another motet known previously only from the Fauvel manuscript, Orbis orbatus / Vos pastores adulteri / Fur non venit. ${ }^{20}$ Its subject are abuses and greed ascribed to higher-ranking members of the clergy. This topic, too, was identified by the same hand as the one found in the obverse of the front pastedown, this time with the words 'de prelatorum avaricia'.

17 See Caldwell 1998 for a succinct overview of the state of research on the fragment at the end of the twentieth century. See also, more recently, Lewis 2000, and the observations by Zayaruznaya 2010, 50-54.

$18 A H, 14$. The manuscript unfortunately cannot be identified with any volume kept by the ÖNB at present under this or a related call number.

19 A full reconstruction will be offered in the forthcoming article about the Koblenz fragments mentioned earlier. The pastedown only contains the text Aaron virga. The binding strips of manuscript Best. 701 Nr. 243 contain parts of the adjacent folio with a fragment of the motetus text starting with 'Isayas ...'.

20 Only the beginning of the tenor survives in Koblenz. The copy in Paris, BnF, fr. 146 is complete. 


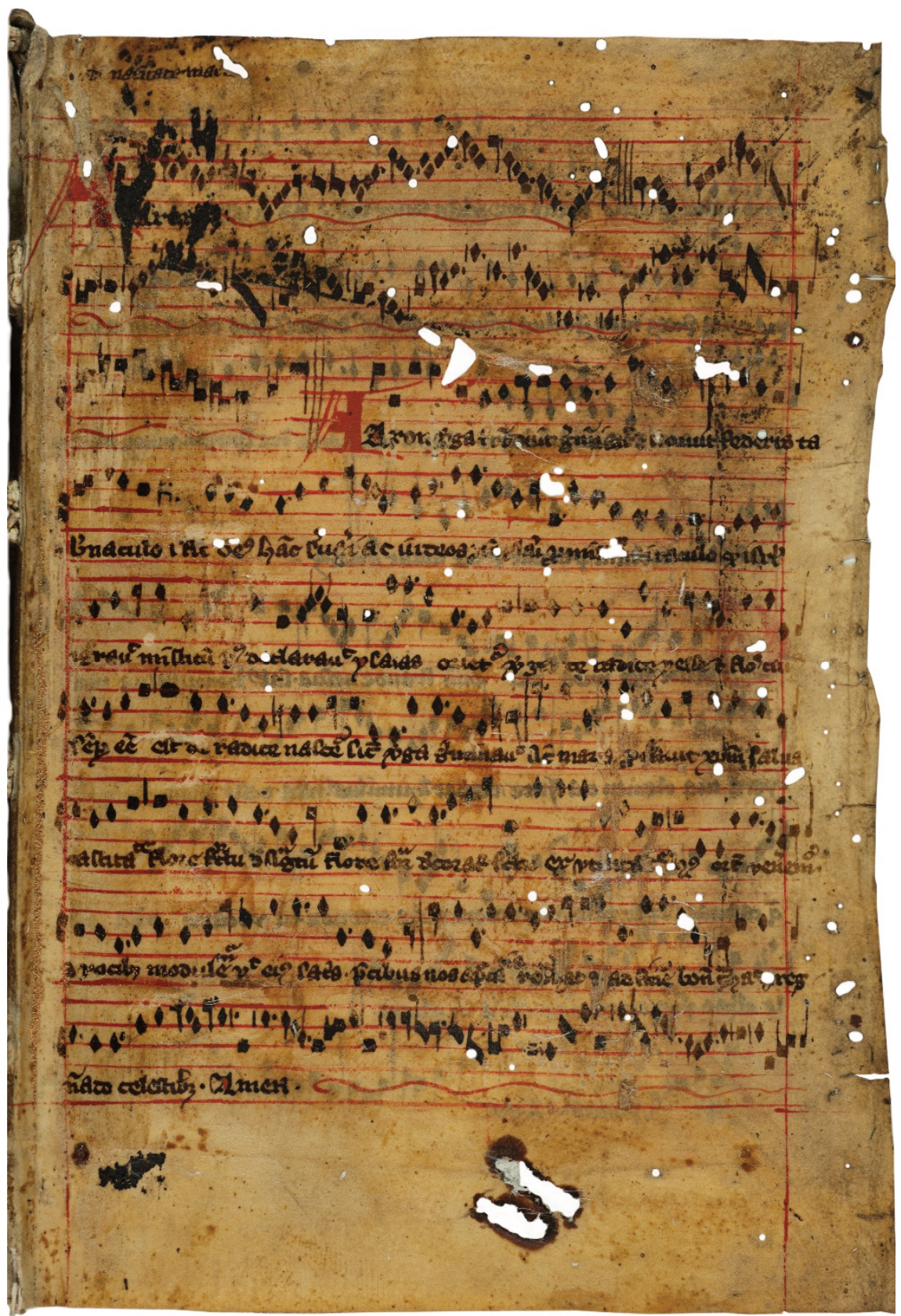

Fig. 1b: Koblenz, Landeshauptarchiv, Best. $701 \mathrm{Nr}$. 243. The front pastedown's verso exposed; (c) Koblenz, Görres-Gymnasium. 


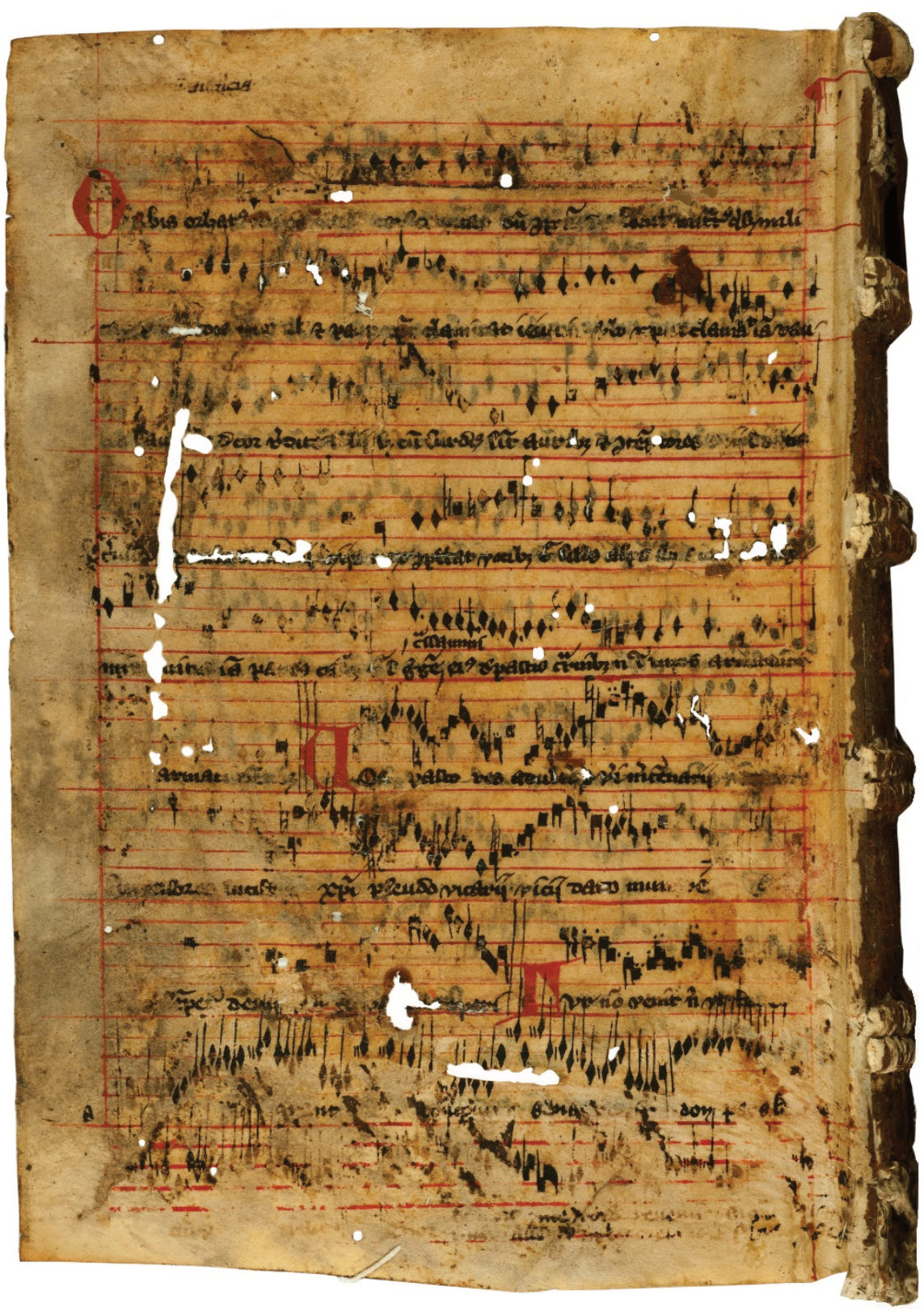

Fig. 2b: Koblenz, Landeshauptarchiv, Best. $701 \mathrm{Nr}$. 243. The rear pastedown's verso exposed; (c) Koblenz, Görres-Gymnasium. 
The final two staves of the obverse are given to a French-texted piece in highly melismatic 'ars nova' notation, probably a rondeau. A palaeographic and codicological comparison shows that both pastedowns were extracted from the same manuscript, a collection of motets interspersed with copies of French-texted chansons added at the page bottom in a copying style cultivated in France and adjacent regions of north- and southwestern Europe in the fourteenth century.

Table 1: Inventory of Koblenz, Landeshauptarchiv, Best. 701 Nr. 243, front and rear pastedowns (RISM siglum: D-KBlha 701-243). [For other RISM library sigla, see Abbreviations, below.]

\section{Front pastedown:}

... turris iustorum/

Gaude virgo/

3vv. motet

B-Br 19606, recto (no. 5);

Oxpisti pietas.Tenor

D-DS 521, 192r (triplum text paraphr.);

D-DS 2653, 74v-75r (triplum text paraphr.)

Aaron virga/Isayas .../ 3vv. motet 'de nativitate Marie'

[Tenor]

\section{Rear pastedown:}

Firmissime/

Adesto/

...

Orbis orbatus/

Vos pastores adulteri/

Fur non venit

$$
+A \text {...grant } / \ldots
$$

3vv. motet

F-Pn fr. 146, 43r;

B-Br 19606, recto (no. 4);

GB-Lbl Add. 28550, 43v-44r

(intabulation);

D-DS 521, 228r (triplum text only)

[olim A-Wn 7977 (motetus text) ${ }^{21}$ ]

3vv. motet F-Pn fr. 146, 7r

'de prelatorum avaricia'

The visible sides of the front and rear pastedowns provide an appealing frame for Jordan of Quedlinburg's sermons, which cover the period from Advent to Palm Sunday. Carefully trimmed and placed on the front and rear covers in a way that achieves maximum legibility, both pastedowns are eyecatchers. Red stave lines and Lombard capitals are coupled with garlands of rhombic and rectangular figurae copied in pitch-black ink and interlaced by the tightly spaced lines of text.

21 Listed in $A H, 14$. 
The pastedowns come across as particularly alluring when put next to the visually bland writing-block of the codex proper. Positioned to match the direction of the text-block, the pastedowns, by their very difference in appearance, entice users to take a peek when picking up the book. Turning the front cover plate, their gaze is met by two Marian, prayer-like texts along with the words $O$ Christi pietas at the page bottom. Although the triplum is actually incomplete, its text, a string of epitheta ornantia for the Virgin cast in Leonine hexameters, easily bears that truncation and can be enjoyed as a poem in its own right. It moves speedily to the customary address for protection found in so many motet texts of the period. The second text, Gaude virgo, follows the same rhetorical strategy: a string of panegyrics to the Virgin culminating in a prayer for intercession. These two prayers to the Virgin are complemented by the slightly enigmatic tenor caption $O$ Christi pietas. That caption offers ample food for rumination on the miracle of Christ's incarnation, the relationship of Christ to his mother as laid down in Scripture and theological writings, and his willingness to act as a pious son towards his Father as well as his Virgin mother during his time on Earth. The front pastedown thus offers something like a poetic epigraph to the sermons that follow, in the form of two opening prayers to the Virgin and a Christological caption. Leafing or reading onward, and having come to the end of the codex, the rear pastedown presents a poem exhorting the reader to stay firm in the faith, followed by a second one invoking the support of the Holy Trinity. Both texts are prayers; re-positioned as the rear pastedown, they offer a post-script to the sermon collection and function as a spiritual send-off for the reader. Taken together, the two pastedowns can be understood as metatexts in relation to the main corpus of the book. They work semantically in a way that is similar to a gloss, commenting on and synthesising the main text. As pastedowns, they are materially adapted to the necessities of three-dimensional space, serving as components of a three-dimensional object, the book and its binding, but their function is similar to that of a two-dimensional gloss. Considering that the manuscript came into existence and was bound in and for a university-trained milieu of mendicants, such associations would hardly have been unfamiliar to the volume's intended users, enabling them to make the necessary associations without difficulty.

But is this hypothesis also in alignment with the technical requirements? As mentioned earlier, there is a preference for gluing the flesh sides of pastedowns onto the wooden plates while keeping the hair sides visible. Unfortunately, in their present state, hair and flesh sides of the two parchment sheets in the 
Koblenz manuscript can no longer be distinguished..$^{22}$ The extent to which the hair-flesh criterion played a role in choosing the two surfaces that were kept visible therefore cannot be verified. We may, however, consider the alternatives that were available to the binder or the individual instructing him, once the two folios had been selected. Had the binder chosen to keep the current obverse sides of the two pastedowns visible, the volume would begin with a pastedown discussing the birth of the Virgin and ending with a setting denouncing the avarice of higher clergy. The difference in effect on the reader would be notable, bookending Jordan's sermons by two texts that strike a rather incongruous note with the content of the volume; they are either very specific (Aaron virga) or have no or at best an embarrassing relation to the main corpus (Orbis orbatus / Vos pastores adulteri / Fur non venit). However, in the absence of evidence about the distribution of hair and flesh sides, this scenario remains speculative; it may never have been on the table.

Another variant, however, can be rehearsed without adducing speculative evidence: the binder would, on purely technical grounds, certainly have had the option of placing the Trinity motet at the front of the book and the Marian motet at its end. The difference, using the exact same materials, might appear slight. However, as mentioned before, the collection of sermons begins with Advent and the Nativity of Christ, and ends with the first day of Holy Week, Palm Sunday. Opening with a motet about the faith and the Holy Trinity, and closing with a Marian motet supported by the exclamation $O$ Christi pietas would certainly be possible. But it seems to invert cause (incarnation through Mary) and effect (redemption). Beginning with a motet about the Mother of God and ending with a piece about the faith and the Holy Trinity seems a considerably more elegant solution, all else being equal. It is in line with the cycle of the liturgical year leading from the Incarnation to the Passion, and positions the Mother of God as the beginning of a chain of events leading to the fulfilment of the salvific plan for humankind. Such a subtle aesthetic and theological fit between the framework of the codex - i.e. its modest binding and the two pastedowns - and the contents of the main corpus can be accounted for with difficulty if the creation of this binding is understood solely as the result of a random string of actions by an indifferent craftsman, or of sheer luck and blind coincidence. Deliberate human agency in selecting and placing the two pastedowns offers a rather more convincing explanation.

22 I thank Dr Anja Ostrowitzki and restoration specialist Petra Schmitz of the Landeshauptarchiv Koblenz for independently verifying this important detail on my behalf (personal communication by e-mail from Dr Ostrowitzki of 5 February 2020). 


\section{Case study 2: the front and rear pastedowns in Karlsruhe, Badische Landesbibliothek, Lichtenthal 82}

Karlsruhe, Badische Landesbibliothek, Lichtenthal 82 is a miscellany copied in the mid-fifteenth century at the Cistercian female house of Lichtenthal in Baden. It contains a German version of Raymond of Capua's vita of St Catherine of Siena (Legenda B. Catharinae Senensis, ff. 2r-140v), followed by a German translation of the Legend of the 10,000 Martyrs (ff. 142r-157r), instructions on how to prepare for receiving communion (ff. 157v-160v), and an extensive gloss on the Pater noster (ff. 160v-202r), the latter two also in German. ${ }^{23}$ Most of the book (ff. 2r-157r) was copied by Sister Regula (d. 1478), a prominent member of the nunnery active as a copyist and translator in Lichtenthal around 1450-70. Today, eleven codices in her hand survive.

The translations from Latin texts into German were prepared by Regula for her fellow nuns and intended for use during the customary readings at mealtimes as well as for individual study. Regula evidently was a highly educated woman and an intellectual leader. She might have come to Lichtenthal from the Cistercian house in Königsbrück near Hagenau/Haguenau (Alsace). Her objective was to spearhead and entrench the monastic reform which Lichtenthal underwent from 1440 onward. ${ }^{24}$ The reform movement placed great importance on education, as attested at Lichtenthal by the intense copying and translating activities of Regula and her followers. Another hallmark of reform was a return to the austere monastic rules laid down by the order's founder, Bernard of Clairvaux. This obviously entailed a rejection of the more relaxed attitudes that had been introduced into Cistercian life in intervening centuries, and in particular during the thirteenth, fourteenth and early fifteenth centuries, including the acquaintance with sophisticated mensural polyphony. In fact, Regula's identity at Lichtenthal appears to have been inextricably - and conspicuously - bound up with this return to an earlier, unadulterated form of Cistercian life. Her very name reveals that she must have seen herself as an instrument to ensure the persistence of reform at Lichtenthal, for her baptismal name was Margaretha, as revealed in a

23 See the description in Heinzer 1987, 199-200. The entire manuscript is available online: <https://digital.blb-karlsruhe.de/blbhs/content/titleinfo/1164591> (accessed 4 Apr. 2020).

24 See the section 'Zur Entwicklung der Lichtenthaler Bibliothek vom 13. bis zum 16. Jahrhundert' in Heinzer 1987, 36-44, and specifically on Sister Regula, 40-43. 
Lichtenthal necrology which refers to her posthumously as 'Margaretha dicta Regula monialis'. Her adopted name, Regula, translates as 'the Rule'. ${ }^{25}$

Lichtenthal 82 survives with an original binding that was in all likelihood produced either at Herrenalb or at Lichtenthal in the late fifteenth century. ${ }^{26}$ It consists of two wooden boards $(215 \times 150 \mathrm{~mm})$ covered in now-faded red leather. The binding contained two pastedowns, one of which has been lost but can be partially reconstructed from its imprint left on the wooden board: it consisted, on the downward side, of a document copied during the tenure of Heinrich (IV) von Magstadt, Abbot of Herrenalb. Heinrich, who died in 1449, was the abbot of the nearby male house that formally acquired paternity of Lichtenthal from the more distant house in Maulbronn by the 1490s. However, Herrenalb had been involved in the reform process at Lichtenthal from the start. ${ }^{27}$ No information is available about the upward, visible side of this pastedown. It may have contained similar material or may have been blank. The rear pastedown was detached from the wooden plate during the twentieth century because of its considerable interest to musicologists but its original placement can be securely established by the imprints on the rear plate. The fragment's former obverse contains a section of a polyphonic piece with the incipit Fa fa mi fa / Ut re mi ut / [Tenor], which is dateable on stylistic grounds to the early fourteenth century, and celebrates the musical accomplishments of the nuns of the Cistercian house of Notre-Dame La Daurade in Cahors. The setting - which has two concordances, both incomplete, in fragments found in Troyes (on which more below) and at the royal monastery of Las Huelgas in Spain - identifies a certain John, cantor or singer in (or of) Liège, as one of the originators of the texts and/or the music. ${ }^{28}$ The

25 Heinzer 1987, 41. Concerning the role of polyphony, see also the recent discussion of Cistercian fragments from the Lake Constance region by Heinzer 2020, in particular 54-57 on Lichtenthal and the Lichtenthal 82 source.

26 On Lichtenthal bindings, see Heinzer 1987, 43-46. See in particular 46 for the unassuming bindings typical of the 'Reformphase' of the fifteenth century. For the binding of Lichtenthal 82, see Heinzer 1987, 200.

27 Krieg von Hochfelden 1836, 237; Pflüger 1958, 162. Maulbronn, at about $60 \mathrm{~km}$ distance from Lichtenthal, and Herrenalb, which is $20 \mathrm{~km}$ away, were jointly entrusted with overseeing reform at Lichtenthal. Maulbronn, being an acknowledged centre of reform at the time, formally assumed paternity at the outset. Herrenalb's greater geographical proximity eventually led to the formal transfer of paternity from Maulbronn to Herrenalb nearly two generations later. See Heinzer 1987, 38-40.

28 For additional information on all sources for this piece, including a thorough description of their codicological structure and their content, as well as images, see Catalunya 2017. The selfidentification pro me vestroque cantore Leodiensi Iohanne allows a number of translations (and 
fragment's formerly invisible obverse also contains a portion of a Marian motet, Flos vernalis, occupying the lower four systems out of a total of seven. Flos vernalis is also found in the Koblenz fragments, where it can be partially reconstructed from the binding strips inside the text-block. It also survives in a highly fragmentary state in a set of binding strips in manuscript Oxford, All Souls 56. Last but not least, the motet survives complete but in intabulated form in the fragment London, British Library, Add. 28550 (ff. 43v-44r). All these sources exhibit various types of links to the Cistercian order. ${ }^{29}$

The originally visible, upward side of the rear pastedown contains three voices in mensural notation that have yet to be explored in detail:

1. the final section of a part carrying the text ...-a mundi / et tibi virginitas / inviolata manet, presumably set at least in part in Latin heptasyllabic verse and ending in a large melisma on the word manet (first system);

2. an almost complete voice beginning with the words [Av]e sidus lux dierum and ending on the words ... ad eterna gaudia (systems 2-6; the notes and syllables missing were lost due to trimming);

3. the opening section of a voice with the words Maria sidus lux dierum beginning in the middle of system 6 and continuing into system 7.

While the many interesting questions arising from these three voices will need to be addressed in a separate study, it is clear that the three voices on the front side of the pastedown set Marian texts, just like Flos vernalis on the obverse. They are also notated in a form of mensural notation typical of complex polyphony of the early decades of the fourteenth century, featuring the characteristic chains of multiple semibreves. Occasionally, semibreves are supplied with downward stems (semibrevis maior). In general, the settings on the upward side of the rear

\footnotetext{
therefore possibilities of interpretation) which cannot be discussed in detail in the context of this essay.

29 For a recent discussion of the Oxford binding strips, see Kügle 2016. The various sources of Flos vernalis are currently being investigated by Cristina Alís Raurich in the context of her ongoing study of the Robertsbridge fragment. See her 'The flores of Flos vernalis: Robertsbridge Codex, Lichtenthal Codex, and the creation of intabulation in the 14th century' (paper delivered at the Annual Medieval and Renaissance Music Conference, Basel, 3-6 July 2019). For the reconstruction of Flos vernalis in Koblenz, see the forthcoming publication on the Koblenz fragments prepared by this author. The role played by the Cistercian order in the dissemination of this cluster of pieces will need to be explored elsewhere.
} 
pastedown correspond in their notational development to the style identified for Fa fa mi fa by Catalunya, but will no doubt benefit from further study..$^{30}$

The rear pastedown provides a testimony of a remarkable musical tradition associated with Cistercian houses across much of Europe in the fourteenth century, involving complex polyphony. Given the strong likelihood that the binding was produced either in Herrenalb or in Lichtenthal using disused parchments from both houses, the cultivation of complex polyphony in the late thirteenth and early fourteenth century seems to have reached Alsace and the right bank of the Upper Rhine river (via the paternity of Neuburg to both Königsbrück and Lichtenthal) in a dissemination pattern that appears to have been powered by a network within the Cistercian order. ${ }^{31}$ For present purposes, however, our attention must now return to some of the material aspects of the Lichtenthal fragment, and its potential role in the internal landscape of Sister Regula's book.

The Lichtenthal fragment was cut quite crudely, almost aggressively. This can be seen from the crooked contours of its present outer margin. All former (original) margins and all clefs at the beginning of stave lines were trimmed, leaving a surface that was cut directly from the core of the original sheet. In its present state, the fragment consists of a beige surface covered with lines of text and music copied in a yellowish-brown faded ink. A bit of colour is added by the red ink of the stave lines and by one smudged red and blue initial $M$ at the text line Maria sidus lux dierum. The preparation of this sheet suggests that - unlike the Koblenz case - there was no concern to preserve any aspects of the source manuscript intact for reading or rumination. Rather, the exact opposite seems to have been the case; removing the outer margins makes a reconstruction of the original text challenging indeed. There are no apparent reasons why this approach might have been justified on technical grounds.

The pastedown was placed into the binding upside down. This may at first be taken as evidence supporting the assumption of carelessness as a matter of course when recycling disused parchment into bindings. The level of carelessness displayed here, however, seems extreme to the point of negligence. There is no apparent technical reason why the fragment needed to be turned upside

30 See Catalunya 2017, 91-97. For general information on early fourteenth-century notational systems, see the recent discussion in Desmond 2018.

31 The Las Huelgas source is associated with another Cistercian female foundation, Santa María la Real de Las Huelgas in Burgos, a lavishly endowed royal foundation closely aligned with the ruling house of Castile. The Troyes source was discovered among the fifteenth-century manuscripts that were owned by the male Cistercian house of Clairvaux. - For a somewhat less sanguine view of the cultivation of complex polyphonic singing in the style of the fragment at Lichtenthal, see Heinzer 2020, 54-57. 
down; it could just as well have been glued onto the wooden cover in the direction of reading. Might the upside-down placement of the polyphonic fragment therefore have been caused by other motives, and be deliberate? Could there be a symbolic charge to such a gesture? Turning things upside down had a clear meaning to late medieval Europeans: it is a form of conscious rejection. The move is classically used in heraldry: a reversed shield (the technical term in heraldry is abatement or rebatement) signifies either the death or the dishonour of its carrier. Recent research suggests that this aristocratic custom was widely recognised across late medieval European societies, including non-noble strata. ${ }^{32} \mathrm{As}$ a foundation of marchioness Irmengard von Baden (c.1200-1260), implemented in 1245 shortly after the death of her husband, Margrave Heinrich V von Baden (r. 11901243), and as the burial site of the house of Baden, moreover, there are additional grounds to assume that such aristocratic conventions would have been sufficiently familiar to the nuns of Lichtenthal in the late fifteenth century for their meaning to be understood. Placing the musical pastedown upside down therefore can be interpreted as a symbolic act - a ringing endorsement by the binder or those instructing her or him of reform, and of Regula's work. Framing Regula's monumental translation of the vita of Catherine of Siena, another strong-willed and austerity-minded nun and intellectual leader, and therefore most certainly a role model for the Lichtenthal community, the folio represents a material validation of the rejection of the old, decadent ways of Cistercian life by the postreform Lichtenthal community. That refutation is made visible in this visual postlude to the codex through choosing what appears as a calculatedly disheveled chunk of parchment extracted from a disused manuscript of complex polyphony to serve as the rear pastedown.

Another detail adds to this reading: the binder - as mentioned earlier, in all likelihood a nun of Lichtenthal or, alternatively, a monk affiliated with Herrenalb - chose the hair side, containing the Fa fa mi fa setting, as the obverse of the pastedown. From a technical point of view, the flesh side with the Marian texts should have been glued onto the plate and therefore been rendered invisible. In the finished binding, the visible side of the pastedown still displayed complex polyphony. But the visible texts more closely resemble the established liturgy than the freely composed texts of Fa fa mi fa and Flos vernalis: Maria sidus

32 For a recent study of the use of coats of arms in medieval visual culture and in urban spaces to indicate contempt or protest, arguing the ubiquity of these visual cues among all layers of society, see Meer 2019 (including copious additional bibliography). Concerning rebatement symbolising the death of the owner of a shield, see Boytsov 2016, in particular 156 for the history of the custom. 
lux dierum is a variant of Ave sidus lux dierum, the incipit of a (monophonic) sequence for the Assumption. Conversely, Fa fa mi fa unabashedly celebrates Cistercian nuns singing complex polyphony, a practice that stands in stark conflict with Cistercian rule (if not historical practice). ${ }^{33}$ Was this text then deemed to be of such transgressive quality that it was thought safer to take the extra step, and conceal it from future Lichtenthal nuns' eyes? ${ }^{34}$

\section{Case study 3: the front and rear pastedowns in Troyes, Médiathèque Jacques Chirac (olim: Bibliothèque municipale), Ms. 1949}

A very different attitude towards a discarded manuscript of sophisticated polyphony emerges from a binding associated with unreformed male Cistercian circles during the same period. Manuscript 1949 of the Médiathèque Jacques Chirac (olim: Bibliothèque municipale) contains two flyleaves cut from a single, fourteenthcentury rotulus. The visible side of the front pastedown transmits the very end of the triplum and the tenor of yet another motet previously known from the aforementioned manuscripts Paris, BnF, fr. 146, and Brussels, KBR, 19606, Super cathedram / Presidentes / Ruina. This is followed by a partial copy of the Fa fa mi $f a$ setting. The visible side of the rear pastedown consists of another large chunk of $\mathrm{Fa} \mathrm{fa} \mathrm{mi} \mathrm{fa}$. Each pastedown measures approximately 210 by $140 \mathrm{~mm}$. Both sheets are still in situ. Their obverses are therefore not known at present, but appear to contain fragments of several more three-voice motets. ${ }^{35}$ Troyes 1949 formerly belonged to the library of Clairvaux. Clairvaux did not undergo reform in the fifteenth century but instead developed a strong scholarly bent, maintaining

33 On the tensions between the Cistercian rule and the cultivation of polyphony among Cistercians in the fourteenth century, see also Leitmeir 2007.

34 Mention should be made that the binding of Lichtenthal 34 (a Breviarium cisterciense copied in the first half of the fourteenth century, with later additions extending into the fifteenth century) also contains mensurally notated music in the form of a Gloria which was chosen to serve as the rear pastedown. The history of this manuscript and of its binding seems to differ from that of Lichtenthal 82, however, and will need to be explored elsewhere. See Heinzer 1987, 123-26; Catalunya 2017, 99-100. - Catalunya once more notes some tantalising musical similarities between the Gloria in this fragment and similar repertory in Las Huelgas.

35 See the discussion in Catalunya 2017, 91-97 (full inventory at 93) and 115-121 (photographs). 
lively connections with the Collège St. Bernard and, by extension, the University of Paris and humanist circles associated with it.

The Troyes codex begins with a manuscript copy of the Parthenice Mariana by the Spanish-Italian Carmelite poet and reformer, Baptista Mantuanus (14471516). It also contains texts by the prominent French humanist and leader of the Trinitarian order, Robert Gaguin (1433-1501), and by Antonio Geraldini, an Italian humanist and poet active in Spain (1447/49-1488). ${ }^{36}$ The main corpus is copied in an Italian humanist hand. Pen trials and ex libris annotations in the book's flyleaves point to one Sulpice Lagarle as the first known user of the volume. He appears to have been a Cistercian and was in possession of the volume prior to its being integrated into the Clairvaux library. The binding is of unknown origin. However, a connection with Cistercian circles in the orbit of the University of Paris seems likely.

Again, the Troyes pastedowns stand out visually. Owing to the conventions applicable to mensural notation, text and music are copied in black ink, staves in red. The source manuscript also included marginal decorations in red and blue, and several fleuronné initials. The binder, his supervisor, or his patron(s) evidently were attracted to the source manuscript by these decorative qualities. They made sure to preserve three fleuronné capitals intact when trimming the folio that was to serve as the front pastedown, sacrificing instead text and musical notation at the opposite margin. The binder also placed the texts and music at a 90-degree angle to the text-block. This oblong format de-emphasises the semantic relevance of the texts and the musical notation while drawing attention to the visual splendour afforded the user by the opulent patterns formed by (vertical) stave lines, note heads, text, and coloured initials. The Troyes manuscript therefore provides an example of a set of musical pastedowns chosen primarily for their flamboyant aesthetic qualities, presumably with the intention to frame a similarly lavish set of neo-Latin poetic texts.

36 According to the online catalogue of the Médiathèque Jacques Chirac, <https://portail. mediatheque.grand-troyes.fr/iguana/www.main.cls?surl=search\&p $=$ *\#recordId $=2.2291 \&$ srch $\mathrm{Db}=2>$ (accessed 27 Apr. 2020). See also the discussion and further references provided in Catalunya 2017. On the text by Mantuanus, see Wiener 2003. On Robert Gaguin, see Collard 2012. On Antonio Geraldini, see Früh 2005. 


\section{Case study 4: the pastedowns in Mainz, Gutenberg Museum, Ink 2276}

The fourth and final example moves away briefly from musical materials in order to explore if and how other kinds of pastedowns might have been deployed to create potential semantic links between pastedowns and their host volume. Mainz, Gutenberg Museum, Ink 2276 is a printed edition of Pietro de' Crescenzi's Ruralia commoda, produced in Strasbourg in 1486 by the print shop of Georg Husner. The Ruralia commoda is the only medieval treatise on agriculture, written by Pietro de' Crescenzi in the early 1300s following a successful career in Bologna and other towns in Italy. ${ }^{37}$ The text was widely disseminated and translated in late medieval and early modern Europe and survives in copious printed and manuscript versions, including many copies coming from monastic libraries. The copy preserved in the Gutenberg Museum reached Mainz through the Carmelite order, who kept significant houses in Cologne, Mainz as well as Boppard (see above). A recent study of the library of the Mainz Carmel demonstrated that Ink 2276 reached the Gutenberg Museum via the Mainz convent, but originally was purchased and bound for the library of the Cologne house. ${ }^{38}$ The volume retains its original binding which consists of two wooden boards with paper pastedowns at both the front and rear inside cover.

The front pastedown, which has been lost but can be reconstructed through its mirror imprint, consisted of a publishing announcement (Bücheranzeige) in Latin and German issued by the Augsburg printer Günther Zainer (active from $1468, d .1478$ ) and dating to after 1474 . Another copy of the same announcement has been removed from Mainz, Gutenberg Museum, Ink 509.39 The rear pastedown consists of the top half of a broadside (Einblattdruck) produced by Peter Schöffer in Mainz. This broadside, dated 1489-1490, contains a German version of a papal bull published by Innocent VIII on 11 December 1488 announcing the indulgences offered in connection with the upcoming Jubilee year of 1500 , as well

37 For further information, including a modern edition and a translation into German, see Vollmann 2007-2008. See also the earlier edition by Richter/Richter-Bergmeier 1995-2001. Also Toubert 1984, <http://www.treccani.it/enciclopedia/pietro-de-crescenzi_(Dizionario-Biografico)> (accessed 5 Apr. 2020). For a recent exploration of the cultural and historical context of the Ruralia commoda and Pietro's biography, see McAvoy et al. 2019, in particular 486-490.

38 See Ottermann 2016, 258-263.

39 See Ottermann 2016, 530-531. On Günther Zainer, see Künast 1997 and the relevant contributions in Gier/Janota 1997. 
as a call to take up the Cross in an anticipated campaign against the Turks. ${ }^{40}$ The choice of disused broadsides for pastedowns has barely been noticed as a phenomenon in the study of late medieval and early modern bindings; for our purpose it will suffice simply to note this as a possibility next to the more familiar use of disused parchment. From an aesthetic point of view, the combination of broadsides with a printed text-block may have created a slightly more homogeneous visual appearance, but the continued prevalence of parchment for use in pastedowns suggests that the inclusion in the binding of Ink 2276 was more a matter of convenience and perhaps cost than anything else. Nor may it seem particularly surprising to find an advertisement for theological literature worked into a binding that was being prepared for a monastic order. ${ }^{41}$ There is, however, more to say about the choice of the papal bull cum indulgence that was used to create the rear pastedown.

In 1489, the Apostolic Protonotary, later (from 1493) Cardinal Raymond Peraudi (1435-1505) arrived at the Carmelite provincial synod, which was being held in Mainz, and took up lodgings in the Carmelite convent. Like the Carmelites, French-born Peraudi was a member of a mendicant order, the Augustinian Hermits. He was without doubt the most influential Church diplomat active in the Holy Roman Empire in the late 1480s; his contacts to Emperor Frederick III (r. 1440-1493) were outstanding. Peraudi was the main promoter of the new trade in indulgences within the Empire which was to become one of the triggers for the Lutheran Reformation. He developed a highly efficient method to push his agenda, employing the game-changing new medium of his time, the printing press, with the utmost skill. A considerable reputation preceded him. ${ }^{42}$ Peraudi's decision to associate himself with the Carmelites during his visit to Mainz - where he was formally to proclaim the promulgation of a new indulgence related to the planned crusade against the Turks and the preparation for the jubilee year 1500 can therefore not be overestimated: it conferred unprecedented prestige upon the order through its being chosen as the logistical base and central point of an event which was to be of vital importance for the cause of the Church, and the promotion of the indulgence within the Empire. ${ }^{43}$

40 On Peter Schöffer, see Schneider 2003.

41 On Günther Zainer's oeuvre as a pioneer of printing in Augsburg, see, recently, Fujii 2007. Also of interest, albeit tangentially, may be the recent study on Günther's younger brother Johann who set up a print shop of his own in Ulm. See Bolton 2016. See also Geldner 1968-1970.

42 On this aspect of Peraudi's activities, see Hamm 1996.

43 For these events, see Kühne 2015; also Kühne 2014. Housley 2006. For a concise biography of Peraudi, see Springer 2002. 
The use of the two broadsides as pastedowns for the agronomic treatise of Pietro de' Crescenzi therefore highlights the political and religious position of the Cologne Carmel in the time around 1500 in a very interesting way. The treatise was certainly a standard work, but it should not be overlooked that by the late fifteenth century the Rhenish Carmelites had amassed significant amounts of agricultural terrain that they needed to manage. The purchase of the Ruralia commoda was therefore far from indulging a purely academic interest. Rather, it was probably acquired also to serve as a reference work, providing guidance when important decisions concerning the exploitation of the estate amassed by the order needed to be taken. Meanwhile, the frame provided for the volume by the book advertisement from Augsburg and the indulgence promulgated by the papal legate in the Carmel at Mainz recalled the prestigious position that the order had acquired in the social fabric of the land. The Cologne Carmel, the establishment which had originally acquired the volume, and for which the binding was prepared, was the oldest and most important Carmelite house in the western regions of the Empire, and one of the order's traditional educational hubs. With the two paper sheets incorporated into its binding, any Carmelite who would pass through the Cologne house and pick up the copy of the Ruralia commoda would have had the opportunity to let himself be reminded of the achievements of his order toward the end of the fifteenth century.

\section{Conclusions}

As stated at the outset, bindings have long been recognised as important elements in determining a book's provenance and historic importance. However, the scrutiny of bindings remained so far almost exclusively focused on their outside appearance. Extending our focus to the insides of bindings and, in particular, to front and rear pastedowns has allowed us to capture some additional meanings that are encoded in the materiality of bindings. When choosing such components, binders and their patrons by necessity created new signifiers and new contexts in their own right. Their decisions involved which discarded piece of material to select for conversion into a pastedown, how exactly to trim it, how to position it with regard to the text-block, and which side of the pastedown to conceal or reveal to the eyes of future users. Such choices can fully be accounted for only if we acknowledge that they are inevitably a product of 'intermediary reading' - of practical and aesthetic considerations combined. The degree to which aesthetic considerations influenced practical matters no doubt varied; its relevance for a particular binding can be assessed only on a case-by-case basis. 
Besides a careful analysis of the material and codicological parameters, a suitable tool is the evaluation of alternative scenarios: what would the binding look like, and what impression would it make on the reader if the pastedowns were placed differently, e.g., with the current front and rear pastedown reversed, the current obverse of a pastedown used as its visible side, or if the parchment had been placed side-wise?

The four case studies illustrated how pastedowns can be arranged in ways designed to invite the reader's gaze (Koblenz), to discourage reading, even admonish (Lichtenthal), to emphasise the decorative aspects of a pastedown (Troyes), or to create a form of institutional memory (Mainz). Pastedowns extracted from manuscripts containing late medieval polyphony perforce occupied a special place due to their relative scarcity and their lively visual appearance. Musical pastedowns therefore are exceptional, and it may be useful, especially for musicologists engaged in the history of polyphony, to bear that special quality in mind. But pastedowns of all kinds share the ability to tell us about the history of their patrons, the workshops, and the institutions involved in their design. Together with the other components of a binding and the text-block that they enclose, pastedowns therefore should be considered part and parcel of an aesthetic ensemble where each element has its own qualities and therefore its idiosyncratic potential for signification. In such a landscape, material, visual, and semantic aspects dynamically interact with each other. Together they form the internal ecology of a codex and generate a cascade of culturally and historically specific messages and meanings that goes far beyond the information contained in sheer words, images, and noteheads.

The phenomena discussed in this essay may have been confined to a relatively narrow window chronologically - the end of the fifteenth century - and to a particular ecclesiastic milieu characterised by a strong affinity to learning, a sophisticated theological awareness, and a distinct corporate or institutional identity. Such sensibilities have long been a part of monastic cultures, and are reflected in the reading habits associated with them. They encouraged readers attuned to these cultures to look at things carefully, and repeatedly, and to expect, and find, connections to be made between them. It is in the context of such a cultural habitus that the pastedowns examined in this essay make most sense. Binders or patrons who saw - and reacted to - the affordances provided them by the materials that came to their hands engaged in a form of reading when creating a new binding and choosing pastedowns for it. In doing so, they created paratexts that became integral to the information incorporated into that book, and could be activated by any future reader-user. Treating them with similar attention to other material facets of manuscripts and early printed books will 
enable cultural historians to recover some of the heightened sense of awareness to detail typical of our forebears; once again, if looked at closely and undogmatically, fragments enable us to access memories and meanings of centuries past long ago.

\section{Acknowledgements}

The author gratefully acknowledges funding for the initial research leading to the present essay through the HERA UP project Sound Memories: The Musical Past in Late-Medieval and Early-Modern Europe (<soundme.eu>) which has received funding from the European Union's Horizon 2020 research and innovation programme under grant agreement no. 649307. Additional funding while preparing the text for publication was received in the context of the ERC Advanced Grantfunded project Music and Late Medieval European Court Cultures (<malmecc.eu $>$ ) at the University of Oxford, which received funding from the European Research Council under the European Union's Horizon 2020 research and innovation programme under grant agreement no. 669190. I am grateful to the editor of this volume Giovanni Varelli, the anonymous reviewers, and the current members of the MALMECC team, David Catalunya, Grantley McDonald and Uri Smilansky, for their feedback on earlier versions of this text; to David Catalunya for advice regarding the Lichtenthal and Troyes fragments; to the Landeshauptarchiv Koblenz for providing the digital images used in this article; and to the owner of the manuscript, Görres-Gymnasium Koblenz, for kind permission to reproduce them.

\section{Abbreviations}

$A H$

$L G B^{\prime \prime}$
Guido Maria Dreves (ed.), Analecta Hymnica Medii Aevi, vol. 4: Hymni inediti. Liturgische Hymnen des Mittelalters, Leipzig: Fues, 1888.

Severin Corsten (ed.), Lexikon des gesamten Buchwesens: zweite, völlig neu bearbeitete Auflage, 9 vols, Stuttgart: Hiersemann, 1987-2016.

RISM library sigla (Table 1):

A-Wn Vienna, Österreichische Nationalbibliothek

B-Br Brussels, KBR

D-DS Darmstadt, Universitäts-und Landesbibliothek

F-Pn Paris, Bibliothèque nationale de France

GB-Lbl London, British Library 


\section{References}

Achten, Gerard, Leo Eizenhofer, and Hermann Knaus (eds) (1972), Die lateinischen Gebetbuchhandschriften der Hessischen Landes- und Hochschulbibliothek Darmstadt, Wiesbaden: Harrassowitz.

Bent, Margaret, and Andrew Wathey (eds) (1997), Fauvel Studies: Allegory, Chronicle, Music, and Image in Paris, Bibliothèque nationale de France, MS français 146, Oxford: Clarendon Press.

Bolton, Clare (2016), The Fifteenth-Century Printing Practices of Johann Zainer, Ulm, 1473-1478, London: Printing Historical Society.

Bosquet, Émile (1894), La reliure. Études d'un praticien sur l'histoire et la technologie de l'art du relieur-doreur, Paris: Lahure.

Boytsov, Mikhail A. (2016), 'Ghostly Knights: Kings' Funerals in 14th-Century Europe and the Emergence of an International Style', in Joëlle Rollo-Koster (ed.), Death in Medieval Europe: Death Scripted and Death Choreographed, London: Routledge, 149-163.

Caldwell, John (1998), 'Robertsbridge Codex', in Die Musik in Geschichte und Gegenwart. Sachteil (MGG) online, <mgg-online.com> (accessed 10 May 2020).

Catalunya, David (2017), 'Nuns, Polyphony, and a Liégeois Cantor: New Light on the Las Huelgas “Solmization Song"', in Journal of the Alamire Foundation, 9: 89-133.

Collard, Franck (2012), 'La Renaissance des Lettres. La correspondance d'un humaniste français de la fin du XVe siècle, Robert Gaguin (1433-1501)', in Bibliothèque d'Humanisme et Renaissance, 74: 19-33.

Desmond, Karen (2018), Music and the moderni, 1300-1350: The ars nova in Theory and Practice, Cambridge: Cambridge University Press.

Dillon, Emma (2002), Medieval Music-Making and the 'Roman de Fauvel', Cambridge: Cambridge University Press.

Früh, Martin (2005), Antonio Geraldini (d. 1488): Leben, Dichtung und soziales Beziehungsnetz eines italienischen Humanisten am aragonesischen Königshof. Mit einer Edition seiner 'Carmina ad lohannam Aragonum', Münster: LIT.

Fuchs, Robert, Christiane Meinert, and Johannes Schrempf (eds) (2001), Pergament: Geschichte, Material, Konservierung, Restaurierung, Munich: Siegl.

Fujii, Akihiko (2007), Günther Zainers druckersprachliche Leistung: Untersuchungen zur Augsburger Druckersprache im 15. Jahrhundert, Tübingen: Niemeyer.

Geldner, Ferdinand (1968-1970), Die deutschen Inkunabeldrucker: Ein Handbuch der deutschen Buchdrucker des XV. Jahrhunderts nach Druckorten, 2 vols, Stuttgart: Hiersemann.

Gier, Helmut, and Johannes Janota (eds) (1997), Augsburger Buchdruck und Verlagswesen: Von den Anfängen bis zur Gegenwart, Wiesbaden: Harrassowitz.

Gillespie, Alexandra (2011), 'Chapter 7: Bookbinding', in Alexandra Gillespie and Daniel Wakelin (eds), The Production of Books in England 1350-1500, Cambridge: Cambridge University Press, 150-172.

Hamm, Berndt (1996), 'Die Reformation als Medienereignis', in Jahrbuch für biblische Theologie, 11: 137-166.

Heinzer, Felix (2020), 'Flirting with the Forbidden? Traces of Polyphony in Southwest-German Cistercian Manuscripts: The Case of Salem Abbey', in Oliver Huck and Andreas Janke (eds), Liturgical Books and Music Manuscripts with Polyphonic Settings of the Mass in Medieval Europe, Hildesheim: Olms, 39-58. 
Heinzer, Felix (1987), Handschriften der Badischen Landesbibliothek in Karlsruhe: Handschriften von Lichtenthal, Wiesbaden: Reichert.

Helwig, Hellmuth (1970), Einführung in die Einbandkunde, Stuttgart: Hiersemann.

Housley, Norman (2006), 'Indulgences for Crusading, 1417-1517', in Robert N. Swanson (ed.), Promissory Notes on The Treasury of Merits: Indulgences in Late Medieval Europe, Leiden: Brill, 277-307.

Irás-Melis, Katalin (1974), 'Die Funde aus einer Buchbinderwerkstatt des 15. Jahrhunderts im königlichen Schloß zu Buda', in Gutenberg-Jahrbuch, 49: 303-310.

Kirchhoff, Albrecht (1889), 'Zur Geschichte der Buchbindereien II: Werkstatts-Einrichtung Leipziger zünftiger Buchbindereien', Archiv für Geschichte des Deutschen Buchhandels, 12: 160-177.

Koch, Adolph (1889), 'Zur Geschichte der Buchbindereien. I. Die Hofbuchbinderei in Heidelberg', Archiv für Geschichte des Deutschen Buchhandels, 12: 152-159.

Krieg von Hochfelden, Georg Heinrich (1836), Geschichte der Grafen von Eberstein in Schwaben, Karlsruhe: Wilhelm Hasper.

Kügle, Karl (2008), 'Two Abbots and a rotulus: New Light on Brussels 19606', in David

B. Cannata et al. (eds), Quomodo cantabimus canticum? Studies in Honor of Edward

H. Roesner, Middleton, WI: American Institute of Musicology, 145-185.

Kügle, Karl (2016), 'Die Fragmente Oxford, All Souls 56 und die mensural notierte Mehrstimmigkeit in Köln um 1400: Ein Zwischenbericht', in Fabian Kolb (ed.), Musik der mittelalterlichen Metropole: Räume, Identitäten und Kontexte der Musik in Köln und Mainz, ca. 9001400. Tagungsbericht Mainz/Köln Oktober 2014, Kassel: Merseburger, 301-324.

Kügle, Karl (2018), 'Vitry in the Rhineland: New Discoveries', in Early Music, 46: 393-402.

Kühne, Hartmut (2014), 'Raimund Peraudis Reise durch Mitteldeutschland', in Norbert Moczarski and Katharina Witter (eds), Thüringische und Rheinische Forschungen: BonnKoblenz - Weimar - Meiningen. Festschrift für Johannes Mötsch zum 65. Geburtstag, Leipzig: Salier, 109-124.

Kühne, Hartmut (2015), 'Raimund Peraudi und der Türkenkreuzzugsablass in Deutschland: Zwei unbekannte Drucke', in Ebbo Bünz and Hartmut Kühne (eds), Alltag und Frömmigkeit am Vorabend der Reformation in Mitteldeutschland: Wissenschaftlicher Begleitband zur Ausstellung 'Umsonst ist der Tod', Leipzig: Universitätsverlag, 429-470.

Künast, Hans-Jörg (1997), 'Getruckt zu Augspurg': Buchdruck und Buch handel in Augsburg zwischen 1468 und 1555, Tübingen: Niemeyer.

Kyriss, Ernst (1957), Der verzierte europäische Einband vor der Renaissance, Stuttgart: Hettler. Lanoë, Guy, and Geneviève Grand (eds) (2008), La reliure médiévale. Pour une description normalisée. Actes du colloque international (Paris, 22-24 mai 2003) organisé par l'Institut de recherche et $d$ 'histoire des textes (CNRS), (Reliures médiévales des bibliothèques de France [IRHT] 5), Turnhout: Brepols.

Leitmeir, Christian (2007), 'Arguing with Spirituality against Spirituality: A Cistercian Apologia for Mensural Music by Petrus dictus Palma ociosa (1336)', in Archa verbi, 4: 155-199.

Lewis, D. (2000), 'Estampie Retrove': Finding a Place for the Music of the Robertsbridge Fragment in 14th-Century European Polyphony, MMus diss., King's College London.

Lickteig, Franz-Bernard (1981), The German Carmelites at the Medieval Universities, Rome: Institutum Carmelitanum.

Marinescu, Ruxandra (2014), The Politics of Deception and the French Lais in the Roman de Fauvel, Manuscript Paris, Bibliothèque nationale de France, fonds français 146, PhD diss., Utrecht University. 
Mazal, Otto (1997), Einbandkunde: Die Geschichte des Bucheinbandes, Wiesbaden: Reichert.

McAvoy, Liz Herbert, Patricia Skinner, and Theresa Tyers (2019), 'Strange Fruits: Grafting, Foreigners, and the Garden Imaginary in Northern France and Germany, 1250-1350', in Speculum, 94: 467-495.

McGrady, Deborah (2006), Controlling Readers: Guillaume de Machaut and His Late Medieval Audience, Toronto: University of Toronto Press.

Meer, Marcus (2019), 'Reversed, Defaced, Replaced: Late Medieval London and the Heraldic Communication of Discontent and Protest', in Journal of Medieval History, 45: 618-645.

Ottermann, Annelen (2013), 'Entdeckungen an Einbänden aus der ehemaligen Bibliothek der Mainzer Karmeliten', in Einbandforschung: Informationsblatt des Arbeitskreises für die Erfassung, Erschließung und Erhaltung historischer Bucheinbände (AEB), 32: 11-28.

Ottermann, Annelen (2016), Die Mainzer Karmelitenbibliothek: Spurensuche - Spurensicherung - Spurendeutung (Berliner Arbeiten zur Bibliotheks- und Informationswissenschaft 27), Berlin: Logos.

Overgaauw, Eef (2002), Die nichtarchivischen Handschriften der Signaturengruppe Best. 701 Nr. 191-992 (Mittelalterliche Handschriften im Landeshauptarchiv Koblenz 2), Wiesbaden: Harrassowitz.

Pflüger, Helmut (1958), Schutzverhältnisse und Landesherrschaft der Reichsabtei Herrenalb von ihrer Gründung im Jahre 1149 bis zum Verlust ihrer Reichsunmittelbarkeit im Jahre 1497 (bzw. 1535), Stuttgart: Kohlhammer.

Richter, Will, and Reinhilt Richter-Bergmeier (1995-2001), Ruralia commoda: Das Wissen des vollkommenen Landwirts um 1300, 4 vols, Heidelberg: Winter.

Riley, Hannah (2017), 'Constructive Parchment Destruction in Medieval Manuscripts', in Book 2.0, 7: 9-19.

Robertson, Anne Walters (1997), 'Which Vitry? The Witness of the Trinity Motet from the Roman de Fauvel', in Dolores Pesce (ed.), Hearing the Motet: Essays on the Motet of the Middle Ages and Renaissance, New York: Oxford University Press, 52-81.

Rück, Peter (ed.) (1991), Pergament: Geschichte, Struktur, Restaurierung, Herstellung, Sigmaringen: Thorbecke.

Saak, Eric Leland (2015), Catechesis in the Later Middle Ages I: The Exposition of the Lord's Prayer of Jordan of Quedlinburg, OESA (d. 1380) - Introduction, Text, and Translation, Leiden: Brill.

Schlechter, Armin, Matthias Miller, and Karin Zimmermann (eds) (2003), Von Ottheinrich zu Karl Theodor: Prachteinbände aus drei Jahrhunderten, Heidelberg: Winter.

Schmid, Wolfgang (2003), 'Rinck, Peter', in Neue deutsche Biographie, vol. 21, Berlin: Duncker \& Humbolt, 625-626.

Schneider, Cornelia (2003), Peter Schöffer: Bücher für Europa, Mainz: Stadt Mainz.

Schreiber, Heinrich (1932), Einführung in die Einbandkunde, Leipzig: Hiersemann.

Springer, Klaus-Bernward (2002), 'Peraudi (Perault), Raymund', in BiographischBibliographisches Kirchenlexikon, vol. 20, Hamm: Traugott Bautz, 1154-1160.

Szirmai, J. A. (1999), The Archaeology of Medieval Bookbinding, Aldershot: Ashgate, 1999 [reprint London: Routledge, 2017].

Toubert, Pierre (1984), ‘Crescenzi, Pietro de’, in Dizionario Biografico degli Italiani, vol. 30, 〈http://www.treccani.it/enciclopedia/pietro-de-crescenzi_(Dizionario-Biografico)> (accessed 5 Apr. 2020). 
Vetter, Eddie (1987), 'Philippe de Vitry and the Holy Trinity: An Early Manifesto of the Ars Nova', in Rob Wegman and Eddie Vetter (eds), Liber amicorum Chris Maas: Essays in Musicology in Honour of Chris Maas on his 65th Anniversary, Amsterdam: Institute of Musicology, 4-14. Vollmann, Benedikt Konrad (ed.) (2007-2008), Erfolgreiche Landwirtschaft: Ein mittelalterliches Lehrbuch. Petrus de Crescentiis, 2 vols, Stuttgart: Hiersemann.

Wiener, Claudia (2003), ‘Hochmittelalterliches Marienlob? Benedictus Chelidonius’ Elegien in ihrem Verhältnis zu Baptista Mantuanus' Parthenice Mariana und Dürers Marienleben', in Beate Czapla, Ralf Georg Czapla, and Robert Seidel (eds), Lateinische Lyrik der Frühen Neuzeit: Poetische Kleinformen und ihre Funktionen zwischen Renaissance und Aufklärung, 1: Arbeitsgespräch der Deutschen Neulateinischen Gesellschaft in Verbindung mit der Werner-Reimers-Stiftung Bad Homburg, Tübingen: Niemeyer, 96-132.

Zayaruznaya, Anna (2010), Form and Idea in the Ars Nova Motet, PhD diss., Harvard University. Zayaruznaya, Anna (2015), 'Quotation, Perfection, and the Eloquence of Form: Introducing Beatius/Cum humanum', in Plainsong \& Medieval Music, 24: 129-66. 

Representations 



\title{
A Collection of Fragments, or a Fragment of a Collection? The Musical Appendix of A-Wn Cod. 5094
}

\begin{abstract}
The musical appendix of Vienna, Österreichische Nationalbibliothek Cod. 5094 contains ten polyphonic pieces and twenty plainsongs, written by twelve different hands in six different types of notation, including letter notation and early German organ tablature. It is not, however, a random collection of disiecta membra, rather an anthology (florilegium) for the use of organists, collected c.1443 by an Austin friar from Munich visiting Vienna, who owned the parent codex.
\end{abstract}

\section{The surviving material}

Archaeological excavations often start with casual findings of small objects such as pottery shards or coins, which may be dispersed over a wider area in the ground. What the specialists then reconstruct from these remains, is usually a larger unit: a single house or a large estate, a Roman villa, a military camp, a village or a town. The question is how to get from the fragments to the hypothetical larger unit. Well-known strategies of reconstruction are the following:

- First, drawing conclusions as to the lost parent unit from the materiality of the surviving material: the paper type, the pottery material, etc.

- Second, comparing the transmissional contents of the material with evidence elsewhere: the forms and styles of the pottery, the notation or genres of the music, the identity of the musical pieces, etc.

- Third, if more than one item has been found, interrogating the spatial, material, and possibly cognitive relationship between the surviving items, for

\footnotetext{
Note: A shorter, German version of this chapter is also available in the online project Musical Life of the late Middle Ages in the Austrian Region, c.1340-c.1520, <https://musical-life.net/ essays/a-wn-cod-5094-souvenirs-aus-einem-wiener-organistenmilieu/ $>$. See also Reinhard Strohm, <https://musical-life.net/kapitel/zeugnisse-einer-wiener-organistenwerkstatt-wn-cod-5094>; Klaus Aringer, <https://musical-life.net/kapitel/fragmente-einer-wiener-organistenwerkstatt> (all websites quoted in this article have been last accessed 15 Sept. 2020).
}

Ә Open Access. ( 2020 Reinhard Strohm, published by De Gruyter. (cc) BY-NC-ND This work is licensed under the Creative Commons Attribution-NonCommercial-NoDerivatives 4.0 International License.

https://doi.org/10.1515/9783110717884-010 
example by finding two broken edges that fit precisely together, or a verbal sentence in one fragment that is continued in another - just as in a puzzle.

- Fourth, considering whether these relationships may point to an original larger unit, and whether this unit may have been disturbed in later times, for example by assembling fragments that belonged to different original units.

- And fifth, if due to accidents of transmission the surviving bits did not originally form a single unit, asking why they are found together. What other denominator might they have in common? When did they belong together, and in what context? To identify a common denominator presupposes a cultural interpretation, for example by suggesting an institution, a person, a practice that was responsible for the collection.

The musical appendix of Cod. 5094 of the Austrian National Library in Vienna raises many of these questions. The source is, at first glance, an almost random collection of eighteen paper leaves, bound as ff. 148-164 at the back of the main codex (on which, see below). An eighteenth- or nineteenth-century ink foliation, no longer visible on all pages, has been complemented by a twentieth-century pencil foliation; the originally unfoliated second leaf received the number $148 \mathrm{a}$ only in pencil foliation. ${ }^{1}$ These leaves contain various forms of musical notation. Only one of the leaves (f. 156) has no music: it is not part of the musical collection but belongs to the first section of the main codex, with which it also shares its scribal hand and watermark. The paper sizes vary, the main and largest size being of $31 \times 22 \mathrm{~cm}$, which matches that of the main codex. The leaves were perhaps cut to size - although no music leaf shows any writing loss through cropping. As far as the tight binding allows to judge this, we have only one bifolium (ff. 154-155) and one group consisting of a bifolium and a single leaf (ff. 160-161, f. 159); the other components are all single leaves, each with individual contents. This is corroborated by the presence of, at least, twelve different paper types. Visible watermarks are 'Scales without circle' (f. 148), 'Anvil in circle' (ff. 148a and 152), 'Mountains with cross' (ff. 154-155), 'Stag with cross' (ff. 159, 160-161), 'Oxhead with cross' (f. 163), 'Mountains with two flowers' (f. 164): these paper types all seem to belong to the 1440 s. Where no watermark is visible, the papers are distinguishable by their colour and thickness. ${ }^{2}$

1 F. 148a was probably not added after the ink foliation had been entered, but was not counted at first because it is of irregular size, being cropped to an almost square shape.

2 A detailed attempt at identifying and dating the paper types has not yet been undertaken, but the available data may suffice for the present analysis. 
The binder has turned one leaf upside down (f. 148a), reversed two (ff. 158, 162) and bound one before, instead of after, its related bifolium (ff. 159; 160-161). The bifolium 154-155 is notated in oblong (landscape) format. ${ }^{3}$ Importantly, several leaves had originally been folded, some only once horizontally, others twice and even three times horizontally and vertically. The landscape format and the folding may be clues to the original uses of the music (see Table 1). ${ }^{4}$

On the evidence presented thus far, these leaves are not fragments of one larger manuscript. However, since, several of them are connected through their musical contents, scribal hands, notational types, and the roughly coeval watermark types, an entirely random assembly also seems improbable.

Table 1: A-Wn, Cod. 5094, ff. 148-164: paper, rastrum, copyists, notations.

\begin{tabular}{|c|c|c|c|c|}
\hline Folio & Paper type & Rastrum & Copyist & Notation \\
\hline 148r blank & $\begin{array}{l}\text { 1: scales without } \\
\text { circle }\end{array}$ & & & \\
\hline $148 v$ & & $9 \times 5$ & A (larger script) & MN full \\
\hline 148ar blank & $\begin{array}{l}\text { 2: anvil in circle, } \\
\text { cropped, } \\
\text { folded once }\end{array}$ & & & \\
\hline $\begin{array}{l}\text { 148av bound } \\
\text { upside down }\end{array}$ & & $8 \times 5$ & B (Chranekker) & MN void and full \\
\hline $149 r$ & 3; folded twice & $18 \times 4$ & A (small script) & $\mathrm{CN}$ \\
\hline $149 v$ & & $18 \times 4$ & A (small script) & $\mathrm{CN}$ \\
\hline $150 \mathrm{r}$ & $3 ;$ folded 3 times & $9 \times 6(!)$ & $\mathrm{C}$ & SN full \\
\hline $150 v$ & & $9 \times 6(!)$ & $\mathrm{C}$ & SN full \\
\hline $151 \mathrm{r}$ & 4; folded once & $11 \times 4$ & $\mathrm{D}$ (pen trials) & $\mathrm{CN}$ \\
\hline $151 v$ & & $11 \times 4$ & $E$ or $A$ & $\mathrm{CN}$ (cantus fractus) \\
\hline $152 r$ & 2; folded once & $19 \times \times 4$ & A (small script) & $\mathrm{CN}$ \\
\hline $152 v$ & & $18 \times 4$ & A (small script) & $\mathrm{CN}$ \\
\hline $153 r$ & 5 ; folded once & $10 \times 4$ & $\mathrm{~F}$ & $\mathrm{CN}$ \\
\hline 153v blank & & & & \\
\hline
\end{tabular}

3 Facsimile in https://musical-life.net/mediengalerie.

4 Abbreviations: $\mathrm{C}=$ Cantus, $\mathrm{T}=$ Tenor, $\mathrm{Ct}=$ Contratenor, $\mathrm{MN}=$ mensural notation (full or void), $\mathrm{CN}=$ chant notation, $\mathrm{SN}=$ stroke notation (full or void), $\mathrm{OT}=$ (early German) organ tablature, $\mathrm{LN}$ = letter notation, frg. $/$ frgs $=$ fragment/s, clefs: $\mathrm{c1}, \mathrm{c3}, \mathrm{f3}$, f4, etc. 
Table 1 (continued): A-Wn, Cod. 5094.

\begin{tabular}{|c|c|c|c|c|}
\hline Folio & Paper type & Rastrum & Copyist & Notation \\
\hline $154 \mathrm{r}$ blank & $\begin{array}{l}6 ; \text { mountains with } \\
\text { cross }\end{array}$ & & & \\
\hline $154 \mathrm{v}$ & & $4 \times 5$ landscape & G & SN \\
\hline $155 r$ & 6 & $4 \times 5$ landscape & G & MN, SN \\
\hline $155 v$ & & $4 \times 5$ landscape & G & $\begin{array}{l}\text { SN, LN, } \\
\text { 9-line staves }\end{array}$ \\
\hline $156 r-v$ & 7 & none & $\begin{array}{l}=\text { Cod. } 5094, \\
\text { f. } 1 \mathrm{r}-3 \mathrm{v}\end{array}$ & none \\
\hline $157 r$ & 8 & $6 \times 5$ & $\mathrm{H}$ & CN (cantus fractus) \\
\hline $157 v$ & & $\begin{array}{l}4 \times 5 \text { (lower half } \\
\text { only) }\end{array}$ & $\mathrm{D}$ (pen trials) & $\mathrm{CN}$ \\
\hline $158 r$ & 2(?); folded once & $\begin{array}{l}9 \times 5 \text {, barlines } \\
\text { over entire page }\end{array}$ & 1 & OT \\
\hline $158 \mathrm{v}$ & & $\begin{array}{l}9 \times 5 \text {, barlines } \\
\text { over entire page }\end{array}$ & 1 & OT \\
\hline $159 r$ & 9; stag with cross & $10 \times 5$ & J & $\begin{array}{l}\mathrm{CN} \text { (belongs to } 160 \mathrm{r}- \\
161 \mathrm{v})\end{array}$ \\
\hline \multicolumn{5}{|l|}{$159 v$ blank } \\
\hline $160 r$ & 9 & $9 \times 5$ & J & $\mathrm{CN}$ \\
\hline $160 v$ & & $9 \times 5$ & J & $\mathrm{CN}$ \\
\hline $161 \mathrm{r}$ & 9 & $9 \times 5$ & J & $\mathrm{CN}$ \\
\hline $161 \mathrm{v}$ & & $9 \times 5$ & J & $\mathrm{CN}$ \\
\hline $162 r$ & 10 & $7 \times 5$ & $\mathrm{~K}$ & $\begin{array}{l}\text { MN full (cantus } \\
\text { fractus, note-value } \\
\text { dots) }\end{array}$ \\
\hline $162 v$ & & $7 \times 5$ & $\mathrm{~K}$ & $\begin{array}{l}\text { MN full (cantus } \\
\text { fractus, note-value } \\
\text { dots) }\end{array}$ \\
\hline $163 r$ & $\begin{array}{l}11 ; \text { oxhead with } \\
\text { cross }\end{array}$ & $7 \times 5$ & $\mathrm{~L}$ & MN full \\
\hline $163 v$ & & $7 \times 5$ & $\mathrm{~L}$ & $\begin{array}{l}\text { MN full (note-value } \\
\text { dots) }\end{array}$ \\
\hline $164 r$ & $\begin{array}{l}\text { 12; mountains } \\
\text { with two flowers }\end{array}$ & $9 \times 5$ & $M$ & MN void \\
\hline $164 \mathrm{v}$ & & $9 \times 5$ & M & MN void \\
\hline
\end{tabular}




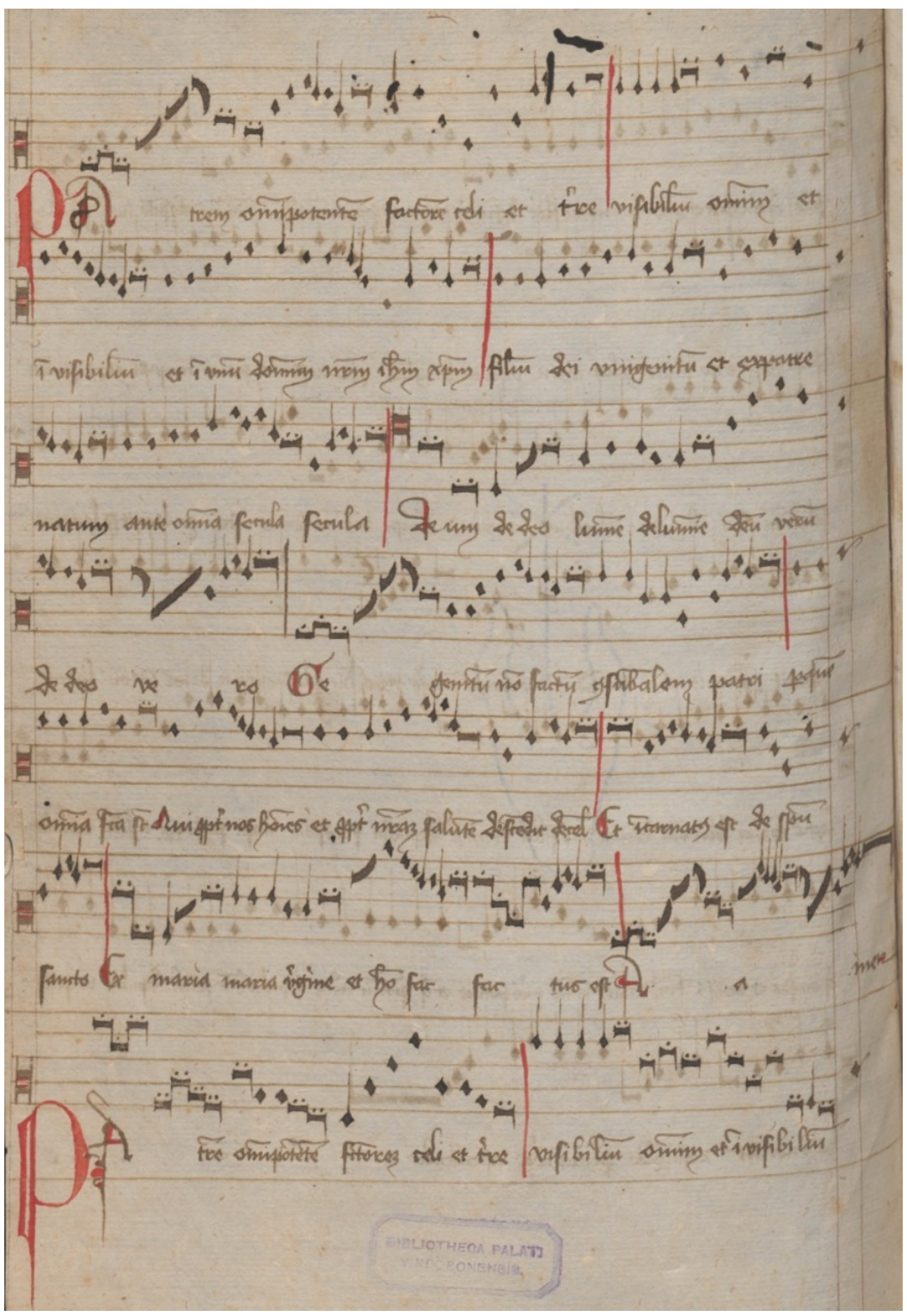

Fig. 1: Note-value dots for sacred music (plainsong in cantus fractus polyphony), A-Wn, Cod. 5094, f. 163v; (C) Vienna, Österreichische Nationalbibliothek. 


\section{The musical contents}

As shown in Table 1, we find either twelve or thirteen different music hands and many different notational genres: mensural full and void, mensural with notevalue dots (see Fig. 1), chant notation (gothic, so-called 'Bohemian-Messine' notation, and square), early German organ tablature, stroke notation and letter notation, cantus fractus (partially-measured chant notation)..$^{5}$ One notator (A) adopts two different script sizes (see ff. 148, 149 and 152).

What sort of collection is this? Would someone unfamiliar with the musical styles have been likely to assemble, in such a restricted space, so many different types of notation, and musical genres, as will be seen? There is here a measure of musical communality and perhaps common agency. Hand A, for example, uses full and void mensural notation for polyphony and chant notation of a much smaller size for plainsong: this musician was multi-tasking. Hand $\mathrm{G}$ brings together stroke and letter notation on the same page. The two notations are demonstrated with two versions of the same sample piece: a three-voice Ave maris stella - the same piece which hand A notates on a different page in void mensural notation. Hands A and G are present together on one page (f. 155v).

The musical contents, ordered by scribal hands, may be listed as follows:

Hand A (larger script)

f. 148v (leaf bound upside down, preceding leaf lost): 3-voice Skack sive celsito[nanti] (Froleich geschrai, Oswald von Wolkenstein), present only $\mathrm{Ct}$ (f3) and T (f3), MN full; Virginem mire (En discort, anonymous Ars Nova ballade), frg. T (f3), MN full; 3-voice Ave maris stella $=$ f. 155v, MN full. ${ }^{6}$

f. 155v bottom (landscape layout): 3-voice Ave maris stella $=$ f. 148v, frg., SN void (9-line stave) and twice in LN (second time frg.).

5 On note-value dots ('Notenwertpunkte'), see Bernhold Schmid, <https://musical-life.net/ kapitel/weitere-notationssysteme-im-codex-5094>. On cantus fractus as a polyphonic plainsong performance, see Marco Gozzi, 'Rhythmischer choralgesang: der Cantus fractus', <https://musicallife.net/essays/rhythmischer-choralgesang-der-cantus-fractus>. Examples from Cod. 5094 in Bernhold Schmid, <https://musical-life.net/kapitel/weitere-notationssysteme-im-codex-5094>. 6 Facsimile in <https://musical-life.net/kapitel/ave-maris-stella-im-wiener-codex-5094>. 
Hand $A$ (small script)

ff. 149r-v, 152r-v: 1-voice Sequences for Dorothea, Catherine, Maria, Michael, Ulrich (adapted for Wolfgang and Rupert), Church dedication, Easter (CN).

Hand B (Wolfgang Chranekker) ${ }^{7}$

f. 148av (leaf bound upside down): 3-voice textless (Ce jour le doibt, Du Fay), MN void and full, in score on two staves. ${ }^{8}$

Hand C

f. 150r: 2-voice textless frg., perhaps a draft for the Salve regina, f. 150v, SN full.

f. 150v: 3-voice Salve regina, present only C (c2), Ct (c5), SN full. Following leaf lost.

Hand D

ff. 151r, 157v: musical pen trials (square $\mathrm{CN}$ ).

Hand $E$ (or $A$ ?)

f. 151v: 1-voice Gloria Primogenitus Marie (CN, cantus fractus), two Kyries, one frg. Sanctus (CN). Following leaf lost.

\section{Hand F}

f. 153r: 1-voice Introitus In Nicolai transitu, Alleluia Stabit Nicolaus (square $\mathrm{CN})$.

\section{Hand $G$}

ff. 154r-155r (landscape layout): 4-voice Segnier Leon / Benedictus qui venit (Du Fay, 1442), SN void.

f. 155v top (landscape layout; different text hand?): 3-voice Ave maris stella $=$ f. 148v, SN void; f. 155v bottom: see hand A.

\section{Hand $H$}

f. 157r: 1-voice Sanctus-Agnus Dei, CN, cantus fractus, end missing.

\section{Hand I}

f. 158r-v (bound in reverse): 3-voice textless 'rundelus' (ars nova motet Apollinis eclipsatur, B. de Cluny), OT.

7 On Chranekker, see below.

8 'Italian organ tablature', a term apparently introduced by Willi Apel for mensural score notation, would technically look similar, but the present notation in score with one voice being distinguished by full red or black notes is found in Italy and Central Europe for polyphonic plainsong; see, for an example, Strohm 1966. 


\section{Hand J}

ff. 159r, 160r-v, 161r-v (begins f. 160r, preceding leaf lost): 1-voice plainsongs for Barbara and Mary, CN.

\section{Hand $K$}

f. 162r-v (reversed): two 1-voice Credo, one of which frg., MN full, note-value dots.

Hand $L$

f. 163 r (preceding leaf lost): 1-voice frg. ...solem qui te rexit (O Maria pya, Monk of Salzburg, contrafactum of his Ju ich jag,), MN full.

f. 163v: 2st. frg. Credo, melody = f. 162r, MN full, note-value dots. Following leaf lost.

\section{Hand $M$}

f. 164r: 2-voice Vivat nobilis prosapie, MN void.

f. 164v: frg. textless draft of a cantus [c1?]; 2-voice textless piece (f3, f3), MN void.

Pages without musical content:

ff. 148r, 148ar, 151r ('Historia de Sancto Livino episcopo et martire', pen trials), 153v, 154r, 157v (liturgical texts, musical pen trials), 159v. F. 156r-v belongs with the main codex (ff. 1-3).

As could be expected, the notational variations often relate to the nature of the music, but this is not always so: the three-voice Ave maris stella is copied by scribe A in mensural notation, and by scribe $G$ in three 'instrumental' types of notation, suggesting systematic variation and collaboration between individuals. It seems to be a learning process in musical notation, with a single piece as a sample. The Salve regina on $\mathrm{f} .150 \mathrm{v}$ is preceded on $\mathrm{f} .150 \mathrm{r}$ by an incomplete copy by the same hand, possibly a composition draft; the motet-like piece on f. $164 \mathrm{r}$ may be related to a compositional sketch by the same hand on $\mathrm{f} .164 \mathrm{v}$ (stave 7).

Notator B is Wolfgang Chranekker, who was organist in St Wolfgang am Abersee in 1441; his name and identity have been discovered by Peter Wright, after Tom Ward had noted the concordance of the scribal hand in the St Emmeram codex. ${ }^{9}$ Chranekker wrote the chanson Ce jour le doibt in a pseudoscore on two staves, a notational type that is technically similar to what we now call '(early) Italian organ tablature', although the score notation and the use of full notes to distinguish a contrapuntal voice are well-known in Italian and

9 On Chranekker, see Rumbold/Wright 2009, 98-107. 
German 'simple' polyphony of the late Middle Ages, usually performed vocally. It is striking that about a third of the musical material in Cod. 5094 uses 'marginal' notational systems such as stroke notation, cantus fractus, tablature, note-value dots - and that all these notations are written by five different hands. There seems to have been a common interest in types of music that are unusual for us today. Since the items do not stem from a common manuscript or author and yet, seem to be assembled with a common focus, what we have here may not be scattered body-parts (disiecta membra), but rather an anthology (florilegium).

\section{Users}

Frederick Crane (1965) and Theodor Göllner $(1967)^{10}$ realised the challenge of apparent heterogeneity in this source. Whereas Crane discussed only the tablature items, taking them as specimens of a more widely diffused practice (which they presumably are), Göllner gave the collection and the practice it represents, a common name: Notationsfragmente aus einer Organistenwerkstatt (notational fragments from an organist's workshop); he could have meant the word 'Organisten' either in the singular or in the plural. But what is an 'organist's (or organists') workshop'? Is it the rood-loft of a church? And what is supposed to happen there? As regards to performance, the leaves notated in landscape layout (ff. 154-155) might fit on an organist's desk, but instead of a tablature they contain letter notation and stroke notation in pseudo-score and choirbook layouts. The choirbook layout of the four-voice Segnier Leon on these pages could be played from, if the two adjacent leaves were placed side by side of each other on the desk, which would only be possible if the bifolium were cut in two single leaves.

The apparent potential for instrumental playing - whether on the organ or other instruments - is not the only common denominator of the collection. Transcriptional exercises point to study and rehearsal; even the 'instrument-related notations' such as letter notation, tablature and score notation seem to have served didactic or study purposes. Two sketchlike items seem to be composition trials (hand C, f. 150, and hand M, f. 164). Heinz Ristory (1985) described the transformations of the Ave maris stella as a 'notational exercise';1 Bernhold Schmid in his contribution to the online project Musikleben des Spätmittelalters

10 Crane 1965; Göllner 1967, 170-77.

11 See Ristory 1985. 
in der Region Österreich (1340-1520) (2016) also emphasised the notational peculiarities. ${ }^{12}$

There is, in addition, the fact that the music is written mostly on single leaves, and sometimes left incomplete or transmitted in an incomplete form. This fragmentation apparently did not happen by force, as when a leaf is torn into two, but rather by the simple loss of a complementing leaf, as if it had accidentally fallen from a table, for example. The material may be of heterogeneous provenance, but it seems to have been brought together not by tearing out fragments from their parent contexts, but by consciously transferring discreet materials in single-leaf form from their original contexts to make more use of them here. The folded leaves imply that the material has travelled or was sent as a letter: this evidence invites speculation about who the users were and what purposes the music had for them.

In 1984, I published a complete handlist of the collection with provisional identifications of the music, and an attempt at distinguishing the scribal hands; this exercise suggested that we are really dealing with an ecclesiastical collection, because eleven of the eighteen leaves contain liturgical vocal music. ${ }^{13}$ These are often notated in a very small script, so that many long chants fit on a few pages. No schola could read from this, but an organist might play from this 'organ plainsong notation'. ${ }^{14}$ This vocal material could have served for instrumental performance, whereas the instrumentally-transcribed material, vice-versa, rather suggests study and learning. Other liturgical items are either set in simple polyphony, or as cantus fractus, a significant fifteenth-century vocal practice. The three-voice Salve regina is written entirely in semibreves ('stroke notation'), containing a few intermittent phrasing dashes without mensural function, and final longs. ${ }^{15}$ Although unmeasured, this seems a highly professional setting of the plainsong in three-voice chanson format.

Not all of the music is sacred in origin. The six secular compositions are, however, presented as Latin contrafacta or have original Latin texts. Even Du Fay's Segnier Leon, with a two-word French incipit has, exceptionally, a Latin liturgical tenor text, Benedictus qui venit. Taking these observations together and asking for a common characterisation, Göllner's term ‘Organistenwerkstatt' remains per-

12 Bernhold Schmid, 'Ave maris stella im Wiener Codex 5094', in <https://musical-life.net/ kapitel/ave-maris-stella-im-wiener-codex-5094>.

13 See Strohm 1984.

14 For a facsimile, see Reinhard Strohm, 'A-Wn, Cod. 5094: Souvenirs aus einem Wiener “Organistenmilieu”', 2018, <https://musical-life.net/essays/wn-cod-5094-souvenirs-aus-einemwiener-organistenmilieu>.

15 On stroke notation, see Van Biezen/Vellekoop 1984 and Strohm 1993, 352-357. 
suasive, as long as we bring all the material into play that is present here, and enquire about the nature of organists' duties at the time.

\section{External relations of the music}

Let us consider the chronological, repertorial and geographical context of the collection. The watermark types are all compatible with the 1440s; Hand B (Chranekker) is documented in 1441 and was probably active in Vienna in the preceding years. Musical concordances lead further. The motet Apollinis eclipsatur seems to have reached Austria early in the century: it is also found in A-Wn, Cod. 922, a fragment of a fourteenth-century liber motetorum. ${ }^{16}$ Virginem mire pulchritudinis, a contrafactum of the virelai En discort, was well-known in the region and popular with organists and theorists; it is mentioned, for example, by the Melk Anonymus in MS 950 of Melk Abbey, a copy dated 1462. ${ }^{17}$ Du Fay's ballade Ce jour le doibt may be of the 1420s; it is transmitted in the Trent codices. ${ }^{18}$ The youngest datable composition is Du Fay's Seigneur Leon, probably composed in Ferrara in $1442 .{ }^{19}$ We also find 'Skack sive celsitonanti', a contrafactum of Oswald von Wolkenstein's Froleich geschrai, but with the additional label 'skak', which in my opinion refers to the exchiquier or Schachtpret; the same label appears in the copy of the original song in Oswald's manuscript A, of $c .1425$, which in 1447 belonged to Duke Albrecht VI of Austria. ${ }^{20}$ The fragment beginning ...solem qui te rexit on $\mathrm{f}$. $163 \mathrm{r}$ has been identified by Michael Shields as part of the contrafactum O Maria pya of the Monk of Salzburg's Singradel Ju, ich jag. ${ }^{21}$ The interest of Hands A and G in three-voice versions of the hymn Ave maris stella is analogous to the appearances of several similar settings of this hymn in Hermann

16 On the fragment Cod. 922 see Cuthbert 2010.

17 On Virginem mire puchritudinis/En discort, see Strohm 1993, 122-124.

18 For facsimiles and transcription of Ce jour le doibt, see Klaus Aringer, <https://musicallife.net/kapitel/fragmente-einer-wiener-organistenwerkstatt>, with facsimiles; Bernhold Schmid, $<$ https://musical-life.net/essays/organisten-und-kopisten $>$.

19 See Fallows 1987, 62-63. Facsimile in <https://musical-life.net/mediengalerie>; a recording of the song by the Ensemble Leones is in <https://musical-life.net/audio/seigneur-leon $>$.

20 See Strohm 1984, 212-213.

21 Shields 2011, 131-147. 
Pötzlinger's section of the St Emmeram codex (Vienna, c.1439). I believe that all these three-voice hymn settings served as compositional exercises. ${ }^{22}$

The Mass ordinary melodies and cantus fractus settings generally belong to the Bavarian/Austrian repertories of the time; the sequence Psallat concors symphonia for St Dorothy may suggest the Passau diocese and perhaps Vienna, where this saint was particularly venerated and this sequence text was current. The sequence Gloriosa fulget dies offers a more specific clue: its underlaid text is formulated here for St Udalricus of Augsburg, but it has also been adapted by the main scribe (hand A) for the Passau diocese (patavia) and for Saints Wolfgang of Regensburg and Rupert of Salzburg. ${ }^{23}$ This scribe apparently copied the piece first in a place connected to Augsburg and later adapted it for a location further east. Gloriosa fulget dies was normally used for Sts Nicholas and Augustine, and in the Passau diocese specially for its patron St Valentin. The pilgrimage church of St Wolfgang am Abersee (= Wolfgangsee), where Chranekker was organist, also belonged to the Passau diocese at that time.

Wolfgang Chranekker showed great competence in void mensural notation in the St Emmeram codex, to which he contributed the latest section around 1441-1443. Johannes Lupi, organist at Trent cathedral from 1447, left only mensural notation in his sections of the Trent codices. ${ }^{24}$ His successor in compiling these manuscripts, Johannes Wiser, may have been an organist previously. ${ }^{25}$ The status of fifteenth-century organists may have to be redefined: these individuals were often academics, all-rounders in music, and teachers. Their daily practice would suit a sacred institution where the organist taught and directed not only other organists (his private pupils), but also singers, even the general choir. The plainsong performances in smaller institutions such as monasteries and friaries would have taken place around the organist's desk; evidence that organists played much of the plainsong, especially hymns, the Mass ordinary and votive antiphons, is as frequent in Austria as in other parts of Europe including England. ${ }^{26}$ Organists were highly respected: when Conrad Paumann from Munich visited Vienna in 1452, he was well paid by the magistrate and carried around on

22 In the forthcoming essay 'Kompositorische Lernprozesse' (<https://musical-life.net/essay/ kompositorische-lernprozesse >), I aim to explain some procedures of sample composition that are involved here.

23 Facsimile in $<$ https://musical-life.net/mediengalerie $>$.

24 Reinhard Strohm, 'Johannes Lupi', in <https://musical-life.net/essays/johannes-lupi/>.

25 The mention of 'Iohannes organista de Monaco', at Vienna University in 1454, was first observed in Pietzsch 1971, 186.

26 See Klaus Aringer, in <https://musical-life.net/essays/orgeln-und-orgelmusik-der-regionoesterreich>. 
a chair in the Corpus Christi procession. ${ }^{27}$ The collectors of the musical material in Cod. 5094 were presumably well-connected musicians.

\section{The parent codex}

It is, however, the relationship of the musical appendix to its parent codex that can throw further light on the origins of this collection. The corpus of Cod. 5094 is even more miscellaneous and seemingly heterogeneous than the musical appendix. It belongs to the type of manuscript the Italians called zibaldone, a commonplace book of useful texts and citations.

The codex is supposed to have belonged to the sixteenth-century physician and historian Wolfgang Lazius (1514-1565) at the University of Vienna, with the shelfmark 'Jur. can. 49'. In 1752 it was bound, including its musical appendix, for the Vienna Hofbibliothek under court physician and librarian Gerard van Swieten, whose initials are stamped on the leather binding. The Tabulae codicum of the Austrian National Library $(1870)^{28}$ divide the contents of the corpus in nine distinct sections, but in reality there are at least forty. A great variety of papers is present; written original datings range from 1411 to 1463 . The contents are extracts from treatises, papal bulls, copies of charters and letters on subjects of canon law, enriched with personal letters, epigrams, humanist model verses, extracts from Prudentius' Metra de S. Monica (f. 140r) and a Latin dictionary of episcopal sees (ff. 134r-135v). Many letters are originals, folded for dispatch and occasionally carrying remnants of seals. Other letters are copies, drafts or templates (model texts). Several charters and letters are translated into German. The sections on ff. 1-57 are excerpted from Decrees of the Council of Constance; hence the volume was entitled Acta concilii constantiensis in 1752. Many documents concern the order of the Austin Friars (Ordo Eremitarum S. Augustini, OESA), particularly its Munich house; there are also links to other Augustinian houses and to Minorites, the latter for example at Nuremberg, 1448 (f. 126r). The Austin friar Berthold of Regensburg (Berthold Puchhauser) writes from Vienna to members of the Munich house, on 24 November 1411 (f. 128r), and again, from Regensburg, in 1421 (ff. 141r-142r). Georg von Schöntal, Provincial of the Austin friars in Bavaria and Austria, writes from Vienna to a certain "Jorgen N. de N."

27 Reinhard Strohm, 'Städtisches Musiklebe', in <https://musical-life.net/essays/städtischesmusikleben>.

28 Mantuani 1864-1899, IV. 
concerning his admission to the order (f. 122r, a model text). Knight Berthold von Stain, who founded an Augustinian friary at Uttenweiler (Upper Swabia), writes to the Munich convent in 1456 (f. 143r). There is some correspondence with a young Augustinian brother, Maurus Venetus, who is studying in Padua (f. 145rv). A recurring topic is the practice of dispensing holy sacraments; the copyist one of these texts, on the eucharist, names himself Nicolaus Mewerl (f. 138v).

Because of its links to the Austin friars of Munich, Göllner and others have proposed that the entire manuscript including its musical appendix originated in that house. But there are no such links in the musical appendix, which is more clearly situated in an Austrian context. Even some documents in the main codex concern the University of Vienna and the Habsburgs. Several letters are by Pope Pius II (Enea Silvio Piccolomini), former secretary of King Frederick III. In one of these, Piccolomini informs the University of Vienna of his election to the papacy, 1458 (f. 124r). F. 139r-v is a fragmentary copy of a missive by King Albrecht II of Habsburg (c.1438). A document on $\mathrm{f}$. 136v concerns a legal dispute between the mendicant friars and professors of the University of Vienna with the choirmaster (senior curate) of St Stephen's church in the early 1440s. This notarial copy (Vidimus) of a charter, written in Vienna on 8 February 1443, leads us to the probable original owner of Cod. 5094 and the all-important connection between its main corpus and appendix.

\section{The original owner of the music collection?}

The legal dispute was about the rights of mendicant friars to dispense the holy sacraments and hear confessions in the collegiate church of St Stephen's, Vienna. Shortly after 1440, the choirmaster Lienhard Orthaber had attempted to ban the friars of the four mendicant orders entirely from his church. The friars protested, presumably because hearing confession and dispensing the holy sacraments were important sources of income from wealthy parishioners.

Many mendicants were members of the university, so that the dispute was carried out between the university and the collegiate church. The charter sets down an apparent final verdict, specifying the conditions under which the friars were allowed to hear confessions and dispense holy sacraments in the church of St Stephen's: they could do so only by special permission from the parish clergy. It was a compromise: rather than being banished from the church altogether, the friars would have been happy to ask for special permissions. The document on 
f. 136v, a notarial transcript (Vidimus) of an original charter, is reproduced here in Fig. 2.

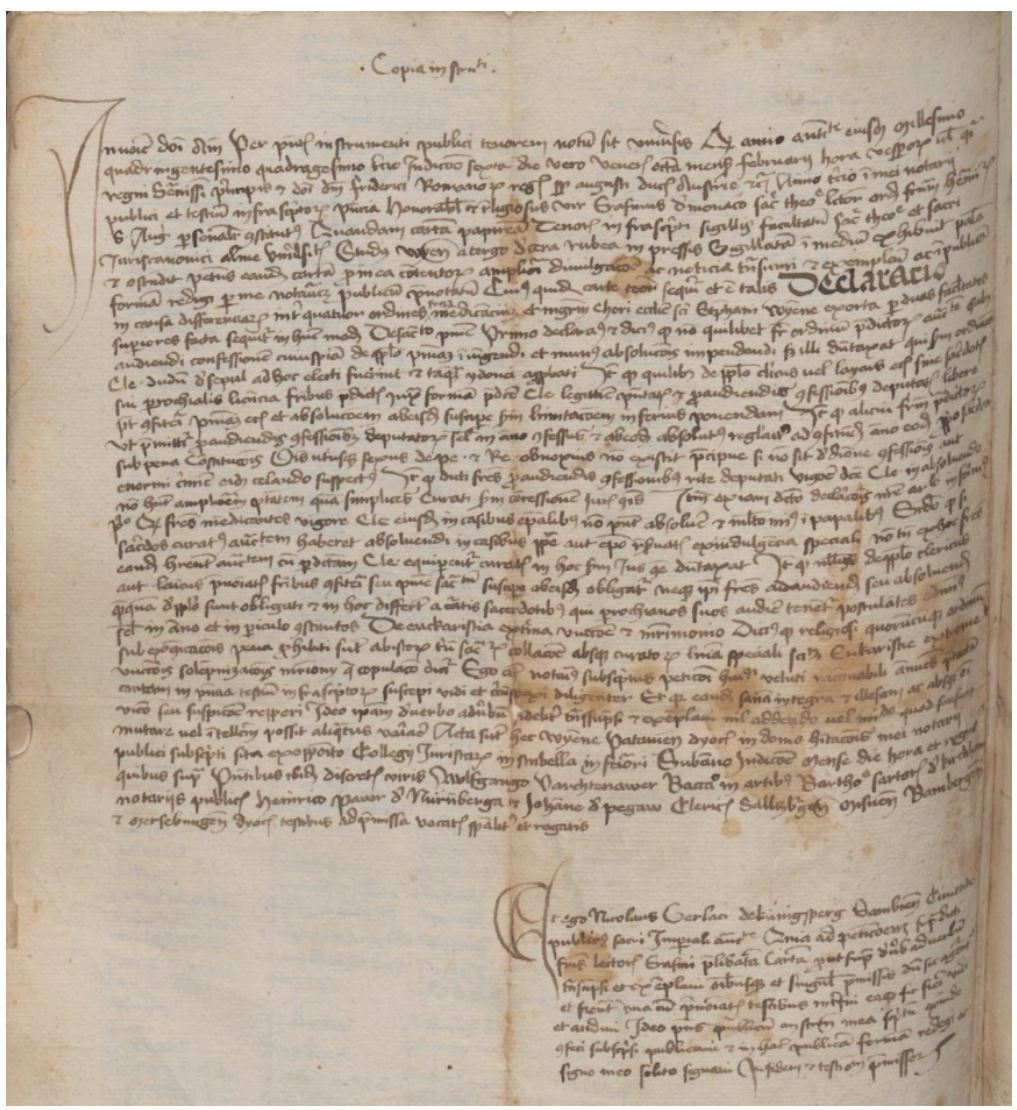

Fig. 2: Charter 1443, presented by Erasmus Gunther de Monaco, A-Wn, Cod. 5094, f. 136v ('Copia instrumenti'); (C) Vienna, Österreichische Nationalbibliothek.

\section{Transcription of the first section:}

In nomine domini... anno... 1443 indictione sexta [of Antipope Felix V.] 8 februarii, ...Friderici Romanorum regis anno tercio in mei notarii publici et testuum infrasciptorum presencia Honorabilis et religiosus vir Erasmus de monaco sacre theologie lector ordinis fratrum heremitarum S. Augustini personaliter constitutus Quandam cartam papiream Tenoris infrascripti sigillis facultatum sacre theologie et sacri Juris canonici alme universitatis Studiorum Wyennensis a tergo de cera rubea im pressis Sigillatam in medium exhibuit [...] cuius quidem carte tenor sequitur et est talis Declaracio [...] 
Summary of the document: On 8 February 1443 Erasmus de Monaco, OESA, Professor of Theology and Canon Law, presents to the public notary Nicolaus Gerlach and witnesses a charter sealed by the two faculties of Theology and Canon Law of Vienna University, on the dispute between the mendicant orders of Vienna and the magister chori of St Stephen's church [between 1439 and 1444: Lienhard Orthaber]. It is declared therein on what conditions the mendicant orders are allowed or disallowed to hear confessions, give absolution and spend the holy sacraments in the church of St Stephen. Essentially, these sacramental actions are permitted only to approved members of the four orders with special and personal permission of the church authorities of St Stephen's. The sacraments of the eucharist, extreme unction and marriage, in particular, require the special permission of the curates of the church. Abstract of the original document, signed by Notary Nicolaus Gerlacius of Nuremberg in the presence of named witnesses, in Vienna, 8 February 1443.

The 'honourable lector of canon law, the Austin friar Erasmus Gunther de Monaco', who announced the settling of the dispute, was most probably the one who struck the deal as an external referee or judge. He was at the time a lector sacre pagine et professor, becoming Prior of the Munich house c.1444, and Provincial of the Bavarian-Austrian province in 1448, succeeding Georg von Schöntal; having distinguished himself as a monastic reformer, he died c.1461, being succeeded by Johannes Ludovici, who then was the studiorum regens of the Augustinian friars at Vienna. ${ }^{29}$ I propose that the miscellaneous collection of the main part of Cod. 5094, which focuses on canonic and practical interests of the Augustinians, belonged to Erasmus Gunther, to whom it provided much useful material of canon law to guide his activity in disputes such as the one of 1443 . But did the musical appendix also belong to him? How did it become associated with the main corpus?

We must assume that, at some stage, the manuscript material of both sections existed as loose leaves. It is not known when the present two sections were bound together: this is most unlikely to have happened in 1752, or even in the sixteenth century, because adding a group of old music leaves to a canonistic miscellany would have contradicted the principles of the respective academic libraries. The fact that one leaf belonging to the first section of the corpus ended up bound amidst the music (f. 156) implies that the musical material was not even bound together as a single unit before it became part of the main codex: rather, at an early stage all the materials were bound or rebound together, having previously existed as scattered leaves or only gathered in fascicles. At that time, also

29 Catalogus 1729, 12. 
some of the losses of single leaves can easily have occurred. Thus, the musical collection was not a fragment, nor an assembly of fragments, but a collection of discreet musical items for the interests of organists and their friends. Who, however, would have wanted to keep these leaves together, and for what reason? Was Erasmus himself interested in the music, or was this a later owner?

The youngest documents in the collection, both dated 1463, were probably added by the person who inherited the manuscript material from Erasmus (d. c.1461). This person may have been Johannes Ludovici, studiorum regens in the Vienna convent and in 1461 successor to Erasmus as Provincial of the order, or Ludovici's successor as Provincial in 1468, who was then lector in the Vienna convent, too: he was Paulus Weygel de Monaco, an addressee of a letter dated 1460 in Cod. 5094 (f. 147r) and author of a charter issued in Munich, 1463 (f. 137v). However, in the 1460s, the musical appendix dating from the 1440s cannot have been of much interest even to amateur musicians among the friars. And, why would they have chosen to add old music to a miscellany of canon law and bind it all together? It seems to me that Erasmus Gunther himself (or a musician closely associated with him) was really the one interested in the music, which was contemporary to his visit to Vienna in 1443 , and that his entire collection of canonistic and musical manuscript materials was left to his successors together. No music more recent than the 1440 s was added, whereas the material of the main corpus was expanded when Erasmus had returned to Munich. That both his successors were lectors at the Vienna convent in the 1460s, readily explains why the codex was returned to, or remained at, Vienna.

There is also strong evidence that the musical material itself was linked to Erasmus Gunther. The evidence is one of the unica, a two-voice mensural composition on the last folio, f. $164 \mathrm{r} .{ }^{30}$ The text is cancelled, but it is possible to transcribe most of it, which is as follows:

Vivat nobilis prosapie inclitus iudex Erasmus, francisci familie ${ }^{*}$ quia quisque* fidus meritus, Totum quod est si ${ }^{*}$ cernas ponit* ut $^{*}$ alter munificus ${ }^{*}$

Primogenitoribus mercantibus exivit.

Quemque francisce optime tuo munimine

fac tue gracie pariterque participem glorie. ${ }^{31}$

Long live the renowned judge, Erasmus, of noble descent, because of his merit (fidus meritus) for the family of St Francis [of Assisi]. [Line 3: uncertain] He abandoned his parents,

30 Facsimile in $<$ https://musical-life.net/mediengalerie $>$.

$31 \star^{\star}{ }^{\star}$ : uncertain readings. fidus: added above the line, perhaps replacing *quisque ${ }^{\star}$. 
merchants [to become a friar]. Dearest Franciscus, make him through your protection a participant of your mercy and equally of your glory. (Translated by the author)

Judge Erasmus is being praised by the Franciscan friars, who benefited as much as did the Augustinians, the Carmelites and the Dominicans from the agreement with St Stephen's in 1443. The common ground of Austin and Franciscan friars in this context was the University of Vienna. Some musician composed a fairly competent two-voice setting of this celebratory text; the piece was added to the collection but the text was then cancelled, whether by Erasmus himself (out of modesty?) or by a later owner (out of jealousy?). The musical and notational style of this piece are compatible with those of the younger section of the St Emmeram codex, of $c .1440-1443$ (see music example in appendix). Erasmus Gunther may have been a musician himself, perhaps an organist. While in Vienna he would have had contact with local organists, at the Augustinian house in particular, who gave him specimens of their musical exercises; others sent them to him in letter form. Yet, if Erasmus was himself a specialised musician, would he not have added more music after the 1440s? Perhaps he turned away from the worldly pursuit of music when he became a monastic reformer. ${ }^{32}$

Whether Erasmus was a musician or an amateur, the musical items may well have been assembled at Vienna in 1443 and perhaps on other visits of those years, which Erasmus must have spent at the Austin friary in the city.

There are many possible names we could give to Cod. 5094: in both its main part and its musical appendix it was an anthology, a zibaldone, a commonplace book or a vademecum. But the music collection also served its owner as a 'souvenir de Vienne': as an anthology of the varied skills of organists in sacred institutions of Vienna in the 1440s. The individual components are not the surviving fragments of one larger whole (disiecta membra), nor haphazardly assembled pieces from many larger entities, but interrelated examples of a collective art. That some of them are accidentally no longer complete in themselves, may make them unfit for re-performance, but does not delete their function of artistic (and didactic) testimonies. This anthology aids the remembrance of a personal past, and even illustrates a moment of musical history.

32 It seems that the original owner of the so-called Lochamer Liederbuch, Judocus von Windsheim, abandoned work on his music collection when he entered the Augustinian friary of Windsheim around 1460. See Salmen/Petzsch 1972 and Lewon 2018. 


\section{References}

Catalogus priorum provincialium Ord. Erem. S. Augustini per provinciam, Munich: Riedlin, 1729.

Crane, Frederick (1965), '15th-Century Keyboard Music in Vienna MS 5094', in Journal of the American Musicological Society, 18: 237-245.

Cuthbert, Michael Scott (2010), 'The Nuremberg and Melk Fragments and the International Ars Nova', in Studi Musicali. Nuova serie, 1/1: 7-51.

Fallows, David (1987), Dufay, London: J.M. Dent [revised paperback].

Göllner, Theodor (1967), 'Notationsfragmente aus einer Organistenwerkstatt des 15. Jahrhunderts', in Archiv für Musikwissenschaft, 24: 170-177.

Lewon, Marc (2018), Reworkings: Transformational Practices in Fifteenth-Century German Music, Ph.D. dissertation, Oxford University.

Mantuani, Josef (ed.) (1864-1899), Tabulae codicum manuscriptorum praeter Graecos et orientales in Bibliotheca Palatina Vindobonensi asservatorum, 10 vols, Vienna: Gerold.

Pietzsch, Gerhard (1971), Zur Pflege der Musik an den deutschen Universitäten bis zur Mitte des 16. Jahrhunderts, Hildesheim: Olms.

Ristory, Heinz (1985), 'Notationstechnische Modifikationen von Vokalvorlagen im Codex Vind. 5094 der Österreichischen Nationalbibliothek (Wien)', in Musica Disciplina, 39: 53-86.

Rumbold, Ian, and Peter Wright (2009), Hermann Pötzlinger's Music Book: The St Emmeram Codex and its Contexts, Woodbridge: Boydell.

Salmen, Walter, and Christoph Petzsch (eds) (1972), Das Lochamer Liederbuch (Denkmäler der Tonkunst in Bayern, N.F., Sonderbd. 2), Wiesbaden: Breitkopf \& Härtel.

Shields, Michael (2011), “'Hidden polyphony” bei Oswald von Wolkenstein. Der Reihen “Ir alten weib” (KI 21)', in Christoph März, Lorenz Welker, and Nicola Zotz (eds), 'leglicher sang sein eigen ticht'. Germanistische und musikwissenschaftliche Beiträge zum deutschen Lied im Mittelalter, Wiesbaden: Reichert, 131-147.

Strohm, Reinhard (1966), 'Neue Quellen zur liturgischen Mehrstimmigkeit des Mittelalters in Italien', in Rivista Italiana di Musicologia, 1: 77-87.

Strohm, Reinhard (1984), 'Native and Foreign Polyphony in Late Medieval Austria', in Musica Disciplina, 38: 205-230.

Strohm, Reinhard (1993), The Rise of European Music, 1380-1500, Cambridge: Cambridge University Press.

Van Biezen, Jan, and Kees Vellekoop (1984), 'Aspects of Stroke Notation in the Gruuthuse Manuscript and other Sources', in Tijdschrift van de Vereniging voor Nederlandse muziekgeschiedenis, 34: 3-25. 
260

Reinhard Strohm

Appendix
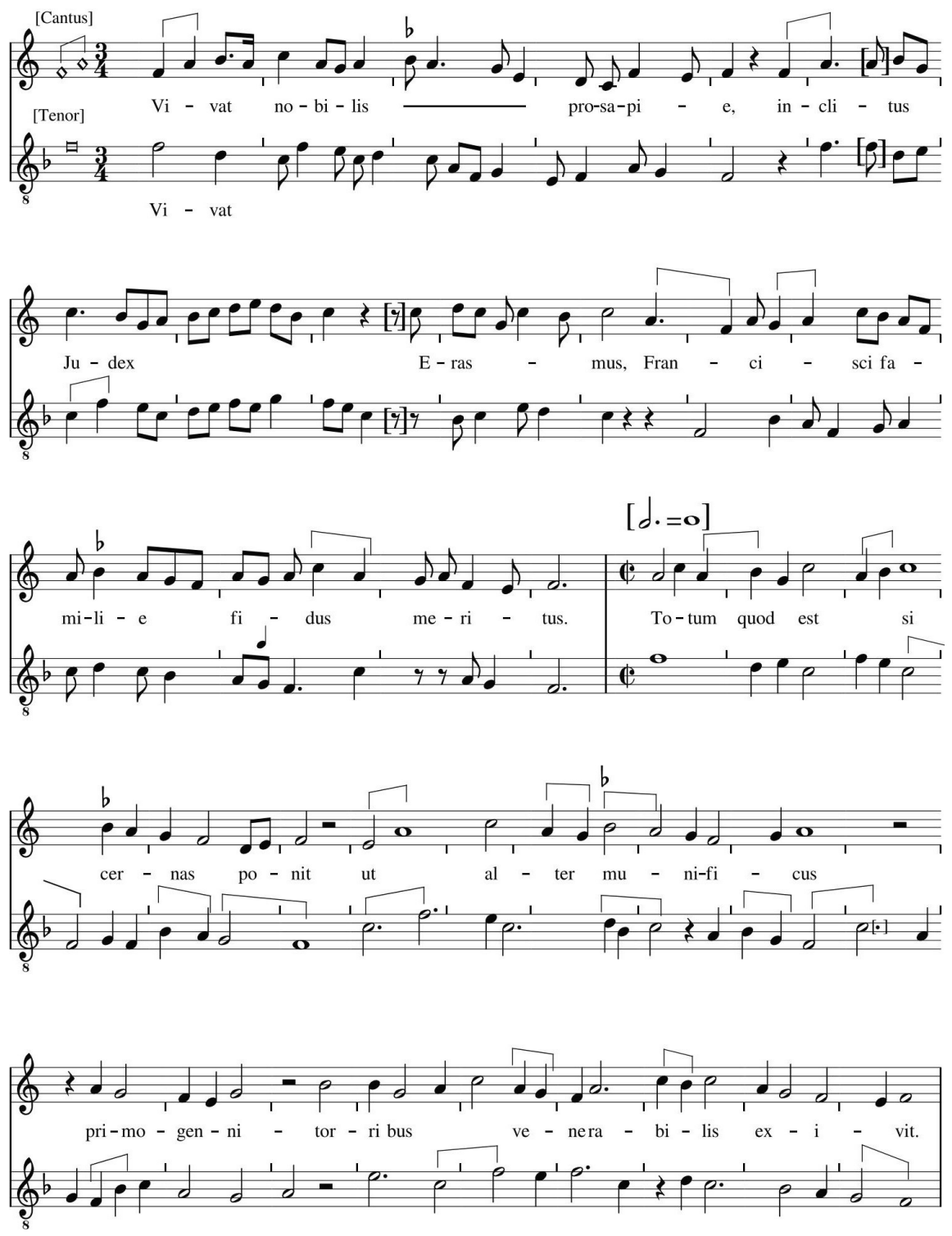

Music example: Vivat nobilis prosapie Cod. 5094, f. 164r. (Transcription by R. Strohm and B. Strohm, p. 1). 

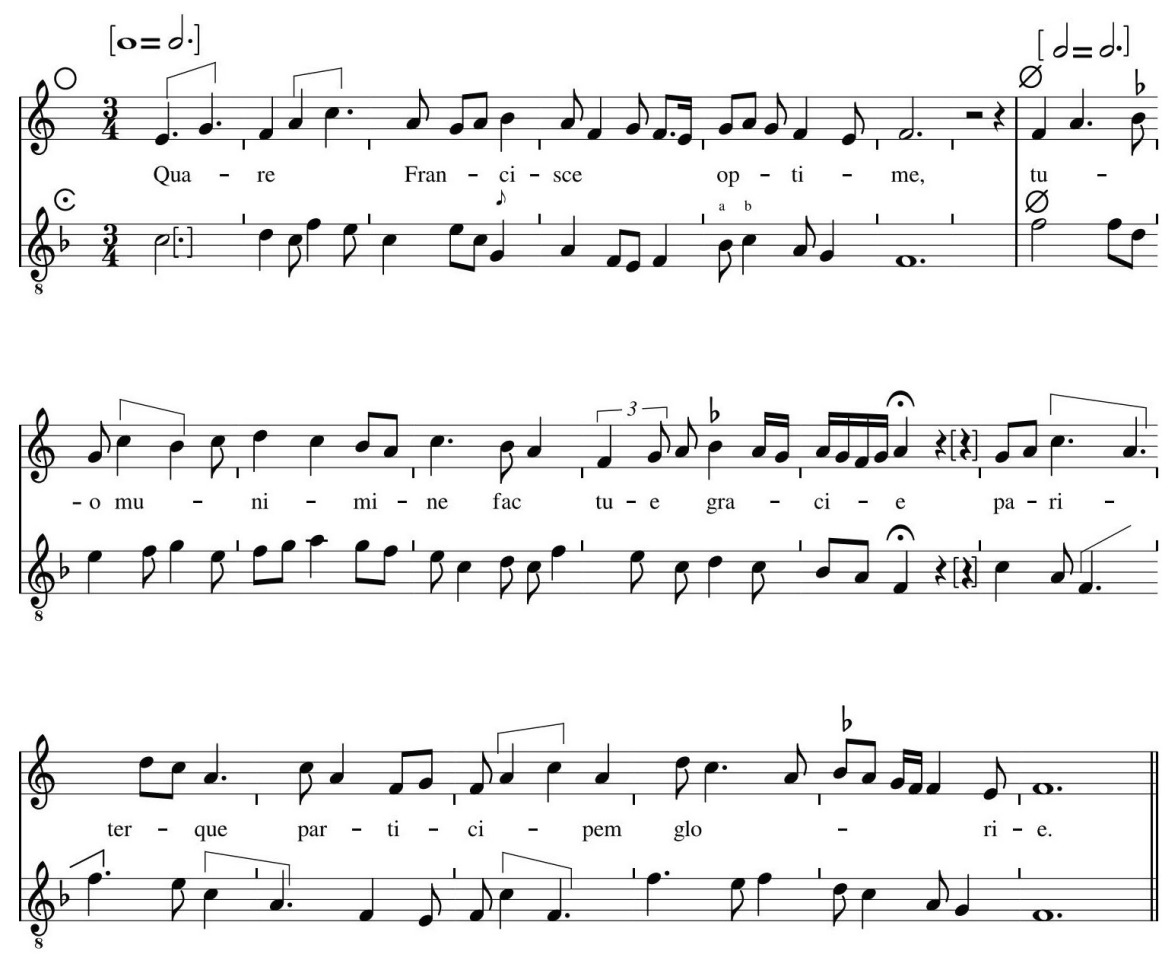

Music example: Vivat nobilis prosapie Cod. 5094, f. 164r. (Transcription by R. Strohm and B. Strohm, p. 2). 



\title{
The Unexpected Song: An Early Italian
} Vernacular Poem, a Neumatic Notation, and How to Detect Their Interrelationships in the Ravenna Charter

\begin{abstract}
In 1999, Alfredo Stussi discovered in Ravenna a love poem written on the back of a charter, now considered the oldest poem in an Italian vernacular. The charter containing it preserves also a series of signs written in adiastematic neumatic notation. The presence of fragmentary musical annotations raises the questions of whether the poetic text may have been set to music and, in such case, in what way. The essay examines how the arrangement of the neumes on the charter's verso follows the formal structure of the song and proposes a possible reconstruction of the original melody.
\end{abstract}

\section{Music written for a text?}

Twenty years after the publication of an authoritative study by Alfredo Stussi - which definitively brought to the surface an underground tradition of studies dating to Giovanni Muzzioli's work in the late 1930s - the importance for the history of Italian literature of charter 15518ter of the Archivio Storico Arcivescovile in Ravenna can no longer be doubted. ${ }^{1}$ This also became clear from the various studies and critical analyses concerning it that have since appeared. ${ }^{2}$

\footnotetext{
1 Stussi 1999b.

2 For the review of previous scholarship see Stussi 1999b, 1-2 and the respective footnotes. See also, Alfredo Stussi 1999a; Stussi 1998; Asperti/Passalacqua 2000; Castellani 2000, I, 524-536; Breschi 2004; Giunta 2006; Tomasoni 2005; Lannutti 2005.
}

Note: The present text is an updated revision of a contribution to the interdisciplinary seminar Tracce di una tradizione sommersa. I primi testi lirici italiani tra poesia e musica held in Cremona on 19-20 February 2004. The Italian version was published in Lannutti/Locanto 2005.

Ә Open Access. (C) 2020 Daniele Sabaino, published by De Gruyter. (cc) BY-NC-ND This work is licensed under the Creative Commons Attribution-NonCommercial-NoDerivatives 4.0 International License.

https://doi.org/10.1515/9783110717884-011 
On the back of charter 15518ter, a notarial document concerning a nunnery, slightly distanced from the conclusion of the canzone in lingua di si, Quando eu stava and, as far as the lower trimming allows us to gather, above the first verse of Fra tuti quî ke fece lu Creature, a scribe wrote down and later erased a series of musical signs, today almost illegible under natural light. ${ }^{3}$ Taken as a whole, the signs seem to indicate a complete composition, subdivided into sub-sections and marked by recurring patterns and melodic fragments. ${ }^{4}$

The coexistence of a literary and a musical text within the same document immediately raises a number of questions. The first and most obvious concerns the nature of the possible relation between verses and neumes: is the proximity of the two texts only factual, resulting purely from chance? Or does it amount to an integrated system of words and music, whose rationale, which cannot be recognised at first, could instead be decoded through adequate research? Surely, the latter is the most elementary question that must precede any serious analysis of the Ravenna charter. From the outset, Stussi himself was aware of the inescapability of this problem, and did not hesitate to commission from Claudio Gallico a Musicological note on the matter, in order to ensure that his enquiry was open to the entire range of problems raised by the charter. ${ }^{5}$ Gallico's verdict was a negative one: he believed that the 'musical fragment [...] does not seem to be related to the poetic text situated above it'. ${ }^{6}$ Gallico's opinion was in line with the idea of a complete 'divorce' between lyrical poetry and music in twelfth-century Italy, as posited some decades ago by De Bartholomeis, Contini and Roncaglia. Such conception had the obvious effect of decreasing greatly the musicological significance of the charter, which eventually lost any trace of singularity,

3 Note that the writing on the verso, the side concerned in our discussion, is inverted with respect to the pagina vendicionis transmitted on the recto.

4 Some musical signs that can be distinguished above literary text B - at least judging by what remains of them, after the damage inflicted by men and time to the lower edge of the charter seem also to be found in the second-last neumatic line of the 'complete' composition notated at the centre of the document: this fact (if it is not due to mere coincidences between simple cadential gestures) could lead one to postulate an operation in which elements were copied from one part to another of the same document - something meaningful for the interpretation of all of the texts found on the charter, as we shall see in the following discussion.

5 This was published as an appendix to Stussi 1999b, 50-51. See, in the same appendix, the Nota paleografica by Antonio Ciaralli and Armando Petrucci (Stussi 1999b, 43-49).

6 Gallico in Stussi 1999b, 51. This conclusion - all too readily accepted - was responsible for the complete oblivion which came over not only the problematic aspects, but also the very existence of the musical signs in parchment 15518ter within academic literature following Stussi 1999b, as well as in educational materials derived from such publication. 
becoming simply one of the many medieval documents emerging on an almostdaily basis from ecclesiastical and civic archives.

Nevertheless, at a closer look, such an emphatically negative response to the question about a possible relation between the poetic and musical text, not only transferred the onus of its examination to the separate domains of Italian philology and medieval musicology, but it also remained far from solving the many problems raised by the source. In fact, if the literary and the musical systems of the charter were entirely separate and self-sufficient, it would be all the more arduous to discuss the nature, genre, form and function of the musical annotation. It would also be rather challenging to account for the graphic elements and the orderly way in which the neumes are set out on the parchment. Furthermore, on the literary side, it would be hard to establish anything whatsoever about the possible relations (complementarity? integration?) that might exist between the texts referred to by Stussi as 'A' and 'B', that is, the canzone proper and the five verses Fra tuti quî ke fece lu Creature.

The complexity of the matter, and the conclusions that might be drawn, deserve therefore at least a second hearing; all the more so given that various elements are, in my opinion, anything but incompatible with the hypothesis of an actual connection between these texts and this music. These elements are:

1. from a general point of view, as mentioned above, the notational signs first handwritten and later erased above text B (Fig. 1) show features resembling part of the second-last line of neumes. ${ }^{7}$ If the trimming eliminated a considerable portion of the parchment as maintained by Stussi, based on what can be deduced from the recto (in particular the almost complete elimination of the noticia testium), it is reasonable to believe that the relationship between the erased neumes and the ' $\mathrm{B}$ ' verses was originally closer and more direct than it currently is (with the literary texts A and B now appearing to be completely detached from the musical text as a whole); ${ }^{8}$

7 See above, note 5. The parchment's trimming, I stress, allows us to grasp the similarities between some of the neumatic profiles, but does not permits us to definitively affirm or deny more extended or widespread correspondences. Nonetheless, for the reasoning we are currently putting forward it is sufficient to note the simple fact that text B too was associated - since the outset - with a musical notation.

8 Stussi 1999b, 4. 


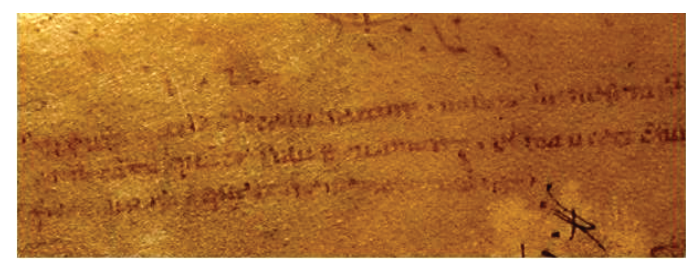

Fig. 1: The notational signs first handwritten and later erased above text B; $\odot$ Ravenna, Archivio Storico Arcivescovile.

2. from a musical point of view, the clear analogies in the melodic profile of the two neumatic sections placed one above the other in the second-last line of the musical annotation (Fig. 2) suggest that, instead of a transitory polyphonic bifurcation as Gallico postulated (which, as such, would not match any known written musical form), these are possibly two distinct endings of a repeated section of music..$^{9}$ That is, the two segments imply a first suspended conclusion, after which the same musical material is repeated from the beginning, finally reaching its ending - generally by way of slight melodic variations - in a more definitive and affirmative way. In other words, this feature would be an occurrence of what current semiographic conventions refer to as 'prima' and 'seconda volta' and that medieval musicology, adopting the terms used in contemporaneous treatises, usually defines as ouvert and clos (aperto and chiuso in medieval Italian, apertum and clausum in Latin). ${ }^{10}$ Indeed, such melodic profiles are not only typical, but also constitutive of the (later) formes fixes;

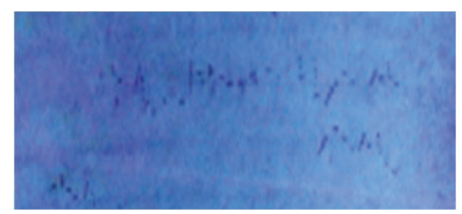

Fig. 2: Two neumatic sections placed one above the other; (c) Ravenna, Archivio Storico Arcivescovile.

9 'Al termine della seconda e della terza linea è evidente la divisione del disegno in due semicori, i quali procedono simultaneamente' ['At the end of the second and the third lines, there is a clear division of the melodic profile into two semi-choirs, which proceed simultaneously'], in Stussi 1999b, 51.

10 See Rohloff 1943, 53. See the entry 'sub voce' in The New Grove (Sadie 2001, vol. 18, 818-819). Hereunder, we will largely use the French terminology. 
3. lastly, again from a musical point of view, the vertical strokes seen in the first and third lines seem to designate well-defined musical sections (Fig. 3). As we will see, not only would such structural sense not be contradicted by a correlation between music and poetry, but it would be made on the contrary all the more significant. ${ }^{11}$
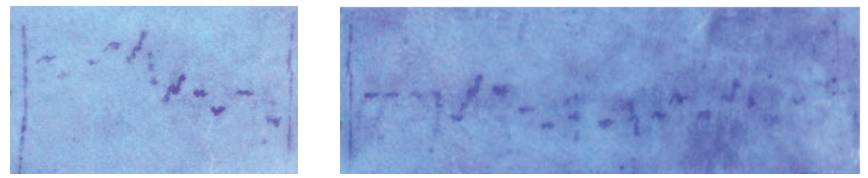

Fig. 3: Vertical strokes as possible marks of defined musical sections; ( Ravenna, Archivio Storico Arcivescovile.

While these are indeed enticing observations, it might be possible to object that they are still overly 'instinctive' to be somehow suitable for resolving the issue. Thus, in order to give a solid and positive consistency to the impression they elicit, we would require at least one clear and unequivocal piece of evidence, ascertaining once and for all that a certainly autonomous section of music contains a number of neumes compatible with an equally autonomous section of the poetic text. Given the conventions of troubadour and trouvere songs, such a section should be at least one verse. As the verses of the canzone are decasyllables, we may assume that, as mentioned above, a number of neumes compatible with a section of the poetic text would mean, at least, ten neumatic signs. Fewer signs would prevent the revelation of any correlation between music and poetry, unless one allows for a single multisonic neumatic sign to be subdivided over more than one syllable, while a higher number can simply imply the presence of one or more melismas. ${ }^{12}$ Naturally, the conditio sine qua non for this type of

11 Gallico, instead, believes that the strokes fall into the domain of practice rather than structure, and could mark either 'due interpunzioni al canto [two cases of articulation within the song] (suspiria, pausationes, respirationes)', or the boundaries of an 'intervento responsoriale [a responsorial passage]', the latter meaning an alternation between solo and choral passages, as would certainly be habitual in religious and ceremonial music, to which Gallico ascribes - even if only 'genericamente [generically]' - the morphology and function of the musical figures on the charter. See Stussi 1999b, 51.

12 A general consensus on this matter has been reached in musicology. The only discordant opinion - formulated pro domo sua, since it represents the necessary precondition for his highly singular rhythmic interpretation of Limousin and Compostela polyphony - is Karp 1992. Karp maintained that it is possible in general (and systematically in the repertory he examined) that 
verification would be the segmentation of the notational continuum into discrete, meaningful, 'certainly autonomous' sections.

A brief glance at the neumes notated in the central area of the parchment (Fig. 4) allows us to readily recognise ten segments of varying length and layout: ${ }^{13}$

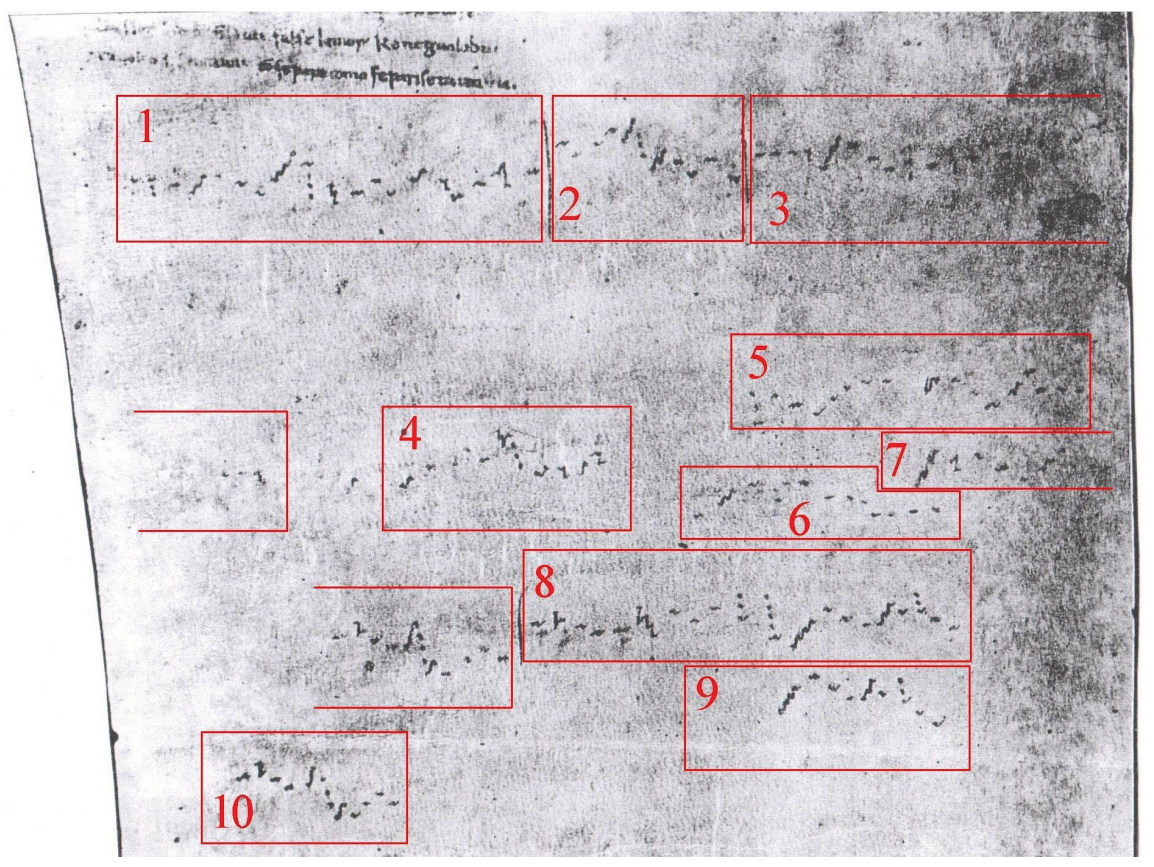

Fig. 4: Sectional grouping of the neumatic notation.

Nevertheless, neither the simple a capo, nor the physical distance between the segments can be positively considered a priori as definite indications of boundaries between sections. For now, it would be thus preferable to limit ourselves to considering only those parts of the text that the scribe explicitly isolated from

the appearance of a new syllable coincides not with the first but the last sound of each neumatic group.

13 The image is a digital enhancement by the author of this chapter and Massimiliano Locanto of Plate 5 published in Stussi 1999b, 56. Note the equivalence of the number of notational segments and with that of the verses in each stanza of Quando eu stava. The pertinence of this fact to the line of research we are presently pursuing is however simply 'evocative', thus it should not be taken into consideration for now. 
what preceded and/or followed by using the aforementioned vertical strokes, the only graphic elements in the charter that unquestionably indicate a deliberate and intentional separation. Among the ten units identified, the only one that fully meets this requirement is the second, isolated by a vertical line both to the right and to the left:

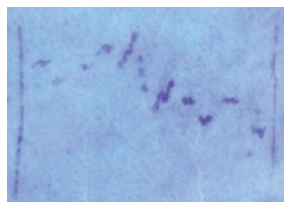

Fig. 5: Neumatic section 2, enlarged; (c) Ravenna, Archivio Storico Arcivescovile.

This section, as can be seen in Fig. 5, consists of precisely ten neumatic groups, some representing a single sound, some more than one. As this number fulfils the preliminary requirement to be met before continuing our enquiry, let us now suppose at least as a working hypothesis that the text(s) and the music of the Ravenna charter are actually linked to one another. This will allow us to direct the inquiry towards two complementary but distinct objectives: on the one hand, to undertake a reconstruction of the melodic profile and on the other, to ascertain if and how this melodic profile can accommodate - and re-express, with its own structures - the poetic structure of the canzone. The deciphering and interpreting of the notational signs necessarily acts as the first phase of research and as a preparation for the second phase of connecting the various melodic sections to the subdivisions and verses of the poetry. I will now present the two phases in order, starting by the charter's semiography and its neumatic code.

\section{A hypothesis for a melodic reconstruction}

\subsection{Type of notation}

Before proceeding with a detailed melodic interpretation of the signs on the Ravenna charter, a few moments should be devoted to examining the type of notation on the charter. ${ }^{14}$ This will allow us to expose once and for all the nature

14 For an in-depth discussion of the matter see Locanto 2005 and Rosa Barezzani 2005. 
of the issues at stake, and the kind of problems facing us both immediately and further on in the analysis.

The main features of the notation are:

1. a general in campo aperto layout, but with a clear diastematic intention;

2. a rather freely-traced ductus;

3. basic morphological features resembling, but not identical to a graphic koinè derived from the Messine (Lotharingian) tradition, mixed at times with more decidedly Italian notational traits.

The first of these three features combines the absence of any material line whether traced in dry-point or ink, around which to organise the notation of the melodic pitches, with a patently scalar layout of the signs, both adjacently and above all over longer distances. This approach differs from that of most notations in campo aperto, especially earlier ones, that approach the spatial organisation of the signs by placing the beginning of each neumatic element at the same distance from a reference line, whether real - generally consisting in the straight line provided by the ruling of the literary text - or virtual.

The second feature is evident almost at first sight, given that the notator - a scribe who certainly had some experience in the writing of music, even though his degree of professional knowledge in the field cannot be established - did not reserve any calligraphic attention for the overall layout of the neumes. At a slightly closer look, moreover, one may detect many signs of haste, e.g. functionally identical neumes - for the most part resembling the Lotharingian uncini - may appear in different sizes (Fig. 6), or of inconsistency, e.g. when the same neumatic sign seems to take on a variety of graphic forms with no apparent difference in meaning, as for the three clives in Fig. 7.

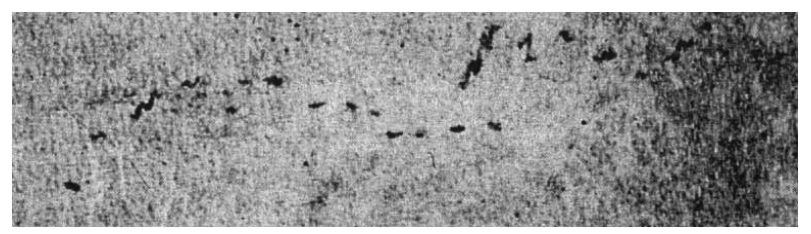

Fig. 6: Different size of the same neumatic form; @ Ravenna, Archivio Storico Arcivescovile. 

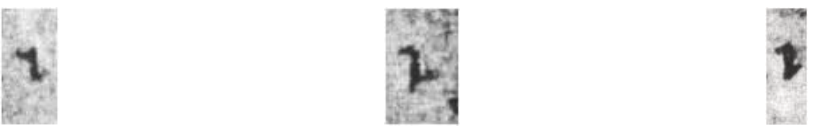

Fig. 7: Different shape of the same neumatic form; @ Ravenna, Archivio Storico Arcivescovile.

The third feature is the coexistence in the charter's notation of a style of music writing similar to the one originated in the Lorraine region in the shape of the monosonic uncini, alongside graphic conventions frequently found over wide areas of Italy, such as the groups of ascending notes whose elements are graphically joint - generally called gradata in Beneventan musical palaeography (Table 1). ${ }^{15}$ Since a detailed study would be too articulated to be presented as part of this paper, I will limit myself to noting it as an undisputed fact, referring to the other essays that have appeared on the topic for an in-depth examination. ${ }^{16}$

Table 1: The notation of the Ravenna Charter.

tractulus
(uncinus)
$\begin{aligned} & \text { punctum } \\ & \text { and (livis (leuble clivis (right) }\end{aligned}$
$\begin{aligned} & \text { scandicus (left) } \\ & \text { and } \\ & \text { four-note scandicus } \\ & \text { (right) }\end{aligned}$

15 On the gradata, see PM XV, 132, 158.

16 See Locanto 2005, 138-146 and Rosa Barezzani 2005, 205-212. 


\subsection{Diastematic conjectures}

One cautionary note is necessary here before moving on to possible melodic interpretation of the neumes. A notation in campo aperto, even when the neumes are carefully placed diastematically, remains a notation that does not allow us to formulate definitive judgements on every detail of the melodic profile it expresses. The interpretation proposed here, even though pondered at length and supported, in my opinion, by a high degree of reliability, remains a hypothesis, and as such susceptible of being refined and perfected, above all in the reading of single neumes. ${ }^{17}$ This is due to one reason that I will mention shortly, as well as to the concrete difficulties that affect the reading of some parts of the musical text. For example, in the right margin of the first line and the zone immediately beside it, the almost complete transparency of the ink and the impurities of the hair side of the parchment make the single signs very hard to decipher.

With all of the caution required by the nature of the object, we shall thus attempt a melodic reading of the neumatic signs. I shall begin with the following considerations:

1. the notator, as mentioned above, did not trace a line around which to set out the neumes; the very concept of 'diastematic intentionality', which I have already referred to, however, implies that the signs are organised around a line that is, at least, virtual;

2. through the direct observation of the charter it was possible to infer that, in order to picture such a virtual line, the scribe took advantage of the lines of texts showing through from the pagina venditionis that appears on the recto: the text thus becomes a sort of 'virtual dry-point line', perfectly suited to provide a reference for the writing of the melody;

3. once it has been established that the notation is spatially organised around a precise reference point, it becomes possible to gauge the degree of regularity with which the notator proportionally set out the various signs while representing the scalar movement of the melody. This regularity proves to be surprisingly consistent over larger distances within the single lines - as could be verified both de visu, and by digital enhancement of the charterand only slightly more ambiguous on the level of successive stepwise movements, especially when they occur within a single neumatic sign. (This

17 See below, § 2.4. 
is neither surprising nor anomalous, considering the requirement for tying together the various strokes that constitute a sign).

On the basis of these premises and of the following equivalences between sign and sound, listed according to the table of neumes explained above, it is possible to obtain the following diplomatic transcription of the melodic line (see Ex. 1 below). ${ }^{18}$

In order to complete the reconstruction, all that is left is to establish the pitch of the reference line - the 'virtual dry-point line' - which will allow for a diastematic reading of the single neumes. This pitch, I maintain, can only correspond to the note $F$ - in the medieval sense of the term - for at least two converging reasons ${ }^{19}$ :

1. the presence, in the notation, of signs placed at the same height as the reference line, which seem to be melodically similar to the distropha and/or the bivirga of the St Gall tradition which, as is well known, is placed only on the degrees above the semitone, and whose position normally corresponds to the reference line $e^{20}$;

2. melodic and modal incongruities which would arise in case of other pitch attributions, e.g. if the melody were to be graphically centred around the pitches $G$ or $A$ it would produce frequent tritonal circuits (which could be corrected per be molle; a note that would, anyway, alternate with the be durum in an absolutely irrational way); or, if graphically centred around $E$ or be durum, would contradict the previous observation.

We can thus disambiguate the previous transcription by adding a clef that defines pitches and introduces definite intervallic relations (see Ex. 2 below).

18 Locanto 2005, 134. In the transcription, the slurs above the notes indicate the single neumatic elements on the charter.

19 That is, designating an interval within a hexachordal reference system and not referring to an absolute pitch.

20 See Rampi/Lattanzi 1991, 463. 


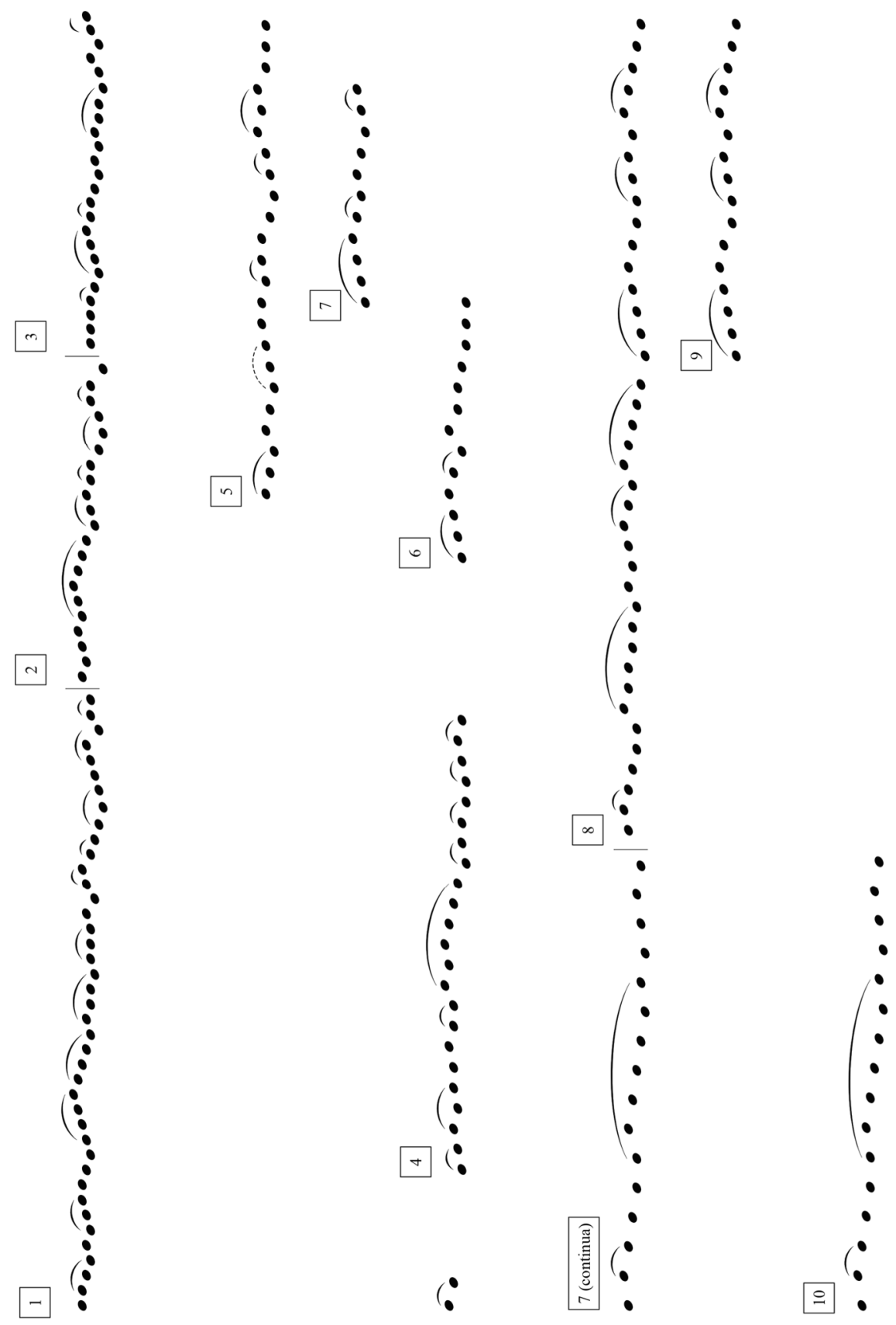

Example 1: Diplomatic transcription of the melodic line. 

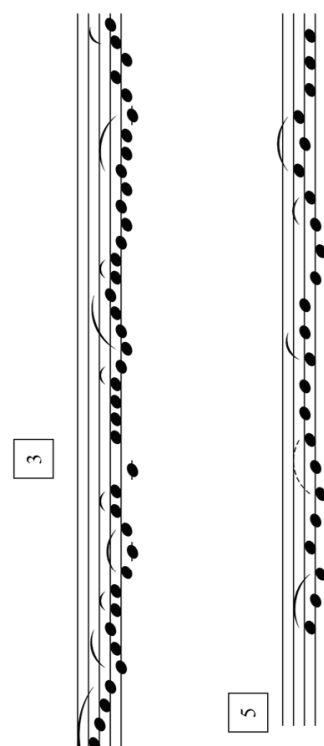

$\sim$
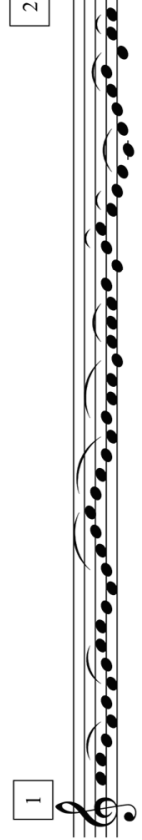
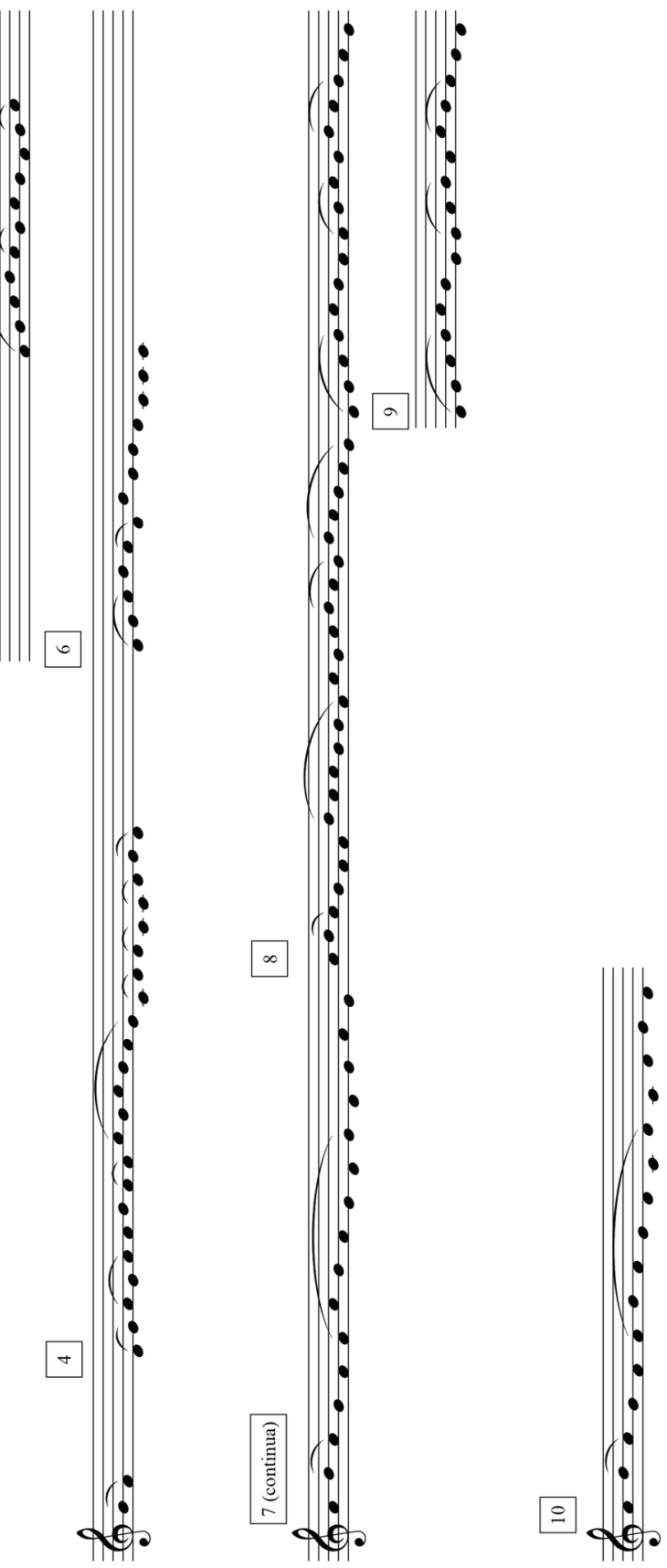

Example 2: Transcription with definite pitch. 


\subsection{Subdivision into sections}

The layout of the music in the previous example intentionally reproduces - in line with the motivations put forward in $\S 1$ - the distribution of the music as it appears on the charter. To refer the melody to the literary text, nevertheless, it is indispensable to define as precisely as possible the limits of each section, in order to obtain homogeneous units for the comparison between the musical and poetical contexts. After an attentive recording and examining of all the manuscript's details that may be relevant to our aim (e.g. vertical strokes, a capo, intraneumatic spaces), it seems possible to state that:

- sections 1 and 2 do not raise any particular problem, since the vertical strokes in the first line are more than sufficient to mark their respective conclusions;

- section 3 begins in the first line of music and ends with the neume seen at the start of the following line; that this is the case can be deduced from:

a. the presence, at the end of the line, of the sign known as a custos, which ordinarily anticipates the first pitch of the next line, and that in the Ravenna charter seems to be used only when a section does not come to a close within the end of the line but continues in the line below without interruption;

b. the considerable gap left (intentionally ${ }^{21}$ ) by the notator between the first neume of the second line and the neumatic groups that follow;

- section 4 is detached in the same way from what follows by a considerable blank space;

- section 5 is made up of, and comes to an end with, the set of neumes in the upper part of the second half of the line, and the fact that this line's limit cannot be breached is proved by the absence of a custos $^{22}$;

- section 6 is also notated halfway through the second line; it is a natural continuation of section 5, owing to the melodic rhyme given by the four repeated notes, and necessarily precedes section 7 , because the charter's notational layout does not contain neumes to be sung in a direct melodic sequence that are placed closely one above the other $;^{23}$

21 A morphologically identical neume, placed at the same height as the neume that opens the fourth section, can in fact be seen just to the left of the 'true' beginning of the section: this fact, in my opinion, not only does not invalidate the meaning of the non-notated space as a separation, but validates it. The scribe, even while having already notated the pes that begins the fourth unit, eventually felt it was the case to interpose even more 'empty space' between the sections (later forgetting to erase the neume that was no longer required).

22 Verified both directly on the parchment and through enlargements of digital reproductions.

23 The beginning of section 7 lies, in fact, slightly to the left of the last note of section 6 . 
- sections 7 and 8, lastly, are much more articulated and complex than could possibly appear at first. Section 7 begins with the middle group of the aggregation of neumes on the second line (with its beginning placed slightly above the end of section 6); the custos therefore informs that it continues on the third line, and the vertical stroke (just as was the case in sections 1 and 2) marks its endpoint. Section 8 begins after the stroke and is clearly binary, having a twofold conclusion, one ouvert and one clos, notated with extreme care one above the other, as mentioned in $\S 1$. It is evident, however, that the short group of notes contained in the fourth and last line of music consists of the same number of notes and the same neumatic progression as the segment which, in the third line, precedes the dividing line. This disposition, in my opinion, represents the scribe's intention to notate, in an abbreviated form, another ouvert/clos repetition: a repetition that during performance naturally recommences from the beginning of the section and proceeds, at the appropriate moment, to the seconda volta. The fact that this seconda volta is not notated vertically (as in section 8), but placed at the end of the piece can only imply a performance indication, i.e. that the sections are to be sung in the following order:

a. firstly, the melody of section 7 with its open cadence (prima volta: $7 \mathrm{a}$ );

b. then section 8 , to be sung twice, consecutively: the first time with its ouvert ending (8a) and the second with the clos (8b);

c. finally, the repetition of section 7 , sealed by its final clos (7b).

A well-defined musical structure thus emerges, to which we will return when discussing its correspondences with the poetic structure of the canzone. For now, let us limit ourselves to visually summarising its constituent elements in Fig. 8. 


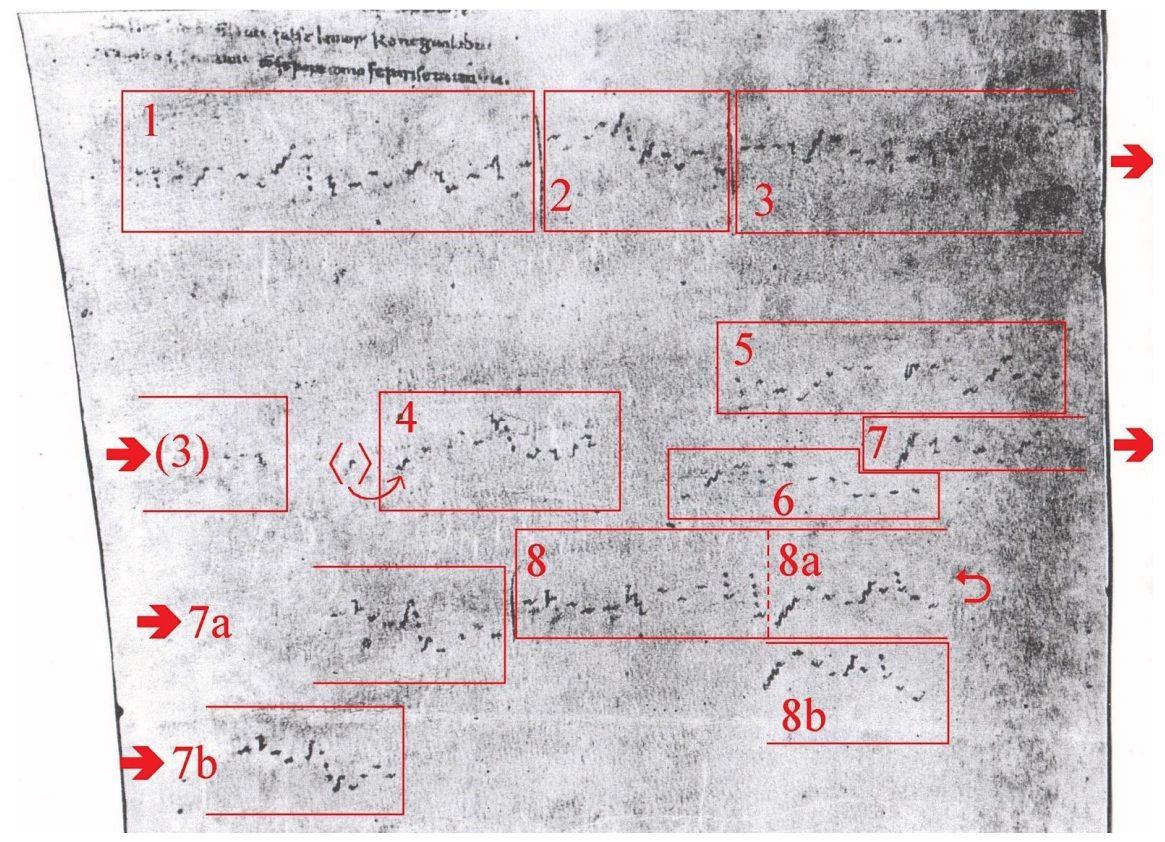

Fig. 8: Continuity and discontinuity of musical sections between lines; @ Ravenna, Archivio Storico Arcivescovile.

\subsection{Melodic-structural transcription and relative observations}

Based on our previous observations, we can further refine the melodic transcription given in $\S 2.2$ by subdividing the notational continuum in such a way as to highlight textual repetitions and recurrences. Formally significant, these instances are also noteworthy since they mark the composition's structural cadences and define, along with the vocal ambitus and the recurrent pitches, the modal region to which the melody is to be ascribed and checked against (Ex. 3). 
1

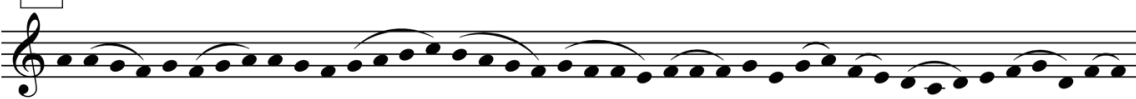
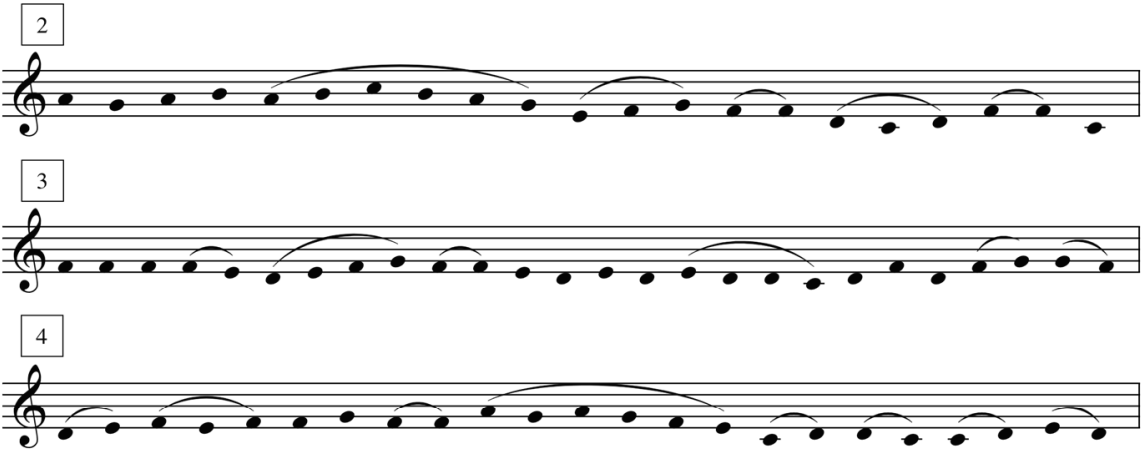

5

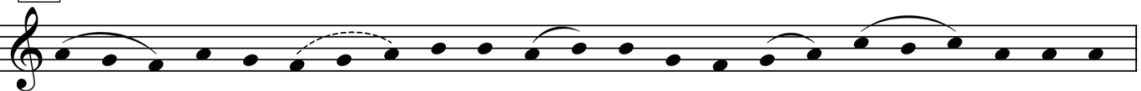

6

2

$7 \mathrm{a}$ (ouvert)
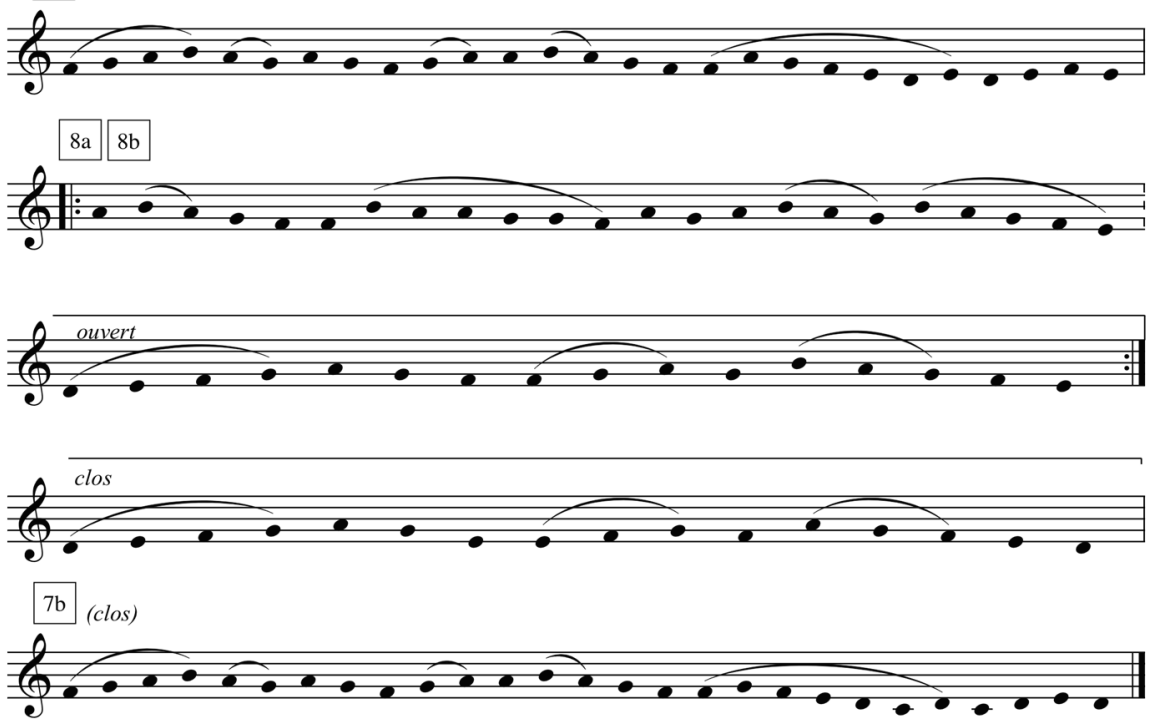

Example 3: Melodic-structural transcription. 
Regardless of any comparison with the features of liturgical, especially trope melodies, and with the particular constructive and formal aspects of the secular repertory, ${ }^{24}$ the conjectural reconstruction of the Ravenna monody shows a remarkably coherent melodic profile in itself, as well as compared to the parameters of melodic conduct of the time. It is noteworthy in the following respects:

1. the precision with which the mode is calibrated, corresponding to a predominantly authentic protus and with an appropriate initial emphasis on the repercussio;

2. the well-considered alternation in the melody's driving movements, which highlights, in a balanced manner, at times the upper and at times the lower area of the modal gamut;

3. the conclusive cadence on the modal final, regularly constructed with an adequate and contrasting use of the subfinalis;

4. the ending of the ouvert degree above the final, as is frequent in the intonation of poetic texts (Ex. 4).

24 For which I refer again to Locanto 2005, 152-156. 
1

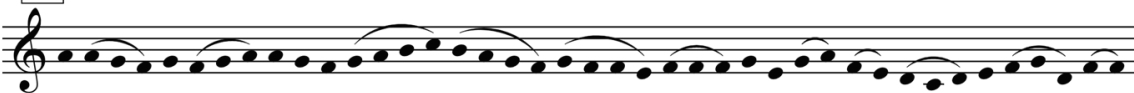

2
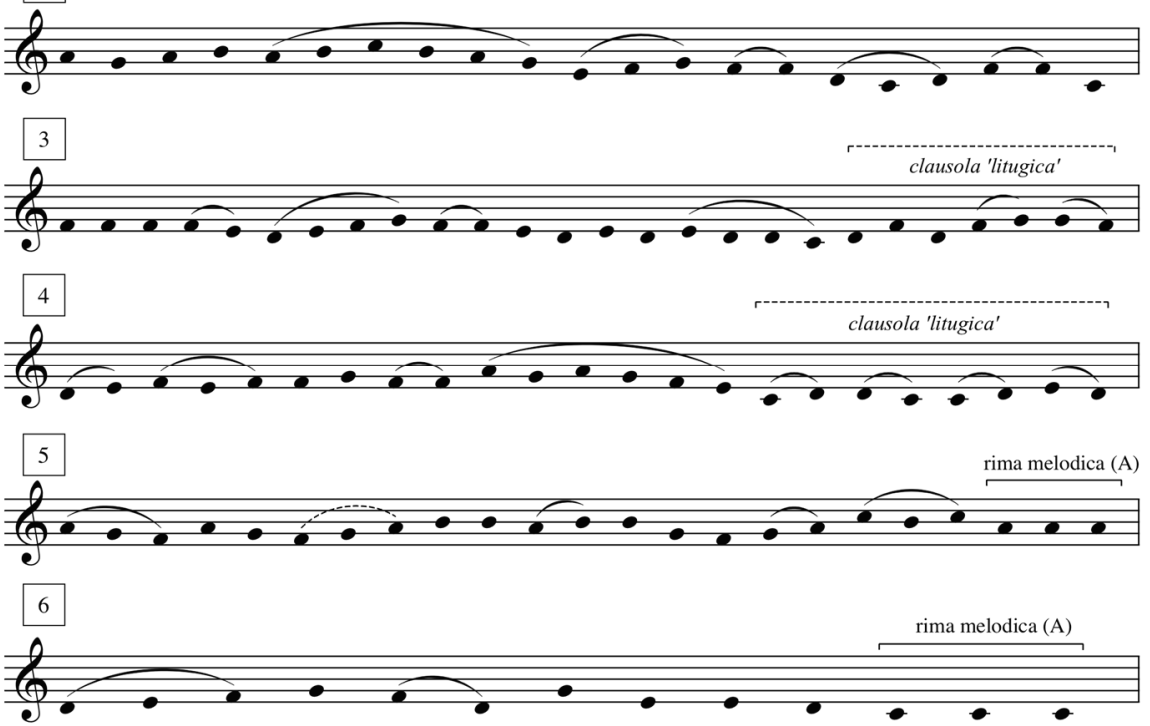

$7 \mathrm{a}$ (ouvert)

rima melodica (B)
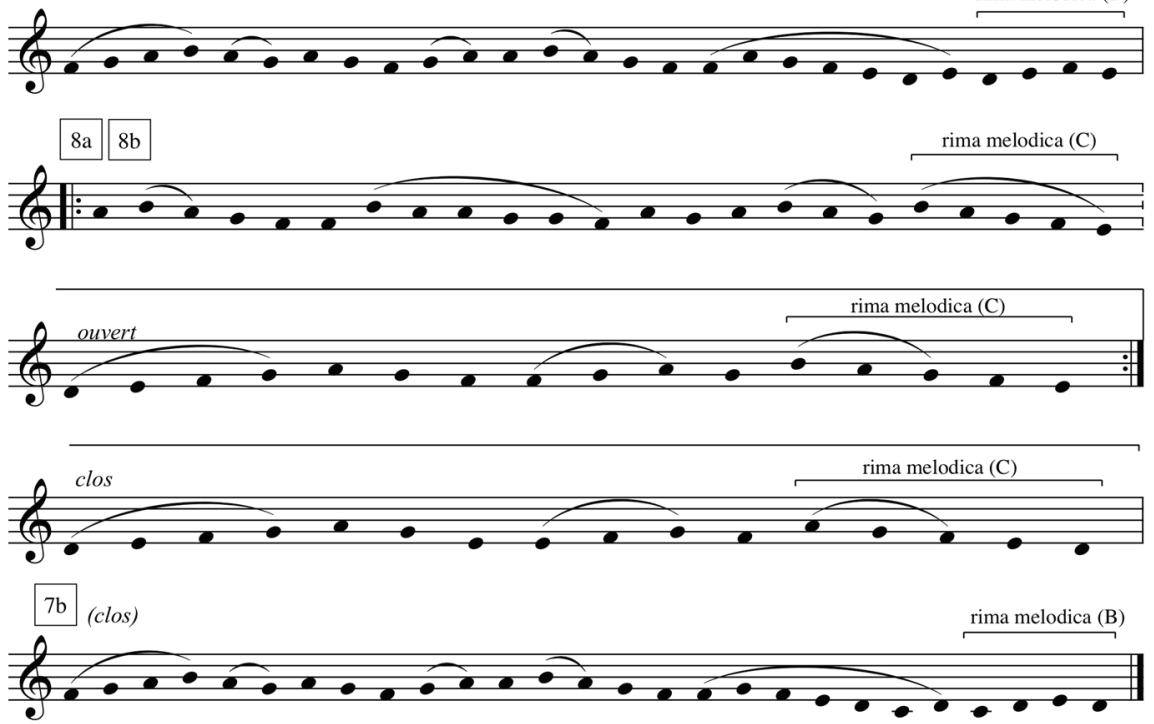

Example 4: Refined melodic-structural transcription. 
The agreement seen between elements situated on different musical and conceptual levels cannot be a mere coincidence, nor can the composition's internal coherence be thought to derive in any way from a fortuitous, albeit fortunate, excess of editorial serendipity. Maintaining that the critical reconstruction developed hereto is fundamentally reliable, it is not tantamount to declaring that some aspects of our reconstructed reading cannot be improved. For example, it is not in the least possible to rule out a different interpretation of some of the neumes, something which on the contrary, in more than one case, is related to the technological progress made in conserving and restoring antique documents. ${ }^{25}$ Nor can it be excluded that a few singles notes might be more precisely diastematically defined (the $G$ that in the first section follows the tristropha, for example, might well be read as another $F) .{ }^{26}$ That which cannot be invalidated by any possible improvement - and I believe I can state this without contradicting the premises accepted as of the outset - concerns instead the piece's overall outline in the form and the layout we have presented in the last few paragraphs. ${ }^{27}$

That being said, we are ready to proceed from the melodic reading of the neumatic signs to the fundamental task at hand: providing indications as to the relation between musical structure and poetic structure.

\section{Musical structure and poetic structure}

\subsection{The correlation between neumes and syllables}

Before attempting to superimpose poetry and music verse by verse and section by section, however, we must reflect for a moment on the rationale that governs

25 In section 2, for example, the third-last group could correspond to a simple uncinus $\mathrm{D}$, rather than to a porrectus D-C-D; and it is perfectly possible that a more advanced digital enhancement than the one presently available will reveal that a few signs interpreted by our transcription as distrophae are actually to be read as more modest monosonic uncini.

26 A different problem is how to consider many of the $B$ s in the melody, i.e. whether they are to be sung as be durum or be mollis. In the final draft of the transcription, the loci where, in my opinion, it makes sense to raise the question are marked by a flat sign in parentheses above the staff, as is customary in modern editions of early music. Each of them, however, serves more to signal the problem than to introduce a necessary call for a single solution which, in any case, would not truly belong to the realm of textual reconstruction, since neither of the two inflections puts into question the correctness of reading the pitch $B$.

27 For an extensive list of instances where the reading is questionable and/or particularly problematic, see the critical commentary which follows the edited musical text. 
the correspondence between syllables and sounds within each identified melodic unit. In the majority of these, in fact, the number of neumatic elements exceeds, by a little or by far, the quantity of syllables available: therefore, the possible placement of melismas, covering from two to $n$ neumatic elements has to be postulated. ${ }^{28}$ What principles, then, can regulate the subdivision of the syllables of a verse among the single neumatic elements? Given the chronological period in which the piece was notated (or composed), and considering the melodic movements that distinguish it, I believe that such principles can be deduced from two semiographic phenomena, well known from the musicological literature on Gregorian chant: 1) the so-called coupure neumatique ('neumatic articulation'), and 2) the progressive disuse - and, from a certain moment on, the definitive graphic disappearance - of special neumes characteristic of the oldest notations (appended strophae, oriscus, trigon, etc.) ${ }^{29}$

The latter, as is well known, are peculiar signs with which numerous adiastematic notations represent on parchment certain elements of performance practice, or suggest - even within the system's lack of diastematic indications obligatory melodic conducts, or recurrent intervallic movements. Musical palaeography has long observed that the evolution of diastematic notation, as well as other musical factors, led to the gradual disappearance of these mnemonicinterpretative signs. Clearly, such evolution did not mean that the sounds represented by those signs fell away, but were progressively transformed into more 'ordinary' musical graphemes. It is therefore possible that isolated notes within a melisma, or at the end of a neumatic group, do not amount to entirely autonomous neumes, but simply represent the 'full' rendering of signs that would once have been notated in those 'special' graphic forms. Therefore, these signs may not necessarily - often cannot - have a syllabic value, and must be read as continuations of the preceding group(s).

All the more important, and with a much wider application in the present context, is the earlier phenomenon, present in those notational families that gave the highest degree of attention to all dimensions of the performance of liturgical monody, known as 'neumatic articulation', the graphic representation of the gesture carried out by scribes who 'raised their pen' after a rhythmically and/or

28 I use the expression 'neumatic element', rather than simply 'neume', because the latter term refers habitually to the entire set of sounds sung to one syllable, which can be graphically subdivided into lesser units.

29 For an overall illustration of these, see Rampi/Lattanzi, 353-408, 474-488. 
structurally conspicuous sound. ${ }^{30}$ Arguably, this particular musical nuance could not be better highlighted graphically than through emulating - 'putting into ink' - the chironomic gesture of conductors, who would stop their hand to make the singers hold a note, before setting into motion once again the rhythm and flow of the melody. ${ }^{31}$ This sort of neumatic 'cut' does not normally allow for any syllabic articulation, and, once again, indicates a prolongation of the syllable sung before it. The principle of neumatic articulation can also be applied to more than one consecutive sound, at times breaking down the entire neume, as can be seen in the second syllable of the following example in which there is an equal number of neumatic elements and sounds: ${ }^{32}$

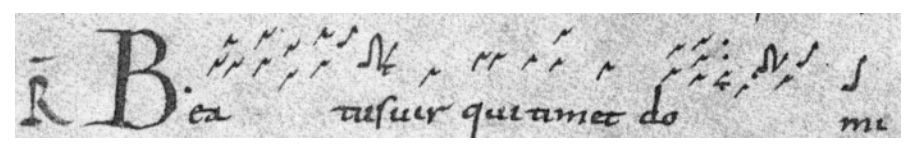

Fig. 9: 'Beatus' taken from f. 29 of the antiphonale missarum, Laon, Bibliothèque municipale, MS. 239 (facsimile edition: $P M X)$.

In much the same way, it is relevant to our study when the notation introduces a graphic separation imposed by the support or the writing tool, even thought it had no significance for the rhythmic interpretation of the melody. ${ }^{33}$

By gathering all these possible instances into a single system, it is possible to establish, for example, that section 3 as well consists of ten neumes, in that the first twelve notes are grouped together within a single neume, sung on a single syllable. This is due to the fact that:

a. the first three monosonic notes can be considered a trivirga; $3^{34}$

b. the two following groups imply an articulation of the low pitches, rhythmically neutral;

30 In later notations, the articulation can also be a secondary consequence of the lesser usage or disappearance of the special neumes mentioned above.

31 On the chironomic appearance of the oldest notations, in the St Gall tradition in particular, see the classic text by Cardine 1968, 4-5.

32 Between the ninth and the tenth sound in the melisma corresponding to 'domi[num]', on the same line, one can instead observe an articulation followed by a neumatic group whose elements are joined together.

33 For a typology of both categories, see Rampi/Lattanzi 1991, 338-346.

34 See Rampi/Lattanzi 1991, 496-500. 
c. the last three sounds - two monosonic ones followed by a downward inflection - can be considered to be the equivalent of the directional melodic movement notated as a trigon (or pressus maior) in St Gall manuscripts, here written out in full: $:^{35}$

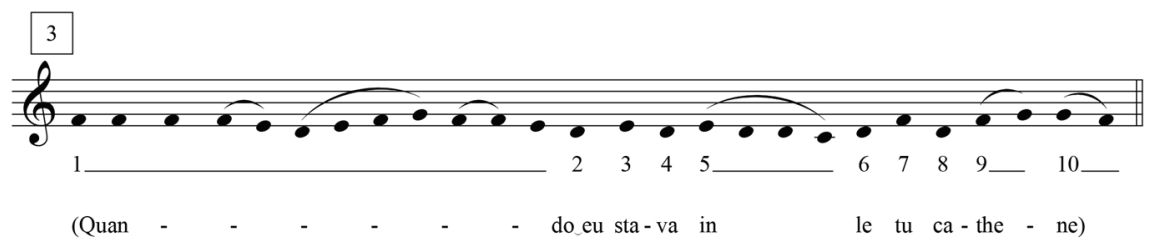

Example 5: Possible correspondence between neumes and syllables in section 3.

Therefore, the correspondence between neumes and syllables in sections 1-7 takes on the configuration shown in Example 6 (detailed motivations are provided in the critical commentary below): ${ }^{36}$

35 In the example I have purposefully placed the first verse under the notes, since the structural symmetry between verses and sections has not yet been verified.

36 I have not taken into consideration section 8 here, so as not to introduce propositions pertaining to the next paragraph ahead of time. 

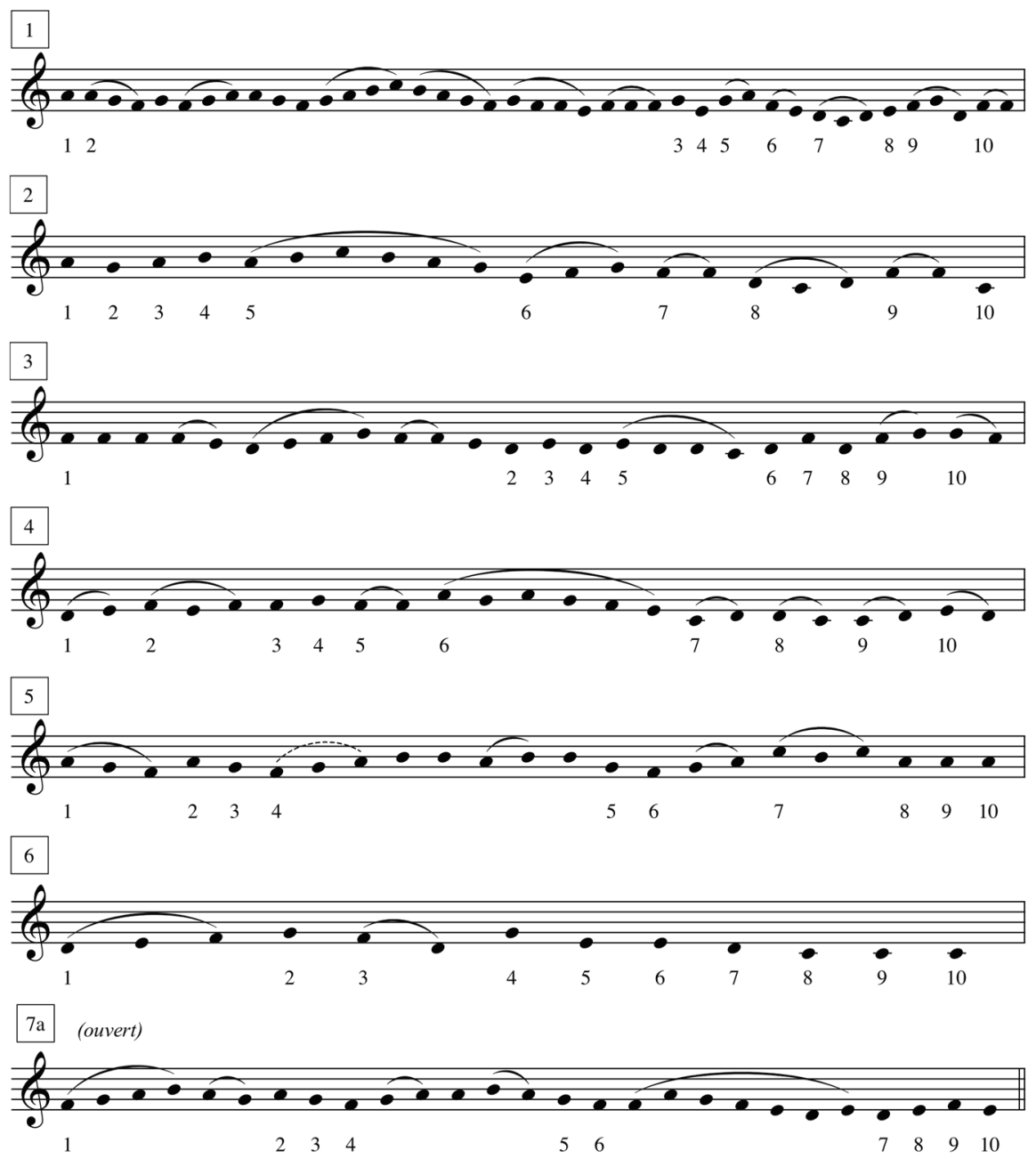

Example 6: Correspondence between neumes and syllables in section 1-7.

\subsection{The coordination between music and poetry}

From the notational dynamics we discussed so far, it has become clear how a text can plausibly be combined with a melody when this features a higher number of sounds than syllables. With the long-standing assumption that each section of music provides the intonation for no more and no less than one verse, we can finally begin to deal with the overall correspondence between poetic structure 
and musical structure, investigating how the verses of the canzone are distributed with respect to the subdivisions of the music. An initial hypothesis for this relation ensues almost directly from an observation that the number of verses in text A matches the overall number of musical sections. The two could therefore be paired according to the following sequence:

Table 2: Text and music coordination - hypothesis 1.

\begin{tabular}{lll}
\hline verses (text A) & $\begin{array}{l}\text { rhymes of the } \\
\text { literary text }\end{array}$ & $\begin{array}{l}\text { sections of the } \\
\text { musical text }\end{array}$ \\
\hline 1 & a & 1 \\
2 & b & 2 \\
3 & a & 3 \\
4 & b & 4 \\
5 & a & 5 \\
6 & b & 6 \\
7 & c & $7 a$ \\
8 & c & $8 \mathrm{a}$ \\
9 & c & $8 b$ \\
10 & d & $7 b$ \\
\hline
\end{tabular}

However, this hypothesis in my opinion gives rise to at least four contradictions:

1. it forces us to underlay the text of sections $8 \mathrm{a}$ and $8 \mathrm{~b}$ breaking all the previous observations regarding special neumes and neumatic articulations; ${ }^{37}$

2. it does not account for the distribution of the vertical strokes used as divisions, since it is hard to conceive why they were used so sporadically and without any logic if their only purpose is to indicate the conclusion of one verse-unit;

3. it matches textual with musical repetitions in a completely disarticulated way, in that, no textual repetition is matched by a musical repetition and vice versa;

37 Even a cursory glance at these sections reveals, indeed, a higher number of neumatic elements than could possibly correspond to ten syllables per section. 
4. it totally disregards the fact that, in the overall layout of the charter, text B too seems to have been set to music since the outset (in a way, moreover, neumatically similar to some portions of the current section 8$)^{38}$.

Each objection, if considered on its own, is most likely not sufficient to invalidate the hypothesis under examination. Taken as a whole, however, the difficulties these points raise would seem to indicate that a relation between text and music, involving a simple continuous progression, might not be feasible. Yet, such a relation is not the only one that can be postulated on the basis of available data. There is, in fact, at least one other possible connection that would not lead to the problems mentioned above, i.e. that the music covers not only the stanzas of text $\mathrm{A}$, but also the five verses of text $\mathrm{B}$, which could be linked to the former according to the following broad outline:

Table 3: Text and music coordination - hypothesis 2.

\begin{tabular}{|c|c|c|c|}
\hline text A & $\begin{array}{l}\text { rses } \\
\text { text B }\end{array}$ & $\begin{array}{l}\text { rhymes in the } \\
\text { literary text }\end{array}$ & $\begin{array}{l}\text { sections of the } \\
\text { musical text }\end{array}$ \\
\hline 1 & & $a$ & 1 \\
\hline 2 & & $\mathrm{~b}$ & 2 \\
\hline 3 & & $a$ & 1 \\
\hline 4 & & $\mathrm{~b}$ & 2 \\
\hline 5 & & $a$ & 1 \\
\hline 6 & & $\mathrm{~b}$ & 3 \\
\hline 7 & & C & 4 \\
\hline 8 & & C & 5 \\
\hline 9 & & C & 6 \\
\hline \multirow[t]{6}{*}{10} & & $d$ & $7 a$ \\
\hline & 1 & $\mathrm{E}$ & \multirow{2}{*}{$8 a$} \\
\hline & 2 & $E$ & \\
\hline & 3 & $\mathrm{E}$ & \multirow{2}{*}{$8 b$} \\
\hline & 4 & $\mathrm{E}$ & \\
\hline & 5 & $\mathrm{~F}$ & $7 b$ \\
\hline
\end{tabular}

38 Cf. n. 6 above. 
There are many advantages to this kind of arrangement:

1. in the first place, text B is now also paired with a passage of music that was connected to it since the first conception of the charter's musical layout;

2. musical sections $8 \mathrm{a}$ and $8 \mathrm{~b}$ now cover two verses each, thus removing the obstacles found in the first table of correspondences;

3. the piedi of the canzone's stanzas are now matched by a repeated passage of music, according to the compositional conventions of the time;

4. the vertical strokes finally make full sense, since they separate those sections - and only those sections - that are to be repeated: the first two strokes isolate, to the right and to the left, the musical material which is to be omitted in the passage from the ouvert of the first two piedi to the clos of the third, while the stroke on the third line marks the point from which to repeat after returning back to the start of the section, as implied by the ouvert, moving then towards the clos.

In truth, this series of correspondences still contains a few stumbling blocks. These, however, turn out to be much more easily overcome than the problems that afflicted the first hypothesis. The most challenging of these obstacles concerns sections $8 \mathrm{a}$ and $8 \mathrm{~b}$, where, at first sight, there does not seem to be sufficient space to accommodate (twice) two hendecasyllables, the metre of the text $\mathrm{B}$. Nonetheless, at a closer look it is possible to note that:

a. the melodic rhyme between the first and second member of the section clearly informs of the end of the first verse of the pair to be sung, each time, to the same music; any possible problem in the compatibility between text and music thus exclusively concerns the second verse;

b. for this too, moreover, the problems may be only superficial: it cannot be entirely ruled out that, when dealing with the textual sequence 'nesune ne neserà senza tenure'39 which already contains one too many ne syllables, the notator recalling the fragment from memory fell into one of the most typical haplographies while copying and retained in his mind something similar to 'nesun-ne serà...', failing to notate the correct quantity of uncini; ;0 $^{40}$

c. this error had consequences in the section's repetition, whose clos, following the model of the ouvert, ended up reproducing its faults.

Thus, from the sum of (a), (b) and (c), it becomes possible also for the second part of the section $(8 \mathrm{~b})$ to support the corresponding hendecasyllable at the minimal

39 Text B, verse 1b, diplomatic transcription: Stussi 1999b, 36.

40 Stussi 1999b, 37. 
cost of introducing one or two repeated notes. This integration is certainly neither overly weighty nor unheard of, and is in any case much less substantial than the interventions required and made by Stussi for a correct rendering of both texts $\mathrm{A}$ and $B$.

The musical form now taking shape may thus be legitimately considered a chanson à refrain: a form that perfectly corresponds to that of the literary text as edited by Maria Sofia Lannutti who, unlike Stussi, maintains that text B is not independent from text $\mathrm{A}$, but is actually its refrain. The final mutual correspondence of text and music can be summarised as follows:

Table 4: Text and music coordination - final hypothesis.

\begin{tabular}{lll}
\hline verses & $\begin{array}{l}\text { rhymes in the } \\
\text { literary text }\end{array}$ & $\begin{array}{l}\text { sections of the } \\
\text { musical text }\end{array}$ \\
\hline 1 & A & 1 \\
2 & $B$ & 2 \\
3 & A & 1 \\
4 & $B$ & 2 \\
5 & A & 1 \\
6 & $B$ & 3 \\
7 & $\mathrm{C}$ & 4 \\
8 & $\mathrm{C}$ & 5 \\
9 & $\mathrm{C}$ & 6 \\
10 & $\mathrm{X}^{41}$ & $7 \mathrm{a}$ \\
$1 \mathrm{R}$ & $\mathrm{Y}$ & $8 \mathrm{a}$ \\
$2 \mathrm{R}$ & $\mathrm{Y}$ & \\
$3 \mathrm{R}$ & $\mathrm{Y}$ & $8 \mathrm{~b}$ \\
$4 \mathrm{R}$ & $\mathrm{Y}$ & $7 \mathrm{~b}$ \\
$5 \mathrm{R}$ & $\mathrm{X}^{41}$ & \\
\hline
\end{tabular}

41 The pair of verses 10-5R, which in Stussi's edition appears as $\mathrm{x}_{10} / \mathrm{X}$ with the rhyme 'plasea' [= IA] : 'die', can according to Lannutti become regular (X/X) by simply reintegrating at the beginning of line 10 the reading ' $a$ cui'of the manuscript, and amending the conclusion of $5 \mathrm{R}$ to become 'dia': see Lannutti 2005, 174. 
If this hypothesis is correct, a few elements immediately come to light that are worthwhile emphasising:

1. the musical form is unitary, that is, a performance of the stanza cannot take place separately from one of the refrain - this is proved by the conclusion of unit $7 \mathrm{a}$, which is a modally suspended ouvert that finds its logical musical conclusion only in the clos of unit $7 \mathrm{~b}$;

2. the melody of the stanza must therefore have been composed at roughly the same time as, or in any case not after the melody of the refrain;

3. the neumes can only have been written on the parchment after both text $\mathrm{A}$ and text B;

4. this neumatic writing, lastly, seems to me to have been set down - unlike what Stussi has demonstrated for the literary text $\mathrm{t}^{42}$ - by memory, and not copied from an exemplar as the layout of the musical signs does not seem to have been planned, neither in itself nor in relation to the text to be sung - see the a capo consisting of a single neume in section 3; the vertical strokes themselves, furthermore, seem to have been added at the very least when the musical writing had already been completed, almost as if to clarify the macro-formal structures that the notator - or, later on, someone in his place - may have felt to be not completely unequivocal.

Whatever may be the case regarding this last issue, having reached this point in the enquiry, we may maintain with almost no critical qualms that the thesis we set out to ascertain concerning a union between music and poetry has been confirmed. The Ravenna charter 15518ter thus transmits both the oldest poetic and musical text in the lingua di sì, which can be eventually transcribed as follows, in compliance with its musical structure: ${ }^{43}$

42 Stussi 1999b, 24.

43 The text included is the first stanza of the canzone and the refrain, following Stussi 1999b 26 for text A (amended at line 10, as explained in note 46), and Lannutti 2005, 154, for text B. 

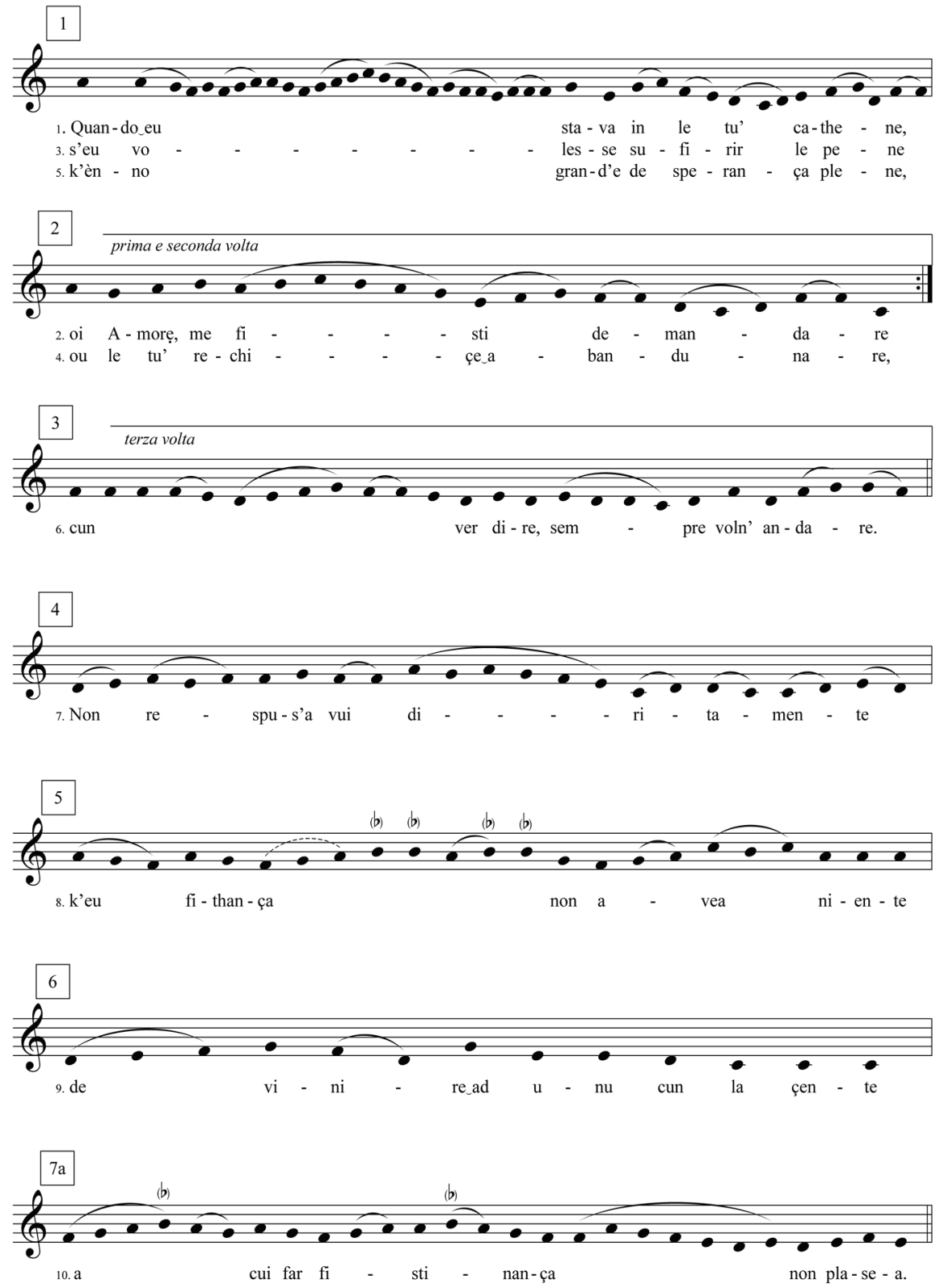

Example 7: Final melodic and poetic reconstruction of Quando eu stava (part 1). 

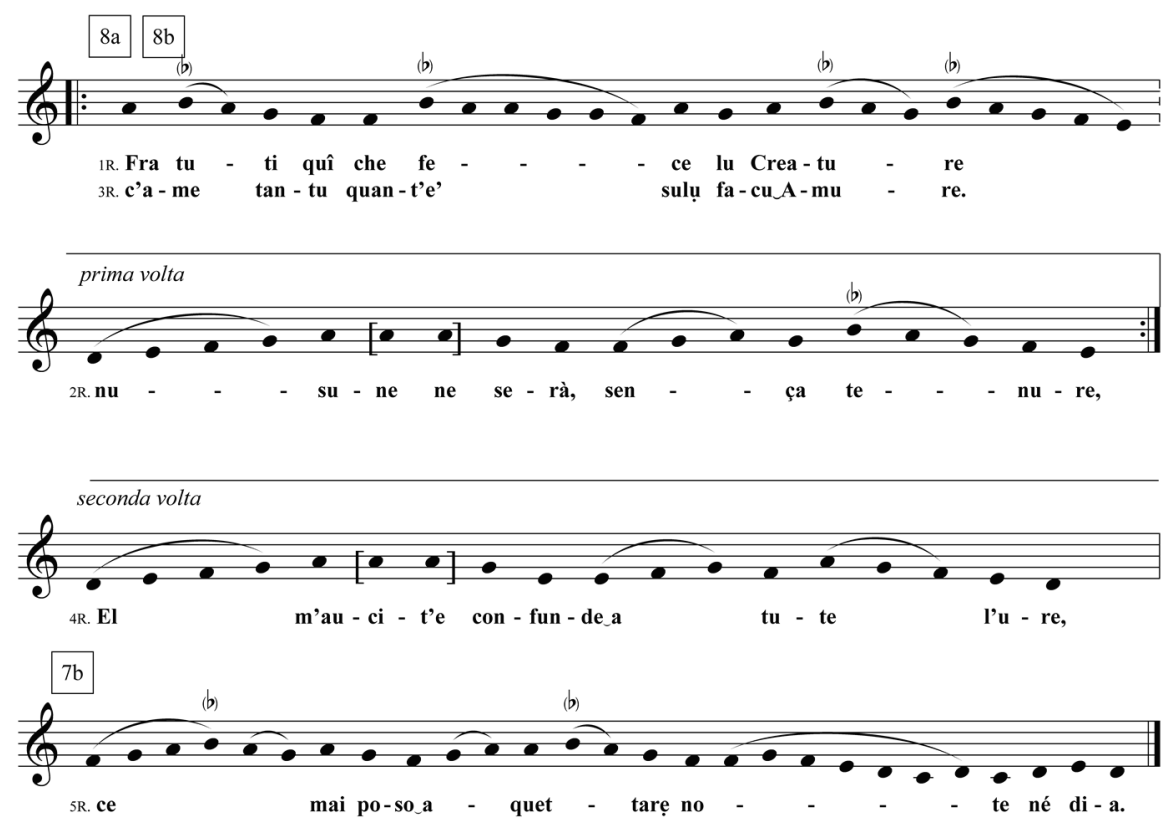

Example 7: Final melodic and poetic reconstruction of Quando eu stava (part 2).

\section{Critical commentary}

The numbers in the column to the left indicate, respectively and referring to the transcription (Ex. 7), section, syllable and where necessary or pertinent note/notes. Moreover:

a. the expression 'neumatic articulation' refers to what follows the indicated note;

b. the interpretation of the rhythmic meaning of neumatic articulations, and the reference made to a 'full' writing of special neumes, both refer to St Gall notation; this does not imply that the charter's musical writing emulates all of the properties and the graphical-semiological functioning of that notation, but only aims to bring out a few semiographic phenomena that are implied in my view by the graphic-notational system of the Ravenna charter. 
$1,2,4$

1,2,8-10

$1,2,10$

$1,2,14$

$1,2,18$

$1,2,22$

1,3

2,7

2,10

$3,1,5$

$3,1,9$

$3,1,10-12$

3,10

5,3

5,4,1-3

5,4,4-5

5,4,4-8

$5,4,8$

$5,6,1$

5,7

6

$6,3-10$

$7 a, 1,4$ neumatic articulation halfway up (with regard to the previous note: or lower articulation with regards to the following note)

neumatic articulation (rhythmically significant)

uncertain diastematic interpretation: the most probable reading is the one given in the text, but it is not impossible that the note should be read as $E$ (possibly in a liquescent form)

disjoint form at the top of the line (rhythmically significant)

neumatic articulation at the bottom of the line (rhythmically neutral)

neumatic articulation at the bottom of the line (rhythmically neutral)

uncertain diastematic interpretation: the most probable reading is the one given in the text, but it is not impossible that the note should be read as $\mathrm{F}$

uncertain diastematic interpretation: unison repercussion or single-pitch neume $\mathrm{F}$

uncertain diastematic interpretation: torculus, as in the text, or single-pitch neume $D$

uncertain reading: unison repercussion or single-pitch neume $F$

uncertain reading: single-pitch neume $C$, or unison repercussion as in the text, or unison repercussion $C$

neumatic articulation at the bottom of the line (rhythmically neutral)

neumatic articulation at the top of the line (rhythmically significant)

writing 'in full' of a special neume such as the trigon

it is unclear whether the sign before the clivis is a stain or a micro-uncinus: the first seems more probable; otherwise the most probable melodic reading is G-G-F (writing 'in full' of a trigon or a pressus maior)

uncertain diastematic interpretation

the neumatic group F-G-A seems to be notated jointly; however, the connecting lines are so thin that a disjoint writing (resulting in an increase of the rhythmic weight of each sound) cannot be excluded

unison repercussion as in the bivirga

uncertain diastematic interpretation: the pitches may be also A, A, G-A, A

writing 'in full' of a strophe

neumatic articulation halfway up (rhythmically significant); uncertain diastematic interpretation: the note could be read also as $\mathrm{E}$

uncertain diastematic interpretation, especially of the second sound (which could be another $\mathrm{C}$ )

it is unclear if at the end of the section there are three or four sounds in unison (the second sign being probably, but not unquestionably, a stain)

another possible diastematic interpretation that takes into account the previous remark as well: $G, E, E, D, C, C, C, C$

neumatic articulation at the top of the line (rhythmically significant) 


$\begin{array}{ll}7 a, 4,1 & \text { neumatic articulation halfway up (rhythmically significant) } \\ 7 a, 5,1 & \text { neumatic articulation at the beginning of the line } \\ 7 a, 7,1 & \text { neumatic articulation at the beginning of the line } \\ 8,6,1-6 & \text { the reading of the neume is highly uncertain: it could be, with almost equal } \\ \text { probability, both a triple and a double clivis; its melodic interpretation can be } \\ \text { the one given in the text or (more simply) A-G-G-F } \\ 8 \mathrm{a} / \mathrm{b}, 3-4 & \begin{array}{l}\text { conjectural reading (discussed in } \S 3.2) \\ 7 \mathrm{~b}, 1-4\end{array} \\ 7 \mathrm{~b}, 5,1 & \text { nepetition of section } 7 \text { a not written out in full in the ms (see } \S 2.3 \text { ) } \\ 7 \mathrm{~b}, 7,1 & \text { neumatic articulation at the beginning of the line: see } 7 \mathrm{a}, 7,1\end{array}$

\section{Concluding observations}

The conclusions reached after the attempts at textual reconstruction and interpretation made can only be presented as a non-definitive summary. I will therefore conclude simply by recalling two salient points that represent the outcome of my study, along with a note that is, instead, of a more general nature.

(1) I began the analysis of the Ravenna charter prefiguring a hypothesis to verify the possible relations between the literary text and the musical text. While I cannot profess, at the end of the path, to have transformed this hypothesis into a certainty, it seems to me, nonetheless, that the evidence and reasoning I have presented allow us to strongly corroborate this hypothesis; drawing on seventeenth-century theological terminology, these conclusions allow us to give our hypothesis the status of an opinio probabilior: an opinio that, while destined to remain such, and with no pretentions of becoming certa et indubitata, is nevertheless more than an opinio probabilis, and infinitely more than a mere opinatio; it is a supposition sustained by a highly remarkable convergence of diversified evidence. For this reason, now the burden of proofing passes to those who believe that the notational signs on the charter do not refer to the texts that this same charter transmitted.

(2) All of the above, is necessarily independent from any possible improvements in single melodic readings that may result from examining enhanced photographic or digital reproductions of the parchment.

(3) More importantly, if referring the music of the text in charter 15518ter is indeed, as I believe, a well-founded statement, what would seem to emerge (and what musicology and the history of literature will have to increasingly consider) is that twelfth-century Italy was a milieu in which an everyday familiarity between music and lyric poetry was still perfectly natural and far from any 
'divorce'. ${ }^{44}$ Along the lines of this metaphor, we do not know whether, and to what extent this relationship was a 'happy' one, nor which of the two arts was the first to be 'unfaithful'. Neither do we know - and perhaps never will - whether this was a long-lasting marriage, nor whether the divorce came about quickly and consensually, or led accusations to be brought against one or the other.

Finally, what seems to be suggested by the document we have examined is that the bond between music and poetry, at the dawn of literature in the lingua di si, may well not have been as the following centuries have shown a lifelong union, yet neither was it a liaison dangereuse, nor - all the less - a secret relationship.

\title{
Abbreviations
}

\author{
PM X Antiphonale missarum Sancti Gregorii, I $X^{e}-X^{e}$ siècle, Codex 239 de la \\ Bibliothèque de Laon (Paléographie musicale 10), Solesmes: Abbaye \\ Saint-Pierre, 1909 [Reprint Bern: Lang, 1974]. \\ PM XV Le Codex VI.34 de la Bibliothèque Capitulaire de Bénévent (Paléographie \\ musicale 15), Solesmes: Abbaye Saint-Pierre, 1937 [Reprint Bern: Lang, \\ 1971].
}

\section{References}

Asperti, Stefano, and Marina Passalacqua (2000), 'Quando eu stava in le tu' cathene: note da un seminario', in Contributi di filologia dell'Italia mediana, 14: 5-20.

Breschi, Giancarlo (2004), 'Quando eu stava in le tu' cathene', in Ravenna, Studi e Ricerche, 11/1: 43-108.

Cardine, Eugene (1968), Semiologia gregoriana, Rome: Pontificio Istituto di Musica Sacra.

Castellani, Arrigo (2000), Grammatica storica della lingua italiana (Collezione di testi e studi. Linguistica e critica letteraria), Bologna: Il Mulino.

Giunta, Claudio (2006), 'Quando eu stava, v. 11', in Pietro Beltrami et al. (eds), Studi di filologia romanza offerti a Valeria Bertolucci Pizzorusso, Lucca: Pacini, I, 653-656.

Karp, Theodore (1992), The Polyphony of Saint Martial and Santiago de Compostela, Oxford: Clarendon.

\footnotetext{
44 This idea had its inception in the first Italian edition of this text, examining the far less problematic 'Piacenza fragment' as well, a poem provided with notation (also of the MetzLotharingian type) only for its refrain, and mutilated on its right side: ' $\mathrm{O}$ bella bella bella madona $\mathrm{p}[$ '.
} 
Lannutti, Maria Sofia (2005), ‘Poesia cantata, musica scritta. Generi e registri di ascendenza francese alle origini della lirica italiana (con una nuova edizione di RS 409)', in Lannutti/Locanto (eds), 157-197.

Lannutti, Maria Sofia, and Massimiliano Locanto (eds) (2005), Tracce di una tradizione sommersa. I primi testi lirici italiani tra poesia e musica, Firenze: Fondazione Franceschini.

Rohloff, Ernst (ed.) (1943), Der Musiktraktat des Johannes de Grocheo, Leipzig: Reineck.

Locanto, Massimiliano (2005), 'Le notazioni musicali della carta ravennate e del frammento piacentino', in Lannutti/Locanto (eds), 123-156.

Rampi, Fulvio, and Massimo Lattanzi (1991), Manuale di canto gregoriano, Milan: E.I.M.A. Editrice Internazionale Musica e Arte [Reprint Cremona: Turris, 1998].

Rosa Barezzani, Maria Teresa (2005), 'Ai margini di un seminario: alcune riflessioni dal sottosuolo paleografico-musicale', in Lannutti/Locanto (eds), 201-219.

Sadie, Stanley (ed.) (2001), The New Grove Dictionary of Music and Musicians, $2^{\text {nd }}$ edn, London: Macmillan, 29 vols.

Stussi, Alfredo (1998), 'Il più antico documento di lirica volgare in volgare italiano', in Accademia Lucchese di Scienze, Lettere e Arti. Atti, s. II, 28: 7-19.

Stussi, Alfredo (1999a), 'La canzone Quando eu stava', in Cesare Segre and Carlo Ossola (eds), Antologia della poesia italiana. Duecento, Turin: Einaudi, 607-620.

Stussi, Alfredo (1999b), 'Versi d'amore in volgare tra la fine del secolo XII e l'inizio del XIII', in Cultura Neolatina, 59/1: 1-69.

Tomasoni, Piera (2005), 'La lingua dei versi d'amore ravennati. Consuntivo delle prime interpretazioni', in Lannutti/Locanto (eds), 69-84. 

Processes 



\title{
Fragmenta Manuscriptorum Musicalium Hungariae Mediaevalis: From Traditional Methodologies Towards a Digital Corpus
}

\begin{abstract}
The paper focuses on the latest results and achievements of the research group Digital Musical Fragmentology established at the Department of Early Music History of the Institute for Musicology in Budapest. The research is closely related to the decades-long musical, liturgical and palaeographical examination of sources, repertories, melodic and notation systems of the cantus planus in Hungary and Central Europe. After discussing the main principles of describing, systemising and analysing notated manuscript fragments on the website Fragmenta Manuscriptorum Musicalium Hungariae Mediaevalis two casestudies are presented in detail: fragments of a fifteenth-century Graduale Strigoniense and those of the Sequentionale Waradiense. Both are contributing to a virtual reunification of disseminated groups of fragments, dispersed in different libraries, towns, countries.
\end{abstract}

The study of manuscript fragments is an especially vital task in a country that has lost the vast majority of its medieval manuscripts. On the basis of extant descriptions, inventories and catalogues, it was estimated that roughly 50,000 manuscripts could have existed in medieval Hungary, while only 1,500 of these survive. ${ }^{1}$ The causes of this considerable loss in Hungary are twofold or, rather, they can be related to two phenomena. The first, expectedly, is rooted in the general vicissitudes of history, the second is a result of the unique historical, political, and cultural context of Hungary, particularly the great difference between the current and the medieval borders of the country. Parallel to other similar trends around Europe, it was in sixteenth- and seventeenth-century Hungary that

1 See the rough estimate made by László Mezey in the late 1970s: Mezey 1978.

Note: The research is funded by the Hungarian National Research, Development and Innovation Office, Project Number 120643.

Ә Open Access. () 2020 Zsuzsa Czagány, published by De Gruyter. (cc) BY-NC-ND This work is licensed under the Creative Commons Attribution-NonCommercial-NoDerivatives 4.0 International License.

https://doi.org/10.1515/9783110717884-012 
old parchment codices were broken up and used as wrappers or to strengthen the bindings of paper books. Several sources indicate that bookbinders bought highquality parchment by the sheet to bind newly printed pages or stacks of documents. ${ }^{2}$ Hungarian scholarly literature often quotes the will of István Báthory, judge royal (comes curialis) of the Kingdom of Hungary, ${ }^{3}$ written in 1603 to indicate a shift in the perception of old liturgical manuscripts in the early Modern Era: 'The old books should be cut up and given to schoolchildren and be used to bind books'. ${ }^{4}$

However, the drastic loss of codices, and the lack of information about them is not only the result of these processes. The fact that the territory of the medieval Kingdom of Hungary was almost three times that of the modern country is also a contributing factor. Once the northern, southern and eastern regions of the medieval kingdom became sovereign states, the manuscripts extant in their territories became, for many years, inaccessible to Hungarian scholars. Twentieth-century Hungarian scholars could only rely on old descriptions and literary references - often predating scientific methodologies - for reconstructing the typology and use of historical documents in these areas. Moreover, scholars had no information about the extent of surviving manuscripts and records in the archives of the old religious centres of Hungary, such as the Pozsony (Bratislava), Szepes (Spiš) and Nagyszombat (Trnava) Chapters in modern day Slovakia, the Bishoprics of Kolozsvár (Cluj-Napoca) and Gyulafehérvár (Alba Iulia) in current Romania, and the Zagreb Cathedral in today's Croatia. Thankfully, in these cases the loss of information was only temporary. Political and cultural shifts that unfolded at the end of the twentieth and beginning of the twenty-first century - the opening up of archives, free movement of information and new forms of scientific and scholarly cooperation resulted in the rediscovery of many sources hitherto thought to be lost, not only in neighbouring countries, but also in regions far from medieval Hungary.

An example directly connected to the field of chant research can shed more light onto this process. In the 1990s, as strict limitations on travel were eased, a group of Hungarian chant scholars and restorers were allowed to visit the Imperial Treasury of the Topkapı Palace in Istanbul. The fact that the Imperial Treasury held artefacts of Hungarian origin among others medieval documents, taken

2 See Mezey in Mezey et al. 1983, 15.

3 István (Stephen) Báthory of Ecsed, judge royal (comes curialis / iudex curiae regiae) from 1585 to 1605 .

4 Parts of the testament were published by Komáromy 1890, 124-141. The full text is available in the edition by Vadász 2002, 36. 
as loot during the 150-year-long Ottoman occupation of Hungary, was well documented in scholarly literature. ${ }^{5}$ The German theologian, Adolf Deissmann published a catalogue in $1933,{ }^{6}$ which listed a medieval gradual, known as the 'Graduale Francisci de Futhak ${ }^{7}$. The fifteenth-century manuscript has been accessible on black and white microfilm since $1972 .{ }^{8}$ In 1989 the news of the discovery of an antiphoner were published along with a few sample images. ${ }^{9}$ The outcome of complex diplomatic negotiations, the 1997 visit was organised primarily to give Hungarian scholars ${ }^{10}$ a chance to examine these manuscripts in Istanbul. Once there, the research group discovered three other complete notated manuscripts beside the gradual and antiphoner. ${ }^{11}$ One of the five codices is the Antiphonale Strigoniense, the so-called 'Istanbul Antiphoner', which was completed around 1360 and was previously only known from some partial reproductions. Since 1999 a high-quality facsimile edition is also available. ${ }^{12}$ The manuscript is an important source for medieval Hungarian music, both for the palaeographical aspect and for its contents, representing the mature Esztergom liturgical and musical tradition.

Musical fragmentology in Hungary began in the 1970s, connected to the beginnings of the study of manuscript fragments as an independent discipline. In fact, it can be said that the first success of 'institutionalised' fragmentology in Hungary was locating and classifying medieval liturgical sources with musical notation. The theoretical father and first researcher in the study of manuscript fragments in Hungary was László Mezey. In 1972, Mezey created the Fragmenta Codicum study group of the Hungarian Academy of Sciences, the first project that began to describe and publish systematically medieval manuscript fragments from Hungary, in parallel with similar initiatives around Europe. Mezey was the

5 The Hungarian scholars Arnold Ipolyi, Imre Henszlmann and Ferenc Kubinyi visited the Topkap1 Palace in 1862. In 1889 the second delegation from the Hungarian Academy of Sciences discovered in the Treasury four liturgical manuscripts of Hungarian origin. See Ungarische Revue, 9/6 (1889), 733.

6 Deissmann 1933.

7 Deissmann 1933, n. 68, olim 2429.

8 Microfilm Archives of the Department of Early Music at the Institute for Musicology of the Hungarian Academy of Sciences.

9 Vízkelety 1989, 99-101.

10 László Dobszay and Janka Szendrei from the Institute for Musicology of the Hungarian Academy of Sciences.

11 Deissmann no. 60: Missale notatum saec. 13; Deissmann no. 49: Missale notatum saec. 14; Deissmann no. 43: Antiphonale OFM pars hiemalis saec. 14/2. For a detailed description of the Istanbul manuscripts see Szendrei 2001.

12 Szendrei et al. 1999. 
first scholar to formulate the thesis that the value of fragments as historical sources goes beyond their incomplete, fragmentary nature, providing researchers with an insight into the original manuscript source. ${ }^{13}$ The Fragmenta Codicum workshop - since 1998 called Res Libraria Hungariae 'Fragmenta Codicum' - published the catalogues of manuscripts and fragments of six Hungarian collections between 1983 and 2007, and it is still active to the present day. ${ }^{14}$

The one and, so far, only catalogue of medieval music manuscript fragments published in Hungary, Notated sources of the Hungarian Middle Ages [A magyar középkor hangjegyes forrásai] by Janka Szendrei, was published in 1981, preceding the first Fragmenta Codicum volume by two years. ${ }^{15}$ The catalogue described 131 complete notated liturgical manuscripts, 68 missals with sporadic musical notation, and 655 fragments. It provided the first overview of notated fragments, defining their liturgical contents, melodic variants of chants, and the type of musical notation. Szendrei's catalogue was the first work to illustrate the importance of an analysis of the musical content in the study of medieval manuscript fragments, emphasising how sometimes the type of musical notation, or a particular melodic variant may be the only information that can be used to infer the origin of a fragment, when other methodologies, like traditional codicological or palaeographical analyses, fail. In the thirty-five years since the publication of the Szendrei catalogue, the number of known notated manuscript fragments in Hungary has increased considerably. A small number of these newly-discovered fragments were included in the Fragmenta Codicum series; those containing musical notation were described in a separate section (Liturgica cum cantu). Alongside codicological descriptions, the particular type of musical notation is also identified, and the results of the musical and liturgical analyses summarised. So far, a total of 342 fragments have been described.

Neither the number of fragments published, nor their short descriptions comply with the professional expectations of music fragment databases in the present day, and the recent trends in research. In comparison to other Central European initiatives (Slovak, Czech or Austrian), Hungary has fallen behind in the publication of fragment catalogues both printed, as well as online. In 2016, the research team at the Department of Early Music of the Institute for Musicology at the Hungarian Academy of Sciences successfully applied for a grant with the

13 Mezey 1973, 211-213. For a summary of the first results see Mezey 1978.

14 Mezey et al. 1983; Mezey et al. 1988; Vizkelety et al. 1993; Vizkelety et al. 1998; Madas et al. 2006; Vizkelety 2007.

15 Szendrei 1981. 
title Codices and Fragments from Late Medieval Hungary. Examining, Reexamining and Online Publishing of Notated Manuscripts and Chant Repertories. ${ }^{16}$ The aim of the project is to discover, classify and describe notated medieval manuscript fragments from Hungary. One of the outcomes of the four-year project is the creation of the Fragmenta Manuscriptorum Musicalium Hungariae Mediaevalis website, which will collect the fragments into a database, make them freely accessible online. ${ }^{17}$

\section{The Database}

The database provides three levels of information: basic data, content, and analytical description.

\subsection{Basic data}

Bibliographical data, genre and date are summarised on the first level of description, alongside information on the extent and physical state of the source(s) (see Table 1). Basic codicological parameters, like page size, dimensions of the writing block, column size, number of lines and columns, and stave height are also listed here. These are complemented by information on the type of text script and musical notation used. As the vast majority of the sources described are of Central European origin, special attention is given to examining the medieval gothic types of musical notation, characteristic of a particular region, on a level that improves the traditional approaches of musical palaeography. Further to the description of the notation, other features of the notational system are also included, such as the colours of the staves, the unique shape of the custos or its absence, and special neume-forms. The first level of description is completed with information on the carrier (liber tradens) and the possessors, as well as relevant bibliographical references, like earlier catalogues. This level does not include information on the contents of the fragment, but only a short indication of the liturgical feast.

16 Grant no. 120643 of the National Research, Development and Innovation Office in Hungary. Project duration: 2016-2020, Principal Investigator: Zsuzsa Czagány.

$17<$ http://fragmenta.zti.hu $>$ (accessed 15 Sept. 2020). 
Table 1: The basic level of fragment description.

\begin{tabular}{ll}
\hline Date & Stave height \\
Archive & Script \\
Shelf-mark & Notation \\
Material & Notation/remarks \\
Extent & Carrier $1 . / 2 . / \ldots$ \\
Page height / width & Possessor \\
Writing block height / width & Content \\
Number of columns / lines & Origin \\
Number of lines & Bibliography / References \\
Width of columns & \\
\hline
\end{tabular}

\subsection{Content}

The in-depth analysis of liturgical contents pertains to the second level of description (see Table 2). All chants in the fragment are identified, and the liturgical use of the original manuscript is also determined on the basis on three, or four parameters: the time of the liturgical year (Tempus), the feast (Dies), the hour (Hora), and the genre, depending on whether the fragment came from a book for the Mass or for the Office, or from the temporale or sanctorale. Musical identification is made possible through the incipit, the mode, and the cantus identification number, which will be connected to the cantus database.

Table 2: Description of the liturgical content of the fragment.

\begin{tabular}{ll}
\hline NUMERUS & HORA \\
RISM & GENRE \\
FOLIO & INCIPIT \\
TEMPUS & MODE \\
DIES & CANTUS ID \\
\hline
\end{tabular}




\subsection{Analytical description}

The third level contains a deeper analysis of unique contents, and draws together the results of the liturgical, musical, and palaeographical observations, in order to propose new pathways for further research on the material (see Table 3).

Even though the work is still in its early stages, and the system of data entry might undergo some modifications during the course of the project, research has already yielded significant results. A number of new fragments have been discovered that not only increase the quantity of sources from Hungary, but shed light also on strong relations within groups of sources, thus revealing the existence of previously unknown scriptoria. In most cases, each fragment is representative of a single, lost original manuscript. However, in some cases, the collected data show connections between fragments that would otherwise be considered unrelated: such correspondences might consist in a complete match, revealing the common provenance of two or more fragments from the same original manuscript; or they might point to a different correlation, through which useful information about medieval book culture, manuscript production, and distribution can be equally gained.

\section{Two case-studies}

The last part of this paper will present two cases for which the detailed examination of both the material form and the content of fragments allowed a more precise reconstruction of the historical document.

\subsection{Fragments of a fifteenth-century Graduale Strigoniense}

One of the first institutions where medieval fragments with musical notations were described was the Collection of Manuscripts and Rarities of the University Library in Budapest. ${ }^{18}$ Among the sixty fragments used as covers of sixteenth- and seventeenth-century books and documents, later detached during restoration and stored in boxes without catalogue numbers, a single folio of a fifteenthcentury gradual was found, removed from the binding of the incunable Inc. 260

18 Special thanks should be given to György Cséka and Zsuzsanna Mód, the previous and current heads of the Collection of Manuscripts and Rarities for supporting our research. 
(see Figs 1a-b). ${ }^{19}$ Despite being torn around the edges and pierced at points, the parchment leaf is almost complete. The fragment contains seven lines of text with musical notation, and was probably part of the commune sanctorum section of a gradual; this is confirmed by the extant chants and their ordering. Table 3 shows the basic codicological and palaeographical data.

Table 3: Fragment Budapest, University Library Inc. 260, Basic Data.

\begin{tabular}{ll}
\hline Date & s. 15 \\
Archive & Budapest, University Library, Collections of Manuscripts and \\
& Rarities \\
Shelf-mark & Inc. 260 (carrier) \\
Material & Parchment \\
Extent & 1 single leaf, incomplete, removed \\
Page height / width & $362 \mathrm{~mm}$ (incomplete) / $235 \mathrm{~mm}$ (incomplete) \\
W. block height / width & $337 \mathrm{~mm}$ (incomplete) / $216 \mathrm{~mm}$ (incomplete) \\
Number of columns / lines & $1 / 7$ \\
Width of columns & - \\
Stave height & $30 \mathrm{~mm}$ \\
Script & gothica textualis \\
Notation & Messine gothic-Hungarian \\
Notation / remarks & 5 -line staves with lines traced in red, C-clef, F-clef, custos \\
Carrier 1. & $\mathrm{n} / \mathrm{a}$ \\
Carrier 2. & Inc. 260 \\
Possessor & $\mathrm{n} / \mathrm{a}$ \\
Content & Commune sanctorum / commune unius martyris pontificis \\
Origin & Hungary \\
Bibliogr./References & \\
\hline
\end{tabular}

19 Ninety-one fragments with musical notation kept in the University Library in Budapest were listed and described in Mezey et al. 1983. The sixty fragments mentioned here are stored separately and are not included in the catalogue. 


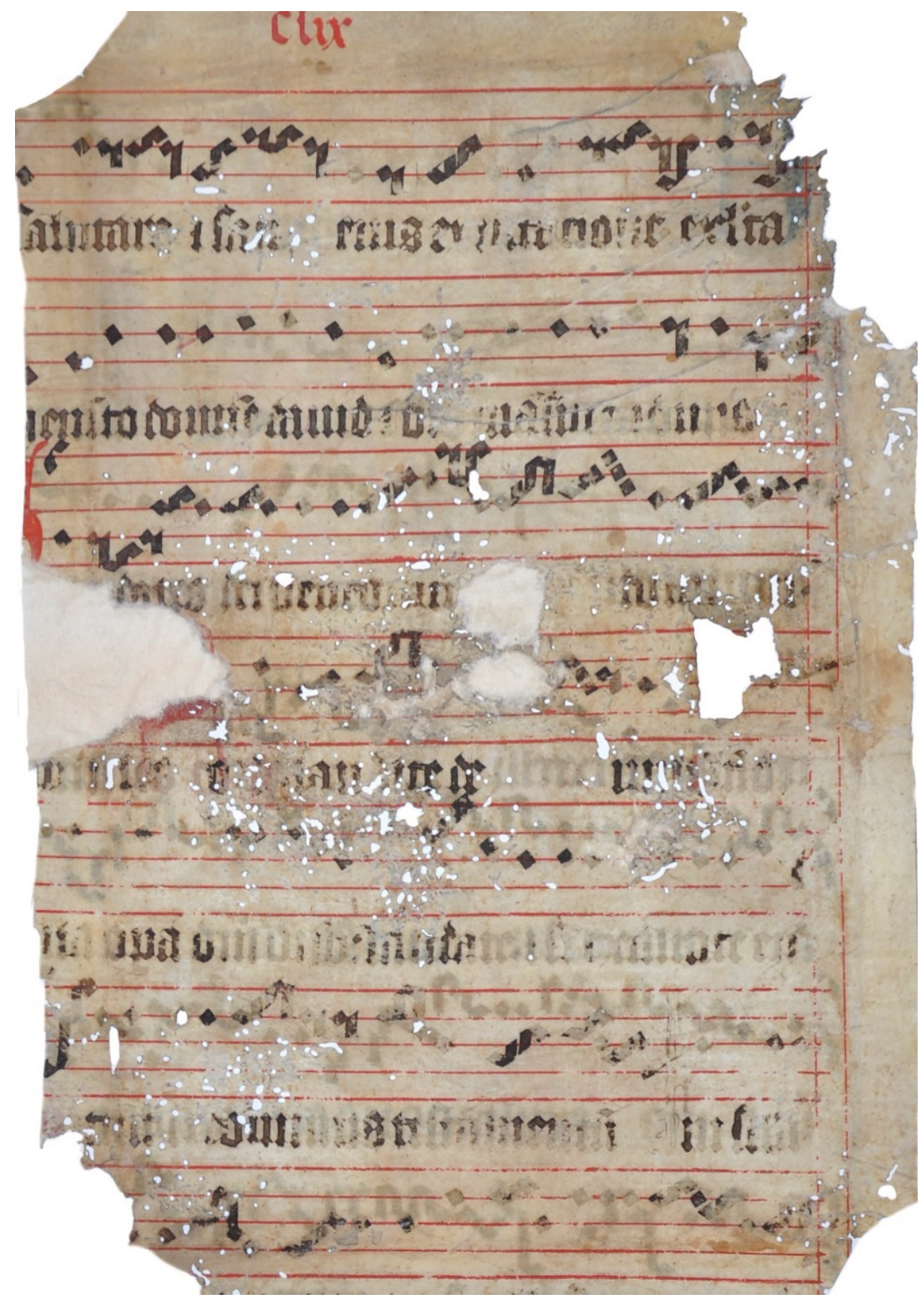

Fig. 1a: Budapest, University Library, fragment removed from Inc. 260, recto; @ Budapest, University Library. 


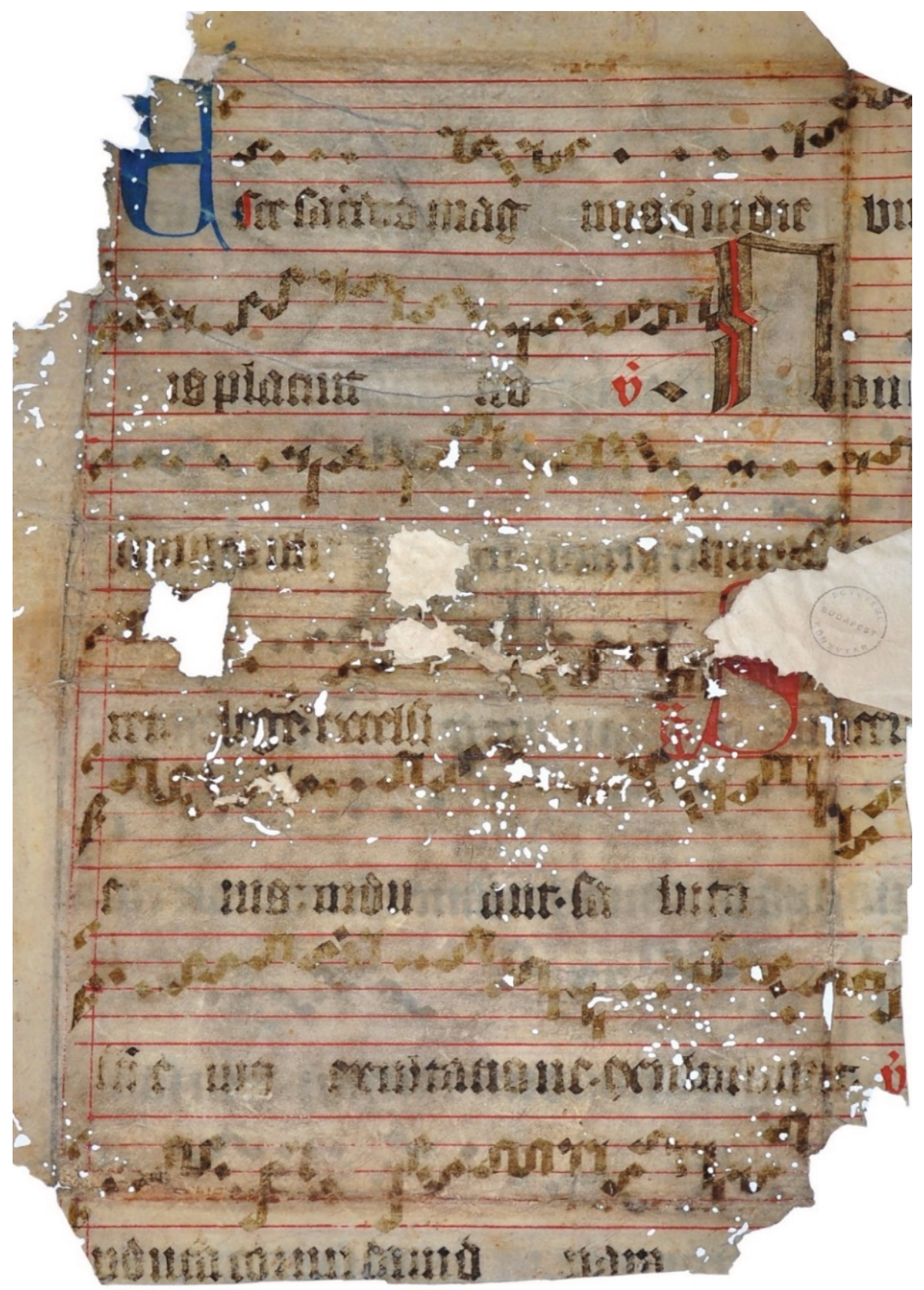

Fig. 1b: Budapest, University Library, fragment removed from Inc. 260, verso; @ Budapest, University Library. 
The recto transmits a series of five introits and their corresponding Psalm verses, while the verso contains four graduals and their verses (see Table 4). Instead of regular Mass-proper cycles following one another - as in the usual organisation of the proprium de tempore, or de sanctis - the fragment lists chants by genre, in a way that can be revealing of the category of saints in the commune sanctorum; in the case of this fragment this was probably the commune unius martyris pontificis.

Table 4: Fragment Budapest, University Library Inc. 260 (F 722), Contents.

\begin{tabular}{|c|c|c|c|c|c|c|c|}
\hline Folio & Tempus & Dies & Hora & Genre & Incipit & Mode & CANTUS ID \\
\hline \multirow[t]{5}{*}{ recto } & & $\begin{array}{l}\text { Commune un. } \\
\text { mart. pont. }\end{array}$ & & Intr & $\begin{array}{l}\text { Sacerdotes eius induant } \\
\quad \text { salutare }^{* 20}\end{array}$ & 2 & g02264 \\
\hline & & & & Intr-V & Memento Domine David & 2 & g02264a \\
\hline & & & & Intr & $\begin{array}{l}\text { Sacerdotes Dei } \\
\quad \text { benedicite Dominum * }\end{array}$ & 6 & g01280 \\
\hline & & & & Intr-V & $\begin{array}{l}\text { Benedicite omnia opera } \\
\text { Domini* }\end{array}$ & 6 & g01280a \\
\hline & & & & Intr & $\begin{array}{l}\text { Statuit ei Dominus } \\
\text { testamentum* }\end{array}$ & 1 & g01271 \\
\hline \multirow[t]{4}{*}{ verso } & & $\begin{array}{l}\text { Commune un. } \\
\text { mart. pont. }\end{array}$ & & Grad & Ecce sacerdos magnus* & 5 & g01332 \\
\hline & & & & Grad-V & Non est inventus* & 5 & g01332a \\
\hline & & & & Grad & $\begin{array}{l}\text { Sacerdotes eius induant } \\
\text { salutare* }\end{array}$ & 1 & g01339 \\
\hline & & & & Grad-V & $\begin{array}{l}\text { Illuc producam cornu } \\
\text { David* }\end{array}$ & 1 & g01339a \\
\hline
\end{tabular}

The notation used in the fragment is a unique combination of Hungarian notation, so-called Strigonian notation, common in medieval Hungary between the twelfth and fourteenth centuries (and used even later in certain workshops), and the Messine-German-Gothic notation, which spread through the fourteenth century and became predominant in various local forms throughout Central-Europe. ${ }^{21}$ This

20 The asterisk indicates that the chant is incomplete.

21 For the description of the various notational types common in late medieval Central European liturgical manuscripts we chose to employ the terminology and typologies developed by 
mixed Messine-Gothic-Hungarian system of notation was used in the mid-fifteenthcentury scriptoria of Buda and Esztergom. Since this notation was particularly wellsuited for the compilation of large display manuscripts, the system was adapted into a monumental late-medieval ornamental writing style. Variants of this notation can be found in the high-grade manuscript production of fifteenth-century Hungary, such as the two-volume Esztergom Antiphoner, ${ }^{22}$ the already-mentioned Graduale Francisci de Futhak, ${ }^{23}$ the Buda Antiphoner ${ }^{24}$, and the Graduale Strigoniense of archbishop and cardinal Tamás Bakócz. ${ }^{25}$

The notational system of the fragment is comparable to that of the first volume of the Esztergom Antiphoner. ${ }^{26}$ Alongside similarities in the layout of the pages and the style of the staves (double lined red margins, five-line red staves, clefs and custodes) both contain neume groupings that can be put in relation to the set, sinuous style of the Strigonian notation. The round pes and the characteristic scandicus are also present, preserving the characteristics of the Esztergom system even in their modified forms. The similarities between the musical notation of the antiphoner and the fragment of the gradual are so great that it would be legitimate to infer that the two codices were written in the same scriptorium. The fragment can, thus, be considered to come from a 'sister' codex of the Esztergom Antiphoner, a hypothetical Graduale Strigoniense, copied in the middle of the fifteenth century. Previously only one folio was known from the gradual, but now, thanks to the new initiative we could discover more fragments from the same manuscript: one in the Diocesan Archives in Szombathely (Savaria), West-Hungary (Figs 2a-b), the second in the Diocesan Library of the same city (Figs 3a-b). ${ }^{27}$

Janka Szendrei, as the result of her fourty-year-long research in music palaeography and manuscript studies. See Szendrei 1986; Szendrei 1988a, 437-446; Szendrei 1988b, 5-234; Szendrei 1997, 257-274; Szendrei 1998, 267-282.

22 Antiphonale Strigoniense I-II: Esztergom, Cathedral Library, MS I. 3. c, I. 3. d; the description and the contents of both antiphoners are accessible on the website Hungarian Chant Database, $<$ hun-chant.eu> (accessed 15 Sept. 2020).

23 Istanbul, Topkapı Sarayı: Deissmann 1933, n. 68, olim 2429.

24 Antiphonale Budense: Štátny archív v Bratislave (Bratislava State Archives) EC Lad 6. Accessible online on the website <cantus.sk $>$.

25 Graduale Strigoniense Thomae card. Bakócz: Esztergom, Cathedral Library, MS I. $1 \mathrm{a}-\mathrm{b}$; the description and the contents are accessible on <hun-chant.eu>. Facsimile edition of the manuscript by Szendrei 1993.

26 Antiphonale Strigoniense II: Esztergom, Cathedral Library, MS I. 3. d.

27 First mentioned by Szigeti 1962, 64-73. 
The repertory of the Holy Week (Hebdomada Passionis) is quite uniform in Western plainchant manuscripts. Part of this uniform repertory is present in the gradual discussed here and illustrated in Table 5.

Table 5: Fragment Szombathely, Diocesan Archives, V. 48/E. fasc. (F901), Contents.

\begin{tabular}{|c|c|c|c|c|c|c|c|}
\hline Folio & Tempus & Dies & Hora & Genre & Incipit & Mode & CANTUS ID \\
\hline \multirow[t]{3}{*}{ recto } & Hebd. Passionis & Feria 5 & & Intr & $\begin{array}{l}\text { Omnia quae fecisti } \\
\text { nobis* }\end{array}$ & 2 & g01237 \\
\hline & & Feria 5 & & Grad & $\begin{array}{l}\text { Tollite hostias et in- } \\
\text { troite in atria* }\end{array}$ & 2 & g00822 \\
\hline & & Feria 5 & & Grad-V & Revelavit Dominus* & 6 & g00822a \\
\hline \multirow[t]{4}{*}{ verso } & Hebd. Passionis & Feria 5 & & Grad-V & $\begin{array}{l}\text { Revelavit Dominus* } \\
\quad \text { (cont.) }\end{array}$ & 6 & g00822a \\
\hline & & Feria 5 & & Off & $\begin{array}{l}\text { Super flumina Babilo- } \\
\text { nis* }\end{array}$ & 1 & g01239 \\
\hline & & Feria 5 & & Comm & $\begin{array}{l}\text { Memento verbi tui } \\
\text { servo tuo* }\end{array}$ & 5 & g01240 \\
\hline & & Feria 6 & & Intr & $\begin{array}{l}\text { Miserere mihi Domine } \\
\text { quoniam* }\end{array}$ & 5 & g00824 \\
\hline
\end{tabular}

The fragment from the Szombathely Diocesan Library (Figs 3a-b), on the other hand, contains the introits and graduals of the commune virginum ordered by genre, similarly to the above-mentioned fragment from the University Library in Budapest (see Table 6). 


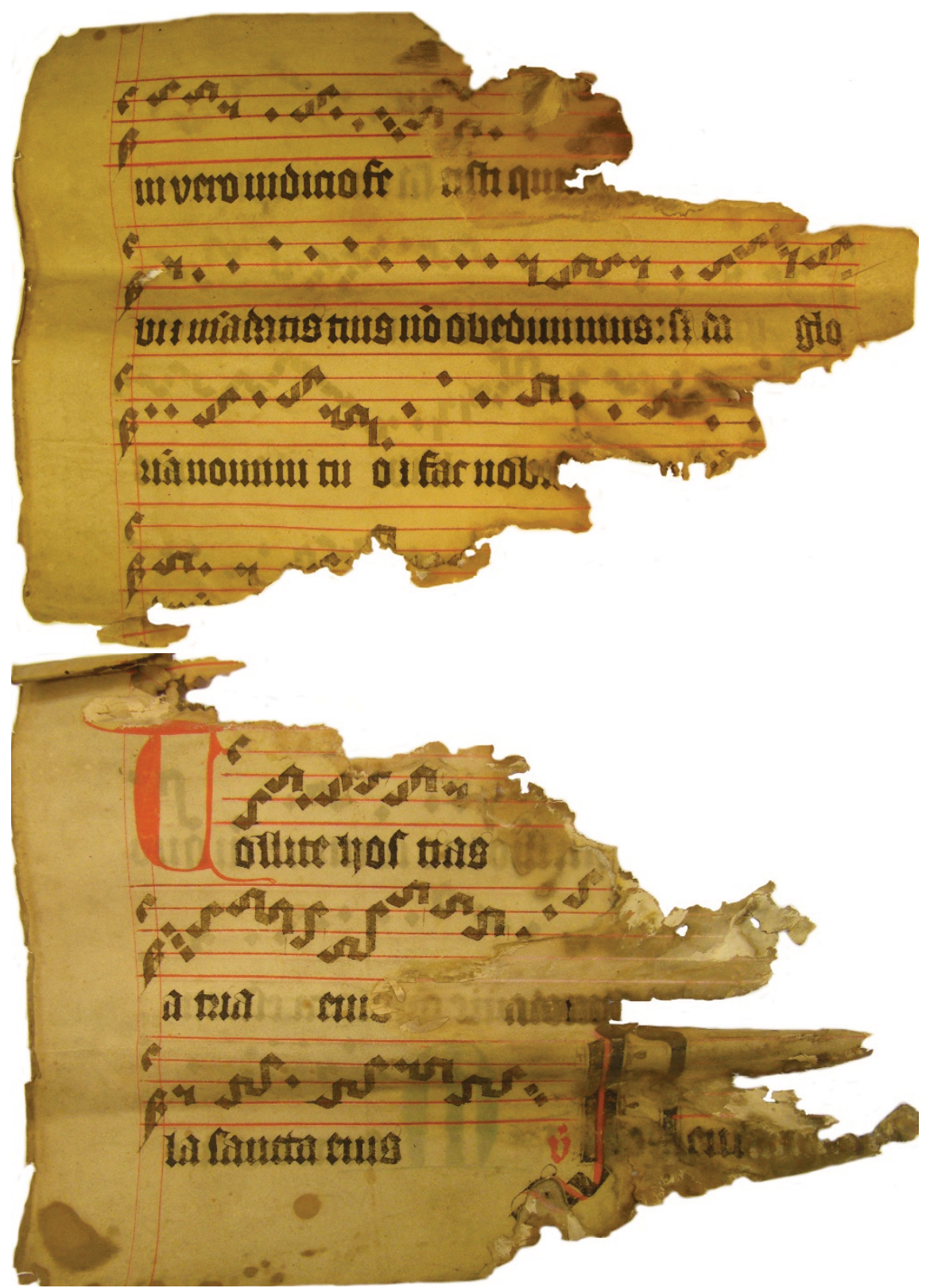

Fig. 2a: Szombathely, Diocesan Archives, fragment V. 48/E. fasc., recto; (c Szombathely, Diocesan Archives. 


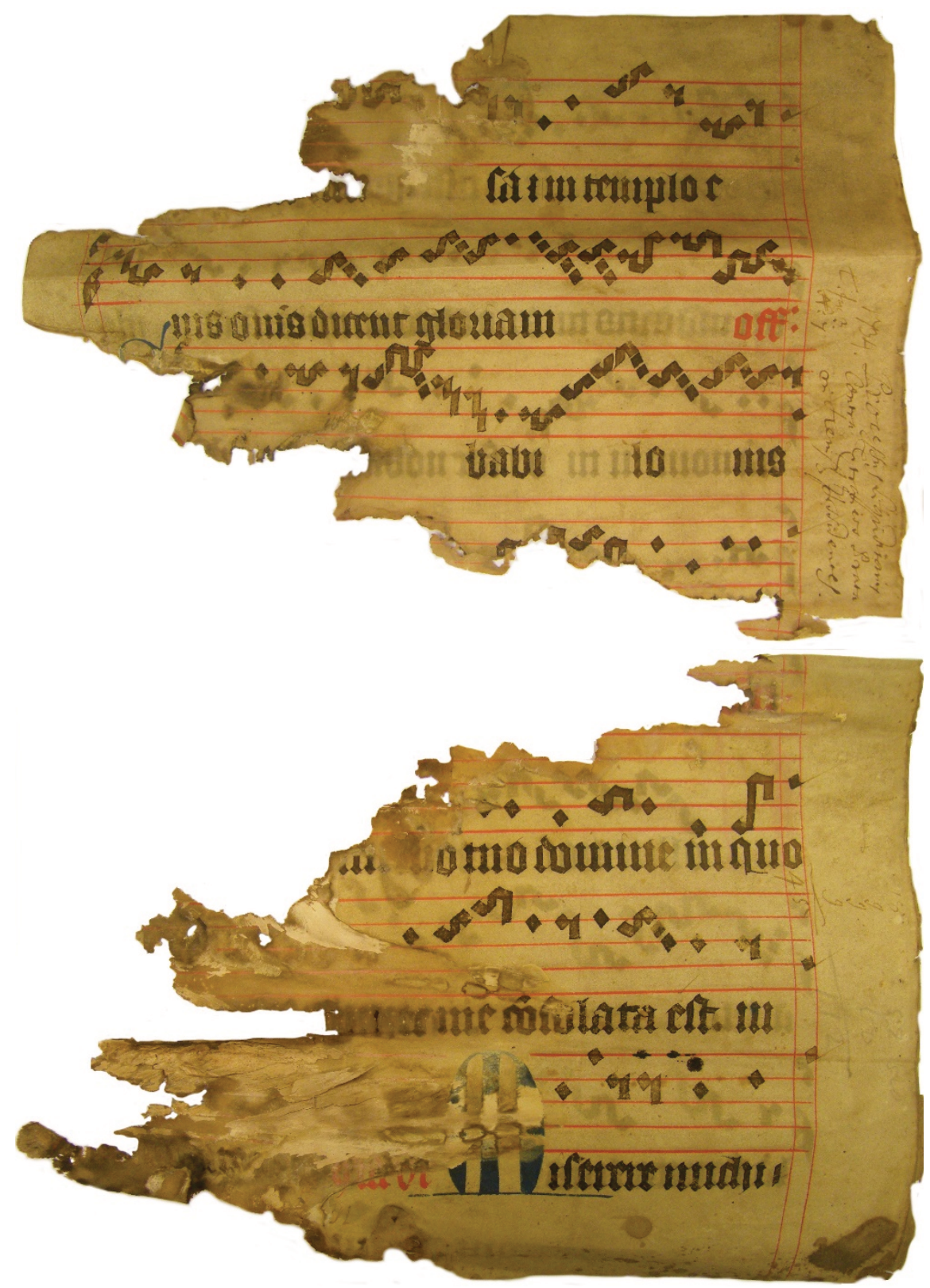

Fig. 2b: Szombathely, Diocesan Archives, fragment V. 48/E. fasc., verso; @ Szombathely, Diocesan Archives. 


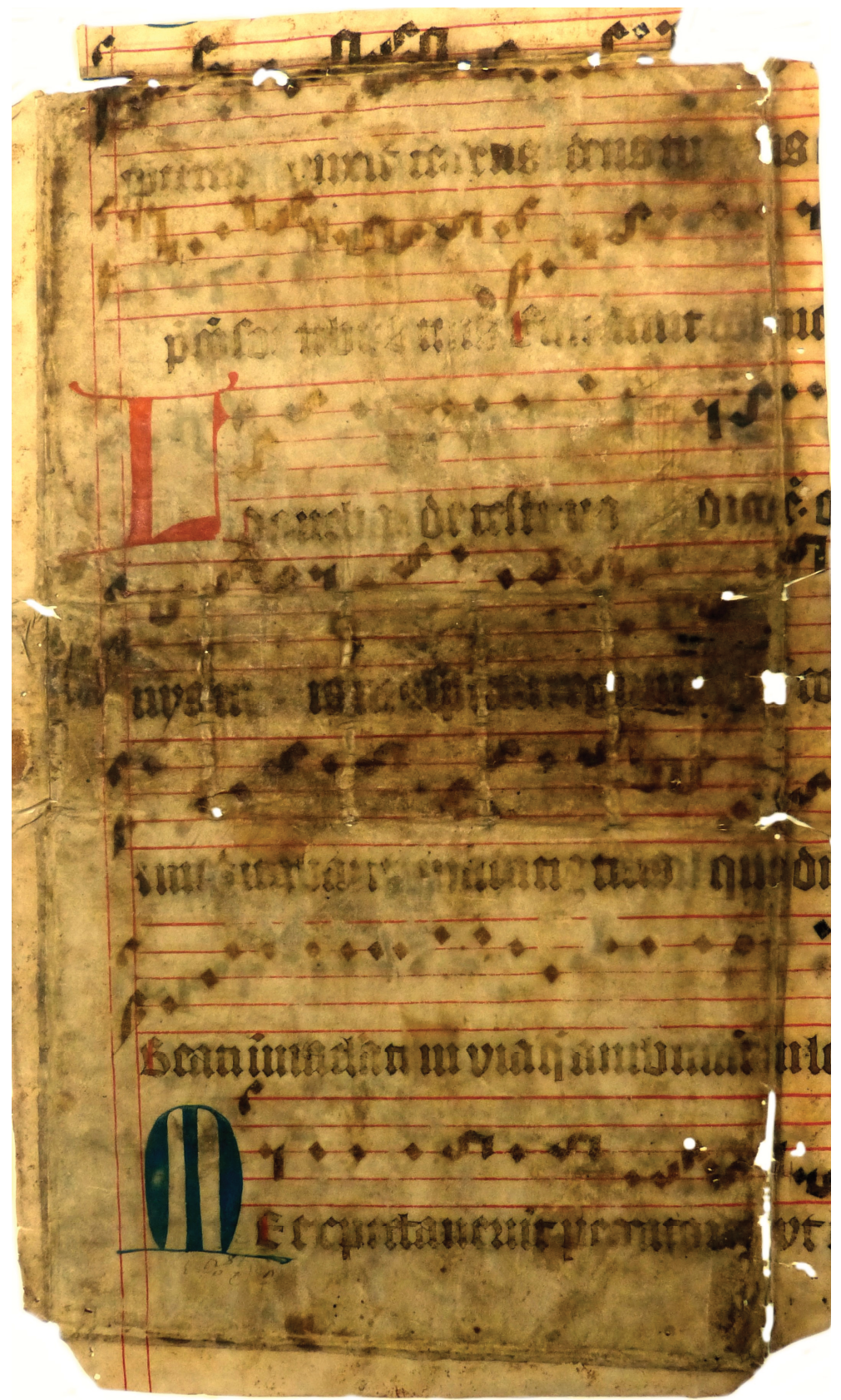

Fig. 3a: Szombathely, Diocesan Library, fragment sine sign., recto; @ Szombathely, Diocesan Library 


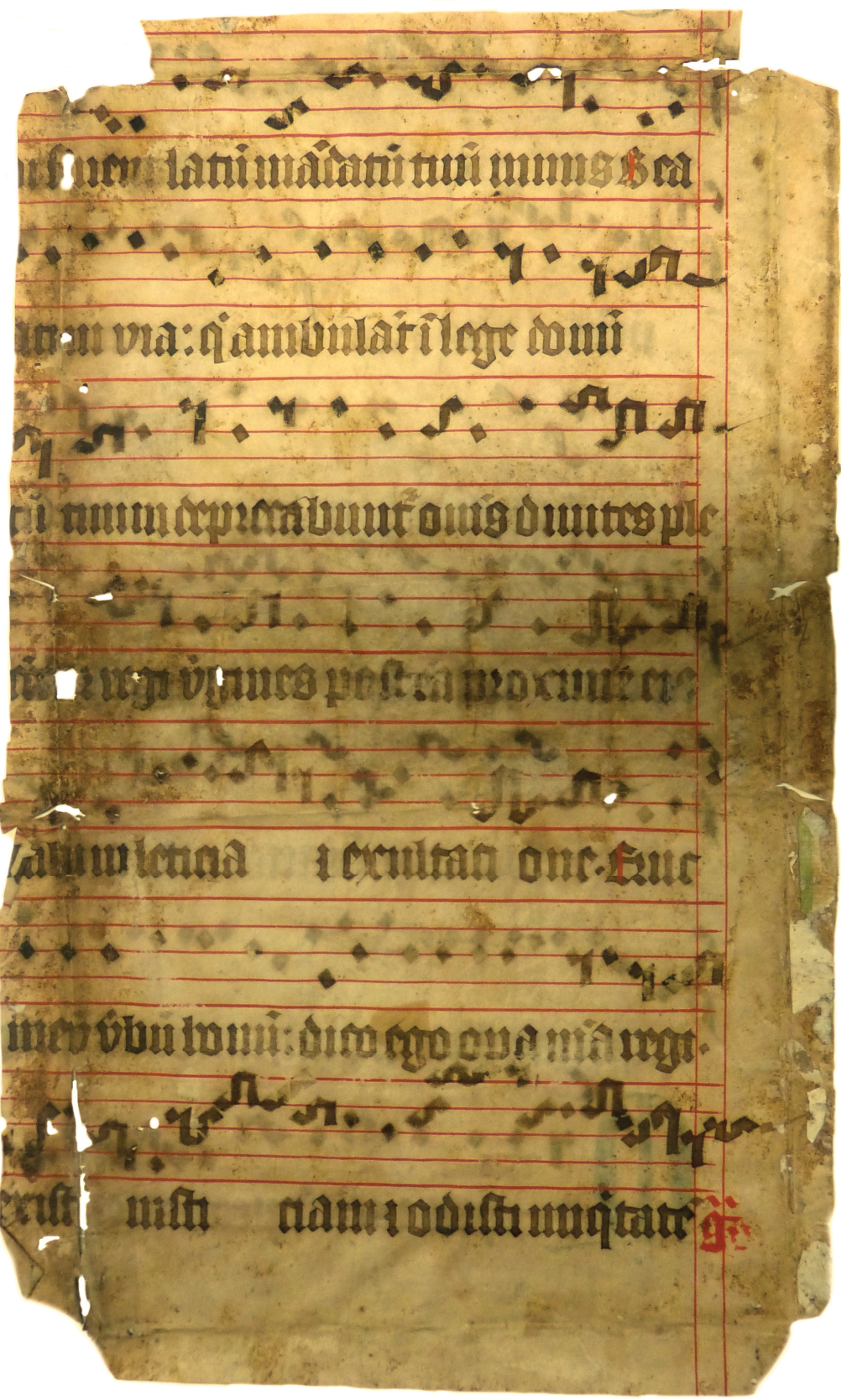

Fig. 3b: Szombathely, Diocesan Library, fragment sine sign., verso; @ Szombathely, Diocesan Library. 
Table 6: Fragment Szombathely, Diocesan Library, sine sign. (F900), Contents.

\begin{tabular}{|c|c|c|c|c|c|c|c|}
\hline Folio & Tempus & Dies & Hora & Genre & Incipit & Mode & CANTUS ID \\
\hline \multirow[t]{5}{*}{ recto } & & Commune vv. (?) & & Intr & $\begin{array}{l}\text { Dilexisti iustitiam et } \\
\text { odisti* }\end{array}$ & 8 & g01380 \\
\hline & & & & Intr-V & Eructavit cor meum* & 8 & g01380a \\
\hline & & & & Intr & $\begin{array}{l}\text { Loquebar de testimoniis } \\
\text { tuis }\end{array}$ & 5 & g00363 \\
\hline & & & & Intr-V & Beati immaculati in via* & 5 & g00363a \\
\hline & & & & Intr & $\begin{array}{c}\text { Me exspectaverunt } \\
\text { peccatores* }\end{array}$ & 2 & g01373 \\
\hline \multirow[t]{5}{*}{ verso } & & Commune vv. (?) & & Intr & $\begin{array}{l}\text { Me exspectaverunt } \\
\text { peccatores* (cont.) }\end{array}$ & 2 & g01373 \\
\hline & & & & Intr-V & Beati immaculati in via* & 2 & g01373a \\
\hline & & & & Intr & $\begin{array}{l}\text { Vultum tuum depre- } \\
\text { cabuntur* }\end{array}$ & 2 & g01390 \\
\hline & & & & Intr-V & Eructavit cor meum* & 2 & g01390a \\
\hline & & & & Grad & $\begin{array}{l}\text { Dilexisti iustitiam et } \\
\text { odisti* }\end{array}$ & 8 & g01366 \\
\hline
\end{tabular}

Both the fragment from Budapest University Library, and the one from the Szombathely Diocesan Library would have been part of the commune sanctorum section of the gradual and adjacent in the original manuscript. ${ }^{28}$

\subsection{Fragments of the Sequentionale Waradiense}

One of the aims of fragmentology is to reconstruct hitherto unknown codices based on the study of the highest possible number of fragments. In specific cases, researchers can even piece together larger continuous sections of the same manuscript, or can complete sources that became fragmented through the

28 According to latest research by Gabriella Gilányi, there might be more fragmentary leaves from the same gradual preserved in various libraries and archives in Hungary. On the reconstruction of the manuscript, as well as to the unique type of musical notation see Gilanyi 2018. The description and analysis of the new discoveries made by Gilányi are available on the website Fragmenta Manuscriptorum Musicalium Hungariae Mediaevalis. 
centuries. The large-format, richly illuminated choirbooks of Várad Cathedral, written at the end of the fifteenth century, are some of the most fragmented liturgical music manuscripts in Hungary. ${ }^{29}$ The series presumably contained manuscripts for the Mass and the Office that included a two-volume antiphoner, a possible two-volume gradual, probably an independent kyriale, and a sequentiary. The large, display codices were used only for a short time in Varad; they were taken from the city in the first half of the sixteenth century, due to the advancing Turkish forces and protestant ideology gaining prominence. The fate of the manuscripts in the following centuries is still unknown. ${ }^{30}$ What remains of the two-volume antiphoner - about a third of the original manuscript - was found in the deposit of Györ Cathedral in Western Hungary in the 1860s. The damaged, truncated leaves were restored and rebound in 1872, ${ }^{31}$ and the manuscript is now hold in the Diocesan Library and Treasury of Györ. ${ }^{32}$ The other volumes of the hypothetical series - the gradual, kyriale and sequentiary - were lost, and information on their contents, structure, and musico-liturgical repertoire can only be inferred from a few surviving fragments. On the basis of comparative studies, the series of sequences originally contained about sixty chants, of which now only seven fragmentary sequences are known. ${ }^{33}$

Research conducted recently in the University Library of Budapest increased this number by another, new fragment (see Fig 4). This fragment is particularly important because it contains part of the sequence Plaudant chori monachorum for St Procopius, the Bohemian hermit and saint canonised in 1204. Procopius was not venerated in Medieval Hungary, and his sequence cannot be found in any other Hungarian source. ${ }^{34}$ How is it possible that the sequence appears in the gradual of Várad Cathedral? The answer may lie in the life of János Filipecz, bishop of Varad in the fifteenth century. ${ }^{35}$ Filipecz was of Moravian origin, and the administrator of the Olomouc bishopric see. It is possible that, when Filipecz became bishop of Várad, he commissioned the production of new chantbooks for

29 Várad/Nagyvárad, Waradinum (lat.), Grosswardein (ger.), Oradea in modern-day Romania. 30 See Körmendy 1988, 33-40; Czagány 2016a, 103-117.

31 The restoration in the 1860s was initiated by the Hungarian archeologist and art historian Flóris Rómer and promoted by János Zalka, bishop of Győr from 1867 until 1901.

32 Győr, Diocesan Library and Treasury, s. s. A facsimile edition of the antiphoner with critical apparatus and commentary was recently published by Czagány 2019.

33 See Czagány 2016b.

34 More on the Bohemian sources of the sequence Plaudant chori monachorum see the Index Sequentiarum Bohemiae Medii Aevi by Hana Vlhová-Wörner: <http://hymnologica.cz/sequences>. 35 János (Johannes) Filipecz, from 1469 was a diplomat, secretary and chancellor of King Matthias Corvinus, from 1477 until 1490 bishop of Nagyvárad. See Kalous 2001. 
the cathedral, probably compiled in one of the leading scriptoria of Bohemia or Moravia; the monumental rhombic notation and the rich decorative style of the manuscript are similar to that of many late fifteenth- and early sixteenth-century Bohemian codices. ${ }^{36}$
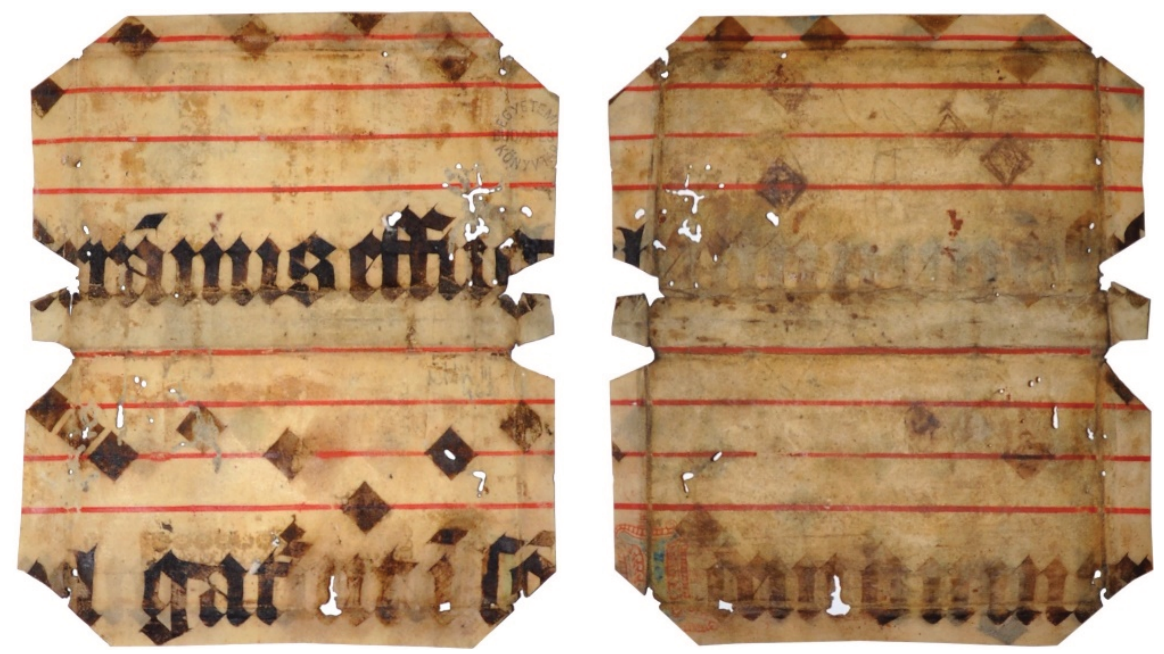

Fig. 4: Budapest, University Library, fragment removed from RMK III/463, recto (left) and verso (right); @ Budapest, University Library.

As can be deduced from the antiphoner, while the basic liturgical repertoire follows the medieval consuetudo of Varad ${ }^{37}$ at certain points, chants or chantcycles of the Bohemian Mass and Office tradition have been added, almost as an exotic touch. Such Bohemian elements are, for example, the historiae of St Martha ${ }^{38}$ and St Matthias ${ }^{39}$ in the antiphoner, or even the recently-discovered Procopius sequence, preserved as a fragment of a folio which once belonged to the lost Waradinum Sequentiary.

36 For example the gradual from Kuttenberg / Kutná Hora (Vienna, Österreichische Nationalbibliothek 15501), the Franus Cantionale (Hradec Králové, Muzeum Východních Čech II A 6), the gradual from Mladá Boleslav (Mladá Boleslav, Okresní muzeum inv. č. 21691). Cf. Czagány 2016a.

37 See Kovács 2010.

38 See Czagány 2004.

39 See Czagány 2009. 
These two case studies aimed at introducing the Fragmenta Manuscriptorum Musicalium Hungariae Mediaevalis database, as well as the prospects and goals of research on the material, which include linking the on-line database with other similar initiatives, in order to identify groups of fragments scattered throughout Europe, and reconstruct lost musical sources.

\section{References}

Czagány, Zsuzsa (ed.) (2004), Historia de sancta Martha hospita Christi, redactio Bohemica. Ein spätmittelalterliches Reimoffizium zu Ehren der heiligen Martha in seiner böhmischen Überlieferung (Musicological Studies series HISTORIAE 65/9), Ottawa: Institute of Mediaeval Music.

Czagány, Zsuzsa (2009), 'Historia sancti Mathiae apostoli - Wege eines spätmittelalterlichen Reihenoffiziums zwischen Prag und Trier', in Cantus Planus. Papers Read at the 13th Meeting, Niederaltaich, Germany, Aug. 29 - Sept. 4 2006, Budapest: Institute for Musicology of the Hungarian Academy of Sciences, 143-156.

Czagány, Zsuzsa (2016a), 'Das Itinerar einer spätmittelalterlichen Prunkhandschrift im 16-17. Jahrhundert. Fragmente des Antiphonale Waradiense in Levoča und Poprad', in Rastislav Adamko (ed.), Musica Mediaeva Liturgica, vol. II, Ružomberok: Katolícka univerzita v Ružomberku, Pedagogická fakulta, 103-129.

Czagány, Zsuzsa (2016b), 'Böhmische “Zutaten” im Waradiner Sequentiar', in Pawet Gancarczyk (ed.), Ars Musica and Its Contexts in Medieval and Early Modern Culture. Essays in honour of Elżbieta Witkowska-Zaremba, Warszawa: Liber Pro Arte, 237-245.

Czagány, Zsuzsa (2019), Antiphonale Varadinense s. XV, vol. I: Proprium de tempore; vol. II: Proprium de sanctis et commune sanctorum; vol. III: Essays (Musicalia Danubiana 26/13), Budapest: Research Centre for the Humanities, Institute for Musicology.

Deissmann, Adolf (1933), Forschungen und Funde im Serai. Mit einem Verzeichnis der nichtislamischen Handschriften im Topkapu Serai zu Istanbul, Berlin: De Gruyter.

Gilányi, Gabriella (2018), Használatitól a müremekig: a 15. századi hangjelzett esztergombudai kódexek [From Ordinary to Masterpiece: the Fifteenth-Century Notated 'EsztergomBuda' codices], in Gabriella Gilányi (ed.) Zenetudományi Dolgozatok 2015-2016. In memoriam Kiss Gábor, Budapest: Institute for Musicology of the Hungarian Academy of Sciences, 24-36.

Kalous, Antonín (2001), John Filipec: His Life and Personality, in Marcell Sebők and Katalin Szende (eds), Annual of Medieval Studies at CEU 7, Budapest: Department of Medieval Studies, CEU, 267-268.

Komáromy, András (1890), 'Báthory István országbíró végrendelete’ [The will of Stephen Báthory], in Századok, 24: 124-141.

Körmendy, Kinga (1988), Az ún. Zalka Antiphonale töredékei [The Fragments of the so-called Zalka Antiphonal], in Zenetudományi Dolgozatok [1988] (<http://real-j.mtak.hu/id/eprint/ 4694>): 33-40. 
Kovács, Andrea (2010), Corpus Antiphonalium Officii Ecclesiarum Centralis Europae, VII/A: Transylvania-Várad Temporale; VII/B: Transylvania-Várad Sanctorale, Budapest: Institute for Musicology of the Hungarian Academy of Sciences.

Madas, Edit, et al. (eds) (2006), Mittelalterliche lateinische Handschriftenfragmente in Sopron, Budapest: Akadémiai Kiadó.

Mezey, László (1973), 'A Fragmenta Codicum szabályzata’ [Statutes of the Fragmenta Codicum], in Magyar Könyvszemle, 89: 211-213.

Mezey, László (1978), ‘Fragmenta codicum. Egy új forrásterület feltárása’ [Fragmenta Codicum. Discovery of a New Source Field], in MTA Nyelv-és Irodalomtudományi Osztályának Közleményei, 30: 65-90.

Mezey, László, et al. (eds) (1983), Fragmenta Latina codicum in Bibliotheca Universitatis Budapestinensis [...], Budapest/Wiesbaden: Harrassowitz/Akadémiai Kiadó.

Mezey, László, et al. (eds) (1988) Fragmenta Latina codicum in Bibliotheca Seminarii cleri Hungariae centralis [...], Budapest/Wiesbaden: Harrassowitz/Akadémiai Kiadó.

Szendrei, Janka (1981), A magyar középkor hangjegyes forrásai [Notated Sources of the Hungarian Middle Ages] (Mühelytanulmányok a magyar zenetörténethez [Studies in Hungarian Music History] 1), Budapest: Institute for Musicology of the Hungarian Academy of Sciences.

Szendrei, Janka (1986), 'The Introduction of Staff Notation into Middle Europe', in Studia Musicologica Academiae Scientiarum Hungaricae, 28: 303-319.

Szendrei, Janka (1988a), 'Choralnotationen in Mitteleuropa', in Studia Musicologica Academiae Scientiarum Hungaricae, 30: 437-446.

Szendrei, Janka (1988b), ‘Geschichte der Graner Choralnotation', in Studia Musicologica Academiae Scientiarum Hungaricae, 30: 5-234.

Szendrei, Janka (ed.) (1993), Graduale Strigoniense (s. XV-XVI) (Musicalia Danubiana 12), Budapest: Institute for Musicology of the Hungarian Academy of Sciences.

Szendrei, Janka (1997), 'Choralnotationen in Polen', in Musica Antiqua Europae Orientalis, 10: 257-274.

Szendrei, Janka (1998), 'Perspektiven der musikalischen Paläographie in der Choralforschung', in Studia Musicologica Academiae Scientiarum Hungaricae, 39: 267-282.

Szendrei, Janka (2001), 'Mittelalterliche Choralhandschriften in Istanbul', in Cantus Planus. Papers Read at the 9th Meeting Esztergom \& Visegrád 1998, Budapest: Institute for Musicology of the Hungarian Academy of Sciences, 71-95.

Szendrei, Janka, et al. (eds) (1999), The Istanbul Antiphonal c.1360, Budapest: Akadémiai Kiadó.

Szigeti, Kilián (1962), ‘A magyar középkor zenei emlékei Szombathelyen’ [Musical Documents of the Hungarian Middle Ages in Szombathely], in Vasi Szemle, 16/2: 64-73.

Vadász, Veronika (2002), Ecsedi Báthory István végrendelete 1603 [The will of Stephen Báthory of Ecsed 1603] (Fiatal Filológusok Füzetei - Korai újkor 1), Szeged: SZTE.

Vízkelety, András (1989), 'Az Isztambuli Antifonále’ [The Istanbul Antiphoner], in Ars Hungarica, 17/1: 99-102.

Vizkelety, András (ed.) (2007), Mittelalterliche lateinische Handschriften der Széchényi Nationalbibliothek (Cod. Lat. 450-556), Budapest: Akadémiai Kiadó.

Vizkelety, András, et al. (eds) (1993), Mittelalterliche lateinische Handschriftenfragmente in Esztergom, Budapest/Wiesbaden: Akadémiai Kiadó/Harrassowitz.

Vizkelety, András, et al. (eds) (1998), Mittelalterliche lateinische Handschriftenfragmente in Györ, Budapest/Wiesbaden: Akadémiai Kiadó/Harrassowitz. 
Julia Craig-McFeely

\title{
Restoration, Reconstruction, and Revisionism: Altering Our Virtual Perception of Damaged Manuscripts
}

\begin{abstract}
The answers to questions about the boundaries of digital retrieval of damaged manuscript content are extremely fluid, dependent on ethical and aesthetic expectations and the intended end-use of the edited images. Digital intervention is currently the only way to restore the contents of many manuscripts to usability. The chapter examines the Forensic Reconstruction of damaged manuscript leaves through a combination of various digital and analog evidence; in particular, what is achievable, the ethical constraints and practical decisions informing the end result, and the palaeographical value of the outputs.
\end{abstract}

Recent work on reconstructing the Sadler Partbooks (Bodleian Library MSS Mus. e. 1-5) found the team of editors reconsidering the poorly-defined and littletravelled field of ethics in digital restoration/reconstruction in search of a solution that would allow the end result of their work to benefit the greatest constituency of end users. Even in an ideal world of unlimited time and money the answers to many questions have extremely fluid boundaries, dependent not only on ethical considerations but also on aesthetics, expectation and the intended end-use of the edited images. Adding the constraints of time and cost that come with working in the real world to idealised goals of content-recovery may result in digital editors feeling as if they have been painted into a corner. Being forced to form a policy on the type of work done on an image by simple logistics can however be both illuminating and liberating. So many manuscripts from so many periods have suffered damage that make them unreadable - from acid burn to scraping or dismemberment and re-use as binding reinforcement - that digital intervention is currently the only way to recover their contents, so we need to be

\footnotetext{
Note: I am grateful for the opportunity to re-examine the corpus of edited images in the DIAMM collection that now spans two decades of work from my earliest experiments in the digital repair to the most recent innovations. All the edited images shown here are the work of the author unless specifically noted otherwise.
}

Ә Open Access. (C) 2020 Julia Craig-McFeely, published by De Gruyter. (cc) BY-NC-ND This work is licensed under the Creative Commons Attribution-NonCommercial-NoDerivatives 4.0 International License.

https://doi.org/10.1515/9783110717884-013 
informed about the tools and techniques we have at our disposal and their practical viability.

It is now over 21 years since the Digital Image Archive of Medieval Music (DIAMM) came into existence, and over 20 years since we 'captured' our first digital image of a manuscript. In the first phase of the project we aimed to digitise every fragment in the UK up to 1400 , adding fragments from other periods if they were in libraries we were already visiting. Complete manuscripts were avoided at this stage because the technology available for imaging at this level required a scanning back; with this technology a shot of a single leaf could take around 6 minutes, or 15 minutes under UV light (because of the increased exposure time required), making the digitisation of large numbers of leaves impractical because of cost. The second phase extended our remit to European fragments and intact manuscripts in the UK, which involved shoots of several large manuscripts such as the Eton and Lambeth choirbooks. ${ }^{1}$ Further phases focused on creating an acceptable online delivery mechanism but added manuscripts and fragments as permitted, while fruitful collaborations with other projects created a steady feed to the image repository. It became clear fairly soon that the website was used as much for access to the metadata as for the images, and attention shifted more proactively to that side of the content. ${ }^{2}$ DIAMM is now the only reference source that lists all known polyphonic sources up to 1600 , having added over 350 newly discovered fragments and intact manuscripts to the lists published in RISM and the Census Catalogue, which were the only comprehensive listings prior to DIAMM. $^{3}$

A distinguishing aspect of the project from its inception was not only early adoption of the use of high-resolution digital imaging at a time when many major institutions had not yet embraced it, but also the possibility that in the digital medium the images could be manipulated and edited if the original manuscripts were too damaged to read. We generally use digital surrogates much as we used analogue ones in the past: simply as a representation of the manuscript as it looks to the naked eye, but to the digital editor these images represent a far richer repository of information than analogue photographs, since the depth of information they store far outstrips that visible to the naked eye. Image-processing

1 Windsor, Eton College Library MS 178, and London, Lambeth Palace Library, MS 1.

2 Being unable to update the online content with any ease was a major problem, solved by a new technical partnership that resulted in an entirely 'live' database. Contributions and corrections are submitted daily by a user base that reached just under 30,000 in the last year, with a high of 4,500 genuine hits during February 2019.

3 See RISM B/IV, 1-4; Wathey 1993; Census. 
software can differentiate between shades of one colour that the unassisted eye cannot, and this is fertile ground for the retrieval of information that has apparently been lost to natural decay or wilful damage.

We might assume that the further we go back in time, the more fragmentary our witnesses become, but the proportion of fragments to complete sources up to 1400 is very similar to the proportions $1400-1550$.

After 1550 there is a dramatic increase in the number of surviving complete sources, somewhat inflated by the rise in partbook copying (where what would previously have been one manuscript is now 4-8 separate books), and the consideration of individual partbooks in a set by DIAMM (for technical and practical reasons such as geographic dispersal) as individual manuscripts rather than being grouped together as single sources. The level of wilful damage increases as we go back in time, partly because of the structural usefulness and reusability of parchment as opposed to paper: techniques for retrieving what survives become more drastic the earlier the source. The advent of paper as the preferred medium for writing brought its own problems, particularly those of acidity of materials, but also the long- and short-term fragility of paper compared with the relatively tough animal skins it replaced.

There is a persistent belief that what survives of medieval polyphony is only the tip of a much larger iceberg of lost works, but this impression is belied by the number of fragmentary sources for which there are concordances. It is rare for a new source to be discovered that preserves completely unknown works. ${ }^{4}$ It seems, in polyphony at least, that the iceberg may be inverted, and what has survived in terms of repertory is considerably more than what has been lost, it is merely the number of witnesses that have been depleted.

\section{Digital intervention}

The majority of users of digital images tend not to do anything more than look at them because a high-resolution colour image can be enlarged and is therefore significantly better than its analogue counterpart. What happens though when the new surrogate still does not deliver what is needed to decipher the text?

Early experiments in digital recovery were often far more successful than anticipated: by using the capacity of the software to differentiate between very similar colours, ink marks that could not be seen by the naked eye could be

4 Cuthbert 2009. 
retrieved. Even uninvested in the outcome however, an editor can be misled by what they think they can discern, so the most difficult aspect of digital recovery is attempting not to recover that which we expect to see, but leaving the machine to find what is actually there. On the whole, sampling colours from pen marks that are undisputed avoids the trap of restoring to expectation rather than on the basis of what is unquestionably there. British Library Add. Ms. 41340, a lifted pastedown, yielded an unexpected block of text in a void in the music that was picked up by colour-selecting based on the visible note-heads (Fig. 1).
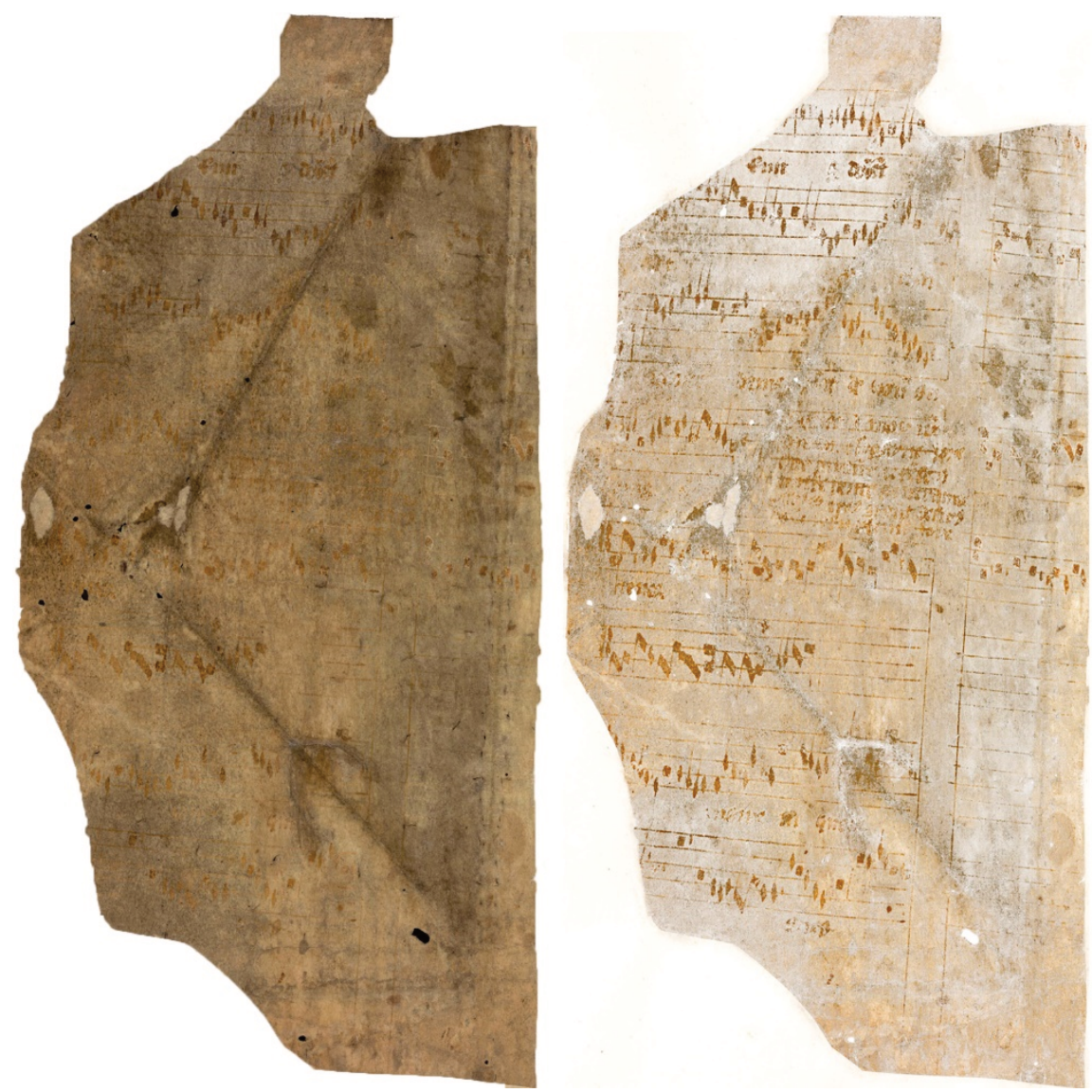

Fig. 1: London, British Library, Add. Ms. 41340; @ London, The British Library: digital editing by Andrew Wathey. 
A more complex array of problems arises in cases where the parchment leaves of a music manuscript have been reused, and the overlaid text may be as important to its own adherents as the lost text is to those who wish to read that. Until the advent of high-resolution colour imaging ultra-violet (UV) was considered the only useful form of photographic investigation for palimpsests. However, UV created the issue that the overwriting would darken as much as (or more than) the palimpsest, causing frustrating levels of interference in what could be read. This was the case particularly when the overlaid text was similar in colour and chemical composition to that which it replaced. Oxford, Corpus Christi College, MS 144 showed that, as long as the resolution was sufficient, RGB images were more useful than the UV, since they could be edited to remove the overwritten text, and the colour selection subtlety of the software could 'find' the lost text just as well as the UV had. ${ }^{5}$ Staged reconstruction of the image below (Fig. 2) shows removal of the overwriting by replacing it with pattern created from the background, then lightening of the background to improve contrast and finally an editorial overlay in which the voids in the note-heads caused by the missing overwriting are filled in manually.

When I first started editing digital image to improve readability I proposed that a restored image should leave the user in no doubt about the fact that it did not represent the original in its present state. This was a response to concern expressed by a single library that if people visited a manuscript after seeing improved images of it they might blame its condition on poor husbandry, so the use of unlikely colours (green, purple) was implemented when selecting and highlighting or retrieving faded or erased ink. Thus, anything which was revealed by a digital process is visually signalled to the end user so that they can evaluate the data based on whether it has been artificially enhanced or not. This method had the unanticipated benefit of making recovered pen-strokes easier to read than simply improving their natural colour since it enables the brain to extrapolate more information than it can when attempting to differentiate between similar colours. At the time I felt that images manipulated in this way were not suitable to publish in print as a permanent record of the document because they looked crude and, despite the improvement in legibility, they seemed to imply disrespect of the original document in a way that might invite criticism.

5 RGB is the term used for digital colour images, and is based on the Red-Green-Blue colour space used for capture by digital cameras. Print outputs are usually converted to CMYK (Cyan, Magenta, Yellow, blacK). 


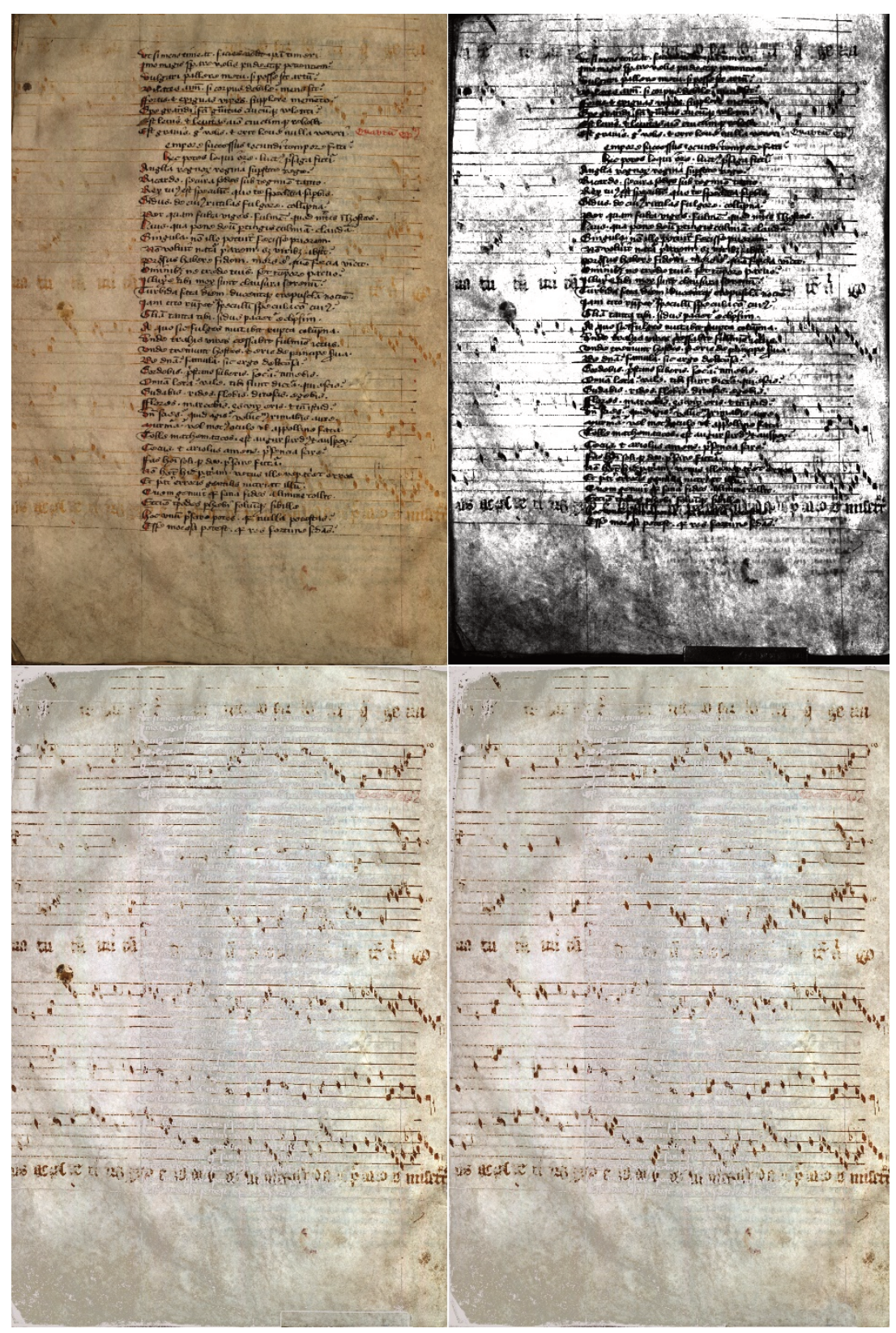

Fig. 2: Oxford, Corpus Christi College, MS 144, from top left to bottom right: original RGB; UV;

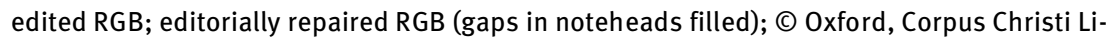
brary. 
The rear cover of a document wrapper in Stratford (Fig. 3) provides another example of the way in which the greater acuity of the software over the eye may return unexpected results, and the way in which 'incorrect' colour supports the reading. The bright colours allow the reader to differentiate between background and retrieved ink marks very easily, particularly if the background colour is also eliminated.

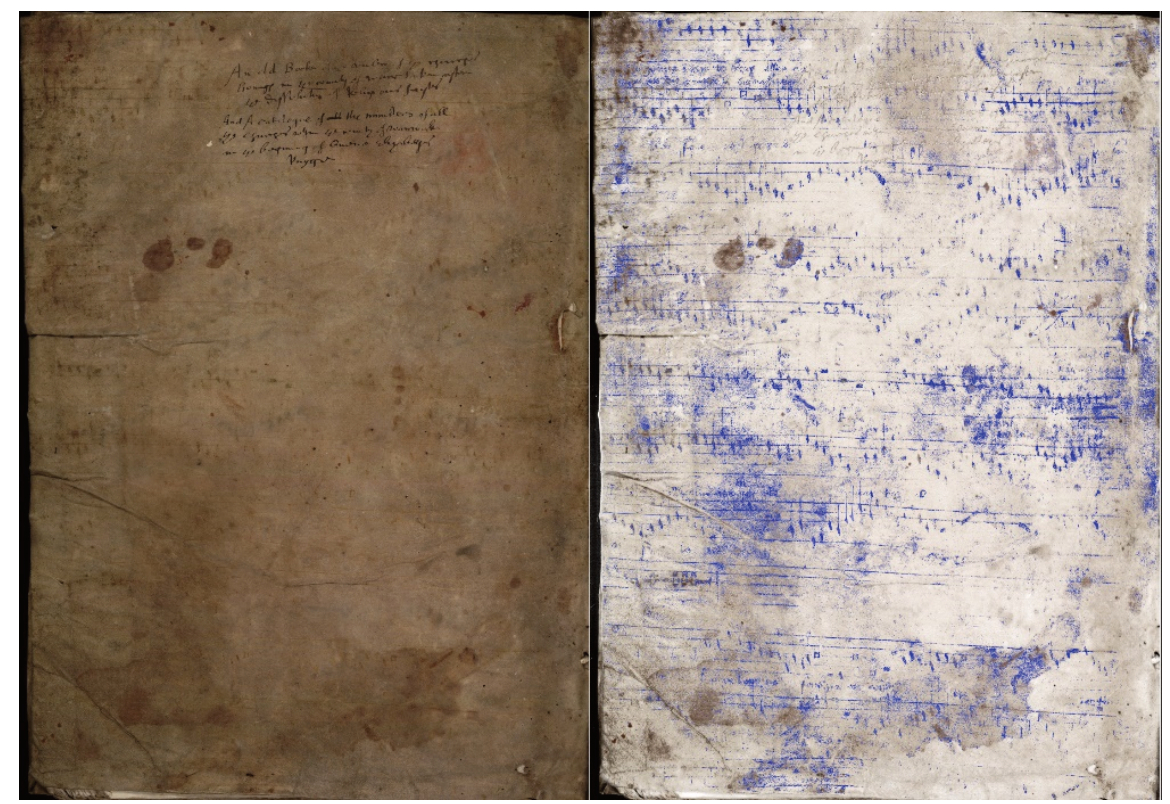

Fig. 3: Stratford, Shakespeare Birthplace Trust, DR37 Vol. 41, back of wrapper, outside face: before and after digital editing; original image (C) Stratford, Shakespeare Birthplace Trust.

The rising scale of notes visible in the centre of the top third of the page correlates to notes written on the reverse, so are the result of showthrough. Showthrough on the verso may therefore provide an additional clue to the writing on the front that is rubbed off, so instead of ignoring (or eliminating) it these colours may be selected, inverted, and used to confirm or improve the reading on the front. Using information from another page changes the nature of the editorial intervention, even if that page is the reverse of the primary, although we are still using layers of photographic evidence that originate in the source. Lifting notation offset onto a binding board and reuniting it with the lifted endpaper involves a similar process, but this is one of conflation rather than adjustment of what is there but too subtle to be seen by the naked eye (Fig. 4). 


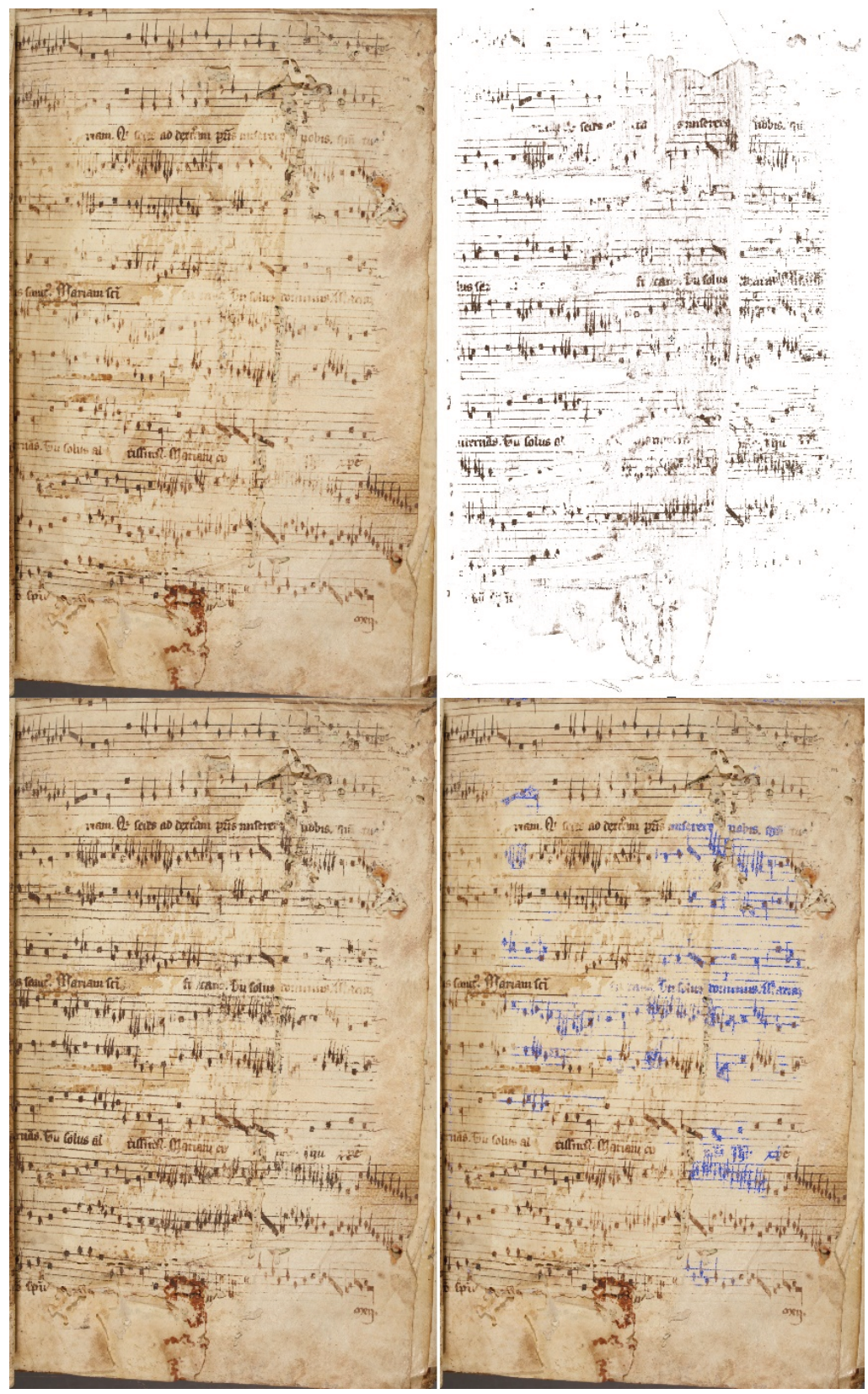

Fig. 4: Oxford, Bodleian Library, Bodley 384: original; notation lifted from the board and flipped; original plus overlaid offset; colour selection instead of overlay; @ Oxford, Bodleian Library. 
The lifted offset has many problems in this case: the position of the pastedown shifted while in situ so there is double offset in places. When inverted and overlaid on the image of the pasted leaf considerable distortion is apparent, probably caused by the lifting process. This made re-laying the offset on its parent leaf not only difficult but unsatisfactory, since it involved so much reshaping that the exact positioning was questionable. Even after considerable time attempting to align the layers note-by-note the result conveys little or nothing that could not be seen on the original image and in some cases creates confusion where none existed before. A limited colour selection focussed on the more damaged areas of the leaf seems more revealing.

There are techniques that require considerable editorial decision-making and active intervention with respect to individual notes and these are usually employed with manuscripts that have suffered the most extreme forms of damage. As a result these techniques are used where the reading is most in question and therefore most at risk of misinterpretation, or perhaps 'over-interpretation'. In such cases one might decide that the editing must be supervised or supplemented by an expert reader whose knowledge of the repertory enables the editor to make critical judgements about content. However, a potential issue of expert readers is that they might be misled by their familiarity with the context, and therefore by their expectation of what should be written on a leaf. ${ }^{6}$ The person who undertakes the digital recovery should therefore not be the person who is most invested in the outcome. The digital reconstruction of Hugh Aston's Te Deum in the Sadler partbooks rendered the only possible reading at one disputed point as one that was technically flawed. ${ }^{7}$ The Sadler witness may of course be a poor transmission of a better original, now lost, but there is no doubt that the recovered reading is what the original scribe recorded.

While musicologists have been tinkering with digital manuscript images on an individual basis for the last 20 years, the software has benefited from continuous development towards automating repair processes. For example, if I wish to remove something on an image that I have decided is a later accretion, the software will now offer me context-sensitive erasure. The results are extraordinary both in the subtlety with which they sample the surrounding material to create a likely solution and the ease with which the process is accomplished (select,

6 More than once I have found myself faced with a source that emphatically does not record what the expert believes it should. Copying errors are uncommon, but they do occur, or perhaps the composer just didn't write what we now consider to be grammatically appropriate.

7 Oxford, Bodleian Library Mus. e. 1-5. 
delete), allowing us to hide foreign objects holding the leaf in place or wormholes with equal facility. Usually, the smaller the area, the more convincing the result (Fig. 5).
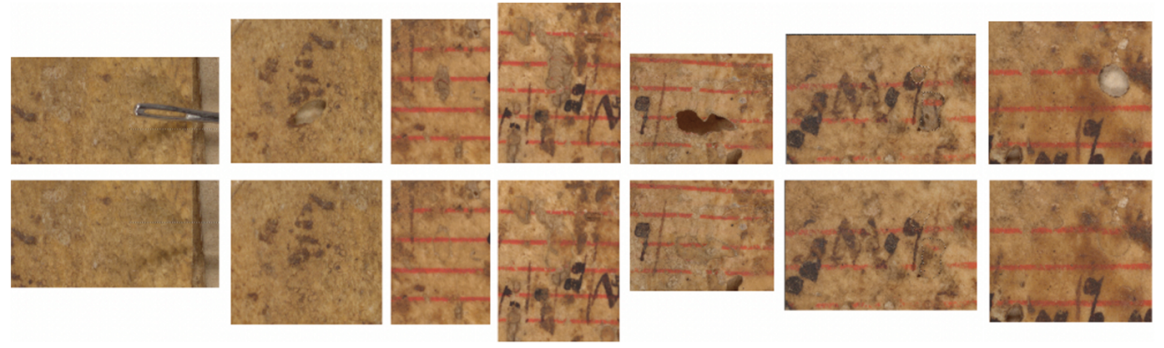

Fig. 5: Worcester, Cathedral Archives, MS Q19, front endpaper, details: before/after clippings of computationally-calculated repairs; ( ) Worcester, Cathedral Archives.

If the solution offered by the computation is unsatisfactory the process can be repeated with varied selections until it renders a result that is more acceptable (Figs 6 and 7).
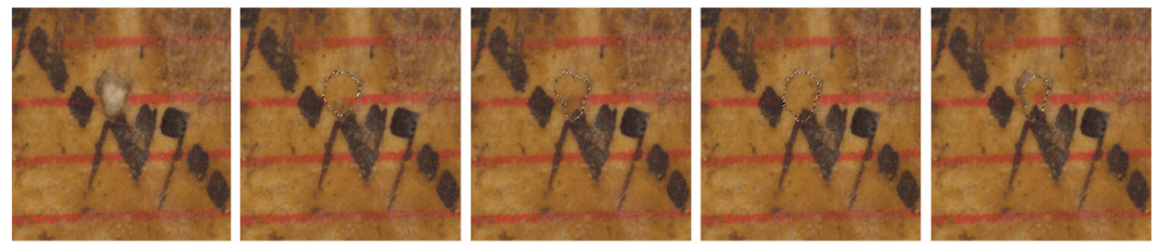

Fig. 6: Worcester, Cathedral Archives, MS Q19, front endpaper, detail: wormhole with different solutions offered by Photoshop software; @ Worcester, Cathedral Archives. 

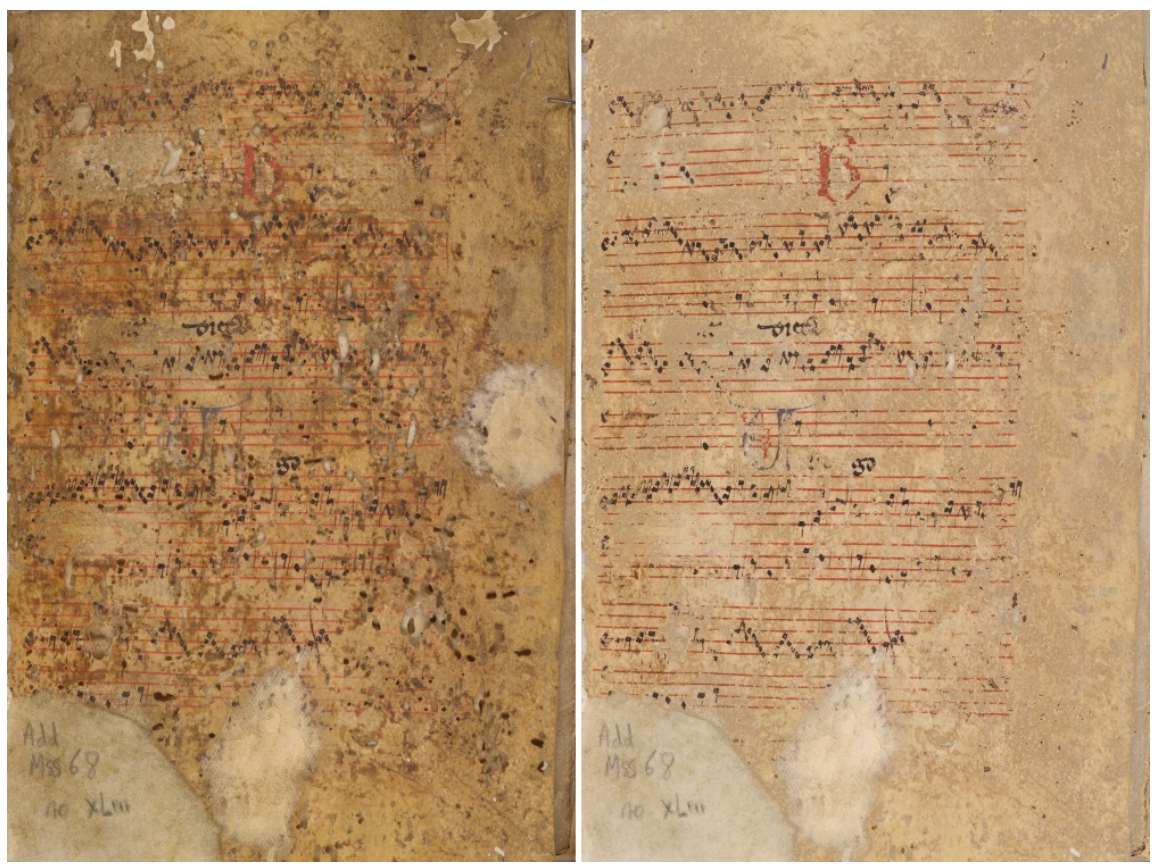

Fig. 7: Worcester, Cathedral Archives, MS Q19, front endpaper: original, and edited version with content-aware machine-generated wormhole repair and manually defined colour-fill; (c) Worcester, Cathedral Archives.

In this case, an improvement to the texture of the document allows us to read it more easily. However, this relatively facile process is fraught with problems. A wormhole that has been 'fixed' may have destroyed a notehead, but without the wormhole the user is not alerted to the potential for a lacuna. If a repair is good enough the reader is too easily misled into believing there was nothing there in the first place, so an editor could very easily present a desired result that falsely represents the witness. Fig. 7 is offered here as an example of the extent to which an entirely computer-determined reconstruction, with no human input aside from the selection of the area that needs to be repaired, is becoming increasingly possible. When used alongside the original, this edited version may support a better reading, but only alongside the original.

Binding strips can suffer from both glue damage and stretching and shrinkage that makes even conjunct strips difficult to re-align. They can however be 'warped' back into shape using a distorting tool, though this is fundamentally 
cosmetic, since it is not difficult to adjust the eye to read across a disjunct break in a leaf as long as there are no lacunae (Fig. 8).
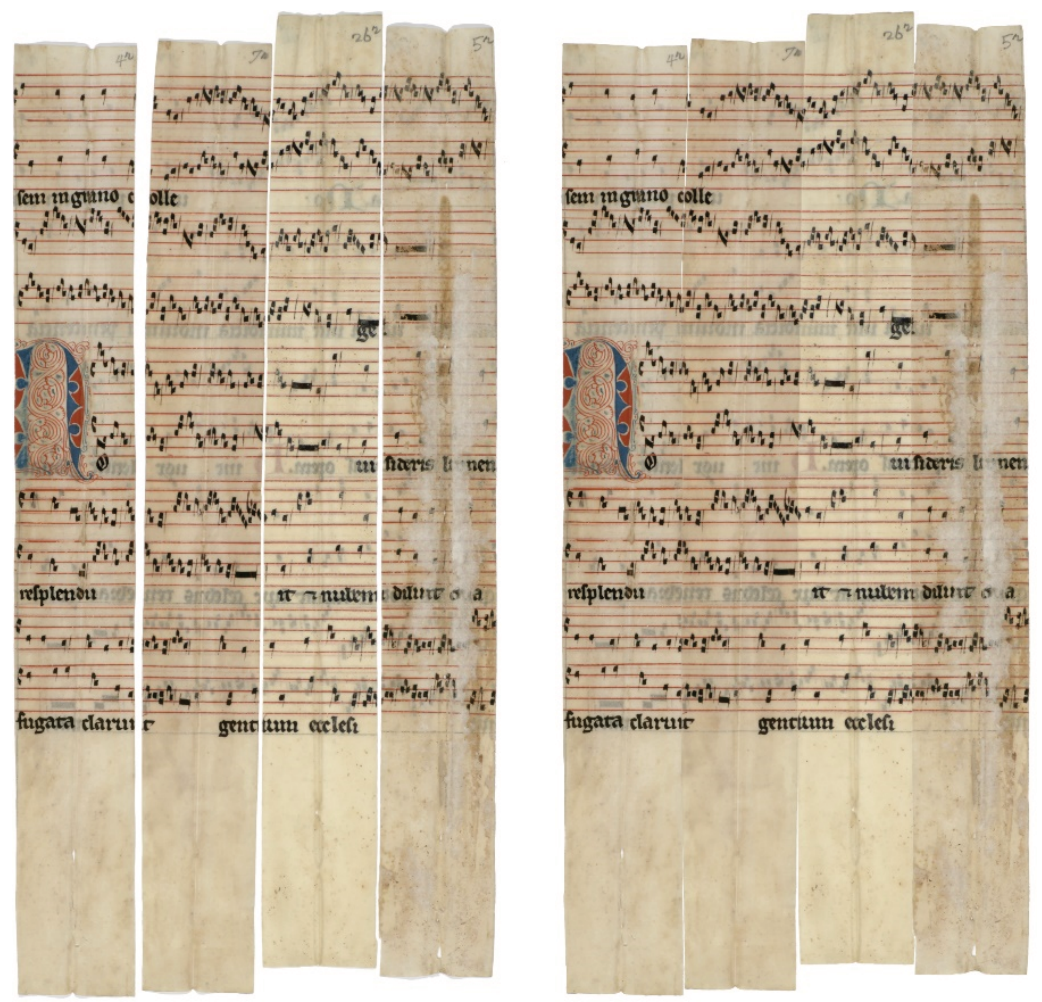

Fig. 8: Cambridge, Jesus College, QB1, fragment $\mathrm{H}$ : laid side by side and digitally joined with slight warping to improve fit; @ Cambridge, Jesus College.

Although a colour master image is considered essential in recovering lost text digitally, a surprising amount can be achieved if the only available image is monochrome. In the case of Harvard, Houghton Library Typ. 122, the leaf is pasted to an endboard and could not be lifted. The library's conservation department treated the leaf to make it temporarily more translucent, so that music on the back could be seen (in reverse), but this brief experiment was only recorded in monochrome. Once scanned to the digital medium the grayscale images could be edited to support the reading of at least some of the music on the hidden face of the leaf. 


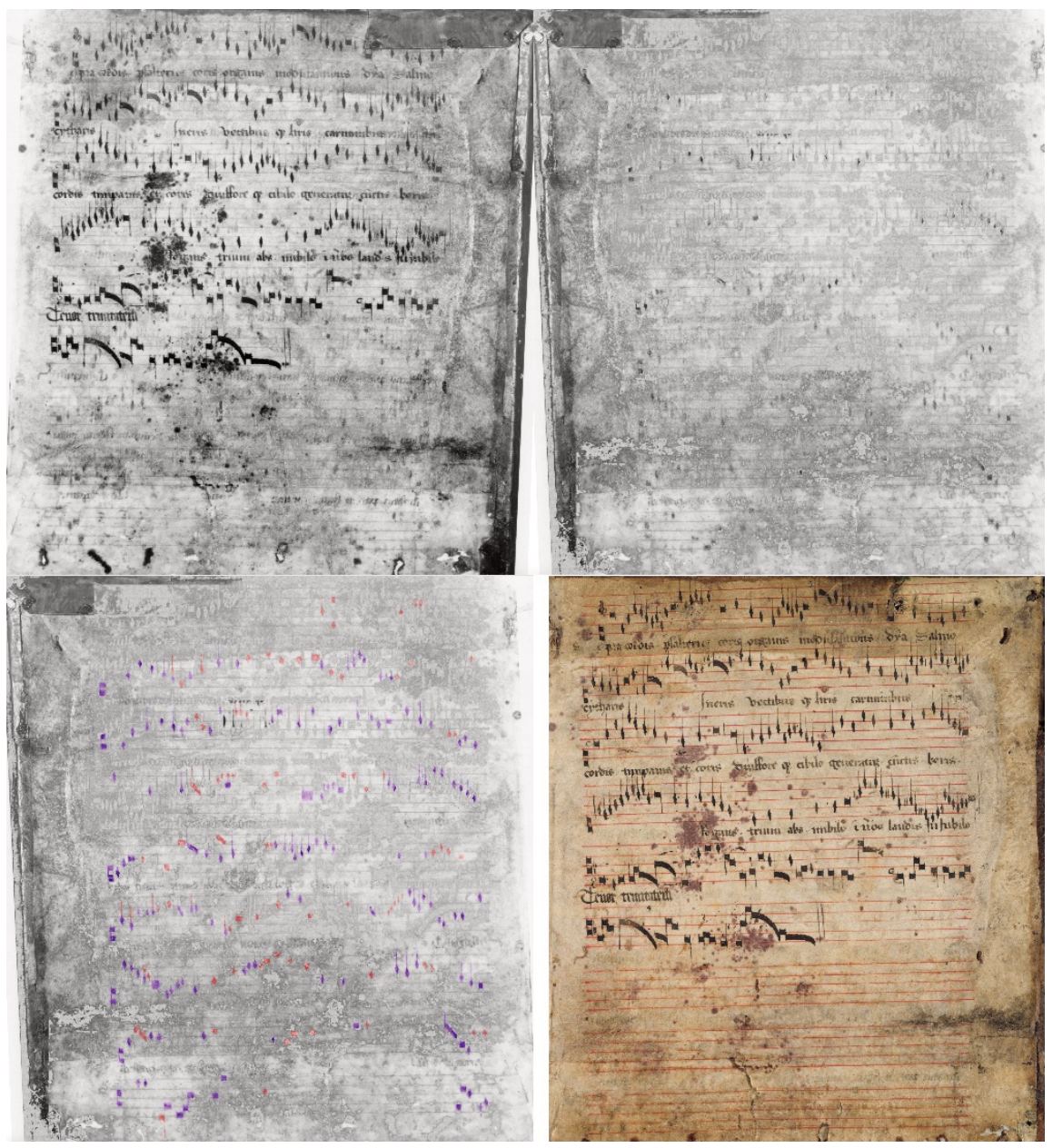

Fig. 9: Harvard, Houghton Library, Typ. 122; @ C Harvard, Houghton Library.

Fig. 9 shows the retrieval of data from the scan of the glossy b/w image taken when the leaf was treated; clockwise from the top left image: the monochrome image; mirror-inversion with the surface writing obscured/eliminated (though retained as a reference layer); the same image with notes that the editor could make out from the reverse picked out in two colours representing two levels of certainty. The stave lines appear to align closely between front and reverse; RGB image taken recently, the leaf still pasted down. 
On the colour image there is an issue that cannot really be resolved without being able to see the reverse of the leaf, namely that some notes that may appear to be showthrough are in fact offsets from a lost facing page which is apparent in the confusion in the stave lines towards the foot of this page.

Different types of digital imaging essentially replicate what has been available in analogue imaging for the last century, the primary focus being accurate colour imaging. What has changed is the facility with which the images can be manipulated or combined, and this is what might provide new information. The types of documents where multispectral imaging (MSI) might be effective are extremely few (limited almost entirely to palimpsests or heavily rubbed sources), so the use of this technique has always been very limited, regardless of the complexity of the process and special equipment required. Multispectral imaging is not new, but there have been significant developments in the last decade, primarily emanating from the field of astronomy, where interference bandpass filters can be fine-tuned to pass extremely limited light spectra, allowing their use to identify single elements such as hydrogen or helium by their spectrum values when viewing or capturing the light output of a star. Contrary to its title, multi-spectral work is actually limited spectral imaging, but the name comes from the process of shooting a series of images either using different bandwidths of light generated by single-spectrum lighting or interference bandpass filters that limit the range of light reaching the camera from full-spectrum lighting. The 'multi-' in the title refers to the number of images taken, each of a limited band in the full RGB light spectrum. The technique will not always reveal information and there are cost and handling implications that must also be considered before attempting this specialised process.

\section{The impact and repercussions of new techniques}

The imaging work of Andreas Janke on the San Lorenzo palimpsest (SL) is one case where multispectral techniques have proven extremely successful, demonstrating the benefits of combining an old (but newly effective) technique with a new medium. ${ }^{8}$ The images offer an unparalleled opportunity to access the contents of a manuscript that has been considered to all intents and purposes lost. The images are reproduced in an edition by John Nádas and Andreas Janke (who

8 Florence, Archivio del Capitolo di San Lorenzo, MS 2211, 'Campione de Beni del 1504'. 
established the methodology) in bright prime colours that separate the different layers of activity in the manuscript. ${ }^{9}$ This is, I believe, the first publication in which the editors have decided to reproduce images of an entire manuscript in a form that does not attempt to represent the way the manuscript looks in the analogue world. It is a persuasive advocate for the use of 'manipulated' images in preference to unedited RGB representations when dealing with a heavily damaged manuscript. Janke's work has been successful in revealing lost text, not only in SL, but I suspect this publication will be influential less for revealing the contents of a particular source, than for breaking the barrier of what we consider acceptable as a printed reproduction of a manuscript. ${ }^{10}$ For the research community dependent on digital manipulation to access the content of a significant portion of their materials, the publication has stimulated a re-examination of attitudes to digital intervention and the ways in which we present our findings to our colleagues.

Janke cited the avoidance of misrepresentation as just one of his reasons for working in what he called 'false colour' in the SL photographs, though the bright prime colours also serve to differentiate layers of ink that to the eye would be difficult to separate if rendered in more natural shades. Rather than limiting the reproduction to only the palimpsest layer, he includes the overwriting, in a differently-coloured layer. His main argument for retaining the overwriting is based on the fact that without it a reader cannot determine whether pen marks (notes, rests, etc.) in the original source might have been lost either completely or partially because they were covered by the overwriting. Without access to the overlaid text, readers may be misled about the content, or at least cannot make an informed decision about what they see, since they lack a vital piece of the puzzle. This is precisely the problem encountered with the removal of wormholes shown in Fig. 5. Unless you can see where the overwriting (or the wormhole) is, you are not able to judge whether something might thereby have been omitted from the revealed text, and you cannot tell in advance where this might happen.

There is no suggestion that the San Lorenzo publication is a 'facsimile'. Something more visually conclusive would have been possible had the editors decided to integrate a further level of digital intervention but the issues of a fuller digital recovery of the manuscript were an editorial bridge that remained uncrossed. The publication is therefore a showcase for the capture and post-processing techniques developed by Janke's team in Hamburg. It is an accurate

9 Nádas/Janke 2016.

10 The methodology is examined in Janke/MacDonald 2014. The methodology was applied to another fragment and written up in Janke et al. 2018. 
record of the object (albeit re-coloured) ${ }_{11}^{11}$ based on technical conditions that capture different layers of information, and shows that much can be achieved without editorial changes, although obviously some decisions have to be made about which combination of images yield the best result. Janke's ongoing research into what can be achieved at the point of capture may result in a capture method that would obviate editorial intervention (which is always based on critical decisions) and this would be the ideal way of accessing texts in damaged sources. The SL images show that what can be achieved, at least at the moment, has limits. The results are still difficult to read and since every manuscript, and often every page, can present quite different technical challenges to retrieval, the Holy Grail of the 'single solution' is currently out of reach. However, as computers and software improve it may eventually be possible to create a suite of tools in which the technical side of the work is less visible. For now, though, digital editing is the only sensible course for publication of damaged sources for which reproduction as they currently appear has no value. Janke's relatively non-interventionist method expects - indeed requires - all the critical decisions about content to be made by the reader, a situation ethically preferable to one in which those decisions have been made for them. Even clearly indicated, editorial decisions cannot fail to influence the reader. Janke's method also obviates questions of whether the realisation of something the editor can see is based purely on physical evidence or involves some critical judgement. ${ }^{12}$

The question of what end-users want to see from reproduction of images of a manuscript as severely damaged as SL is problematic: some feel we could - and therefore should - go further editorially before publishing if doing so is more productive and not misleading; Janke and Nádas leave most decisions to the reader, but they have made it considerably easier to make those decisions than it was before. The answer seems to be to make both types of reproduction available: 'non-interventionist' photographic material, and some sort of edited version of the images that will make that material accessible to someone not expert in the particular field. The first purely presents the evidence, while the second draws it

11 Although Janke in private correspondence with the author has said that the output is not entirely unedited since "processing, using statistical analysis, was involved. "photographic" does not summarize the technique'.

12 The main disadvantage in this approach is to the non-expert, who has to wait for the publication of a modern edition of the content, and there are many reasons why cutting the performer or non-expert off from the original notation is undesirable. In an environment where study of music from earlier periods is increasingly dropped from university curricula, the burden of making the content of these types of sources accessible falls increasingly on the diminishing number of people who can read them. 
together with the critical apparatus of the expert to present a conclusion. The obvious delivery medium is the digital one, since in many cases there will be multiple surrogates, and possibly also multiple solutions. In terms of editing quite often one technique improves part of a page while disimproving another part; different techniques have to be used on different areas of the page; there may be a variety of 'solutions' to the content on the page. Selection for print can involve discarding some solutions of limited success in favour of one that elucidates the largest area of damage, even if doing so means that some small areas that could be retrieved with bespoke work are not revealed.

In the case of the Sadler books (see below) there were for some pages four different surrogates that contributed evidence to its final reconstruction, all of which should be accessible to those evaluating and using the result. The disadvantage of digital delivery is its impermanence: there is no guarantee that an online resource will still be here in ten years, or even in five, nor that a complex technical solution to delivery issues will not be broken by the next web architecture upgrade. Far from replacing print, the digital delivery world is increasingly aware of its ephemerality in comparison with print media. After all, an extraordinary amount of the medieval and early modern world has survived thanks to the culture of book production that preserved and disseminated its knowledge and artistic life. We can be sure that $99 \%$ of what is now on the web will not be there in 100 years (assuming the web itself is even there), but the likelihood of print publications still being on library shelves is high.

SL was photographed by DIAMM in 2011 with a very high-resolution scanning back in standard RGB mode (in analogue language, a colour photo)..$^{13}$ Colour UVs were taken at the same time and these are rendered in monochrome since the limited wavelength is basically only delivering information in one colour. The RGB image can be edited to remove the overwriting, complete the stave lines from their remnants, and retrieve what is left of the lost music by employing a finelytuned colour selection (Fig. 10); the result is shown in bright blue.

13 PhaseOne FX 144 Mpx scanning back. Only recently has PhaseOne produced a single-shot camera back that exceeds this resolution. 


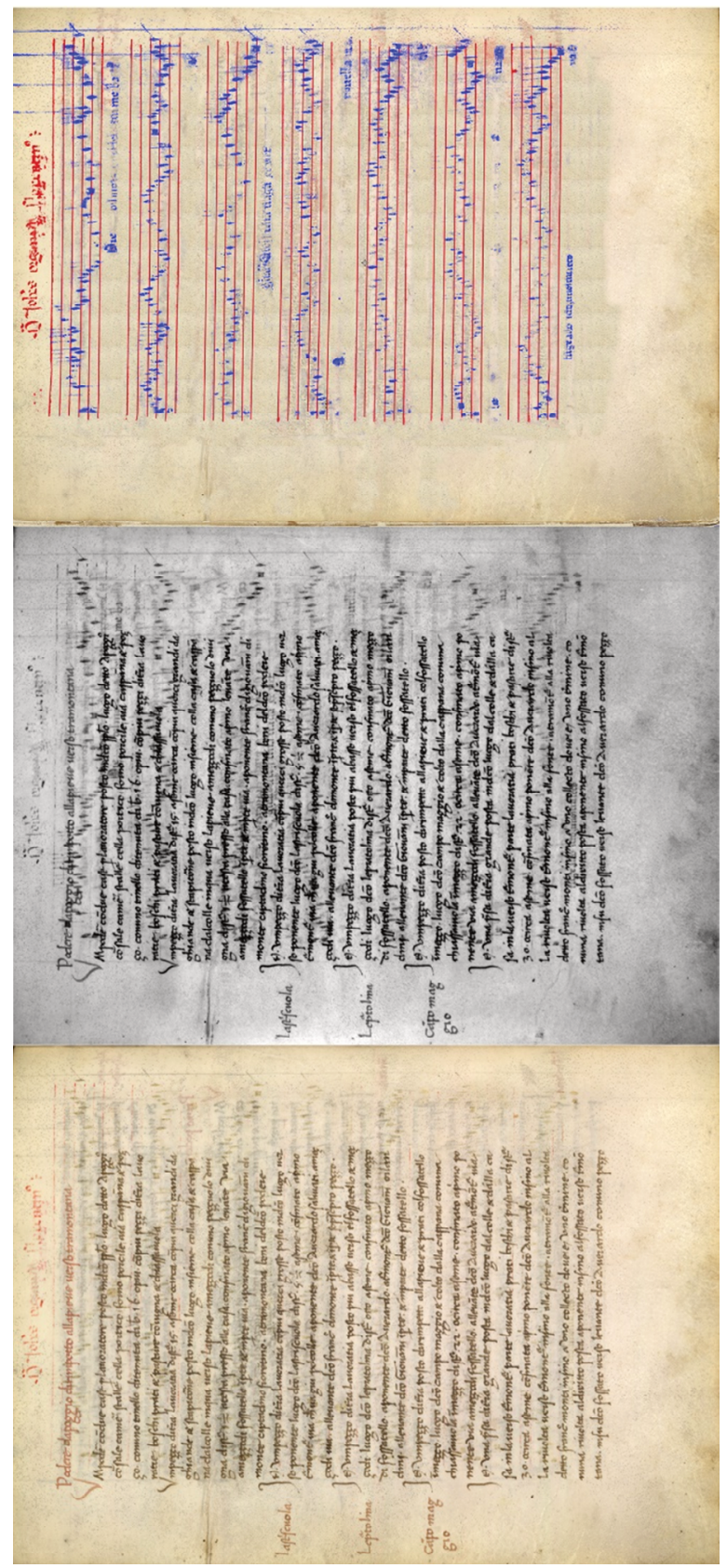

Fig. 10: Florence, Archivio del Capitolo di San Lorenzo, MS 2211, f. 22v: master RGB image; UV image; RGB image edited; ( ) Florence, Archivio del Capitolo di San Lorenzo. 
The ghost of the lost text is visible in the right-hand margin in the RGB image and in the body of the page have been found by colour-selecting on these notes. As in the case of Corpus Christi MS 144 (Fig. 2), the UV shows much of the palimpsest, but darkens the overwriting as well. There is no consistency between pages of SL in the extent of the damage, and this example is of a moderately good page. Many are far more intractable.

Janke's images show far more information than the RGB or UV images taken by DIAMM, but the overwriting, retained in yellow in his reproduction, interferes significantly with attempts at a reading. Even so, a forest of stems can now be added to the visible palimpsest, and the information from Janke's image can be added to that of the edited image. Bearing in mind Janke's concerns about notes hidden under the surface writing, if we interpose another layer of editing - call it 'restoration' or 'reconstruction' - there is also the need for some critical discrimination to deal with the inevitable lacunae, introducing another layer of complexity - and potentially error - to the reconstruction. ${ }^{14}$

The cuts and gaps in the noteheads caused by removal of the overwriting can be filled in if desired with a reasonably clear conscience. Fig. 11 shows the previous blue selection shown in Fig. 10 but now including additional stems, noteheads and text revealed on Janke's images. The middle image shows the top four stave-lines edited to infill cuts left by the removal of the overwriting. The final image shows the result rendered in more naturalistic colours. By removing the unusual colour, the reader may be misled into thinking that the rendering is more true to the original than it actually is.

14 There are numerous solutions to how one might present the reader with notes that must be there but cannot be seen, but these need not be discussed here. 

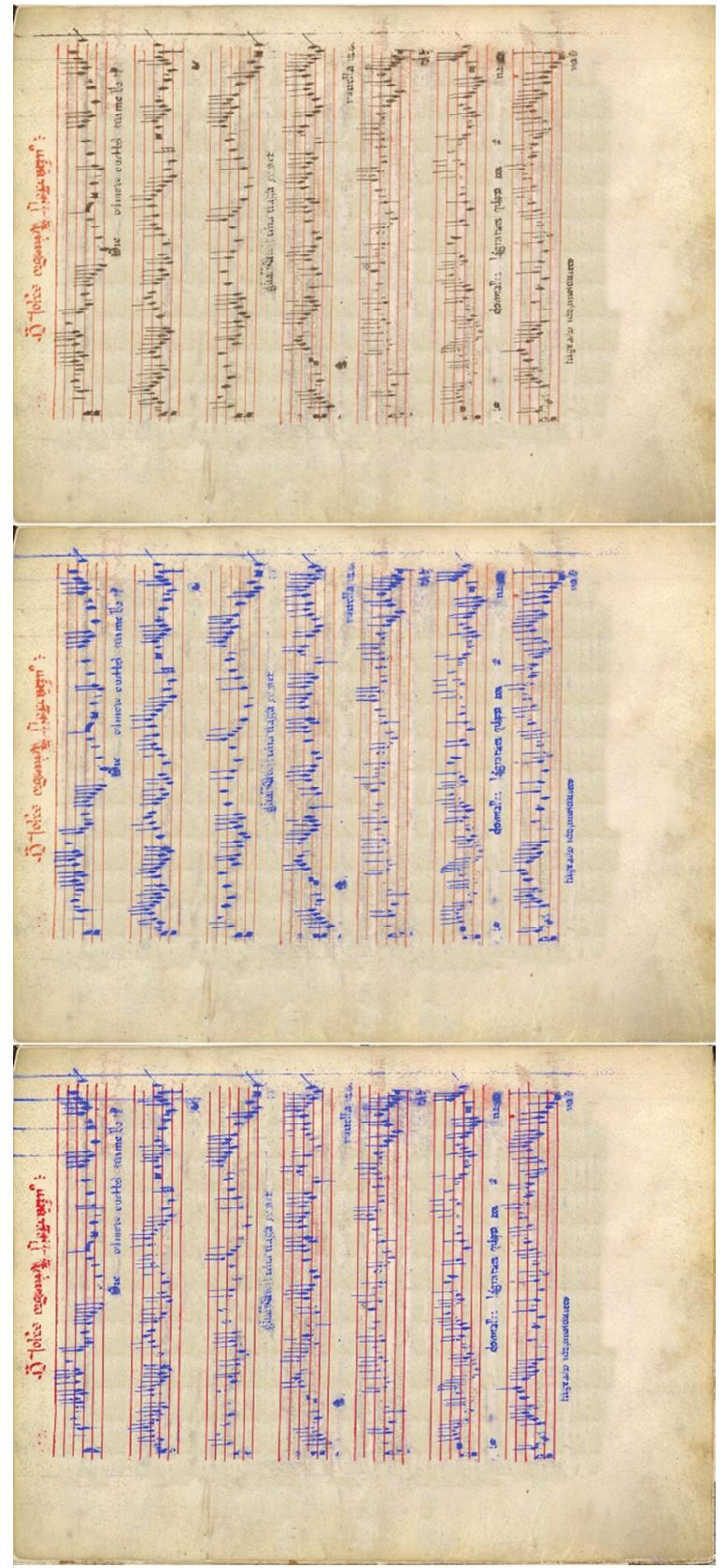

Fig. 11: Florence, Archivio del Capitolo di San Lorenzo, MS 2211, f. 22v, further edited; (c) Florence, Archivio del Capitolo di San Lorenzo. 
This editing work has been extended to an end point that is more extreme than usual in order to explore the potential gains that might be achieved by combining the different layers of evidence now available, but every retrieved note, stem or line now visible can be justified by reference to some version of the original document, in RGB, UV or multispectral form. By combining automated and manual methods, we have the ability to create an image that can be read, and possibly played from, and can be made to approximate the appearance of the original had it not been damaged, if we wish. Even supported by Janke's data though, this rendering remains incomplete - and this is one of the less-damaged pages in the book. In many other pages the loss is much greater, so creating a usable reconstruction of the entire manuscript would require high levels of speculative suggestion from an editor, and only a few pages might offer reasonable levels of retrievable data.

The process above certainly involved quite heavy editing, so the way it is described is problematic, and the term 'restoration' is inappropriate. A more justifiable term for a process like this, since it is the result of a composite of information provided by a variety of surrogates that are combined with the aid of editorial decisions (about what to include and exclude) and editorial input to realise missing notes, would be editorial reconstruction.

A publication of a manuscript as extensive as SL, incorporating both Janke's approach and further digital retrieval to reconstruct the pages, might require unrealistic amounts of time and input from its editors. ${ }^{15}$ This is true of the process of reconstructing the images, but the musicological input would probably be little more than that required to make a modern-notation edition of the music. The main argument against this level of intervention is that the editors make informed but, nevertheless, discriminatory decisions about the pitch and value of missing notes (which can be indicated in many ways). Any imposition by an editor, while not obviating the consideration of alternative readings, does tend to affect a reader's critical apparatus, particularly among less expert readers. Since so little of the original pen-strokes can be retrieved, is this level of editing even appropriate?

15 Each image would take about a day, but continuous work of this kind on a day-to-day basis is physically impossible. 


\section{Forensic reconstruction}

The Sadler Partbooks (Oxford, Bodleian Library MSS Mus. e. 1-5), are a set of five sixteenth-century paper music books severely damaged by acid burn-through and lacing. Returning these books to readability and usability was a long-term project as the extent of the work was considerable, involving 700 images of pages in various states of disintegration and (il-)legibility. The bulk of the work was funded by the AHRC as part of the Tudor Partbooks project from 2014-2017, with refinement still ongoing. All aspects of the nature and extent of the digital intervention were qualified by practical considerations of time and manpower, as well as the end use to which the finished images might be put. These books would reach a wider public than one might encounter with medieval fragments, since a large constituency of amateur and professional musicians would potentially use the 'restored' books for performance.

SL and the Sadler partbooks represent polarised aspects of the legibility issue. In the case of Sadler there is too much ink, in the case of SL too little. In Sadler the interfering ink is coming through from beneath the text, in SL it is laid on top. In Sadler the destruction is incidental and unintentional, in SL it is deliberate: the intention was to obliterate the original text which is the one we now want to read. Despite these differences questions about intervention are much the same. Multispectral imaging was not attempted on Sadler because the process primarily enhances information that has been lost and therefore would not have been effective in a situation where the ink has effectively multiplied. MSI imaging would also not have revealed anything that was not shown in the infra-red spectrum. Infra-red imaging has limited applications, but in this case was extremely revealing. Moreover, for conservation reasons the Bodleian could not allow extra handling that extensive further imaging would necessitate and conservation must always take priority over the desire to have an ideal set of images of a manuscript. In this case, imaging work to the extent of that undertaken on SL would have been out of the question.

There is a conflict between scholar and owner/keeper that can never really be reconciled: the owner is concerned with preserving the object, but the scholar wants and needs to access the information that it contains. As manuscripts age and deteriorate, re-photographing using newly developed techniques is increasingly problematic; ultimately we may be forced to deal with some sources only from their basic RGB surrogates. Libraries have long understood that obtaining the highest possible resolution at the outset is a preservation priority. It is, therefore, incumbent on us to develop methods that retrieve as much information as possible from the basic imaging to support the conservation of the primary 
source. The development of new photographic techniques is unlikely to find its way to the Sadler Partbooks, but to a great extent the work done by the Tudor Partbooks team should minimise that necessity.

The Sadler Partbooks were withdrawn from public access some time in the 1960s; only a monochrome microfilm has been available to readers for over 40 years, taken during conservation in the 1970s. Although a good portion of the text underlay is legible in the microfilm, the bulk of the music is completely obscured, as shown in Fig. 12. This set of manuscripts presented a major challenge for digital recovery, not only in the extent of the damage but in the scale of the job.

In order to facilitate access with images of a quality that would also allow digital intervention the Bodleian Library digitised the set of five books in highresolution colour in 2014 (Fig. 13). The advantage of this set of surrogates over the microfilm is manifest. It can be extremely frustrating to attempt to read a manuscript in this condition. All the ink we needed to see was on the page but it was obscured by a great deal of other ink contemporary with the primary copying. In other sources where later copying has obscured earlier work it is possible to see degrees of colour separation due to age or the use of different materials. In this case the fact that the inks were contemporary meant that there was no colour separation that would have allowed us to separate layers of ink based on colour or intensity.

The process was therefore one of removal of the superfluous ink, rather than one of retrieval of lost ink. The editors had to remove the accretions and damage to the page in such a way that the end result was useful not only to the majority of the potential audience who would use the books as a musical repository, but also the smaller community who wished to study the books as a historical record of a particular place and time. ${ }^{16}$

16 The editing work involved a team of three in-house editors (two musicologists and one graphics expert who could read music), and 31 volunteer editors with various levels of expertise ranging from a graphic designer with an interest in playing early music from facsimile, to a marine engineer with no prior image-editing skills who could not read music, but had an excellent eye for shapes and pen-strokes. 


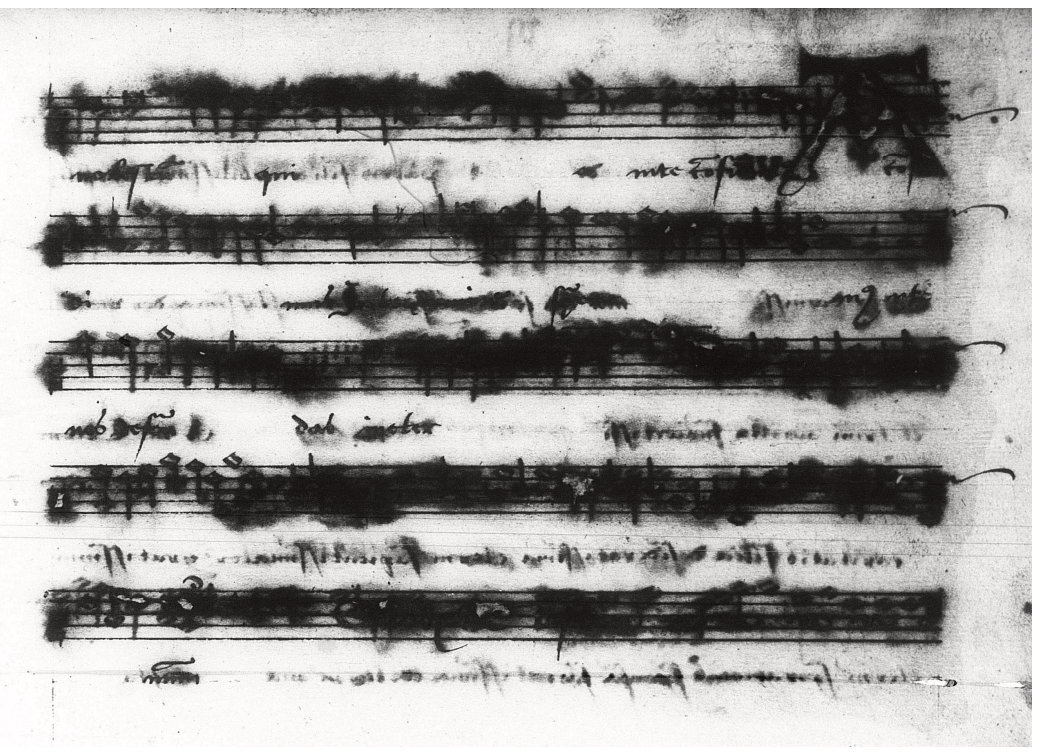

Fig. 12: Oxford, Bodleian Library, MS Mus. e. 2, f. 16r: microfilm image (c.1974); @ Oxford, Bodleian Library.

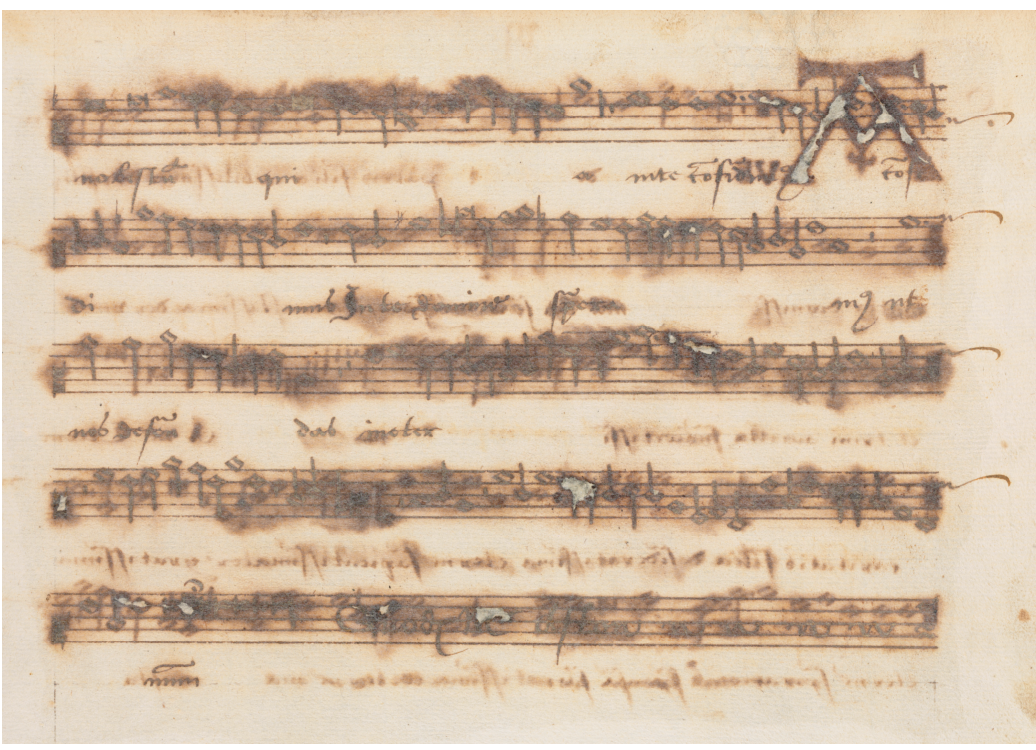

Fig. 13: Mus. e. 2, f. 16r: modern RGB digital image (2014); @ Oxford, Bodleian Library. 
My first attempts at repairing acid burn through in the late 1990s created images that despite being unattractive facilitated a reading (Fig. 14). These images were only intended for use by one person in order to make a modern edition, so there was little concern for the aesthetic appearance of the repaired page.

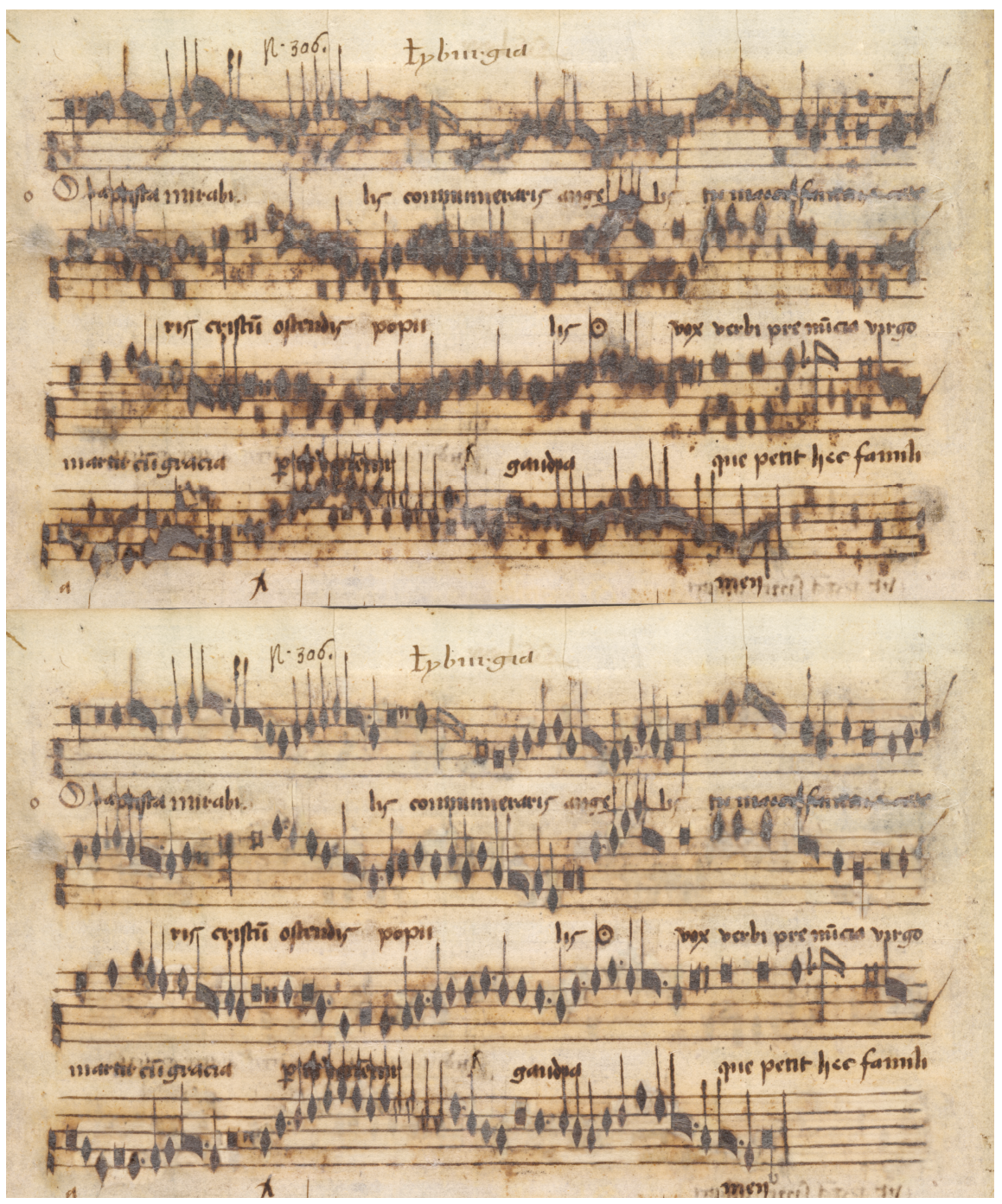

Fig. 14: Bologna, Museo Internazionale e Biblioteca della Musica, MS Q. 15, f. 309v: detail before and after editing; (c) Bologna, Museo Internazionale e Biblioteca della Musica. 
Like SL however, the Sadler books are destined for paper publication, ${ }^{17}$ and like SL the extent makes publishing images of the whole set in both their original state and post-editing impractical, to say nothing of being largely pointless, since so little of the original can be read..$^{18}$ The damage to individual pages is so variable that the intervention in each image had to be customised. There were some processes that could be semi-automated, but they still required manual refinement. The question of parity is particularly relevant in Sadler because of the large editorial team, but in this case the question is parity of final appearance, not that of methodology.

Restoration implies the return of an object to a previous state. At what point in a manuscript's life are we aiming in a repair of this sort? In this set of books there is really no 'original' we can recall since there is evidence that even at the time of copying there was some interference from showthrough. Attempting to create a snapshot of the books at any point in their history is impossible.

Descriptions of the books in sale catalogues prior to their acquisition by the Bodleian Library do not mention their physical condition, but James Burke's recent research relates that they went through various misadventures before acquisition that may have hastened their decay, including possibly surviving a warehouse fire. ${ }^{19}$ The earliest photographic records indicate that showthrough was a very significant issue 100 years ago so there would be no point in 'restoring' the manuscripts to their state at that time. Ultimately, we can only attempt to create a factitious representation of how the manuscripts might look today had they not suffered the attrition caused by the heavy, acidic ink, and poor-quality paper. Fortunately, there was at least one scribe in the books whose legacy was a few pages that are almost undamaged; these leaves provided a template on which to base intervention policy for the other pages.

Fig. 15 shows an untouched image from the partbooks that was used as one of the baselines for the editing of the remaining leaves, including a scratched-off erasure at the end of line 3.

17 The reconstructed books will be published in Craig-McFeely/Range 2020.

18 The original images of the Sadler books are available online (without charge) for comparison, <https://www.diamm.ac.uk/sets/127> (accessed 16 June 2019).

19 Burke 2016. 


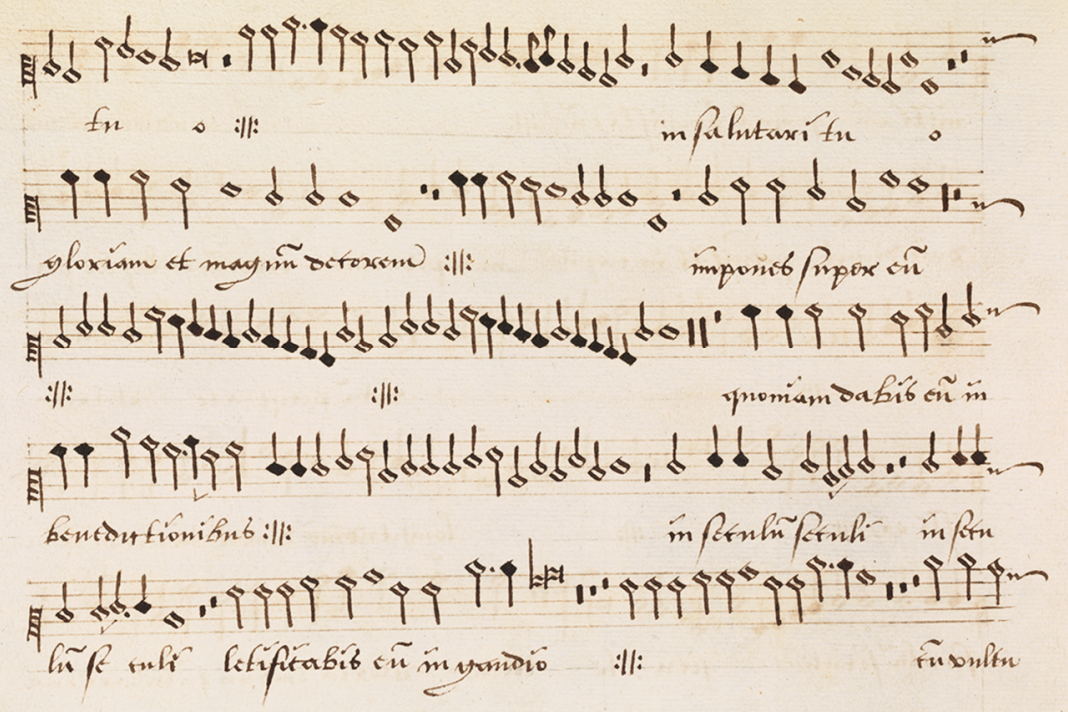

Fig. 15: Oxford, Bodleian Library, MS Mus. e. 2, f. 44v (un-edited image); @ Oxford, Bodleian Library.

As well as baseline images from the books themselves, there are other sets of similar manuscripts from the same period and environment which are in excellent condition, so there are good contemporary models for the style of finish appropriate to the Sadler books. ${ }^{20}$

Around $98 \%$ of the notes and text on the reconstructed pages appear as the scribe wrote them, and in his original ink thanks to a staged process of Forensic Reconstruction..$^{21}$ This involved the collation of different layers of evidence, both direct and circumstantial, to create a representation of the content of each page that is as true as possible, not simply to the lost music but to the orthography and calligraphy of the original scribes, the process of copying, correcting and recopying, and the interactions of the various scribes and users of the books. The layers of evidence used in the reconstruction are described below.

20 Oxford, Christ Church, Mus. 979-83, 'Baldwin partbooks'; Oxford, Christ Church, Mus. 9848, 'Dow partbooks'.

21 The technical process is discussed in more detail with accompanying images in CraigMcFeely 2018. 


\subsection{Master high-resolution RGB images}

The modern colour digital images were of sufficient resolution that the images could be enlarged to allow scrutiny of very fine detail of the text that would not have been visible if examining the original leaves. The colour depth allowed image-processing software to determine colour separation where the naked eye could not. These images were the primary source of information. It was possible to read approximately $85 \%$ of the text from these pages, given enough time and with questioned readings supported by other surrogates or indirect sources of evidence such as concordances.

Magnified images showed crystals that had formed on the ink on the surface of the paper, assisting differentiation between the surface ink and the showthrough (Fig. 16). Unfortunately, 189 pages had been repaired and stabilised with Japanese tissue, sometimes covering only the most damaged sections, so the crystals were lost, making these pages particularly problematic since they were also usually the most damaged.

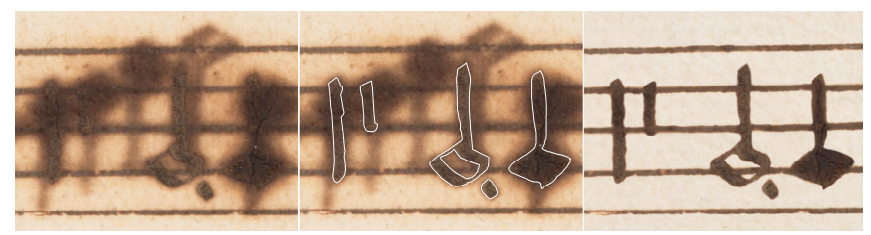

Fig. 16: Pen strokes delineated by superficial crystalline deposits; @ Oxford, Bodleian Library.

The most severe areas of damage were on the staves; repairing this was challenging because of the small size of the units of information and their uniqueness in their context. The text underlay presented its own problems but the showthrough was less extreme and the texts were standard ones, so with internal word-repetition and texts repeated across the books the only difficulties were presented by the occasional misspelling perpetrated by a scribe (which was retained in the reconstruction).

\subsection{TCM Photostats}

In the early 1920s the Carnegie Trust offered a grant to the editors of the Tudor Church Music series (TCM) to make negative Photostats of the majority of the 
pages of the Sadler books. These are preserved in Senate House Library in London. $^{22}$

The Photostats show the manuscripts as they appeared nearly a century ago (Fig. 17): even when showthrough is apparent it is easier to differentiate between the surface writing and the showthrough in these surrogates, even in monochrome, than in the modern colour images. Once scanned, the images can be inverted to positive if required, though this rarely enhanced the reading. They provide a reference point to evaluate the rate of decay between the early 1920s and the 1970s conservation that stabilised the acidity. Many of the modern holes were considerably smaller 100 years ago, but a few areas are more difficult to read as they are obscured by gauze from an early unrecorded conservation (perhaps undertaken to stabilise the leaves for this reprography), some of which is visible in this image covering the last quarter of the top line of music.

22 London, Senate House Library, Tudor Church Music Box 48. The pages reproduced were: Mus. e. 1, fols 8v-10r, 12r-18v, 22r-40v, 42r-57v, 60r-61v, 66v-67v (of 75); Mus. e. 2, fols 6v-8r, $10 \mathrm{v}-17 \mathrm{v}, 22 \mathrm{r}-57 \mathrm{v}, 59 \mathrm{v}-61 \mathrm{r}, 66 \mathrm{r}-67 \mathrm{v}$ (of 75); Mus. e. 3, fols 6v-8r, 10v, 11v-17v, 21r-50v, 51v-58r, 59v-60v, 66rv (of 75); Mus. e. 4, fols 5v-7r, 9r-15v, 18v-56r, 57v-59r, 64v-66r (of 66); Mus. e. 5, fols $6 \mathrm{v}-8 \mathrm{r}, 10 \mathrm{r}-17 \mathrm{r}, 19 \mathrm{v}-20 \mathrm{r}, 22 \mathrm{v}-53 \mathrm{v}, 55 \mathrm{rv}, 60 \mathrm{v}-61 \mathrm{v}$ (of 69). The exact date of the imaging is unknown; the dating comes from identification of the handwriting of a librarian who retired in the late 1920s on labelling shown in the images. We are immensely grateful to the department of Special Collections in Senate House Library and their administrator, Charles Harrowell, who have preserved these Photostats and kindly allowed me to visit them with a high-resolution scanner to make scans for the reconstruction project. They have also given permission for the scans of the Photostats to be made available online alongside the original and reconstructed images, at diamm.ac.uk. Information about the TCM collection may be seen here: <http://www.senatehouselibrary.ac.uk/our-collections/special-collections/printed-specialcollections/tudor-church-music-collection $>$ (accessed 1 Nov. 2017). 


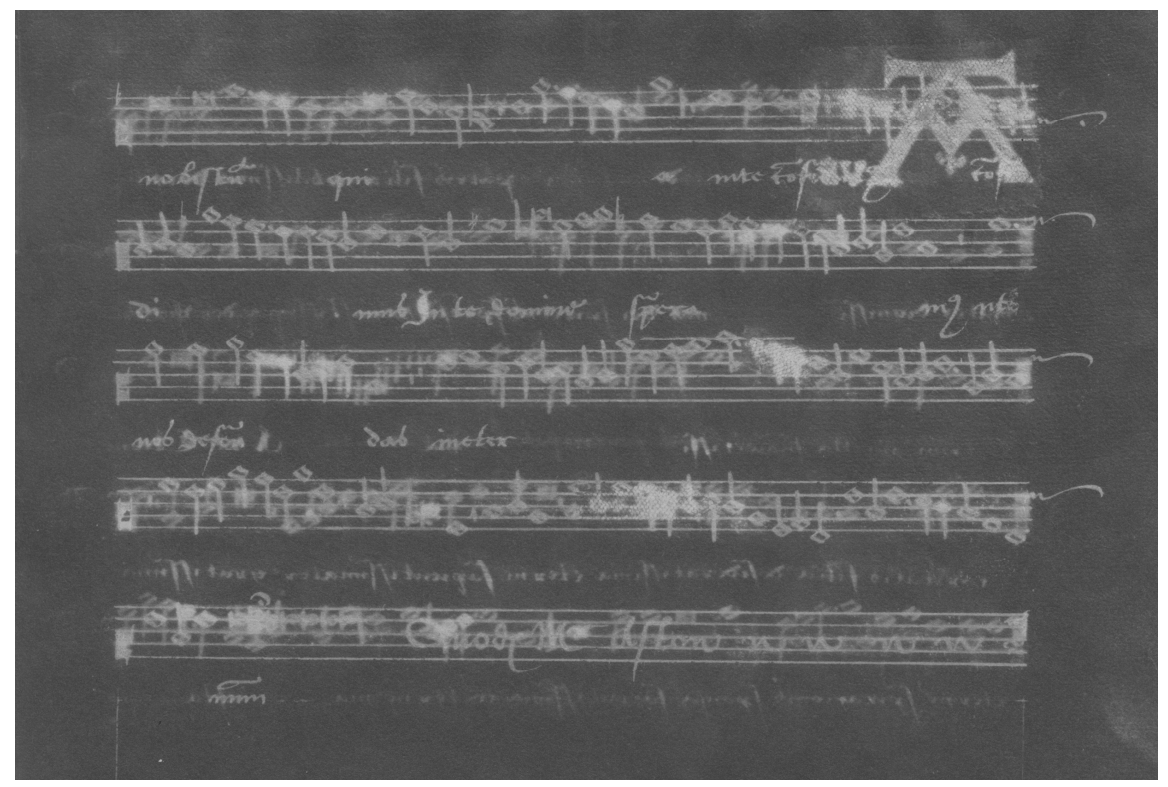

Fig. 17: Oxford, Bodleian Library, MS Mus. e. 2, f. 16r: TCM negative Photostat scanned at high resolution. (See Figs 12 and 13 for microfilm and RGB versions of the same leaf); $\odot$ London, Senate House Library.

When lost or damaged notes on the RGB images were visible in the Photostats, editors could use them as a template to draw around the pen strokes after carefully-aligned superimposition, revealing on the master layer the pen-work of the original scribe with absolute confidence as to pitch, position and shape.

Superimposition is, however, far from straightforward. The changes wrought by time and interference between the manuscript and the Photostat prints were manifest: there was shrinkage and distortion in the manuscript due to the leaves no longer being stretched in a binding, with disintegration of the leaf structure as holes appeared, sometimes abetted by the conservation processes which could not always reliably retain the original shape of the leaves or the position of detached areas. The Photostats too are beginning to deteriorate, with cockling and shrinkage particularly around the edges, abetting the discrepancies between the shapes of the pages as shown in the new digital images and the scans of the Photostats. This meant that simply dropping one image on top of the other did not align staves and pen strokes. The superimposed image had to be subtly reshaped ('warped', in Photoshop terminology) to fit exactly over the notes of the master image, and even this process had to be limited by the amount of time 
available when added to the time needed for reconstructive editing and the number of pages so edited. Rather than attempting to align all the notes on the page perfectly therefore, the alignment was fine-tuned primarily to areas where the reading was critical. ${ }^{23}$

\subsection{Infra-red images}

Infra-red imaging was undertaken on a very limited number of leaves towards the end of the project mainly to confirm areas that could not be read or extrapolated from the Photostats or RGB master images. Most of the remaining questioned readings were due to lacing, leaving only a few places where the paper remained intact but the RGB and Photostat images were indecipherable. Because of the fragility of the manuscript the number of pages to be re-shot was limited to 30, so only leaves where readings could not be confirmed in any other way were photographed under IR conditions (Fig. 18). ${ }^{24}$ It was immediately apparent that the infra-red images provided us with far better information than any of the other surrogates, not only in clarifying the questioned readings, but in revealing the quality of the original penwork, and serendipitously confirming variations between ink types. ${ }^{25}$ As far as the palaeography of the verbal text is concerned, the IR images revealed a more refined picture of the scribal work than had either the RGB or Photostat images: fine pen-strokes and elegant execution emerged that is obscured by the bleed of the ink into the paper at the point of writing due to the porous quality of the paper. These few images serve to demonstrate the value of infra-red imaging in clarifying damage caused by burn-through; it is rarely as successful in other types of damage.

23 Creating the facility for users to superimpose images online requires the same level of detailed work in creating the image sets; building an image viewer that would allow users to add layered images or apply a 'fade-through' option is a technical challenge with concomitant costs. A viewer offering this type of feature requires constant updates and maintenance to keep abreast of changes in web architecture, a cost rarely considered by end users.

24 Mus. e. 1: 13r, 13v, 19v, 20v, 22r, 32r; Mus. e. 2: 8r, 8v, 13r, 14r, 18v, 20r, 26v, 29v; Mus. e. 3: 10v, 18v, 20r, 21r, 30r, 31v, 71r; Mus. e. 4: 12r, 12v, 15r, 26r; Mus. e. 5: 10v, 17r, 19v, 44v.

25 The IR results obviated the need for further multispectral imaging, though that option was in any case not available because of limited access to the original leaves. 


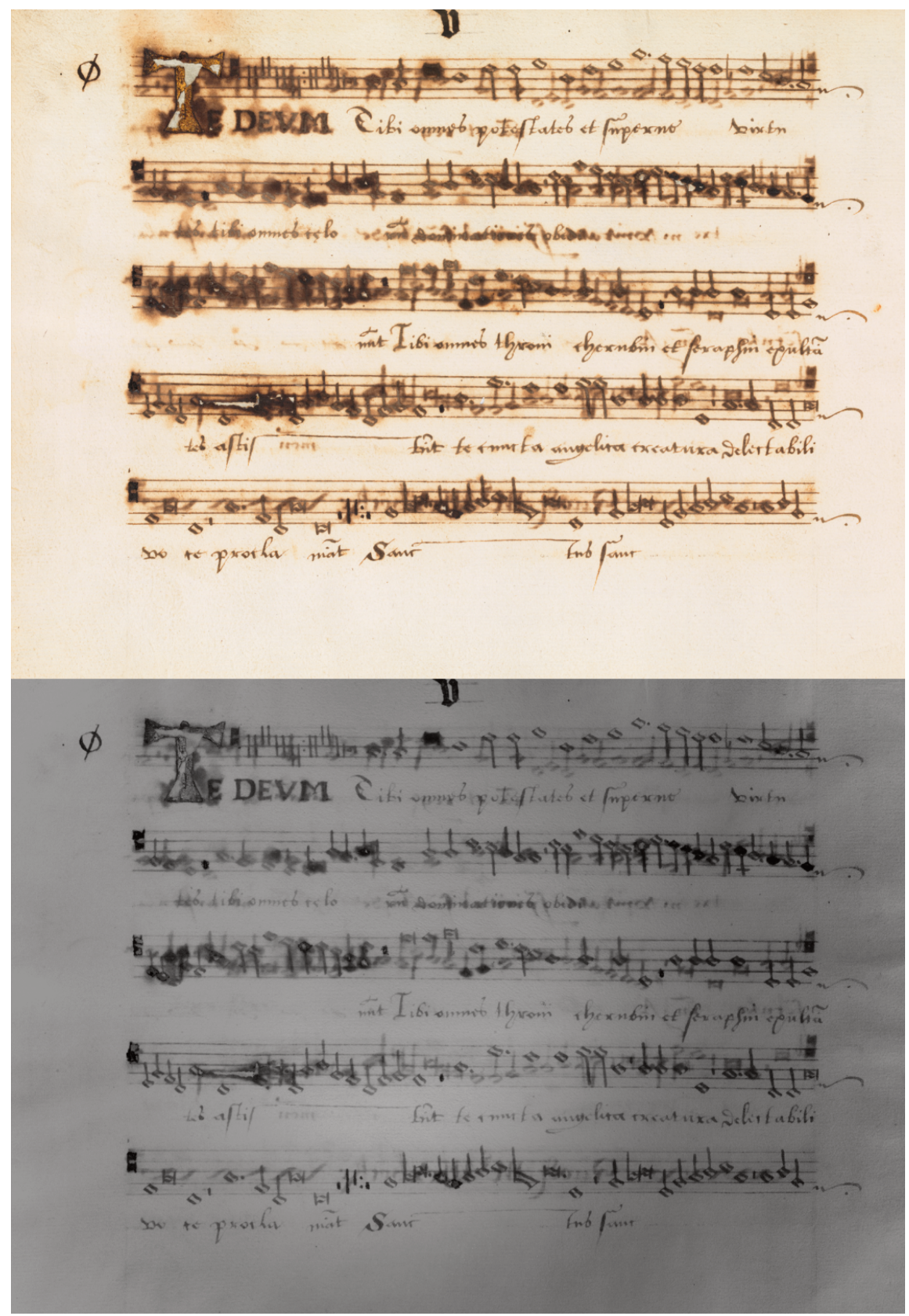

Fig. 18: Mus. e. 4, f. 12v: RGB image @ Oxford, Bodleian Library; IR image $\odot$ author. 
Fig. 19 shows a detail of a page at different stages in data recovery leading to a final reading.

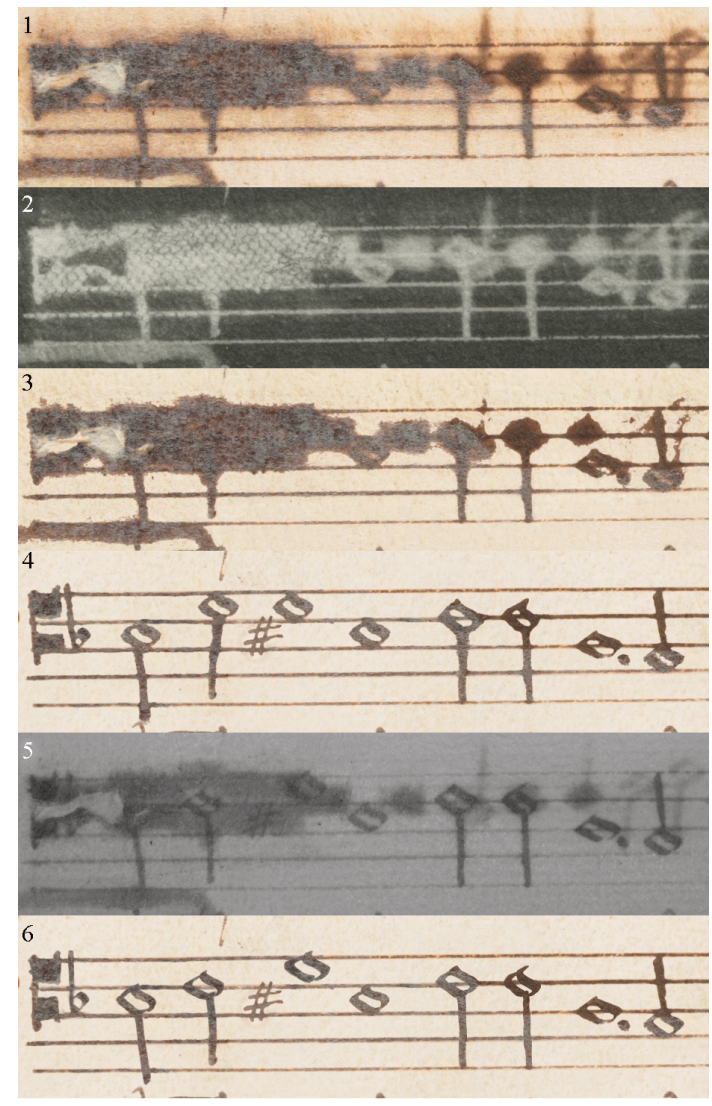

Fig. 19: Detail of Mus. e. 3, f. 10v: different stages in data recovery leading to a final reading; original image (C) Oxford, Bodleian Library; negative photostat (C) London, Senate House Library; other stages by the author.

1. The original image: the problem is caused by a large decorative final on the reverse, obscuring several notes and leaving a hole in the paper repaired by the conservator with a clot of tissue. The first part of the line also has tissue overlay, while the latter part is uncovered and therefore easier to read.

2. Scan of the negative Photostat. The void at the start of the line is slightly smaller, but the burn-through still hides at least three notes, with difficulty 
in reading compounded by an earlier restoration using gauze overlay. The head of the antepenultimate note is just discernible as a void;

3. The first stage of editing on the RGB master which has replaced differentiated showthrough with a pattern-fill made from a clean part of the same page.

4. The first stage of recovery work: the number of notes hidden by the burnthrough could be established from the syllabic word-underlay (not shown here), stems and general spacing; note values and pitch were difficult to determine but this shows a first attempt to interpret the variable densities in the dark area as note shapes appropriate to the horizontal context. The 'feet' of the sharp are just visible in the original RGB image and its overall shape and slant could be seen when enlarged, as could the shapes of the noteheads that were not obscured by the final. At this point concordances and editions are not consulted as those readings might influence the editor into seeing something that is not there, thus losing a variant reading;

5. The infra-red image supplies a clear reading of shape, pitch and value for the notes and sharp sign obscured by the final; all note-head shapes are clarified, particularly the position and shape of the dot following the penultimate note;

6. The final reconstruction corrects the pitch of the second note, position of third note and refines shapes of note heads, stems and other signs using the superimposed IR image as a template. The incorrect pitch of the second note in this detail was the only such error in the reconstruction across the manuscripts, demonstrating the palaeographical importance of the IR images.

\subsection{Global adjustment versions}

Adjustments to contrast can improve readability - but not aesthetic appearance - by increasing the visible separation of colours that are otherwise too close for differentiation by the naked eye (Fig. 20). In many cases pages which looked at first to be intractably damaged improved considerably in readability after the application of whole-page adjustments such as thresholding, level adjust, colourbalance or contrast adjust. The result was only used as a reading aid since it was strange in appearance and destroyed paler ink strokes. 


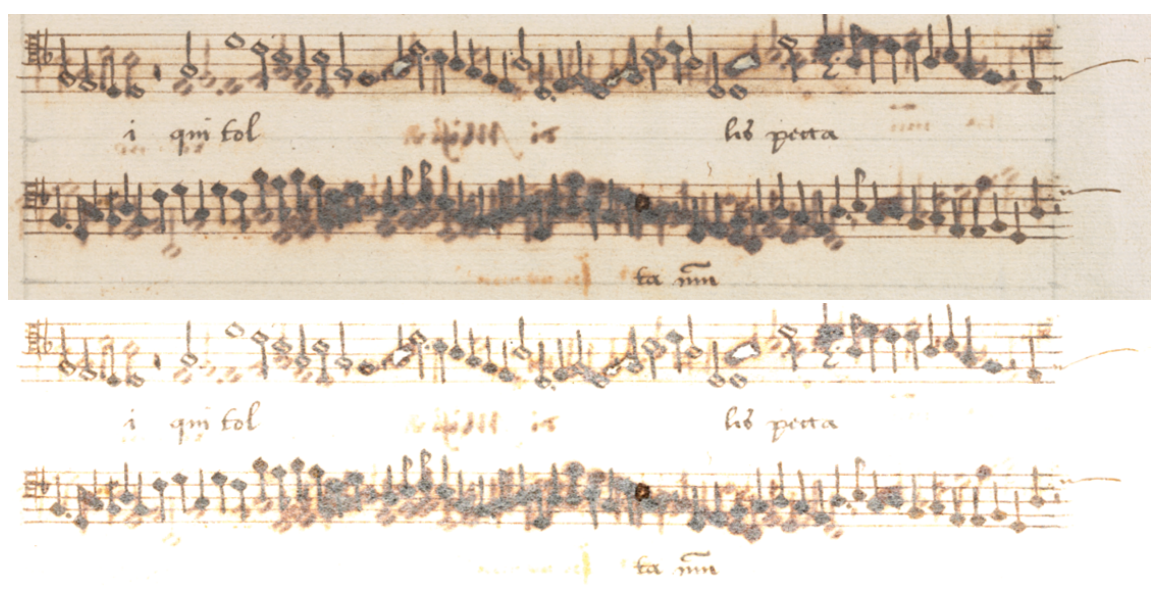

Fig. 20: Mus. e. 3, f. 71r detail: original image $\odot ~ 0 x f o r d$, Bodleian Library and global-adjustment version.

\subsection{Extrapolation or elimination}

Some notes could not be convincingly retrieved from any of the surrogates, but it was possible to deduce both value and pitch from the visible context. In a string of minims, for example, a single missing notehead could be deduced in value from the tail and positioning within rhythmic perfection. To a great extent pitch could be determined from the length of the tail, as well as from eliminating pitches that were visibly clear of notes. An example of a tail-less note problem (either a breve or a semibreve) is shown in Fig. 21.

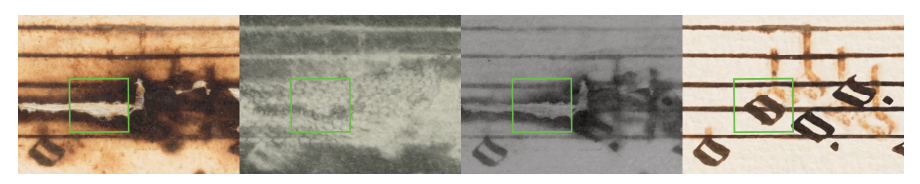

Fig. 21: Mus. e. 4, f. 12v (detail of line 4): original RGB ( Oxford, Bodleian Library; negative photostat $\odot$ London, Senate House Library; IR image (C) author; reconstruction (including erasure) (c) author.

The shape of only one note (boxed in the image) could not be confirmed by reference to any of the surrogates. However, this can be reconstructed following different criteria: 
1. the missing note must be on the second stave line up, and is not in either of the vertically adjacent spaces;

2. it has no tail so must be a void breve or semibreve;

3. the context does not allow for a coloured note. ${ }^{26}$

The Photostat contributes nothing to the reading because of gauze overlay. The infra-red image however confirms the two semibreves (diamonds) following the boxed note and the absence of vertical downstrokes necessary if the missing note is a breve (a box shape). It confirms that the note is placed on the second line up and strongly suggests a diamond rather than box shape. The value of the note is confirmed by transcription of all parts, since any other value knocks the polyphony out of alignment. The missing note can only therefore be a semibreve on the second line up. Because nothing of the note survives, the reconstruction is effected by cloning the missing note from a matching value elsewhere on the same page (thus from the same scribe) and it is boxed to indicate that it is editorial and therefore should be excluded from palaeographical consideration of the page.

\subsection{Contemporary concordances}

Although the example above is of the only source for the tenor part of that work, concordant copies are not uncommon in the repertory surviving from this period. The Baldwin and Dow partbooks, and particularly the Baldwin set (though lacking its Tenor book), provided readings for a number of works that were close enough to the surviving Sadler version, including the position of occasional ligatures, that the few missing Sadler notes were highly unlikely to have recorded a variant reading. ${ }^{27}$

26 There are clearly tails erased above the note - the erasure of the note-heads originally miscopied here having contributed to the damaged area as the paper was scratched thinner and two layers of ink were applied on the upper face.

27 The newly recovered Tenor book in the Sadler set will be used in the musicological reconstruction of the missing Baldwin Tenor book. 


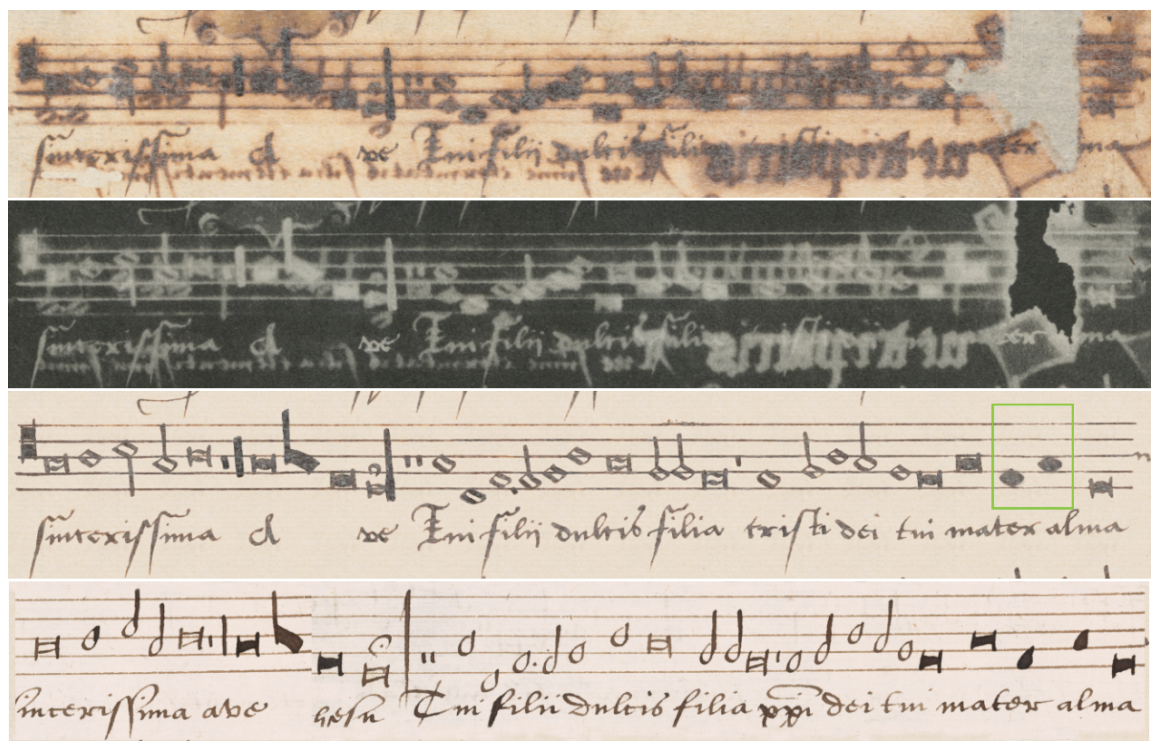

Fig. 22: Mus. e. 3, f. 22v (detail of line 3): original image (c) Oxford, Bodleian Library; Photostat (c) London, Senate House Library; reconstruction () author; concordance for the line from the corresponding Baldwin partbook @ Oxford, Christ Church Library (line-ends do not correspond, so the line is joined after the first ligature to match the Sadler version).

Concordant sources were primarily used in supporting a questioned reading, but because of its closeness to the Sadler books in note values and cleffing the Baldwin partbooks were used to supply pitches and values for a number of notes that had been lost to disintegration in the Photostats. Notes reconstructed in this way were indicated by boxing as shown in Fig. 22. Because only a few works in the books are unica musicological reconstruction (i.e. reconstruction based entirely on stylistic appropriateness when no contemporary source was available) was not required; in places where the damage was so extreme that significant passages of music were lost, the missing notes were supplied by concordances.

\subsection{Modern editions}

Since the reconstruction team had access to images of sources that were concordant with Sadler when dealing with questioned readings, modern score editions were only made for works that had no concordant sources in order to ensure the music fitted together as it should. The Sadler copyists were far from completely accurate: many errors in copying remain and are not corrected in the 
reconstructions. Instead the errors are footnoted so that performers are warned of the errors and given the correct reading.

The first question asked of the edited images is in relation to their palaeographical value: are they actually no better than a diplomatic typographical transcription? The notes in the Sadler books were revealed by painstakingly 'cleaning' around the original pen-strokes. This involved painting a paper pattern over the unwanted showthrough or bleed in a new layer, in order to hide it. Overcleaning was corrected by masking out unwanted areas of the overlaid pattern layer to 're-reveal' the original image. Where the note could not be seen on the original RGB image but could be seen on the Photostat or the IR image, the edges of the note shown on the alternative image were traced around, so that the pen stroke, as it should be, was left showing on the master image. If the shape was filled by tissue or void because of lacing the ink colour was filled in with a pattern created from ink fill elsewhere on the page, as close as possible to the missing note, and indicated with a coloured box. Very few notes were completely irretrievable and, in these cases, the replacements inserted are clearly marked.

Only damage related to acid decay was eliminated, and considerable care was taken to retain all other aspects of the books that reveal their copying and usage. Erasures were preserved, providing evidence that the underlay was copied in tandem with the music, as were other marks such as library stamps and fingerprints (see Figs 23-25).

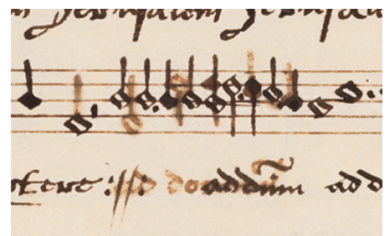

Fig. 23: Unedited erasure

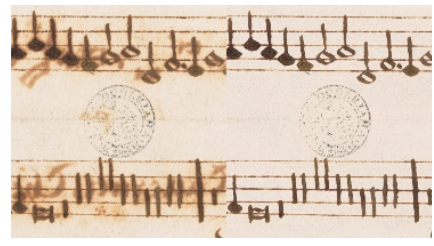

Fig. 24: Bodleian Library stamp

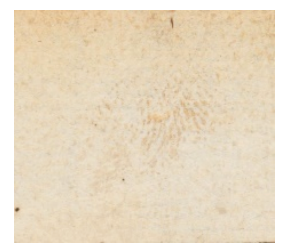

Fig. 25: Fingerprint

Damage that was not caused by acidity, such as water staining, was left visible even though it makes the leaf more difficult to read (see Fig. 26). This is because water staining is not the result of acid damage and in some cases it provides evidence of disturbance to the page order. Overwriting, which is almost easier to see on the unaltered images, is also preserved (see Fig. 27). 


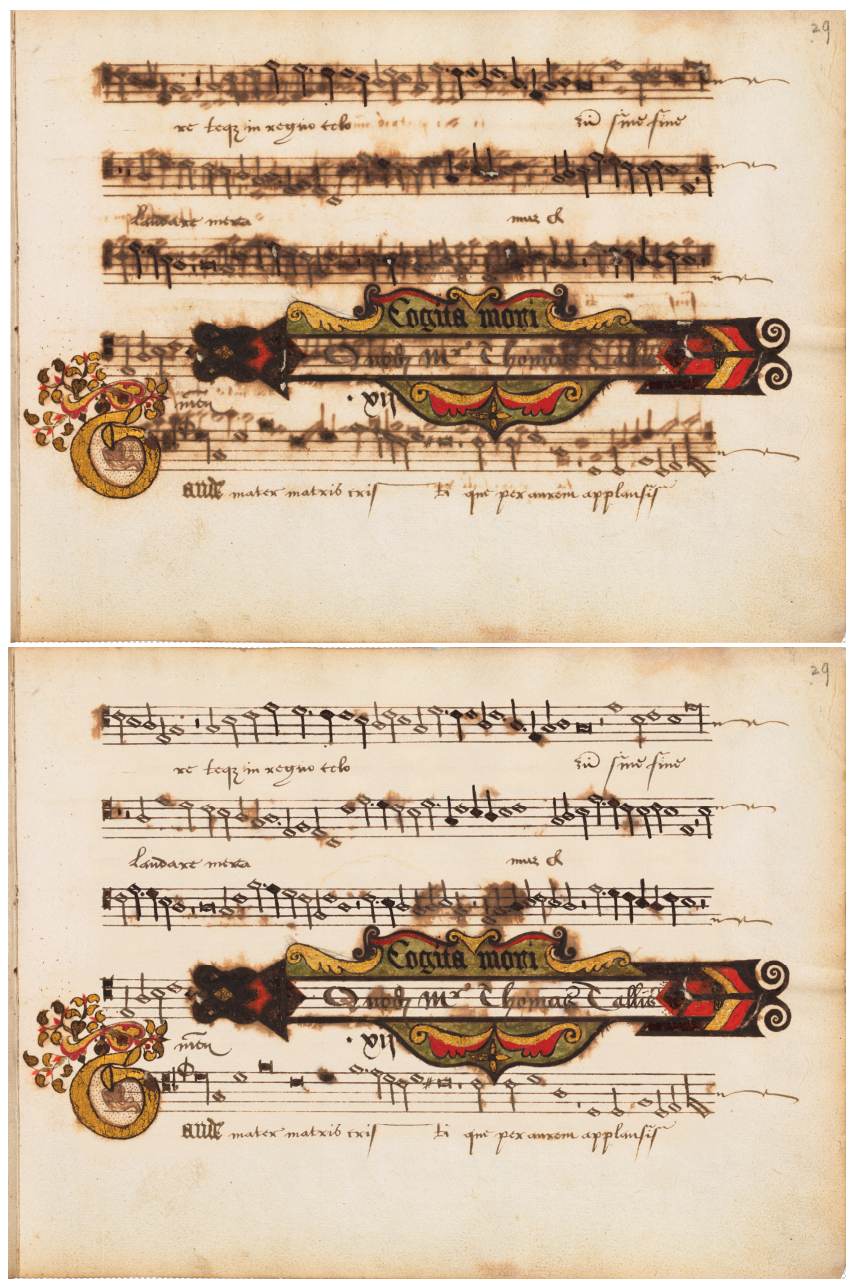

Fig. 26 Mus. e. 3, f. 29r: water staining; (c Oxford, Bodleian Library.

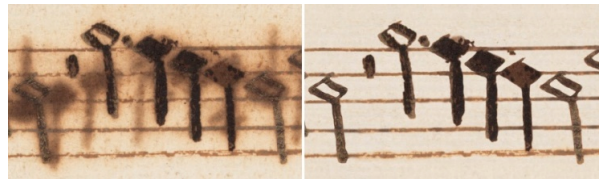

Fig. 27: Overwriting before and after repair; (c) Oxford, Bodleian Library. 
The edited images are true enough to the original pen-strokes that it is now possible to examine the scribal activity in the manuscripts, revealing them to be the work of a number of scribes, a possibility that had not been considered since the books were first described in a nineteenth-century sale catalogue as being 'written by John Sadler, ${ }^{28}$

Mus. e. 3, f. 22v is one of the most damaged leaves (see Fig. 28). However, all but three notes and a rest (indicated with green boxes) on this page could either be seen on the RGB master with some effort or on the Photostat. The values and pitches of the lost notes were supplied by a close concordance in the Baldwin books (shown in Fig. 22) and these shapes were cloned from others on the page. ${ }^{29}$

During a proofing playthrough using reconstructed images of leaves from the Sadler books one of the musicologists commented that it was almost impossible to tell that the images had been edited. Although flattering to the editors this is potentially a problem since, quite apart from the issue of misrepresentation, the reader may believe that the editorial intervention was very light, and therefore the reading is unquestionable. The problem of rendering has therefore circled back to that expressed earlier, that false colour (or pseudo-colour in the case of SL) ensures the reader cannot be misled in what they see, but the aesthetic effect is distressing. Although the process employed in reconstructing the Sadler books will be described in detail in the introductory study it is clear that this part of a publication is rarely read as closely as the author/editor might desire. In an attempt to counter the natural abhorrence we seem to have for reading an instruction manual (or in this case a technical description), the print publication of the Sadler books will include reproductions of some images in their original state in an appendix to each partbook. These should be more difficult to ignore than a wordy discussion of the editing process in the introductory volume, and certainly more visually indicative of the extent of the image editing.

28 See Burke 2016, 248.

29 Because the two versions of the work are so similar between the two partbook sets, the reconstructed tenor part in the Sadler partbooks can supply the missing part in the Baldwin set. 


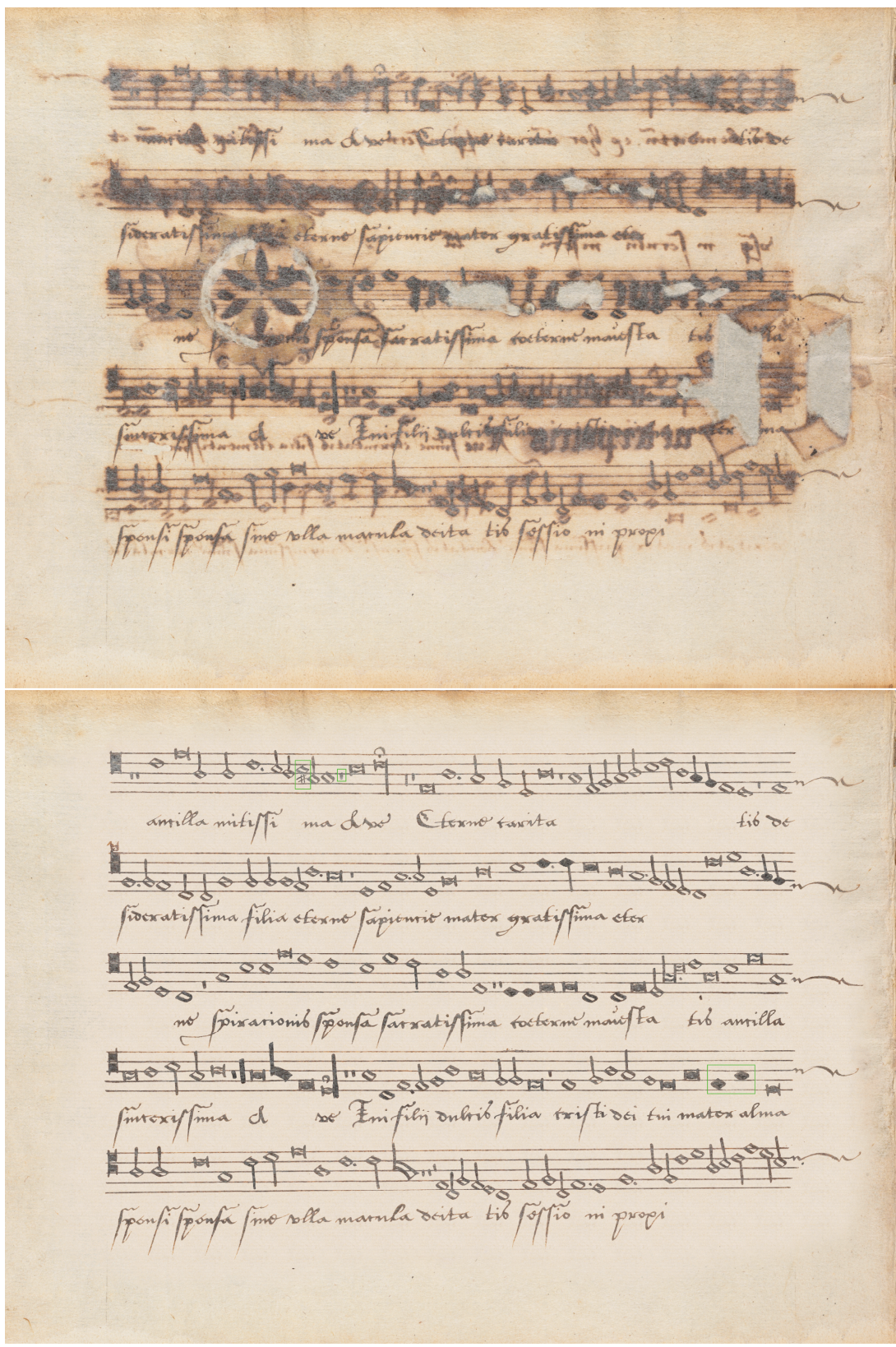

Fig. 28: Mus. e. 3, f. 22v: original RGB image (C) Oxford, Bodleian Library, and forensic reconstruction. 
The checking process for the editing work was extensive: as well as repeatedly checking the edited version against the original and the other surrogates, the copy was read through against a reliable edition where one existed and, where one did not, a new edition was made from the Sadler books to ensure the parts would fit together correctly; printoffs were used for playing or singing by groups experienced in performing from facsimile. However, with so many pages and the number of notes on each page, it is statistically possible that a few errors remain..$^{30}$

The editing work has been saved in layers in order to preserve a corpus of ground-truth data that will inform the development of automated processes which may eventually allow us to roll back the effects of attrition more easily and therefore cheaply. Speed and automation are essential in minimising costs, ultimately making it possible to repair more manuscripts in surrogacy, but fast automated processes have limited applications; an ideal situation would allow for many types of imaging and would combine automation with manual fine-tuning, aggregating every piece of evidence and every technique available, but the cost implications are significant.

\section{Final outputs}

Paper outputs are still preferred as representations of books, particularly those where the appearance is as interesting as the content. There is no other way to get a sense of the book as a physical object, but colour reproduction is expensive and one-off: once a set of edited images is published they will not be reprinted with minor improvements, something only easily done with web delivery. ${ }^{31}$ Therefore at the point of publication the images need to show the maximum possible information. Because the original manuscript behind the images is going to continue to age and deteriorate, the print may also be the most important record of its contents.

Creating a universal digital solution to repair manuscript degradation and facilitate scholarly and wider access to otherwise-lost content is not viable. Damage is so particular to a source, and even to individual pages in a source that each image has to be considered individually. However there are clear signs that a

30 Circa 122,000 notes, rests and other musical symbols were individually edited.

31 Images of the Sadler partbooks both before and after reconstruction will be available on <www.diamm.ac.uk>, and eventually it will be possible to see these along with the Photostats and IR images in a form that will allow users to superimpose the images over one another. 
higher level of automation - with or without manual assistance - may not be far away. In terms of output, there are now good precedents for a more interventionist approach to representations that can appear not only online but also in print, as the end-user community becomes acclimatised to the possibilities inherent in digital intervention and the sometimes alarming appearance of these methods; this type of output may also become more commonplace as tools emerge to enhance and accelerate the process.

In the world of fragment studies publication has often been impossible because of the illegibility of the documents. Fortunately colour reproduction is far cheaper than it was, and colour addresses issues of legibility for a large proportion of damaged sources. For those that remain illegible digital editing is proving invaluable and there are clear signs that digital intervention has come of age and will be increasingly espoused in the print medium in the future, where access to the content is not dependent on access to the web, and a sense of the physicality of the object can be communicated.

\section{Abbreviations}

RISM B/IV

Census
Répertoire international des sources musicales, Series B/IV: Manuscripts of polyphonic music, 11-16 centuries, Munich/Duisburg: G. Henle Verlag, 5 vols.

1 Gilbert Reaney (ed.), Manuscripts of Polyphonic Music. 11th-Early 14th Century, 1966.

2 Gilbert Reaney (ed.), Manuscripts of Polyphonic Music (c.1320-1400). With supplement to B/IV/1, 1969.

1-2 (suppl.) Andrew Wathey (ed.), Manuscripts of Polyphonic Music. The British Isles, 1100-1400, 1993.

3-4 Kurt von Fischer and Max Lütolf (eds), Handschriften mit mehrstimmiger Musik des 14., 15., und 16. Jahrhunderts, 2 vols., 1972.

5 Nanie Bridgman (ed.), Manuscrits de musique polyphonique, XVe et XVIe siècles. Italie, 1991.

Charles E. Hamm and Herbert Kellman (eds), Census-Catalogue of Manuscript Sources of Polyphonic Music 1400-1550, 5 vols (Renaissance Manuscript Studies), Neuhausen-Stuttgart: American Institute of Musicology/ Hänssler Verlag, 1979-2000. 


\section{References}

Burke, James (2016), John Sadler and the 'Sadler' Partbooks (GB-Ob MSS Mus. e. 1-5), DPhil dissertation, University of Oxford.

Craig-McFeely, Julia (2018), 'Recovering lost texts, rebuilding lost manuscripts', in Archive Journal Digital Medieval Manuscript Cultures. Special edition (<www.archivejournal.net/ essays/recovering-lost-texts-rebuilding-lost-manuscripts> (accessed 14 June 2019).

Craig-McFeely, Julia, and Matthias Range (eds) (2020), The Sadler Partbooks: a collaborative reconstruction and introductory study (DIAMM Facsimiles 7), Oxford: DIAMM Publications (forthcoming).

Cuthbert, Michael Scott (2009), 'Tipping the Iceberg: Missing Italian Polyphony from the Age of Schism', in Musica Disciplina, 54: 39-74.

Janke, Andreas, and Claire MacDonald (2014), 'Multispectral Imaging of the San Lorenzo Palimpsest (Florence, Archivio del Capitolo di San Lorenzo, Ms. 2211)', in manuscript cultures, 7: 113-125.

Janke, Andreas, et al. (2018), 'The Atri Fragment Revisited I: Multispectral Imaging and Ink Identification', in manuscript cultures, 11: 141-156.

Nádas, John, and Andreas Janke (eds) (2016), The San Lorenzo Palimpsest. Florence, Archivio del Capitolo di San Lorenzo Ms. 2211. Introductory Study and Multispectral Images (Ars Nova, n.s. 4), Lucca: Libreria Musicale Italiana. 
Indexes 



\section{Index of Manuscripts and Fragments}

Aachen, Domarchiv

G 20213

Albi, Bibliothèque municipale

44 [= Albi] $\quad 48,54,56$

Aosta, Seminario Maggiore

15 [= Aosta Codex] 32

Apt, Cathédrale Sainte-Anne, Trésor

16bis [= Apt 16bis] $\quad 118,138$

Barcelona, Arxiu Diocesà

Visites Pastorals XII 121

Barcelona, Arxiu de la Catedral

Miscel-lànea 23-5 143

Barcelona, Arxiu de la Corona d'Aragó

Frag. 144 [= Bac 144] 157

Barcelona, Biblioteca de Catalunya

853 [= Ba 853(b, c/d)] 119-127, 129, 139-143

971 [= Ba 971(b)] 129-135, 137-138

Arxiu Històric Perg. 310 (Registre 20940)

122

Barcelona, Biblioteca de l'Orfeó Català

$2[=$ Orf 2] 127-129, 132

Bologna, Museo Internazionale e Biblioteca della Musica

Q.15 15-16, 19, 29, 347

Bamberg, Staatsbibliothek

Msc. lit. $5 \quad 85$

Msc. lit. 6 [= Ba 6] 48, 51, 59, 62

Berlin, Staatsbibliothek - Preußischer

Kulturbesitz

Mus. Ms. 40047 [= Be 40047, Quedlinburg

Antiphoner] 61-62

Bratislava, Miestne Pracovisko Matice

Slovenskej

(fragment in) Inc. 33 (lost) 178
Bratislava, Slovenský národný archív

EC Lad. 6. [= Buda Antiphoner] 312

Brussels, KBR (olim Bibliothèque royale)

10127-10144 [= B] $\quad 49,74$

$19606213,219,227$

Budapest, Eötvös Loránd Tudományegyetem Egyetemi Könyvtár

U.Fr.l.ch.299 178

Budapest, Országos Széchényi Könyvtár

Cod. lat. 243 [= Trnava Manuscript] 167, 178

Cod. lat. 534 168-169, 171-173, 178

Budapest, University Library

(fragment in) Inc. 260 308-311

(fragment from) RMK III/463 320

Cambrai, Bibliothèque municipale

C $647 \quad 26$

Cambridge, Corpus Christi College

4144

473 [= Winchester Troper] 26

Ferrell $1[=\mathrm{Vg}$, Ferrell-Vogüé Machaut manuscript] 154-155

Cambridge, Jesus College

QB1, Fragm. H 334

Český Krumlov, Státní oblastní archiv v

Třeboni

$179172,174,177$

Chantilly, Bibliothèque du château

564144

Chartres Bibliothèque municipale

*47 (destroyed) [= Ch 47] 48, 51, 53-54, $56-58,60$

Chrudim, Regionální muzeum

$12580 \quad 172-174,177$ 
Copenhagen, Det Arnamagnæanske Institut AM 687B 4 172, 178

Darmstadt, Universitäts- und Landesbibliothek

521 [= Darmstadt 521] 213, 216, 219

2653 [= Darmstadt 2653] 213, 219

Durham, Cathedral Library

A.IV.19 44

C.I.20 27

Einsielden, Stiftsbibliothek

121 [= Ei 121] $\quad 48,51,54$

Engelberg, Benediktinerkloster, Musikbibliothek

314 [= Engelberg Codex] 167, 171, 177

\section{Esztergom, Cathedral Library}

I. 1 a-b [= Graduale Strigoniense] 301, 307-312

I. 3. c + I. 3. d [= Antiphonale Strigoniense

I-II, Esztergom Antiphoner] 303, 312

Faenza, Biblioteca Comunale

117 [= Faenza 117, Codex Faenza] 25

Florence, Archivio del Capitolo di San

Lorenzo

2211 [= SL, San Lorenzo palimpsest], 336344, 348, 362

Florence, Biblioteca Medicea Laurenziana

Pal. 87 [= Squarcialupi Codex] 21-24

Pluteus 29.1 [= F] 121

Frankfurt am Main, Stadt- und

Universitätsbibliothek

Fragm. lat. VII $20 \quad$ 173, 178

Gdańsk, Polska Akademia Nauk - Biblioteka

Gdańska

2153a $168-169,174,178$

Gerona, Arxiu Capitular

9134

33/I-II 135-138
Göttingen, Niedersächsiche Staats- und Universitätsbibliothek

Nachlass Ludwig XXX,1 168-174, 178

Graz, Universitätsbibliothek

\begin{tabular}{ll}
$30 \quad 87$ \\
\hline
\end{tabular}

Győr, Diocesan Library and Treasury

s.s. 319

Harvard, Houghton Library

Typ. 122 334-335

Heidelberg, Universitätsbibliothek

Cod. Pal. germ. 839210

Helsinki, National Library of Finland

A.ö.ll.29 191

A.ö.II.33 198

C.III.19 [= Codex Westh] 198

C.ö.III.17 198

C.ö.IV.12 196

Coll. 762.3196

F.m.I.137 196

F.m.l.145 189

F.m.l.219 189

F.m.I.232 189

F.m.II.44 196-197

F.m.ll.47 188-189

F.m.II.66 199

F.m.II.77 191

F.m.ll.96 190

F.m.II.120 189

F.m.III.119 192

F.m.III.125 193-194

F.m.IV.89 189

F.m.IV.168 191-193

Hradec, Králové Muzeum východních Čech II A 6 [= Franus Codex/Cantionale] 166, 172, 177, 320

II A 7 [= Speciálník Codex] 166, 172, 177

II A 13a 177

II A $14 \quad 171,177$

II A $15 \quad 177$

Ipswich, Suffolk Record Office

HA 30: 50/22/13.15 27

$\mathrm{S} 1 / 2 / 40 \quad 14$ 
Istanbul, Topkapı Sarayı Müzesi

Deissmann 42 [= Istanbul Antiphoner]

Deissmann 68 (olim 2429) [= Graduale Francisci de Futhak] 303, 312

Ivrea, Biblioteca Capitolare

$115[=$ Iv 115] 118,126

Karlsruhe, Badische Landesbibliothek

Aug. perg. 60 [= Karlsruhe 60] 92

Lichtenthal $34 \quad 227$

Lichtenthal $82 \quad 222-227$

Klatovy, Vlastivědné muzeum Dr. Hostaše 403 172-174, 177

Koblenz, Landeshauptarchiv

Best. 701 Nr. 243 212-221, 214-215, 217-219

Kraków, Biblioteka Jagiellońska

8 a 172,178

2188168,178

$2464171-172,174-176,178$

Kutná Hora České muzeum stř̌ibra

rkp. sign. $88 / 85 \quad 172-173,177$

Laon, Bibliothèque municipale

239284

Leipzig, Universitätsbibliothek

1236 171-174, 178

Rep 19344

Leuven, Alamire Foundation

s.s. [= Leuven chansonnier] 32

Ljubljana, Historical Archives

LJU/0338, Maculatures II (3) 102, 112-113

Ljubljana, National and University Library

11963112

inv. 11/97 106

inv. n. S. f. 48/5 107-109

Ljubljana, Archiepiscopal Archives

102, 75 106-107

London, British Library

Additional $24198 \quad 27$

Additional 28550 [= Robertsbridge fragment] 216, 219, 224

Additional 29704-5 17
Additional $41340 \quad 326$

Additional $57950 \quad 13,19,31$

Egerton $3307 \quad 32$

London, Lambeth Palace Library

1 [= Lambeth choirbook] 324

Lucca, Archivio Arcivescovile

97 [= Lucca choirbook] 27

Lucca, Archivio di Stato

184 [= Lucca codex, Codice Mancini] 27

238 [= Lucca choirbook] 27

Mainz, Gutenberg Museum

Ink 2276 (pastedowns) 229-231

Maribor, Archiepiscopal Archives

Limbuš, R 1624-1646 112

Melk, Stiftsbibliothek

950251

Merseburg, Domstiftsbibliothek

Hs. 13b $173,175,178$

Milan, Biblioteca Ambrosiana

D 84 inf. [= Bobbio missal] 47

Mladá, Boleslav Okresní muzeum inv. č. 21691320

Modena, Biblioteca Estense

a.M.5.24 [= ModenaA] 24, 138

Montecassino, Biblioteca dell'Abbazia

$871 \quad 149$

Montserrat, Biblioteca de la Abadia

$1[$ = Mo 1, Llibre vermell $] \quad 118,157$

Munich, Bayerische Staatsbibliothek

2 Inc.c.a.3375d 29

Clm $536 \quad 81-83$

Clm $9921 \quad 89$

Clm 12027 90-93

Clm 14274 [= St Emmeram Codex] 171, 173-174, 176, 178, 248, 252, 258

Clm $14870 \quad 80$

Clm $17212 \quad 87-89$

Clm $22025 \quad 89$

Clm 23037 [= Prüfening breviary] $\quad 89,91-92$

Clm $26220 \quad 93$ 
Clm $26221 \quad 92-93$

Clm 29316(38 78-80

Mus. ms. 322428

Müstair, Benediktinerinnenkloster St Johann

XX/48 no. 14 [= Müs] 39-41, 43-45, 47, $50-51,59,61-65,74$

Novo mesto, Franciscan Monastery

inv. n. 7202, 101

Opava, Slezské zemské muzeum

RC 4 171-173, 177

Oxford, Bodleian Library

Bodley $384 \quad 330$

Don. e. 24816

Douce $31 \quad 17$

Douce $266 \quad 17$

Douce $267 \quad 17$

Douce $372 \quad 17$

Douce $381 \quad 17$

E Mus. $7 \quad 27$

Mus. e. 1-5 [= Sadler partbooks] 324, 332, 344-363

Oxford, Christ Church College

Mus. 979-983 [= Baldwin partbooks] 349, 358-359, 362

Mus. 984-988 [= Dow partbooks] 349, 358

Oxford, Corpus Christi College

$144 \quad 25,327$

Oxford, New College

$362 \quad 27$

368/1-3 14

Padua, Archivio di Stato

Santa Giustina $553 \quad 27$

Paris, Bibliothèque nationale de France

fr. $146213,219,227$

lat. 903 [= Pa 903] 60

lat. $2990 \mathrm{~A} \quad 80$

lat. $5264[=\mathrm{Pa}$ 5264] 131, 135

lat. $12050[=\mathrm{K}] \quad 48$

lat. $17436[=\mathrm{C}] \quad 48,54,60$

nouv. acq. fr. $23190 \quad 154$
Paris, Bibliothèque Sainte-Geneviève

$111[=\mathrm{S}] \quad 48$

Perugia, Biblioteca Comunale

3065 [= Lucca codex, Codice Mancini] 27

Pisa, Archivio Arcivescovile - Biblioteca

Maffi

cartella 11/III [= Lucca choirbook] 27

Prague, Archiv hlavního města Prahy

7847173,177

Prague, Knihovna Národního muzea

I A $17 \quad 172,178$

IV B 9178

XIII A $2 \quad 172,178$

Prague, Národní archiv

376172,178

Prague, Národní knihovna ČR

Hudební oddělení 59 R 5116 172-173, 178

VH $11 \quad 173,178$

VI B $24 \quad 172,178$

VIC 20a 173,178

VI G 10a 173,178

XVII A $3 \quad 171-172,178$

XVII A $32 \quad 178$

XVII A 53a 178

NG $3 \quad 172,178$

Prague, Národní muzeum - České muzeum hudby

AZ 34 171, 173, 178

Prague, Strahovskáknihovna

inv.č.290/sign. TresI-7/m 109

Ravenna, Archivio Storico Arcivescovile

15518ter 263-296

Regensburg, Staatliche Bibliothek

Theol.syst. $704 \quad 85-87$

Rodez, Archives départementales de

l'Aveyron

J2001 14

Rychnov nad Kněžnou, Muzeum Orlických hor, 829/87 173, 178 
Schlägl, Stiftsbibliothek

Cpl $262 \quad 83-85$

Sedlčany, Městské muzeum

M-3 173, 178

Solsona, Arxiu Diocesà

109 [= Sol 109] 151-153

St Gall, Stiftsbibliothek

18 [= SG 18] 39, 47, 50-54, 56, 58-59, 61$62,71-73$

$339[=$ SG 339] 59

376 [= SG 376] 61-62

390-391 [= SG 390-391, Hartker Antiphoner] $43,59,61,63$

392173,177

484 [= SG 484] 59

Stockholm, National Archives

MPO Fr $284 \quad 190$

MPO Fr 4286 199-200

MPO Fr $8581 \quad 188$

MPO Fr $2580 \quad 195-196$

MPO Fr 25288190

MPO Fr 27059190

MPO Fr $27087 \quad 190$

MPO Fr $27097 \quad 188$

MPO Fr $27677 \quad 190$

MPO Fr 28080190

MPO Fr 28093190

MPO Fr 28109190

MPO Fr $28127 \quad 190$

MPO Fr 28130190

MPO Fr 28159190

MPO Fr 28175190

MPO Fr $28203 \quad 188$

MPO Fr 28205 189, 190

MPO Fr 28222190

MPO Fr $28245 \quad 190$

MPO Fr $28248 \quad 188$

MPO Fr 28254190

MPO Fr 28306190

MPO Fr 28346189

MPO Fr $28349 \quad 189$

MPO Fr 30883189

MPO Fr 30884189
Strasbourg, Bibliothèque municipale

222 C.22 [= Strasburg manuscript] 12

Stratford, Shakespeare Birthplace Trust DR37 Vol. 41 (wrapper) 329

Szombathely, Diocesan Archives

V. 48/E. fasc. (F901) 313-315

Szombathely, Diocesan Library

s.s. $\quad 316-318$

Tábor, Státní okresní archiv

s.s. 178

Tarragona, Arxiu Històric Arxidiocesà

Frags. 2 and 3 [= Ta 2, Ta 3] 143-148

Frag. 4 [= Ta 4] 148-150

Frag. $21.14 \quad 144$

Teplice, Regionální muzeum Knihovna

2 (olim MS B) 172-173, 178

Toronto, Thomas Fisher Rare Book Library 9700 (olim 9255) 21

Třeboň, Státní oblastní archiv

A 4 171, 178

Trento, Castello del Buonconsiglio

87-92 [= Tr 87-92, Trent codices] 13, 252

Trier, Stadtbibliothek

322/1994 171-172, 178

$1245 / 5978^{\circ} \quad 44$

Troyes, Médiathèque Jacques Chirac

1949 227-228

Turin, Biblioteca Nazionale Universitaria

J.II.9 12 [= Cyprus manuscript]

Turku, Municipal Archives - Loimaa Parish

Archives

III d.1 191, 193

Uppsala, Landsarkiv Pärmfynd

$23 \quad 199$

Uppsala, University Library

C.415 188

Utrecht, Universiteitsbibliotheek

$406 \quad 213$ 
Ustí nad Orlicí, Státní okresní archiv

$$
\text { A } 3 \text { 171-172, } 178
$$

\section{Vadstena, National Archives}

Dannäs kyrkoarkiv P IV 1196

Järstads kyrkoarkiv P IV 2198

Rumskulla kyrkoarkiv P IV 1198

Östra Husby kyrkoarkiv P IV 1198

Vatican City, Biblioteca Apostolica Vaticana

Pal. lat. 489 [= Pal. 489] 46

Vat. lat. $10644 \quad 47$

Vic Arxiu i Biblioteca Episcopal

Frag. V/60 [= Vic 60] 153

Vienna, Österreichische Nationalbibliothek

$573 \quad 89$

$922 \quad 251$

$1248 \quad 112$

$1797 \quad 112$

1888 [= Wi 1888] 46, 48, 56

$2212 \quad 112$

$3081 \quad 112$

$50945,172,177,241-259$

$7977 \quad 216$

15501320

Fragm. $661 \quad 28$

Vodňany, Městké muzeum a galerie inv. 18551178

Vöyri, Church Archives

Käsik. la 191

Käsik. Ib 193
Vyšší Brod, Knihovna cisterciáckého kláštera

42 [= Hohenfurter Liederhandschrift] $\quad 167,178$

Warsaw, Biblioteka Narodowa

*F.I.378 (destroyed) 177-178

BOZ 64a 169-170, 173, 178

Windsor, Eton College Library

178 [= Eton choirbook] 26, 30, 324

Wroctaw, Biblioteka Uniwersytecka

IF $269169,173,178$

IV Q $223 \quad 174,178$

XV Q 1066a $170,172,178$

Wolfenbüttel, Herzog August Bibliothek Gud. lat. 334 89, 106

Worcester, Cathedral Archives

Q19 24, 332-333

Zagreb, National and University Library $179 \quad 21$

Zurich, Zentralbibliothek

Rheinau 28 [= Rheinau Breviary] 43

Zwickau, Ratsschulbibliothek

17.8.39 (olim 84,2) 173, 178

$119,1 \quad 172,178$

* Location unknown (private collection)

Antiphoner of Mont Renaud [= MR] 48-49, $51,53-56,74$ 


\section{Index of Chants and Compositions}

\section{Office chants}

Antiphons

Ad te domine levavi 66

Adnuntiate populis / Annuntiate 66

Adoramus te Christe 85

Ambulate sancti Dei ad locum 54, 71

Ambulate sancti Dei ingredimini $\quad 54,71$

Ananias Azarias Misahel 91

Annunciate inter gentes 53,71

Ante diem festum 60-61, 65, 71

Archangelus domini Michael 54

Auditu auris audivi 70

Ave regina 136-137, 142

Beata es Maria 65

Beatus Petrus dum penderet $\quad 56,71$

Caritas est summum / Karitas... 60

Caminus ardebat 91

Cena facta dixit Ihesus $\quad 60-61,65,71$

Christe qui regnas 71

Cito euntes dicite 68

Cives mei vermes 70

Clamabat Heliseus / Eliseus 69

Cognoverunt omnes 69

Concupivitrex 67

Confitemini domino $\quad 49,68,71$

Congregavi nos in unum 60

Congregavit nos Christus 60

Constantes estote 66

Convalium 67

Convertere domine aliquantulum 71

Crucem tuam ... ecce enim 71

Crucem tuam ... quia uenit 71

Cum appropinquarent 71

Cum audisse lob 70

Cum audissetpopulus 71

Cum fabricator 71

Cum iucunditate $\quad 49,53,67-68,71$

Cum rex glorie 67,71
Cum surrexisset dominus $\quad 59$

Custodit dominus $\quad 53-54,71$

Dabit ei dominus sedem 65

De lerusalem / Hierusalem exeunt 53-54, 68

Deprecamur te domine $\quad 51,68,71$

Desiderans speciem eius 86

Deus canticum novum 56

Deus caritas est $\quad 60,62,65$

Deus cuius dextera beatum Petrum 56,71

Deus qui es benedictus 53

Dicit dominus: videte videte 56

Dicta sunt gloriosa 87

Diligamus nos invicem $\quad 59,62,65,71$

Dimitte domine peccata nostra 51,71

Dimitte domine peccata populi 51,71

Dimitte nobis domine debita $\quad 68,71$

Discumbens dominus accepit 60

Dixit autem Ihesus 60

Dixitque David ad dominum 69

Doleo super te frater 69

Domine Deus noster $\quad 49,68,72$

Domine imminuti $\quad 49,68,72$

Domine miserere nostri 72

Domine non est alius $\quad 51,72$

Domine non tantum pedes $60-61,65$, 72-73

Domine rex Deus Abraham $\quad 55,72$

Domine rigans montes 55,72

Domine tu mihi lavas $\quad 60-61,72$

Ps Domine non tantum

Dominus lhesus postquam $\quad 59,65,72$

Ps Deus misereatur nostri

Dominus legifer noster $\quad 63,66$

Dominus possedit me 70

Dum duceretur Petrus $\quad 56,72$

Dum fabricator mundi 72

Ә Open Access. () 2020 Giovanni Varelli, published by De Gruyter. (cc) BY-NC-ND This work is licensed under the Creative Commons Attribution-NonCommercial-NoDerivatives 4.0 International License.

https://doi.org/10.1515/9783110717884-015 
Ecce ancilla domini $\quad$ 65-66

Ecce lignum 72

Ecce nunc palam 68

Ecce populus custodiens 53

Ecce Sion filii 54

Ego in altissimis 70

Ego sum Deus patrum $\quad 49,68,72$

Egregius Dei martyr Georgius 91

Emitte agnum 66

Ex eius tumba 87

Ex quo facta est 65

Exaudi Deus deprecationem 51, 72

Exaudi domine deprecationem 51,72

Exaudi domine lacrimas 55

Exaudi domine populum tuum 72

Exaudi nos domine qui exaudisti 72

Exclamemus omnes $\quad 49,67-68,72$

Exite sancti orate 53

Exivi a patre 68

Expectetur sicut pluvia 66

Exurge domine 49,67-68

Ps Deus auribus nostris

Gaude coetus fidelium 193

Gaudete iusti 53

Gloria laus et honor 57

Hoc est testimonium 65

Hodie scietis quia $\quad 63,66$

Homo iste fecit mirabilia 72

lerusalem civitas 54

In die resurrectionis 67,72

In diebus illis mulier $\quad 65,72$

Ps Magnus dominus

In excelsis tuis 69

In Galilea Ihesum 68

In hoc cognoscent $59,61,65,72$

In medio templi regis 86

In nomine domini Dei nostri 54

In omnibus his non peccavit 70

In populis annuntiemus 87

In sanctis gloriosus es $\quad 53,72$

Inclina domine aurem tuam 51, 56, 72

Inclita sancte virginis 86

Ingredere benedicte 54,72

Iniquitates nostrae domine

72
Inundaverunt aquae 72

Invocantes dominum $\quad 51,72$

Inmutetur habitum / Immutemur

habitu $\quad 56,68$

Iratus rex Saul 69

Ista est speciosa 67

Iustitia tua sicut montes 55

Laudate et superexaltate 91

Levita Laurentius bonum 190

Libera domine populum tuum 72

Locutus est dominus 60

Locutus est omnipotens 59

Loquere domine 69

Magna enim sunt 70

Mandatum novum $59,61-62,65,72$

Ps Beati immaculati

Maneat in vobis spes 60

Manete autem 60

Maria autem unxit 60

Memento congregationis 53

Miserere domine plebi tuae 51, 72

Ps Miserere meiDeus 65

Missus est Gabriel 65

Mulier quae erat 60

Multa sunt domine $\quad 51,72$

Ne nos demergat tempestas 56

Nolite expavescere 68

Non in iustificationibus 72

Non nos demergat domine 56

Nonne iste est David 69

Numquid est in idolis $\quad 55,73$

Numquid valet 51

O beatum pontificem 191

O Christum pontificem 191

O quam venerandus 73

O rene gudz lamb 199

O sapientia 65

Obsecro domine quia 69

Omnipotens Deus mestorum 68,73

Omnis enim qui petit 68

Omnis sapientia 70

Omnis vallis implebitur 65

Oremus dilectissimi $\quad 68,73$

Ornatam in monilibus 67 
Parce domine $\quad 49,67-68,73$

Passionem gloriose virginis Katherine

Paulus et lohannes dixerunt 189

Pax vobis ego sum 68

Peccavimus domine $\quad 51,73$

Per memetipsum 56

Petite et accipietis 68

Petrus apostolus et Paulus doctor 189

Plateae lerusalem / Hierusalem 54, 68, 73

Popule meus 75, 73

Populus Sion convertimini $\quad 49,68$

Post plurima supplicia 87

Postquam surrexit dominus 73

Ps Domine tu mihi lauas

Ps Domine non tantum

Prebe fili cor tuum 70

Preciosus Christi martyr Emmerammus 80

Prevaluit Dauid 69

Prophetae predicaverunt 66

Propitius esto domine $\quad 59,68$

Pulchrafacie 67

Quantas habeo 70

Quia eduxite 57

Quia ego eduxi te 73

Quid ultra debui facere 73

Quis enim in omnibus 69

Quomodo fiet istud 65

Recordare mei domine quid 55

Respice domine quia aruit 55, 73

Rexautem David 69

Saluator mundi salva nos 73

Sanctificabo te Hierusalem / lerusalem 54, 73

Sanctifica nos domine $\quad 67-68$

Sapientia aedificavit 70

Sapientia clamitat 70

Scio quod lhesum 68

Si ego dominus $59,61,65,73$

Ps Deus misereatur nostri

Si ergo vos cum sitis 68

Si oblitus fuero 68

Sicut malum inter lingua $\quad 70$

Sidrach Misac Abdenago quasi ex uno ore 91

Simile est regnum 67

Speciem tuam 67
Stetit angelus 73

Ps Crucifixum in carne

Ps Recordamini quomodo

Suffragante domino beato Gallo 73

Surgite sancti 53, 68

Surrexit enim sicut dixit dominus 73

Suscepimus Deus $\quad 60,62,73$

Tota pulchra est 67

Tres pueri iussu regis 91

Tu es qui venturus $\quad 39,65$

Tubis inductilibus 87

Tunc praecinxit 60

Ubi est caritas 60

Ubi est gaudium 60,62

Ubi fratres in unum $\quad 62,65,73$

Ps Ecce quam bonum

Unxerunt Salomonem 69

Urbs fortitudinis 66

Usque modo 68

Usquequo domine 51

Via iustorum 54

Virtutum dominus susceptor 86

Veni electam meam 67

Venite populi 73

Vidiaquam $\quad 67,73$

Vidi portam civitatis 67

Vidispeciosam 67

Vos vocatis me ... et vos debetis $\quad 60,73$

Vos vocatis me ... etenim $\quad 60,62,73$

\section{Responsories}

A facie furoris tui Deus 91

V. Converte nos Deus

Adesto dolori 70

V. Versa est in luctum

Aduersio paruulorum 69

V. $O$ viri ad vos

Angustie mihi sunt undique 91

V. Si enim hoc egero

Antequam comedam 70

V. Nolo multa

Audi domine 69

V. Respice domine

Audi fili mi 69

V. Honora dominum 
Auditu auris 70

V. Unum locutus sum

Collegerunt pontifices 71

V. Unus autem

Clama in fortitudine 66

Da mihi domine 69

V. Domine pater

Desiderium meum 70

V. Nolo multa fortitudinem

Domine pater

V. Da mihi domine 69

Domine si conversus 69

V. Si peccaverit

Ecce iam veniet 66

Egredietur virga 66

Emitte agnum domine 66

Emitte domine sapientiam 69

V. Da mihi domine

Exaudisti domine

V. Domine qui custodis

69

Factum est dum tolleret 69

V. Elevabitque pallium

Felix regina 87

Festina ne tardaveris $\quad 63,65$

V. Veni domine

Fili noli deficere 69

V. Audi fili mi

Genti peccatrici populo 91

V. Esto placabilis

Girum caeli 69

V. Ego in altissimime

Haec dies $\quad 42,198$

V. Confitemini

Haec est Hierusalem 68

Haec quinquagenos oratores

V. Efficiens testes fidei

In principio Deus antequam

69

V. Ego in altissimis

Inclina faciem tuam 70

V. Que est enim

Induta est caro mea 70

V. Dies mei sicut umbra
Initium sapientie 69

V. Dispersit dedit

Laudabilis populus quem dominus 91

V. Beata gens cuius est dominus

Magna enim sunt 69

V. Deduxisti sicut

Memento mei Deus 70

V. De profundis clamavi

Misi dominus angelum suum 91

V. Misi Deus misericordiam suam

Modo veniet domina 66

Muro tuo inexpugnabili 91

V. Erue nos Domine

Ne abscondas me 70

V. Voca me et respondebo

Ne derelinquas 69

V. Apprehende

Ne tradas 91

Nocte os meum perforatur 70

V. $O$ custos hominun

Non auferetur 65

Nonne cognoscit

V. Quis det ut veniat

Numquid dominus

V. Apprehende domine

Orietur stella 66

Paucitas dierum 70

V. Ecce in pulvere

Peto domine ut de vinculo 70

Prebe filicor 69

V. Attende fili mi

Preparate corda 69

V. Auferte deos alienos

Putasne mortuus homo rursum 91

V. Ecce in pulvere

Quare detraxisti 70

V. Militia est vita

Que sunt in corde 69

V. Imperfectum meum

Qui celorum contines thronos 91

Qui consolabitur 70

V. Fletum deduxerunt 
Quis mihi tribuat 70

V. Numquid sicut

Recordare domine 69

V. Quiescat domine

Regum mundi 87

Sanctificamini hodie 66

V. Hodie scietis quia

Scio domine 70

V. Si ascendero

Scio enim quia redemptor meus vivit 91

V. Surgent

Sibona suscepimus 70

V. In omnibus his

Super muros tuo 91

V. Qui reminiscimini

Super salutem 69

V. Dixi sapientiae

Surge virgo 87

V. Pulchre Sion filia

Sustinuimus pacem 91

V. Peccavimus cum patribus nostris

Utinam apprehenderentur 70

V. Quasi arena maris

Verbum iniquum 69

V. Ne forte satiatus

Versa est in luctum 70

v. $O$ custos hominum

Virgo veneranda 87

Hymns

Agyos o theos 57,71

Ave maris stella 191, 246, 247-251

Crux fidelis 52,57

Gaude coetus fidelium 193

Pange lingua 52, 57, 73

O rene gudz lamb 199

\section{Mass Chants}

\section{Introits}

Dilexisti iustitiam 318

Ps Eructavit cor meum

In Nicolai transitu 247
Loquebar de testimoniis 318

Ps Beati immaculati in via

Me exspectaverunt 318

Ps Beati immaculati

Omnia quae fecisti nobis 313

Sacerdotes Dei benedicite dominum 311

Ps Benedicite omnia

Sacerdotes eius induant 311

Ps Memento domine David

Statuit ei dominus testamentum 311

Vultum tuum deprecabuntur 318

Ps Eructavit cor meum

Kyrie

$33,127,132,136-137,140,142,155,157$, 196, 198-199, 247

[de Apostolis] 199

Ave desiderii 140

Herra armahda meidem pällem 196

Herre förbarma tigh 199

O sacra 140, 142

Reximmense 140

Summe clementissime 142

Virgo sancta 140

Gloria

$123,127,132,135-136,140,142-146,151$, 196, 198, 227, 247

Cunnia olkon Jumalan corceuxes $\quad$ 196, 198

Primogenitus Mariae 247

Graduals

Dilexisti iustitiam 318

Ecce sacerdos magnus 311

V. Non est inventus

Sacerdotes eius induant 311

V. Illuc producam cornu David

Tollite hostias 313

V. Revelavit dominus

Viderunt omnes 121

Alleluia

Epulemur in azimis 67

Laetamini in domino $\quad 105,107$

Pasca nostrum 67 
Stabit Nicolaus 247

\section{Sequences}

Ave sidus lux dierum $\quad 227$

Gloriosa fulget dies 252

Jesus Christus han ähr worden 195

Praecursorem summi regis 188-189

Psallat concors symphonia 252

Rex omnipotens 196

Romana, sequence melody $\quad 42,67$

Sancte spiritus 196

Stola jocunditatis 190-191

Victimae paschali laudes 195-196

\section{Credo}

127, 135-136, 140, 142, 150-151, 153, 172, 248

\section{Offertories}

Super flumina Babilonis

313

In omnem terram 125

\section{Sanctus}

19, 107-108, 132, 136, 137, 140, 142, 247

\section{Agnus Dei}

127, 136-137, 142, 196, 199, 247

Reximmense 140

O Jumalan Caritza 196

\section{Communions}

Memento verbi tui 313

Emitte angelum 57, 72

Venite populi 57,73

\section{Songs and Polyphonic compositions}

Ce jour le doibt $\quad$ 247-248, 251

Compangant omnes 172

Concrepet infanti / Nate Dei / Exordium quadruplate / Verbum caro 172

Congaudemus pariter / En lux immensa 172

Dies iam letitie 172

Ecce renascentis testatur 172

Exstirpe paganorum 172

Genti confer opem 172 lacob scalam / Pax eterna / Terribilis 172

Ihesus Christus nostra salus 172

Laudes dicat omnis 172

Lamentationes leremiae $\quad 149,171$

Methaphisice saliit / In tempesto adiit / Ordo naturae 172

Nicolai solempnia 172

Novus annus adiit 172

Panis ecce / Panis ewus / Pange exul / Patribus / Tantum ergo 172

Paraclitus egrediens 172

Phonicorum ethicorum 171, 173

Pneuma eucaristiarum / Veni vere / Dator eia / Paraclito tripudia 173

Poligena exanimes 173

Pomi morsum / Hominem / Sed paratus / Paraneuma eructemus 173

Preconia etroclita 173

Predulcis eurus 173

Presidiorum erogatrix 173

Presulem ephebeatum 173

Probleumata enigmatum 173

Procedentem sponsum 173

Resonet in laudibus 173

Resultet gens angelica 173

Salve domina / Recordare virgo / Alma re demptoris 174

Segnier Leon / Benedictus qui venit 247, 249-250

Sophia nasci fertur / O quam pulchra / Magi videntes 174

Surrexit Christus hodie 174

Vivat nobilis prosapie $\quad 248,257,260-261$

Voce cordis / Pulchre Syon 171

\section{Canzone}

Quando eustava 264, 268, 292-293

Caccia

Tosto che l'alba 22

\section{Conductus}

Vite perdite 121 


\section{Contrafacta}

Elend du hast-Madamme helas 149

Non gusto - An gusto 149

O Maria pya-Juich jag 248, 251

Skack sive celsitonanti - Froleich geschrai 246, 251

Virginem mire - En discort $\quad 246,251$

\section{Motets}

[Apollinis] / Zodiacum 119, 122-123, 125126, 132, 144

Aaron virga / Isayas / [Tenor] 216, 219, 221

Apollinis eclipsatur 247, 251

Colla iugo / [Bona condit] 144

Degentis vita / Cum vix 132
Fa fa mi fa / Ut re mi ut / [Tenor] 223, 225-227

Firmissime / Adesto / [Tenor] 213, 216, 219 Flos vernalis 224, 226

Mater formosa / Gaude virgo / [Tenor] 213 Orbis orbatus / Vos pastores adulteri / Fur non venit $216,219,221$

Super cathedram / Presidentes / Ruina 227 Voce cordis / Pulchre Syon 171, 174

Zolomina / [Nazarea] 119, 123

[...] turris iustorum / Gaude virgo / O Christi pietas 213, 219, 220

\section{Organum}

Gr. Viderunt omnes 121 



\section{General Index}

Aachen 213

Åbo 196

Abukhanfusa, Kerstin 202

Achten, Gerard 213, 234

Adriatic 107, 109-110

Advent $39-40,43,45,63,92,199,219$, 221

Agricola, Mikael 149,198

Alberni, Anna $\quad$ 155, 158

Albiero, Laura $\quad 50,56-57,59,61,71,75$

Albrecht II of Habsburg, king 254

Albrecht VI, duke 251

Alexandria, Great Library 15

Alfonso, kings of Aragon, see 'Aragon'

Alleluia 42, 48, 54, 67-68, 107, 134, 247

Altés i Aguiló, Francesc Xavier 157-158

Altisent, Agustí $\quad 138-139,144,150,159$

Amalarius of Metz $\quad 40$

Ambrožič, Matjaž $\quad 110,114$

analogue imaging $\quad 324-325,336,339$

Anglès, Higini $118-119,128-129,133,135$, $138,140-141,150,152,155,157,159-$ 160

antiphoner $17,21-22,40,44,48,58,61$, $62,63-64,75,77-80,83-85,90,92-$ 93, 103, 107

Antiphonale Strigoniense, see Index of

Manuscripts and Fragments

(Esztergom, Cathedral Library,

I. 3. c + I. 3. d)

Buda Antiphoner / Antiphonale

Budense, see Index of Manuscripts and Fragments (Bratislava,

Slovenský národný archív, EC Lad. 6)

Esztergom Antiphoner, see Index of

Manuscripts and Fragments

(Esztergom, Cathedral Library, I. 3. $c+$ I. 3. d)

Hartker Antiphoner, see Index of Manu-

scripts and Fragments (St Gall,

Stiftsbibliothek, 390-391)
Istanbul Antiphoner, see Index of Manuscripts and Fragments (Istanbul, Topkapı Sarayı Müzesi, Deissmann 42)

Mont Renaud Antiphoner, see Index of Manuscripts and Fragments

(* location unknown)

Quedlinburg antiphoner, see Index of Manuscripts and Fragments (Berlin, Staatsbibliothek Preußischer Kulturbesitz, Mus. Ms. 40047)

antiphon $2,17,11-12,39-40,43-44,46$, $48-64,66,69-71,79-80,84,86,92-$ 93, 189-191

ad Benedicite $\quad 63,92$

ad Benedictus $\quad 63,83,93$

fraction 57

processional $43,46,48-59,62,64$

votive 252

Apel, Willi 274

Aquileia

Patriarchate of 102, 110

rite 111

Aragon

Alfonso IV 128

Alfonso V (the Magnanimous) 149 , 150, 152

court in Naples 149

crown 118-119, 138, 154-155

Ferdinand I of Naples 149

Ferdinand II / Fernando II of Aragon (the Catholic) 149-150

Isabel I / Isabella I of Castile (wife of Ferdinand II) 150

James II 152

John I 117, 122, 132-135, 138-139, 144, 154-155, 157

John II 150

manuscripts, sources 117-118, 156

Martin I 117, 122, 131, 135

Ә Open Access. () 2020 Giovanni Varelli, published by De Gruyter. (cc) BY-NC-ND This work is licensed under the Creative Commons Attribution-NonCommercial-NoDerivatives 4.0 International License.

https://doi.org/10.1515/9783110717884-016 


\author{
royal chapel 129,150 \\ Royal House $129,138,157$ \\ Arbeo of Freising $\quad 80$ \\ Aribo of Mainz $\quad 40$ \\ Arn, abbot and archbishop $\quad 80$ \\ Arnabat Mata, Ramon 132, 159 \\ Arnold of St Emmeram $\quad 80$ \\ Armer / Armetis, Jean 133 \\ Atlas, Allan W. 149, 159 \\ ars antiqua 121 \\ ars nova $117-118,121-122,128,134-135$, \\ $139,143,151,153-158$ \\ Ascension 43-44, 46, 50, 67 \\ Ash Wednesday 46 \\ Asperti, Stefano $\quad 263,296$ \\ Assisi 12 \\ St Francis 258 \\ Assumption of Mary 79 \\ Aston, Hugh 331 \\ Augsburg 89, 106, 229-231, 252
}

St Ulrich and Afra, abbey $\quad 89,106,247$

Augustinian 45, 212, 230, 241, 253-254,

256, 258

liturgical books 45

Hermits 230

Austin, see 'Augustinian'

Austria 3, 83, 102, 111, 251-254, 255, 304

Avignon 117, 133, 154-155

Avril, François 135,159

$\begin{array}{ll}\text { Baden } & 222,226 \\ \text { bailiff } & 185-188,198-199 \\ \text { Bagà } & 157\end{array}$

Baldelló, Francesc 129, 152, 159

Baldwin partbooks, see Index of

Manuscripts and Fragments (Oxford, Christ Church College, Mus. 979-983)

Barcelona 117-118, 119-122, 127-129, 133, 139-141, 154, 157-158

Cathedral 121-122, 127, 129, 134, $143,153,155$

Chapel Royal 119, 129

royal palace $121-122,155$

royal court 154

Santa Maria del Mar 128-129

Barcelona Mass 129

Barral i Altet, Xavier $\quad$ 152, 159

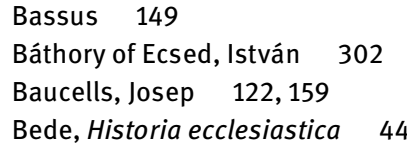

Beheading of St John the Baptist, feast 78

Benedictus, canticle 63,83

Benedicite, canticle $63,83,91-93$

Bent, Margaret $\quad 3,11,13,15,19,25,28,30$, 32, 34, 122, 125, 149, 158-159, 213, 234

Bern of Reichenau $\quad 40$

Bernhard, Michael $\quad 44,75$

Berntson, Martin 187, 199, 202

Berry, Duke of 154

Berschin, Walter 77-78, 93-94

Berthold of Regensburg, see 'Puchhauser, Berthold'

Besseler, Heinrich $32,117,119,127-128$, 160

Bevilacqua, Gregorio $\quad 121,160$

Billett, Jesse D. $\quad 39,44,75$

binding $1,2,4,11,13,14-15,20,24-31$, $33,83,101,104-105,109-112,136-137$, 140, 142-143, 187, 201, 205-212, 216, 220-221, 223-232, 242, 253, 302, 307, $323,329,333,352$

bookbinding 13,15, 25, 104, 187, 206 rebinding 13

Bischoff, Bernard 47, 74, 80

Björkvall, Gunilla 188-190, 202

boards 25, 29, 31, 211, 223, 229

Bohemia 85, 166-169, 171, 174, 176, 319320

manuscripts 85

Bohlin, Folke 199, 202

Bologna 12, 229

Bolton, Clare 230, 234

book of hours 20

Boppard, Carmelite convent 212, 229

Bosmajian, Haig A. 176, 179

Bosquet, Émile 206, 234

Bower, Calvin M. 42, 75

Boytsov, Mikhail A. 226, 234

Bratislava 178, 302, 312

Breschi, Giancarlo 263, 296

breviary 77, 83, 103, 192

Chertsey breviary 17

Rheinau breviary, see 'Rheinau' 
Prüfening breviary, see 'Prüfening' Brewer, Charles E. $\quad 168,171,175,179$ broadside / Einblattdruck 229-231 Brown, Elizabeth A. R. $\quad 10,34$

Brown, T. Julian $\quad 44,75$

Brownrigg, Linda L. $\quad 14,34,98,114$

Bruckner, Albert $\quad 42,75$

Brunius, Jan $98,114,186,187,188-189$, 202

Buda 312

Budapest $169,171,178,301,307-311$, 313, 318-320

Bukofzer, Manfred F. $\quad 31,34$

Burgos 225

Burgundy, Duke of 139,154

Burke, James $\quad 348,362,366$

Caldwell, John 216, 234

calendar, manuscript 143

Cambrai, St Stephen's Chapel 11

Camilot-Oswald, Raffaella 102, 114

cant d'orga / cant d'orgue 128, 153

cantio/-nes 165,167-168, 171

cantional 166, 318

cantor $39,45,64,121-122,133,223$

cantrix 16

CANTUS, database $83,86,92$

cantus fractus $199,243-247,249-250$, 252

cantus planus 301

canzone 264-265, 267, 269, 277, 287, 289, 291

Capdevila, Sanç $\quad 143,160$

Carbonell i Buades, Marià $\quad 120,160$

Cardine, Eugene 284, 296

Carinthia 110

Carmelite 229-231, 258 missal 18,33

Carniola 110

Carolingian 57, 80-81

Carreras i Candi, Francesch 120,160

Carrero Santamaría, Eduardo 122, 160

Carthusian, liturgical books 103

Carvajal González, Helena 149, 160

Catalan, language 119

glosses 151

Catalonia $\quad 117,118,121,144,153,157-158$
Principality $121,134,138,151-152$, 154

Catalunya, David $\quad 4,121-122,153,160$, 223, 225, 227-228, 233-234

Census catalogue 324,365

Černý, Jaromír $\quad 167,179$

Cervera 117, 151-153, 155

St Mary, church 151-153

chanson 219, 248, 250

à refrain 290

chansonnier 32,133

Charles IV, emperor 108

Charles V, king 154

charter 5, 111, 211, 253-257, 263-265, 267, 269-273, 276, 288-289, 291, 293, 295

checker, keyboard instrument $\quad 133,135$

Chicago 20

choir 153, 252

choirbook 14, 26, 27, 29, 30, 31, 249, 319,324

choirboy 166

choirmaster 254

choir school 134

semi-choir 266

Chranekker, Wolfgang, organist $\quad 243,247-$ 248, 251-252

Christmas $39,57,135,193$

Day 40

Eve $40,43,63$

Ciaralli, Antonio 264

Ciconia, Johannes, composer $\quad 33,177$

Ciglbauer, Jan 171, 179

Cistercian 225-228

liturgical books $\quad 15,45,103,144,157$, 167, 224

notation, see 'notation'

nuns 16, 227

Clairvaux, Cistercian abbey 225

library 227-228

Bernard of Clairvaux 222

Clarke, Mark 132, 160

Clément, Gisèle $\quad 61,75$

Cleveland, Museum of Art 20

codicology / codicological 3,130, 136, 139-140, 142, 210, 223, 232, 304-305, 308 
Colette, Marie-Noël $\quad 48,75$

Colinet le Forestier, cleric and singer

138

Collard, Franck 228, 234

Cologne 206, 212-213, 229, 231

Columbia, University Library 31

commune sanctorum 308, 311, 318

commune unius martyris pontificis 308 , 311

commune virginum 313

Companys i Farrerons, Isabel 143-144, 148,160

composite codex/-ices 138

conductus $26,121,167$

contrafactum, - $a \quad 149,248-251$

contratenor $123,125,132,145,155,243$

Constance 223

Council of 253

Cornago, Johanes 149

Cornet, Berenguer 120

Corneta, Francina 119-120

Cornets, family 120

Corvinus, Matthias, king 319

Cotton, Robert 17

covers $14,27,143,185-187,206,208$, 219, 307

Craig-McFeely, Julia $\quad 5,25-26,32,348$, 366

Crane, Frederick 249, 259

Crescenzi, Pietro de' 229, 231

Crivello, Fabrizio $\quad 47,75$

Croatia 107-108, 302

Crocker, Richard $\quad 42,75$

cropping 242-243

cum triplo 134

cursus

cursus saecularis / monasticus 85

Benedictine 78

secular 84

Curtis, Gareth 30,34

Cuscó i Clarasó, Joan 133-134, 160

customary, manuscript 134

Cuthbert, Michael S. 24, 27-28, 32, 34, 251, 259, 325, 366

cuttings $15-17,20-21,23,33$

Cyprus, polyphony manuscript, see Index of Manuscripts and Fragments (Turin,
Biblioteca Nazionale Universitaria, J.II.9)

Czagány, Zsuzsa $\quad$ 5, 305, 319-321

Czech Republic / Czechia 3, 83, 166, 167, 171, 304

Dannäs 196

Dante, Inferno 151

Darmstadt 213, 216, 233

De Diego Rodríguez, Natividad $\quad 150,160$

De Hamel, Christopher $\quad 20,27,34$

Deissmann, Adolf $\quad 303,321$

Derolez, Albert 123,160

Desmond, Karen 225, 234

DIAMM [Digital Image Archive of Medieval Music] 32-33, 323-325, 339, 341, 351, 364

diastematic $270,272-273,282-283,294$ adiastematic $\quad 100,104,112,263$

Diessen 78

digital editing $25-26,326-327,329,331$, $339,343,345,352,364-364$

digital imaging multispectral imaging (MSI) 336, 343-344, 353

RGB imaging 327-328, 335-337, 339-341, 343-344, 346, 350, 352-354, $356-357,360,362-363$

digital recovery $3,325-326,331,337,345$, 355-356

Dillon, Emma $\quad 213,234$

Divine Office $2-4,39,42,44-45,48,62-$ 63, 77-78, 80-81, 83, 89, 91-92, 103, 134, 138, 188, 213, 306, 319, 321 Vespers $\quad 42,63,79-80,83,93,191$ Matins / Nocturns 78, 80, 83-84, $86,-87,92-93,207$

Lauds $\quad 40,44,63,78,80,83,86-87$, 92-93

Prime $\quad 42,67$

Sext 42,67

None 42,67

rhymed 213

divisio, prima / secunda 107

Dobszay, László 303

Dolç i Cartanyà, Jordi $\quad 118,160$ 
Dominican

chant books 45

music scribes 123

monks 153, 258

Douce, Francis 17

Dow partbooks, see Index of Manuscripts and Fragments (Oxford, Christ Church

College, Mus. 984-988)

Drava / Drau 110

Duba, William 5

ductus 270

Du Fay, Guillaume $\quad 11,29,175,247,250-$ 251

Dunstaple, John 31

duplum 122, 123, 144, 213

Earp, Lawrence $\quad 155,161$

Easter 42-44, 48, 57-59, 247

Easter liturgy

Maundy Thursday, Mandatum ceremony $43,45,57-63,65,72$

Good Friday 57-58, 127

Eben, David 109, 114

Ege, Otto 20

Egidi, Francesco $\quad 12,35$

Egidius de Francia, composer 22

Eichner, Hans 9,35

Einsiedeln, Benedictine abbey $\quad 48,56-57$

Emmaus, Benedictine abbey 108-109

endpaper 13, 329, 332-333

Engelberg Codex, see Index of Manuscripts and Fragments (Engelberg, Benediktinerkloster, Musikbibliothek, 314)

England 27, 32, 78, 205, 213, 252

Erasmus Gunther, see 'Gunther, Erasmus' erasure $119,132,331,348,358,360$

Escalas, Romà 149,161

Español, Francesca $128,152,161$

Esztergom 303, 312

Antiphoner, see 'antiphoner'

Ewerhart, Rudolf $171,175,179$

Exaltation of the Cross, feast 83

exaquier, see 'checker'

exchiquier / Schachtpret / Skak 251

Fallows, David $\quad 11,35,149,251,259$
Felix V, antipope 255

Ferdinand I of Naples, see 'Aragon'

Ferdinand II / Fernando II of Aragon (the Catholic), see 'Aragon'

Fernandez, David Andrés 46, 75

Ferrara 251

Ferrer, Fra Vicenç, abbot 138

filigrees 131

Filipecz, János, bishop 319

Finestres y de Monsalvo, Jaime $\quad 150,161$

Finland 185, 193

Finnish, language $\quad 4,187,193,195-198$

Finno, Jacobus 198

Fischer, Kurt von, see 'Von Fischer, Kurt'

Fistch, Johan 141

Florence 12, 15

San Lorenzo, basilica 11

florilegium 249

Flüeler, Christoph 5

flyleaf / -ves 4, 14, 89-91, 205-206, 227

Foix, Count of 154

Folkärna 199

Forensic Reconstruction $\quad 323,344,349$, 363

forgery 9,21

formes fixes 266

Fragmenta Membranea 185-186, 190

fragmentology $\quad 5-6,24,167,301,303,318$

Francia

$$
\text { East Frankish } \quad 43,50,59,61-62
$$

West Frankish $\quad 42,53,57-58,60$

Franciscan

chant books 45,103

friars 258

Fransén, Natanael 199, 202

Frederick III, emperor 110, 230, 254

Freising 77

Früh, Martin 228, 234

Fuchs, Robert 211, 234

Fujii, Akihiko $\quad 230,234$

Fulleda $139,144,149-150,155$

Gaguin, Robert 228

Gallican 56-57

Gallico, Claudio $\quad 264,266-267$ 


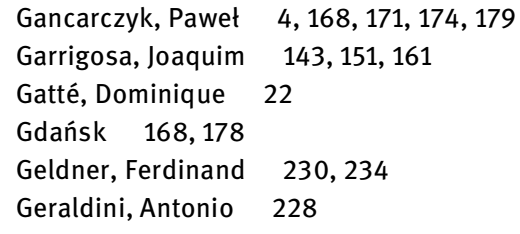

Gerardello da Firenze, composer 22

Gerona 117, 121, 134-135, 137, 141, 155-156 cathedral 128, 134-135, 153, 155

Gerlach / Gerlacius, Nicolaus 256

Gier, Helmut 229, 234

Gilányi, Gabriella $\quad 318,321$

Gillespie, Alexandra $\quad$ 205, 234

Giraud, Eleanor J. 123, 161

Giunta, Claudio 263, 296

Glagolitic script $\quad 4,103,107,109$

Glanshammar 199

Göllner, Theodor 249-250, 254, 259

Göttingen 171, 178

Gómez Muntané, Maricarmen $\quad 121-122,125$, $127,129-130,133,135,138-139,142-$ 144, 151-155, 157, 161

Gozzi, Marco 246

gradual

liturgical book $\quad 46-48,50,52,57-62$, 64, 104, 107, 166, 176, 188, 303, 307-308, 312-313, 318-321

chant $42,102-103,311$

Graduale Francisci de Futhak, see Index of Manuscripts and Fragments (Istanbul, Topkapı Sarayı Müzesi, Deissmann 68)

Graduale Strigoniense, see Index of Manuscripts and Fragments (Esztergom, Cathedral Library I. 1a-b)

Graduale Aboense 187, 196

Graham, Barry F. H. 165, 176-177, 179

Grand, Geneviève 206, 235

Granyena 151, 155

Granyena, Pere 152-153

Grudencz, Petrus Wilhelmi de, see 'Petrus Wilhelmi'

Gudayol, Anna $\quad 141,143,161$

Guido, composer 144,146

Guido of Arezzo 106

Micrologus 106

Prologus in Antiphonarium 106
Guilielmus de Francia, composer 22

Gunther (de Monaco), Erasmus 255-258

Gunyalons y Bou, Bartomeu 160

Gustav Vasa, king 186, 201

Gwara, Scott 20, 35

Gwynn, Dominic 13-14

Győr, cathedral 319

Gyulafehérvár / Alba lulia 302

Haapanen, Toivo $\quad$ 186, 188-193, 198, 202

Habsburg, family 254

Hagenau/ Haguenau 222

Hamburg 337

Hamm, Berndt 230, 234

Hannikainen, Jorm 187, 196, 198, 202-203

Hanrott, family 18

Haubrichs, Wolfgang 44,75

Hauke, Hermann 78, 93

Heidelberg 209

Heikkilä, Tuomas 176, 179, 186-187, 203

Heinrich IV von Magstadt, abbot 223

Heinrich V, Margrave of Baden 226

Heinrich of Montabaur 212

Heinzer, Felix $\quad 222-223,225,227,234-$ 235

Helwig, Hellmuth 206, 235

Henricus Johannis, bishop 199

Henry V, king 31

Henry VI, king 31

Hermannus Contractus 89

Hernando i Delgado, Josep $\quad 127,161$

Herrenalb 223, 225-226

Hildebert, archbishop 87

Hindman, Sandra 17, 20, 35

historia/-ae 44, 77, 80, 83, 89, 320

Hlávková, Lenka 166-167, 179-180

Höfler, Janez 106, 113

Hohler, Christopher 44, 75

Holy Innocents, feast 134

Holy Roman Empire 102, 230

Holy Trinity 220-221

Holy Week / Hebdomada Passionis 221, 311

Hopes, Margarete 16

Horyna, Martin 166, 179

Housley, Norman 230, 235 
Hradec Králové $\quad$ 166, 176-177, 320

Church of the Holy Spirit 166

Huesca 155

Hughes, Anselm 42, 75

Huglo, Michel $39,45-47,56-57,59,64$, $71,75,92$

Hungary $\quad 3,110,168,301-305,307-308$, 311-312, 318-319

Hus, Jan 177

Hussite $109,166,174$

hymn 57, 191, 193-194, 251-252

hymnal $103,188,193,198$

Iglesias, J. Antoni 121,127-129, 161

Immaculate Conception, feast 134

Improperia 57

incunable/s, incunabula $23,28-29,307$

Indiana University, Lilly Library 80

initial/s, letters $16,19,22,122,135,144$, 151, 157, 225

ink $23,132-132,164,219,225,228,242$, $270,272,284,325,327,329,337,344-$ $345,348-350,353,356,358,360$

Innocent VIII, pope 229

introit (introitus) 247, 311, 313

lohannes, organista de Monaco 252

Irás-Melis, Katalin 209, 235

Irmengard, marchioness of Baden 226

Isabel I / Isabella I of Castile, see 'Aragon'

Istanbul 303, 312

Topkapı Palace $\quad 302,303,312$

Istria 103

Izola 103

James II, see 'Aragon'

Janke, Andreas $\quad 24,25,35,336-338,341$, 343, 366

Janini, José $\quad 143-144,148,162$

Janota, Johannes 229,234

Jesuit 176

John, kings of Aragon, see 'Aragon'

John, cantor / singer (in / of Liège) 223

Jordan of Quedlinburg 212, 219, 221

Joseph II, emperor 176

Josquin 166

Junyent, Eduard 153, 162
Kalous, Antonín $\quad 319,321$

Kamnik, Franciscan monastery 112

Kamp, Cistercian abbey 213

Kanazawa, Masakata 149,162

Kangasala 201

Karp, Theodore 267, 296

Keller, Hagen $\quad 175,180$

Kells, Book of 20

Ker, Neil R. 24, 27, 35

Kirchhoff, Albrecht $\quad 210,235$

Kjöllerström, Sven 187, 203

Klauser, Theodor $\quad 39,76$

Klosterneuburg, Augustinan monastery 89

Klugseder, Robert $\quad 28,34,78,89,92,94,112$

Knaus, Hermann 234

Knibbs, Eric $\quad 40,76$

Knighton, Tess 149,162

Knuutila, Jyrki 187, 198

Koblenz 212-219, 221, 224-225, 232-233

Koch, Adolph 210, 235

Koehler, Wilhelm 48,76

Kolozsvár / Cluj-Napoca 302

Komáromy, András 302, 312

Königsbrück, Cistercian abbey 222, 225

Koper / Capodistria 103, 110

Kopp, Johannes, abbot 90

Körmendy, Kinga 319, 321

Kostanjevica / Landstrass 110

Kovács, Andrea 320,322

Kraków 168, 171, 178

Krieg von Hochfelden, Georg H. 223, 235

Krug, llana 21, 35

Kubinová Kateřina 114

Kügle, Karl 4, 126, 147, 158, 162, 212-213, 224, 235

Kühne, Hartmut $\quad 230,235$

Künast, Hans-Jörg $\quad 229,235$

Kungsåra 199-200

Kurvinen, Pietari J. I. 193, 203

Kyriale 103, 198, 319

Kyriss, Ernst 206, 235

Lacoste, Debra 83

Lähnemann, Henrike 16, 35

Lafitte, Marie-Pierre $\quad 48,76$

Lagarle, Sulpice 228

Lamentations / Lamentationes leremiae 149 
Landini, Francesco

portrait 21

tomb-slab 11

landscape layout $\quad$ 243-244, 246-247, 249

Lannutti, Maria S. 157, 162, 263, 290-291, 297

Lanoë, Guy 206, 235

L'Aquila 12

Las Huelgas $\quad 223,225,227$

Latin, language $\quad 5,23,105,119,166,186-$ 188, 191, 193, 195-196, 198-199, 201,

222, 224, 228-229, 250, 253, 266

Lattanzi, Massimo 273, 283-284, 297

Lazius, Wolfgang 253

Lefferts, Peter M. 26, 35

Legend of the 10,000 Martyrs 222

Lehmann, Paul 46,76

Leitmeir, Christian $\quad 3,15,227,235$

Leipzig $\quad 44,74,171,178,210$

Lempiäinen, Pentti 193, 198, 203

Leonine hexameters 220

Leuven chansonnier, see Index of Manu-

scripts and Fragments (Leuven, Alamire Foundation, s.s.)

Lewis, D. 216, 235

Lewis, John F. 20

Lewon, Marc 258-259

L'homme armé, masses 21

liber cantus 188

Lichtenthal, Cistercian convent $\quad 222-223$, 225-227

Lickteig, Franz-Bernard $\quad$ 212, 235

Liège 213, 223

Stavelot-Malmedy 213

Limbuš 112

Lindelöf, Uno $\quad 44,76$

Lindsay Ricketts, Coella 20

lingua di si 264, 291, 296

Litany

antiphons $\quad 46,50-51$

Major $43-44,48,50-52,57-59$

Minor 43-44

litterati $166,175-176$

Ljubljana 97, 106,109-111

diocese 111

Llibre Vermell, see Index of Manuscripts and Fragments (Montserrat, Biblioteca de la Abadia, 1)
Locanto, Massimiliano $\quad 263,268,270-$

271, 273, 280

Lochamer Liederbuch 258

Louis IX / Saint Louis 10

Sainte Chapelle, foundation 10

Low Countries 213

Lubieniecki, Ryszard $\quad 175,180$

Lucca choirbook fragments 27

Ludovici, Johannes 256-257

Ludwig, Friedrich $32,128,162$

Lupi, Johannes 252

lute 133

Lutheran 16, 186, 201, 230

Lütolf, Max 165, 179, 365

MacDonald, Claire $\quad 337,366$

Machaut, Guillaume de 207

$\mathrm{Vg}$ (manuscript), see Index of Manuscripts and Fragments (Cambridge, Corpus Christi College, Ferrell 1)

Madas, Edit 304, 322

Magdalen College $\quad 2-3,6,27,31,32$

magister chori 256

magister organorum 129

Magnificat, canticle $\quad 29,39,63,79,80,83$, 86,93

Mainz $\quad 40,48,56,212,229-232$

St Alban's abbey $\quad 48$

Mallorca 154

Mandatum, see 'Easter liturgy'

Mantuani, Josef 253, 259

Mantuanus, Baptista 228

Parthenice Mariana 228

Marbod, bishop 87

marginalia 98

Marian 220-221, 224, 226

devotion 192

Marimon i Llucià, Ma Rita $\quad 120,162$

Marinescu, Ruxandra 213, 235

Martimort, Georges $\quad 46,76$

Martin I, see 'Aragon'

Martin le Franc 10

Mass $\quad 39,40,47,62,64,102,117,123$, 126-127, 129, 132-134, 141, 165, 166, 168, $185,196,199,201,252,306,319-320$

Proper 48, 311 
Mass, Ordinary $\quad 139,143,196,252$

Kyrie $\quad 33,127,132,136-137,140,142$, 155, 157, 196, 198-199, 247

Credo 127, 135-136, 140, 142, 150-151, 153, 172, 248

Gloria $123,127,132,135-136,140$, 142-146, 151, 196, 198, 227, 247

Sanctus $19,107-108,132,136,137$. $140,142,247$

Agnus Dei 127, 136-137, 142, 196, 199, 247

Maulbronn, Cistercian abbey 223

Maurus Venetus 254

Mazal, Otto 205-206, 236

Mazovia 168-169

McAvoy, Liz H. 229, 236

McGrady, Deborah 207, 236

Medeltida pergamentsomslag 185-186

Medici, family 21

Medingen 16

Meer, Marcus 226, 236

Meinert, Christiane 234

melisma / melismatic $83,191,196,198$, 219, 224, 267, 283, 284

Melk, abbey 28, 251

Memelsdorff, Pedro $\quad 25,35$

mendicant order $212,220,230,254$, 256

Messan på Swensko 199

Mewerl, Nicolaus 254

Mezey, László $\quad 301-304,308,322$

microfilm 12, 31, 303, 345, 346, 352

minister de corda 133

minstrel/s 132-133, 153-154

missal $1,3,18-19,24,33,46-47,98$, 103-104, 188, 201, 210, 302-304

Bobbio missal, See Index of Manuscripts and Fragments

(Milan, Biblioteca Ambrosiana, D 84 inf.)

Missale Aboense 188, 201

Missale Lincopense 188

Missale Strengnense 188

Miller, Matthias 236

Miret i Nin, M. Montserrat $\quad 134,162$

Miró i Baldrich, Ramón $\quad$ 152, 151, 162

Moberg, Carl-Allan 188, 203 modality $44,273,278,280,291$

ambitus 278

ouvert - clos / aperto - chiuso /

apertum-clausum 266, 277, 280, 289, 291

protus 280

subfinalis 280

Modena A, see Index of Manuscripts and Fragments (Modena, Biblioteca Estense, Q.M.5.24

Möller, Hartmut $\quad 61,76$

Monclús Guitar, Ricard $\quad 138,162$

Montserrat, Benedictine abbey 118, 157

Llibre Vermell 118, 157

Monzón, cathedral 154-155

moranza 149

Morris, William 17

Moselle 212

motet $119,122-123,125-126,129,132$,

$134,139,144,166,168,171,212-213$,

216, 219-221, 227, 247-248, 251

Italian 33

Marian 221, 224

motet book / liber motetorum 138, 155, 251

polytextual $165,167,171$

Provençal-Occitan 135-136

Trinity 221

motetus 213, 216, 219

Mozart, Wolfgang A., Requiem $\quad 9-10$

Mráčková [Hlávková], Lenka 166,180

Mundó, Anscari M. 152

Munich 241, 252-254, 256-257

Murall, Oriol 121, 162

Müstair, Benedictine convent $\quad$ 40-41

fragment, see Index of Manuscripts and

Fragments (Müstair,

Benediktinerinnenkloster

St Johann, XX/48 no. 14)

Mütherich, Florentine $\quad 48,76$

Nádas, John $\quad 25,27,35,336,337-338,366$

Nagyszombat / Trnava 302

Naples 15, 21, 149-150

Nastulczyk, Tomasz 177,180

Nativity of Christ 221

Nativity of Mary 78 
Neuburg, Benedictine abbey 225

neumatic, notation $\quad 5,83,89,102,263-273$,

276-277, 282-4, 287-288, 291, 293-

295

Beneventan 271

Bohemian-Messine 246

Cistercian 103

climacus 271

clivis / flexa 101-102, 109, 271, 294295

coupure neumatique 283

Gothic 102, 109

gradata 271

Hufnagel $\quad 100,102$

Hungarian / Strigonian 311-312

in campo aperto 270,272

liquescent neumes 85

Lotharingian / Messine 89, 270, 296

Messine-German-Gothic 311

Messine-Gothic-Hungarian 312

oriscus 283

porrectus 271, 282

pressus maior 285-294

punctum $89,101,191,271$

quilisma 100-101

scandicus $100-101,271,312$

staffless 211

strophae, distropha, tristropha $\quad 273$, 282-283

strophici 271

torculus 109, 191, 271, 294

tractulus 271

trigon 283

uncinus 271, 282, 294

virga, bivirga, trivirga $\quad 89,100-102$, 109, 273, 284, 294

Nicolau dels orguens 133

Nordlind, Tobias 187, 203

notation

Cistercian 103

clef/s $123,169,225,243,273,308$, 312, 359

custos/-des 123-124, 169, 276-277, $305,308,312$

Italian mensural 106

letter notation 241

longs 250 mensural 121, 151, 165-166, 168-170, 174, 224, 227-228, 243, 247-248, $250,252,257$

mensural full / void 246

mensural signs 169

organ tablature, Italian / German 216, 219, 224, 241, 243, 246-249

semibreves $224,250,358$

semibrevis maior 224

square / chant notation $85,100,102$, 103, 107, 111, 211, 243, 246

staff notation $\quad 78,80,83,89-91$

staff / stave $123,144,147,157,282$, 312

stroke notation $\quad 243,246,249-250$

notator / notator $112,246,248,270,272$, 276, 289, 291

Notker, Liber ymnorum 42

Notre-Dame La Daurade (Cahors), Cistercian house 223

Obradors Suazo, Carolina $\quad 120,162$

offertory 125

Old Church Slavonic $\quad 4,107-109$

Old Testament 92, 216

books 92

Isaiah, Tree of Jesse 216

Ommundsen, Åslaug 176, 179, 187, 203

Opava 171, 177

organ 129, 133-134, 139, 152, 249-250

Barcelona Cathedral 122

fragment in 104

positive organ 122

St Mary of Cervera 152

tablature, see 'notation'

Weatheringsett tudor organ 13-14

organist/s 133, 153, 242, 248-252, 258

organum 121

orguens menors 152

Ottermann, Annelen 206, 229, 236

Ottobeuren, Benedictine abbey 89

Ottoman 303

Otto of Bamberg, bishop 93

Ottosen, Knud 91-92, 94

Overgaauw, Eef 212, 236

overwriting $25,327,337,339,341,360$,

361 
Ovid 127

De arte amandi 127

De remedio amoris 127

Padre Martini, Giovanni Battista 32

Padua 32, 254

Santa Giustina, monastery 27

Page, Christopher $\quad 24,133,162$

pagina venditionis 272

palaeography 3,351

musical 271, 305, 312

palaeographical $122,135,219,302-304$, 307-308, 324, 356, 358

Palazzo, Eric $\quad 45,76$

Palm Sunday 57

palimpsest $15,24,25,47,210,235,336-$ 337, 341

San Lorenzo palimpsest (SL) 25, 32, 337

papal bull 229-230, 253

parchment $13,15,23,63,98,106,109$, 130-131, 135, 143, 166, 175, 185-186, 190, 199-201, 211, 220, 226, 232, 265, $268,272,276,283,291,295,308$ reuse $1,4,10-11,14,24-25,104$, $118,148,157,187,325,327$

waste / scrap $26,29,33,121-122$, 148, 151, 205-206, 209, 210, 225. 230, 302

hair / flesh sides 130-131, 211, 220, 221, 226

Paris $\quad 48,74,80,131,135,137,154,212-$ 213, 216, 227-228, 233

Collège St Bernard 228

Parkes, Henry $39,40,76,89$

partbook $323,325,331,344-345,348-$ $349,358-359,362,364$

pastedown $4,14,24,25,30,31,87,205-$ $232,326,331$

Passalacqua, Marina $\quad 263,296$

Passanant 144

Passau 83

diocese 252

liturgy 83

Paucker, Günther Michael 59,76

Paumann, Conrad 252

Pepys, Samuel 17
Peraudi, Raymond, cardinal 230

Perz, Mirostaw 171, 177, 180

Petrucci, Armando 264

Petrucci, Ottaviano 149

Lamentationum 149

Petrus Wilhelmi, composer $\quad 165,168,171-175$

Petzsch, Christoph 258-259

Pfeil, Brigitte 15,35

Pflüger, Helmut $\quad 223,236$

Philadelphia, Free Library 20

Philip V, king 213

photography 11, 216

infra-red (IR) 344, 353-356, 358, 360,364

ultra-violet (UV) $\quad 120,124,135,144$, 324, 327-328, 339-341, 343

Photostats $350-353,359,364$

Piacenza fragment 296

Piccolomini, Enea Silvio 254, see 'Pius II, pope'

piedi 289

Pietzsch, Gerhard $\quad$ 252, 259

pilgrimage 252

pilgrims 157-158

Piquer, Josep Joan $\quad 141,162$

Pius II, pope 254

plainchant/plainsong $4,98-100,103-$ 104, 107, 109-112, 125, 141, 143, 151,

$155,170,241,245-248,250,252,313$

Poblet $\quad 138-139,141,144,148,150,157$

Abbey Church 150

Royal Monastery, Cistercian $\quad 117,139$, 141, 143-144, 155

polyphony $4,13,28,98,125,132,143$, $154,155,165,166,167,168,170,171$, 176, 223, 224, 225, 226, 227, 232, 245, 246, 249, 325

French 32, 117

Italian 32

ars nova $117-118,122,128,134-135$, $139,151,153,155-158$

books / manuscripts / collections of $39,64,119,121,129,141,153$

mensural 211-212, 222, 257

cantus fractus polyphony 245

Limousin 267

Compostela 267 
Pomerania 169

Pomian, Krzysztof $\quad 167,175-176,177,180$

pontificals 98

Pope, Isabel 149, 162

Pötzlinger, Hermann 176, 252

Pozsony, see 'Bratislava'

Prague 109, 166, 177-178

Emmaus, Benedictine abbey 108

St George, basilica 80

Premonstratensian $\quad 45,83,85$

procession $48,50,52,58-59,64,134$, 152, 253

processional

chants, antiphons $3,39,43,45-46$, $55-59,61-62,64$

liturgical book $45-46,57,64$

production, manuscript $1,4,97,100,105$, 109, 112, 135, 137, 155, 201, 307, 312, 319

proprium de tempore / de sanctis 311, 321

Provençal 135

Prudentius, Metra de S. Monica 253

Prüfening, monastery 89-93

breviary, see Index of Manuscripts and

Fragments (Munich, Bayerische

Staatsbibliothek, Clm 23037)

Prüll, monastery $\quad 81,83$

Prüm, monastery 44

Psalms 148

Book of 198

psalter 16, 98, 103, 110-111, 153

Puchhauser, Berthold 253

Purification, feast 46

Quedlinburg 61-62, 89, 212, 219

quire $127,129,131,142-143,187$ guards 206

Radomski, Mikotaj, composer 177

Rajeczky, Benjamin $\quad 168,180$

Range, Matthias 346,364

Rankin, Susan $\quad 3,44,47,76$

Rampi, Fulvio 273, 283-284, 297

rastrum 147, 199, 243, 244

rastration $\quad 135,144,147$

Rating de Berka, Amplonius 15
Ravenna 5, 263-264, 266-267, 269-271, 276, 278, 280, 291, 293, 295

Raymond of Capua 222

reform 2, 4, 28, 31, 89, 97, 200-201, 205, 222-223, 226-228, 256, 258

Reformation $13,17,33,176,185-188$, 190-191, 193, 195, 198-199, 200-201, 205, 230

refrain 57,296

refrain 290-291

Regensburg $\quad 48,59,61-62,76,79-81$, 85-87, 89-90, 93-94, 176, 252-253

St Emmeram, abbey $\quad 48,79,176$

Regino of Prüm, Epistola de armonica institutione 44

Regula of Lichtenthal 222-223, 225-226

relics $10,52,54$

responsory $42-45,63,83,85,89,93,213$

Rheinau breviary, see Index of Manuscripts and Fragments (Zurich, Zentralbibliothek, Rheinau 28)

Rhine

Lower Rhine 213

Middle Rhine 212

Upper Rhine 225

Richter, Will 229, 236

Richter-Bergmeier, Reinhilt $\quad 229,236$

Rickert, Margaret $\quad 18,35$

Ricomà, Francesc $\quad$ 143-144, 148, 162

Riley, Hannah 205, 236

Rinck, Peter 206

Ristory, Heinz 249, 259

Robertsbridge

Cistercian abbey 216

fragment, see Index of Manuscripts and Fragments (London, British Library, Additional 28550)

Robertson, Anne Walters $\quad$ 213, 236

Roda de Isábena 155

rogation 43-46, 50-51

Rohloff, Ernst 266, 297

Rolandus de Casalis, humanist monk 27

Roman liturgy $\quad 56-57,65,107,111$

Roman-Franciscan 45

Romano-Frankish, chant repertory $\quad 55,85$

Romania 302, 319

rondeau 219 
Rosa Barezzani, Maria Teresa $\quad$ 270-271, 297

Rott-am-Inn 77

rotulum/-a, genre 168,171

rotulus 213,227

Rovira, Guillem 127-128

Rowe, Nina 17, 20, 35

royal commission $\quad 130,138$

rubric/s $39-40,43,48,51,55-57,64,198$

Rück, Peter 211, 236

Rumbold, Ian 176, 180, 248-259

rundelus 247

Ruralia commoda, see 'Crescenzi, Pietro de'

Ruskin, John 15

Rytterne 199

Saak, Eric Leland $\quad 212,236$

Sabaté i Marín, Glòria 151, 162

Sadler partbooks, see Index of Manuscripts and Fragments (Oxford, Bodleian Library, Mus. e. 1-5)

Saints

Afra of Augsburg $\quad 77,87,89,91$

Alban 78

Anianus 77

Augustine of Canterbury $\quad 78$

Barbara 248

Catherine $\quad 85-87,213,222,226,247$

Chrysogonus 77

Corbinian 77

Dominic 10

Dorothy 252

Etheldreda of Ely 78

Emmeram 48, 77-81

Francis 10

George 77, 90-93

Henrik 193

Hellarus 111, 113

John the Baptist $\quad 58,78,188$

John the Evangelist 16

Juliana 77

Lawrence $\quad 42,190$

Livinus 248

Margaret $\quad 77,85-87$

Marinus 77

Martha 318

Mary $78,157,221,248$

Maurice $\quad 78-80$
Mechthlid 78

Nicholas 87, 252

Oswin of Deira 78

Paul 189

Peter 56, 58, 189

Procopius 319-320

Quirinus 77

Rupert 252

Tatianus 111, 113

Ulrich (Udalricus) of Augsburg $\quad 247,252$

Valentin 252

Vitus $77,81,83$

Waudru 11

Wolfgang 252

Salisi i Clos, Josep M. 141, 162-163

Salmen, Walter 258-259

Salzburg 80,110

Salzburg, Monk of, composer $\quad 248,251$

Sankt Emmeram, abbey, see Regensburg

Codex, see Index of Manuscripts and Fragments (Munich, Bayerische Staatsbibliothek, Clm 14274)

Sankt Gallen, abbey $\quad$ 47-62

liturgy $\quad 42,53,56,61-62$

liturgical books $\quad 43,47-48,55,57-$ $59,62,74,177$

script 42

Sant Martí de Maldà 149-150, 155

Sant Martí de Riucorb 149

Santes Creus, abbey 148

Sarum 45

Savonarola 15

Scandinavia 4, 78, 176

Schäftlarn, abbey 87

Schlager, Karlheinz $\quad 89,94$

Schlägl, abbey $\quad 83-85$

Schlechter, Armin $\quad 210,236$

Schlegel, Friedrich 9

Schmeller, [Johann] Andreas 93-94

Schmid, Bernhold $\quad 169,180,246,249-251$

Schmid, Wolfgang 206, 236

Schneider, Cornelia $\quad 230,236$

Schöffer, Peter, printer 229-230

schola 250

Schöntal, Georg von 253, 256

Schrade, Leo 117, 127, 163

Schrempf, Johannes 234 
Scott, Peter James David $\quad 149,163$

scribe/s 22, 31, 64, 106, 122-127, 132,

137, 139, 142-143, 147, 149, 151, 169, 191, 196, 201, 207, 248, 252, 257, 264, 269-270, 272, 276, 283, 331, 348-350, $352,358,362$

scriptoria $307,312,320$

semiographic/semiography 266,269 , 283, 293

semiophore $\quad 175-177$

semiotic $165,174-177$

sequence/s, genre $42-43,103,188-191$, 193, 195-196, 247, 252, 319-320

sequentiary 103-104, 319-320

Sequentionale Waradiense 301 , 318-321

Shields, Michael 251, 259

showthrough $329,336,348,350-351$, 356,360

Silesia $\quad 4,168-169,171$

Skinner, Patricia 236

Slovakia 168-169, 302

Slovenia/n 3-4, 97-99, 102-103, 106, 109, 110-112

Småland 196

Smith, Margaret M. 14, 34, 98, 114

Snoj, Jurij $\quad 4,97-98,101,103-104,107$, $110,111,114$

Sobrino González, Miguel $\quad 122,163$

song/s $5,149,157,165-167,174,171,251$, 263, 267

songbook 23

Spierinck, Nicolas, binder $\quad 30-31$

spine $87,138,206$

Spiš 168,302

Spunar, Pavel 180

Squarcialupi Codex, see Index of Manuscripts and Fragments (Florence, Biblioteca

Medicea Laurenziana, Med. Pal. 87)

Stäblein, Bruno 101, 114, 135, 161

Stäblein-Harder, Hanna 117, 163

Staehelin, Martin 168,180

Stain, Berthold von 254

staining 360-361

Šter, Katarina 103, 115

Stična / Sittich, Cistercian abbey

Stockholm 185, 187, 195, 199, 200
Stoessel, Jason $\quad 138,163$

Stone, Anne $\quad 24,35,138,163$

Strasbourg 12, 229

Stratford 329

Strohm, Reinhard $\quad 5,27-28,35,241,247$, 250-253, 259

Stussi, Alfredo $\quad$ 263-267, 289-291, 297

St Wolfgang am Abersee (Wolfgangsee) 248, 252

Summers, William J. 26, 35

Sureda i Jubany, Marc 134, 163

Sweden 4, 185-186, 201

Swedish, language $\quad 4,185,187,193,195-$ 197, 199, 201

Szendrei, Janka $\quad 89,94,98,101,114,303-$ 304, 312, 322

Szepes, see 'Spiš'

Szigeti, Kilián $\quad 312,322$

Szirmai, J. A. 205-206, 211, 236

Szombathely 312-318

Szyller, Stawomir 168,180

Taitto, Ilkka $\quad$ 186-188, 190-191, 193, 196, 203

talea 123

Tamás Bakócz 312

Tarragona 121, 128, 132, 139, 143-144, $147,148,150,153,155$

Tegernsee, Benedictine abbey $\quad 78,80$

Tempus, liturgy $\quad 306,311,313,318$

tenor $122,125,144-145,149,155,213$, $216,219-220,223,227,243,250,256$, 358,362

Theology 120, 216, 256

theoretical treatise, music $98,106,129,266$

Tinctoris, Johannes 10

Tomasello, Andrew $\quad 127,138,140,163$

Tomasoni, Piera $\quad 263,297$

Toronto 21

Torres Lobo, Nuria 160

Tortuna 199

Toubert, Pierre 229, 236

Toy, John 79-94

tradens, codex / liber 206, 209, 305

Trecento 11

Trém 154

Trent 31, 251-252

cathedral 252 
Tridentine reforms 97

Trier 44, 74, 171, 178, 212

trimming 224, 228, 264-265, 231

Trinitarian order 228

triplum 122-126, 144, 213, 216, 219-220, 227

Třǐška, Josef 180

Tronzo, William 10, 36

trope $59,127,155,157,280$

troper $26,39,64,85$

trouvère 267

Troyes 223, 225, 227-228, 232-233

trumpet 134

Tuppurainen, Erkki $\quad 188,196,198,202-203$

Turin 12

Turku, Diocese 196

Tyers, Theresa 236

Tyson, Alan 9-10, 35

Ulm 230

unicum/-a 12, 61, 119, 122, 126, 139, 144, 153, 257, 359

United Kingdom (UK) 324

Uppsala 199

Ustí nad Orlicí 171,178

Utraquists 165-171, 174-177

Utrecht 213

St Mary 213

Uttenweiler, Augustinian friary 254

Vadász, Veronika $\quad 302,322$

vademecum 258

Valencia 154

Vallentuna 187

Van Biezen, Jan 250, 259

Van den Borren, Charles 12, 36

Van Swieten, Gerard 253

Van Waesberghe, Joseph Smits $\quad$ 106, 115

Várad 320

cathedral 319

Vasa, Gustav, king 186, 201

Västerås 200

Recess 186

diocese 199

Västmanland 199

Vellekoop, Kees 250, 259
Veneto 28-29

Venice 29,110

La Fenice, theater 12

Verdés Pijuan, Pere 152,163

Verdú $\quad 139,141,143,149-150,155$

Veselovská, Eva 98, 112, 115

Vetter, Eddie 213, 237

Vidal i Pla, Jordi $\quad 132,159$

Vidal, Jacobo $\quad 128,160$

Vienna $23,28-29,74,89,111,177,233$, 241-242, 251-254, 256-258

University 253-254, 256, 258

Augustinian convent 257

St Stephen's, cathedral 254, 256

Vilafranca del Penedès $117,121,129,132-$ 134, 141, 155

St Mary, church 134

St Francis, monastery 134

Violant de Bar, queen $\quad 133,154$

Virgili i Gasol, M. J. $\quad 143-144,160$

vita, hagiography' 77, 80, 222, 226

Vízkelety, András $\quad 303-304,322$

Vodňany 176,178

Vollmann, Benedikt Konrad 229, 237

Von Fischer, Kurt $\quad$ 12, 22, 36, 175, 179, 365

watermark 149-150, 168, 242, 251

Wathey, Andrew $\quad 30,32,34,213,234,324$, 326, 365

Ward, Tom R. $\quad 171,180$

Warsaw $170,177,178,180$

Weatheringsett, see 'organ'

Weber, Jaroslav 171-180

Weihenstephan, Benedictine abbey $\quad 28-30$

Weimar, Duchess Anna Amalia Library 12

Welker, Lorenz $\quad$ 12, 36, 171, 181, 259

Wernher, abbot 81

Wesel, Charterhouse 213

Weygel (de Monaco [from Munich]), Paulus 257

Wiener, Claudia $\quad 228,237$

Wilhelmi, Petrus, see 'Petrus Wilhelmi'

Williamson, Magnus 26,36

Winchester Troper, see Index of Manuscripts and Fragments (Cambridge, Corpus Christi College, 473) 
Windsheim, Augustinian abbey 258

Windsheim, Judocus von 258

Wiser, Johannes 252

Wolkenstein, Oswald von 246, 251, 259

Worcester fragments $24,2627,332-333$

wrapper/s 1, 40,110,118-119, 139, 149, 157, 302, 329

Wright, Peter $\quad 176,180,181,248,259$

Ycart, Bernhard 149

Yeager, Travis N. 80, 94

Yerevan 22, 24
Zacara da Teramo, Antonio, composer

Zainer, Günther, printer $\quad$ 229-230

Zainer, Johann 230

Zagreb 21, 24

Cathedral 302

Zaragoza 155

Zayaruznaya, Anna $\quad 213,216,237$

zibaldone 253, 258

Žiče/Seitz 110

Zimmermann, Karin 236

Zwolińska, Elzbieta $\quad 168,181$ 